\title{
Geochronology, Correlation and Magnetic Studies of Quaternary Ignimbrites in the Taupo Volcanic Zone, New Zealand
}

Tasha Maria Black

A thesis submitted for the degree of Doctor of Philosophy in Geology

Victoria University of Wellington

1995 


\section{Abstract}

Voluminous, rhyolitic ignimbrites erupted from calderas in the Taupo Volcanic Zone (TVZ) of North Island, New Zealand during the last ca. 1.6 Ma, are characterised by geochemical, paleomagnetic, magnetic fabric and isotopic age techniques to determine their stratigraphy and source vent areas.

Most of the welded ignimbrites record distinctive thermoremanent magnetism (TRM) directions that can be defined with a precision of $<5^{\circ}$. On this basis, individual ignimbrites may be identified and correlated. These data indicate that the voluminous Whakamaru group ignimbrites, mapped by various names in different parts of the TVZ, were probably erupted over a period of as little as 100 years. The Kaingaroa and Matahina ignimbrites display very similar TRM directions and may have been emplaced contemporaneously. Ahuroa and Mamaku ignimbrites display TRM directions widely different to that expected from a dipole field, and were emplaced during polarity transitions in Earth's magnetic field.

Geochemically, glasses and FeTi-oxides from the TVZ ignimbrites are homogeneous and typical of high- $\mathrm{SiO}_{2}(>75 \mathrm{wt} \%)$ rhyolites. They indicate little evidence of derivation from physically or compositionally zoned magma chambers, and allow individual eruptives to be fingerprinted. Variable compositions of whole pumice clasts from welded units, previously interpreted as evidence for chemical zonation can be explained by glass alteration and variable mineral components. Geochemical and chronological data suggest the Rocky Hill Ignimbrite and/or Unit E ignimbrite (ca. $1 \mathrm{Ma}$ ) may be correlatives of the Potaka tephra, found in sedimentary basins outside the TVZ.

Rock magnetic fabric studies using anisotropy of magnetic susceptibility of ignimbrites allow paleoflow patterns to be determined. These patterns are generally consistent with source areas inferred from other data. The source for Mamaku Ignimbrite is consistent with an area on the western margin of Lake Rotorua. The Whakamaru group ignimbrites appear to have originated north of Lake Taupo, and in particular from an area near the Western Dome Belt.

Glass shards from nonwelded bases of ignimbrites are well suited to dating by the isothermal plateau fission track (ITPFT) method. Any partial fading of the spontaneous tracks has been corrected by a single-step heat treatment of $150^{\circ} \mathrm{C}$ for 30 days. The resulting ages and their uncertainties are comparable to ${ }^{40} \mathrm{Ar} /{ }^{39} \mathrm{Ar}$ plagioclase determinations. The following new eruption ages were determined: Whakamaru group ignimbrites $(0.34 \pm 0.03 \mathrm{Ma})$, Matahina Ignimbrite $(0.34 \pm 0.02 \mathrm{Ma})$, Kaingaroa ignimbrite $(0.33 \pm 0.02 \mathrm{Ma})$, informally named unit Downer $8(0.33 \pm 0.02 \mathrm{Ma})$, and Mamaku Ignimbrite $(0.23 \pm 0.01 \mathrm{Ma})$. These data suggest a major phase of activity, with several different caldera forming events in the interval ca. 0.35-0.32 Ma. The age of Mamaku Ignimbrite constrains the paleomagnetic excursion recorded in the unit to ca. $0.23 \mathrm{Ma}$, similar to the age of the Pringle Falls geomagnetic episode recorded in the western USA. 


\section{Acknowledgements}

This study was funded by a VUW Postgraduate Scholarship, held for 3 years. Two research grants from the Internal Grants Committee supported fieldwork in 1991-1993. Additional funding was provided by Prof. John Westgate (University of Toronto) in the form of a part-time research fellowship. He also provided physical and financial assistance with another season of fieldwork in 1995.

Dr Paul Froggatt suggested and supervised this thesis. He encouraged the use of Anisotropy of Magnetic Susceptibility as a tool for determining flow patterns, assisted in the field and in the acquisition of data. Professor John Westgate kindly provided office space at the University of Toronto for 1994-1995, and the use of his paleomagnetic measurement equipment. The scope of this study was greatly extended with the acquisition of ITPFT ages from John's lab.

I am grateful to Drs Brad Pillans and Brent Alloway for providing the samples of Fordell Ash, Upper Griffin Rd and Lower Griffin Rd tephra for EMA analysis. Dave Manning provided samples of Matahina (B 52) and Kaingaroa ignimbrites (B 56) from his extensive collection, and we held many interesting discussions on our related thesis topics. Paul Froggatt was the source of the Kaingaroa ignimbrite (sample B 55).

Ken Palmer maintained the electron microprobe at VUW, and ran the XRF analyses in double-quick time. Dr Claudio Cermignani introduced the wonders of the Cameca probe at the $\mathrm{U}$ of $\mathrm{T}$. Eric Broughton is thanked for his patience in providing and maintaining the paleomagnetic sampling gear at VUW. Many thanks to Jim Charters (U of T) for his assistance with computer problems.

Last, but certainly not least is the invaluable contribution made to this thesis by my husband, Dr Phil Shane. His assistance in the field, in the laboratory, and his impatience in the final stages of write-up has resulted in the completion of this study. 


\section{Contents}

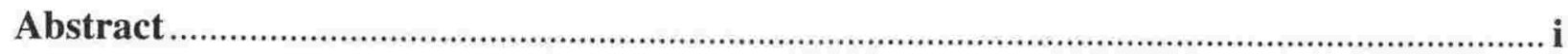

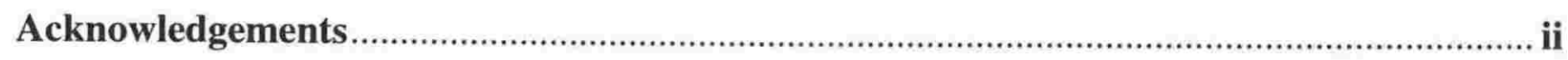

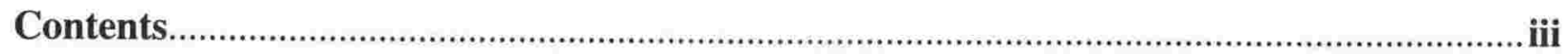

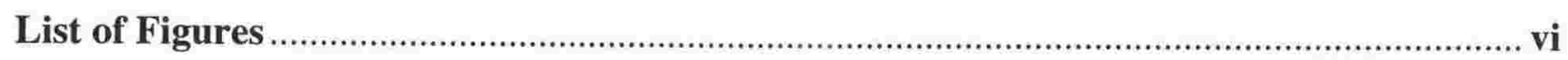

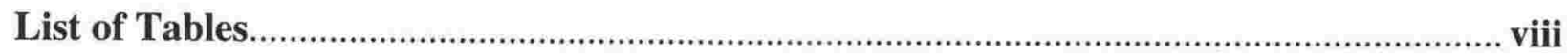

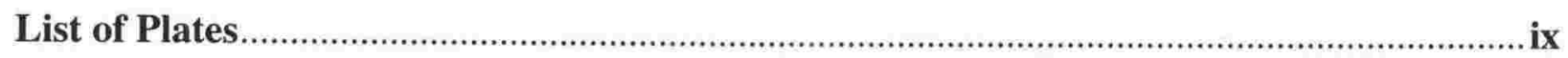

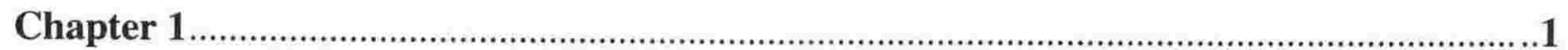

INTRODUCTION

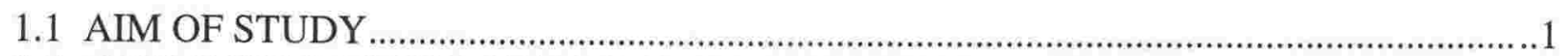

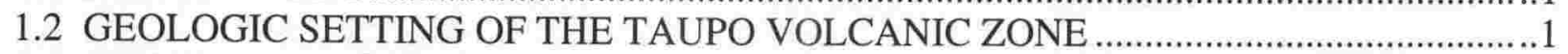

1.3 CHRONOLOGICAL AND CORRELATION STUDIES OF THE TAUPO VOLCANIC

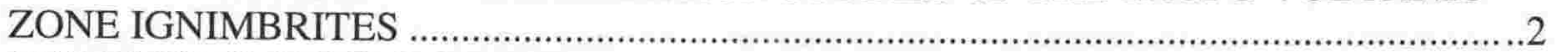

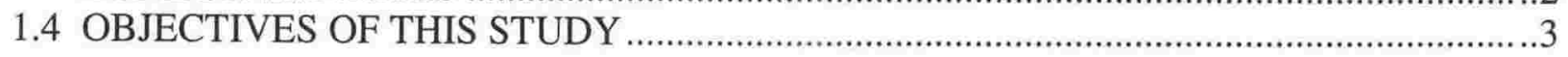

Chapter 2 ......

CALDERAS AND IGNIMBRITE STRATIGRAPHY

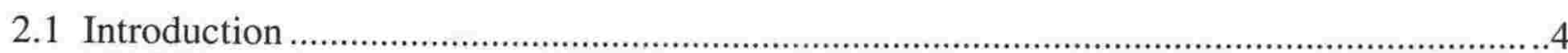

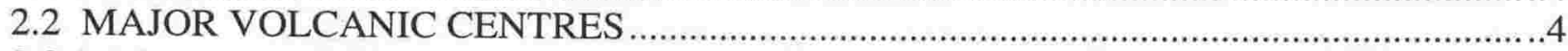

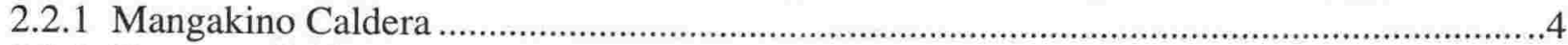

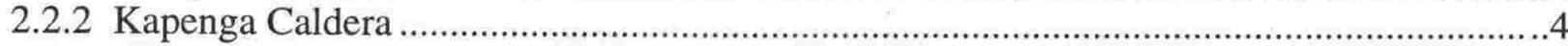

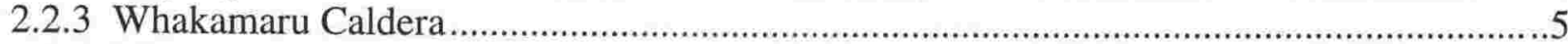

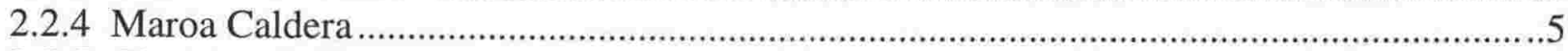

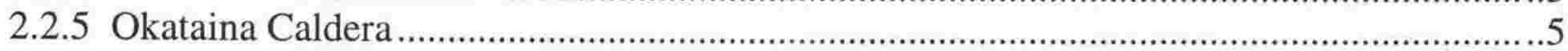

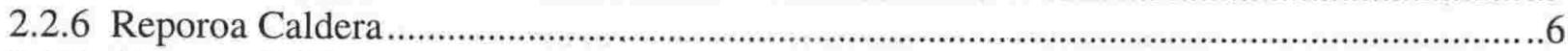

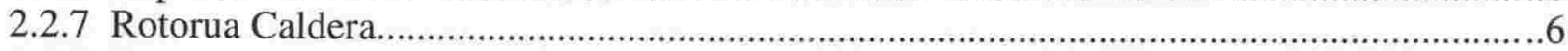

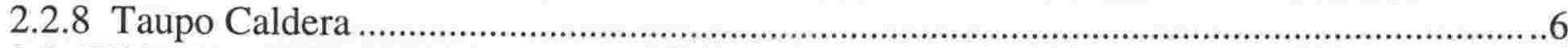

2.3 IGNIMBRITES AND PYROCLASTIC UNITS EXAMINED IN THIS STUDY...............7

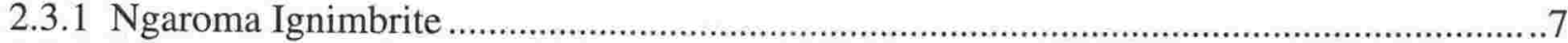

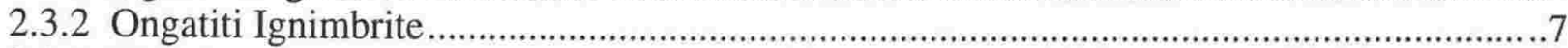

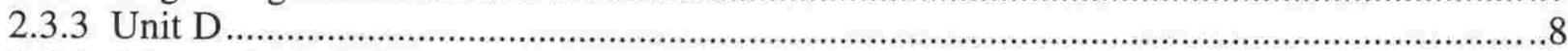

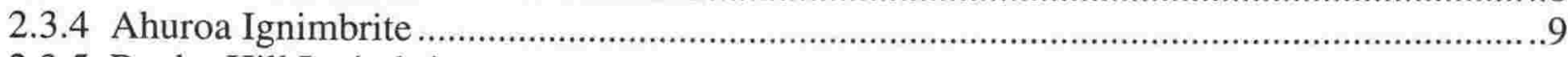

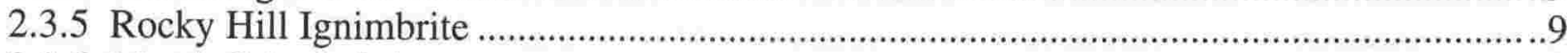

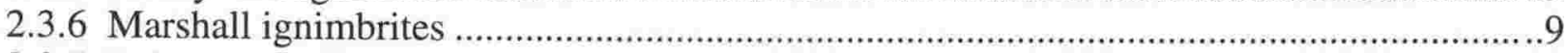

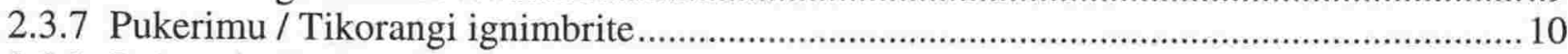

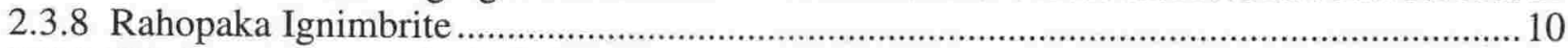

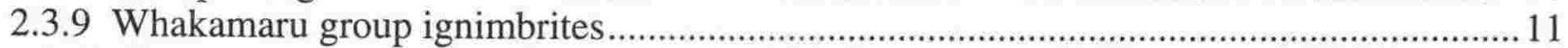

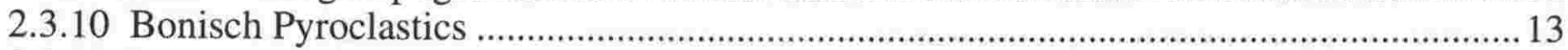

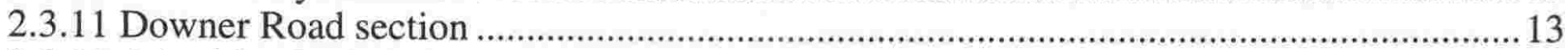

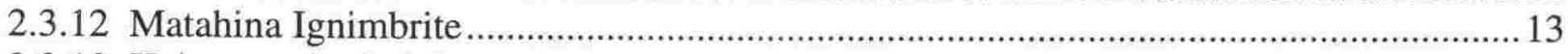

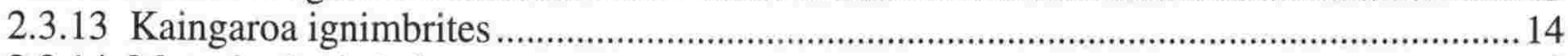

2.3.14 Mamaku Ignimbrite............................................................................................... 15

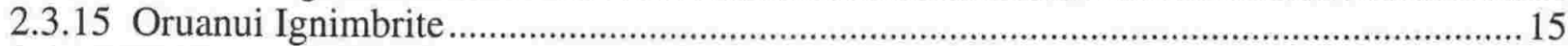

2.4 DISCUSSION OF IGNIMBRITE CORRELATION TECHNIQUES ............................. 16 


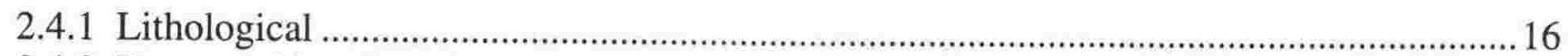

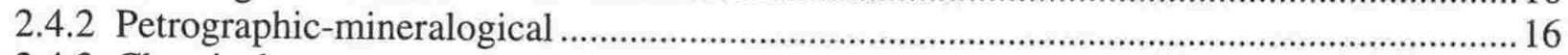

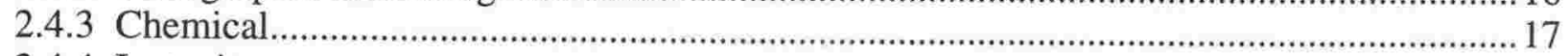

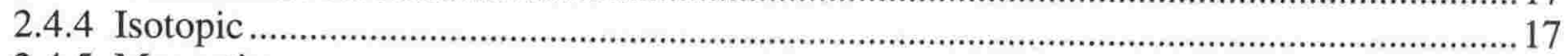

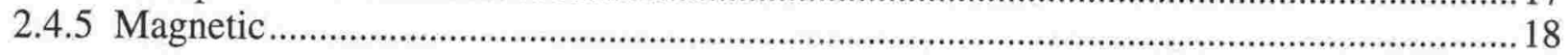

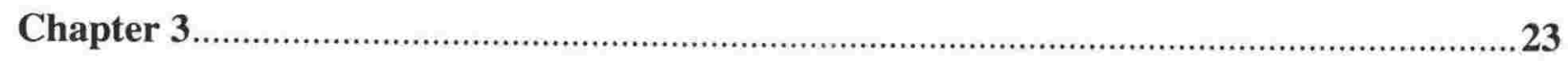

\section{PALEOMAGNETISM}

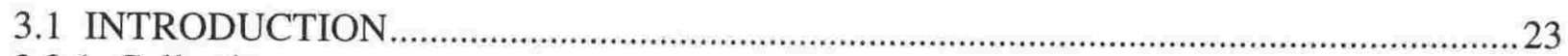

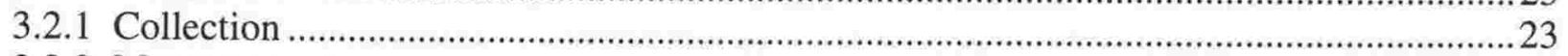

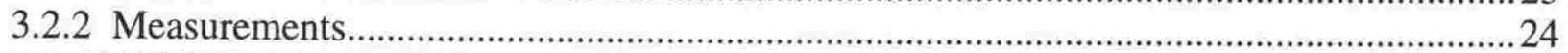

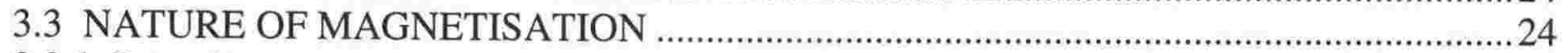

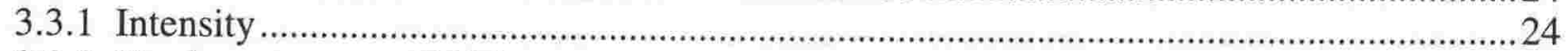

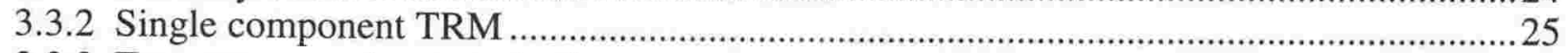

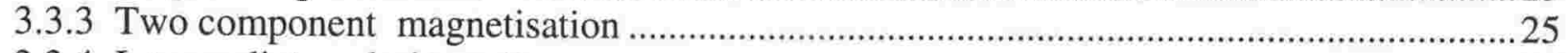

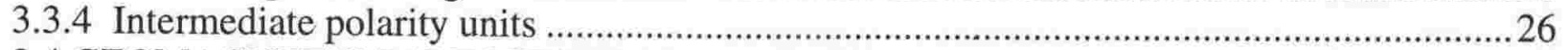

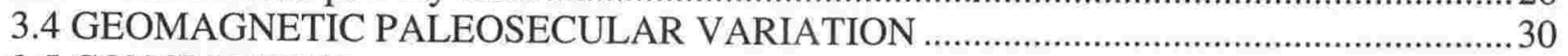

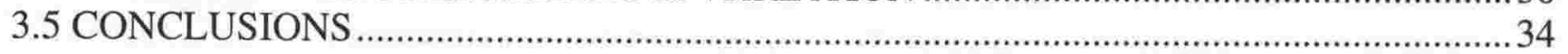

Chapter 4

\section{GEOCHEMISTRY}

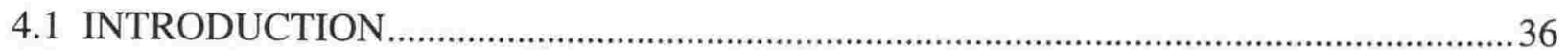

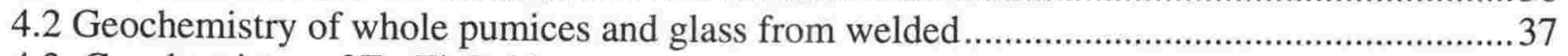

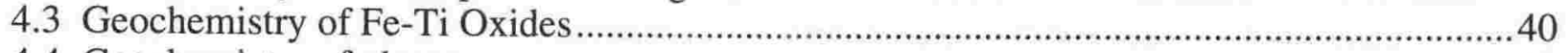

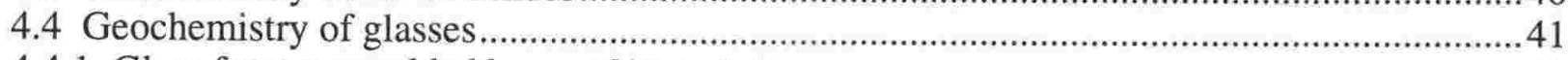

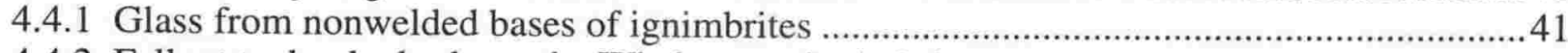

4.4.2 Fallout tephra beds above the Whakamaru ignimbrite.......................................................4 44

4.4.3 Numerical comparison of tephra compositions...............................................................4. 46

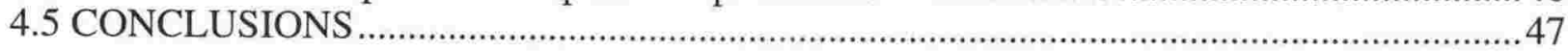

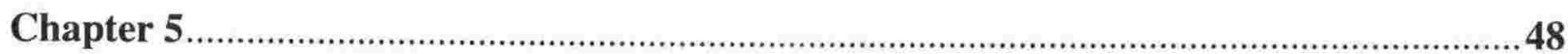

ANISOTROPY OF MAGNETIC SUSCEPTIBILITY STUDIES OF TVZ IGNIMBRITES

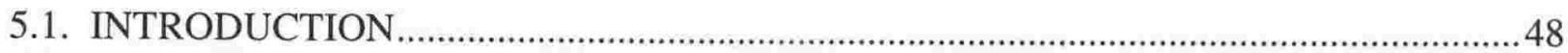

5.2. ANISOTROPY OF MAGNETIC SUSCEPTIBILITY _....................................................

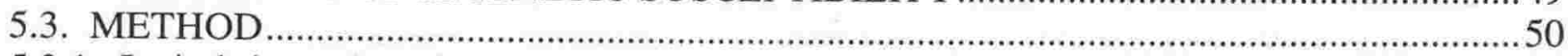

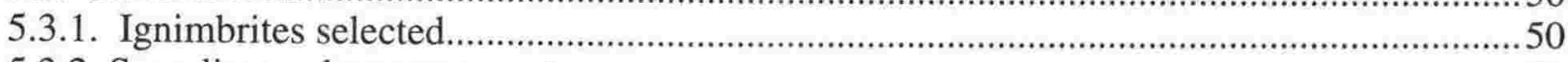

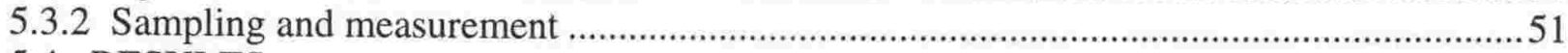

5.4. RESULTS

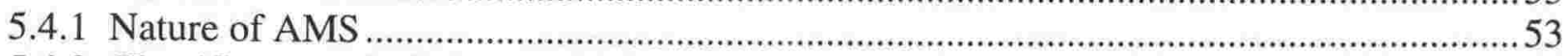

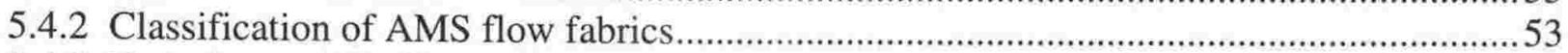

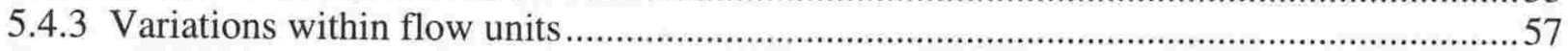

5.5 INFERRED PALEOFLOW PATTERNS FOR TVZ IGNIMBRITES...................................59

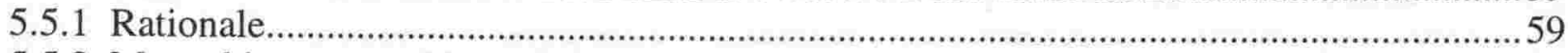

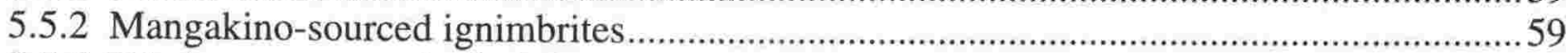

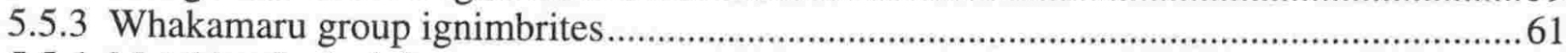

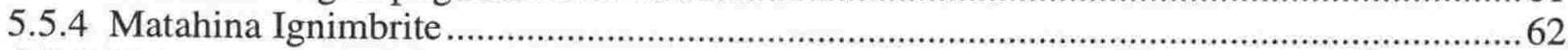

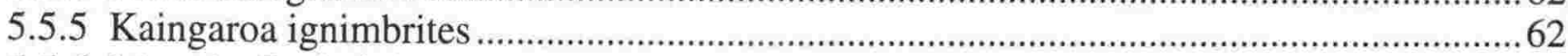

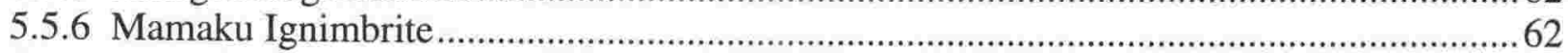

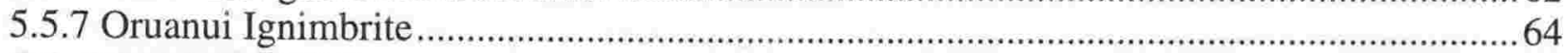

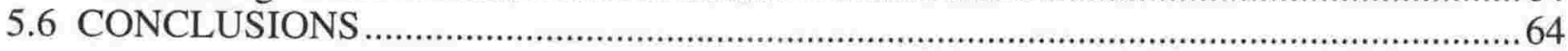


Chapter 6.

ISOTHERMAL PLATEAU FISSION-TRACK GEOCHRONOLOGY

6.1 INTRODUCTION. .66

6.2 FISSION-TRACK DATING METHOD

6.3 Partial fading of tracks

6.3.1. Track size measurement method (Storzer and Wagner 1969)

6.3.2. Thermal correction methods.

6.3.3 Isothermal Plateau Fission-Track method ........................................................................6 69

6.4 METHODS.

6.4.1 Sample preparation

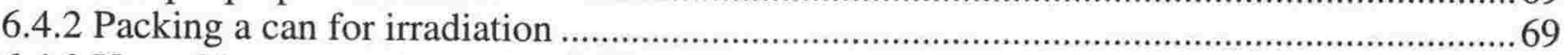

6.4.3 Unpacking, mounting and polishing …………......................................................... 70

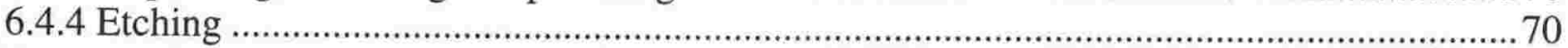

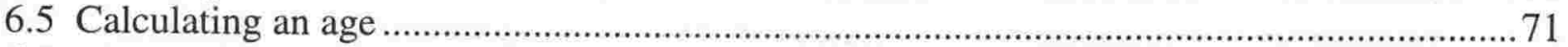

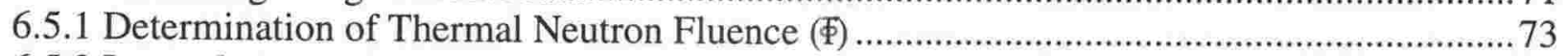

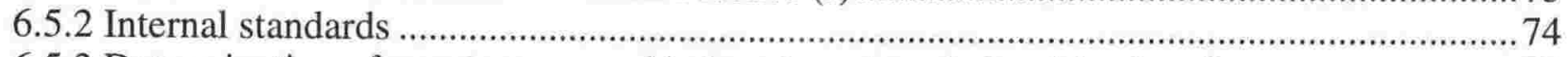

6.5.3 Determination of spontaneous and induced areal track densities (rs, ai) ............................74

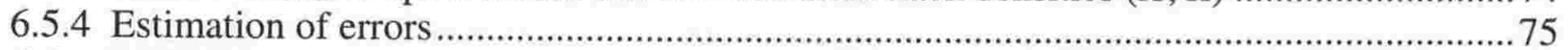

6.6 RESULTS.

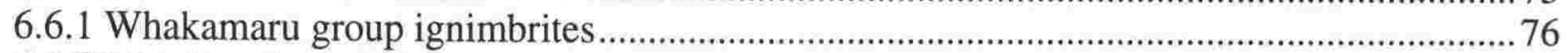

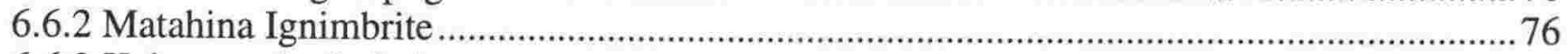

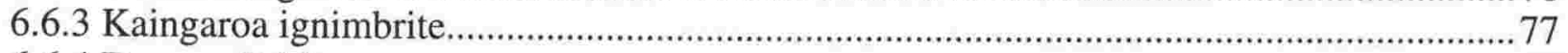

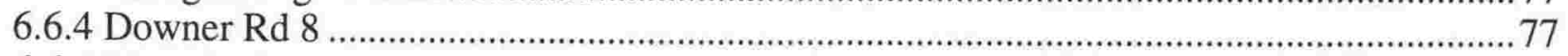

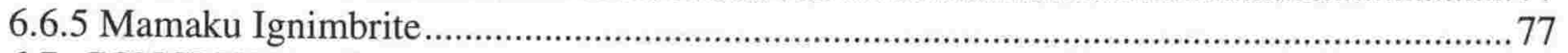

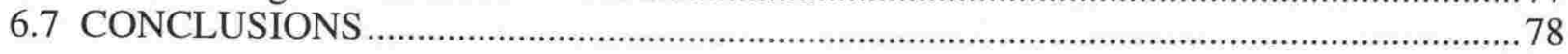

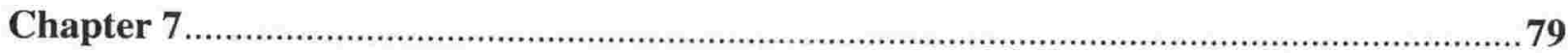

NEW IMPLICATIONS FOR THE STRATIGRAPHY AND CHRONOLOGY OF THE TVZ

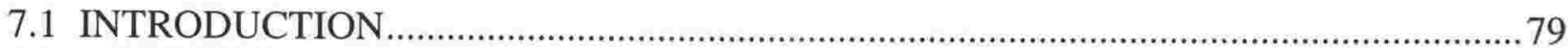

7.2 RECOGNITION OF A LATE QUATERNARY PALEOMAGNETIC EXCURSION ........79

7.2.1 Paleomagnetic record of the Brunhes Chron....................................................................79

7.2.2 A geomagnetic polarity episode recorded in the Mamaku Ignimbrite ....................................... 80

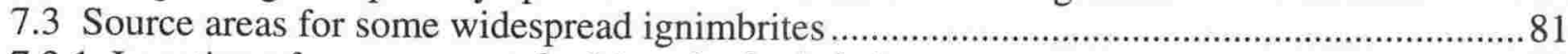

7.3.1 Location of a source vent for Mamaku Ignimbrite ……................................................ 82

7.3.2 Source of the Whakamaru ignimbrite ………….......................................................... 82

7.4 STRATIGRAPHY AND CHRONOLOGY OF MAJOR TVZ IGNIMBRITES .....................8 84

7.4.1 Geochemistry of early Mangakino-derived ignimbrites ................................................... 84

7.4.2 Possible correlation of Rocky Hill Ignimbrite/Unit E to the Potaka tephra..........................85

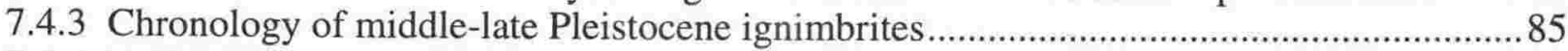

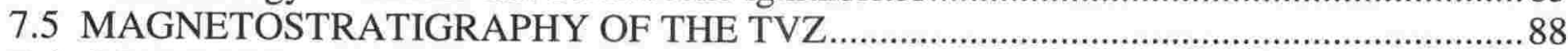

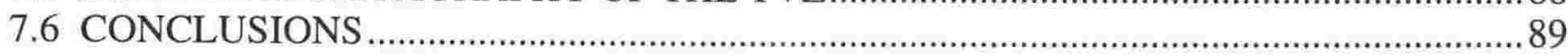

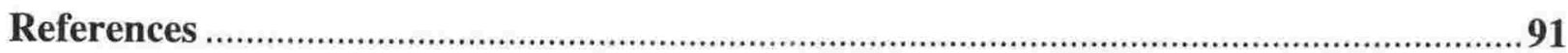

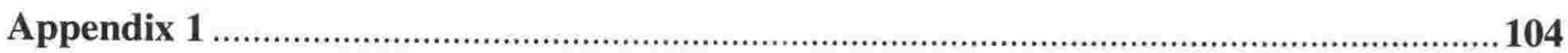

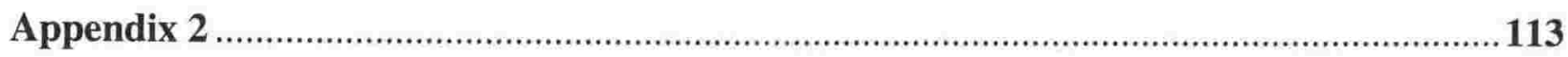

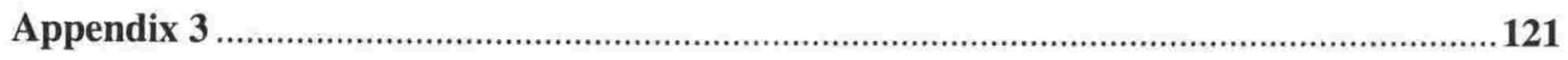

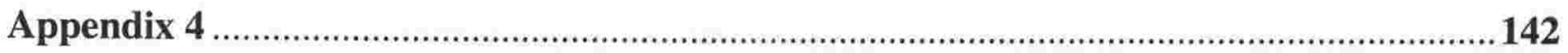




\section{List of Figures}

f denotes facing page

1.1 Map showing NZ in relation to plate boundary ………............................................ 2

2.1 Map of the TVZ showing inferred calderas ................................................................ 4

2.2 Map of the central North Island, showing localities mentioned in the text ................. 5

2.3 Map of King Country showing ignimbrite sample sites …………………................ 7

2.4 Map of Matahana Basin showing ignimbrite sample sites ……………................... 10

2.5 Map showing outcrop distribution of Whakamaru group ignimbrites .......................... 11

2.6 Map showing outcrop distribution of Matahina Ignimbrite ...................................... 14

2.7 Map showing outcrop distribution of Kaingaroa ignimbrite ..................................... 15

2.8 Map showing outcrop distribution of Mamaku Ignimbrite ....................................... 16

2.9 Map showing outcrop distribution of Oruanui Ignimbrite .......................................... 17

3.1 Paleomagnetic intensity behaviour during demagnetisation .................................... 25

3.2 Typical demagnetisation behaviour of normal polarity specimens ............................ 25

3.3 Typical demagnetisation behaviour of reversed polarity specimens ......................... 26

3.4 Demagnetisation behaviour of specimens with multi-component magnetism .......... 27

3.5 Demagnetisation behaviour of specimens from Mamaku Ignimbrite ...........................27

3.6 Stereographic projection of Mamaku Ignimbrite paleomagnetic data ........................ 30

3.7 Demagnetisation behaviour of specimens from Ahuroa Ignimbrite ........................... 31

3.8 Stereographic projection of Ahuroa Ignimbrite paleomagnetic data ............................31

3.9 Stereographic projection of Whakamaru group paleomagnetic data ......................... 32

3.10 Stereonet of paleomagnetic data from Matahina and Kaingaroa ignimbrites ...........f 33

3.11 Stereographic projection of Oruanui Ignimbrite paleomagnetic data .............................33

3.12 Stereographic projection of paleomagnetic data from Matahana Basin ignimbrites ...33

3.13 Stereographic projection of Ongatiti Ignimbrite paleomagnetic data ....................... 34

3.14 Stereographic projection of paleomagnetic data from Marshall ignimbrites .............. 35

4.1 Compositions of pumice and glasses from welded ignimbrites ...................................39

4.2 Fe-Ti oxide compositions of Ongatiti Ignimbrite ..................................................... 40

4.3 Fe-Ti oxide compositions of Ahuroa and Matahina ignimbrites ............................... 41

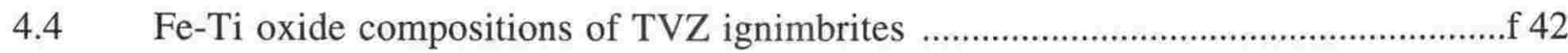

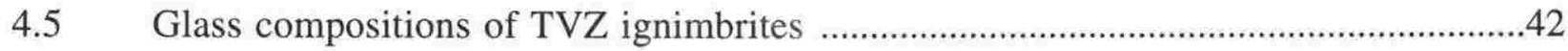

4.6 Geochemistry of tephra beds at Murupara section …….......................................... 43

4.7 Trace element compositions of TVZ ignimbrites .................................................... 44

4.8 Geochemistry of tephra beds at Downer Rd section ……........................................45

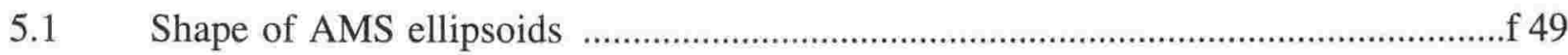


5.3 Examples of AMS sites classified as Type 1

5.4 Examples of AMS sites classified as Type 2 f 55

5.5 Examples of AMS sites classified as Type 3 .55

5.6 Examples of AMS sites classified as Type 4 . 56

5.7 Examples of AMS sites classified as Type 5 .56

5.8 Examples of AMS sites classified as Type 6 . 57

5.9 Examples of AMS sites classified as Type 7 f 57

5.10 AMS measurements of Whakamaru Ignimbrite sites at Maraetai dam f 58

5.11 AMS measurements of Whakamaru group ignimbrite sites at Waipunga Falls . .58

5.12 AMS measurements of Whakamaru group ignimbrite sites . 59

5.13 AMS measurements of Mamaku Ignimbrite sites at Mangaorewa Gorge f 60

5.14 Map of AMS sites collected in the King Country 60

5.15 Map of AMS sites collected from Whakamaru group ignimbrites .............................. 61

5.16 Map of AMS sites collected from Matahina Ignimbrite ............................................. 62

5.17 Map of AMS sites collected from Kaingaroa ignimbrite ............................................. 63

5.18 Map of AMS sites collected from Mamaku Ignimbrite ……………….......................63

5.19 Map of AMS sites collected from Oruanui Ignimbrite ............................................... 64

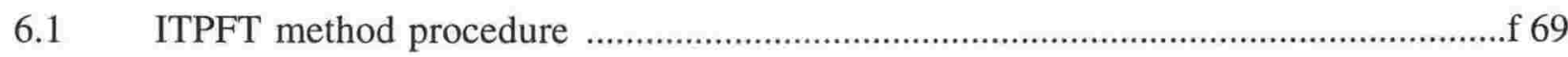

6.2 Diagram of sample arrangement for irradiation …………......................................

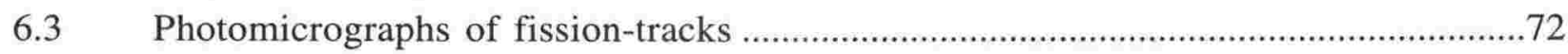

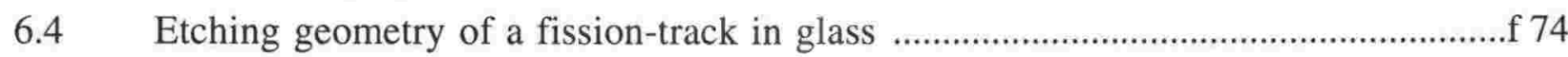

6.5 Example of counting stability in fission-track dating ............................................... 75

6.6 Fission-track size distributions for Mamaku Ignimbrite .......................................... 77

6.7 Fission-track size distributions for late Pleistocene ignimbrites .............................. 78

7.1 Nomenclature and ages of Brunhes Chron paleomagnetic episodes ......................... 79

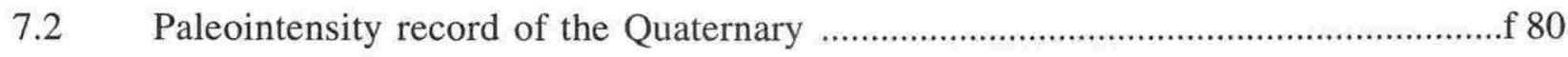

7.3 Paleomagnetic directions of late Quaternary ignimbrites .......................................... 81

7.4 Map showing inferred paleoflow directions of the Mamaku Ignimbrite ..................... 82

7.5 Map showing inferred paleoflow directions of the Whakamaru group ignimbrites f 83

7.6 Glass and Fe-Ti oxide compositions of Rocky Hill Ignimbrite and Potaka tephra f 85

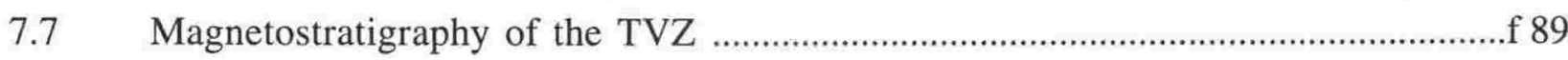




\section{List of Tables}

f denotes facing page

1.1 Summary table of existing age data for TVZ ignimbrites ............................................. 3

3.1 Paleomagnetic data for Taupo Volcanic Zone ignimbrites ...................................... 28

4.1 Whole pumice clast major element XRF data from welded ignimbrites .................... 37

4.2 Composition of glass in pumice from welded ignimbrites determined by EMA ......... 38

4.3 Mean glass compositions of nonwelded ignimbrite and tephra beds from the TVZ ...38

4.4 EMA analyses of glass standard UA Obsidian ....................................................41

4.5 Trace element composition of glasses, determined by XRF ........................................ 44

4.6 Similarity coefficient matrix comparing Bay of Plenty ignimbrites with tephra beds $\mathrm{f} 46$

5.1 Mean AMS measurements for TVZ ignimbrites ................................................... 52

6.1 Thermal neutron fluence determinations for ITPFT study ......................................... 75

6.2 Fission track ages of Moldavite tektite from Ries Crater, Germany ........................ 75

6.3 ITPFT ages of glass shards from ignimbrites in the TVZ ....................................... 76

7.1 Comparison of ${ }^{40} \mathrm{Ar} /{ }^{39} \mathrm{Ar}$ ages with ITPFT data on late Pleistocene ignimbrites ......86

7.2 Similarity coefficient matrix of late Pleistocene ignimbrites and tephra beds ............f 88 


\section{List of Plates}

Plate 1 Base of Ongatiti Ignimbrite .19

Plate 2 Base of Whakamaru group ignimbrites at Waipunga Falls 19

Plate 3 Murupara section

Base of Matahina Ignimbrite .20

Plate 4 Downer Rd section

Base of Downer 8 ignimbrite

Plate 5 Base of Mamaku Ignimbrite at site 141

Base of Mamaku Ignimbrite at site 148 .22 


\section{Chapter 1 \\ INTRODUCTION}

\subsection{AIM OF STUDY}

The purpose of this study is to establish a chronology and stratigraphic framework for widespread Quaternary rhyolitic ignimbrites in the central North Island of New Zealand. These eruptive units are the major products of volcanism associated with the Taupo Volcanic Zone (TVZ). The ignimbrite plateaus and calderas are important geomorphic features, and eruptive units act as marker horizons in sedimentary sequences. Rhyolitic ignimbrites allow a variety of methods of characterisation, including geochemistry, paleomagnetism and radiometric dating. Their chronology has implications for the Quaternary history of the central North Island.

\subsection{GEOLOGIC SETTING OF THE TAUPO VOLCANIC ZONE}

Since the beginning of the Miocene, New Zealand has been located at a convergent plate boundary where the Pacific Plate is being subducted beneath the Australian Plate east of the North Island (Figure 1.1). The present day tectonic setting of the North Island consists of a forearc basin and accretionary wedge in the east coast region. The Tonga-Kermadec Arc continues south into the Bay of Plenty region, and is expressed as a chain of currently active andesitic volcanoes (Cole 1990). West of the andesite arc is a region of extension, high heat flow and geothermal activity where the Quaternary rhyolitic calderas are located.

The central North Island has been the site of voluminous rhyolitic caldera-forming eruptions as a result of back arc spreading. From 18 to $4 \mathrm{Ma}$, activity occurred mainly in the Coromandel area (Skinner 1986; Adams et al. 1994). Beginning at ca. 1.6 Ma (Houghton et al. 1995), the locus of rhyolitic volcanism shifted south to the Taupo-Rotorua area to produce the TVZ. From this zone, there has been at least 27 major (volume $>30 \mathrm{~km}^{3}$ ) ignimbrite-forming events from 8 calderas. The TVZ has also been the source of numerous small volume eruptions of intermediate composition along its eastern margin.

The scale of rhyolitic volcanism in the TVZ is comparable to the better known Yellowstone-Snake River Plain volcanic region (Christensen and Blank 1972). Eruptions in the TVZ in the last ca. 1.6 Ma have been smaller but more frequent than at Yellowstone, presumably due to a thinner crust and active extension in the central North Island (Wilson et al. 1984). Also unlike the Yellowstone region, caldera formation has occurred randomly throughout the length of the zone and younger vents are superimposed on older calderas, largely obscuring the pre-existing vents. In conjunction with tectonic uplift and erosional downcutting in the western part of the zone and normal faulting throughout the TVZ, the eruptive sequence is difficult to decipher. 


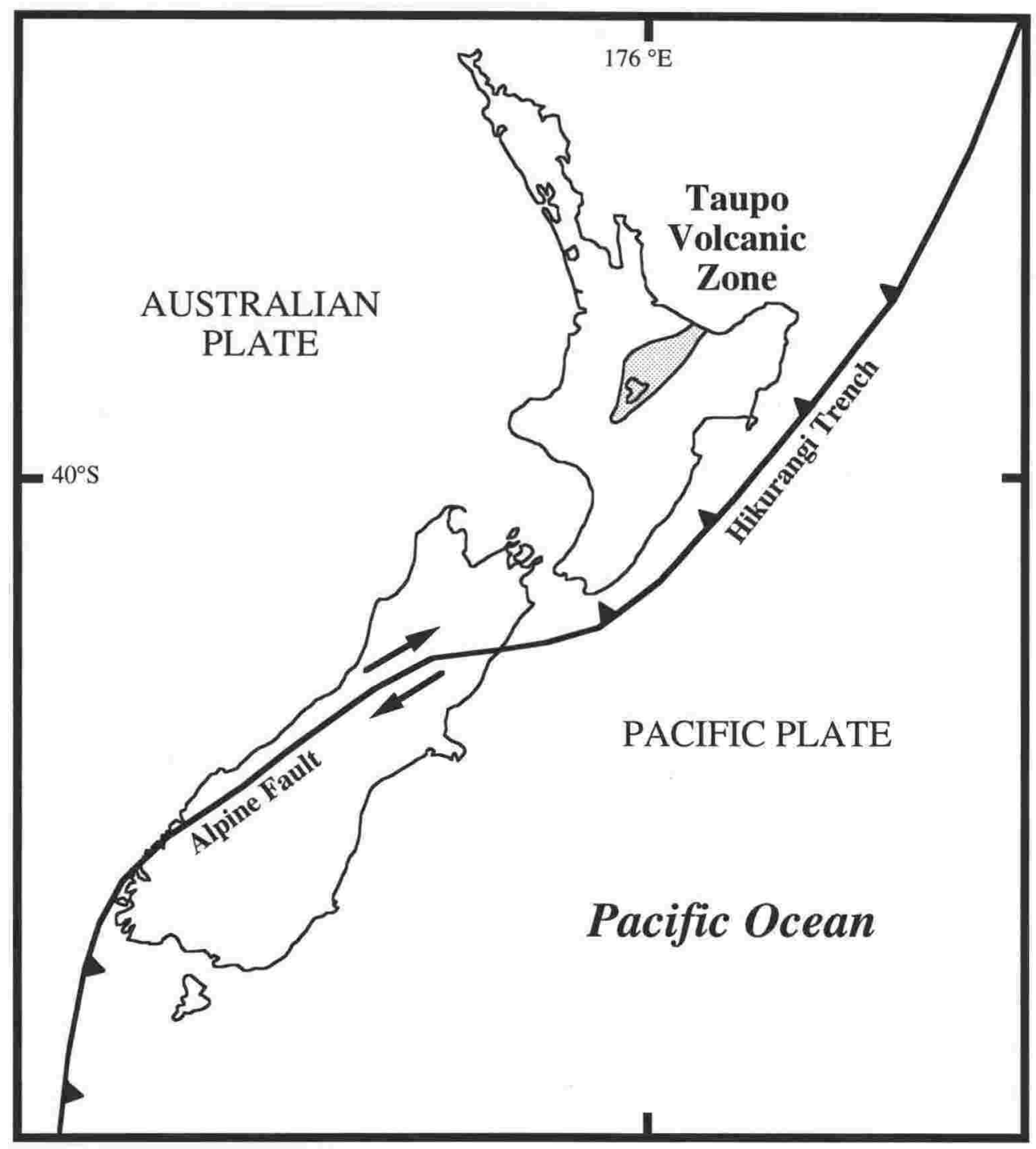

Figure 1.1 Map of New Zealand showing the plate boundary and location of the Taupo Volcanic Zone. 
Sedimentary basins surrounding the TVZ, in the east coast and Wanganui regions, record the distal tephra fallout and volcaniclastic sediment from the rhyolitic eruptions in marine and nonmarine sequences (Froggatt 1983; Shane 1991, 1994; Shane et al. 1995; Pillans et al. 1994). Records of this volcanism also occur in deep sea sediments in the oceans around New Zealand (Nelson et al. 1986).

\subsection{CHRONOLOGICAL AND CORRELATION STUDIES OF THE TAUPO VOLCANIC ZONE IGNIMBRITES}

The lack of exposures of long depositional sequences of early middle Pleistocene age in the TVZ due to erosion, burial and vegetation cover has largely hindered the field determination of the eruptive sequence for the ignimbrite sheets. Drill core studies have revealed long records of volcanism (e.g. Houghton et al. 1987), however correlation to surface exposures has not been demonstrated through geochemical or paleomagnetic data.

Early field mapping (e.g. Martin 1961) used sparse exposures, topographic positions and the extent of dissection of ignimbrites to propose eruptive sequences in the central and northern TVZ. This was relatively successful in the western margin of the region (e.g. Blank 1965), where older units are tectonically uplifted and dissected. Later field studies have greatly revised the sequence, due to the recognition of younger units within topographically low areas of older dissected units (Wilson et al. 1984; Wilson 1986). Determining the location and relative formation sequence of calderas is also problematic, due to the superposition of vents, and subsequent burial by younger deposits. Calderas have been inferred from lithological (Wilson et al. 1984; Wilson 1986), structural (Nairn et al. 1994), and geophysical (Rogan 1982) data. Recently, Lamarche and Froggatt (1993) used Anisotropy of Magnetic Susceptibility to determine flow directions and suggested a source location for the Whakamaru group ignimbrites.

The lack of reliable geochronological data beyond the range of ${ }^{14} \mathrm{C}$ has limited the numerical constraints on the timing of the volcanism. In an early study, Cox (1971) showed the potential to recognise individual eruptive units by their paleomagnetic secular variation record, and reported both reversed and normal polarity flows. This extended the known time range of activity back at least to the Matuyama Chron ( $>0.78 \mathrm{Ma}$ ). Early numerical chronology for the TVZ ignimbrites came from fission-track studies using glass (Kohn 1973) and zircon (Murphy and Seward 1981) which produced ages in the range 1.1 - 0.1 Ma. The recognition of partial track fading in glass and problems with calibration (e.g. Seward 1979) resulted in uncertainty in the ages. Soengkono et al. (1992) presented K-Ar data on bulk samples for older units in the western TVZ, extending the chronology back to ca. 1.6 Ma and showed the previous fission-track chronology had underestimated some ages. This is largely supported by Ar-Ar data presented by Houghton et al. (1995) on plagioclase mini-bulk samples from 17 different units. In spite of these recent chronological constraints, some units 


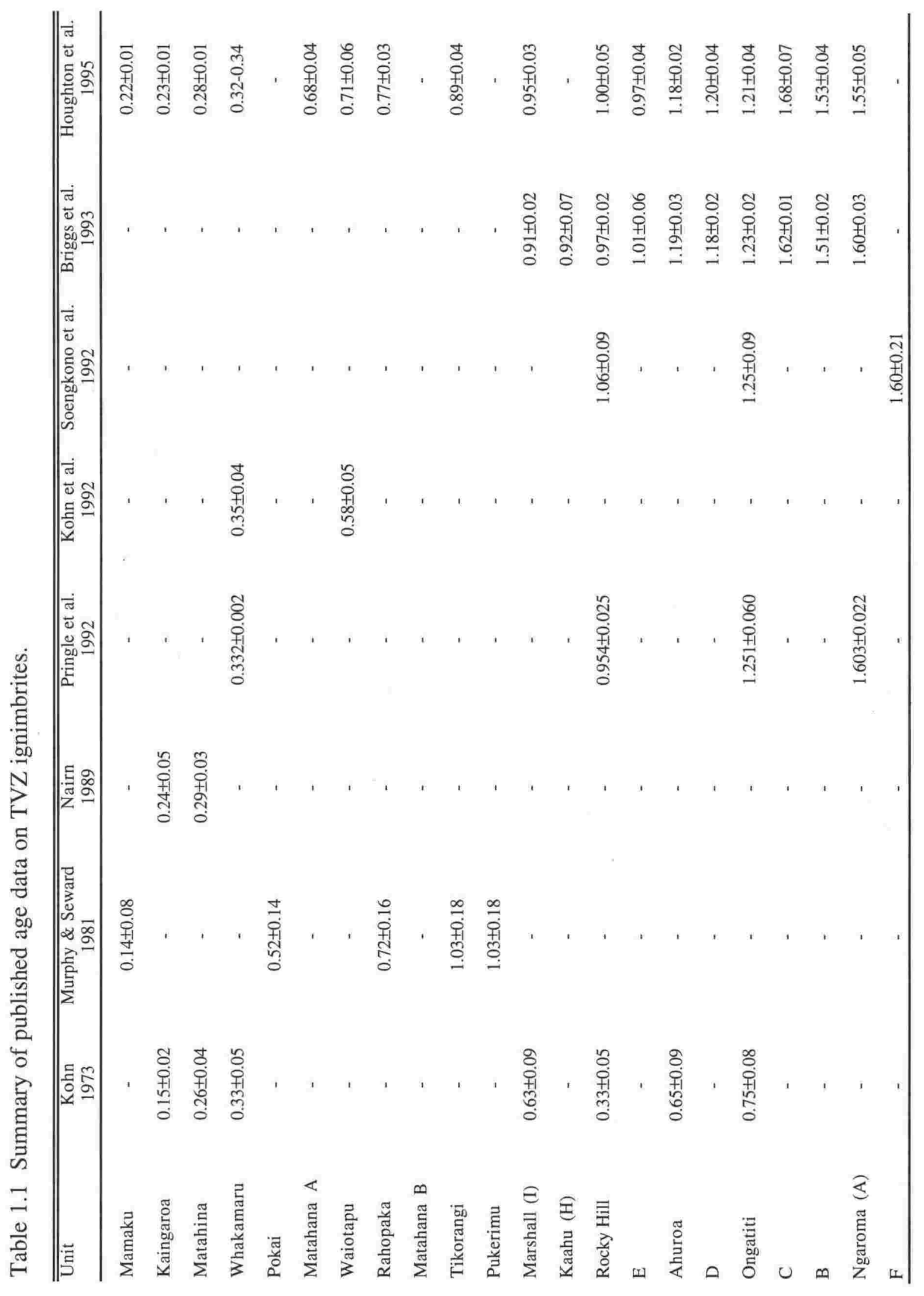


remain un-dated, and nearly all are reliably dated by only one technique and from one locality (Table 1.1). In addition, locality information was not presented for many of the ages determined. Similarly, little paleomagnetic data has been presented, and most units have not been sampled from multiple localities. As a result, correlation depends mainly on subtle lithological differences.

Few attempts have been made to chemically characterise the large ignimbrite units in the TVZ for correlation purposes, due to the pervasive welding and vapour-phase alteration found in the older units. Geochemical characterisation is important for correlation in studies linking proximal units to tephra in distal sequences, and Quaternary stratigraphy. Some success has resulted from glass analyses of nonwelded bases of the flow units (Froggatt et al. 1986), and from pumices and glasses in nonwelded flows (Froggatt 1982; Shane and Froggatt 1994). Other studies have concentrated on whole rock samples and whole pumice clasts from welded units (Briggs et al. 1993). However, these data can be affected by differing crystal contents and alteration states.

\subsection{OBJECTIVES OF THIS STUDY}

Four major objectives were identified for this study:

1. Characterise the paleomagnetic record of major rhyolitic ignimbrites from multiple sites. This involves determining the geomagnetic paleosecular variation recorded in the flows, and obtaining a magnetostratigraphy. Such studies can be useful to identify individual eruptive events as well as geomagnetic events such as excursions.

2. Geochemically fingerprint the major rhyolitic ignimbrites. This involves the use of titanomagnetite and glass chemistry, which can have implications for geochemical evolution as well as being a tool for correlation. Such data may also allow correlation to distal tephra beds outside the TVZ.

3. Investigate the flow directions in large ignimbrites using Anisotropy of Magnetic Susceptibility (AMS). Magnetic fabrics in these units may be indicative of source location.

4. Obtain radiometric ages of key eruptive events. The use of the isothermal plateau fissiontrack (ITPFT) method on glass (Westgate 1989) provides an opportunity to obtain high resolution ages on TVZ eruptives. These data would provide insight into the timing of volcanism and give a chronology for Quaternary events. 


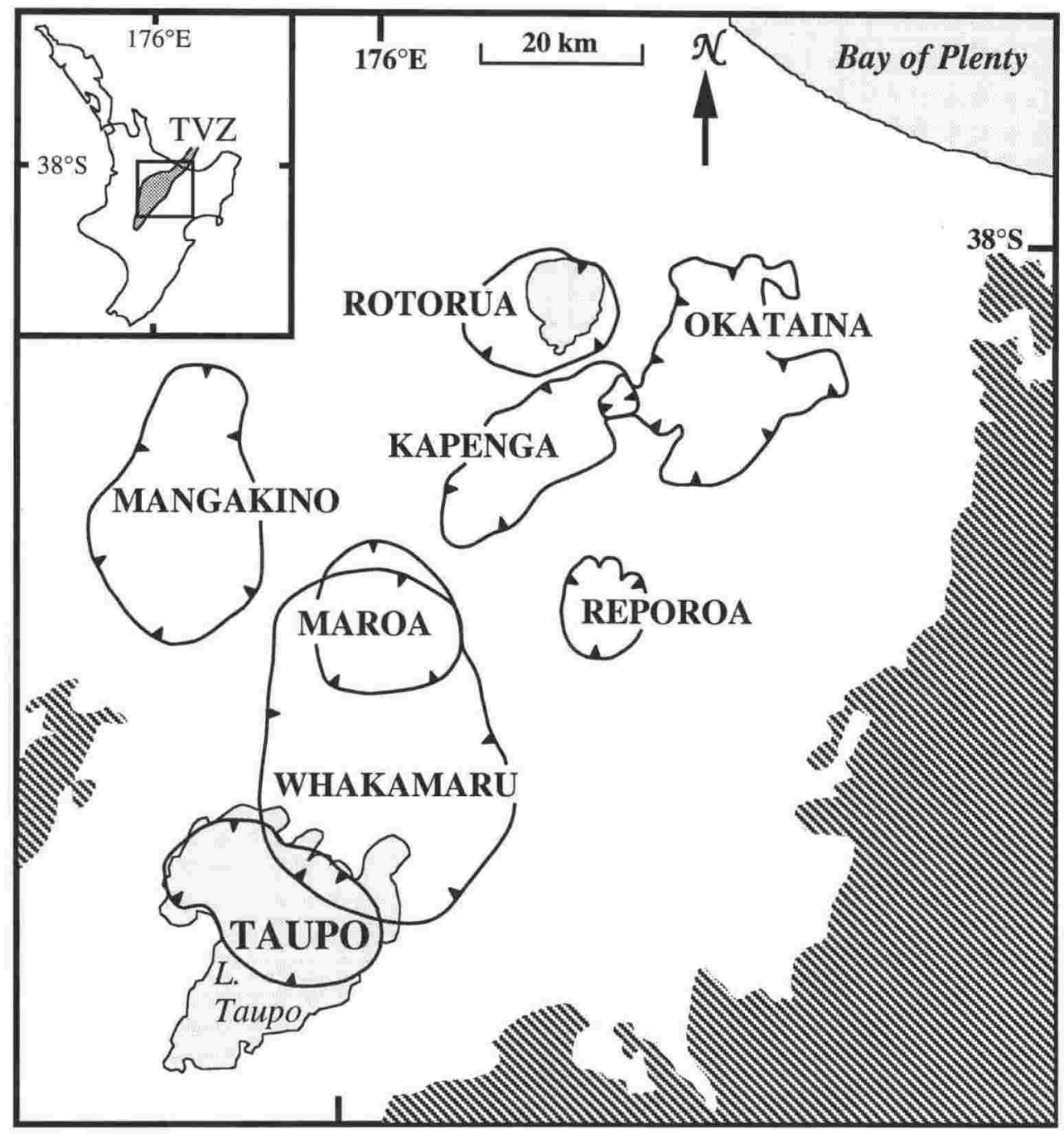

Figure 2.1 Location and names of major calderas in the TVZ inferred from mapping and geophysical data (Nairn et al. 1994). Striped pattern represents Mesozoic greywacke basement. 


\section{Chapter 2 \\ CALDERAS AND IGNIMBRITE STRATIGRAPHY}

\subsection{INTRODUCTION}

The TVZ is known to have been active for at least $1.6 \mathrm{Ma}$ (Houghton et al. 1995) and perhaps closer to $1.8 \mathrm{Ma}$, based on distal tephra records (Shane pers. comm. 1995). During this period, volcanic activity has been dominated by voluminous rhyolitic eruptions from large calderas, with minor andesite and basaltic volcanism. The Tongariro Volcanic Centre (Healy 1964) and the Tuhua Volcanic Centre (Froggatt and Lowe 1990) are intermediate in composition and not discussed here.

\subsection{MAJOR VOLCANIC CENTRES}

Eight major rhyolitic centres are recognised in the TVZ (e.g. Healy 1962; Cole 1979; Wilson et al. 1984, 1986; Nairn et al. 1994). They are defined from collapse structures and faulting, lag breccia deposits and geophysical anomalies (Figure 2.1). In many cases the caldera expression is not clearly revealed in the field, due to lack of exposure and burial by younger units. This section summarises the evidence and the definition of the major calderas in the TVZ. Localities discussed in the text are shown in Figure 2.2.

\subsubsection{Mangakino Caldera}

Mangakino was originally described by Blank (1965) and was inferred from grainsize and the distribution of ignimbrites from the western TVZ. A Bouguer gravity low was noted by Rogan (1982) and Stern (1986) but was assumed to represent a tectonic depression. Soengkono et al. (1992) interpreted the major negative anomaly to be caused by widespread reversely magnetised rocks infilling a $20 \times 30 \mathrm{~km}$ caldera, on the basis of low-altitude aeromagnetic data. Wilson et al. (1984) proposed the Mangakino Caldera as a major volcanic centre and the stratigraphy was presented in Wilson (1986). Briggs et al. (1993) presented geochemical data and ages that suggested the Mangakino Caldera was active from $1.60 \pm$ 0.03 to $0.91 \pm 0.02 \mathrm{Ma}$. These ages have since been revised to $1.68 \pm 0.07 \mathrm{Ma}$ and $0.95 \pm$ $0.03 \mathrm{Ma}$ (Houghton et al. 1995). Being the site of the earliest volcanism from the TVZ, the topographic expression has been infilled and largely obliterated by subsequent eruptions.

\subsubsection{Kapenga Caldera}

This structure was inferred by Rogan (1982) to be a caldera on the basis of geophysical evidence, as it possesses a $25 \mathrm{~km}$ diameter broad negative gravity anomaly with 


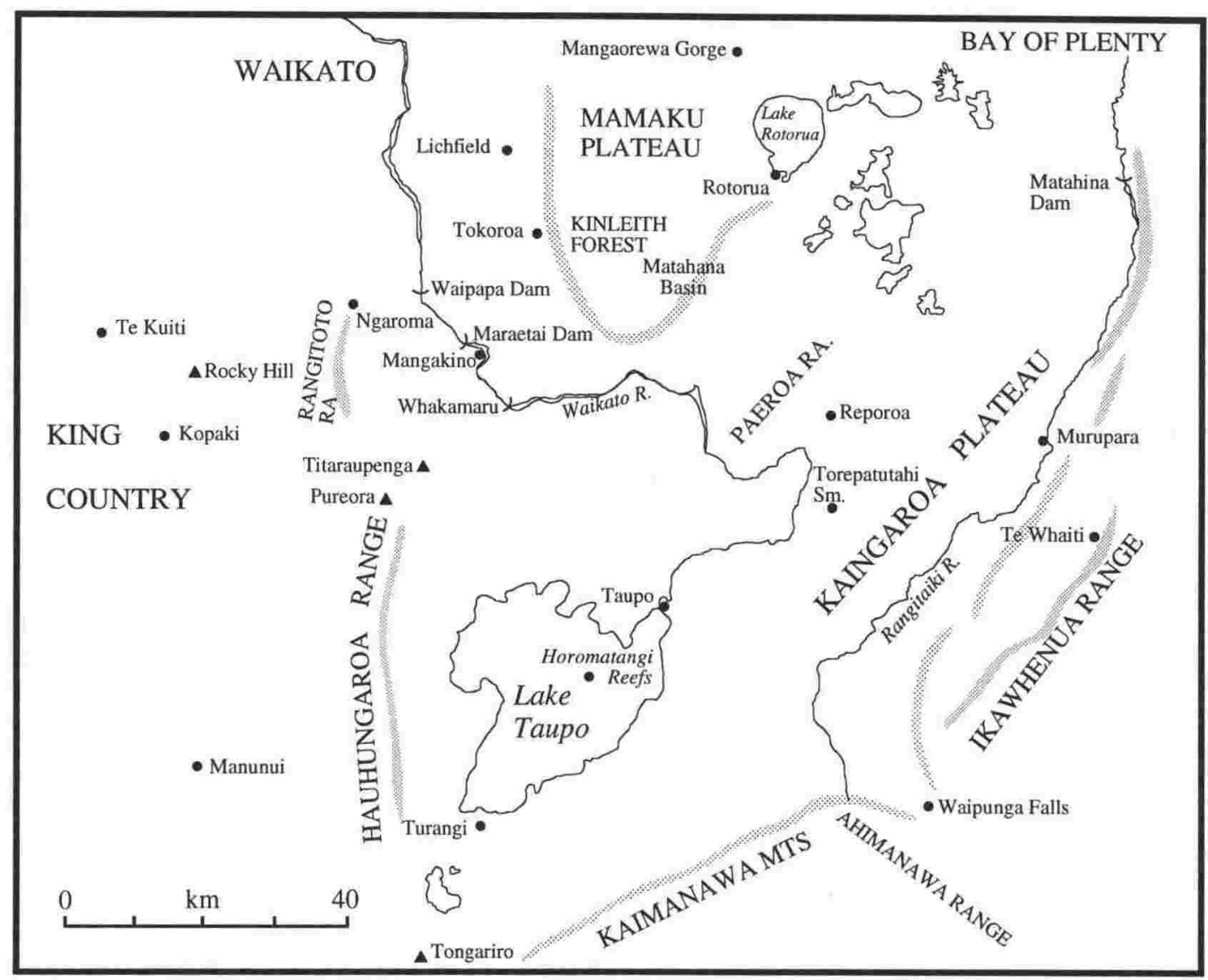

Figure 2.2 Map of central North Island showing localities mentioned in the text. 
2 centres. Wilson et al. (1984) suggested that the Waiotapu ignimbrite, some of the ignimbrites found in the Paeroa fault block (Martin 1961) and some reversely magnetised units exposed in the Matahana Basin (Murphy and Seward 1981) may have originated from the southern centre of the caldera. If this is the case, then this caldera may have been active alongside Mangakino. The northern centre has been proposed to be the source of the ca. $50 \mathrm{ka}$ Earthquake Flat tephra (Wilson et al. 1984; Froggatt and Lowe 1990).

\subsubsection{Whakamaru Caldera}

This caldera was first inferred by Wilson et al. (1986) as the site of the voluminous Whakamaru-group ignimbrites (332 \pm 2 ka, Pringle et al. 1992). Previously, the eruption site for these units had been assumed to be the Western Bay of Lake Taupo (e.g. Grindley 1960; Briggs 1976). A source north of Lake Taupo, in the Maroa area, would mean the deposits are more symmetrical around the proposed vent. Drill hole data suggest great thicknesses of ignimbrite, consistent with intracaldera facies, also occur in this area (Wilson et al. 1986). The Western Dome Belt with K-Ar ages of 287-314 ka (Houghton et al. 1991) on obsidian flow carapaces, and associated downfaulting defines the western edge of the caldera rim. Rhyolite domes southeast of Maroa may have been formed along the eastern margin. The south rim is masked by the later formation of the Taupo Caldera.

\subsubsection{Maroa Caldera}

A mildly negative geophysical anomaly defines the proposed caldera (Rogan 1982). Maroa was first thought to be a dome complex within the Mokai Ring Complex (Healy 1964), but later mapping showed 4 small ignimbrites to have been sourced there also (Wilson et al. 1984, 1986) i.e. the Ohakuri, Atiamuri, Orakonui and Pukeahua ignimbrites. No large ignimbrites appear to have erupted from this $25 \times 16 \mathrm{~km}$ caldera which is superimposed on the Whakamaru Caldera. Ignimbrite emplacement postdates the 332 ka Whakamaru ignimbrite and in turn is overlain by the distal Mokai member of the Mamaku Ignimbrite. At least 70 domes are aligned along NE trending faults, and small amounts of basalt reached the surface along the same features. Dome activity at Maroa mainly postdates the eruption of Mamaku, and ceased with the 15 ka eruption of Puketarata (Wilson et al. 1986).

\subsubsection{Okataina Caldera}

This caldera has a major negative gravity anomaly (Rogan 1982) associated with it and consists chiefly of the Haroharo Caldera. The Haroharo Caldera has been active since its formation by the eruption of the Matahina Ignimbrite (Bailey and Carr 1994). It is an elongated N-S trending depression $16 \times 28 \mathrm{~km}$ in dimension. The latest eruption to cause 
caldera collapse is the nonwelded Rotoiti tephra (Vucetich and Pullar 1969; Froggatt and Lowe 1990) whose age has been recently constrained to $64 \mathrm{ka}$ (Wilson et al. 1992). PostRotoiti activity has been confined to small rhyolitic plinian caldera-infilling eruptions, confined to fissures trending $050^{\circ} \mathrm{E}$ (Wilson et al. 1984).

\subsubsection{Reporoa Caldera}

Recently described by Nairn et al. (1994), this $15 \times 10 \mathrm{~km}$ caldera has been identified as the eruptive centre for the Kaingaroa ignimbrites. Previously, the Okataina Volcanic Centre had been assumed as the source of this unit (Healy et al. 1964; Nairn 1989). Scalloped collapse scarps were mapped by Nairn (1973) around the northern margins of the Reporoa Depression, and were believed to be the signs of a caldera, but this went unconfirmed since no large pyroclastic deposit was known to be associated with the area. The Reporoa Depression was previously considered to be a fault-angle depression between the Paeroa Block and Kaingaroa Fault scarp. More recently, sequences of thick lithic lag breccias have been mapped and described by Nairn et al. (1994) within the Kaingaroa ignimbrites exposed on the Kaingaroa Fault scarp, which defines the eastern margin of the Reporoa Depression. These deposits thin rapidly eastward, indicating a source within the basin. This, along with other geophysical and topographic evidence, confirms the existence of the Reporoa Caldera.

\subsubsection{Rotorua Caldera}

This caldera is a single-event collapse structure formed by the eruption of the Mamaku ignimbrite (Wilson et al. 1984). It is defined by a modest negative gravity anomaly (Rogan 1982) which corresponds to a $20 \mathrm{~km}$ diameter topographic depression, now infilled by Lake Rotorua. Dome formation occurred around the margin of the caldera after ignimbrite emplacement.

\subsubsection{Taupo Caldera}

Two major caldera-forming eruptions have occurred at this $15 \times 25 \mathrm{~km}$ centre. The voluminous Kawakawa Tephra Formation (22.5 ka, Froggatt and Lowe 1990) erupted from a vent within northern Lake Taupo (Wilson et al. 1986). A buried intrusive plug, inferred from magnetic data is the assumed vent location (Northey 1982; Wilson et al. 1984). Outcrops of co-ignimbrite lag breccia occur around the northern part of the lake, but the southern margin is poorly defined due to the absence of gravity data and the presence of the lake.

The Taupo Tephra Formation (1850 $10 \mathrm{ka}$, Froggatt and Lowe 1990, Wilson 1993) erupted from Horomatangi Reefs (Froggatt et al. 1981). Evidence for this includes topographic 


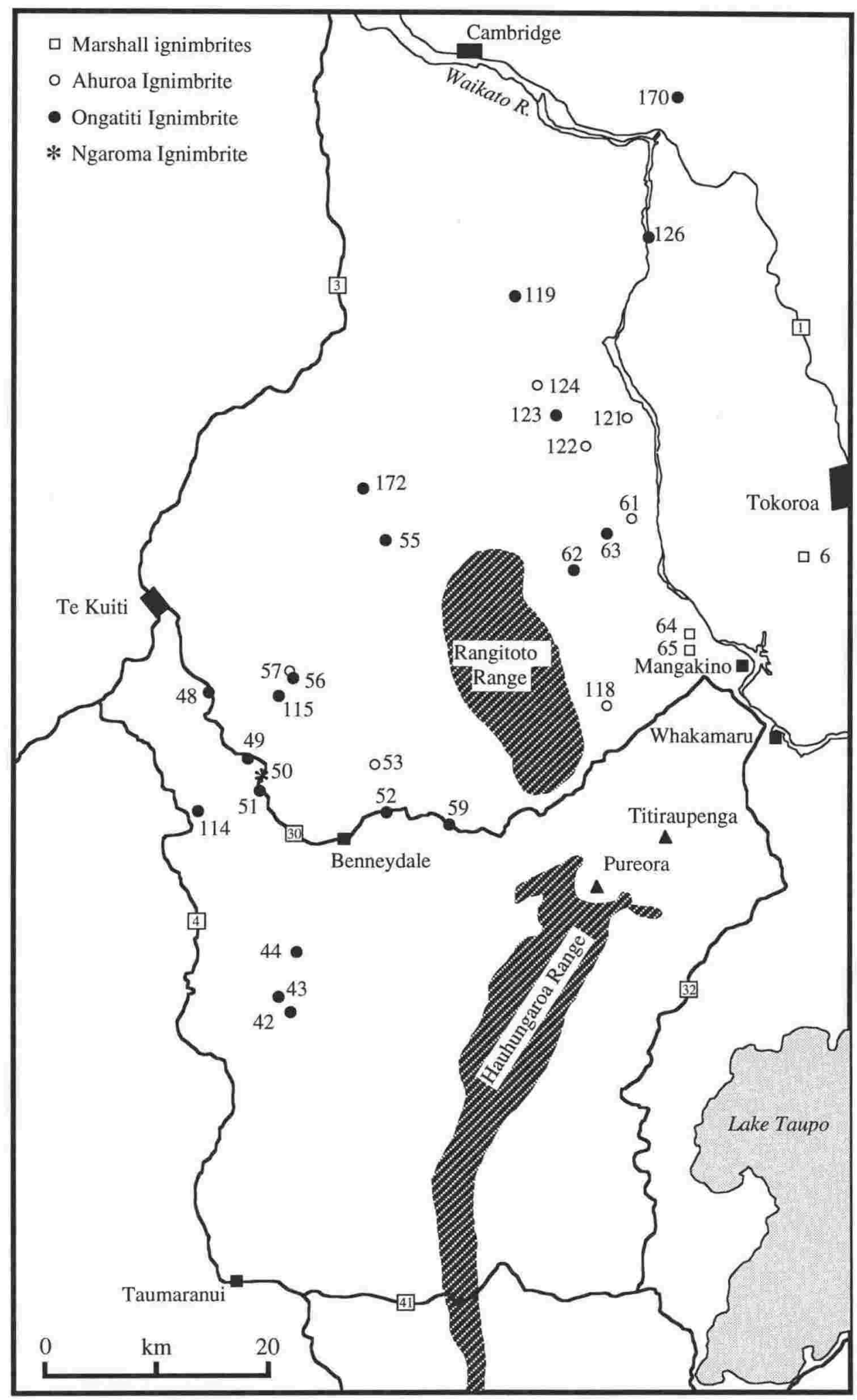

Figure 2.3 Map of the western margin of the TVZ and the King Country, showing ignimbrite sample localities examined in this study. Striped pattern represents Mesozoic greywacke ranges. 
expression, a radial distribution of logs contained within the Taupo ignimbrite, and isopach maps of the tephra, which place the greatest thickness in this area of the lake.

\subsection{IGNIMBRITES AND PYROCLASTIC UNITS EXAMINED IN THIS STUDY}

This section describes the major volcanic units examined in this study and in particular refers to key exposures of stratigraphic contacts. For many units, the stratigraphic contacts or sequence order are not clearly revealed in the field. A summary of geochronological data is also presented.

\subsubsection{Ngaroma Ignimbrite}

The Ngaroma Ignimbrite is the oldest widespread ignimbrite in the Mangakino area. Martin (1961) defined the type section as a quarry three quarters of a mile WNW of Ngaroma school. The ignimbrite was renamed the Ngaroma Lenticulite by Blank (1965), and renamed again by Wilson (1986) as Unit A. This study uses the name Ngaroma Ignimbrite as first defined by Martin (1961).

Exposures of Ngaroma Ignimbrite are scattered throughout the Mangakino area (Figure 2.3). The ignimbrite is characterised by pervasive alteration, due to vapour-phase activity, producing purple and orange colours. Pumices are flattened and sheared, and impart a eutaxitic texture to the ignimbrite commonly parallel to the depositional surface (Wilson 1986). Both pumices and matrix are crystal poor. Sparse fine phenocrysts of plagioclase are present, along with trace hornblende and hypersthene. Many Fe-Ti oxide crystals have been altered, yielding weak paleomagnetic remanence directions (Chapter 3).

The Ongatiti Ignimbrite occurs stratigraphically above Ngaroma, exposed in a road cut on Chindie Road, north of Tauraroa (site 55, S16/198218). Along Highway 30, north of Kopaki (site 50, S17/092993) the nonwelded base of Ngaroma is exposed. Here, $\sim 10 \mathrm{~m}$ of welded ignimbrite is underlain by $1.5 \mathrm{~m}$ of nonwelded flow containing bedded white/purple streaked pumices. The Ngaroma Ignimbrite has been ${ }^{40} \mathrm{Ar} /{ }^{39} \mathrm{Ar}$ dated by Houghton et al. (1995) at 1.55 $\pm 0.05 \mathrm{Ma}$.

\subsubsection{Ongatiti Ignimbrite}

This voluminous ignimbrite forms extensive deposits west of the Hauhungaroa Range and extends into the Waikato region where it is mined as a building stone under the name Hinuera stone (Figure 2.3). It commonly overlies greywacke, Tertiary mudstone and sparse exposures of older ignimbrites such as Ngaroma. Ongatiti forms part of the Pakamanau Group of Kear (1960) and was first described as a separate unit by Martin (1961). The type locality 
is at Rocky Hill, in the road cut above the Ongatiti stream. There it underlies the Ahuroa Ignimbrite. At other exposures (e.g. site 53, S17/189022) Unit D overlies Ongatiti Ignimbrite.

Exposures of the unit are commonly cream coloured and fine grained. Welding is variable, ranging from weakly to densely welded. Some outcrops contain large pumices within the flow unit, such as at site 55 (S16/198218). Ongatiti Ignimbrite is crystal rich (commonly $25 \%$ ) and phenocryst phases present include plagioclase, quartz, hypersthene, hornblende, Fe-Ti oxides and trace zircon. The nonwelded base was examined at two localities. At S17/092993 on Highway 30, Ongatiti overlies Tertiary mudstone with a steeply dipping depositional contact. Here, the ignimbrite contains large pumices, rip-up clasts of the underlying mudstone and crystalline lithics. The $\sim 30 \mathrm{~cm}$ nonwelded base has been altered to clay and the mudstone directly below has been baked to a red colour (Plate 1). Along the Waimiha-Ongarue road (S17/098843,) a $\sim 20 \mathrm{~cm}$ fine glassy nonwelded base of Ongatiti Ignimbrite is exposed resting on a red paleosol developed into Tertiary mudstone.

Martin (1961) suggested a vent for the Ongatiti Ignimbrite, located near Pureora. Blank (1965) used variations in size and abundance of phenocrysts and lithics, degree of welding and amount of flattening to conclude that the source of the Ongatiti Ignimbrite was located SE of the Rangitoto Range and E or NE of the Hauhungaroa Range (Figure 2.2).

A glass fission-track age of $0.75 \pm 0.08 \mathrm{Ma}$ was determined by Kohn (1973) and on that basis the ignimbrite was correlated to a deep sea ash layer occurring below the BrunhesMatuyama transition. ${ }^{40} \mathrm{Ar} /{ }^{39} \mathrm{Ar}$ data from Houghton et al. (1995) gives an age of $1.21 \pm 0.04$ Ma, consistent with the magnetostratigraphy, which places Ongatiti within the Lower Matuyama Reversed Chron (Tanaka et al. 1991). A glass ITPFT age of $1.25 \pm 0.12$ Ma has also been determined (Shane, pers comm 1995).

\subsubsection{Unit $D$}

First described by Wilson (1986), Unit D occurs between Ongatiti and Ahuroa ignimbrites at site 53 (S17/189022) and is poorly exposed elsewhere (Figure 2.3). It consists of a fallout unit $0.5-1 \mathrm{~m}$ thick, over which a $\sim 4 \mathrm{~m}$ nonwelded ignimbrite has flowed. The fallout is well bedded and poorly sorted, with pumice-rich beds. Unit D ignimbrite is fine grained, cream coloured, and contains small pumices up to $3 \mathrm{~cm}$ in size. Its nonwelded nature is indicative of a phreatomagmatic origin, similar to the Oruanui Ignimbrite (Wilson 1986). The phenocryst assemblage is notable for its absence of quartz, however plagioclase, hypersthene, hornblende, FeTi oxides and zircon are all present.

Unit D fallout rests on a paleosol developed on top of the Ongatiti Ignimbrite at site 53. Wilson (1986) reports a paleosol developed on Unit D, which was not observed in this study. Houghton et al. (1995) report a ${ }^{40} \mathrm{Ar} /{ }^{39} \mathrm{Ar}$ age of $1.20 \pm 0.04$ Ma for Unit D. 


\subsubsection{Ahuroa Ignimbrite}

Ahuroa Ignimbrite overlies Unit D at site 53 (S17/189022). The deposit displays inverse thermal zonation, being intensely welded at the top and characterised by crazed fractures. Ahuroa Ignimbrite forms a veneer deposit, draping paleotopography (e.g. at site 118, T17/403077) suggesting it was emplaced energetically (Wilson 1986). Dark brown and orange pumices are found throughout the unit.

A single source has been inferred by Wilson (1986) for the three sheets which form the compound cooling unit, based on maximum clast sizes and variations in welding intensity. Its distribution in the northern part of the King Country (Figure 2.3), and the exclusive presence of rhyolite lava lithics indicates Ahuroa probably erupted from a different location than Ongatiti (Wilson 1986).

A glass fission-track age of $0.65 \pm 0.09 \mathrm{Ma}$ was determined by Kohn (1973). This has recently been revised to $1.18 \pm 0.02 \mathrm{Ma}\left({ }^{40} \mathrm{Ar} /{ }^{39} \mathrm{Ar}\right.$, Houghton et al. 1995). Paleomagnetic studies (Tanaka et al. 1991, this study) have shown that Ahuroa displays an anomalous paleomagnetic pole direction. The new age would suggest that the Ahuroa Ignimbrite was erupted in the Cobb Mountain subchron.

\subsubsection{Rocky Hill Ignimbrite}

Rocky Hill Ignimbrite is a widespread, but poorly exposed unit in the King Country which overlies Ahuroa Ignimbrite. Originally defined by Martin (1961), its type section is at Rocky Hill (S16/117107). There it consists of blocks of welded, pumice-rich ignimbrite which are not insitu.. A sequence of tephra beds and nonwelded ignimbrite is present between Ahuroa and Rocky Hill ignimbrites at the type locality, which are possibly correlative to Unit E of Wilson (1986).

Soengkono et al. (1992) presented a K-Ar age of $1.06 \pm 0.09$ Ma for Rocky Hill Ignimbrite. Pringle et al. (1992) and Houghton et al. (1995) have reported ${ }^{40} \mathrm{Ar} /{ }^{39} \mathrm{Ar}$ ages of $0.95 \pm 0.03$ and $1.00 \pm 0.05 \mathrm{Ma}$, respectively.

\subsubsection{Marshall ignimbrites}

Martin (1961) defined the type locality of the Marshall ignimbrites as N84/210970 in the valley north from Marshall's Lookout. It was described as consisting of 4 pumice rich ignimbrite members of differing degrees of welding and compaction (Martin 1961). Later investigations assumed other exposures of similar appearance were correlatives. Cox (1971) sampled 'Marshall Ignimbrite' from a small quarry near Lichfield (Figure 2.2) for paleomagnetic analysis and the specimens were found to have normal polarity. The exposure 


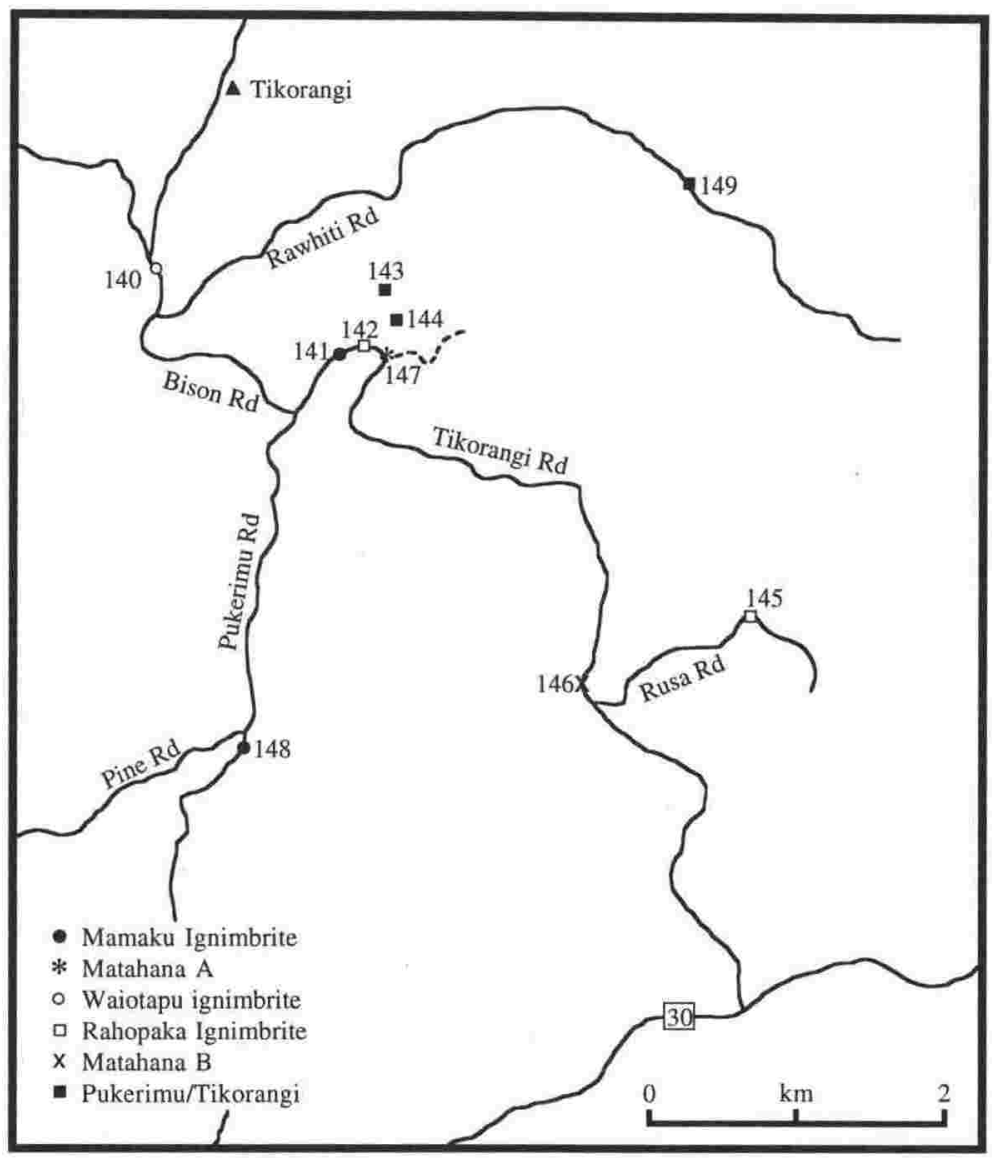

Figure 2.4 Map showing the location of ignimbrite sample sites within the Matahana Basin, Kinleith Forest. 
was resampled in this study (site 128, T16/588398) and it is now considered that the unit Cox (1971) sampled is Whakamaru Ignimbrite.

A glass fission-track age of $0.63 \pm 0.09$ Ma was determined by Kohn (1973) on an exposure near Waipapa (Figure 2.2), now considered by Wilson (1986) to be Ahuroa Ignimbrite.

Murphy and Seward (1981) correlated a pumice rich ignimbrite found in the Matahana Basin with Marshall, and determined a zircon fission-track age of $0.52 \pm 0.14 \mathrm{Ma}$. This ignimbrite is now considered to be a different, younger unit called the Pokai Ignimbrite (B. F. Houghton, pers. comm. 1995).

Wilson (1986) redefined Marshall Ignimbrites as consisting of 3 separate and unrelated ignimbrites ( $\mathrm{G}, \mathrm{H}$ and $\mathrm{I}$ ), pre-Whakamaru ignimbrite in age, and considered them to have been erupted shortly after cessation of activity at Mangakino, further east. Ignimbrite I has a ${ }^{40} \mathrm{Ar} /{ }^{39} \mathrm{Ar}$ age of $0.95 \pm 0.03 \mathrm{Ma}$ (Houghton et al 1995). Ignimbrite $\mathrm{H}$ has been renamed the Kaahu Ignimbrite, with a ${ }^{40} \mathrm{Ar} /{ }^{39} \mathrm{Ar}$ age of $0.92 \pm 0.07 \mathrm{Ma}$ (Briggs et al. 1993).

\subsubsection{Pukerimu / Tikorangi ignimbrite}

The Pukerimu/Tikorangi ignimbrite is a compound cooling unit exposed in the Matahana Basin (Figure 2.4). Murphy and Seward (1981) described the two members as separate ignimbrites. The Pukerimu Ignimbrite is at the base of the sequence. The base is obscured, and welding decreases from highly welded near the base to partly welded at the top. The ignimbrite is highly altered to an orange colour and contains orange and white pumices. Tikorangi Ignimbrite overlies Pukerimu with a gradational contact. Tikorangi is a dark grey moderately welded ignimbrite containing black pumices and fiamme at the densely welded base. The Pukerimu/Tikorangi ignimbrite is generally crystal poor, with plagioclase, hypersthene, hornblende, FeTi oxides and lacking quartz. Murphy and Seward (1981) report Ca-poor clinopyroxene in the Tikorangi Ignimbrite and quartz in the upper third of the flow.

Paleomagnetic data collected by Murphy and Seward (1981) indicated that Pukerimu and Tikorangi are both reversely magnetised with identical paleomagnetic pole directions. From this, and field evidence that they form a compound cooling unit, Murphy and Seward (1981) concluded they should be identical in age. A zircon fission-track age of $1.03 \pm 0.18 \mathrm{Ma}$ was determined on the Tikorangi ignimbrite by Murphy and Seward (1981). Houghton et al. (1995) have determined a ${ }^{40} \mathrm{Ar} /{ }^{39} \mathrm{Ar}$ age of $0.89 \pm 0.04 \mathrm{Ma}$ for the Tikorangi Ignimbrite.

\subsubsection{Rahopaka Ignimbrite}

The Rahopaka Ignimbrite is described by Murphy and Seward (1981) as a moderately to densely welded grey brown ignimbrite. It is exposed in several places in the Matahana Basin and the type section has been defined as a $300 \mathrm{~m}$ roadside section extending east from 


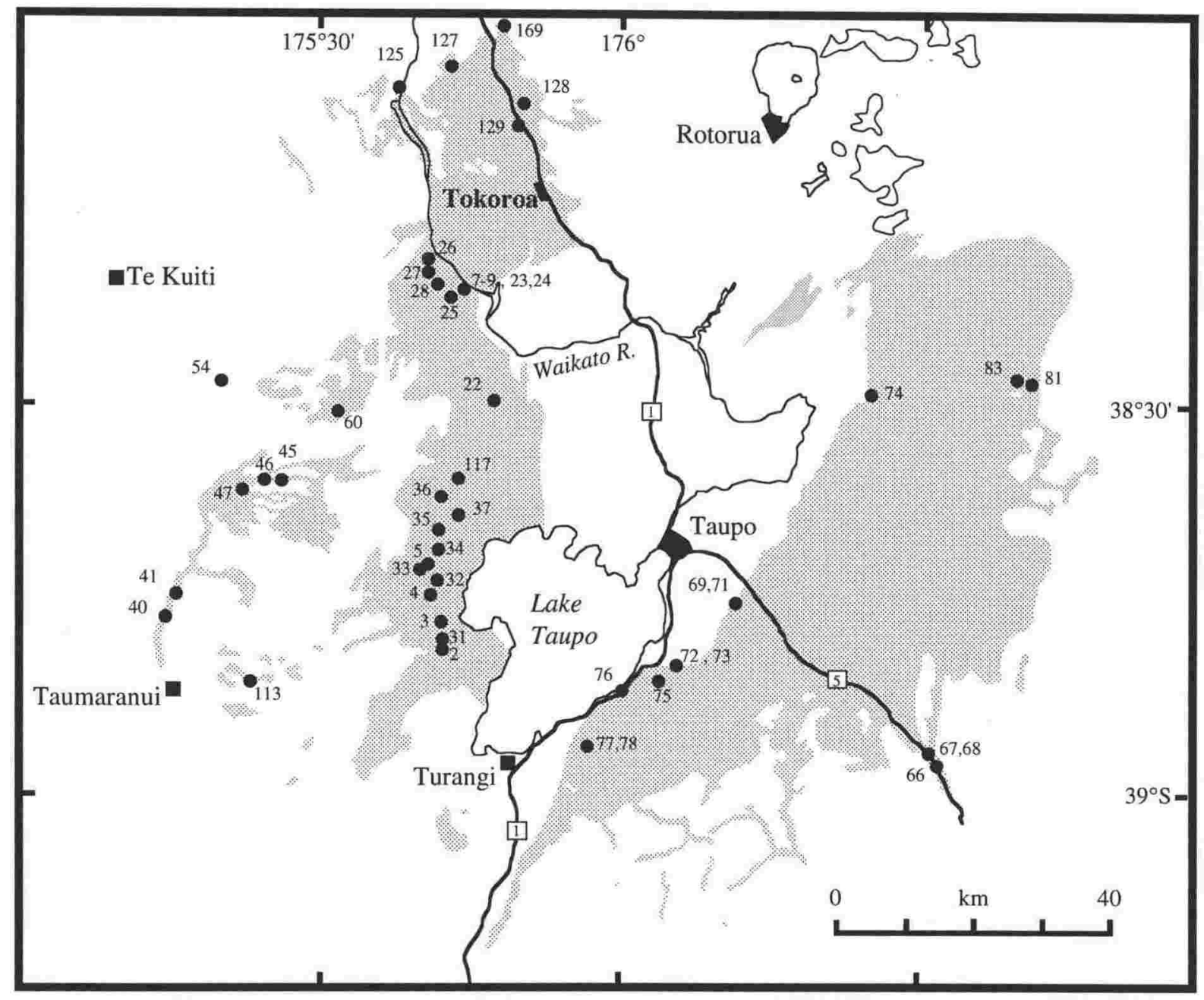

Figure 2.5 Map showing the distribution of Whakamaru group ignimbrites (stippled area, from Wilson et al. 1986) and location of sample sites. 
the Pukerimu-Tikorangi Roads junction at N85/546873 to 550874 which translates into NZMS 260 U16/788205 (Fig 2.4). The Rahopaka Ignimbrite is crystal rich and contains plagioclase, quartz, hornblende, FeTi oxides and hypersthene. The abundance of large phenocrysts of hornblende is a characteristic feature of the deposit.

Paleomagnetic analysis yielded a reversed magnetic polarity for 2 sites of Rahopaka Ignimbrite (Murphy and Seward 1981; Chapter 3, this study). This is in contrast to Baksi et al. (1991) who report that the 'Rahopeka' Ignimbrite has a normal magnetic polarity. Murphy and Seward (1981) report a zircon fission-track age of $0.72 \pm 0.16$ Ma for Rahopaka. Houghton et al. (1995) report an unpublished zircon fission-track age of $0.72 \pm 0.05 \mathrm{Ma}$ determined by B. P. Kohn, and a ${ }^{40} \mathrm{Ar} /{ }^{39} \mathrm{Ar}$ age of $0.77 \pm 0.03 \mathrm{Ma}$ for 'Rahopeka Ignimbrite'.

\subsubsection{Whakamaru group ignimbrites}

The Whakamaru group (Wilson et al. 1986) is a complex set of eruptions, producing widespread crystal-rich, densely welded ignimbrites (Figure 2.5). They have been mapped as several different units, on the basis of geographic location and eruption style.

The term 'Whakamaru Ignimbrites' was first used by Hatherton (1954) to describe and correlate a series of ignimbrite exposures at Whakamaru, Waipapa and Maraetai dam sites, north of Lake Taupo. Maraetai Gorge was named by Healy (in Fleming 1959) as the type section for the Whakamaru Ignimbrite. It is characterised by a coarse phenocryst mineralogy including quartz, plagioclase, hypersthene, hornblende, biotite, sanidine and magnetite. The base is densely welded, with a pumice rich vapour phase alteration zone at the top. Martin (1961) considered the Whakamaru ignimbrites to have erupted from a source to the south of Maraetai Gorge, due to the abundance and size of phenocrysts.

Near Maraetai dam, the ignimbrite thins over a paleohigh and its nonwelded base is exposed on Waipapa road (site 25, T16/464134). Whakamaru Ignimbrite is in contact with a red-baked Marshall ignimbrite at this location. The base varies in thickness from 10 to $50 \mathrm{~cm}$ and is a coarse mineral rich white ash which grades into creamy, moderately welded ignimbrite with dark grey lenticules.

The Manunui ignimbrite(s) was first named by Martin (1961) who considered it to be a similar age and appearance to Whakamaru, possibly a fine grained lateral equivalent. Manunui forms pumice poor veneer and valley fill deposits in the west of the TVZ.

Grindley (1960) described the Te Whaiti ignimbrites outcropping over greywacke in the northeastern Kaingaroa Plateau, infilling valleys in the Kaimanawa, Ahimanawa and Ikawhenua Ranges. The type locality for the Te Whaiti ignimbrites is at Waipunga Falls, and the nonwelded base has been exposed on the Napier-Taupo Road nearby (V19/149443). The ignimbrite is densely welded and fine grained. The $20-30 \mathrm{~cm}$ base is coarse, crystal rich and deposited on a wedge of greywacke colluvium up to $1 \mathrm{~m}$ thick (Plate 2). 
The Rangitaiki ignimbrites were originally named and mapped in the eastern TVZ by L. R. Allen in an unpublished Geological Survey report. Martin (1961) reports a type locality (suggested by Grindley) at Torepatutahi Stream, near Reporoa. The unit is extremely coarse grained with large quartz phenocrysts and the upper part of the flow is pumiceous.

All four ignimbrite units were assumed to have erupted separately between ca. 330$230 \mathrm{ka}$ (Wilson et al. 1986). These authors argue that Manunui and Whakamaru are separate events, with the finer grained and more eroded Manunui being more violently emplaced than the crystal and pumice-rich Whakamaru, which was erupted up to 50-100 ka later. A similar interpretation was used for the Te Whaiti and Rangitaiki ignimbrites on the eastern side of the TVZ.

Cox (1971) measured paleomagnetic remanence directions on Manunui, Te Whaiti and Rangitaiki ignimbrites and noted that the pole directions were all statistically the same, and similar to the pole for Whakamaru, obtained by Hatherton (1954). He concluded that any discontinuities seen in the field must only represent several centuries or less. Recent ${ }^{40} \mathrm{Ar} /{ }^{39} \mathrm{Ar}$ ages on the Whakamaru group by Pringle et al. (1992) suggest that they were all erupted in less than $50 \mathrm{ka}$, and perhaps in a single event at $332 \pm 2 \mathrm{ka}$ which is consistent with the paleomagnetic data (Chapter 3).

The Paeroa, Te Kopia and Te Weta ignimbrites exposed on the Paeroa Range are a similar age to the Whakamaru group ignimbrites. These units were assumed to have erupted from separate vents by Keall (1988) who obtained K/Ar ages of $0.37 \pm 0.03 \mathrm{Ma}$ (sanidine) and $0.39 \pm 0.06 \mathrm{Ma}$ (biotite) for the Paeroa ignimbrite, and an age of $0.39 \pm 0.04 \mathrm{Ma}$ (sanidine) for a sample of Whakamaru. The upper and middle Te Kopia ignimbrites display a NRM pole position identical to the Whakamaru group (Cox 1969, Chapter 3), but the Lower Te Kopia and Paeroa ignimbrites plot in more easterly directions (Keall 1988). The Te Kopia ignimbrites were not considered by Keall (1988) as Whakamaru group correlatives on the basis of a previous age estimate of ca. $570 \mathrm{ka}$ (fission-track on glass, Kohn 1973). The Paeroa ignimbrites erupted at a similar time to the Whakamaru group, and Wilson et al. (1986) suggested they may be related. The differing NRM measurement of Paeroa, determined by Keall (1988), may be due to mis-orientation of a field block that was subsequently cored at VUW for analysis. The Paeroa Range Group have now been included in the Whakamaru group ignimbrites on the basis of new ${ }^{40} \mathrm{Ar} /{ }^{39} \mathrm{Ar}$ ages (Pringle et al. 1992, Houghton et al, 1995).

Kohn et al. (1992) produced a weighted mean of $0.35 \pm 0.04$ Ma from zircon fissiontrack ages for various members of the Whakamaru group and the associated widespread fallout tephra, Rangitawa Tephra. 


\subsubsection{Bonisch Pyroclastics}

A $\sim 3 \mathrm{~m}$ thick sequence of lapilli and ash occurs between the Whakamaru and Matahina ignimbrites in a roadcut on Highway 83 near Murupara (site 83, V17/307993). At least 3 well developed paleosols, and several other more weakly developed, occur between pumice-rich lapilli shower beds (Plate 3). The Bonisch Pyroclastics have been described by Nairn (in press).

The ignimbrite at the base of the section (site 81) is the Murupara member of the $\mathrm{Te}$ Whaiti ignimbrite (Healy et al. 1964), and confirmed to be part of the Whakamaru group through paleomagnetic analysis (Chapter 3). At this outcrop it is soft, vapour phase altered and contains small pumices. The basal contact of the Bonisch Pyroclastics is obscured.

A strongly developed paleosol caps the pyroclastic sequence, and is overlain by up to $40 \mathrm{~cm}$ of pumice lapilli, interpreted to be the plinian phase of the Matahina eruption (Plate 3). At least $10 \mathrm{~m}$ of Matahina Ignimbrite is exposed at the top of the section, with a coarse vitric ash at the base and grading into welded material at the top.

\subsubsection{Downer Road section}

A section on Downer Road in the Kinleith Forest (T16/646336 top - 646338 base) preserves a $6.7 \mathrm{~m}$ sequence of ash and lapilli between two ignimbrites (Plate 4). Six paleosols are developed on top of several of these units, which are characterised by rhythmic shower bedding and grading. The soft, vapour phase altered top of the basal ignimbrite has a $\sim 40 \mathrm{~cm}$ paleosol developed on top. It has a coarse phenocryst mineralogy including quartz, plagioclase and hornblende. Large pumices (up to $20 \mathrm{~cm}$ ) are throughout the unit, also containing large phenocrysts. This unit is correlated to the Whakamaru group ignimbrite on the basis of lithology.

A nonwelded base is preserved underneath a welded ignimbrite capping the section. It consists of 10-20 cm of fine white ash (+ pumice and lithics) overlying a deeply weathered paleosol with a sharp irregular contact. The ash grades quickly into coarser, grey, lightly welded ignimbrite (Plate 4). This unit is likely to be the Chimpanzee ignimbrite (C. J. N. Wilson, pers. comm.) exposed throughout the Kinleith Forest. The Chimpanzee ignimbrite has not been documented in the literature, but its age is inferred to be between that of Whakamaru and Matahina ignimbrites (Houghton et al. 1995). This unit is informally referred to as the Downer 8 ignimbrite in this study.

\subsubsection{Matahina Ignimbrite}

Erupted from the Haroharo Caldera in the Okataina Volcanic Centre, the Matahina Ignimbrite is widespread in the eastern TVZ. A proposed type locality is at Matahina dam 


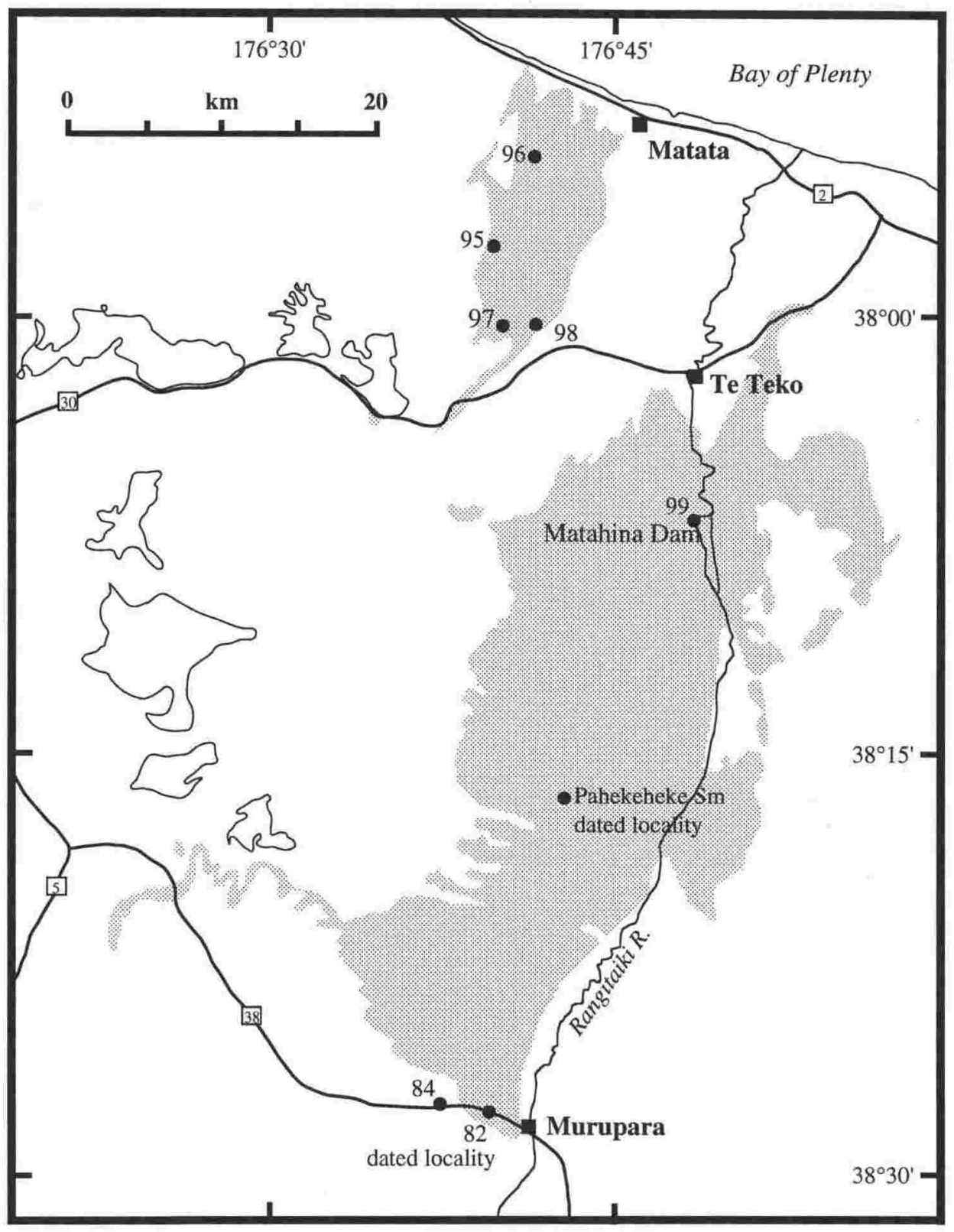

Figure 2.6 Map showing the outcrop distribution of Matahina Ignimbrite (stippled area, from Bailey and Carr 1994) and location of sample sites. 
(Martin 1961), where the ignimbrite is ponded into a thickness of ca. $140 \mathrm{~m}$ and highly welded. Bailey and Carr (1994) describe the volcanological aspects of the Matahina eruption and divided the ignimbrite into 3 flow members. Cooling and compaction modelling estimated that the time interval between flow pulses was 20 - 60 days (Bailey and Carr 1994).

A systematic eastward decrease in the size of lithics from the middle member of the ignimbrite points toward a western source, the Haroharo Caldera. Exposures of the ignimbrite around the caldera are limited to the northeast, east, southeast and scattered remnants to the southwest (Figure 2.6). The ignimbrite may not have been deposited in the western sectors around the Haroharo Caldera (Bailey and Carr 1994).

The Matahina Ignimbrite overlies the Whakamaru group ignimbrites on the Kaingaroa Plateau. The base of Matahina is exposed at a section near Murupara (site 83, V17/307993) where nonwelded basal ash overlies $40 \mathrm{~cm}$ of shower bedded plinian fallout (Plate 3 ). This in turn overlies a sequence of pyroclastics deposited on top of the Te Whaiti member of the Whakamaru group (see above for description of sequence). Overlying Matahina are the Kaingaroa ignimbrites, deposited on the western part of the Kaingaroa Plateau.

A fission-track age of $0.26 \pm 0.04 \mathrm{Ma}$ was determined on glass from the Matahina Ignimbrite (Kohn 1973). A zircon fission-track age of $0.29 \pm 0.03$ Ma was determined by B. P. Kohn (Nairn 1989; Nairn and Beanland 1989), and quoted as $0.28 \pm 0.03 \mathrm{Ma}$ in Bailey and Carr (1994) and Houghton et al. (1995). This older age is in accord with a ${ }^{40} \mathrm{Ar} /{ }^{39} \mathrm{Ar}$ age of $0.28 \pm 0.01 \mathrm{Ma}$ on feldspar by Houghton et al. (1995).

\subsubsection{Kaingaroa ignimbrites}

The Kaingaroa ignimbrites have recently been identified as the products of the newly named Reporoa Caldera (Figure 2.7). They consist of 2 major members $k g_{1}$ and $k g_{2}$, and a poorly exposed smaller sheet $k g_{0}$ with a restricted distribution close to the Kaingaroa scarp (Nairn et al. 1994). $k g_{0}$ is nonwelded, grey/brown and up to $40 \mathrm{~m}$ thick near source (Nairn et al. 1994). $k g_{1}$ is partly welded in places, black with a sandy matrix, whereas the top sheet $\left(k g_{2}\right)$ is a densely welded grey lenticulite. Both sheets are often 20-30 m thick. Andesite lithics are absent in the underlying pyroclastic surge and fallout deposits, but are throughout the ignimbrite flow sheets. Crystal contents are low (less than 10\%) and are composed of fine plagioclase, hypersthene, FeTi oxides and rare quartz.

Lithic lag breccias overlie $k g_{0}$ and are interbedded within the lower part of $k g_{1}$. Most lithics observed in Kaingaroa are andesite, but a higher diversity of lithic types in $\mathrm{kg}_{1}$ and $\mathrm{kg}_{2}$ indicates vent widening and caldera collapse occurred after the deposition of $\mathrm{kg}_{0}$ (Nairn et al. 1994).

An unpublished zircon fission-track age by B. P. Kohn on $k g_{1}$ has been variously quoted as $0.24 \pm 0.05 \mathrm{Ma}$ (Nairn 1989; Nairn et al. 1994) and $0.23 \pm 0.04 \mathrm{Ma}$ (Houghton et al. 1995). A ${ }^{40} \mathrm{Ar} /{ }^{39} \mathrm{Ar}$ of $0.23 \pm 0.01 \mathrm{Ma}$ was obtained by Houghton et al. (1995) 


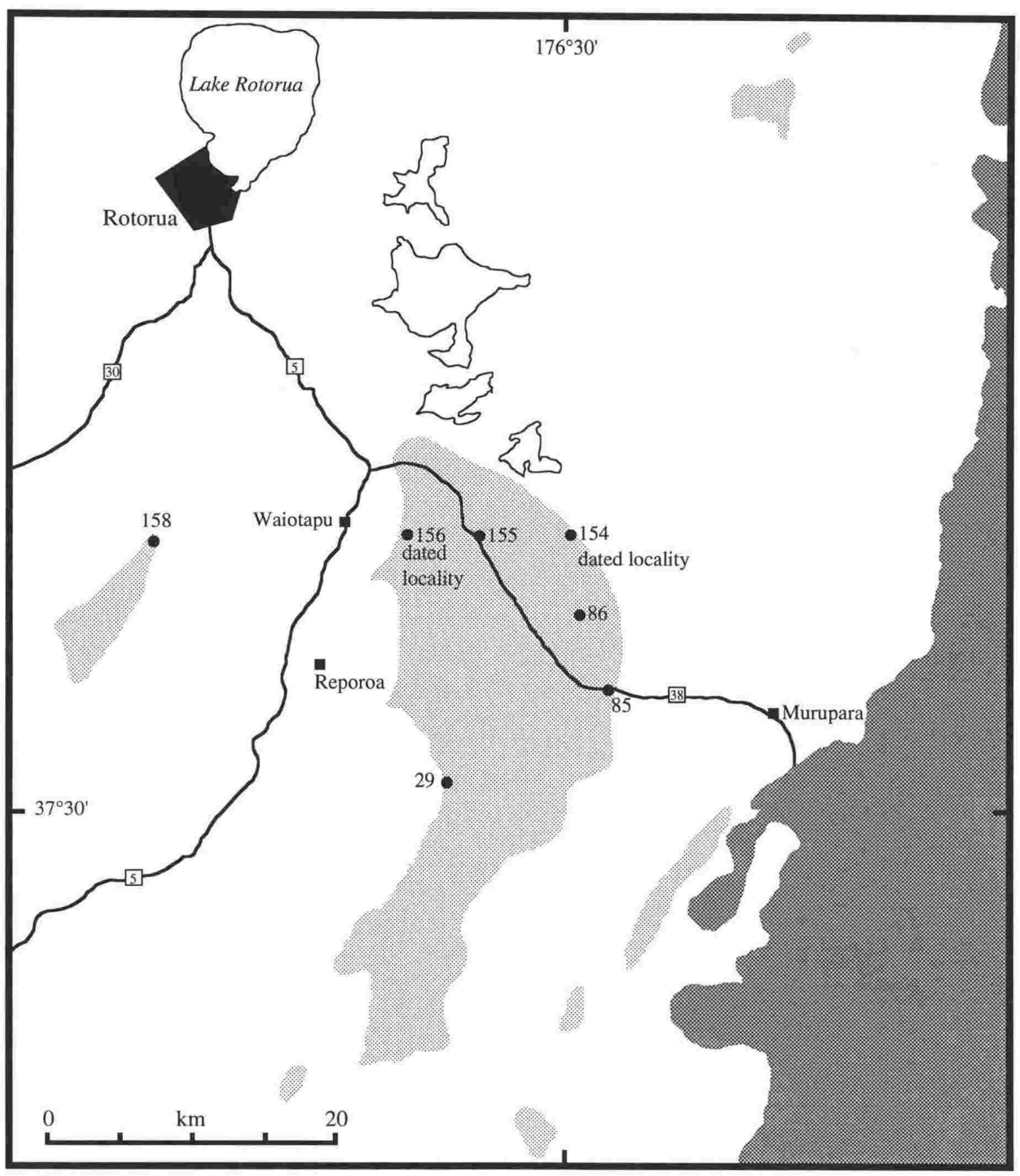

Figure 2.7 Map showing the outcrop distribution of Kaingaroa ignimbrites (stippled area, from Nairn et al. 1994) and location of sample sites. Dark pattern indicates Mesozoic greywacke ranges. 


\subsubsection{Mamaku Ignimbrite}

The Mamaku Ignimbrite is the youngest of the large welded ignimbrite sheets from the TVZ. It forms a large plateau to the west of Lake Rotorua, with isolated remnants still preserved to the southwest near Lake Taupo (Figure 2.8). Exposures of the ignimbrite generally consist of vapour phase altered glass shards and small pumices, considered to be near the top of the flow. The type locality is a thick section exposed in the gorge of the Mangaorewa Stream at the junction with Tauranga Direct Road (U15/887552-883556). Here, a thickness of over $100 \mathrm{~m}$ of densely welded Mamaku Ignimbrite grades into a soft pink/purple vapour phase altered top.

The $\sim 1 \mathrm{~m}$ thick, poorly sorted nonwelded base is exposed in the Matahana Basin (Figures 2.2, 2.4) at site 141 at the junction of Tikorangi and Pukerimu roads (sample B12, U16/784204) and site 148 along Pukerimu Road, $100 \mathrm{~m}$ south of the intersection with Pine Road (sample B21, U16/777178). Site 141 displays the base resting on a section containing sands and conglomerates which in turn overlie the Pokai ignimbrite. Here, the glass has undergone partial alteration to clay. At site 148, the glass is vitric and fresh and rests on a paleosol developed on Pokai ignimbrite. The phenocryst assemblage is plagioclase, quartz, hypersthene, and FeTi oxide.

Cox (1971) reported a normal polarity for the Mamaku Ignimbrite, and from the pole direction concluded that it erupted at different time than the Matahina or Kaingaroa ignimbrites. An anomalous pole position was obtained by Tanaka et al. (1991) for Mamaku, and tentatively assigned to the Blake Event on the basis of a zircon fission-track age of 0.14 $\pm 0.08 \mathrm{Ma}$ (Murphy and Seward 1981). An ITPFT age of $0.23 \pm 0.01 \mathrm{Ma}$ from site 148 (Shane et al. 1994; Chapters 6,7) indicate an older age for this unit, and a ${ }^{40} \mathrm{Ar} /{ }^{39} \mathrm{Ar}$ age of $0.22 \pm 0.01$ $\mathrm{Ma}$ (Houghton et al. 1995) is in agreement.

\subsubsection{Oruanui Ignimbrite}

The Oruanui Ignimbrite is a voluminous nonwelded ignimbrite that represents the pyroclastic flow portion of the Kawakawa Tephra Formation (Froggatt and Lowe 1990; Figure 2.9). It was erupted, forming the Taupo Caldera at $22.59 \pm 0.23 \mathrm{ka}\left({ }^{14} \mathrm{C}\right.$, Wilson et al. 1988).

Wilson et al. (1986) describe 4 phases in the eruption sequence. Phase 1 and 2 consist chiefly of plinian and phreatomagmatic fallout. Phase 3 consists of the bulk of the high energy pyroclastic flows, with the coarser lithic rich phase 4 ignimbrite found in low-lying areas. Caldera collapse probably occurred at the onset of phase 4 , implied by the presence of a coignimbrite lag breccia and a larger proportion of lithics (Wilson et al. 1986). Oruanui Ignimbrite (= phase 3$)$ is completely nonwelded, pink in colour, and contains small pumices (< $1 \mathrm{~cm})$. 


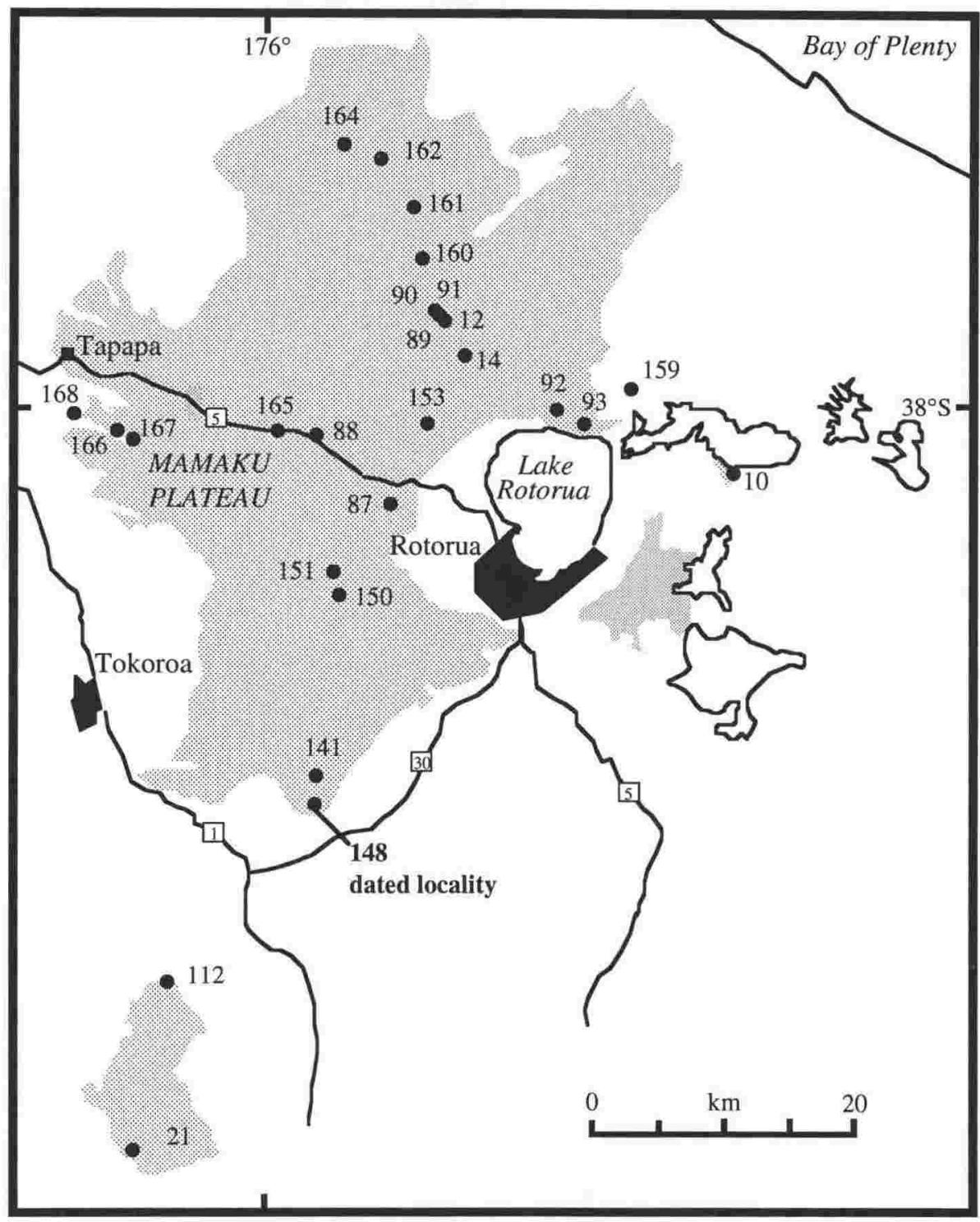

Figure 2.8 Map showing the outcrop distribution of Mamaku Ignimbrite (stippled area) and location of sample sites. 


\subsection{DISCUSSION OF IGNIMBRITE CORRELATION TECHNIQUES}

In order to locate a source vent for an eruption or series of eruptions, it is necessary to identify the deposits that were produced. Some basis has to be established upon which a particular unit can be positively identified. The topographic constraints and patchy preservation of many TVZ ignimbrites has meant that a method has had to be established that would allow outcrop-to-outcrop correlation over a wide area. Several mutually supportive lines of evidence should be used in correlating individual ignimbrites.

Methods commonly used for correlation of ignimbrites have been summarised in Hildreth and Mahood (1985) where they divide the criteria for correlation into 5 groups:

\subsubsection{Lithological}

Colour, number of cooling units, basal surge or plinian fallout, degree of welding or jointing and weathering characteristics as well as the presence and type of lithics and pumices can be a useful initial approach. However, all these features can be highly variable within a single sheet. Welding and cooling vary greatly with distance from source and topography in the central volcanic region of New Zealand. Generally, welding intensity decreases with distance from source and the deposits become finer grained, better sorted and lose their distinguishing lithics and pumices. Ignimbrite sheets from the same eruptive episode may erupt at different velocities and/or flow to different areas, thereby forming different types of deposits. These may differ in colour and contain varying assemblages of pumices and lithics. Caution must therefore be used as lithologically distinct units may have erupted from essentially the same vent, geologically instantaneously.

\subsubsection{Petrographic-mineralogical}

Total phenocryst content, size and relative proportions of phenocryst species and composition of matrix are all intrinsic properties of an erupting magma and can be useful for correlation. Mechanical sorting of phenocrysts into crystal-rich zones within a pyroclastic flow, pre-eruptive crystal fractionation, and net loss of crystals with increased distance from source can all contribute to observed variation within a single flow unit. Selective weathering or dissolution of some species may also take place, e.g. hypersthene weathers more quickly than hornblende. In the TVZ, eruptives from different rhyolitic centres have similar mineral assemblages. Some ignimbrites contain large quartz phenocrysts, such as Whakamaru. Mafic assemblages are more distinct than the total phenocryst content. Biotite is present in a third of TVZ rhyolitic eruptions, and cummingtonite is distinctive of the Haroharo caldera in the Okataina complex. 


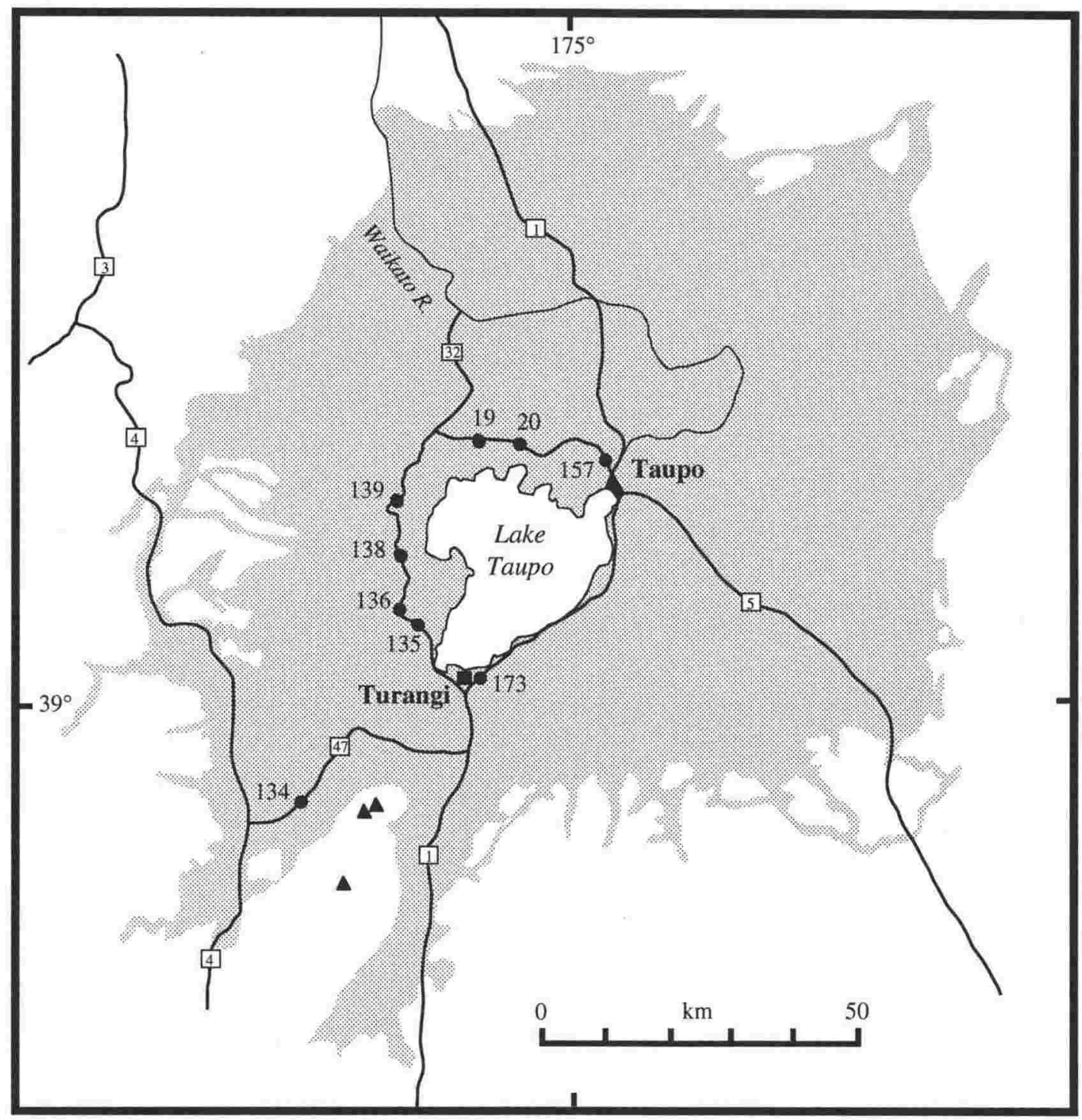

Figure 2.9 Map showing the outcrop distribution of Oruanui Ignimbrite (stippled area, from Wilson 1991) and location of sample sites. 


\subsubsection{Chemical}

Attempts to characterise and correlate ignimbrites have used bulk rock analyses, phenocryst and glass chemistry. Analysis of bulk rock samples is not recommended, due to contamination from xenoliths and xenocrysts, differing concentrations of phenocrysts, zoning of the magma chamber and post depositional alteration of the ignimbrite e.g. welding and devitrification, resulting in mobility of elements (Froggatt 1992). Single pumices or fiamme are recommended by Hildreth and Mahood (1985) but problems are even encountered with these due to vapour phase alteration of the glass (Chapter 4).

Phenocryst chemistry from microprobe analysis can often be inconclusive, due to individual phenocryst zoning and the broad range of compositions encountered in a single unit, especially if from a zoned magma chamber. Titanomagnetite and ilmenite compositions are sensitive to eruption temperature and can be very useful in correlation, but often become exsolved during welding or devitrification.

Electron microprobe analysis of glass shards, or trace elements by INAA, XRF or Laser Ablation ICPMS have been successful in correlating fallout deposits and distal tephra (Sarna-Wojcicki and Davis 1991) This technique is applicable to proximal deposits associated with ignimbrites if unaltered glass is available such as in nonwelded flows, nonwelded bases, basal plinian fallout and surge. Alteration and contamination can be detected since microprobe is grain specific.

\subsubsection{Isotopic}

In cratonic provinces, isotope ratios of $\mathrm{H}, \mathrm{O}, \mathrm{Ar}, \mathrm{Sr}, \mathrm{Nd}$ and $\mathrm{Pb}$ can be very diagnostic and are less susceptible to eruptive fractionation and mixing. However devitrification, vapourphase alteration and secondary alteration can all produce isotopic fractionation and contamination. Also, often the ratios are simply not discriminatory enough, especially in non cratonic settings like New Zealand.

Isotopic ages are becoming widely used a correlation tools. Most popular methods are $\mathrm{K} / \mathrm{Ar}$ and ${ }^{40} \mathrm{Ar} /{ }^{39} \mathrm{Ar}$ as the errors are commonly $1-3 \%$, but care has to be taken to prepare uncontaminated samples for bulk analyses. Also, Ar loss or extraneous Ar can affect ages. Single crystal laser fusion ${ }^{40} \mathrm{Ar} /{ }^{39} \mathrm{Ar}$ on sanidine produces the most reliable ages. Fissiontrack ages are also used, zircon and glass being the most popular dating materials. Some ignimbrites lack sufficient zircon to date and unaltered glass is necessary for this method, which generally has less resolution (5-10\%) than the Ar methods, however contamination is detectable. Precise ages are required for correlation purposes as errors can be close to the recurrence interval of the volcanic field. Similar aged units can also erupt from different centres, so chemical data are also required to prove a correlation. 


\subsubsection{Magnetic}

The determination of an instantaneous paleomagnetic pole position can be very useful in proving non-correlation of units as well as correlation. Ignimbrites that have a stable TRM will provide accurate paleomagnetic directions. Identical remanence directions can be found for composite, multiflow distal-proximal units which shows that the time between emplacement events was short and can confirm correlations between units of different field appearance. Over longer time periods an ignimbrite field may be able to be correlated to the geomagnetic time scale, with some units erupting at times of different polarity. A flow that records a transitional direction or an excursion is especially distinctive (Shane et al. 1994).

Sometimes post-depositional alteration decreases the magnetic stability and results in overprinting which can be difficult to remove. This may cloud the magnetic signal and produce erroneous results. Tilting and deformation in tectonically active areas should also be compensated for. 


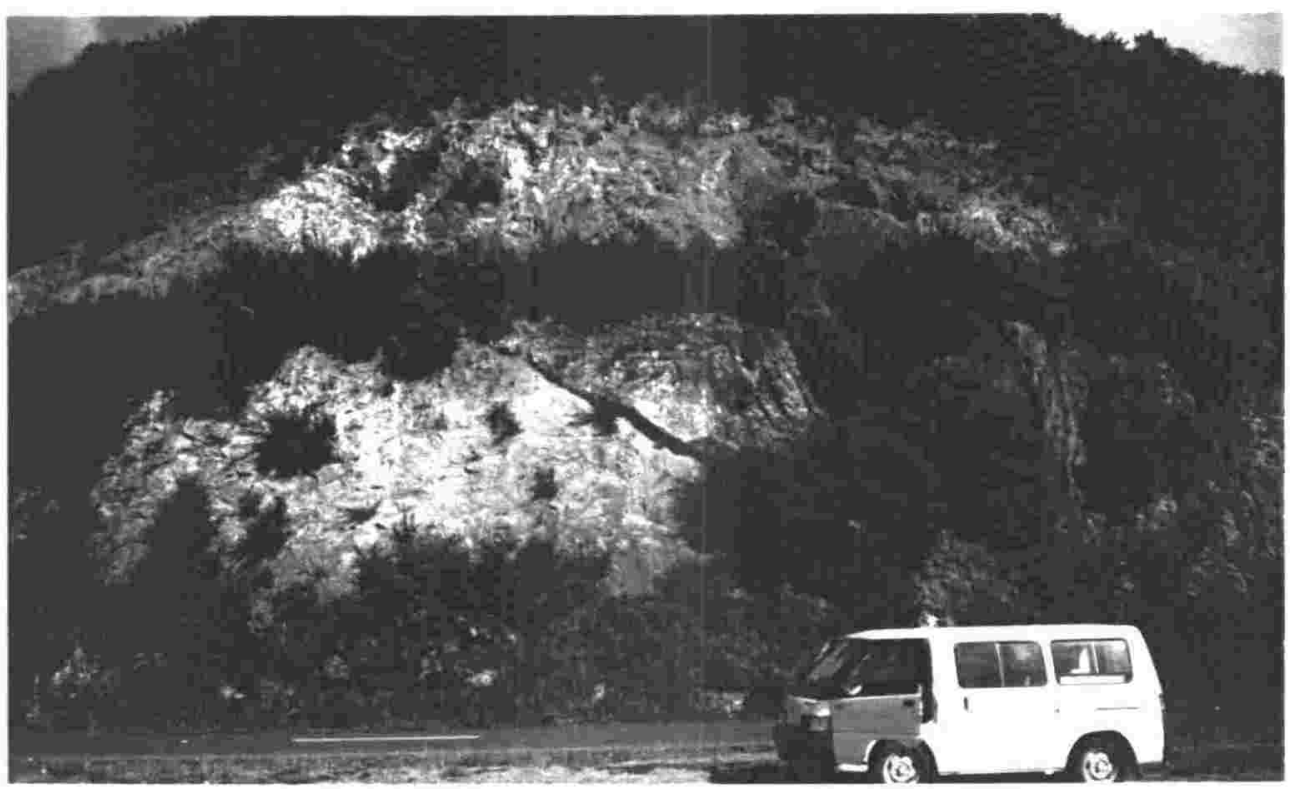

Plate 1 Ongatiti Ignimbrite overlying mudstone with a steeply dipping depositional contact, exposed along Highway 30 (S17/092993) in the King Country.
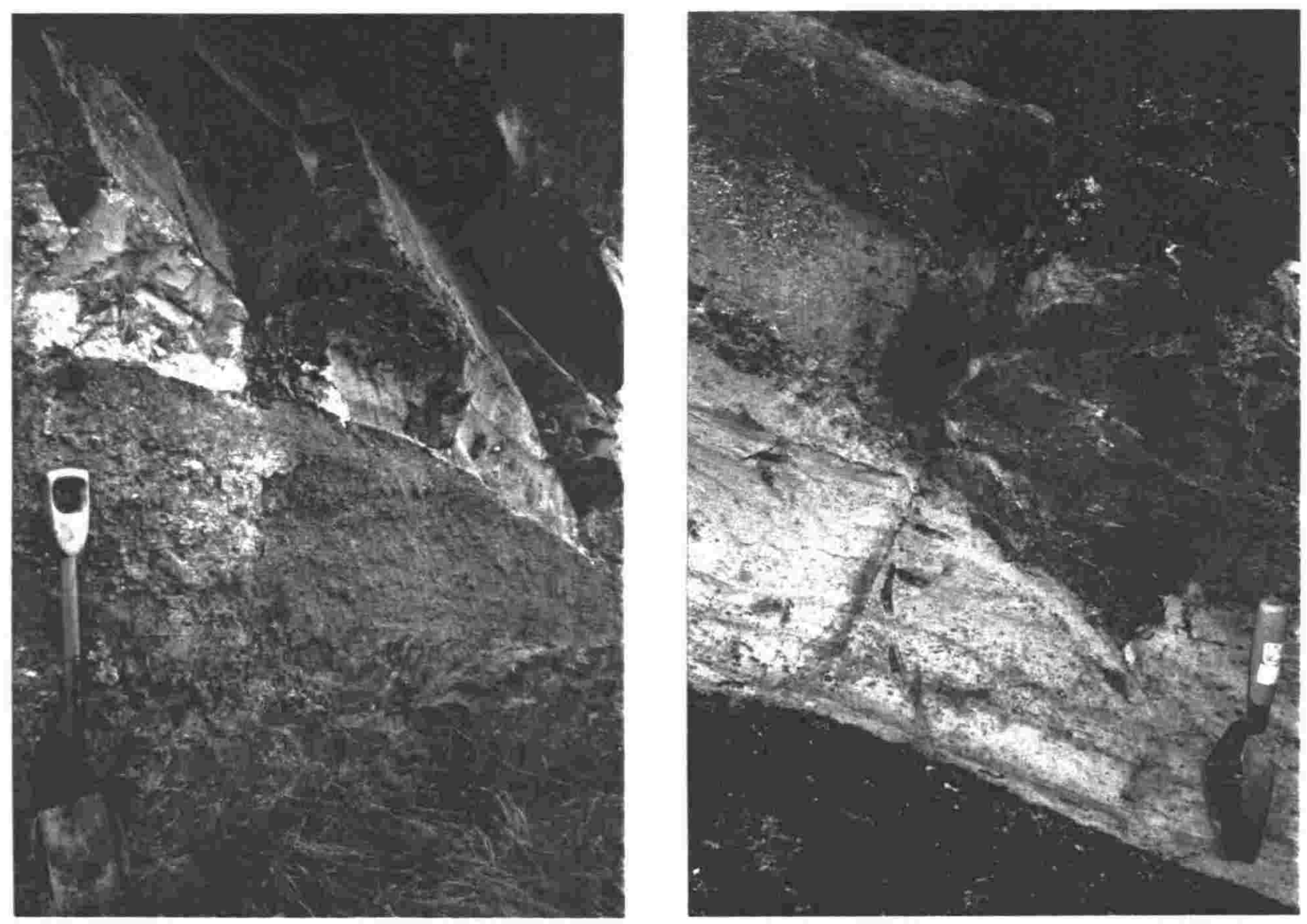

Plate 2 The nonwelded base (creamy white) of the Te Whaiti member of the Whakamaru group ignimbrites, exposed in a roadcut on the Napier-Taupo Road near Waipunga Falls (V19/149443). (left) Ignimbrite overlies a wedge of colluvium. (right) Close-up of nonwelded base, which grades rapidly into the densely welded phase. 

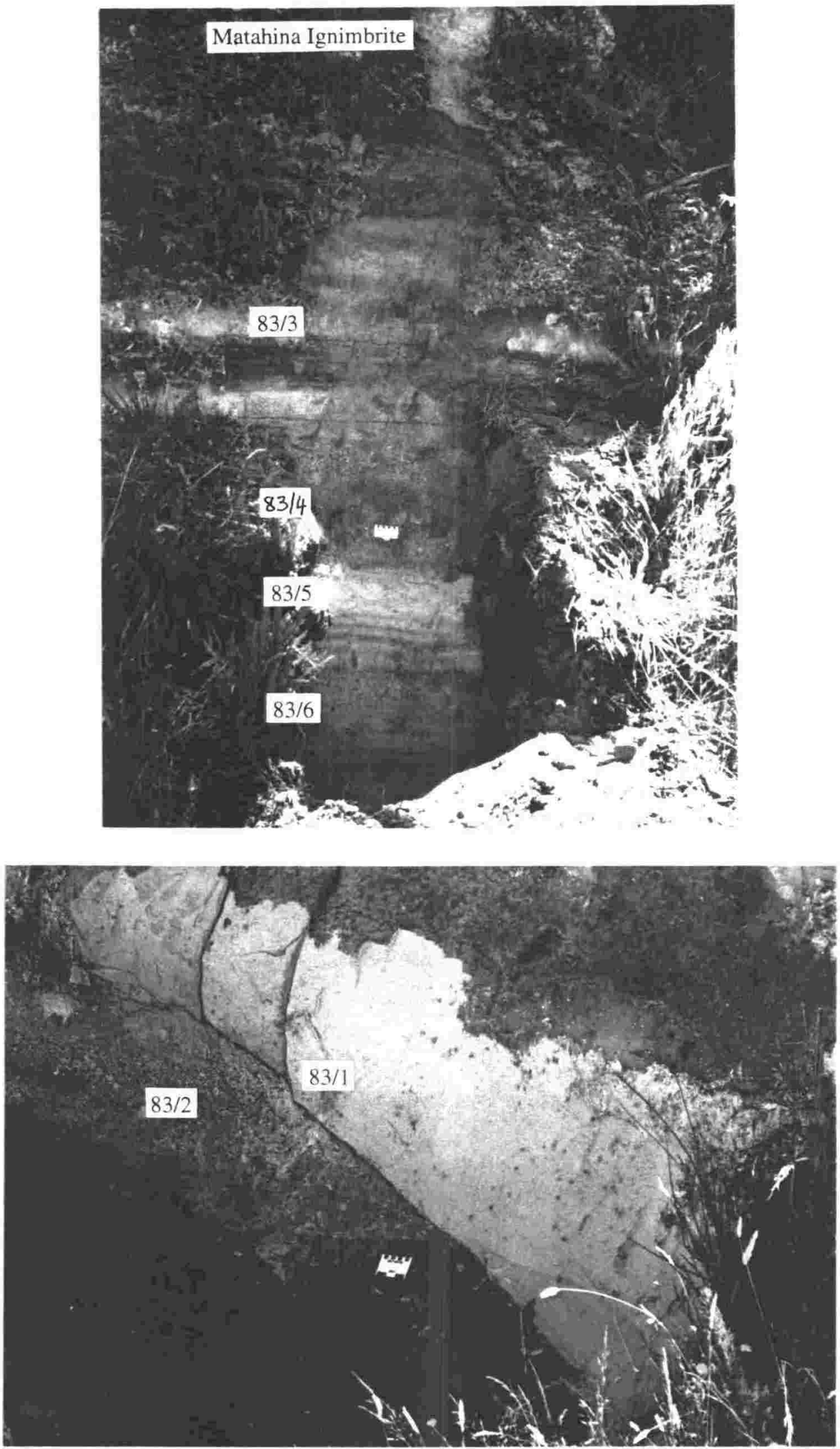

Plate 3 (Top) A sequence of fallout tephra beds and paleosols, overlying Whakamaru group ignimbrite (not shown, but exposed along strike) in a road cut on Highway 83 (V17/307993). Tephra sample locations are labelled. Matahina Ignimbrite occurs at the top of the sequence, resting on a well-developed paleosol. (lower) Detailed photograph of the nonwelded base of Matahina Ignimbrite, overlying fallout lapilli. 


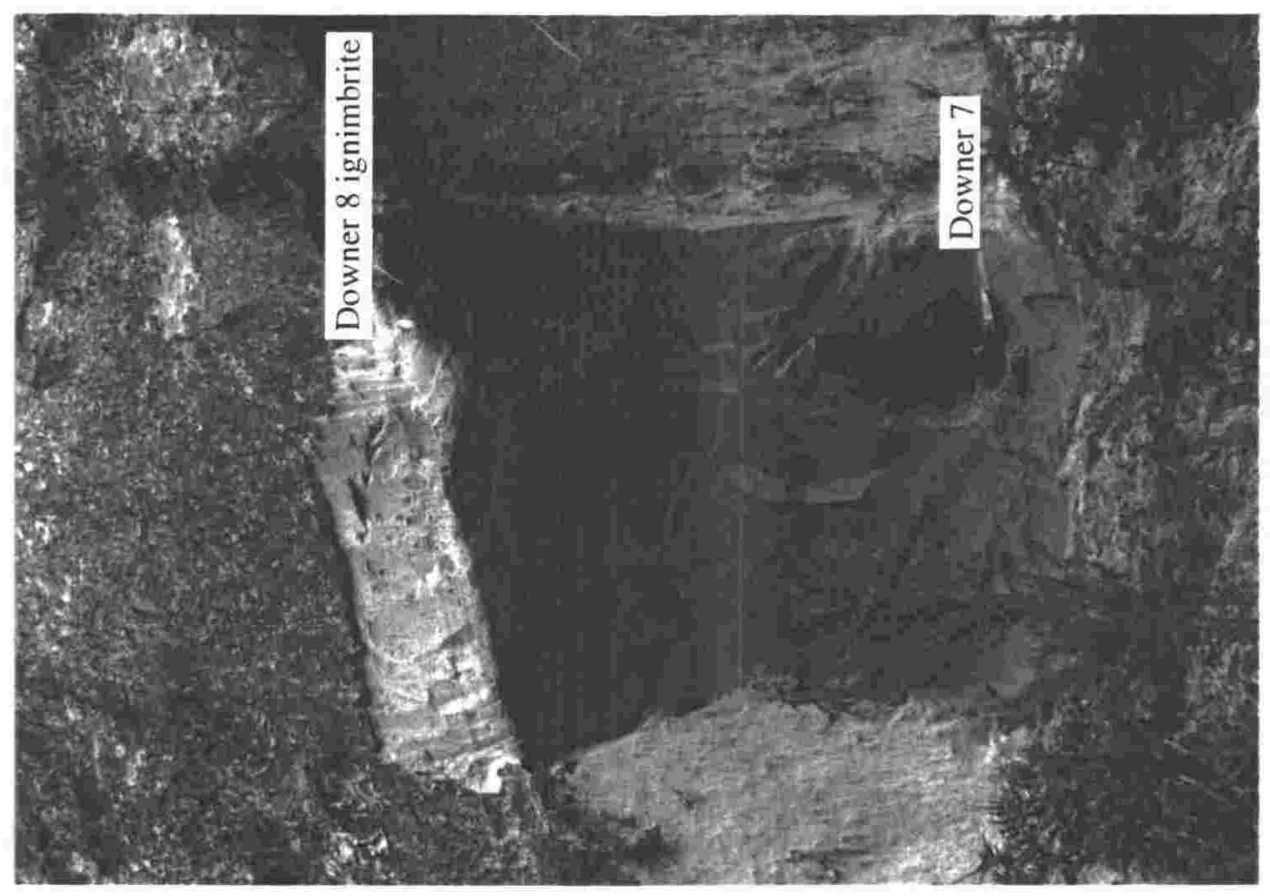

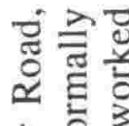

可产

옹.

on

들 을 응

러워

过

지용

응

气

है $<0$

豆。

이잉

릉

㤩导导

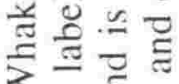

○

워워

흔

ว

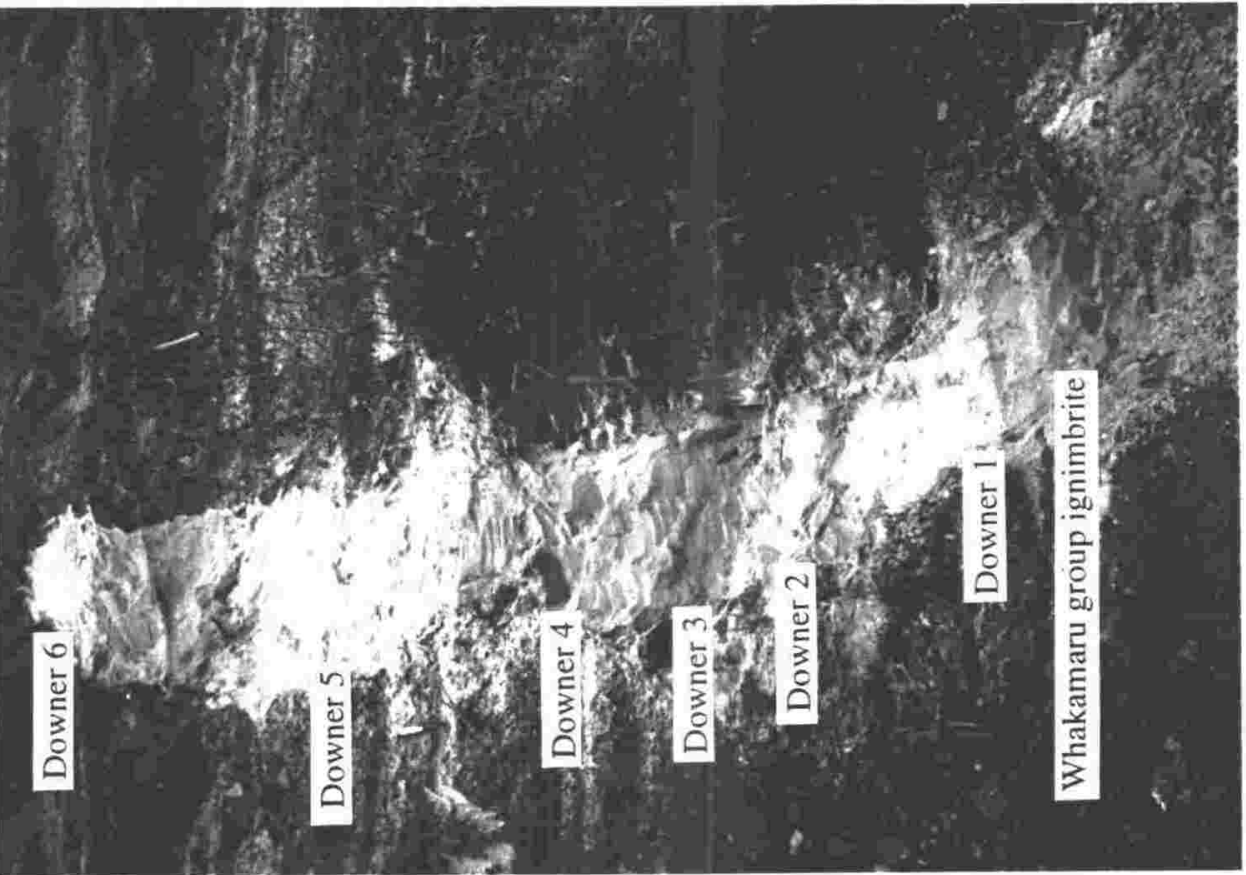

을 응

\& $=0$

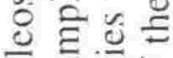

范范

可吉声

응 웡

능

$\circ \dot{\infty}$.

๘

츠. 아

잉

흐 흥

¿

可记

ซํํ สั

仜 9

《氜可

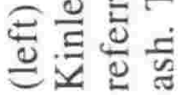

$\frac{\nabla}{\frac{0}{2}}$ 


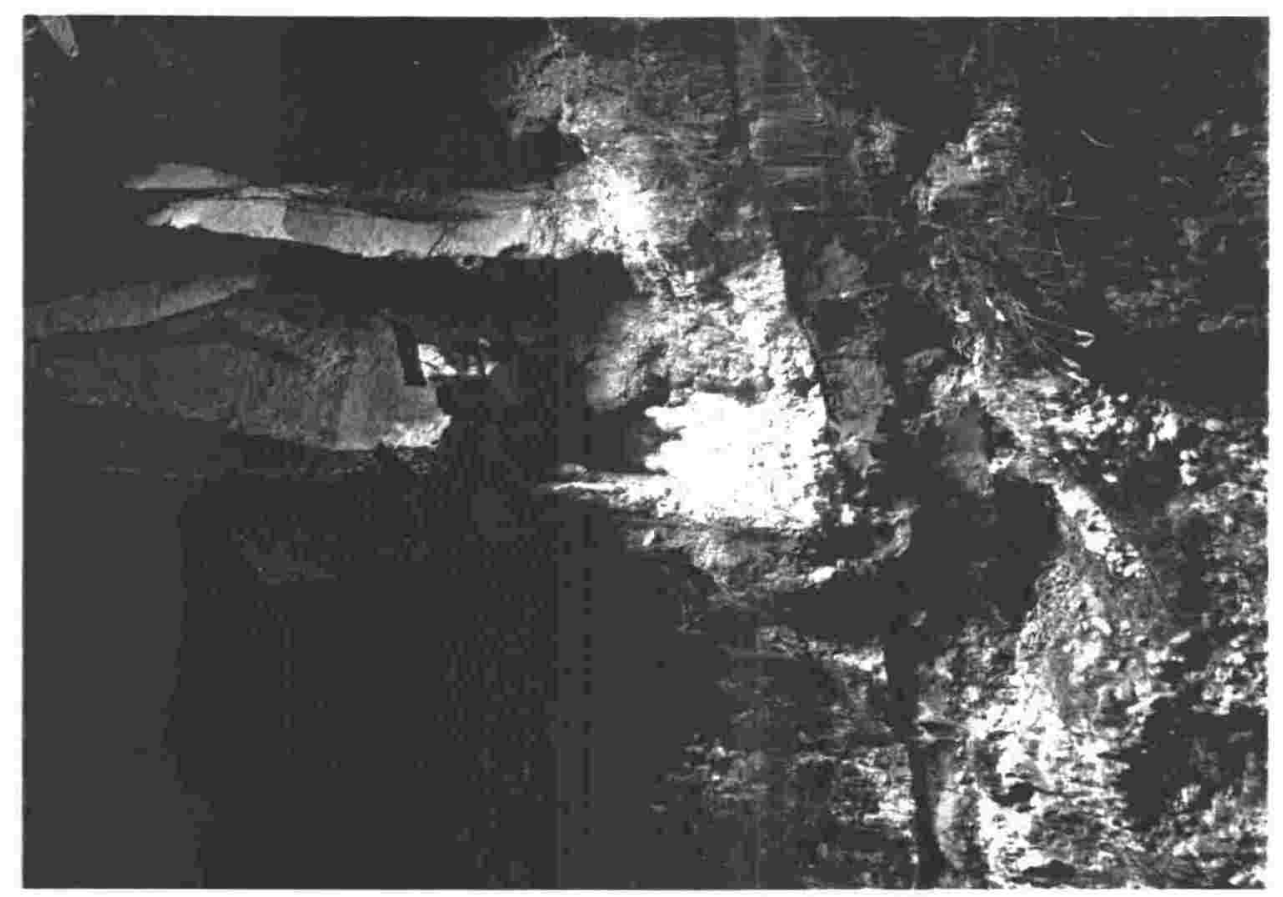

E

- I엉

ن. 007

E

家

ID

EN

EI

$\leqq \Xi$

空

$\infty \infty$

芯㐫

胥氙

$\sum^{\pi} 0$

을

$\cong \frac{1}{2}$

$\equiv 0$

气 क क

으모음

픙 종

으를

○部

¿

ํㅀㅀ छ

迄

융

文药

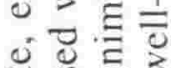

.

है छ

㤩苞光

क्)

可

姜的品

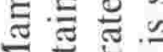

$\sum$ है.

Ð0 0

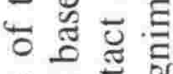

밀.

:

퐁

응

我记

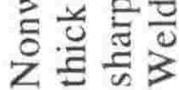

n

$\frac{0}{\square}$ 


\section{Chapter 3 \\ PALEOMAGNETISM}

\subsection{INTRODUCTION}

The occurrence of reversals and paleosecular variation of the geomagnetic field provides an opportunity to characterise individual ignimbrite flow units via their recorded paleomagnetic signal. Rapidly cooled lava flows and ignimbrites are an ideal geologic record of the paleomagnetic field, provided that overprints can be removed. Recent studies have characterised and correlated individual lava flows erupted over periods as little as 10-100 years (Hagstrum and Champion 1994; Champion and Donnely-Nolan 1994).

Hatherton (1954) presented the first paleomagnetic data for volcanic rocks in New Zealand when he used magnetic susceptibility measurements to define sheet boundaries within the Whakamaru Ignimbrite. Cox (1969) published a study of paleosecular variation in Brunhes Chron ignimbrites from the TVZ, and later expanded this work (Cox 1971) where results from both normal and reversely magnetised volcanics from the TVZ were presented. Murphy and Seward (1981) presented age and paleomagnetic data for a sequence of reversely magnetised ignimbrites in the Matahana Basin, not previously recognised. Soengkono et al. (1992) investigated the magnetic stratigraphy of older ignimbrites from the Mangakino Caldera, western TVZ. Ongoing work by Tanaka and others has been presented at several conferences, concerning the refinement of the magnetostratigraphy of the TVZ.

The purpose of this investigation is to establish an internally consistent magnetostratigraphy of the TVZ to: (1) construct of a chronology for the area and, (2) evaluate its use as a fingerprinting technique or correlation tool within single ignimbrite units. To achieve these aims, multiple sites of major units needed to be collected, which had not been carried out previously in New Zealand.

\subsection{SAMPLING AND MEASUREMENT}

\subsubsection{Collection}

Many sites consist of hard welded ignimbrite and were easily sampled by using a portable diamond corer powered by either an electric or petrol motor. Cores were drilled and then oriented in situ with respect to azimuth and dip using a magnetic compass. The cores were then inscribed with an orientation mark before extraction. Some outcrops proved more problematic, especially if pumices are abundant. The softer material, such as pumice, caused cores to break off prematurely. This was found to be the case for the Whakamaru Ignimbrite around the Western Bay area, where the pumice rich top of the flow is exposed. Also encountered were units where the matrix was sufficiently nonwelded that it produced sandy, 
friable cores. In some cores of the Whakamaru group ignimbrites, quartz phenocrysts were then able to rotate along the core barrel during drilling, producing scored cores.

Some sites of the Mamaku and Oruanui ignimbrites were sufficiently soft to require a different collection technique. Cubes $(2 \times 2 \times 1.5 \mathrm{~cm})$ were cut into a horizontal bench of the unit and plastic boxes placed over the sample and oriented in the field. This was easily accomplished with the Mamaku Ignimbrite as it is homogeneous and consolidated. Sampling of Oruanui Ignimbrite was less successful as it contains small hard pumices which tend to rotate rather than cut through.

Eight to twenty specimens were obtained from 4-6 cores drilled from each outcrop. From softer sites, 4 cubes were obtained. Initial sample spacing was a $0.5 \mathrm{~m}^{2}$ cluster, but then progressed to a 3-4 m lateral spacing of cores which was considered to be more representative of the outcrop as a whole. Care was taken where possible to drill the resulting holes in unobtrusive places and plug them with loose material. The specimens were placed in mu metal shields to prevent further overprinting and to allow any viscous overprints to decay in zero field. Sample sites are shown on Figures 2.3-2.9 in Chapter 2.

\subsubsection{Measurements}

Natural Remanent Magnetism (NRM) measurements were carried out before Anisotropy of Magnetic Susceptibility measurements (see Chapter 5), followed by demagnetisation. Paleomagnetic measurements were made on a Molspin spinner magnetometer which has a noise limit of $0.03 \mathrm{~mA} / \mathrm{m}$, well below all the intensity of the specimens. Most site measurements were determined at VUW, except cube sites 160-173, which were measured using identical equipment at the University of Toronto, Scarborough Campus.

At least 1 specimen from each site was sequentially demagnetised in a Molspin 2axis spin alternating field demagnetiser, in steps of 5-10 $\mathrm{mT}$ up to a maximum of $99 \mathrm{mT}$. Subsequent demagnetisation of the rest of the site specimens was carried out in 1-2 steps, at the designated optimum level, often equivalent to the median destructive field.

\subsection{NATURE OF MAGNETISATION}

\subsubsection{Intensity}

Measured intensities ranged from 0.09 to $4070 \mathrm{~mA} / \mathrm{m}$, but most are in the range 100$1000 \mathrm{~mA} / \mathrm{m}$. The higher values were mainly obtained from intensely welded specimens, whereas cubes of nonwelded ash displayed the lowest intensities. Many of the older units studied also had lower NRM intensities and had to be demagnetised further to remove overprinting. 

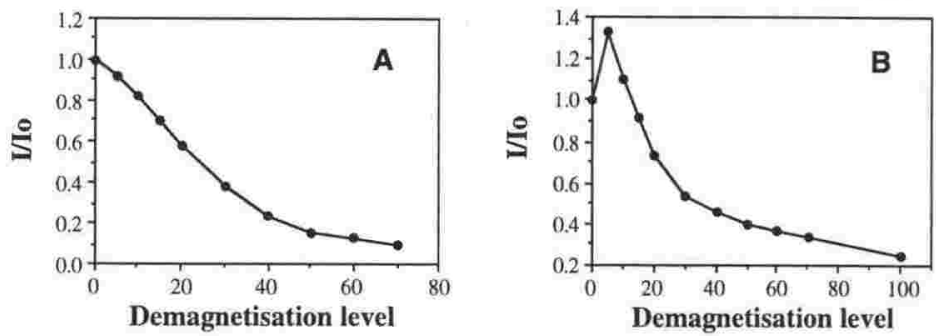

Ongatiti site $49(190.2)$

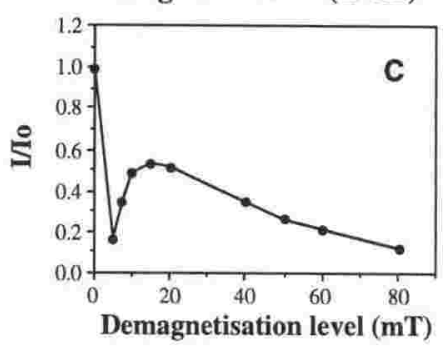

Figure 3.1 Intensity (I) / NRM intensity (Io) plotted against AF demagnetisation field level reveals three commonly observed behaviours in the specimens examined. (A) Typical, single component normal polarity specimen. (B) Reversed polarity specimen displaying a viscous normal overprint. (C) Specimen with two-component magnetisation, where the components have partially overlapping coercivity ranges. Specimen number in brackets.

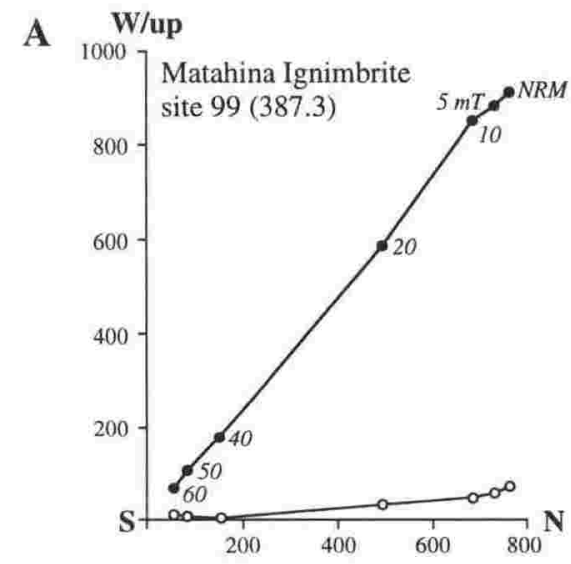

B Whakamaru ignimbrite site $9(040.2)$
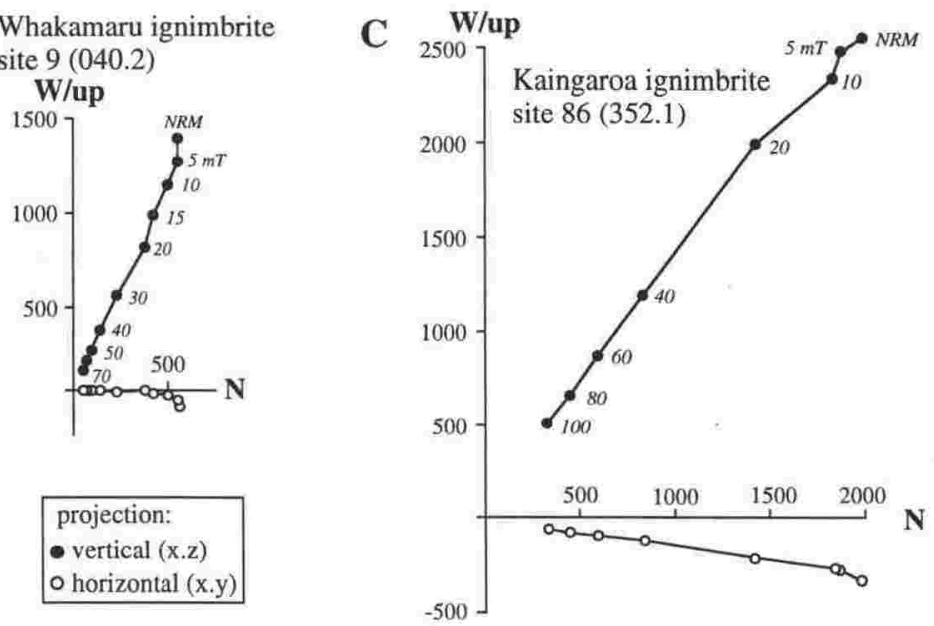

Figure 3.2 Typical demagnetisation behaviour of normal polarity specimens displayed on orthogonal component plots: (A) Matahina Ignimbrite, (B) Whakamaru ignimbrite, and (C) Kaingaroa ignimbrite. 
Progressive demagnetisation and studies of intensity and directional changes were used to assess the nature of the paleomagnetic signal from the specimens (Butler 1992). The behaviour of specimens during demagnetisation fall into 3 groups:

(a) a progressive decrease in intensity during sequential demagnetisation (Figure 3.1a);

(b) an initial increase in intensity, then decreasing at higher levels of demagnetisation (Figure $3.1 b)$;

(c) more complex behaviour with an initial decrease, followed by an increase, then drop off in intensity at higher levels of demagnetisation (Figure 3.1c).

The first group is typical behaviour from a normally magnetised specimen with a single component of remanence. The magnetism is progressively removed. The second group shows a lower coercivity viscous overprint removed at low levels of demagnetisation (typically 5-15 $\mathrm{mT}$ ) to reveal the primary high coercivity magnetisation, which is then similarly removed as in the first group. The increase in intensity is caused by the overprint being of opposite polarity and thereby cancelling out or masking each other. The third group also shows the effects of overprinting, but in this case, the coercivities of the overprint and primary magnetisations only partially overlap, so there is initially a decrease in intensity as the viscous overprint alone is sequentially removed. When the primary magnetisation is reached, the intensity increases until all the lower coercivity overprint magnetisation is removed, then the intensity drops off as in the above examples.

The behaviour of intensity during demagnetisation therefore provides insight into the nature of a specimen's magnetism, indicating whether it is single or two-component in nature.

\subsubsection{Single component TRM}

Many samples display a stable single component magnetism, inferred to be thermoremanent magnetisation (TRM). These samples are in group (a) as above. Some normally magnetised specimens have a slight overprint caused by the present day field which is easily removed by AF demagnetisation in fields of 5-15 mT. Orthogonal component plots (Figure 3.2) of samples displaying this behaviour have straight paths leading to the origin, some with a slight inflexion at the beginning. Most of the normally magnetised ignimbrite sites (e.g. Whakamaru, Matahina, Kaingaroa) are in this group.

\subsubsection{Two component magnetisation}

In some cases, the NRM of a sample is not the original TRM. Upon demagnetisation, the remanence direction changes, indicating the progressive removal of a magnetic overprint. In an orthogonal component plot this behaviour is expressed by a change in direction, often initially away from the origin, which indicates the lower coercivity viscous overprint was 
Rahopaka Ignimbrite site 142 (553.1)

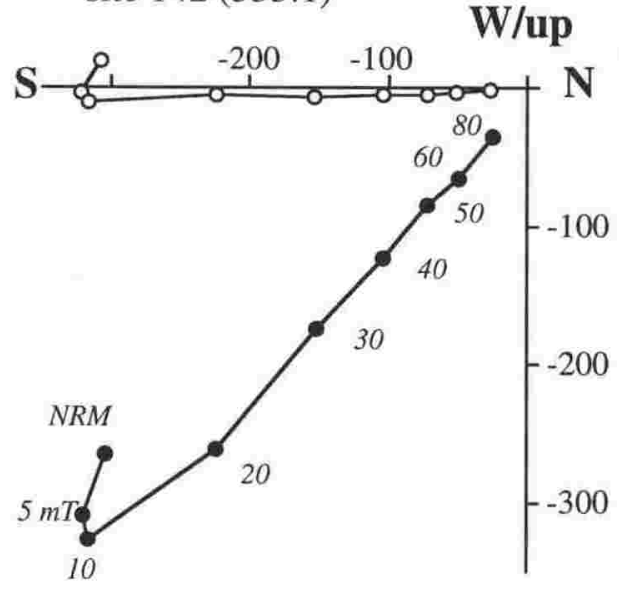

Marshall ignimbrite site $6(025.3)$

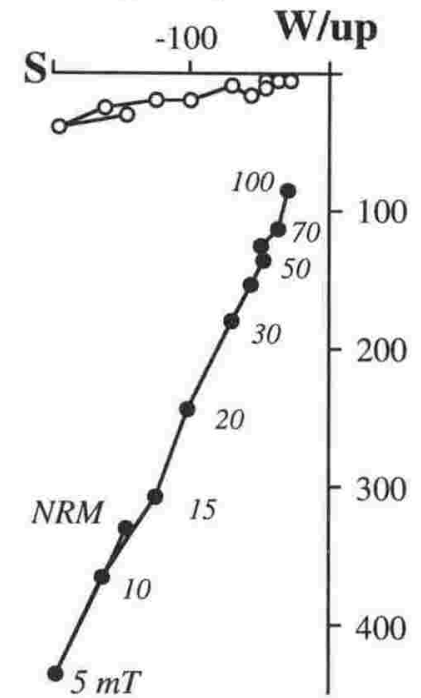

Figure 3.3 Typical demagnetisation behaviour of reversed polarity specimens. Note the presence of a very weak normal viscous overprint which is removed at $5-10 \mathrm{mT}$. 
caused by an opposite field direction (as in a normally overprinted reversed specimen, Figure 3.3). This change in direction is mirrored in the intensity vs. demagnetisation plot of the same sample (Figure 3.1b) where the inflexion point indicates removal of the overprint. After this, the specimen moves toward the origin in a relatively straight line, indicating the decay of the stable higher coercivity primary TRM. In an example of a more severely overprinted specimen of Ongatiti Ignimbrite (Figure 3.4a), the NRM initially plots in the 'normal' quadrant and moves toward the origin during demagnetisation. At $10 \mathrm{mT}$ the intensity of the sample increases, indicating the lower coercivity overprint has been joined by the primary magnetism and both decay until $20 \mathrm{mT}$ when the sample path abruptly turns toward the origin. This shows that only the primary TRM is left.

Overprinting is mostly found in reversely magnetised units, such as Ongatiti, Marshall, Pukerimu, Tikorangi and Rahopaka. In some cases, complete removal of the overprint is not possible, and this adds to directional scatter. In one case, a site of Whakamaru ignimbrite (site 129) was found to have an NRM with a reversed declination and very low normal inclination. Upon demagnetisation, the overprint was completely removed (Figure 3.4b). In this case, the cause of the overprint may be due to a lightning strike, or due to an excursion of the earth's magnetic field.

\subsubsection{Intermediate polarity units}

In this study, two units displayed instantaneous pole positions inconsistent with a typical dipole field. These are the Mamaku and Ahuroa ignimbrites. Various degrees of overprinting were encountered in both units, but typically the older Ahuroa Ignimbrite is more severely overprinted. Because times of intermediate polarity also correspond to lows in paleointensity (Valet and Meynadier 1993), overprints from subsequent higher intensity fields are more likely to mask the TRM.

Two examples of orthogonal component plots given in Figure 3.5a show the range of overprinting encountered in the Mamaku Ignimbrite. Stereo plots of the pole position at each demagnetisation step (Figure 3.5b) show the declination traversing to a more southerly destination. In every case, the resulting direction is almost a completely reversed declination and normal inclination (Table 3.1, Figure 3.6) From 25 site means, an average declination of $141^{\circ}$ and inclination of $-72^{\circ}\left(\mathrm{k}=64, \alpha_{95}=3.7^{\circ}\right)$ was obtained. This suggests the paleomagnetic direction is stable and indicates the Mamaku Ignimbrite records an excursion of the earth's magnetic field. A similar direction (declination $=118^{\circ}$, inclination $=-84^{\circ}$ ) is given in Cox (1971) for sample site NZ 9, who interpreted it to be normal polarity. The distinctive paleomagnetic direction recorded in Mamaku Ignimbrite allows it to be easily correlated. Ignimbrite exposures mapped as Mokai ignimbrite, north of Lake Taupo, also display this paleomagnetic direction (Figure 3.6) and are considered correlatives. The 
A

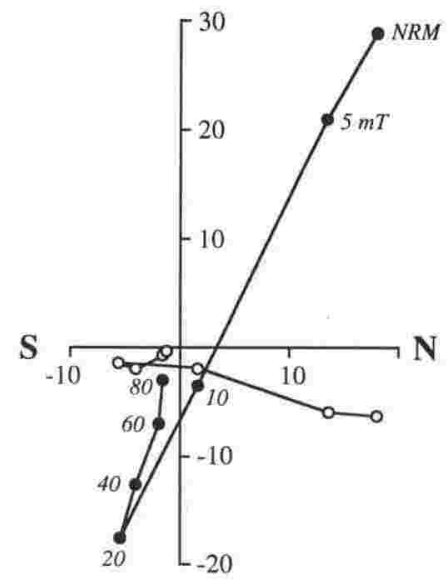

projection:

- vertical (x.z)

o horizontal (x.y)

B

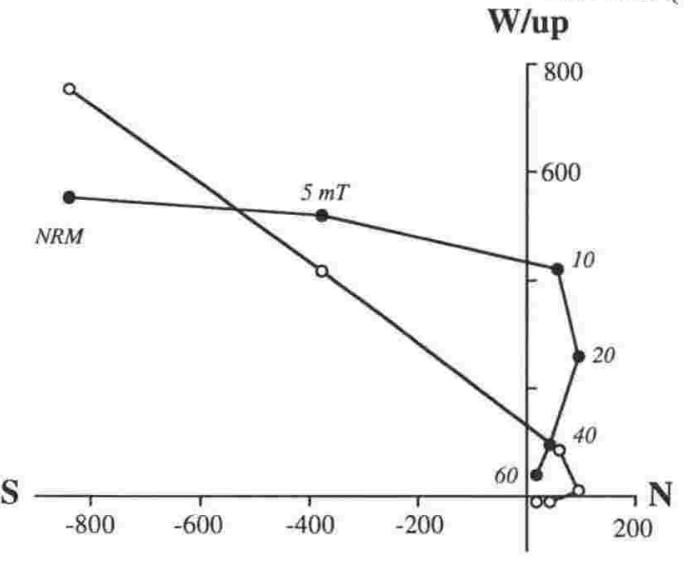

Ongatiti Ignimbrite site $115(466.1)$

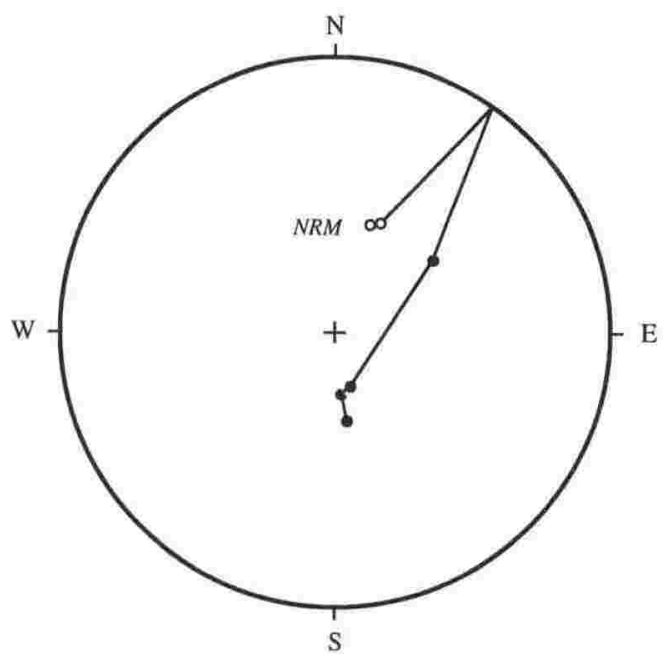

Whakamaru ignimbrite

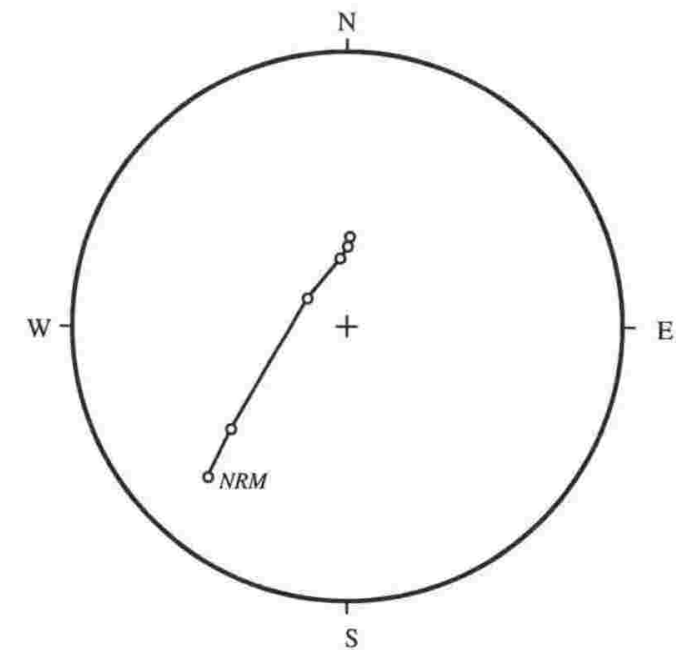

Figure 3.4 Demagnetisation behaviour of specimens with two or multi-component magnetisation, presented on orthogonal component plots and stereographic projections. (A) Reversed polarity specimen overprinted by a viscous normal overprint that is removed after 20 mT. (B) Normal polarity specimen overprinted by a reversed polarity component. 
A

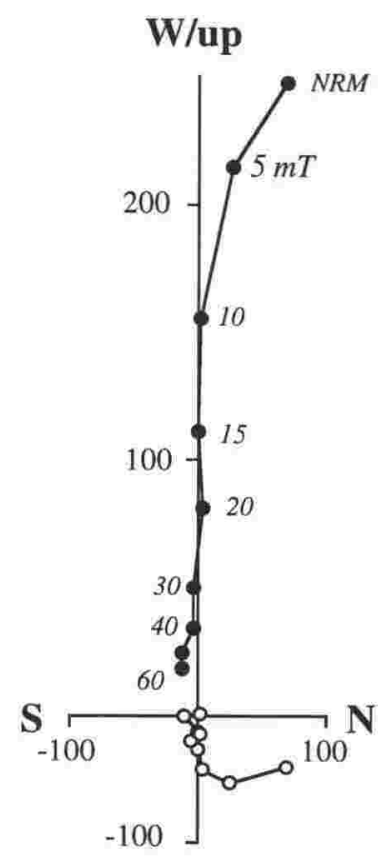

Site 12 (51.2)

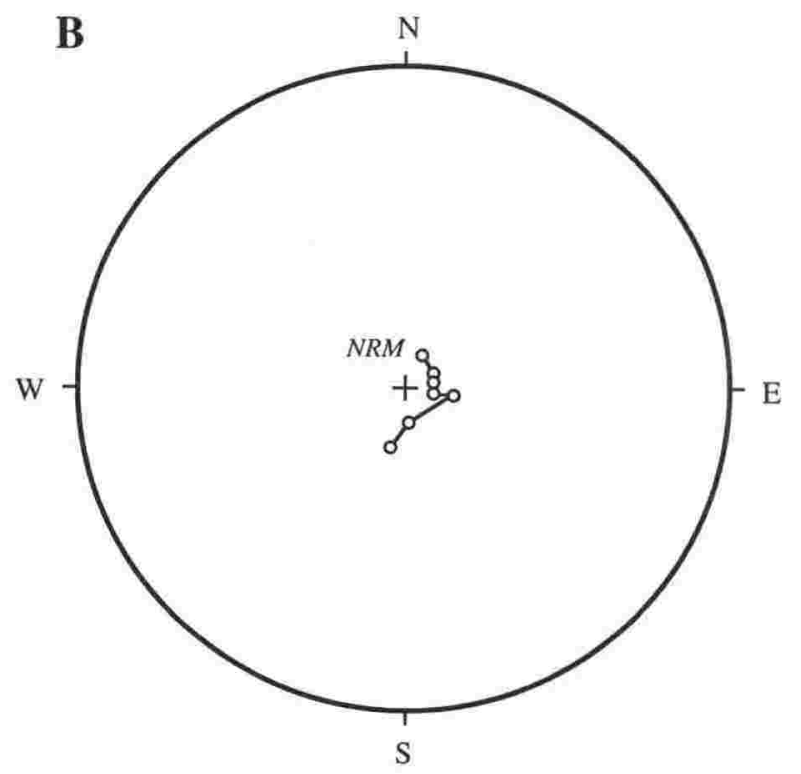

projection:

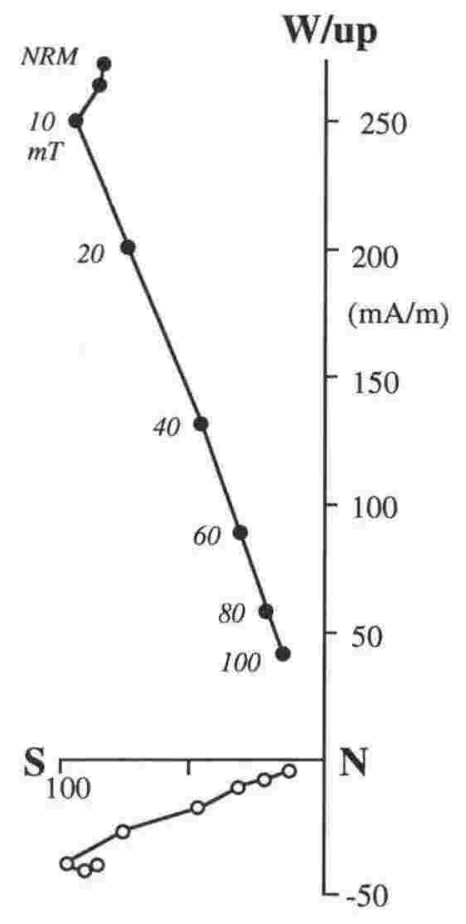

Site $89(356.1)$
- vertical (x.z)

o horizontal (x.y)

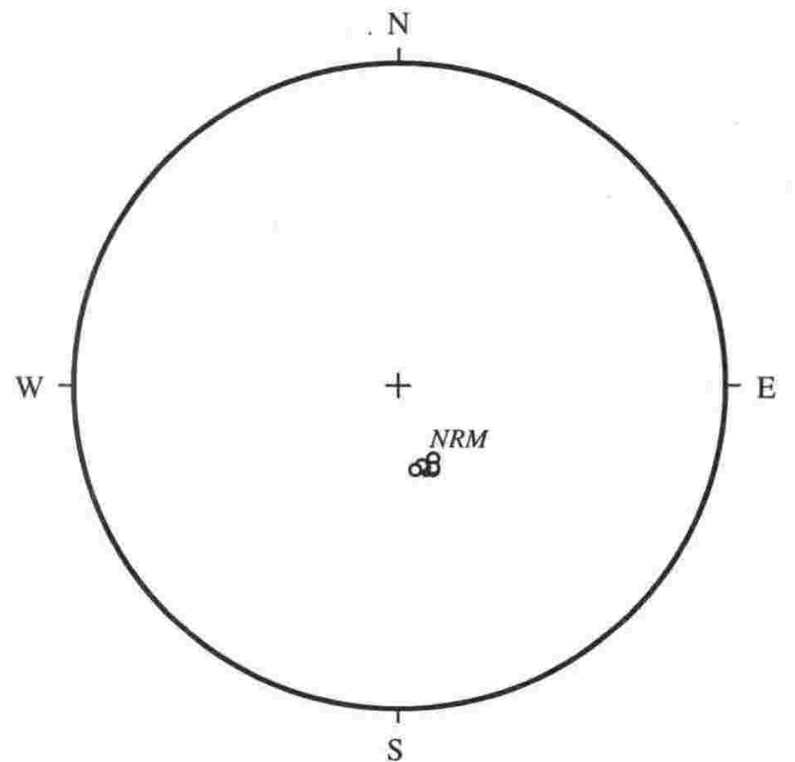

Figure 3.5 Demagnetisation behaviour of two specimens from sites of the Mamaku Ignimbrite. (A) Orthogonal component plots. (B) Upper hemisphere stereographic projections of the same specimens. 
Table 3.1 Paleomagnetic data for Taupo Volcanic Zone ignimbrites.

\begin{tabular}{|c|c|c|c|c|c|c|c|c|}
\hline Site & Locality & Grid ref. & $\mathrm{n}$ & Decl. & Incl. & $\mathrm{K}$ & $\alpha_{95}$ & odf \\
\hline \multicolumn{9}{|c|}{ Ngaroma Ignimbrite } \\
\hline 50 & Highway 30 & S17/092013 & 7 & 190 & 64 & 641 & 2.4 & 50 \\
\hline \multicolumn{9}{|c|}{ Ongatiti Ignimbrite } \\
\hline 42 & Waimiha-Ongarue $\mathrm{Rd}$ & S17/114804 & 6 & 183 & 64 & 360 & 3.5 & 30 \\
\hline 43 & Waimiha-Ongarue Rd & S17/104818 & 6 & 181 & 68 & 608 & 2.7 & 20 \\
\hline 44 & Takiri Rd & S17/121853 & 6 & 202 & 70 & 1273 & 1.9 & 20 \\
\hline 48 & Highway 30 & S17/039088 & 6 & 177 & 70 & 942 & 2.2 & 20 \\
\hline 49 & Highway 30 & S17/076025 & 12 & 184 & 65 & 161 & 3.4 & 10 \\
\hline 51 & Highway 30 & S17/087001 & 6 & 184 & 68 & 1128 & 2.0 & 25 \\
\hline 52 & Highway 30 & S17/202981 & 6 & 179 & 68 & 1119 & 2.0 & 40 \\
\hline 55 & Chindie Rd & S16/198218 & 8 & 179 & 67 & 3982 & 0.9 & 35 \\
\hline 56 & Rocky Hill (type locality) & S17/118099 & 8 & 169 & 72 & 393 & 2.8 & 25 \\
\hline 59 & Highway 30 & S17/259966 & 6 & 188 & 68 & 678 & 2.6 & 40 \\
\hline 62 & Wairehi Rd & T16/368197 & 6 & 191 & 65 & 720 & 2.5 & 20 \\
\hline 63 & Huirimu Rd & T16/398231 & 7 & 196 & 62 & 293 & 3.5 & 15 \\
\hline 114 & Kopaki Rd & S17/034985 & 7 & 194 & 67 & 150 & 4.9 & 50 \\
\hline 115 & Manu Rd & S17/105086 & 7 & 180 & 68 & 372 & 3.1 & 50 \\
\hline 119 & Kihikihi-Arapuni Rd & $\mathrm{T} 15 / 314440$ & 3 & 178 & 67 & 9.9 & 33.1 & 50 \\
\hline 123 & Aotearoa Rd, Waipari Ig & $\mathrm{T} 16 / 354336$ & 6 & 157 & 69 & 99 & 6.2 & 40 \\
\hline 126 & Horahora Rd, Waikato R. & $\mathrm{T} 15 / 437495$ & 9 & 177 & 68 & 498 & 2.3 & 60 \\
\hline 170 & $\mathrm{~N}$ of Hinuera Quarry & $\mathrm{T} 15 / 463618$ & 14 & 177 & 74 & 699 & 1.5 & NRM \\
\hline 172 & Gorge Rd & S16/179272 & 19 & 183 & 71 & 482 & 1.5 & NRM \\
\hline Mean & 19 sites & & & 183 & 68 & 308 & 1.9 & \\
\hline
\end{tabular}

Ahuroa Ignimbrite

$\begin{array}{ll}53 & \text { Mangaokewa Rd } \\ 57 & \text { Rocky Hill, type locality } \dagger \\ 61 & \text { Waipapa Rd } \dagger \\ 118 & \text { Ranginui Rd } \\ 121 & \text { Mangare Rd } \\ 122 & \text { Kahorekau Rd } \\ 124 & \text { Aotearoa Rd } \\ \text { Mean } & \mathbf{5} \text { sites († not included) }\end{array}$

$\begin{array}{llrrrrr}\text { S17/189022 } & 5 & 020 & 52 & 5.4 & 36.3 & 40 \\ \text { S16/113103 } & 5 & 356 & -51 & 44 & 11.7 & 5 \\ \text { T16/423237 } & 7 & 045 & 8 & 437 & 2.9 & \text { NRM } \\ & 1 & 339 & 73 & & & 40 \\ \text { T17/403077 } & 5 & 354 & 66 & 18 & 18.6 & 40 \\ \text { T16/418331 } & 5 & 026 & 71 & 275 & 4.6 & 40 \\ \text { T16/382306 } & 5 & 354 & 78 & 86 & 7.4 & 40 \\ \text { T16/337360 } & 6 & 340 & 63 & 102 & 6.1 & 30 \\ & & \mathbf{0 0 4} & \mathbf{6 7} & \mathbf{3 4} & \mathbf{1 1 . 9} & \end{array}$

\section{Marshall ignimbrites}

$\begin{array}{llllllrll}6 & \text { I, Whakamru Rd } & \text { T16/578211 } & 9 & 171 & 68 & 776 & 1.9 & 25 \\ 64 & \text { Jn of Mustang and Maverick Rd } & \text { T16/470142 } & 6 & 173 & 57 & 1212 & 1.9 & 40 \\ 65 & \text { I, Forestry track off Waipapa Rd } & \text { T16/471131 } & 5 & 165 & 67 & 681 & 2.9 & 30\end{array}$

\section{Pukerimu/Tikorangi ignimbrite}

$\begin{array}{ll}143 & \text { Old Tikorangi Rd } \\ 144 & \text { Old Tikorangi Rd } \\ 149 & \text { Rawhiti Rd }\end{array}$

146 Tikorangi Rd $\begin{array}{lll}\text { U16/787209 } & 6 & 182\end{array}$

$\begin{array}{lll}\text { U16/788207 } & 4 & 181\end{array}$

U16/808216

$\begin{array}{ll}5 & 189\end{array}$

48
42

389

1573

326

$\begin{array}{ll}3.4 & 30 \\ 2.3 & 50 \\ 4.2 & 40\end{array}$

Matahana B ignimbrite

$\begin{array}{lllllll}\text { U16/801183 } & 7 & 178 & 26 & 447 & 2.9 & 60\end{array}$


\begin{tabular}{ll}
\hline \hline Site & \multicolumn{1}{c}{ Locality } \\
\hline & \\
142 & $\begin{array}{l}\text { Pukerimu Rd (type locality) } \\
145\end{array}$ \\
Rusa Rd
\end{tabular}

140

Rawhiti Rd quarry

147

Jn. Pukerimu / Tikorangi Rd*

Grid ref.

n Decl. Incl.

K

$\alpha_{95}$ odf

\section{Rahopaka Ignimbrite}

$\begin{array}{lllllll}\mathrm{U} 16 / 788205 & 6 & 181 & 52 & 824 & 2.3 & 50 \\ \mathrm{U} 16 / 813187 & 9 & 172 & 55 & 529 & 2.2 & 80\end{array}$

\section{Waiotapu ignimbrite}

$\begin{array}{lllllll}\mathrm{U} 16 / 772211 & 6 & 355 & -65 & 495 & 3.0 & 20\end{array}$

\section{Matahana A ignimbrite}

U16/787205

$4 \quad 359$

$-59$

266

4.9

20

\section{Whakamaru group ignimbrites}

Highway 32, Western Bay Rd Highway 32, Western Bay Rd Highway 32, Western Bay Rd Highway 32, Western Bay Rd Maraetai Dam top Maraetai Dam middle

Maraetai Dam base

Highway 32, Tihoi Rd

Waipapa Rd

Waipapa Rd

Waipapa Rd

Waipapa Rd

Highway 41

Highway 32, Western Bay Rd Highway 32, Western Bay Rd Highway 32, Western Bay Rd Highway 32, Western Bay Rd Western Bay Rd

Tihoi Rd

Highway 32

Ongarue Back Rd

Ongarue back Rd

Okauaka Rd

Okauaka Rd

Ongarue Stream Rd

Mangaokewa Rd

Highway 30 , Pureora forest turnoff

Napier-Taupo Rd

Waipunga Falls

$10 \mathrm{~m}$ above site 67

Motukino Boundary Rd

$50 \mathrm{~m}$ below site 69

Straight Line Rd

adjacent to site 72

Torepatutahi Stream

Hinemaiaia A Dam

Toki Point

Tauranga - Taupo R.

$20 \mathrm{~m}$ below site 77

Highway 38

Highway 38

Picket Ridge Farm

Pureora Forest entrance

Mangare Rd

Arapuni Dam

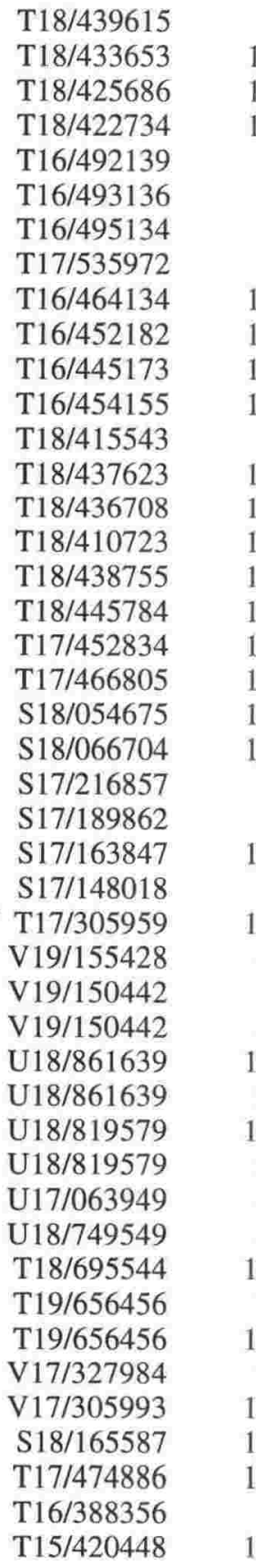

$8 \quad 355$

$19 \quad 007$

$16 \quad 008$

$10 \quad 348$

$7 \quad 004$

$4 \quad 359$

$4 \quad 000$

$7 \quad 002$

$11 \quad 010$

$10 \quad 359$

$11 \quad 009$

$14 \quad 003$

$8 \quad 000$

$12 \quad 318$

$13 \quad 003$

$13 \quad 358$

$12 \quad 359$

$12 \quad 006$

11005

$10 \quad 004$

$10 \quad 003$

$10 \quad 002$

$8 \quad 349$

$9 \quad 002$

$15 \quad 001$

$4 \quad 006$

$10 \quad 004$

$4 \quad 004$

$8 \quad 017$

$6 \quad 006$

$13 \quad 011$

$9 \quad 021$

$13 \quad 004$

9003

$4 \quad 355$

$5 \quad 009$

$14 \quad 022$

$7 \quad 002$

$10 \quad 353$

$\begin{array}{ll}7 & 007\end{array}$

$12 \quad 357$

$10 \quad 358$

$10 \quad 358$

358
004

3
16

$\begin{array}{rr}-63 & 82 \\ -63 & 329 \\ -67 & 535 \\ -72 & 261 \\ -67 & 234 \\ -63 & 112 \\ -64 & 276 \\ -67 & 1068 \\ -61 & 824 \\ -69 & 621 \\ -63 & 1154 \\ -65 & 884 \\ -68 & 1965 \\ -62 & 175 \\ -68 & 2582 \\ -66 & 1413 \\ -69 & 1374 \\ -66 & 2305 \\ -63 & 1202 \\ -68 & 3999 \\ -65 & 167 \\ -67 & 541 \\ -42 & 2154 \\ -64 & 1630 \\ -67 & 1113 \\ -59 & 267 \\ -64 & 1297 \\ -69 & 906 \\ -62 & 4430 \\ -67 & 126 \\ -68 & 404 \\ -67 & 1978 \\ -66 & 599 \\ -65 & 592 \\ -65 & 302 \\ -65 & 99.2 \\ -47 & 496 \\ -68 & 2024 \\ -66 & 575 \\ -67 & 1028 \\ -69 & 1225 \\ -65 & 395 \\ -70 & 290 \\ -65 & 419 \\ -61 & 1170 \\ \end{array}$

6.2

NRM

1.9 NRM

1.6 NRM

$3.0 \quad$ NRM

$1.9 \quad 25$

$8.7 \quad 25$

$\begin{array}{ll}5.5 & 25\end{array}$

1.9 NRM

1.6 NRM

1.9 NRM

1.3 NRM

1.3 NRM

$1.3 \quad 25$

3.3 NRM

$0.8 \quad$ NRM

1.1 NRM

1.2 NRM

0.9 NRM

1.3 NRM

$0.8 \quad$ NRM

$3.7 \quad 20$

$2.1 \quad 30$

1.2 NRM

1.3 NRM

1.2 NRM

$5.6 \quad 10$

1.3 NRM

$3.1 \quad 20$

0.8 NRM

6.0 NRM

2.1 NRM

1.2 NRM

1.7 NRM

$2.1 \quad$ NRM

$5.3 \quad 20$

7.7 NRM

1.8 NRM

1.3 NRM

2.0 NRM

$1.7 \quad 40$

1.2 NRM

2.4 NRM

2.8 NRM

$\begin{array}{lll}015 & -61 & 1170\end{array}$ 


\begin{tabular}{llrrrrrrr}
\hline \hline Site & \multicolumn{1}{c}{ Locality } & Grid ref. & $\mathrm{n}$ & Decl. & Incl. & $\mathrm{K}$ & $\alpha_{95}$ & odf \\
\hline 127 & Poikawhenua Stream & $\mathrm{T} 15 / 488463$ & 10 & 358 & -66 & 882 & 1.6 & NRM \\
128 & Lichfield Quarry & $\mathrm{T} 16 / 588398$ & 14 & 355 & -63 & 1739 & 0.9 & NRM \\
129 & Highway 1, S of Lichfield & $\mathrm{T} 16 / 588398$ & 9 & 003 & -64 & 284 & 2.9 & 40 \\
169 & Whites Rd & $\mathrm{T} 15 / 569497$ & 8 & 354 & -60 & 317 & 2.9 & NRM \\
171 & Old Taupo Rd & $\mathrm{T} 15 / 487415$ & 17 & 005 & -52 & 234 & 1.2 & NRM \\
Mean & $\mathbf{1 2}$ sites (demagnetised) & & & $\mathbf{0 0 2}$ & $\mathbf{- 6 5}$ & $\mathbf{6 6 4}$ & $\mathbf{1 . 6}$ & \\
& $\mathbf{5 0}$ sites & & & $\mathbf{0 0 3}$ & $\mathbf{- 6 5}$ & $\mathbf{1 5 0}$ & $\mathbf{1 . 7}$
\end{tabular}

$\begin{array}{ll}82 & \text { Highway } 38 \\ 84 & \text { Highway 38 } \\ 95 & \text { Manawahe Rd } \\ 96 & \text { Herepuru Rd } \\ 97 & \text { McIvor Rd } \\ 98 & \text { McIvor Rd } \\ 99 & \text { Matahina Quarry (type locality) }\end{array}$

Mean 7 sites

130 Downer Rd (Chimpanzee?)

132 Galaxy Rd

\section{Matahina Ignimbrite}

$\begin{array}{lrrrrrr}\text { V17/307993 } & 12 & 011 & -57 & 1248 & 1.2 & 25 \\ \text { V } 17 / 275996 & 12 & 359 & -47 & 1571 & 1.1 & \text { NRM } \\ \text { V } 15 / 316523 & 12 & 006 & -52 & 417 & 2.0 & 50 \\ \text { V15/342576 } & 8 & 002 & -53 & 1929 & 1.2 & 20 \\ \text { V15/318477 } & 7 & 005 & -49 & 294 & 3.3 & 20 \\ \text { V } 15 / 343478 & 7 & 011 & -54 & 323 & 3.1 & 20 \\ \text { V16/440353 } & 7 & 004 & \mathbf{- 5 0} & 667 & 2.2 & 30 \\ & & \mathbf{0 0 5} & \mathbf{- 5 2} & \mathbf{3 0 2} & \mathbf{3 . 2} & \end{array}$

\section{Pokai ignimbrite}

$\mathrm{T} 16 / 672261$

$001 \quad-57$

652

2.0

30

$123 \quad 4.4 \quad 60$

\section{Kaingaroa ignimbrites}

$\begin{array}{ll}29 & \text { Plateau Rd } \\ 85 & \text { Highway } 38 \\ 86 & \text { Kaingaroa Quarry (type locality) } \\ 154 & \text { Northern Boundary Rd } \\ 155 & \text { N Boundary Rd/Highway } 38 \\ 156 & \text { Old Waiotapu Rd } \\ \text { Mean } & 6 \text { sites }\end{array}$

V17/108936

V17/217003

V17/194054

V16/194112

V16/128106

U16/085108

$010 \quad-59$

7
6
7
8
9
7

013

009

007

010

010

006

009

$-54$

$-53$

$-51$

$-52$

$-58$

$-49$

$-53$
1545

2564

419

347

182

526

469
1.5

1.2

2.7

2.8

3.6

2.4

2.8
65

30

40

60

30

50

\section{Mamaku Ignimbrite}

$\begin{array}{ll}10 & \text { Ruato Bay, L. Rotoiti } \\ 12 & \text { Mangaorewa Gorge (type section) } \\ 14 & \text { Te Pu } \\ 21 & \text { Mokai, Poihipi Rd } \\ 87 & \text { Dansey Rd* } \\ 88 & \text { State Highway } 5^{*} \\ 89 & \text { Mangaorewa Gorge above 12 } \\ 90 & \text { Mangaorewa Gorge above } 89^{*} \\ 91 & \text { Mangaorewa Gorge below } 90 \\ 92 & \text { Te Waerenga Rd* } \\ 93 & \text { Hamurana Rd* } \\ 112 & \text { Tirohanga Rd } \\ 141 & \text { Pukerimu Rd } \\ 148 & \text { Pukerimu Rd } \\ 150 & \text { South Rd* } \\ 151 & \text { South Rd* } \\ 153 & \text { Oturoa Rd* } \\ 159 & \text { Okere Falls } \\ 160 & \text { Pyes Pa Rd } \\ 161 & \text { Pyes Pa Rd } \\ 162 & \text { Taumata Rd } \\ 164 & \text { Peers Rd } \\ 165 & \text { Highway 5 } \\ 166 & \text { Leslie Rd, Waimakariri? } \\ 167 & \text { Leslie Rd, Waimakariri? }\end{array}$

V15/110439
U15/887552
U15/904523
T17/642901
$\mathrm{U} 15 / 840408$
$\mathrm{U} 15 / 781470$
$\mathrm{U} 15 / 885556$
$\mathrm{U} 15 / 882557$
$\mathrm{U} 15 / 884555$
$\mathrm{U} 15 / 976480$
$\mathrm{U} 15 / 000464$
$\mathrm{~T} 17 / 672043$
$\mathrm{U} 16 / 784204$
$\mathrm{U} 16 / 777178$
$\mathrm{U} 16 / 804340$
$\mathrm{U} 16 / 801364$
$\mathrm{U} 15 / 868472$
$\mathrm{U} 15 / 038495$
$\mathrm{U} 15 / 874607$
$\mathrm{U} 15 / 872644$
$\mathrm{U} 15 / 832677$
$\mathrm{U} 15 / 804693$
$\mathrm{U} 15 / 746476$
$\mathrm{~T} 15 / 635469$
$\mathrm{~T} 15 / 642468$

7
8
5
10
4
4
9
4
8
4
3
9
11
7
4
4
4

4
5
4
4
5
4
4

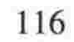

127

158

123

127

129

161

154

152

151

153

166

137

157

145

146

87

166

145

149

122

143

087

093

-63
-79
-65
-67
-75
-82
-64
-67
-64
-67
-55
-72
-77
-64
-71
-77
-77

-71
-66
-74
-71
-68
-81
-86

511
207
576
1243
116
151
90
874
378
232
585
1994
488
457
1654
299
358

162
120
267
202
135
725
214

2.5

20

$3.6 \quad 15$

$2.9 \quad 30$

$1.3 \quad 15$

$8.6 \quad 25$

$6.5 \quad 70$

$5.2 \quad 60$

$2.7 \quad 25$

$2.7 \quad 50$

$5.2 \quad 25$

$4.2 \quad 40$

1.1220

260

$2.6 \quad 60$

220

$4.6 \quad 30$

$4.2 \quad 40$

$6.3 \quad 20$

6.320

$4.9 \quad 20$

$5.6 \quad 20$

$5.9 \quad 30$

$3 \quad 30$

$\begin{array}{ll}5.5 & 20\end{array}$ 


\begin{tabular}{|c|c|c|c|c|c|c|c|c|}
\hline Site & Locality & Grid ref. & $\mathrm{n}$ & Decl. & Incl. & $\mathrm{K}$ & $\alpha_{95}$ & odf \\
\hline 168 & Waimakariri ignimbrite & $\mathrm{T} 15 / 595484$ & 4 & 073 & -75 & 40 & 12.8 & 30 \\
\hline Mean & 25 sites & & & 141 & -72 & 64 & 3.7 & \\
\hline \multicolumn{9}{|c|}{ Oruanui Ignimbrite } \\
\hline 19 & Whangamata $\mathrm{Rd}^{*}$ & $\mathrm{~T} 17 / 554833$ & 4 & 012 & -64 & 219 & 6.2 & 20 \\
\hline 20 & Whangamata Rd* & $\mathrm{T} 17 / 618830$ & 4 & 359 & -61 & 12 & 28 & 20 \\
\hline 134 & Highway $47^{*}$ & S19/285270 & 5 & 356 & -62 & 165 & 5.3 & 20 \\
\hline 135 & Highway $41^{*}$ & T18/453523 & 4 & 359 & -65 & 87 & 8.6 & 20 \\
\hline 136 & Highway $32 *$ & T18/431557 & 4 & 333 & -50 & 45 & 12 & 20 \\
\hline 138 & Highway $32 *$ & $\mathrm{~T} 18 / 431654$ & 4 & 019 & -63 & 412 & 3.9 & 20 \\
\hline 139 & Highway $32 *$ & $\mathrm{~T} 18 / 428741$ & 4 & 351 & -71 & 104 & 7.8 & 20 \\
\hline 157 & Poihipi $\mathrm{Rd}^{*}$ & U18/763794 & 4 & 354 & -65 & 654 & 3.1 & 20 \\
\hline 173 & Turangi bridge & T19/543426 & 3 & 334 & -56 & 131 & 8.8 & 20 \\
\hline Mean & 9 sites & & & 354 & -63 & 64 & 6.1 & \\
\hline \multicolumn{9}{|c|}{ Miscellaneous } \\
\hline 79 & Waiotapu? Waikite Valley Rd & U16/998147 & 5 & 028 & -69 & 217 & 5.2 & 40 \\
\hline 80 & Highway 38 at Te Whaiti & V17/394844 & 5 & 148 & 66 & 131 & 6.7 & 60 \\
\hline 100 & Waingarara ignimbrite, McCoy Rd & W15/676454 & 14 & 011 & -54 & 72 & 4.7 & 10 \\
\hline 101 & Puaiti Rd & $\mathrm{U} 17 / 876068$ & 10 & 016 & -71 & 1420 & 1.3 & 50 \\
\hline 102 & Dods Rd & U17/845053 & 6 & 013 & -46 & 487 & 3.0 & 40 \\
\hline 103 & Poutakataka Rd & $\mathrm{U} 16 / 862104$ & 12 & 347 & -61 & 608 & 1.7 & NRM \\
\hline 104 & Galatos Rd & U16/842124 & 10 & 347 & -63 & 288 & 2.7 & NRM \\
\hline 106 & Poutakataka Rd & U16/872157 & 14 & 346 & -63 & 214 & 2.6 & NRM \\
\hline 108 & Galatos Rd & $\mathrm{U} 16 / 831135$ & 10 & 336 & -62 & 767 & 1.7 & NRM \\
\hline 109 & Ohakuri Dam & U17/797058 & 8 & 350 & -56 & 79 & 5.9 & NRM \\
\hline 110 & Maleme Rd & $\mathrm{U} 17 / 821083$ & 12 & 358 & -68 & 393 & 2.1 & NRM \\
\hline 111 & Dunkirk Rd & U17/787078 & 12 & 344 & -62 & 105 & 4.1 & NRM \\
\hline 133 & Poihipi Rd & U17/757803 & 9 & 024 & -61 & 170 & 4.0 & NRM \\
\hline
\end{tabular}

Grid ref. from the NZMS map series. $*$ denotes cube specimens. $\mathrm{n}=$ number of specimens.

Fisher precision statistics: $\mathrm{K}$ and $\alpha_{95}$. odf $=$ optimum demagnetisation field $(\mathrm{mT})$. 


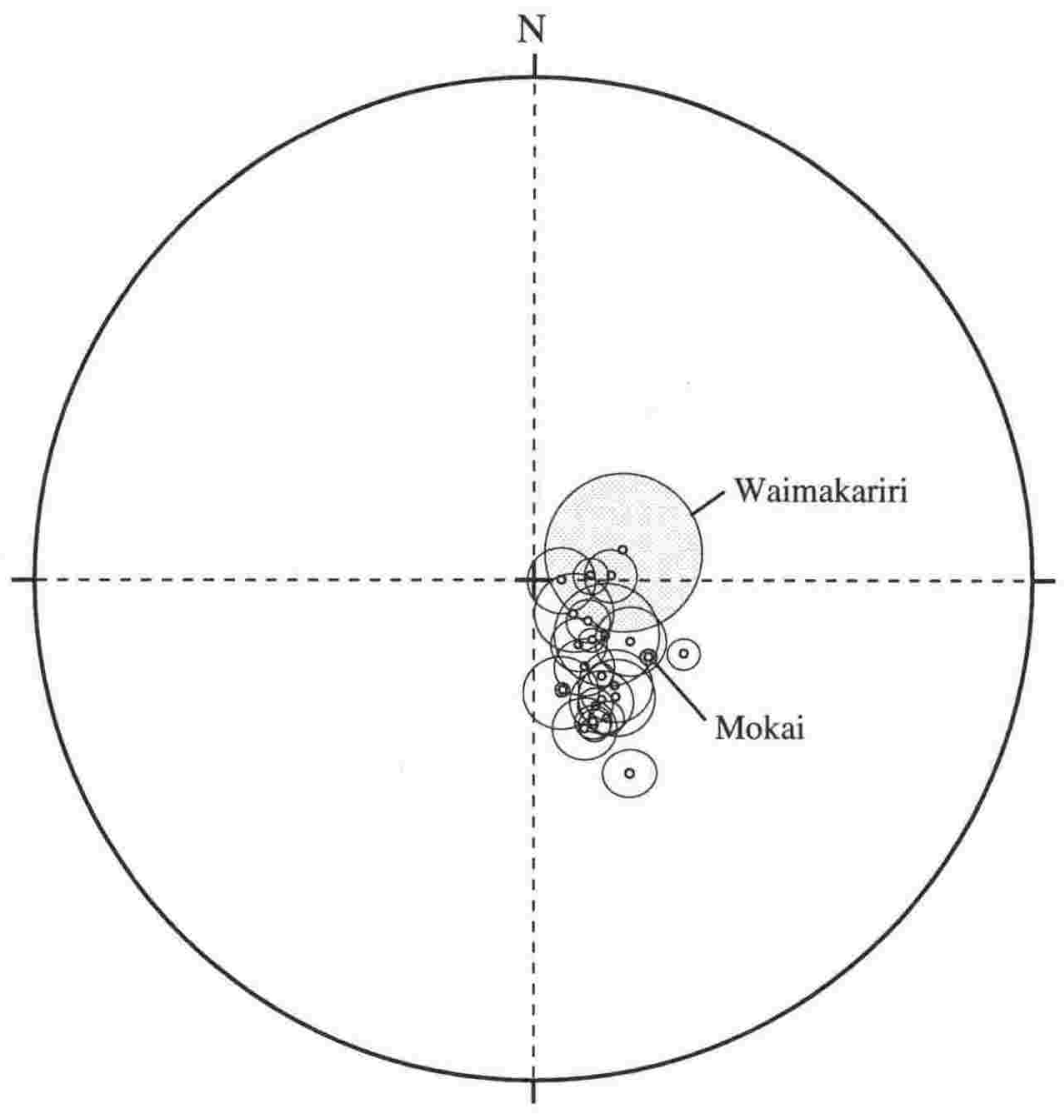

Figure 3.6 Equal area stereoplot of paleomagnetic data from sites of the Mamaku Ignimbrite. Sites plotted on the upper hemisphere as a mean and radius of $95 \%$ confidence $\left(\alpha_{95}\right)$. Sites mapped as Mokai and Waimakariri ignimbrites (shaded) are also shown. Data from Table 3.1. 
Waimakariri Ignimbrite of Fransen (1982), exposed west of Lake Rotorua is also considered a correlative on this basis (Figure 3.6).

The Ahuroa Ignimbrite is characterised by a normal declination, but has a very steeply dipping reversed inclination. Severe overprinting was encountered in this unit. Orthogonal component plots (Figure 3.7a) show curved demagnetisation paths to the origin, indicating a near complete overlap of the primary and secondary coercivity spectra. A stable end point was often not reached, even at high levels of demagnetisation. When viewed on a stereonet (Figure 3.7b), the declination changes little, and the inclination steepens with progressive demagnetisation. From the means of 5 demagnetised sites, an average declination of $004^{\circ}$ and inclination of $67^{\circ}\left(\mathrm{k}=34, \alpha_{95}=11.9^{\circ}\right)$ was obtained (Table 3.1; Figure 3.8). This suggests that Ahuroa records an intermediate paleomagnetic pole position. Ahuroa Ignimbrite was also sampled by Cox (1971) but the direction was not published as he considered the results to be rather unstable, but normally magnetised. Soengkono et al. (1992) reported similar directions (declination, inclination $=346^{\circ}, 82^{\circ}$ and $091^{\circ}, 82^{\circ}$ ) to this study, and interpreted Ahuroa to be reversely magnetised. As for the Mamaku Ignimbrite, the unique paleomagnetic direction of Ahuroa Ignimbrite allows easy identification.

\subsection{GEOMAGNETIC PALEOSECULAR VARIATION}

The geomagnetic field is known to vary in both inclination and declination with time (secular variation). Detectable variation occurs in the order of 10-100 years (Hagstrum and Champion 1994). Therefore individual ignimbrite emplacement events are likely to record different paleomagnetic pole positions if the eruptions are spaced over periods of ca. 100 years. Positive characterisation of an ignimbrite by its paleomagnetic direction depends on the degree of laboratory isolation of the TRM. In this study, a specimen displaying single component magnetism over a wide coercivity range is considered to preserve the original TRM direction. For specimens with a more complicated magnetic history, i.e. overprinting, there are varying degrees of success in removing the overprint completely. This results in a less defined TRM direction. Small variation between sites of the same depositional unit is also likely to be due to tectonic deformation. In most cases this is difficult to compensate for, as steep depositional contacts have been observed which may be misinterpreted as regional deformation. For example, at S17/092993 the Ongatiti Ignimbrite overlies mudstone with a $30^{\circ}$ planar depositional dip (Plate 1 ).

Two units were sampled vertically at sections preserving the thickest sequence of ignimbrite to assess any vertical variations in magnetic record. Whakamaru Ignimbrite was sampled vertically where it reaches ca. $220 \mathrm{~m}$ thick at Maraetai Dam (sites 7-9, ) and the results presented in Table 3.1. Mamaku Ignimbrite was sampled at its type locality (180 $\mathrm{m}$ thick) in the gorge of the Mangaorewa River (sites 12, 89-91; Table 3.1). In both cases, the paleomagnetic remanence direction was similar throughout the exposure, suggesting no 
A W/up

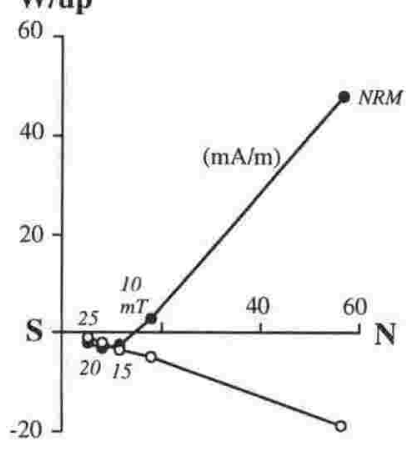

Site 53 (207.1)

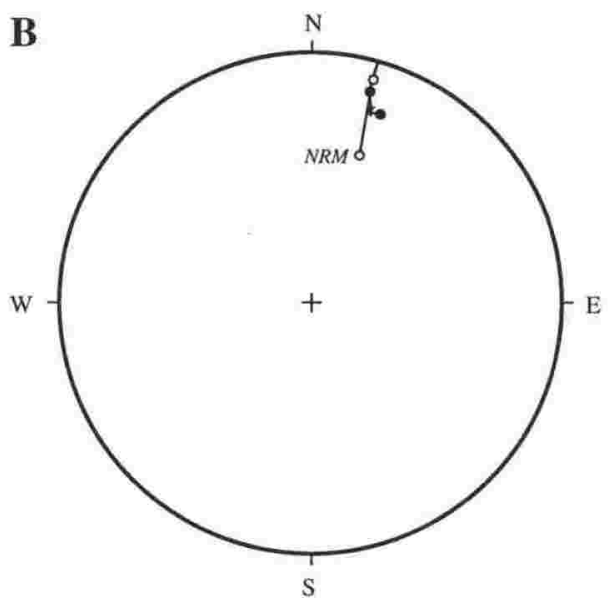

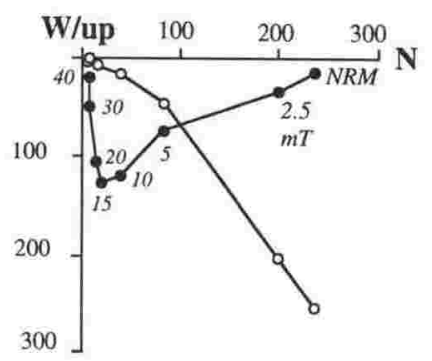

Site 61 (243.1)

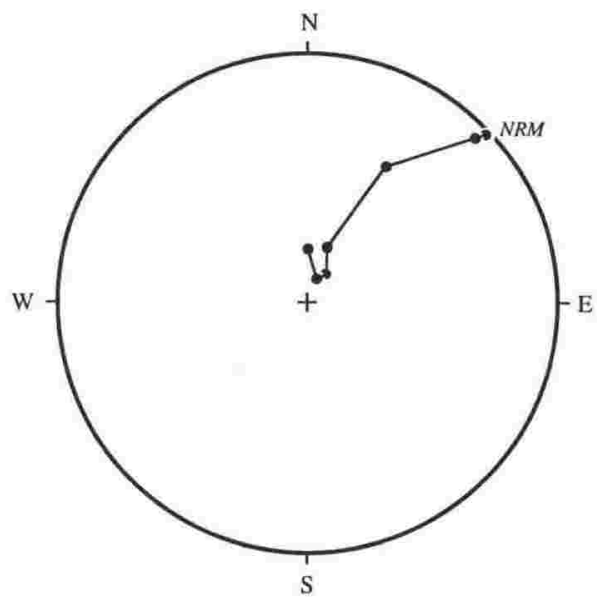

Figure 3.7 Demagnetisation behaviour of two specimens from sites of the Ahuroa Ignimbrite. (A) Orthogonal component plots. (B) Lower hemisphere stereographic projections of the same specimens. Open circles represent negative (normal) inclination. Filled circles represent positive (reversed) inclination. 


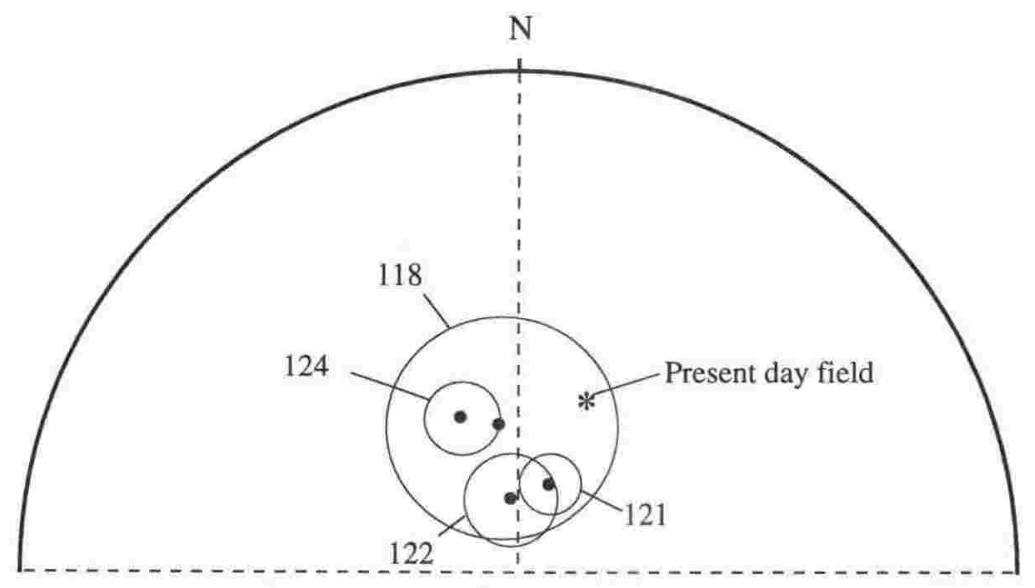

Figure 3.8 Equal area stereoplot of paleomagnetic data from sites of the Ahuroa Ignimbrite. Sites plotted on the lower hemisphere as a mean and radius of $95 \%$ confidence $\left(\alpha_{95}\right)$. Data from Table 3.1. Star represents present day field (on upper hemisphere). 

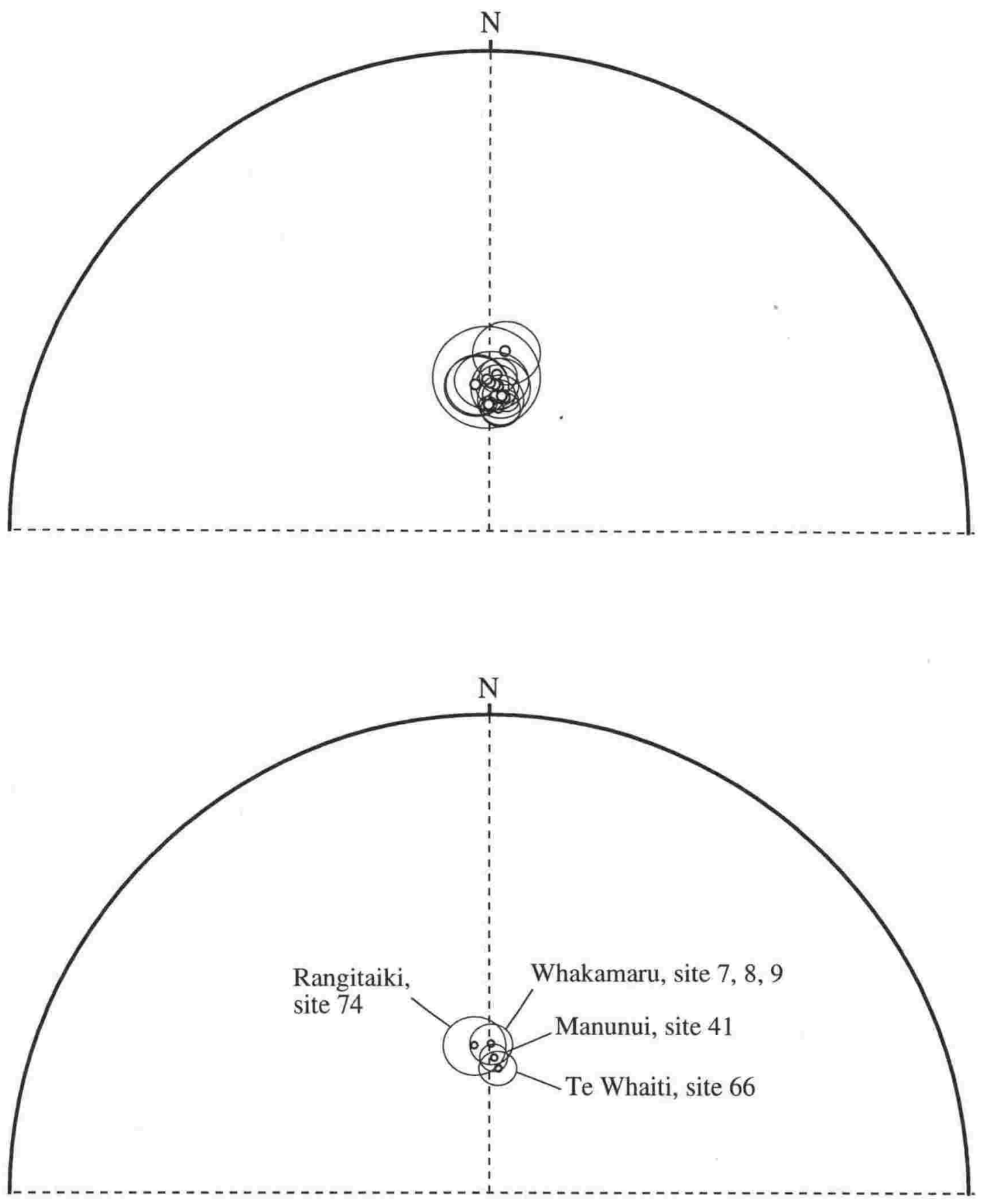

Figure 3.9 Equal area stereoplot of paleomagnetic data from demagnetised sites of the Whakamaru group ignimbrites. Sites plotted on the upper hemisphere as a mean and radius of $95 \%$ confidence $\left(\alpha_{95}\right)$. Data from Table 3.1. The lower plot shows an example of each of the mapped members of the Whakamaru group. 
significant paleosecular variation had taken place during the total period over which the samples cooled through their Curie Point.

Other units that have been

sampled at different stratigraphic positions from different exposures also display identical TRM directions. This has two important implications: (1) thick units that may consist of successive flow pulses were emplaced geologically instantaneously; and (2) other exposures of the same ignimbrite, regardless of their stratigraphic position or distance from each other, have identical pole positions and therefore may be used as a correlation criterion. Lateral homogeneity in paleomagnetism over distances of over $60 \mathrm{~km}$ is shown by widespread sampling of the Mamaku Ignimbrite on the Mamaku Plateau (Table 3.1).

Ignimbrites of the Whakamaru group, variously mapped as Whakamaru, Te Whaiti, Manunui and Rangitikei, have been dated at ca. 0.32 - 0.34 Ma (Houghton et al. 1995). Each of these units display a stable TRM (Table 3.1) and an identical paleomagnetic direction within measurement limits (Figure 3.9). This similarity in recorded magnetic field is consistent with their concordant ages, suggesting the entire group was emplaced within an interval of less than 100 years. This is consistent with the lack of significant depositional breaks or paleosols. The mean TRM direction of the Whakamaru group is significantly different from that of the present day field (Figure 3.9). Of similarly aged late Pleistocene ignimbrites in the Bay of Plenty region studied here, Matahina, Kaingaroa, and Pokai ignimbrites display different paleomagnetic directions to Whakamaru (Table 3.1) and thus can be distinguished on this basis. However, Matahina and Kaingaroa ignimbrites display very similar TRM directions (Figure 3.10). Five sites of Matahina Ignimbrite give a declination of $005^{\circ}$ and inclination of $-52^{\circ}\left(\alpha_{95}=3.2^{\circ}\right)$, and 6 sites of Kaingaroa Ignimbrite give a declination of $009^{\circ}$ and inclination of $-53^{\circ}\left(\alpha_{95}=2.8^{\circ}\right)$ (Table 3.1). Therefore the two units may have been erupted nearly contemporaneously (see Chapter 6).

Oruanui Ignimbrite of the Kawakawa tephra formation (Froggatt and Lowe 1990) erupted ca. $22 \mathrm{ka}$ ago and was the youngest unit sampled for paleomagnetic study (Table 3.1). Nine sites of this ignimbrite were sampled, using plastic cubes. The resulting paleomagnetic data displays more within-site scatter $\left(\alpha_{95} 3-28^{\circ}\right)$ than welded ignimbrites (e.g. Ongatiti Ignimbrite). The nonwelded nature and coarse lapilli, susceptible to rotation and deformation, within the unit is considered to be the cause of the greater variability. The mean paleomagnetic remanence directions for Oruanui Ignimbrite are broadly consistent between sites, and are different from the present day field (Figure 3.11). Froggatt (1988) obtained similar paleomagnetic data for members of the Kawakawa tephra formation.

Older, reversed polarity ignimbrites in the Bay of Plenty region are exposed in the Matahana Basin. Isolation of their TRM is complicated by residual and overlapping normal overprints after demagnetisation. Characterisation of their TRM directions is less successful compared to the late Pleistocene units. The Pukerimu/Tikorangi and Rahopaka ignimbrites differ in inclination and this may provide potential for fingerprinting (Table 3.1, Figure 3.12).

The oldest units examined in this study occur in the King Country region. Geochronological data suggest they were emplaced during the Matuyama Chron (Houghton et 


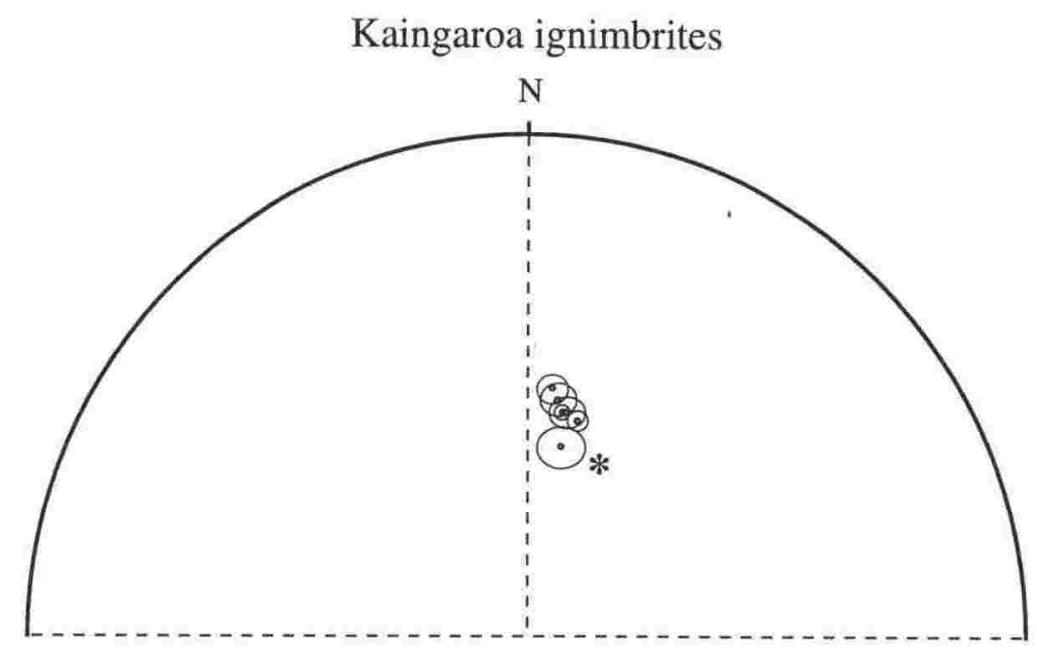

Matahina Ignimbrite
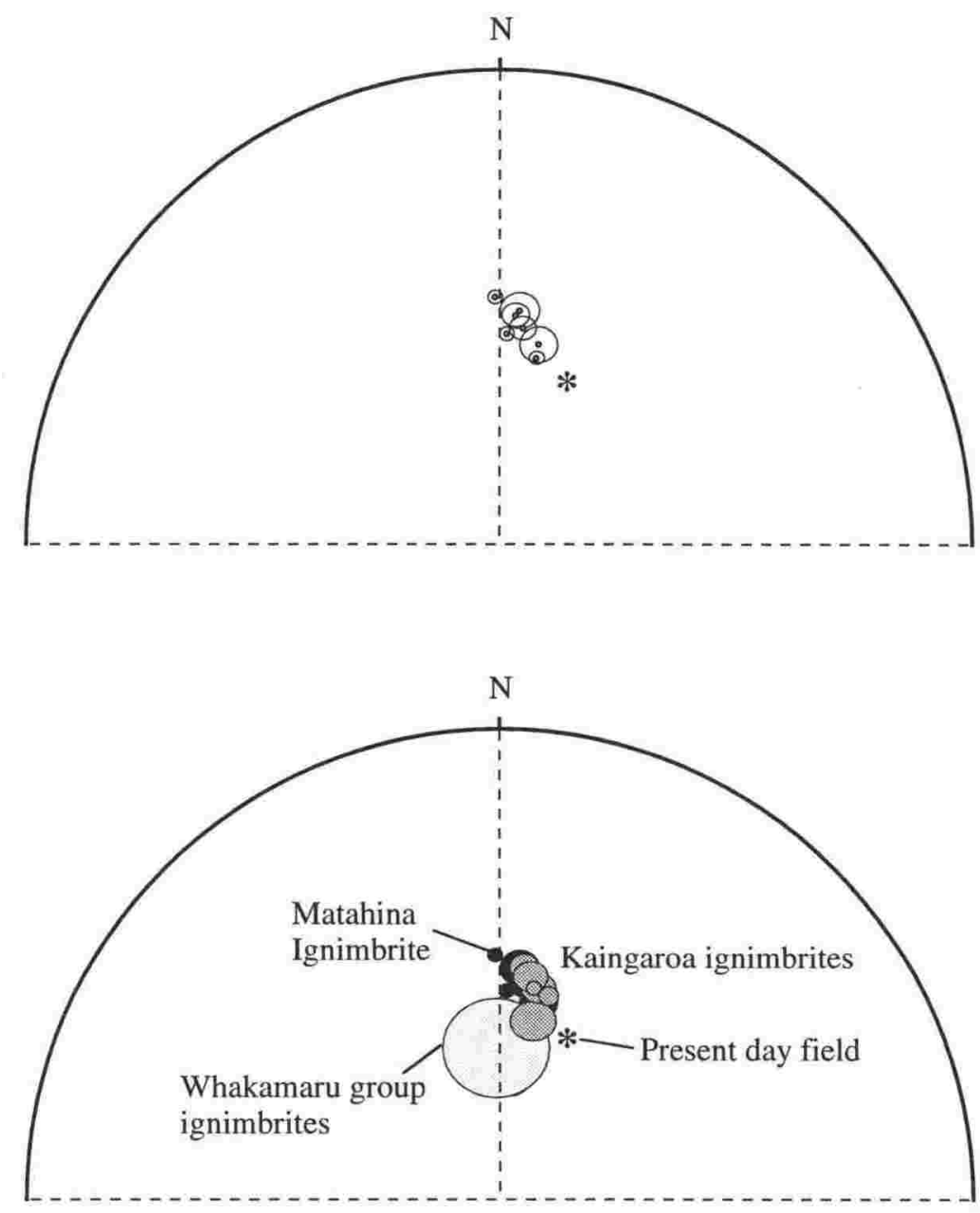

Figure 3.10 Equal area stereoplot of paleomagnetic data from sites of the Matahina and Kaingaroa ignimbrites. Sites plotted on the upper hemisphere as a mean and radius of $95 \%$ confidence $\left(\alpha_{95}\right)$. Data from Table 3.1. The similarity in paleomagnetic direction for both units is exemplified in the lower diagram. The field of Whakamaru group ignimbrites is also plotted for comparison. 


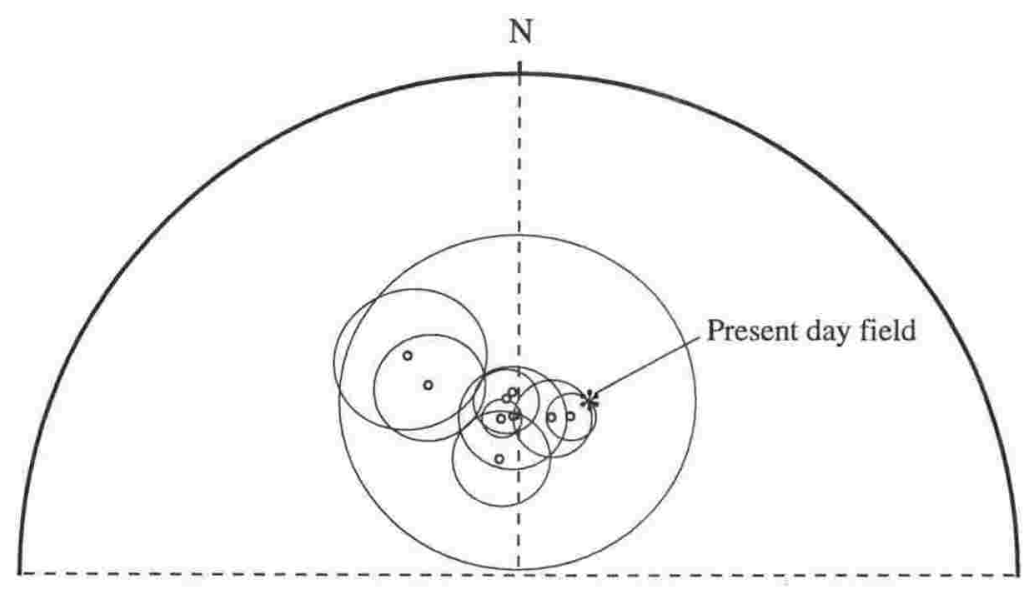

Figure 3.11 Equal area stereoplot of paleomagnetic data from sites of the Oruanui Ignimbrite. Sites plotted on the upper hemisphere as a mean and radius of $95 \%$ confidence $\left(\alpha_{95}\right)$. Data from Table 3.1 .

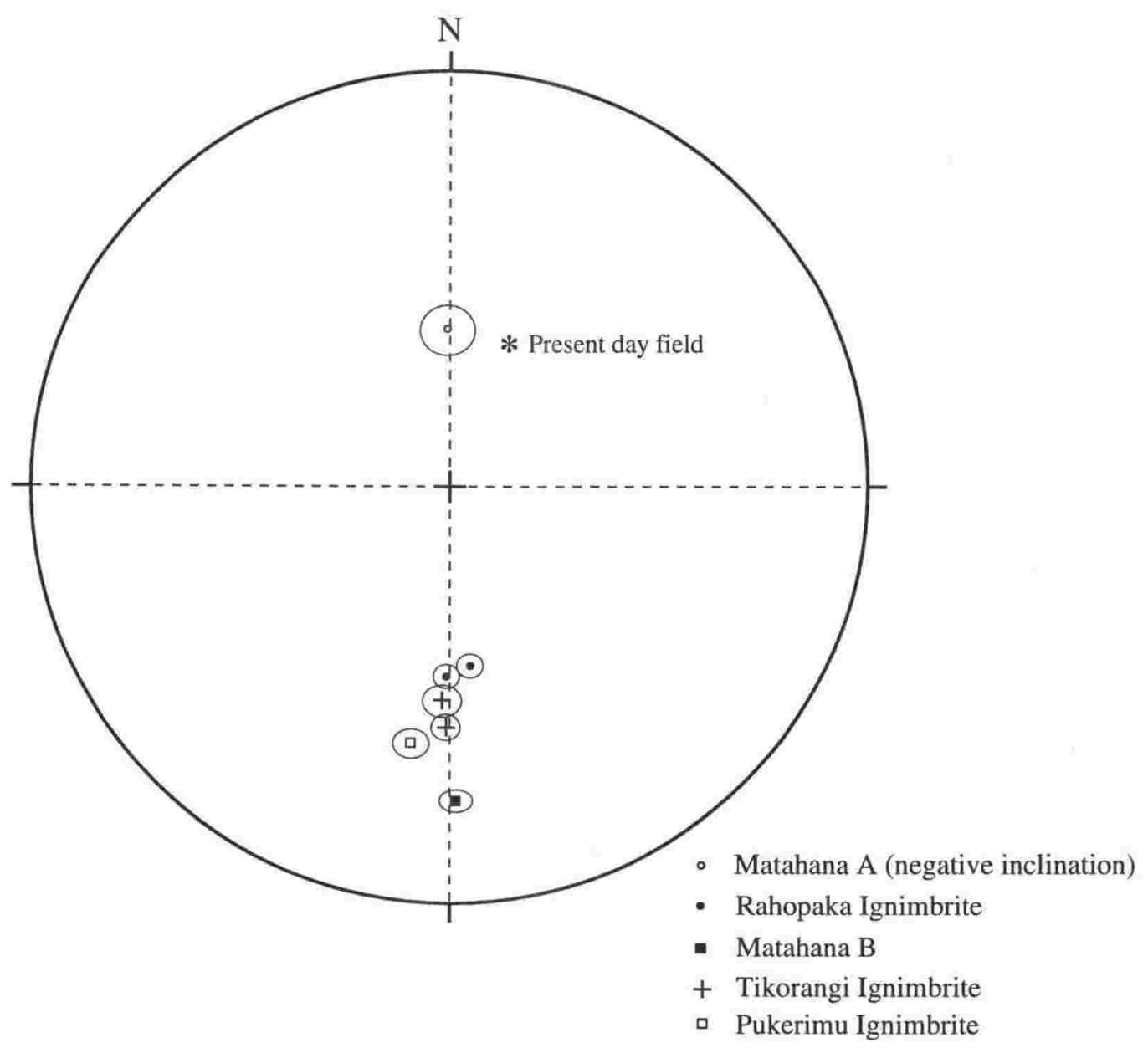

Figure 3.12 Equal area stereoplot of paleomagnetic data from ignimbrites exposed in the Matahana Basin. Sites plotted as a mean and radius of $95 \%$ confidence $\left(\alpha_{95}\right)$. Data from Table 3.1. 


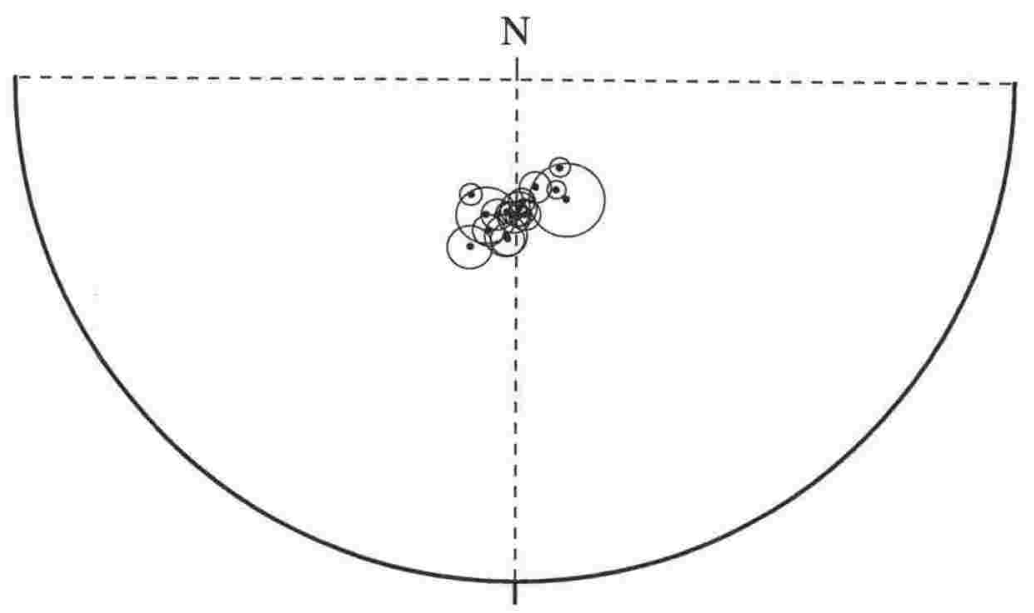

Figure 3.13 Equal area stereoplot of paleomagnetic data from sites of the Ongatiti Ignimbrite. Sites plotted on the lower hemisphere as a mean and radius of $95 \%$ confidence $\left(\alpha_{95}\right)$. Data from Table 3.1. 
al. 1995). The widespread Ongatiti Ignimbrite was sampled at 19 localities spread over a large area (Figure 2.3). Isolation of the TRM was successful for most of these sites (Table 3.1), revealing a consistently reversed polarity pole direction (Figure 3.13). Some of the between site variation in the pole positions reflects tectonism as in places the Ongatiti ignimbrite has been uplifted and tilted. Many of the depositional surfaces of the ignimbrite are erosional and the attitude of deformation could not be determined. The oldest Mangakinosourced unit, Ngaroma Ignimbrite, underlies Ongatiti and was sampled for paleomagnetic study at only one site (site 50) due to the lack of suitable exposure. Data from this site (Table 3.1) reveals a similar TRM to that of Ongatiti. This reflects chance as the two units are separated in age by $340 \mathrm{ka}$ (Houghton et al. 1995).

Ahuroa Ignimbrite displays a unique TRM, reflecting a geomagnetic excursion (see section 3.3.4) and can be easily distinguished from other Mangakino ignimbrites. The youngest Mangakino units studied here, Marshall ignimbrites, were sampled from 3 localities and display a reversed paleomagnetic pole which can be distinguished from Ongatiti and Ngaroma ignimbrites by their more easterly declination (Table 3.1, Figure 3.14). Differences seen between the 3 sites of Marshall may result from the different flow units they represent. At least 3 different flows have been assigned to the Marshall group (Wilson 1986), and the disparate paleosecular signatures indicates temporal differences between each ignimbrite.

\subsection{CONCLUSIONS}

1. Post-emplacement geomagnetic fields have imposed overprints on many ignimbrite units, including those as young as the late Pleistocene (last $400 \mathrm{ka}$ ). Overprinting is most severe in the older units from the Matuyama Chron. These units often display weaker NRM intensities and therefore the original paleomagnetic signal can be difficult to resolve.

2. Most of the TVZ ignimbrites have TRM directions that can be defined with a precision $\left(\alpha_{95}\right)$ of $<5$. A very high precision $\left(\alpha_{95}=1-2\right)$ can be obtained for some units, especially highly welded ignimbrites of the late Pleistocene. The recorded TRM direction can be affected however, by localised tectonic tilting, undetected block rotation, and residual high coercivity magnetic overprinting.

3. The TVZ ignimbrites show no evidence of paleosecular variation during the time of emplacement of individual stratigraphic units. Hence, thick sequences (e.g. $200 \mathrm{~m}$ ) of flow units were erupted and deposited nearly instantaneously.

4. Members of the Whakamaru group ignimbrites, previously mapped under different names, have identical TRM directions. This suggests eruption and emplacement of the entire group 

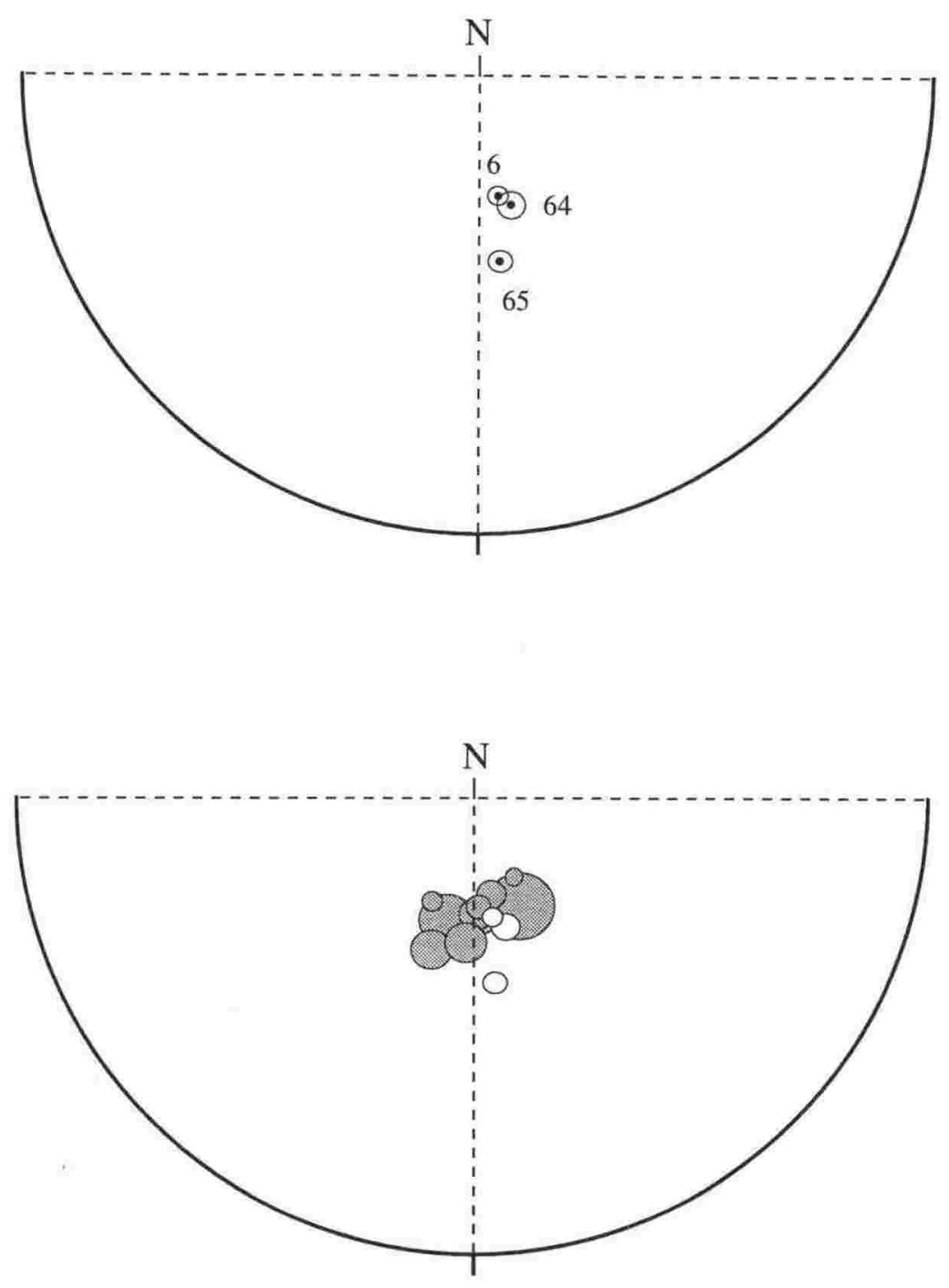

Figure 3.14 Equal area stereoplot of paleomagnetic data from sites of the Marshall ignimbrites. Sites plotted on the lower hemisphere as a mean and radius of $95 \%$ confidence $\left(\alpha_{95}\right)$. Data from Table 3.1. A comparison is made to the Ongatiti Ignimbrite (shaded field) in the lower plot. 
over a short period of time. By analogy to secular variation studies on lava flows elsewhere, this period may be as short as 100 years.

5. Matahina and Kaingaroa ignimbrites, although representing separate events sourced from different calderas, have similar TRM directions. This could either reflect near-simultaneous eruption, or a fortuitous return of the magnetic field over time.

6. Ahuroa and Mamaku ignimbrites both display TRM directions widely different from what is expected from a dipole magnetic field. These units were deposited during transitional phases in the geomagnetic field, and preserve the instantaneous field direction at the time of eruption. 


\section{Chapter 4 \\ GEOCHEMISTRY}

\subsection{INTRODUCTION}

An erupting magma body consists of liquid, which cools rapidly to form glass and phenocrysts. Chemical compositions of minerals and glass are commonly used to identify or fingerprint individual eruptive units. Their chemistry may be unique because they reflect multiple factors which control a magma's composition including: source fractionation, incorporation of crustal partial melts, residence time and eruption temperature.

Few detailed chemical studies have been carried out on TVZ proximal eruptives. Whole pumice and microprobe glass shard analyses of latest Pleistocene and Holocene eruptives from Taupo volcano reveal they are chemically homogeneous with respect to major and trace elements (Froggatt 1982). From single whole pumice analyses of nonwelded units erupted in the last ca. $50 \mathrm{ka}$, Dunbar et al. (1989a) concluded there was little evidence for compositional gradients within magmas of Taupo and Okataina calderas. Similarly, glass inclusions within phenocrysts show little evidence of pre-eruptive compositional variation in these units (Dunbar et al. 1989b). Tephra deposits in areas distal to the TVZ are also chemically homogeneous (Froggatt 1983; Shane 1991; Shane 1993). Note this is in contrast to Hildreth (1981) who suggests that all rhyolitic eruptions greater than $1 \mathrm{~km}^{3}$ in volume are chemically zoned. Although the Holocene eruptives of the TVZ are not compositionally zoned, the older distal tephras may represent only part of the eruption and thus zoning may not have been detected.

Briggs et al. (1993) presented chemical data for 5 units from the Mangakino Caldera: Ngaroma, Ongatiti, Ahuroa, Rocky Hill and Marshall. From their data, they concluded that there was evidence for compositional variation within the units, arising from inefficient magma convection underneath the Mangakino Caldera. However, these data were based on pumices and whole rock samples from welded units that are subject to vapour phase alteration and variations in phenocryst and lithic content.

In this study, samples for geochemical analysis were collected from nonwelded bases of ignimbrites, where available. Samples of pumices containing apparently fresh glass were also collected from welded parts for comparison. Glass separates and Fe-Ti oxides were analysed by electron microprobe in an attempt to fingerprint each unit's chemistry for correlation purposes and to investigate their homogeneity. 
Table 4.1 Composition of whole pumices from welded ignimbrites, determined by XRF.

\begin{tabular}{|c|c|c|c|c|c|c|c|c|c|c|}
\hline $\mathrm{SiO}_{2}$ & $\mathrm{TiO}_{2}$ & $\mathrm{Al}_{2} \mathrm{O}_{3}$ & $\mathrm{FeO}$ & $\mathrm{MnO}$ & $\mathrm{MgO}$ & $\mathrm{CaO}$ & $\mathrm{Na}_{2} \mathrm{O}$ & $\overline{\mathrm{K}} \mathrm{K}_{2} \mathrm{O}$ & $\overline{\mathrm{P}_{2} \mathrm{O}_{5}}$ & LOI \\
\hline B 31 & \multicolumn{10}{|c|}{ Ongatiti Ignimbrite (S17/137913) } \\
\hline 70.54 & 0.38 & 16.73 & 2.76 & 0.04 & 0.40 & 2.30 & 3.64 & 3.09 & 0.06 & 3.13 \\
\hline 71.44 & 0.34 & 15.55 & 2.42 & 0.04 & 0.38 & 2.23 & 3.83 & 3.67 & 0.06 & 3.05 \\
\hline 70.86 & 0.35 & 15.71 & 2.69 & 0.04 & 0.41 & 2.36 & 4.05 & 3.06 & 0.07 & 3.01 \\
\hline 71.58 & 0.37 & 15.29 & 2.59 & 0.05 & 0.37 & 2.09 & 3.63 & 3.90 & 0.07 & 3.05 \\
\hline 70.39 & 0.36 & 16.76 & 2.84 & 0.04 & 0.37 & 2.33 & 3.62 & 3.16 & 0.06 & 3.89 \\
\hline 71.51 & 0.35 & 15.16 & 2.80 & 0.05 & 0.40 & 2.08 & 3.43 & 3.92 & 0.07 & 4.05 \\
\hline B 32 & \multicolumn{10}{|c|}{ Ongatiti Ignimbrite (S16/198218) } \\
\hline 70.66 & 0.37 & 15.60 & 3.01 & 0.08 & 0.52 & 2.14 & 3.84 & 2.99 & 0.09 & 3.35 \\
\hline 68.71 & 0.39 & 16.89 & 3.46 & 0.12 & 0.54 & 2.35 & 3.96 & 2.94 & 0.08 & 5.22 \\
\hline 71.45 & 0.35 & 15.43 & 2.95 & 0.06 & 0.55 & 2.07 & 3.70 & 2.74 & 0.07 & 4.47 \\
\hline 70.30 & 0.34 & 16.14 & 2.77 & 0.06 & 0.49 & 2.19 & 3.91 & 3.04 & 0.09 & 3.63 \\
\hline B 34 & \multicolumn{10}{|c|}{ Rocky Hill Ignimbrite (S16/117110) } \\
\hline 71.28 & 0.32 & 16.55 & 2.03 & 0.08 & 0.32 & 1.86 & 3.63 & 3.14 & 0.07 & 5.07 \\
\hline 74.64 & 0.22 & 14.85 & 1.42 & 0.04 & 0.24 & 1.53 & 3.06 & 3.88 & 0.10 & 4.03 \\
\hline 71.19 & 0.33 & 16.74 & 1.85 & 0.06 & 0.36 & 2.32 & 3.82 & 3.07 & 0.11 & 3.92 \\
\hline 71.93 & 0.34 & 16.04 & 2.03 & 0.08 & 0.41 & 2.01 & 3.65 & 3.12 & 0.08 & 4.63 \\
\hline B 35 & \multicolumn{10}{|c|}{ Whakamaru ignimbrite (U18/749549) } \\
\hline 72.34 & 0.33 & 14.83 & 2.35 & 0.06 & 0.68 & 2.41 & 3.54 & 3.29 & 0.06 & 2.17 \\
\hline 72.57 & 0.30 & 14.64 & 2.02 & 0.06 & 0.49 & 2.18 & 3.46 & 3.66 & 0.05 & 2.53 \\
\hline 72.89 & 0.36 & 14.50 & 2.30 & 0.06 & 0.65 & 2.52 & 3.38 & 3.17 & 0.07 & 1.95 \\
\hline 73.01 & 0.30 & 14.23 & 1.89 & 0.06 & 0.48 & 2.15 & 3.55 & 3.76 & 0.06 & 2.19 \\
\hline 73.55 & 0.26 & 14.08 & 1.75 & 0.05 & 0.42 & 2.18 & 3.54 & 3.45 & 0.05 & 2.21 \\
\hline
\end{tabular}

Analyses recalculated to $100 \%$ on a volatile free basis. LOI $=$ original loss on ignition.

Determined by a Philips PW 1404 automatic sequential X-ray fluorescence spectrometer. The procedure, operating conditions and detection limits are described in Palmer (1990) 


\subsection{GEOCHEMISTRY OF WHOLE PUMICES AND GLASS FROM WELDED IGNIMBRITES}

Pumice clasts were collected from the main flow units of three ignimbrites: Ongatiti, Rocky Hill and the Rangitaiki member of the Whakamaru group ignimbrites. These were individually crushed and made into discs for whole rock XRF major element analysis (Table 4.1). Aliquots of each pumice were magnetically separated to produce pure glass separates for microprobe analysis (Table 4.2). For the Ongatiti, Rocky Hill and Whakamaru ignimbrites, nonwelded basal ash was available from some sites, and the glass was microprobed for comparative purposes (Table 4.3, Appendix 1).

A FeO/CaO binary plot of all data sets for each ignimbrite (Figure 4.1) reveal a large separation between the bulk XRF analyses and glass microprobe analyses of the same samples. The bulk pumice samples consist of glass + phenocrysts, while the glass analyses reflect the liquid phase only. Therefore the enrichment in $\mathrm{FeO}$ and $\mathrm{CaO}$ is due to the minerals present in the samples, such as feldspar and ferromagnesian phases. The more pronounced scatter observed in the bulk analyses, as compared to the single-shard compositions, reflects differing crystal contents in each pumice.

Glass microprobe analyses from nonwelded basal ash from Ongatiti, Rocky Hill and Whakamaru ignimbrites plot in tight groups (Figure 4.1) and indicate no compositional zonation. In contrast, glass analyses from pumice are depleted in many oxides. Mobile element contents of single shards from pumices show a marked depletion in $\mathrm{Cl}$ and $\mathrm{Na}_{2} \mathrm{O}$, as well as less volatile oxides such as $\mathrm{FeO}$ and $\mathrm{CaO}$, in comparison with glass from nonwelded zones. However, $\mathrm{K}_{2} \mathrm{O}$ is generally greater in pumice glasses (Table 4.2, 4.3). The samples from pumices within welded units have therefore experienced movement of volatile and mobile elements. High $\mathrm{K}_{2} \mathrm{O} / \mathrm{Na}_{2} \mathrm{O}$ ratios in the glass analyses are indicative of alkali exchange with groundwater, which often takes place during devitrification (Scott 1971). Alteration such as this has been documented from other welded ignimbrites (Hildreth and Mahood 1985). Compositional variation is expected in TVZ ignimbrites as they are welded and have experienced vapour phase alteration (Carr 1981, 1984).

Briggs et al. (1993) used whole pumice XRF analysis to document compositional variation in TVZ magmas. Microprobe data from a nonwelded base of Ongatiti Ignimbrite revealed a homogeneous glass composition which plotted as an extension of their bulk analyses. This was interpreted by Briggs et al. (1993) as being evidence for homogeneous glass, but variable pumice chemistry. Negative $\mathrm{Ce}$ anomalies were noted in samples analysed by Briggs et al. (1993) and were interpreted to represent alteration of the pumice due to weathering or hot oxidising gases percolating through the ignimbrite during and/or after deposition. This study concludes that the variability in pumice composition is mostly due to inhomogeneous distribution of phenocrysts and various degrees of alteration. This would 
Table 4.2 Composition of glass in pumice from welded ignimbrites, determined by EMA

\begin{tabular}{|c|c|c|c|c|c|c|c|c|c|}
\hline $\mathrm{SiO}_{2}$ & $\mathrm{Al}_{2} \mathrm{O}_{3}$ & $\overline{\mathrm{TiO}_{2}}$ & $\mathrm{FeO}$ & $\mathrm{MgO}$ & $\mathrm{CaO}$ & $\mathrm{Na}_{2} \mathrm{O}$ & $\overline{\mathrm{K}_{2} \mathrm{O}}$ & $\overline{\mathrm{Cl}}$ & Water \\
\hline B 31 & \multicolumn{9}{|c|}{ Ongatiti Ignimbrite (S17/137913) } \\
\hline 78.52 & 12.22 & 0.13 & 0.43 & 0.03 & 0.56 & 3.20 & 4.91 & 0.00 & 4.27 \\
\hline 78.18 & 12.37 & 0.13 & 0.46 & 0.09 & 0.55 & 3.40 & 4.82 & 0.00 & 4.63 \\
\hline 77.75 & 12.43 & 0.18 & 0.51 & 0.07 & 0.72 & 2.56 & 5.69 & 0.10 & 11.41 \\
\hline 77.45 & 12.22 & 0.13 & 1.13 & 0.08 & 0.74 & 3.43 & 4.64 & 0.20 & 3.16 \\
\hline 77.80 & 12.50 & 0.06 & 0.92 & 0.00 & 0.66 & 2.68 & 5.36 & 0.03 & 5.38 \\
\hline 78.36 & 12.22 & 0.08 & 0.44 & 0.00 & 0.65 & 2.73 & 5.47 & 0.02 & 4.52 \\
\hline B 32 & \multicolumn{9}{|c|}{ Ongatiti Ignimbrite (S16/198218) } \\
\hline 77.86 & 12.04 & 0.15 & 1.22 & 0.09 & 0.85 & 3.66 & 3.88 & 0.27 & 3.57 \\
\hline 79.09 & 12.44 & 0.13 & 1.09 & 0.05 & 0.72 & 2.75 & 3.53 & 0.23 & 4.56 \\
\hline 78.42 & 12.03 & 0.10 & 0.89 & 0.07 & 0.74 & 3.29 & 4.12 & 0.35 & 9.36 \\
\hline 91.75 & 4.98 & 0.12 & 0.17 & 0.31 & 0.46 & 0.82 & 1.36 & 0.04 & 10.11 \\
\hline 78.92 & 12.10 & 0.10 & 0.73 & 0.10 & 0.92 & 3.57 & 3.33 & 0.22 & 4.47 \\
\hline 79.24 & 11.82 & 0.08 & 0.88 & 0.11 & 0.69 & 3.74 & 3.24 & 0.21 & 5.32 \\
\hline 78.64 & 12.22 & 0.18 & 0.79 & 0.09 & 0.88 & 3.63 & 3.36 & 0.22 & 4.06 \\
\hline B 34 & \multicolumn{9}{|c|}{ Rocky Hill Ignimbrite (S16/117110) } \\
\hline 79.29 & 12.14 & 0.12 & 0.27 & 0.00 & 0.88 & 3.61 & 3.59 & 0.10 & 4.63 \\
\hline 78.75 & 12.17 & 0.13 & 0.29 & 0.00 & 0.80 & 3.68 & 4.05 & 0.13 & 8.32 \\
\hline 78.15 & 12.45 & 0.12 & 0.40 & 0.01 & 0.96 & 3.83 & 3.91 & 0.15 & 9.46 \\
\hline 76.92 & 13.03 & 0.14 & 0.48 & 0.06 & 1.02 & 4.14 & 4.13 & 0.09 & 14.80 \\
\hline 78.69 & 12.39 & 0.18 & 0.32 & 0.02 & 1.00 & 3.73 & 3.58 & 0.08 & 7.61 \\
\hline 78.69 & 12.60 & 0.16 & 0.29 & 0.00 & 1.03 & 3.53 & 3.63 & 0.10 & 7.38 \\
\hline 78.59 & 12.57 & 0.10 & 0.48 & 0.05 & 0.99 & 3.49 & 3.61 & 0.11 & 8.34 \\
\hline 78.23 & 12.97 & 0.07 & 0.31 & 0.02 & 0.95 & 3.84 & 3.53 & 0.10 & 10.44 \\
\hline 77.67 & 13.34 & 0.09 & 0.28 & 0.01 & 0.74 & 4.00 & 3.77 & 0.10 & 13.27 \\
\hline 77.58 & 13.16 & 0.14 & 0.67 & 0.01 & 1.08 & 6.10 & 1.15 & 0.11 & 12.44 \\
\hline 79.37 & 12.21 & 0.07 & 0.37 & 0.01 & 0.62 & 3.60 & 3.65 & 0.09 & 3.94 \\
\hline B 35 & \multicolumn{9}{|c|}{ Whakamaru ignimbrite (U18/749549) } \\
\hline 78.36 & 12.16 & 0.12 & 0.97 & 0.17 & 0.57 & 2.74 & 4.72 & 0.18 & 2.41 \\
\hline 77.98 & 12.21 & 0.22 & 0.82 & 0.06 & 0.67 & 2.64 & 5.24 & 0.16 & 2.49 \\
\hline 78.29 & 12.16 & 0.22 & 0.97 & 0.11 & 0.61 & 2.57 & 4.90 & 0.17 & 2.80 \\
\hline 77.85 & 12.05 & 0.23 & 0.88 & 0.10 & 0.65 & 2.77 & 5.25 & 0.23 & 3.54 \\
\hline 77.68 & 12.28 & 0.21 & 0.90 & 0.15 & 0.59 & 2.58 & 5.37 & 0.26 & 5.27 \\
\hline
\end{tabular}

Analyses recalculated to $100 \%$ on a volatile-free basis. All Fe as FeO. Determined by a Jeol 733 Superprobe using a $8 \mathrm{nA}$ current at $15 \mathrm{kV}$ and a $20 \mu \mathrm{m}$ beam diameter. Method and standards as in Shane and Froggatt (1992). 
Table 4.3 Composition of glasses from nonwelded ignimbrites and fallout beds from the TVZ, determined by EMA.

\begin{tabular}{|c|c|c|c|c|c|c|c|c|c|c|c|c|}
\hline Tephra & $\mathrm{SiO}_{2}$ & $\mathrm{Al}_{2} \mathrm{O}_{3}$ & $\mathrm{TiO}_{2}$ & $\mathrm{FeO}$ & $\mathrm{MnO}$ & $\mathrm{MgO}$ & $\mathrm{CaO}$ & $\mathrm{Na}_{2} \mathrm{O}$ & $\mathrm{K}_{2} \mathrm{O}$ & $\mathrm{Cl}$ & water & $\mathrm{n}$ \\
\hline B21 Mamaku & $\begin{array}{l}77.83 \\
(0.22)\end{array}$ & $\begin{array}{l}12.34 \\
(0.13)\end{array}$ & $\begin{array}{c}0.08 \\
(0.04)\end{array}$ & $\begin{array}{c}1.04 \\
(0.06)\end{array}$ & $\begin{array}{c}0.05 \\
(0.04)\end{array}$ & $\begin{array}{c}0.09 \\
(0.03)\end{array}$ & $\begin{array}{c}0.81 \\
(0.06)\end{array}$ & $\begin{array}{c}3.90 \\
(0.15)\end{array}$ & $\begin{array}{c}3.68 \\
(0.09)\end{array}$ & $\begin{array}{c}0.20 \\
(0.03)\end{array}$ & $\begin{array}{c}2.70 \\
(0.96)\end{array}$ & 15 \\
\hline B 55 Kaingaroa & $\begin{array}{r}77.49 \\
(0.32)\end{array}$ & $\begin{array}{l}12.27 \\
(0.23)\end{array}$ & $\begin{array}{c}0.14 \\
(0.02)\end{array}$ & $\begin{array}{c}1.29 \\
(0.09)\end{array}$ & $\begin{array}{c}0.05 \\
(0.03)\end{array}$ & $\begin{array}{c}0.10 \\
(0.02)\end{array}$ & $\begin{array}{c}0.89 \\
(0.08)\end{array}$ & $\begin{array}{c}3.64 \\
(0.11)\end{array}$ & $\begin{array}{c}3.92 \\
(0.09)\end{array}$ & $\begin{array}{c}0.22 \\
(0.05)\end{array}$ & $\begin{array}{c}1.58 \\
(1.04)\end{array}$ & 12 \\
\hline B 56 Kaingaroa & $\begin{array}{l}77.92 \\
(0.24)\end{array}$ & $\begin{array}{l}12.21 \\
(0.11)\end{array}$ & $\begin{array}{c}0.13 \\
(0.03)\end{array}$ & $\begin{array}{c}1.21 \\
(0.07)\end{array}$ & $\begin{array}{c}0.05 \\
(0.04)\end{array}$ & $\begin{array}{c}0.10 \\
(0.03)\end{array}$ & $\begin{array}{c}0.82 \\
(0.06)\end{array}$ & $\begin{array}{c}3.58 \\
(0.08)\end{array}$ & $\begin{array}{c}3.81 \\
(0.09)\end{array}$ & $\begin{array}{c}0.19 \\
(0.03)\end{array}$ & $\begin{array}{c}1.85 \\
(0.87)\end{array}$ & 11 \\
\hline B 52 Matahina & $\begin{array}{l}77.70 \\
(0.15)\end{array}$ & $\begin{array}{l}12.37 \\
(0.08)\end{array}$ & $\begin{array}{c}0.10 \\
(0.04)\end{array}$ & $\begin{array}{c}1.06 \\
(0.05)\end{array}$ & $\begin{array}{c}0.04 \\
(0.04)\end{array}$ & $\begin{array}{c}0.08 \\
(0.02)\end{array}$ & $\begin{array}{c}0.84 \\
(0.03)\end{array}$ & $\begin{array}{c}3.90 \\
(0.13)\end{array}$ & $\begin{array}{c}3.67 \\
(0.07)\end{array}$ & $\begin{array}{c}0.24 \\
(0.03)\end{array}$ & $\begin{array}{c}3.62 \\
(0.50)\end{array}$ & 12 \\
\hline 83/1 Matahina* & $\begin{array}{l}77.38 \\
(0.45)\end{array}$ & $\begin{array}{c}12.54 \\
(0.27)\end{array}$ & $\begin{array}{c}0.12 \\
(0.02)\end{array}$ & $\begin{array}{c}1.07 \\
(0.07)\end{array}$ & - & $\begin{array}{c}0.11 \\
(0.02)\end{array}$ & $\begin{array}{c}0.88 \\
(0.05)\end{array}$ & $\begin{array}{c}3.91 \\
(0.15)\end{array}$ & $\begin{array}{c}3.83 \\
(0.17)\end{array}$ & $\begin{array}{c}0.18 \\
(0.02)\end{array}$ & $\begin{array}{c}5.04 \\
(1.95)\end{array}$ & 13 \\
\hline B $28^{*}$ & $\begin{array}{r}77.80 \\
(0.16)\end{array}$ & $\begin{array}{l}12.00 \\
(0.10)\end{array}$ & $\begin{array}{c}0.13 \\
(0.03)\end{array}$ & $\begin{array}{c}0.93 \\
(0.09)\end{array}$ & . & $\begin{array}{c}0.12 \\
(0.02)\end{array}$ & $\begin{array}{c}0.80 \\
(0.05)\end{array}$ & $\begin{array}{c}3.37 \\
(0.06)\end{array}$ & $\begin{array}{c}4.63 \\
(0.11)\end{array}$ & $\begin{array}{c}0.22 \\
(0.04)\end{array}$ & $\begin{array}{c}2.73 \\
(0.57)\end{array}$ & 7 \\
\hline B $33 *$ & $\begin{array}{l}75.67 \\
(0.41)\end{array}$ & $\begin{array}{l}13.00 \\
(0.15)\end{array}$ & $\begin{array}{c}0.19 \\
(0.04)\end{array}$ & $\begin{array}{c}2.12 \\
(0.10)\end{array}$ & - & $\begin{array}{c}0.15 \\
(0.03)\end{array}$ & $\begin{array}{c}1.33 \\
(0.05)\end{array}$ & $\begin{array}{c}4.13 \\
(0.27)\end{array}$ & $\begin{array}{c}3.21 \\
(0.13)\end{array}$ & $\begin{array}{c}0.21 \\
(0.02)\end{array}$ & $\begin{array}{c}6.7 \\
(0.99)\end{array}$ & 9 \\
\hline B 49 Ongatiti* & $\begin{array}{l}77.38 \\
(0.19)\end{array}$ & $\begin{array}{l}12.13 \\
(0.08)\end{array}$ & $\begin{array}{c}0.15 \\
(0.04)\end{array}$ & $\begin{array}{c}1.30 \\
(0.07)\end{array}$ & - & $\begin{array}{c}0.11 \\
(0.03)\end{array}$ & $\begin{array}{c}0.94 \\
(0.06)\end{array}$ & $\begin{array}{c}3.64 \\
(0.10)\end{array}$ & $\begin{array}{c}4.05 \\
(0.11)\end{array}$ & $\begin{array}{c}0.30 \\
(0.03)\end{array}$ & $\begin{array}{c}4.27 \\
(0.54)\end{array}$ & 10 \\
\hline B50 Rocky Hill* & $\begin{array}{r}77.69 \\
(0.29)\end{array}$ & $\begin{array}{r}12.13 \\
(0.10)\end{array}$ & $\begin{array}{c}0.13 \\
(0.03)\end{array}$ & $\begin{array}{c}1.21 \\
(0.14)\end{array}$ & - & $\begin{array}{c}0.11 \\
(0.03)\end{array}$ & $\begin{array}{c}0.96 \\
(0.13)\end{array}$ & $\begin{array}{c}3.67 \\
(0.10)\end{array}$ & $\begin{array}{c}3.88 \\
(0.15)\end{array}$ & $\begin{array}{c}0.24 \\
(0.02)\end{array}$ & $\begin{array}{c}3.70 \\
(0.40)\end{array}$ & 12 \\
\hline B51 (clear)* & $\begin{array}{c}77.44 \\
(0.32)\end{array}$ & $\begin{array}{c}12.13 \\
(0.15)\end{array}$ & $\begin{array}{c}0.09 \\
(0.08)\end{array}$ & $\begin{array}{c}1.51 \\
(0.12)\end{array}$ & - & $\begin{array}{c}0.06 \\
(0.03)\end{array}$ & $\begin{array}{c}0.60 \\
(0.21)\end{array}$ & $\begin{array}{c}4.37 \\
(0.13)\end{array}$ & $\begin{array}{c}3.61 \\
(0.22)\end{array}$ & $\begin{array}{c}0.21 \\
(0.13)\end{array}$ & $\begin{array}{c}7.65 \\
(2.17)\end{array}$ & 6 \\
\hline (brown)* & $\begin{array}{l}76.02 \\
(0.59)\end{array}$ & $\begin{array}{l}12.63 \\
(0.24)\end{array}$ & $\begin{array}{c}0.18 \\
(0.03)\end{array}$ & $\begin{array}{c}2.07 \\
(0.11)\end{array}$ & - & $\begin{array}{c}0.10 \\
(0.02)\end{array}$ & $\begin{array}{c}1.00 \\
(0.07)\end{array}$ & $\begin{array}{c}4.45 \\
(0.15)\end{array}$ & $\begin{array}{l}3.37 \\
(0.12)\end{array}$ & $\begin{array}{c}0.19 \\
(0.02)\end{array}$ & $\begin{array}{c}3.66 \\
(1.23)\end{array}$ & 13 \\
\hline B 53 Unit D fall* & $\begin{array}{r}76.96 \\
(1.120\end{array}$ & $\begin{array}{l}12.18 \\
(0.42)\end{array}$ & $\begin{array}{c}0.13 \\
(0.05)\end{array}$ & $\begin{array}{c}1.63 \\
(0.37)\end{array}$ & - & $\begin{array}{c}0.07 \\
(0.02)\end{array}$ & $\begin{array}{c}0.77 \\
(0.21)\end{array}$ & $\begin{array}{c}4.32 \\
(0.16)\end{array}$ & $\begin{array}{c}3.73 \\
(0.11)\end{array}$ & $\begin{array}{c}0.21 \\
(0.06)\end{array}$ & $\begin{array}{c}4.91 \\
(0.73)\end{array}$ & 10 \\
\hline B 54 Unit D flow* & $\begin{array}{l}77.27 \\
(0.69)\end{array}$ & $\begin{array}{l}12.10 \\
(0.28)\end{array}$ & $\begin{array}{c}0.13 \\
(0.05)\end{array}$ & $\begin{array}{c}1.58 \\
(0.26)\end{array}$ & - & $\begin{array}{c}0.08 \\
(0.03)\end{array}$ & $\begin{array}{c}0.73 \\
(0.18)\end{array}$ & $\begin{array}{c}4.25 \\
(0.09)\end{array}$ & $\begin{array}{c}3.66 \\
(0.14)\end{array}$ & $\begin{array}{c}0.21 \\
(0.03)\end{array}$ & $\begin{array}{c}4.48 \\
(1.26)\end{array}$ & 11 \\
\hline Downer 1 & $\begin{array}{l}77.82 \\
(0.72)\end{array}$ & $\begin{array}{l}12.37 \\
(0.14)\end{array}$ & $\begin{array}{c}0.10 \\
(0.04)\end{array}$ & $\begin{array}{l}1.02 \\
(0.07)\end{array}$ & $\begin{array}{c}0.05 \\
(0.03)\end{array}$ & $\begin{array}{c}0.11 \\
(0.02)\end{array}$ & $\begin{array}{c}0.89 \\
(0.05)\end{array}$ & $\begin{array}{c}3.69 \\
(0.16)\end{array}$ & $\begin{array}{c}3.73 \\
(0.82)\end{array}$ & $\begin{array}{c}0.22 \\
(0.05)\end{array}$ & $\begin{array}{c}5.40 \\
(0.99)\end{array}$ & 12 \\
\hline Downer 2 & $\begin{array}{l}77.97 \\
(0.27)\end{array}$ & $\begin{array}{l}12.24 \\
(0.12)\end{array}$ & $\begin{array}{c}0.15 \\
(0.04)\end{array}$ & $\begin{array}{c}1.07 \\
(0.05)\end{array}$ & $\begin{array}{c}0.06 \\
(0.04)\end{array}$ & $\begin{array}{c}0.15 \\
(0.02)\end{array}$ & $\begin{array}{c}1.01 \\
(0.05)\end{array}$ & $\begin{array}{c}3.63 \\
(0.30)\end{array}$ & $\begin{array}{c}3.50 \\
(0.31)\end{array}$ & $\begin{array}{c}0.22 \\
(0.04)\end{array}$ & $\begin{array}{c}6.17 \\
(0.79)\end{array}$ & 12 \\
\hline Downer 3 & $\begin{array}{l}77.16 \\
(0.52)\end{array}$ & $\begin{array}{l}12.54 \\
(0.20)\end{array}$ & $\begin{array}{c}0.18 \\
(0.05)\end{array}$ & $\begin{array}{l}1.21 \\
(0.10)\end{array}$ & $\begin{array}{c}0.05 \\
(0.02)\end{array}$ & $\begin{array}{c}0.16 \\
(0.04)\end{array}$ & $\begin{array}{c}1.12 \\
(0.13)\end{array}$ & $\begin{array}{c}3.85 \\
(0.23)\end{array}$ & $\begin{array}{c}3.52 \\
(0.21)\end{array}$ & $\begin{array}{c}0.21 \\
(0.05)\end{array}$ & $\begin{array}{c}5.25 \\
(0.93)\end{array}$ & 12 \\
\hline Downer 4 & $\begin{array}{r}77.69 \\
(0.16)\end{array}$ & $\begin{array}{l}12.36 \\
(0.12)\end{array}$ & $\begin{array}{c}0.08 \\
(0.03)\end{array}$ & $\begin{array}{c}0.96 \\
(0.05)\end{array}$ & $\begin{array}{c}0.05 \\
(0.02)\end{array}$ & $\begin{array}{c}0.09 \\
(0.02)\end{array}$ & $\begin{array}{c}0.78 \\
(0.03)\end{array}$ & $\begin{array}{c}3.74 \\
(0.21)\end{array}$ & $\begin{array}{l}4.00 \\
(0.17)\end{array}$ & $\begin{array}{c}0.24 \\
(0.04)\end{array}$ & $\begin{array}{c}4.45 \\
(0.77)\end{array}$ & 12 \\
\hline Downer 5 & $\begin{array}{l}77.66 \\
(0.17)\end{array}$ & $\begin{array}{l}12.37 \\
(0.10)\end{array}$ & $\begin{array}{c}0.07 \\
(0.03)\end{array}$ & $\begin{array}{c}0.97 \\
(0.05)\end{array}$ & $\begin{array}{c}0.05 \\
(0.03)\end{array}$ & $\begin{array}{c}0.08 \\
(0.02)\end{array}$ & $\begin{array}{c}0.73 \\
(0.05)\end{array}$ & $\begin{array}{c}3.74 \\
(0.09)\end{array}$ & $\begin{array}{c}4.13 \\
(0.12)\end{array}$ & $\begin{array}{c}0.21 \\
(0.04)\end{array}$ & $\begin{array}{c}4.70 \\
(0.40)\end{array}$ & 12 \\
\hline Downer 6 & $\begin{array}{l}77.18 \\
(0.35)\end{array}$ & $\begin{array}{r}12.43 \\
(0.26)\end{array}$ & $\begin{array}{c}0.14 \\
(0.03)\end{array}$ & $\begin{array}{c}1.22 \\
(0.08)\end{array}$ & $\begin{array}{c}0.03 \\
(0.03)\end{array}$ & $\begin{array}{c}0.12 \\
(0.03)\end{array}$ & $\begin{array}{c}1.01 \\
(0.09)\end{array}$ & $\begin{array}{c}3.84 \\
(0.17)\end{array}$ & $\begin{array}{c}3.79 \\
(0.21)\end{array}$ & $\begin{array}{c}0.23 \\
(0.03)\end{array}$ & $\begin{array}{c}4.56 \\
(0.47)\end{array}$ & 11 \\
\hline Downer 7 & $\begin{array}{l}77.55 \\
(0.40)\end{array}$ & $\begin{array}{l}12.38 \\
(0.18)\end{array}$ & $\begin{array}{c}0.11 \\
(0.05)\end{array}$ & $\begin{array}{c}1.04 \\
(0.16)\end{array}$ & $\begin{array}{c}0.04 \\
(0.03)\end{array}$ & $\begin{array}{c}0.09 \\
(0.04)\end{array}$ & $\begin{array}{c}0.85 \\
(0.13)\end{array}$ & $\begin{array}{c}3.71 \\
(0.24)\end{array}$ & $\begin{array}{c}4.00 \\
(0.40)\end{array}$ & $\begin{array}{c}0.23 \\
(0.04)\end{array}$ & $\begin{array}{c}3.80 \\
(0.78)\end{array}$ & 12 \\
\hline Downer 8 & $\begin{array}{c}75.77 \\
(0.19)\end{array}$ & $\begin{array}{l}13.06 \\
(0.13)\end{array}$ & $\begin{array}{c}0.17 \\
(0.03)\end{array}$ & $\begin{array}{c}1.63 \\
(0.04)\end{array}$ & $\begin{array}{c}0.07 \\
(0.04)\end{array}$ & $\begin{array}{c}0.14 \\
(0.02)\end{array}$ & $\begin{array}{c}1.17 \\
(0.03)\end{array}$ & $\begin{array}{c}4.30 \\
(0.09)\end{array}$ & $\begin{array}{c}3.46 \\
(0.09)\end{array}$ & $\begin{array}{c}0.23 \\
(0.03)\end{array}$ & $\begin{array}{c}3.90 \\
(0.46)\end{array}$ & 12 \\
\hline $83 / 2$ & $\begin{array}{c}77.73 \\
(0.22)\end{array}$ & $\begin{array}{l}12.36 \\
(0.12)\end{array}$ & $\begin{array}{c}0.08 \\
(0.04)\end{array}$ & $\begin{array}{c}1.05 \\
(0.06)\end{array}$ & $\begin{array}{c}0.03 \\
(0.03)\end{array}$ & $\begin{array}{c}0.08 \\
(0.01)\end{array}$ & $\begin{array}{c}0.85 \\
(0.04)\end{array}$ & $\begin{array}{c}3.80 \\
(0.07)\end{array}$ & $\begin{array}{c}3.76 \\
(0.09)\end{array}$ & $\begin{array}{c}0.24 \\
(0.04)\end{array}$ & $\begin{array}{c}3.55 \\
(0.39)\end{array}$ & 11 \\
\hline $83 / 3$ & $\begin{array}{l}77.38 \\
(0.42)\end{array}$ & $\begin{array}{c}12.53 \\
(0.18)\end{array}$ & $\begin{array}{c}0.13 \\
(0.04)\end{array}$ & $\begin{array}{c}1.20 \\
(0.15)\end{array}$ & $\begin{array}{c}0.04 \\
(0.02)\end{array}$ & $\begin{array}{c}0.15 \\
(0.05)\end{array}$ & $\begin{array}{c}1.09 \\
(0.17)\end{array}$ & $\begin{array}{c}3.69 \\
(0.14)\end{array}$ & $\begin{array}{c}3.57 \\
(0.24)\end{array}$ & $\begin{array}{c}0.21 \\
(0.05)\end{array}$ & $\begin{array}{c}3.76 \\
(0.32)\end{array}$ & 10 \\
\hline $83 / 4$ & $\begin{array}{l}77.61 \\
(0.44)\end{array}$ & $\begin{array}{r}12.45 \\
(0.26)\end{array}$ & $\begin{array}{c}0.13 \\
(0.03)\end{array}$ & $\begin{array}{c}1.12 \\
(0.10)\end{array}$ & $\begin{array}{c}0.04 \\
(0.03)\end{array}$ & $\begin{array}{c}0.13 \\
(0.03)\end{array}$ & $\begin{array}{c}1.07 \\
(0.17)\end{array}$ & $\begin{array}{c}3.63 \\
(0.19)\end{array}$ & $\begin{array}{c}3.61 \\
(0.12)\end{array}$ & $\begin{array}{c}0.21 \\
(0.04)\end{array}$ & $\begin{array}{c}4.07 \\
(0.27)\end{array}$ & 10 \\
\hline $83 / 5=$ & $\begin{array}{l}77.59 \\
(0.26)\end{array}$ & $\begin{array}{l}12.45 \\
(0.12)\end{array}$ & $\begin{array}{c}0.10 \\
(0.04)\end{array}$ & $\begin{array}{c}1.05 \\
(0.06)\end{array}$ & $\begin{array}{c}0.05 \\
(0.05)\end{array}$ & $\begin{array}{c}0.08 \\
(0.03)\end{array}$ & $\begin{array}{c}0.87 \\
(0.04)\end{array}$ & $\begin{array}{c}3.67 \\
(0.17)\end{array}$ & $\begin{array}{c}3.91 \\
(0.11)\end{array}$ & $\begin{array}{c}0.23 \\
(0.03)\end{array}$ & $\begin{array}{c}3.95 \\
(0.54)\end{array}$ & 12 \\
\hline $83 / 6$ & $\begin{array}{c}77.61 \\
(0.15)\end{array}$ & $\begin{array}{l}12.49 \\
(0.12)\end{array}$ & $\begin{array}{c}0.11 \\
(0.04)\end{array}$ & $\begin{array}{c}1.04 \\
(0.06)\end{array}$ & $\begin{array}{c}0.03 \\
(0.02)\end{array}$ & $\begin{array}{c}0.09 \\
(0.02)\end{array}$ & $\begin{array}{c}0.87 \\
(0.05)\end{array}$ & $\begin{array}{c}3.72 \\
(0.12)\end{array}$ & $\begin{array}{c}3.82 \\
(0.08)\end{array}$ & $\begin{array}{c}0.23 \\
(0.04)\end{array}$ & $\begin{array}{c}4.48 \\
(0.49)\end{array}$ & 12 \\
\hline
\end{tabular}




\begin{tabular}{|c|c|c|c|c|c|c|c|c|c|c|c|c|}
\hline Tephra & $\mathrm{SiO}_{2}$ & $\mathrm{Al}_{2} \mathrm{O}_{3}$ & $\mathrm{TiO}_{2}$ & $\mathrm{FeO}$ & $\mathrm{MnO}$ & $\mathrm{MgO}$ & $\mathrm{CaO}$ & $\mathrm{Na}_{2} \mathrm{O}$ & $\mathrm{K}_{2} \mathrm{O}$ & $\mathrm{Cl}$ & water & $\mathrm{n}$ \\
\hline $83 / 7$ & $\begin{array}{r}77.79 \\
(0.31)\end{array}$ & $\begin{array}{c}12.37 \\
(0.10)\end{array}$ & $\begin{array}{c}0.08 \\
(0.03)\end{array}$ & $\begin{array}{c}0.93 \\
(0.19)\end{array}$ & $\begin{array}{c}0.03 \\
(0.03)\end{array}$ & $\begin{array}{c}0.08 \\
(0.01)\end{array}$ & $\begin{array}{c}0.92 \\
(0.04)\end{array}$ & $\begin{array}{c}3.86 \\
(0.08)\end{array}$ & $\begin{array}{c}3.68 \\
(0.12)\end{array}$ & $\begin{array}{c}0.26 \\
(0.02)\end{array}$ & $\begin{array}{c}3.25 \\
(1.98)\end{array}$ & 12 \\
\hline $83 / 8$ & $\begin{array}{l}77.75 \\
(0.18)\end{array}$ & $\begin{array}{l}12.37 \\
(0.13)\end{array}$ & $\begin{array}{c}0.09 \\
(0.02)\end{array}$ & $\begin{array}{c}0.99 \\
(0.09)\end{array}$ & $\begin{array}{c}0.05 \\
(0.03)\end{array}$ & $\begin{array}{c}0.09 \\
(0.01)\end{array}$ & $\begin{array}{c}0.93 \\
(0.05)\end{array}$ & $\begin{array}{c}3.88 \\
(0.10)\end{array}$ & $\begin{array}{c}3.59 \\
(0.10)\end{array}$ & $\begin{array}{c}0.26 \\
(0.05)\end{array}$ & $\begin{array}{c}2.57 \\
(0.28)\end{array}$ & 12 \\
\hline $83 / 9$ & $\begin{array}{r}77.74 \\
(0.29) \\
\end{array}$ & $\begin{array}{r}12.41 \\
(0.15) \\
\end{array}$ & $\begin{array}{c}0.09 \\
(0.03) \\
\end{array}$ & $\begin{array}{c}0.98 \\
(0.16) \\
\end{array}$ & $\begin{array}{r}0.06 \\
(0.04) \\
\end{array}$ & $\begin{array}{c}0.08 \\
(0.02) \\
\end{array}$ & $\begin{array}{r}0.94 \\
(0.04) \\
\end{array}$ & $\begin{array}{c}3.86 \\
(0.08) \\
\end{array}$ & $\begin{array}{c}3.63 \\
(0.08) \\
\end{array}$ & $\begin{array}{c}0.22 \\
(0.03) \\
\end{array}$ & $\begin{array}{r}2.68 \\
(0.29) \\
\end{array}$ & 10 \\
\hline
\end{tabular}

Analyses recalculated to $100 \%$ on a volatile-free basis and presented as a mean and standard deviation on $\mathrm{n}$ shards.

Sample locations as in Appendix 1.

All Fe recalculated as FeO. Analysed by a CAMEBAX SX-50 microprobe at the University of Toronto with operating conditions of $15 \mathrm{kV}$ and $10 \mathrm{nA}$, scanning over a $10 \mu \mathrm{m}$ area. Standard analyses in Table 4.4. * Determined by a Jeol 733 Superprobe using a $8 \mathrm{nA}$ current at $15 \mathrm{kV}$ and a $20 \mu \mathrm{m}$ beam diameter. Method and standards as in Shane and Froggatt (1992) 


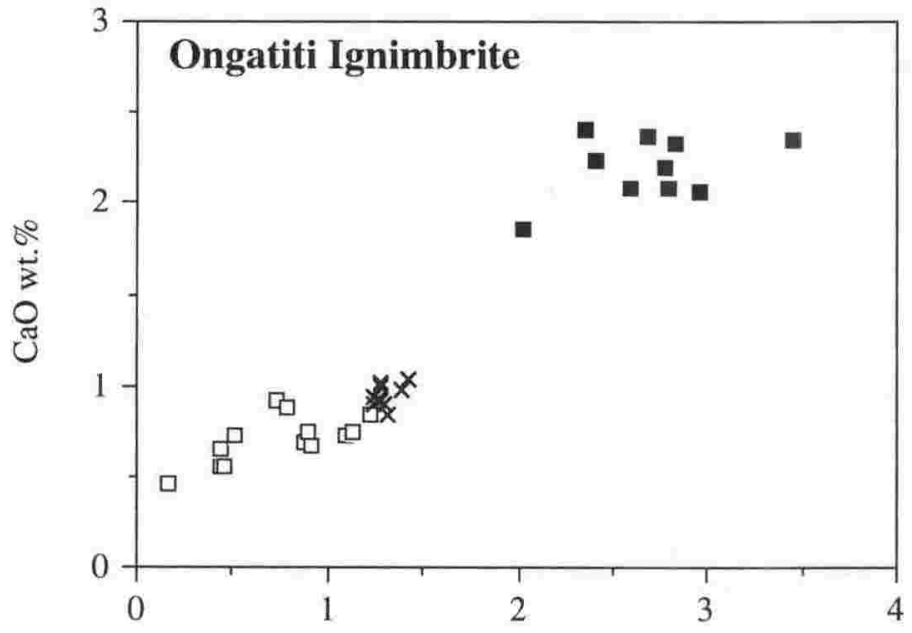

$\mathrm{FeO}$ wt.\%
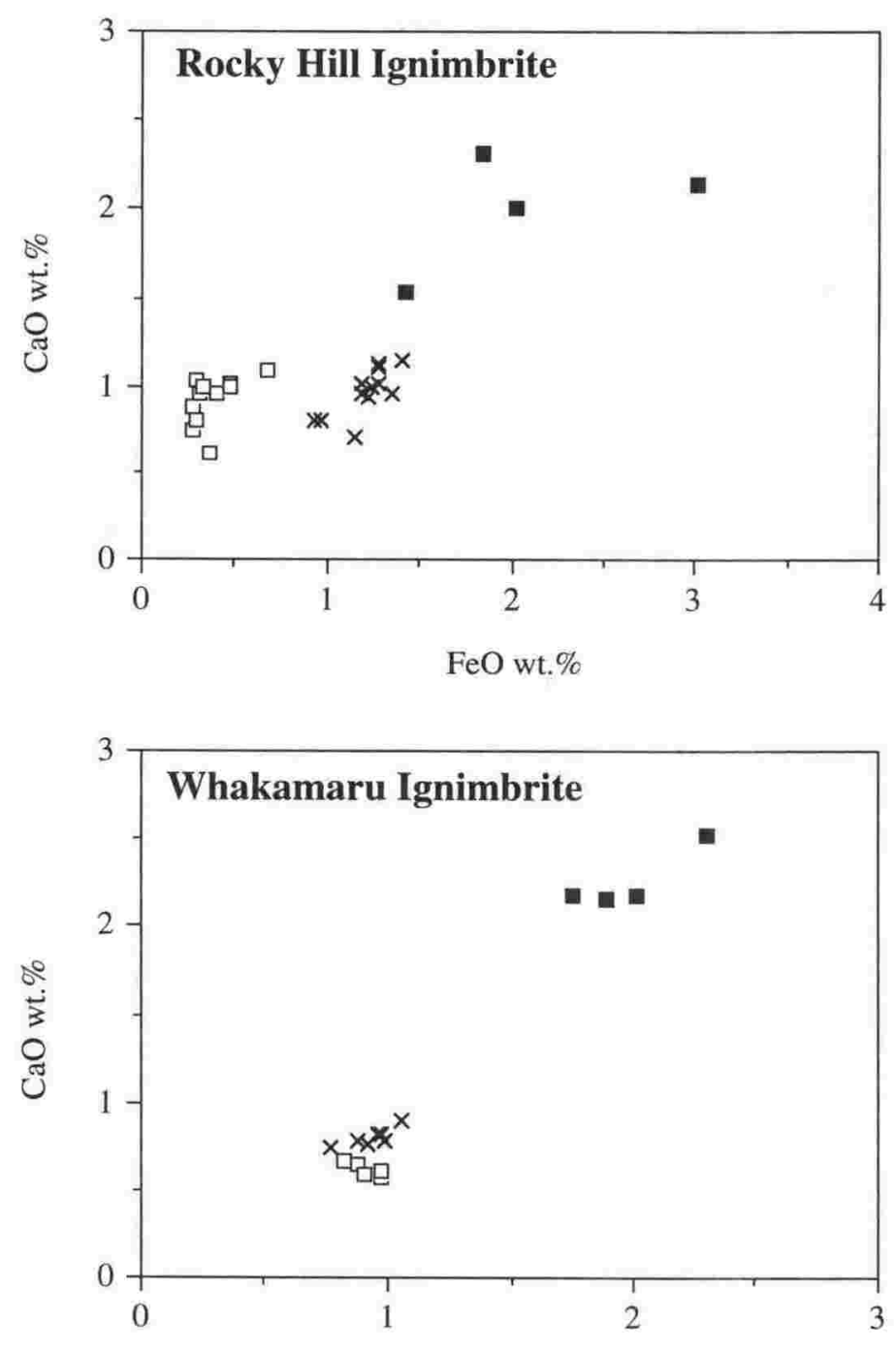

$\mathrm{FeO}$ wt. \%
Welded zone:

- whole pumice XRF (B 32)

ㅁ pumice glass EMA (B 32)

Nonwelded zone:

$\times \quad$ glass shards EMA (B 49)

Welded zone:

- whole pumice XRF (B 34)

ㅁ pumice glass EMA (B 34)

Nonwelded zone:

$\times \quad$ glass shards EMA (B 50)

Welded zone:

- whole pumice XRF (B 35)

ㅁ pumice glass EMA (B 35)

Nonwelded zone:

$\times \quad$ glass shards EMA (B 28)

Figure 4.1 Comparison of compositions of pumices from welded ignimbrites with glass from nonwelded bases. 


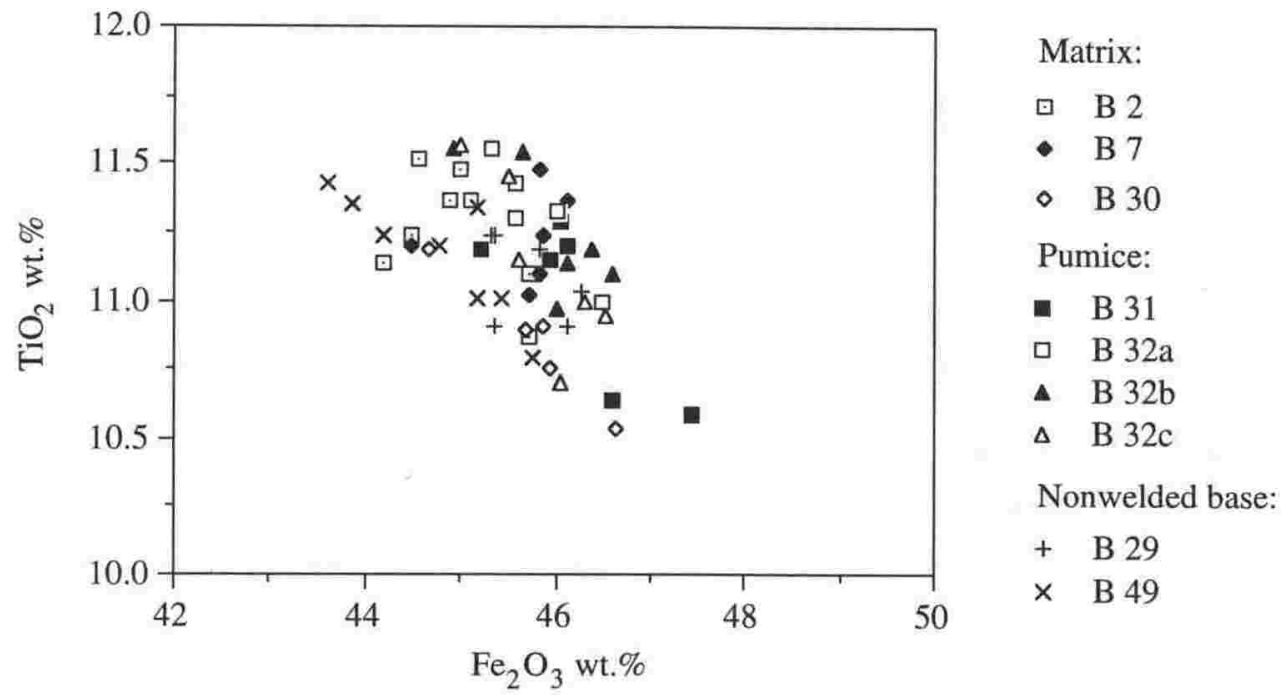

Figure 4.2 Fe-Ti oxide compositions (determined by EMA) from different sites of the Ongatiti Ignimbrite. 
explain why Briggs et al. (1993) reported no systematic compositional gradient with stratigraphic height, in contrast to other zoned eruptives (e.g. Hildreth 1981).

\subsection{GEOCHEMISTRY OF FE-TI OXIDES}

The compositions of titanomagnetite and ilmenite are sensitive indicators of eruption temperature and $\mathrm{f}_{\mathrm{O}_{2}}$, and are closely related to the coexisting glass phase. In New Zealand, previous investigations into $\mathrm{Fe}-\mathrm{Ti}$ oxide chemistry have produced promising results in correlation and identifying source areas (Kohn 1970, 1979; Froggatt 1982; Lowe 1988, Shane 1994) using both major and trace element determinations. Hildreth and Mahood (1985) noted that in large compositionally zoned eruptions there is a large variation in Fe-Ti oxide composition. Multiple populations of titanomagnetite compositions have also been reported in distal tephras (Westgate et al. 1977). Therefore, a grain-discrete method of analysis such as microprobe is preferred to bulk methods.

The Fe-Ti oxides were analysed from most samples collected for analysis of the coexisting glass phase. Several sites of Ongatiti, Ahuroa, Whakamaru, Matahina, Kaingaroa and Mamaku ignimbrites were analysed and single samples of many other units. Crystals from altered pumices and welded matrix were also analysed and compared with fresh samples from nonwelded bases.

Fe-Ti oxides typically represent $<1 \%$ of a field sample and $<10 \%$ of crystal content. The majority of this fraction is spinel phase titanomagnetite with ulvospinel of $20-50$ mol. $\%$ (Stormer model). Total $\mathrm{FeO}\left(\mathrm{FeO}+\mathrm{Fe}_{2} \mathrm{O}_{3}\right)$ is $75-85$ wt.\% and $\mathrm{TiO}_{2}$ comprises 5 - 15 wt.\%. Other elements analysed for are $\mathrm{Al}_{2} \mathrm{O}_{3}, \mathrm{MnO}, \mathrm{MgO}, \mathrm{ZnO}$ and $\mathrm{SiO}_{2}$, in decreasing abundance. Rhombohedral phase ilmenites are less abundant and analyses were not obtained for every sample. $\mathrm{FeO}$ (total) and $\mathrm{TiO}_{2}$ contents are 40 - 50 wt.\% each (Appendix 2).

Microprobe analyses of titanomagnetites from several sites of Ongatiti Ignimbrite are shown in Figure 4.2. Samples B29 and B 49 are from nonwelded bases and B31, 32a-c are from variably altered pumices within the welded unit. All cluster in good agreement with each other, and any alteration affecting the glass in samples B31 and 32 (Figure 4.1, Table 4.2) has not affected the titanomagnetites.

Welding and other post-emplacement alteration can affect $\mathrm{Fe}$-Ti oxide crystals, causing them to exsolve. Evidence of exsolution occurring in welded and altered zones was encountered in the Ahuroa Ignimbrite (Figure 4.3) where titanomagnetites were analysed from 3 locations. Two samples plot in a tight cluster, but sample B5 shows wide variation. In some samples, different locations of the same crystal gave different microprobe analyses, indicating exsolution had taken place. This is shown with multiple analyses from the same crystal from the Matahina Ignimbrite (Figure 4.3). Here, the $\mathrm{TiO}_{2}$ content ranges from 5.84 16.41 wt. $\%, \mathrm{Fe}_{2} \mathrm{O}_{3} 34.63$ - 56.05 wt.\% and ulvospinel varies from 0.17 - 0.50 (Appendix 2). Exsolved crystals also occur in other samples analysed in this study (Appendix 2). Magmatic 

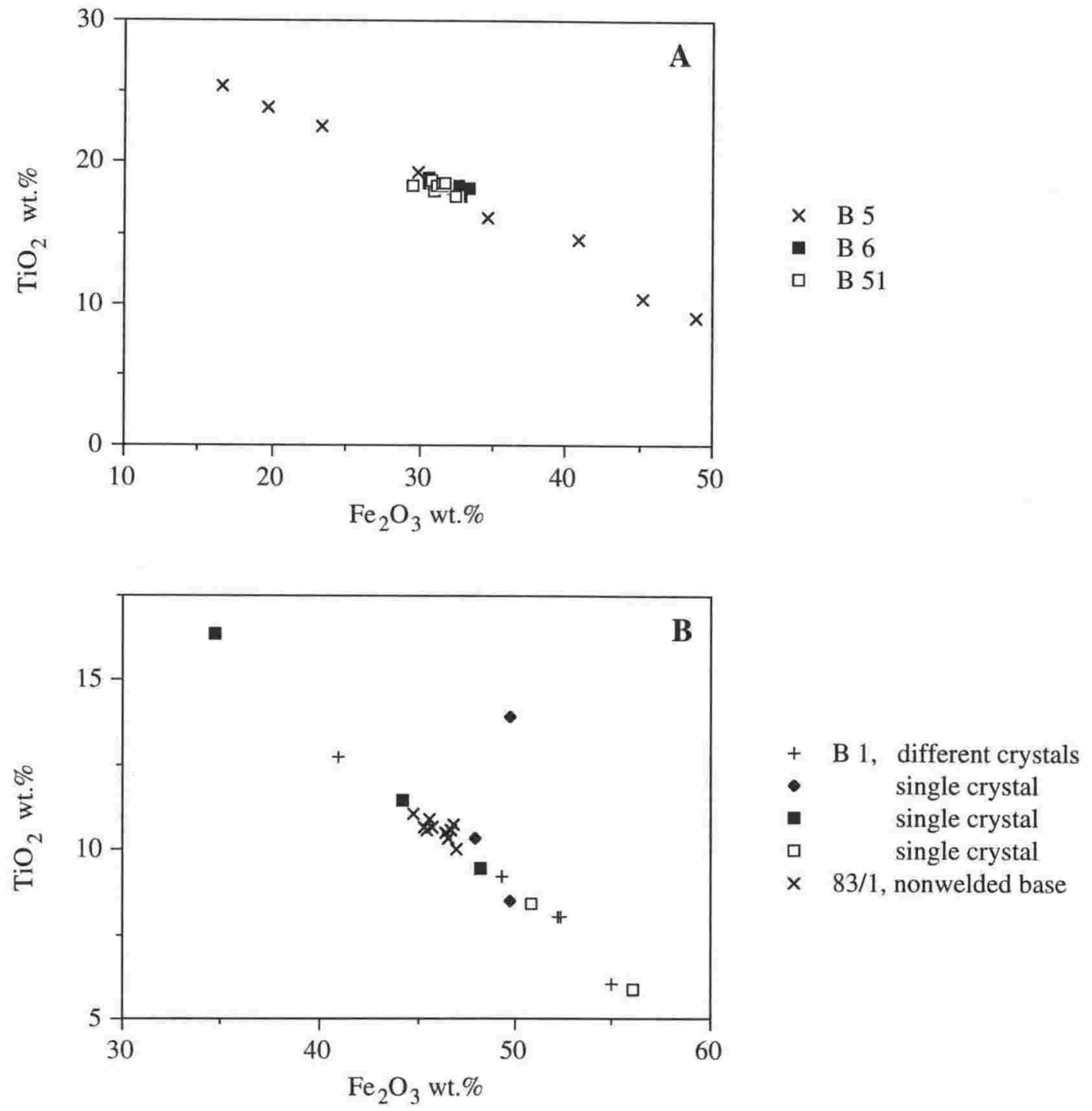

Figure 4.3 Fe-Ti oxide compositions determined by EMA from (A) Ahuroa Ignimbrite and (B) Matahina Ignimbrite. In (A), 2 samples plot together, with a third sample displaying a range of compositions. In (B), crystals from sample 83/1 have a uniform composition, suggesting they are unexsolved. Differing analyses on the same crystal, as shown in B 1, suggests exsolution has taken place. 
compositional variation would be represented by unexsolved homogeneous crystals of different compositions. This was not observed in this study. All of the observed compositional variation can be explained by alteration, either thermal or weathering.

In samples with no evidence of exsolution, differences in composition between ignimbrites is usually reflected in the $\mathrm{TiO}_{2} / \mathrm{Fe}_{2} \mathrm{O}_{3}$ ratio. Good separation is seen between many units (Figure 4.4), on the basis of titanomagnetite chemistry and may be used in conjunction with glass chemistry for correlation purposes.

\subsection{GEOCHEMISTRY OF GLASSES}

\subsubsection{Glass from nonwelded bases of ignimbrites}

Nonwelded ash from the base of units was collected where available from Ngaroma, Ongatiti, Unit D, Ahuroa, Rocky Hill, Whakamaru, Matahina, Kaingaroa and Mamaku ignimbrites. Most of the microprobe analyses are typical of fresh glasses found elsewhere (e.g. Shane and Froggatt 1994) and show little evidence of alkali exchange or leaching. The units sampled are all typical calc-alkaline rhyolites, with mean $\mathrm{SiO}_{2}$ contents ranging from 75.67 to 77.97 wt.\%, after recalculation to $100 \%$ on a volatile-free basis (Table 4.3 , Appendix 1). The deficiency from $100 \%$ in the analytical totals is mainly due to secondary hydration (Froggatt 1983) and accounts for 1.58 - 7.65 wt.\%. At least 10 individual shards were probed from each sample and the analyses averaged to give a mean composition representative of the magma liquid at the time of eruption. The standard deviations obtained on all elements (e.g. 0.20 wt.\% for $\mathrm{SiO}_{2}$ and $\mathrm{FeO}, 0.8$ wt.\% for $\mathrm{CaO}, 0.15$ wt.\% for $\mathrm{K}_{2} \mathrm{O}$; Table 4.3) are similar to the variation from replicate analyses on glass standards (Table 4.4) and therefore can be considered to be due mainly to instrumental uncertainty.

Table 4.4 Electron Microprobe analyses of glass standard UA Obsidian, used as an internal standard at the University of Toronto. Operating conditions as in Table 4.3.

\begin{tabular}{lccccccccccc}
\hline \hline & $\mathrm{SiO}_{2}$ & $\mathrm{Al}_{2} \mathrm{O}_{3}$ & $\mathrm{TiO}_{2}$ & $\mathrm{FeO}$ & $\mathrm{MnO}$ & $\mathrm{MgO}$ & $\mathrm{CaO}$ & $\mathrm{Na}_{2} \mathrm{O}$ & $\mathrm{K}_{2} \mathrm{O}$ & $\mathrm{Cl}$ & total \\
\hline & 73.92 & 13.04 & 0.07 & 1.71 & 0.00 & 0.03 & 0.75 & 4.02 & 5.02 & 0.43 & 98.99 \\
& 74.00 & 13.19 & 0.09 & 1.62 & 0.07 & 0.05 & 0.75 & 4.1 & 5.06 & 0.44 & 99.37 \\
& 74.33 & 13.11 & 0.05 & 1.53 & 0.09 & 0.04 & 0.71 & 3.82 & 5.06 & 0.44 & 99.18 \\
& 74.44 & 12.92 & 0.13 & 1.62 & 0.01 & 0.04 & 0.75 & 3.98 & 5.08 & 0.46 & 99.43 \\
& 74.45 & 13.19 & 0.08 & 1.66 & 0.08 & 0.06 & 0.65 & 3.91 & 4.98 & 0.44 & 99.50 \\
& 73.98 & 13.12 & 0.16 & 1.63 & 0.10 & 0.05 & 0.76 & 3.84 & 4.91 & 0.48 & 99.03 \\
& 74.20 & 13.06 & 0.06 & 1.58 & 0.05 & 0.01 & 0.72 & 3.99 & 5.13 & 0.43 & 99.23 \\
mean & $\mathbf{7 4 . 1 9}$ & $\mathbf{1 3 . 0 9}$ & $\mathbf{0 . 0 9}$ & $\mathbf{1 . 6 2}$ & $\mathbf{0 . 0 6}$ & $\mathbf{0 . 0 4}$ & $\mathbf{0 . 7 3}$ & $\mathbf{3 . 9 5}$ & $\mathbf{5 . 0 3}$ & $\mathbf{0 . 4 5}$ & $\mathbf{9 9 . 2 5}$ \\
stdev & $\mathbf{0 . 2 2}$ & $\mathbf{0 . 0 9}$ & $\mathbf{0 . 0 4}$ & $\mathbf{0 . 0 6}$ & $\mathbf{0 . 0 4}$ & $\mathbf{0 . 0 2}$ & $\mathbf{0 . 0 4}$ & $\mathbf{0 . 1 0}$ & $\mathbf{0 . 0 7}$ & $\mathbf{0 . 0 2}$ & $\mathbf{0 . 2 0}$ \\
\hline
\end{tabular}

Many of the ignimbrite samples are homogeneous and display no evidence for compositional zoning, at least in the initial eruption phases, which is represented by the basal ash. When compared with each other, basal ash from different ignimbrites are distinctive enough to be able to identify individual eruptive events on major oxide compositions alone (Figure 4.5). 


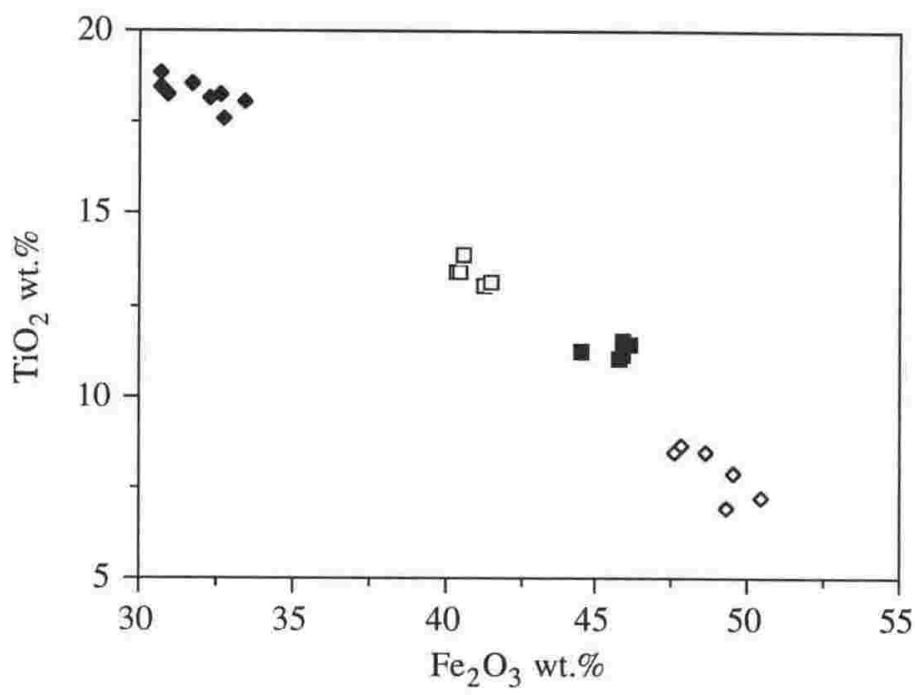

- Matahana A (B 20)

口 Waiotapu (B 11)

- Ahuroa (B 6)

- Ongatiti (B 7)

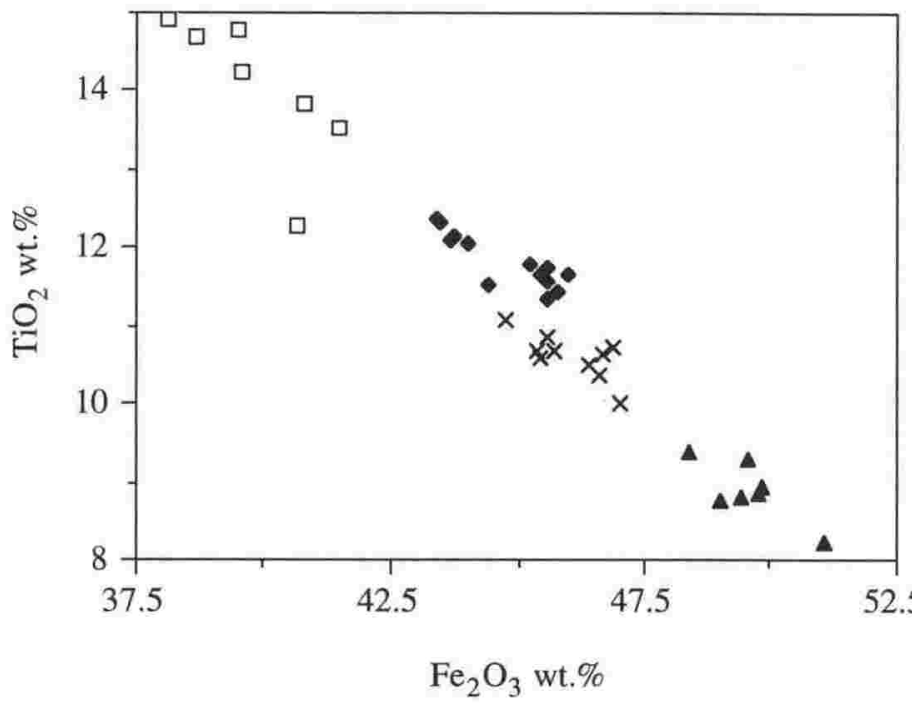

- Mamaku (B 12, 21)

$\times$ Matahina (83/1)

$\triangle$ Whakamaru (B 28)

ㅁ Pokai (B 13)

Figure 4.4 Composition of Fe-Ti oxides (determined by EMA) showing the potential to discriminate between different eruptive units from the TVZ. 

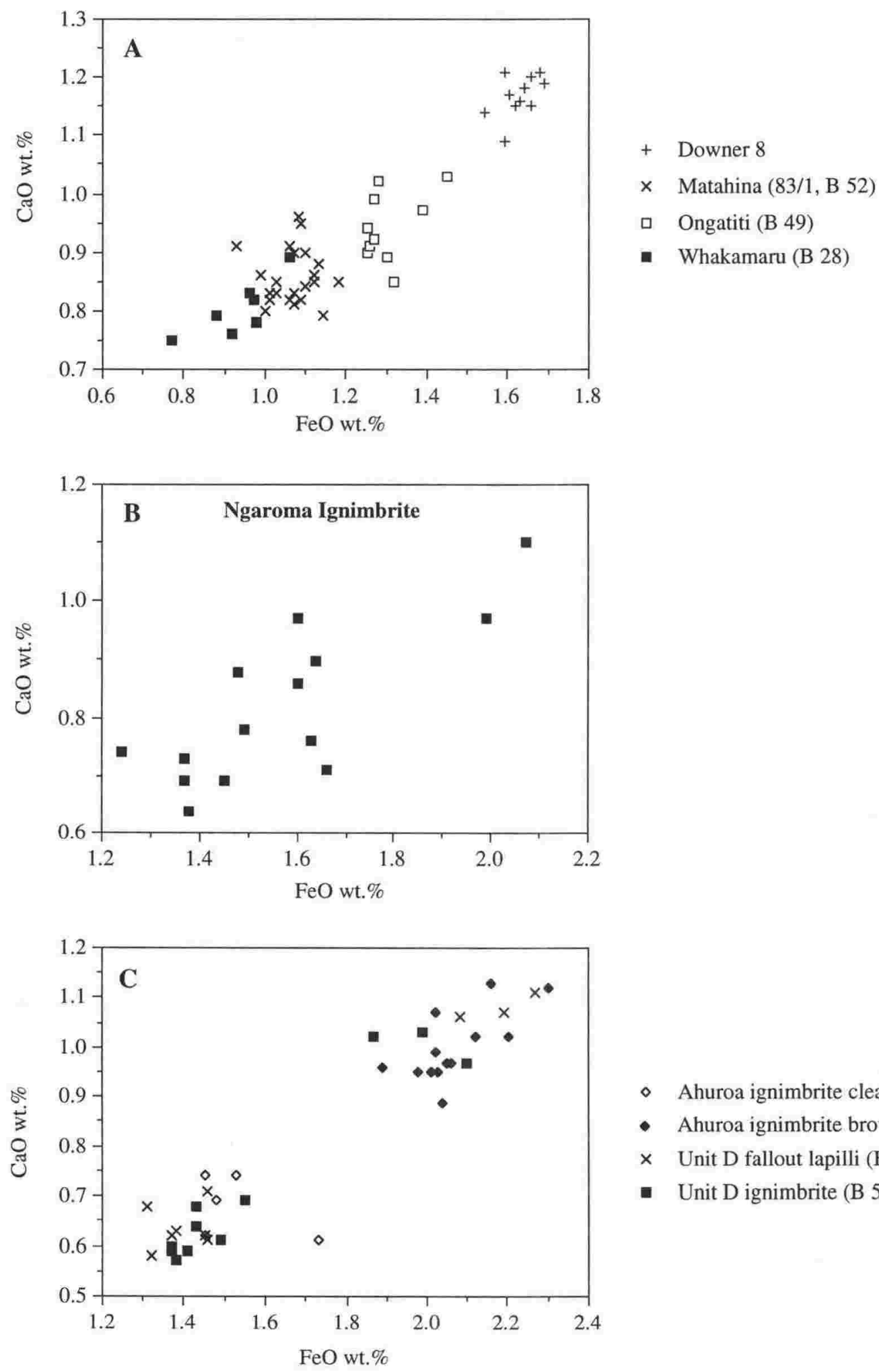

- Ahuroa ignimbrite clear glass (B 51)

- Ahuroa ignimbrite brown glass (B 51)

$\times$ Unit D fallout lapilli (B 53)

- Unit D ignimbrite (B 54)

Figure 4.5 (A) Glass composition of chemically homogeneous and discrete ignimbrite units. Data points represent individual shard compositions from EMA.

(B) Individual shard compositions of basal nonwelded zone of Ngaroma ignimbrite, showing some chemical variability.

(C) Individual shard compositions of the basal fallout lapilli and ignimbrite of Unit $\mathrm{D}$, and the overlying basal nonwelded Ahuroa ignimbrite. These units have two glass populations. 


\section{Murupara Locality}
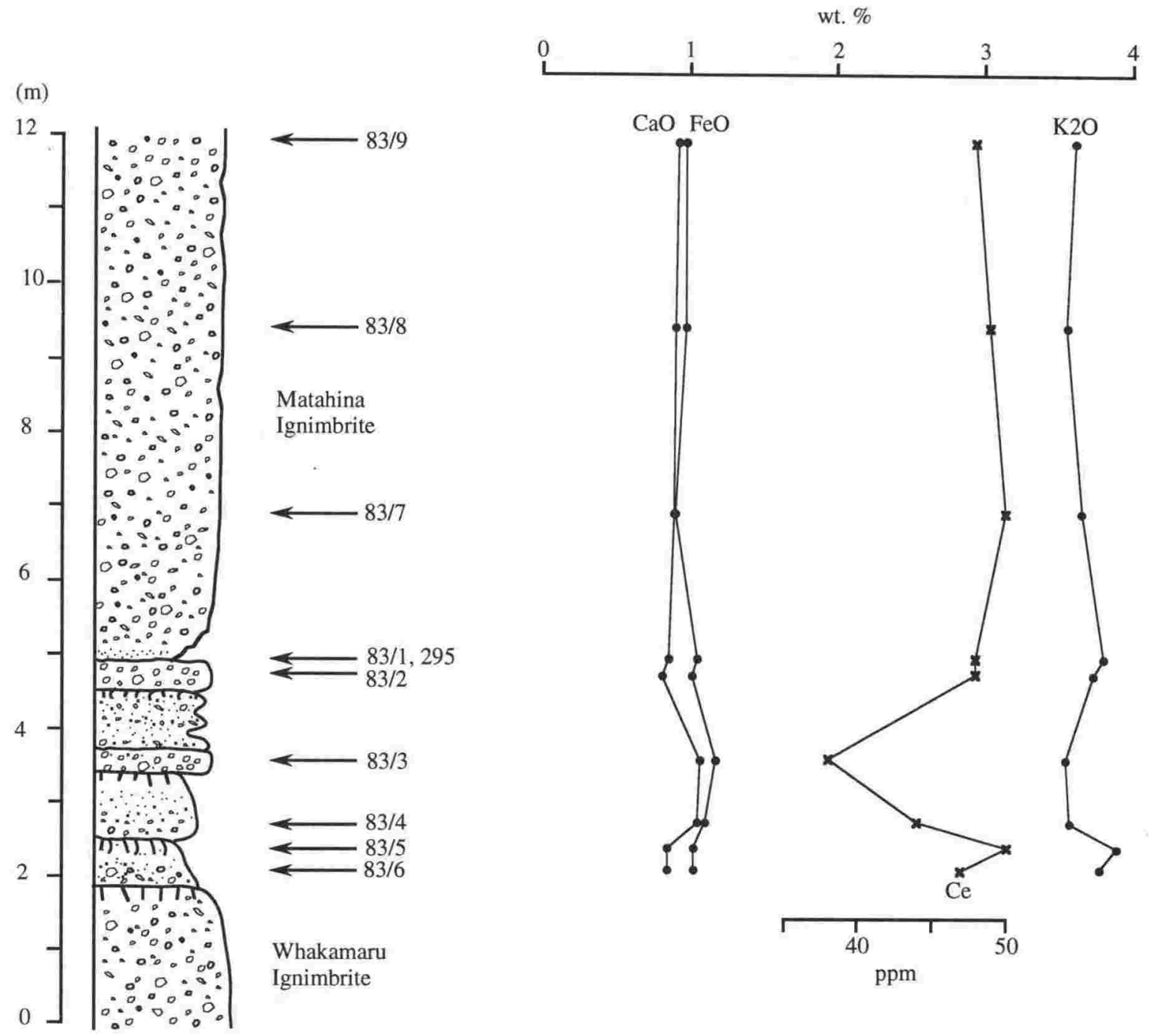

Figure 4.6 Stratigraphic column of fallout tephra beds between Whakamaru ignimbrite and Matahina Ignimbrite (at site 83), exposed along Highway 83 near Murupara. Sample positions and geochemical data (Table $4.3,4.5$ ) are also shown. 
$\mathrm{CaO}, \mathrm{FeO}$ and $\mathrm{K}_{2} \mathrm{O}$ often have the best discriminatory powers. A sample of the basal ash of Ngaroma Ignimbrite does show some variation in composition (Figure 4.5b), and may represent a limited zonation in the magma. These shards are also characterised by high $\mathrm{K}$, which may be due to alkali exchange.

The nonwelded Unit D ignimbrite was sampled at Site 53 (S17/189022) where it underlies the Ahuroa Ignimbrite. Sample B 53 is from the bedded fallout lapilli underlying the flow unit, B 54 is from the basal $20 \mathrm{~cm}$ of the ignimbrite, and B 51 was collected $10 \mathrm{~m}$ above, from the nonwelded base of the Ahuroa Ignimbrite (Wilson 1986). All samples are unaltered, compositionally identical, and each contains glass shards that fall into two compositional groups, as seen on variation diagrams (Table 4.3, Figure 4.5c). Two populations of glass shards may result from magma mixing (Carey and Sigurdsson 1978) or disruption of a stratified magma chamber. The compositional range seen in Unit D is greater than found in most New Zealand tephras (Froggatt 1983) and represents a range in $\mathrm{SiO}_{2}$ of $74.95-78.02$ wt.\% (Appendix 1), which is comparable to compositionally zoned high-silica rhyolite ignimbrites reported elsewhere (e.g. Hildreth 1981). A mixture of clear and brown glass shards was observed in all three samples. In sample B 51 from the basal Ahuroa Ignimbrite, these were able to be magnetically separated and microprobed separately. The brown glasses have a composition with lower $\mathrm{SiO}_{2}$ and high $\mathrm{FeO}$ compared to the clear glasses from the same sample. This correlation between colour and composition is likely to be the case in each of the samples. The identical chemical compositions of Unit D and nonwelded Ahuroa suggest they were erupted within a very short time from the same source, which is supported by their identical ${ }^{40} \mathrm{Ar} /{ }^{39} \mathrm{Ar}$ ages (Houghton et al. 1995).

For the similarly aged ignimbrites (Whakamaru, Matahina, Kaingaroa, Downer 8 and Mamaku) which were the subject of ITPFT studies (Chapter 6), EMA is a prerequisite for investigating compositional variation and identification. Each of these units are broadly

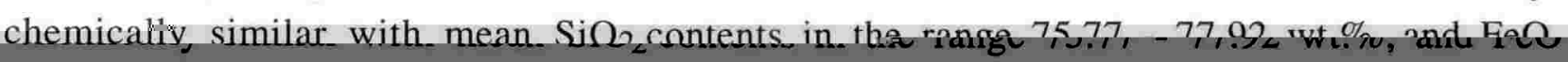
contents of near 1 wt \% excent. Downer 8 (Tahle 4.3), Whakamaru and Kaingaroa ignimbrites are distinguished hv $\mathrm{Na} / \mathrm{K}<1$ esnecially for the former upit Tho two anmmlan anah fan tho

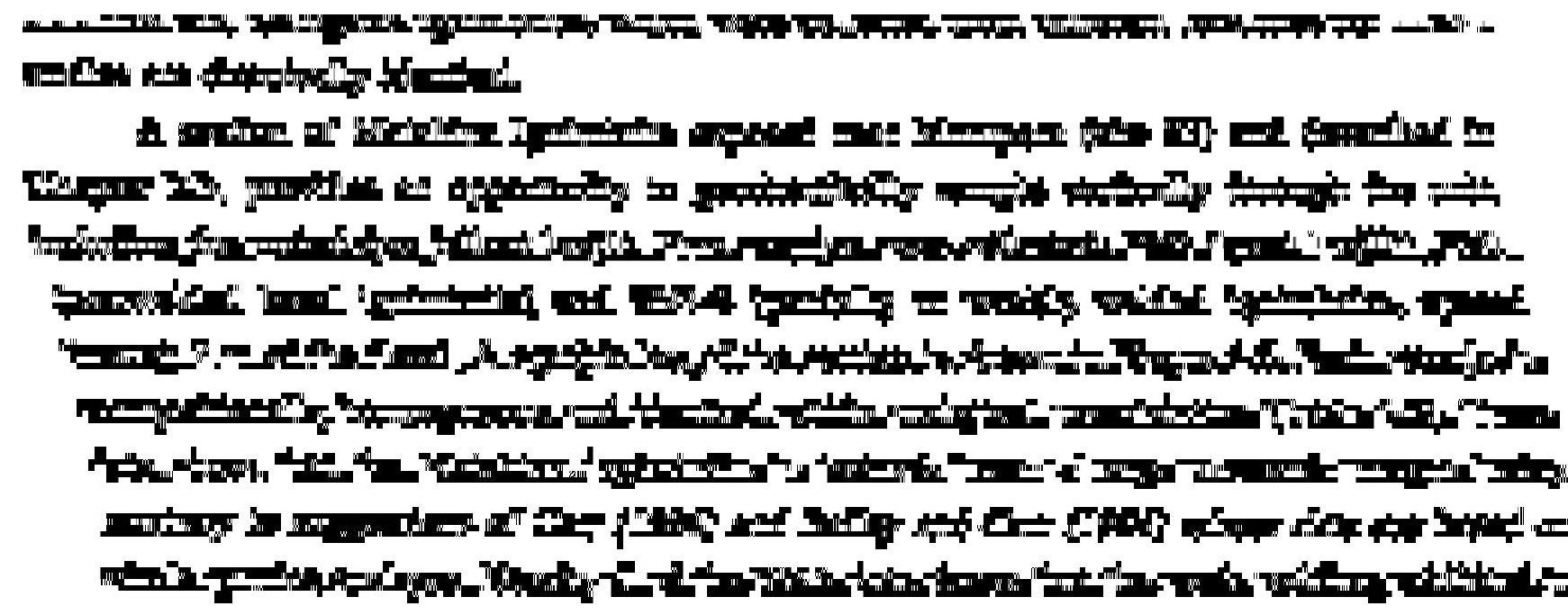




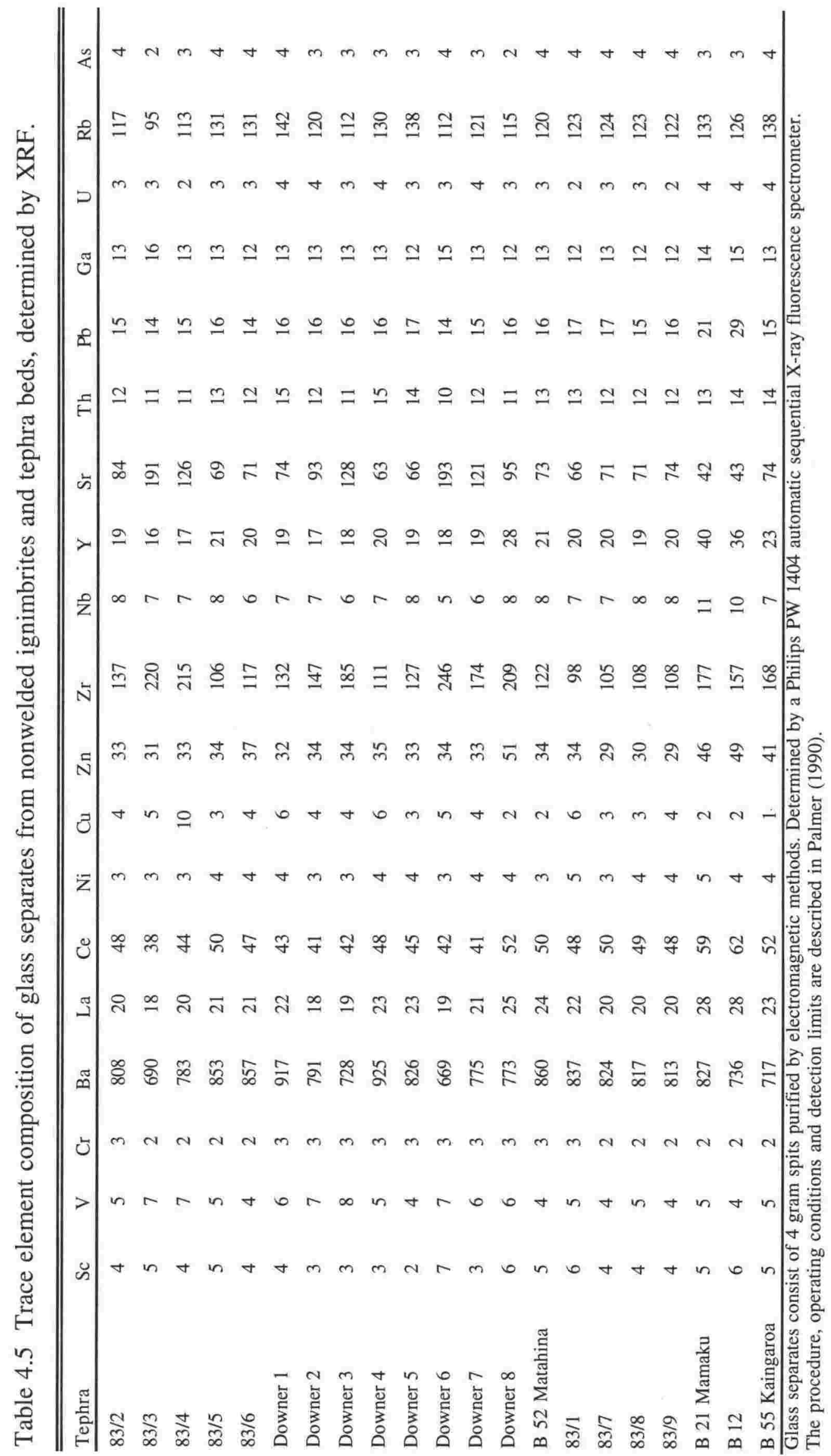


the upper part of the flow has not affected the geochemistry of the glass at this site as the composition is similar to the fallout lapilli. There is little or no evidence for alkali exchange or depletion of $\mathrm{FeO}$ and $\mathrm{CaO}$ as in strongly welded flow units (section 4.2). Samples 83/7 - 9 contain a few (4) anomalous shards with low FeO (ca. $0.5-0.72$ wt.\%) and high water contents (up to 9.4 wt.\%, Appendix 1). These few shards may display the initial stages of devitrification and vapour phase alteration.

Purified glass separates (ca. $4 \mathrm{~g}$ ) were analysed by XRF to obtain trace element compositions for some of the late Pleistocene units (Table 4.5). Multiple samples of Whakamaru ignimbrite and Matahina Ignimbrite are compositionally uniform, showing they are not affected by mineral contamination. Any mafic minerals or inclusions present in the separates would affect elements such as $\mathrm{Sc}, \mathrm{V}, \mathrm{Cr}, \mathrm{Ni}, \mathrm{Cu}, \mathrm{Zn}$. Feldspar contaminants could affect $\mathrm{Ba}, \mathrm{Sr}, \mathrm{Rb}$ contents.

As with the major element compositions, all the ignimbrites exhibit a broadly similar trace element chemistry. However, some elements allow the units to be distinguished, in particular, Ce, Y, Zr (Figure 4.7). Using these data, the Mamaku Ignimbrite is easily distinguished from the other ignimbrites. In contrast, Downer 8, which has a distinctive major element composition, is more difficult to separate from the other units using trace elements (Figure 4.7).

Trace element data from vertical stratigraphic sampling through the Matahina Ignimbrite (near Murupara, site 83) shows no variation, in accord with the major element chemistry (Figure 4.6, Table 4.5). This suggests that the ignimbrite was not derived from a magma with trace element zonation and confirms that the unit has not undergone significant post-depositional alteration at this locality.

\subsubsection{Fallout tephra beds above the Whakamaru ignimbrite}

In the proximal volcanic areas of the TVZ, sections of fallout ash are not well exposed for sequences older than ca. $50 \mathrm{ka}$. Two sections of fallout tephra beds between the Whakamaru group ignimbrite and an overlying ignimbrite sheet are exposed along Downer Rd in the Kinleith Forest on the western margin of the TVZ, and along Highway 83 near Murupara, on the eastern margin of the TVZ. The two sections (Figures 4.6, 4.8) are separated by $70 \mathrm{~km}$ and are described in Chapter 2.3. Since both sections represent approximately the same time interval i.e. post-Whakamaru, vertical samples were collected from each fallout unit which is bounded by a paleosol. All the units analysed are geochemically similar (Table 4.3, Figures 4.6, 4.8). At site 83 near Murupara, some beds $(83 / 5,83 / 6)$ are similar to Matahina in composition but may be distinguished by $\mathrm{Na} / \mathrm{K}>1$. In this respect, they are similar in character to the underlying Whakamaru ignimbrite. These beds are in turn overlain by 2 units $(83 / 3,83 / 4)$ with a higher FeO content. A similar sequence of beds occurs at Downer Rd (Figure 4.8), however more units are recorded, which show a repeated eruption 

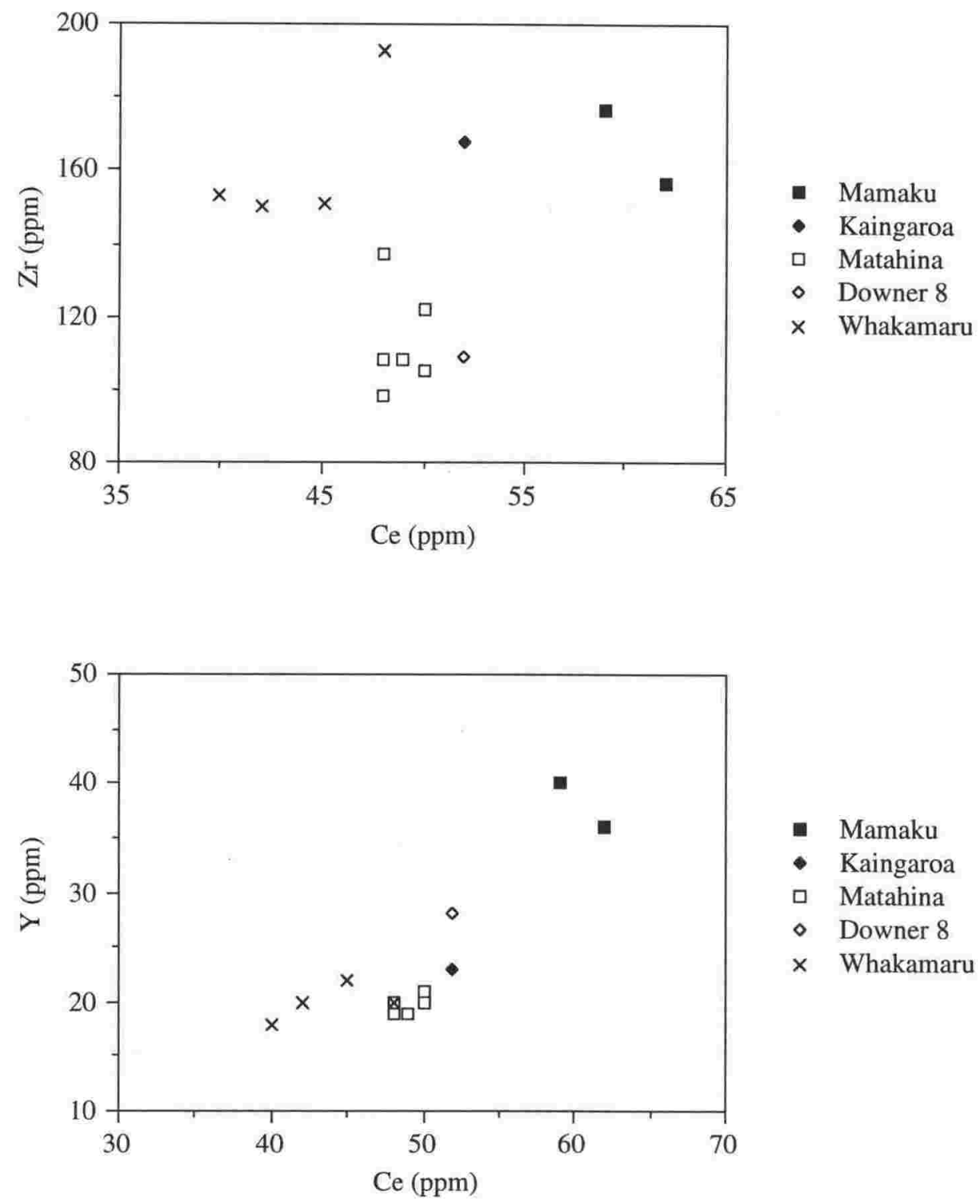

Figure 4.7 Trace element glass compositions of late Pleistocene ignimbrites from the TVZ. Whakamaru ignimbite data from Shane and Froggatt (1994). 
Downer Road Locality
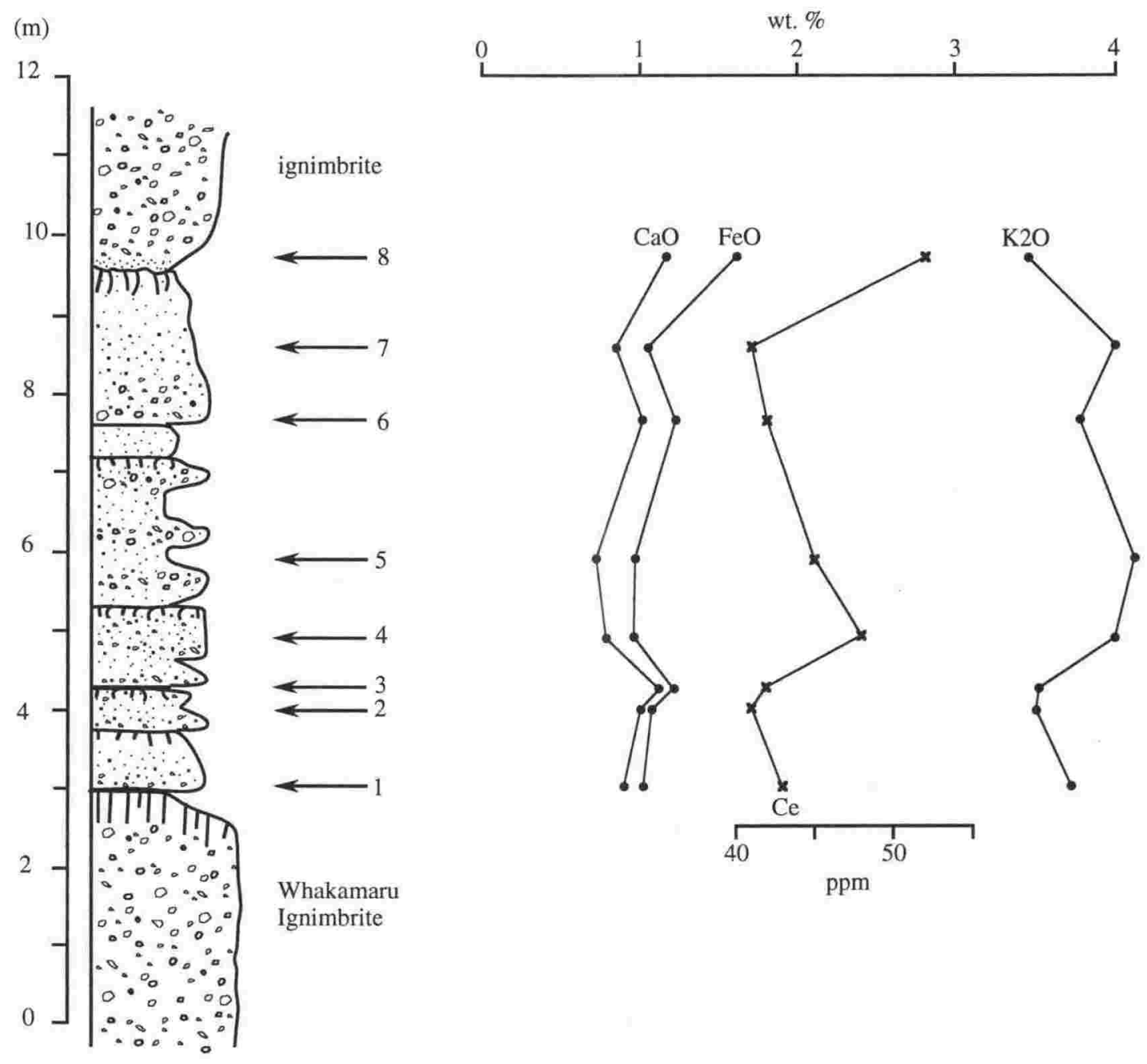

Figure 4.8 Stratigraphic column of fallout tephra beds between Whakamaru ignimbrite and an overlying ignimbrite (Downer 8), exposed along Downer Rd. Sample positions and geochemical data (Table 4.3, 4.5) are also shown. 
Table 4.6 Similarity Coefficient matrix comparing late Pleistocene ignimbrites and tephra beds from the Bay of Plenty region.

\begin{tabular}{|c|c|c|c|c|c|c|c|c|c|c|c|c|c|c|c|c|c|c|c|c|}
\hline & $83 / 1$ & B 52 & B56 & $\overline{\mathrm{B} 55}$ & $\overline{\mathrm{D} 8}$ & D7 & $\overline{\mathrm{D} 6}$ & $\overline{\mathrm{D} 5}$ & $\overline{\mathrm{D} 4}$ & $\overline{\mathrm{D} 33}$ & $\overline{\mathrm{D} 2}$ & $\overline{\text { DI }}$ & $83 / 2$ & $83 / 3$ & $83 / 4$ & $83 / 5$ & $83 / 6$ & $83 / 7$ & $83 / 8$ & $\overline{83 / 9}$ \\
\hline $83 / 1$ & 1 & & & & & & & & & & & & & & & & & & & \\
\hline B 52 & .93 & 1 & & & & & & & & & & & & & & & & & & \\
\hline B 56 & .94 & .91 & 1 & & & & & & & & & & & & & & & & & \\
\hline B 55 & .93 & .89 & .97 & 1 & & & & & & & & & & & & & & & & \\
\hline D8 & .83 & .79 & .82 & .84 & 1 & & & & & & & & & & & & & & & \\
\hline D7 & .95 & .95 & .93 & .93 & .79 & 1 & & & & & & & & & & & & & & \\
\hline D6 & .94 & .88 & .93 & .95 & .88 & .89 & 1 & & & & & & & & & & & & & \\
\hline D5 & .86 & .92 & .86 & .85 & .73 & .91 & .82 & 1 & & & & & & & & & & & & \\
\hline D4 & .90 & .93 & .89 & .88 & .75 & .95 & .85 & .96 & 1 & & & & & & & & & & & \\
\hline D3 & .87 & .83 & .86 & .87 & .92 & .83 & .92 & .77 & .79 & 1 & & & & & & & & & & \\
\hline D2 & .90 & .86 & .89 & .90 & .89 & .87 & .93 & .80 & .83 & .93 & 1 & & & & & & & & & \\
\hline D1 & .96 & .95 & .92 & .92 & .81 & .95 & .91 & .89 & .92 & .85 & .89 & 1 & & & & & & & & \\
\hline $83 / 2$ & .91 & .97 & .90 & .88 & .77 & .94 & .86 & .94 & .96 & .81 & .85 & .93 & 1 & & & & & & & \\
\hline $83 / 3$ & .90 & .86 & .91 & .90 & .89 & .87 & .94 & .80 & .82 & .95 & .95 & .89 & .84 & 1 & & & & & & \\
\hline $83 / 4$ & .93 & .88 & .92 & .91 & .88 & .89 & .95 & .82 & .85 & .92 & .95 & .91 & .86 & .97 & 1 & & & & & \\
\hline $83 / 5$ & .93 & .98 & .91 & .91 & .78 & .97 & .88 & .92 & .93 & .82 & .86 & .95 & .96 & .86 & .88 & 1 & & & & \\
\hline $83 / 6$ & .96 & .96 & .94 & .93 & .80 & .99 & .90 & .90 & .94 & .84 & .88 & .96 & .94 & .88 & .90 & .97 & 1 & & & \\
\hline $83 / 7$ & .89 & .95 & .87 & .87 & .77 & .91 & .86 & .94 & .95 & .81 & .84 & .92 & .97 & .83 & .85 & .94 & .92 & 1 & & \\
\hline $83 / 8$ & .92 & .95 & .89 & .89 & .80 & .94 & .88 & .91 & .95 & .83 & .87 & .95 & .95 & .86 & .88 & .94 & .95 & .96 & 1 & \\
\hline $83 / 9$ & .91 & .96 & .88 & .88 & .79 & .93 & .87 & .92 & .93 & .83 & .86 & .93 & .96 & .85 & .87 & .95 & .94 & .98 & .98 & 1 \\
\hline
\end{tabular}


cycle of these chemical changes. Fewer eruptions are recorded at the Murupara locality due to erosion of the upper part of the sequence, as indicated by significant paleorelief present beneath the Matahina Ignimbrite.

Trace element data for the tephra beds in the two sections are also similar (Table 4.5). Trends in incompatible elements, such as Ce content, parallel trends in the major element composition (Figures 4.6, 4.8). The general chemical similarity between the two sections show they are related to each other, but not chemically identical to any of the bounding ignimbrite units.

\subsubsection{Numerical comparison of tephra compositions}

The tephra compositions may be compared numerically using a similarity coefficient (Borchardt et al. 1971; Sarna-Wojcicki et al. 1987). A similarity coefficient (SC) compares the composition of two samples by a mean ratio of their oxide contents and is defined as:

$$
\mathbf{d}(\mathbf{A B})=[\Sigma \mathbf{R i} / \mathbf{n}]
$$

where,

$\mathrm{d}(\mathrm{AB})=\mathrm{SC}$ between analyses of tephras $\mathrm{a}$ and $\mathrm{b}$.

$\mathrm{i}=$ oxide number

$\mathrm{n}=$ number of oxides

$\mathrm{Ri}=\mathrm{XiA} / \mathrm{XiB}$ or $\mathrm{XiB} / \mathrm{XiA}$, whichever is $<1.0$

$\mathrm{XiA}=$ concentration of oxide $\mathrm{i}$ in sample $\mathrm{A}$

$\mathrm{XiB}=$ concentration of oxide $\mathrm{i}$ in sample $\mathrm{B}$

An identical match would produce an SC of 1.0. This is not usually found when comparing identical samples, due to analytical uncertainty and natural variability. The SC value used to support a correlation between two samples depends on which elements are used, and their analytical error. Elements of low concentration (e.g. $\mathrm{MnO}, \mathrm{TiO}_{2}, \mathrm{MgO}$ ) present two problems: (1) they have a high analytical uncertainty $(30-100 \%)$, and (2) because of their low absolute concentration, small absolute differences represent a greater percentage difference compared to oxides with greater abundance. The latter is an inherent problem with Similarity Coefficients. $\mathrm{MnO}$ is poorly determined for some analyses, and below the detection limit in some samples while $\mathrm{Cl}$ is generally invariant between different TVZ glasses. This leaves the oxides of $\mathrm{Si}, \mathrm{Al}, \mathrm{Ti}, \mathrm{Fe}, \mathrm{Mg}, \mathrm{Ca}, \mathrm{Na}, \mathrm{K}$ to determine $\mathrm{SC}$ values. This array of elements, determined on similar instruments, usually produces SC values $>0.9$ for chemically similar tephra beds (Shane and Froggatt 1991; Kohn et al. 1992).

Comparison of each of the different ignimbrite units (Whakamaru, Matahina, Kaingaroa, Downer 8) produce SC values $<0.91$, indicating they are compositionally different 
(Table 4.6). The exception is the SC for sample 83/1 (Matahina base), which show greater similarity (0.93 - 0.94) for some comparisons. This sample was analysed on a different instrument (see Table 4.3) and therefore these SC values probably reflect calibration differences.

All of the fallout beds can be distinguished from Whakamaru, having SC values in the range $0.85-0.90$. Downer 8 is also distinctive, with Downer $3(\mathrm{SC}=0.92)$ the closest match. The best compositional matches for the remaining ignimbrites: Matahina closely matches the composition of 83/5,83/6, Downer 1 and Downer 7 ( $\mathrm{SC}>0.94$ ) but can be distinguished by $\mathrm{NaO} / \mathrm{K} 2 \mathrm{O}>1$ for Matahina Ignimbrite and lapilli samples only. The high SC values for many tephra bed comparisons makes it difficult to precisely identify correlative tephra beds. Cyclic activity is confirmed, with tephra beds 1 and 4 from Downer Rd being closely similar to tephra bed 7 stratigraphically above in the same section.

\subsection{CONCLUSIONS}

1. Bulk compositional variation between different pumice clasts within welded ignimbrites is mainly due to differing phenocryst contents. The glass phase in many of these clasts has undergone alteration.

2. Glass from the nonwelded bases of large flow units is often unaltered and allows the unit to be geochemically fingerprinted, often by as few as two major oxides e.g. $\mathrm{FeO}$ and $\mathrm{CaO}$.

3. Fe-Ti oxide compositions may fingerprint individual eruptive events. They allow both welded and nonwelded units to be identified and correlated, as long as they have not undergone any exsolution. Homogeneous un-exsolved oxide compositions found in this study do not support derivation from magma chambers with physical or chemical gradients.

4. Exsolution is common in Fe-Ti oxides from TVZ ignimbrites, even of late Pleistocene age. Compositional variation in $\mathrm{Fe}_{2} \mathrm{O}_{3}$ of $62 \%$ and $\mathrm{TiO}_{2}$ of $36 \%$ can result.

5. Vertical stratigraphic sampling through the basal lapilli and flow unit of the widespread Matahina Ignimbrite shows no major or trace element compositional variation in the glass phase. This shows large volume ignimbrites may be derived from homogeneous magma chambers with no evidence of physical or compositional gradients. 


\section{Chapter 5 \\ ANISOTROPY OF MAGNETIC SUSCEPTIBILITY STUDIES OF TVZ IGNIMBRITES}

\subsection{INTRODUCTION}

Anisotropy of magnetic susceptibility (AMS) in rocks and sediment results from the alignment of magnetic grains to produce a magnetic fabric (Ellwood 1982; Jackson and Tauxe 1991). This magnetic fabric can result from a variety of geologic processes, such as fluid flow during emplacement of igneous rocks. Therefore the measurement of the magnetic fabrics in rocks can give insights into flow directions and paths. In the case of widespread ignimbrites such as in the TVZ, the magnetic fabrics may provide information on the location of source vents and the paleotopography.

In the TVZ, most large ignimbrite sheets lack megascopic flow indicators such as fiamme, or exposures are too few to be of use in assessing regional flow patterns. The measurement of the microscopic alignment of elongated crystals requires multiple oriented thin sectioning and is time consuming. Few examples of paleoflow studies of TVZ ignimbrites are in the literature. Froggatt et al. (1981) demonstrated a radial alignment of logs within the Taupo Ignimbrite around its source within Lake Taupo.

AMS has been used to constrain eruptive vents of large ignimbrites in several volcanic provinces elsewhere. Knight et al. (1986) used AMS to infer vent locations of the Toba tuffs in Sumatra. MacDonald and Palmer (1990) studied the Upper Bandelier Tuff at Valles Caldera, New Mexico, where the source was already well constrained. From a radial distribution of sample sites they found that AMS data was in good agreement with oriented pumice clasts and crystals, and showed that the axis of maximum susceptibility was in the direction of paleoflow. Hillhouse and Wells (1991) found that the imbrication of the foliation plane (the axis of minimum susceptibility) dips toward the vent, while the maximum susceptibility is generally parallel to flow. They used these data to constrain the source of the Peach Springs Tuff in Nevada. Magnetic fabrics of ignimbrites from the Mogollon-Datil volcanic field, New Mexico (Seaman et al. 1991) compare well with lineation directions derived from center-to-center analysis on phenocrysts (Seaman and Williams 1992), again suggesting an accord between crystal alignment and susceptibility. Paleoflow directions have also been determined for lava flows using AMS (e.g. Knight and Walker 1988, Cañón-Tapia et al. 1995). Some studies have shown that magnetic fabrics measurements are largely unaffected by the relative abundance of fiamme, matrix and lithics within the specimens (e.g. Wolff et al. 1989). This is analogous to paleomagnetic remanences.

Syn- and post-depositional compaction of the ignimbrite has a major effect on the resulting magnetic fabric. Most of the above studies have found that the direction of minimum magnetic susceptibility (equivalent to the shortest crystal axis) is nearly perpendicular to the 

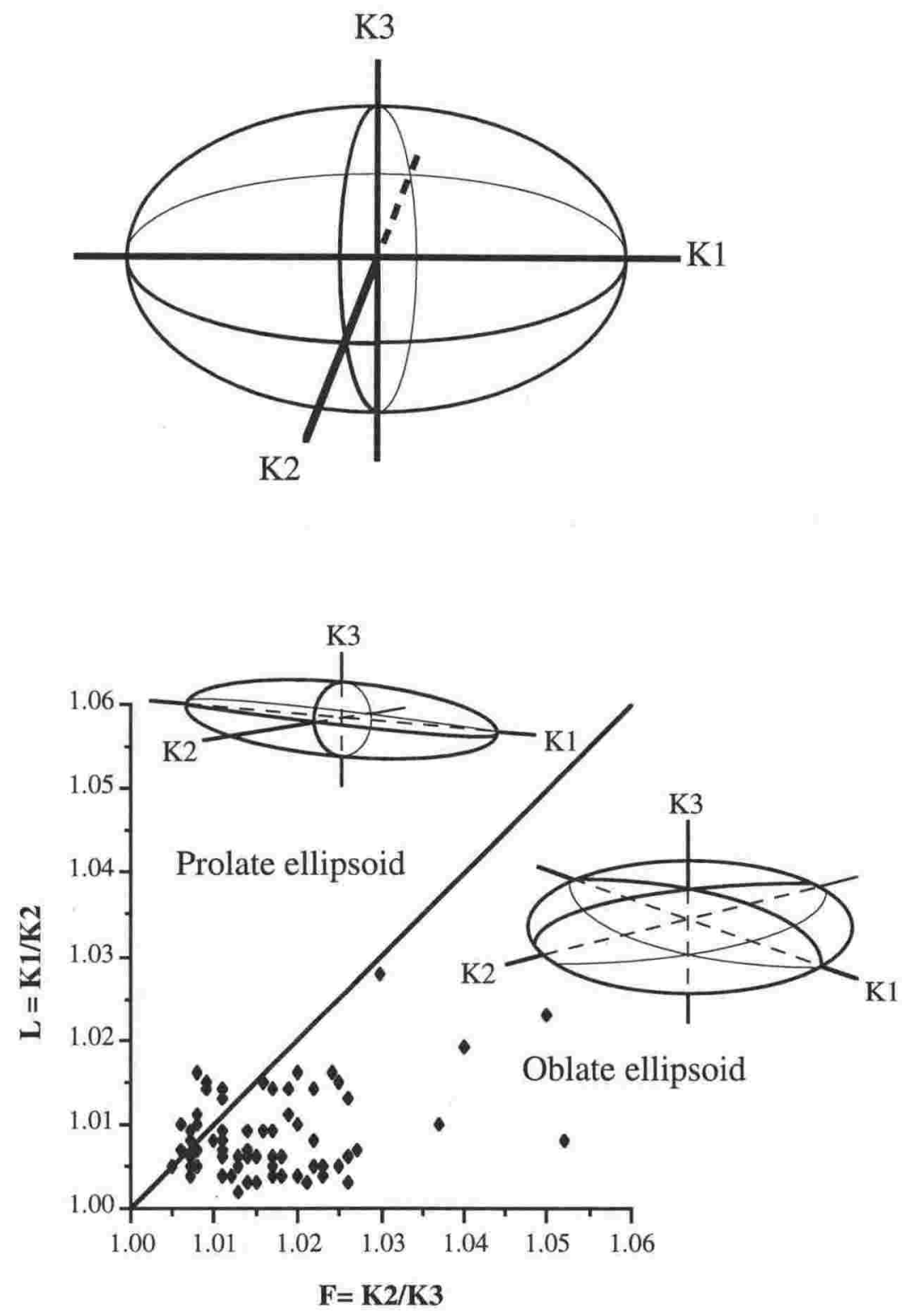

Figure 5.1 The AMS ellipsoid is defined by three orthogonal axes, where $\mathrm{K} 1>\mathrm{K} 2>\mathrm{K} 3$. Ellipsoids may be classified as oblate $(\mathrm{K} 2 / \mathrm{K} 3>\mathrm{K} 1 / \mathrm{K} 2)$ or prolate $(\mathrm{K} 1 / \mathrm{K} 2>$ $\mathrm{K} 2 / \mathrm{K} 3$ ). The field for each is defined on a plot of $\mathrm{L}$ vs. F. Means for each site are shown above (data from Table 5.1), and plot mainly in the oblate field. 
depositional surface. Therefore most ignimbrites have a well defined minimum susceptibility direction, even when the maximum susceptibility direction is poorly defined (e.g. Anders et al. 1989). This minimum susceptibility axis may then give insight to the attitude of the depositional surface and/or tectonic deformation.

In the first study of AMS in ignimbrites of the TVZ, Lamarche and Froggatt (1993) proposed multiple source vents for the Whakamaru Ignimbrite. The present study extends this seminal work on the Whakamaru Ignimbrite and obtains AMS data on other widespread ignimbrites in the TVZ, in particular the Mamaku and Ongatiti ignimbrites. The source for the Mamaku Ignimbrite is relatively well constrained from geologic mapping, and can be used as a test of magnetic fabric data. The non-welded Oruanui Ignimbrite was also examined. Its source is also well constrained, but its unconsolidated lithology may pose special problems for AMS studies.

\subsection{ANISOTROPY OF MAGNETIC SUSCEPTIBILITY}

Elongated grains or crystals are anisotropic in their physical properties, such as magnetisation. Anisotropy of a rock as a whole is not often seen in igneous and sedimentary rocks as the orientations of minerals are random, cancelling out any directional effects. Anisotropic fabrics are caused by the alignment of anisotropic minerals and can be seen in all types of rocks:

1. Metamorphic- lineations and foliations formed due to solid-state recrystallisation of minerals in a preferred orientation due to stress. The orientation of greatest anisotropy is perpendicular to the stress direction, so this may be used as a strain indicator in rocks.

2. Sedimentary- elongated particles become imbricated in the presence of unidirectional flow, such imbricated cobbles in a river bed. Here, the grain imbrication is parallel to the flow direction of the river.

3. Igneous- similar to the sedimentary case. Flow directions in lavas, dikes and ignimbrites can be determined as grains, shards or crystals align themselves parallel to the flow direction.

AMS may be used to assess the degree and type of alignment of magnetic particles in a rock i.e. the bulk rock fabric. Magnetic volume susceptibility $(\mathrm{K})$ is defined as being the ratio of the induced magnetisation $(\mathrm{M})$ of a rock to an applied magnetic field $(\mathrm{H})$. Measurements of $\mathrm{K}$ in orthogonal directions gives the maximum (K1), intermediate (K2) and minimum (K3) directions of anisotropy, which defines the axes of an ellipsoid (Figure 5.1), the orientation and dimensions of which parallels the major fabric of a rock.

If an ignimbrite is assumed to flow along a semihorizontal surface, the axis of maximum anisotropy (K1) should lie in the horizontal plane (Figure 5.1). After flow has ceased, compaction (due to gravity) will cause the direction of minimum anisotropy (K3) or 

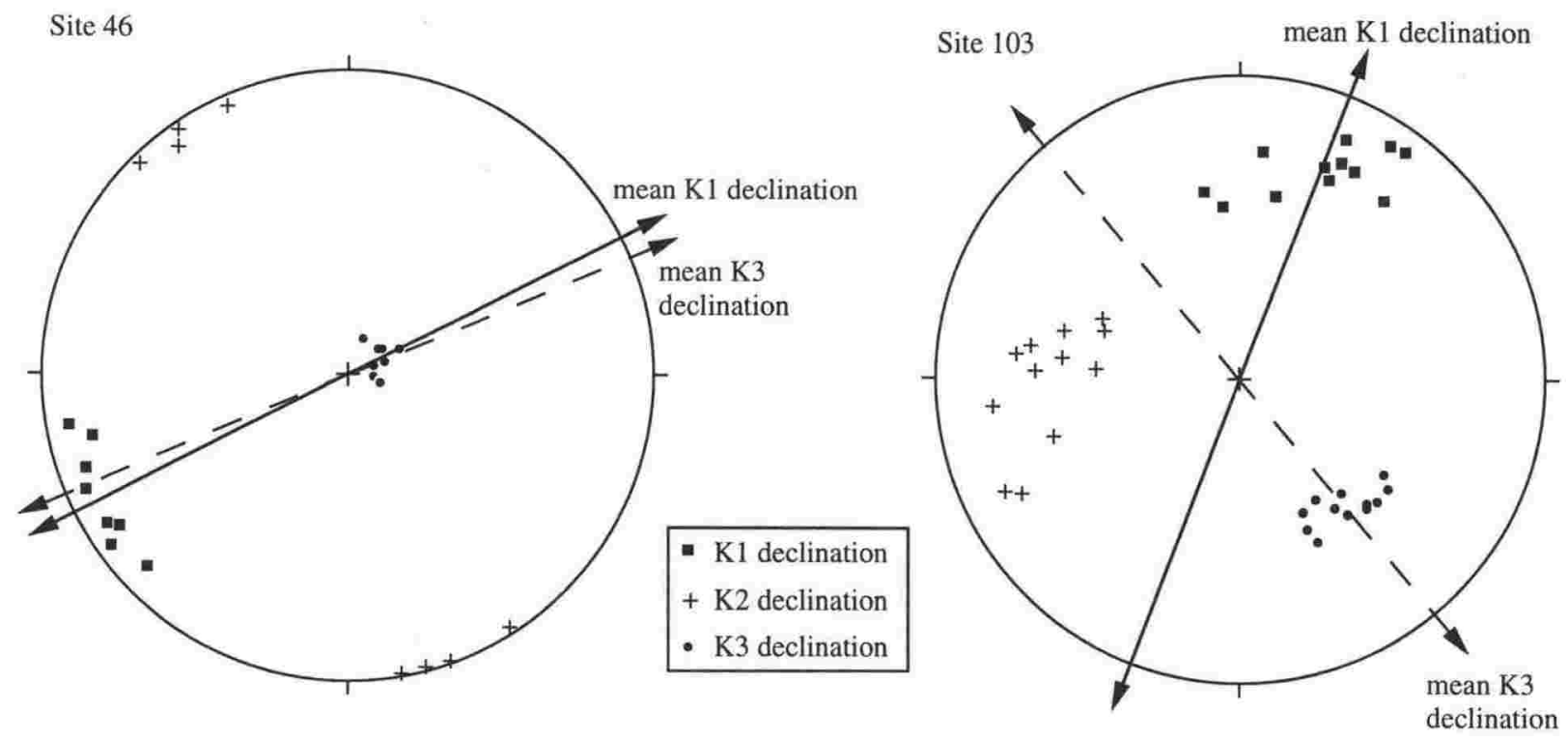

Figure 5.2 Directional data from AMS measurements may be represented on stereographic projections. The magnetic susceptibility axes are tensors and therefore define two directions, $180^{\circ}$ apart. For clarity, all measurements are plotted on the lower hemisphere. The inferred flow directions using $\mathrm{K} 1$ and $\mathrm{K} 3$ declinations are shown.

In site 46, $\mathrm{K} 2$ is subhorizontal and therefore the declination of the $\mathrm{K} 1$ and $\mathrm{K} 3$ axes are similar, and both indicate the same flow direction. In site $103, \mathrm{~K} 2$ is inclined and the $\mathrm{K} 3$ declination is oblique to $\mathrm{K} 1$. In this case, the inferred flow directions from $\mathrm{K} 1$ and $\mathrm{K} 3$ are not concordant. 
crystal short axis to be near vertical. Standard parameters have been developed to quantify AMS (Ellwood et al. 1988). The bulk magnetic susceptibility (K) is equal to (K1 + K2 + $\mathrm{K} 3) / 3$. Magnetic foliation $(\mathrm{F}=\mathrm{K} 2 / \mathrm{K} 3)$ and lineation $(\mathrm{L}=\mathrm{K} 1 / \mathrm{K} 2)$ describe whether the anisotropy ellipsoid is oblate $(\mathrm{F}>\mathrm{L})$ or prolate $(\mathrm{L}>\mathrm{F})$. The degree of anisotropy $(\mathrm{P})$ is expressed as $\mathrm{K} 1 / \mathrm{K} 3$. An oblate ellipsoid is saucer shaped and the resulting lineation may not be well developed (Figure 5.1) if $\mathrm{K} 1$ and $\mathrm{K} 2$ are similar in magnitude. A prolate ellipsoid is cylindrical in shape if $\mathrm{K} 2$ and $\mathrm{K} 3$ are both much smaller than $\mathrm{K} 1$, therefore a strong flow fabric will be present.

The axis of maximum magnetic susceptibility (K1) is parallel to the flow direction. Being a tensor, the mean $\mathrm{K} 1$ declination could represent either of two directions $180^{\circ}$ apart (Figure 5.1, 5.2). K3 is orthogonal to $\mathrm{K} 1$ and $\mathrm{K} 2$, and can also be thought of as the pole to a plane defined by $\mathrm{K} 1$ and $\mathrm{K} 2$ on a stereographic projection. When $\mathrm{K} 3$ is inclined, the magnetic susceptibility ellipsoid has a plunge. Therefore, the mean $\mathrm{K} 3$ declination should also be indicative of flow direction (Figure 5.2). The direction inferred from $\mathrm{K} 1$ and $\mathrm{K} 3$ would be similar as long as the $\mathrm{K} 2$ axis is subhorizontal. Tilt of the $\mathrm{K} 2$ axis greatly affects the azimuth of the steeply inclined $\mathrm{K} 3$ axis. Therefore, in sites with inclined $\mathrm{K} 2$ axes, the declination of $\mathrm{K} 3$ is oblique to the $\mathrm{K} 1$ declination and would not reflect the paleoflow direction (Figure 5.2).

The shape and orientation of the susceptibility ellipsoid for a specimen is controlled by the fabric of ferromagnetic minerals. In igneous rocks, including ignimbrites, AMS is strongly controlled by magnetite. Studies of ignimbrite flow units elsewhere (Hillhouse and Wells 1991), and for the Whakamaru Ignimbrite (Lamarche and Froggatt 1993) suggests titanomagnetite is the main cause of the susceptibility. Titanomagnetite crystals from several exposures were characterised by electron microprobe analysis in this study and used for correlation purposes in Chapter 4. The alignment of the crystals result from laminar flow during emplacement. The degree of anisotropy may be increased by compaction and/or the post-depositional replacement growth of hematite (Seaman et al. 1991).

\subsection{METHOD}

\subsubsection{Ignimbrites selected}

Widespread units, such as Whakamaru and Ongatiti ignimbrites were selected for analysis. A radial distribution of sample sites around the proposed source area is necessary for constraining the vent location and many ignimbrites (especially the older ones) have a sparse outcrop distribution due to burial and erosion. Pervasive welding aids sampling and allows multiple specimens to be collected from each site. However, Mamaku Ignimbrite was also selected since its source, the Rotorua Caldera is reasonably certain and may be used as a test for this method, and the cube sampling technique. Oruanui ignimbrite is also a test for this technique. 
Mapping of late Quaternary ignimbrites in the TVZ has shown that there is not always a radial deposition of ignimbrite around the source vent, such as Matahina and Kaingaroa ignimbrites (Figures 2.6, 2.7). Here, the flow facies is restricted mostly to one side of the caldera. Samples from each unit were taken from as radial a distribution as possible.

\subsubsection{Sampling and measurement}

Samples for AMS analysis were the same ones used for the paleomagnetic investigation. As many specimens as possible were collected at each site over a wide area so that the direction obtained is fully representative of the site. From the cores drilled at the outcrop, each specimen was cut so that the ratio of length to width was 0.85 , to minimise shape effects. Samples of other dimensions have been shown to control the AMS, rather than the magnetic fabric (Jelinek 1978). Shape abnormalities, such as pumice holes, abnormally large pumices or lithics were noted in case the measurements were anomalous compared to the rest of the site. Cores that tended to crumble were coated with polyurethane to keep the specimens intact during the measurement process. In the case of the Oruanui and some sites of Mamaku Ignimbrite where cubes were cut, only 4 specimens per site were obtained.

AMS measurements were made on a Sapphire Instruments SI-2 low-field susceptibility meter. This instrument measures the inductance change in a coil, first for an air reading, then with a sample in the coil. Measurements were carried out in 6 orientations with 2 repeats at each position. The results are averaged for each position and the eigenvalues are calculated (Stupavsky 1985) to give the direction and magnitude of the principal axes of magnetic susceptibility (K1, K2 and K3 which define the specimen's ellipsoid). R95 is a measurement of scatter, similar to $\alpha_{95}$ in paleomagnetic data, which takes into account the bipolar (Bingham) distribution of axes in AMS. Some workers have calculated the areas of ellipses to quantify the scatter of data points on stereographic projections as this better approximates their distribution at low inclinations (Jelinek 1978; Hillhouse and Wells 1991). This approach produces a smaller value for scatter and is useful in the treatment of poorly clustered data. In this study, much of the data is well clustered (see Appendix 3) and the circular R95 estimates closely reflect the mean azimuth on stereographic projections. $\mathrm{R}_{95}$ values are also preferred as they give a more conservative estimate for well clustered, but low anisotropy specimens within a site.

The bulk magnetic susceptibility $(\mathrm{K})$, foliation $(\mathrm{F})$ and lineation $(\mathrm{L})$ parameters are calculated for each specimen, and the results averaged for each site (Table 5.1). As well as considering site statistics, the visual representation of AMS data on stereonets (Appendix 3) is important in assessing fabric azimuths and data reliability. 
Table 5.1 Mean AMS measurements for TVZ ignimbrites.

\begin{tabular}{|c|c|c|c|c|c|c|c|c|c|}
\hline Site & $\bar{N}$ & $\overline{\mathrm{K} 1}$ & $\overline{\mathrm{K} 2}$ & $\overline{\mathrm{K} 3}$ & $\begin{array}{c}\mathrm{Km}(\mathrm{SD}) \\
10^{-3} \\
\end{array}$ & $\begin{array}{c}\mathrm{K} 1 / \mathrm{K} 3 \\
\mathrm{P} \\
\end{array}$ & $\begin{array}{c}\mathrm{K} 1 / \mathrm{K} 2 \\
\mathrm{~L}\end{array}$ & $\begin{array}{c}\mathrm{K} 2 / \mathrm{K} 3 \\
\mathrm{~F}\end{array}$ & $\overline{\text { Typ }}$ \\
\hline \multicolumn{10}{|c|}{ Ngaroma Ignimbrite } \\
\hline 50 & 11 & $004-9(23)$ & $27519(24)$ & $06070(13)$ & $0.38(0.09)$ & 1.040 & 1.016 & 1.024 & 2 \\
\hline \multicolumn{10}{|c|}{ Ongatiti Ignimbrite } \\
\hline 42 & 10 & $301-5(21)$ & $04252(28)$ & $046-45(23)$ & $5.35(0.29)$ & 1.010 & 1.005 & 1.005 & 5 \\
\hline 43 & 10 & $050-6(18)$ & $317-17(24)$ & $34470(26)$ & $3.89(0.35)$ & 1.013 & 1.007 & 1.006 & 5 \\
\hline 44 & 9 & $0847(24)$ & $354-21(27)$ & $32568(21)$ & $8.33(0.38)$ & 1.018 & 1.008 & 1.010 & 2 \\
\hline 48 & 8 & $07153(6.5)$ & $344-32(8.3)$ & $075-35(6.8)$ & $2.05(0.11)$ & 1.023 & 1.013 & 1.011 & 1 \\
\hline 49 & 12 & $02826(7)$ & 2949 (7) & $006-63(4)$ & $3.70(0.21)$ & 1.040 & 1.016 & 1.024 & 1 \\
\hline 51 & 10 & $329-49(7)$ & $0508(8)$ & $31441(6)$ & $2.27(0.07)$ & 1.015 & 1.007 & 1.008 & 1 \\
\hline 52 & 9 & $304-25(33)$ & 0151 (34) & $28463(6)$ & $7.80(0.35)$ & 1.015 & 1.004 & 1.011 & 3 \\
\hline 55 & 12 & $329-22(26)$ & $05021(26)$ & $28060(5)$ & $7.38(0.47)$ & 1.022 & 1.004 & 1.018 & 3 \\
\hline 56 & 10 & $31655(9)$ & $08117(25)$ & $005-28(25)$ & $2.38(0.21)$ & 1.024 & 1.016 & 1.008 & 5 \\
\hline 59 & 10 & $081-5(15)$ & $35315(16)$ & $341-76(11)$ & $6.38(0.35)$ & 1.015 & 1.007 & 1.008 & 1 \\
\hline 62 & 7 & $0443(33)$ & 3134 (33) & $073-86(10)$ & $8.27(0.49)$ & 1.021 & 1.006 & 1.015 & 2 \\
\hline 63 & 11 & $031-3(23)$ & $300-7(23)$ & $32382(4)$ & $11.62(0.06)$ & 1.023 & 1.004 & 1.018 & 2 \\
\hline 114 & 11 & $076-5(5)$ & $346-15(8)$ & $00475(8)$ & $5.08(0.04)$ & 1.021 & 1.012 & 1.009 & 1 \\
\hline 115 & 12 & 07427 (23) & $342-1(24)$ & $065-65(13)$ & $6.27(0.07)$ & 1.016 & 1.007 & 1.009 & 2 \\
\hline 119 & 6 & $299-4(19)$ & 0290 (19) & $28785(7)$ & $3.83(0.02)$ & 1.032 & 1.007 & 1.025 & 2 \\
\hline 123 & 10 & $310-11(23)$ & $050-14(25)$ & $02576(16)$ & $6.07(1.06)$ & 1.021 & 1.007 & 1.014 & 2 \\
\hline 126 & 16 & $354-5(15)$ & $086-3(16)$ & $02784(8)$ & $5.96(0.70)$ & 1.021 & 1.006 & 1.013 & 2 \\
\hline 170 & 14 & $28822(9)$ & $014-4(14)$ & $276-67(13)$ & $2.26(0.18)$ & 1.019 & 1.008 & 1.011 & 4 \\
\hline 172 & 19 & $084-36(23)$ & 01920 (21) & $296-52(16)$ & $0.46(0.06)$ & 1.014 & 1.008 & 1.006 & 7 \\
\hline
\end{tabular}

\section{Ahuroa Ignimbrite}

\begin{tabular}{|c|c|c|c|}
\hline 53 & 8 & $3365(26)$ & $0661(26)$ \\
\hline 57 & 7 & $28719(11)$ & $007-31(20)$ \\
\hline 61 & 8 & $346-2(25)$ & $076-10(25)$ \\
\hline 118 & 12 & $282-15(9)$ & $015-15(10)$ \\
\hline 121 & 8 & $090-7(27)$ & $3590(26)$ \\
\hline 122 & 12 & $3430(24)$ & $072-24(24)$ \\
\hline 124 & 11 & $3448(25)$ & (25) \\
\hline
\end{tabular}

$\begin{array}{llllll}325-83(6) & 8.56(2.09) & 1.022 & 1.005 & 1.017 & 2 \\ 04053(18) & 3.00(0.27) & 1.015 & 1.007 & 1.008 & 1 \\ 05680(5) & 6.72(0.23) & 1.017 & 1.003 & 1.014 & 2 \\ 32970(4) & 9.13(0.23) & 1.026 & 1.005 & 1.021 & 1 \\ 07982(8) & 5.59(0.41) & 1.027 & 1.007 & 1.019 & 2 \\ 06371(8) & 2.54(0.13) & 1.011 & 1.004 & 1.007 & 2 \\ \mathbf{0 5 7 - 7 3 ( 7 )} & 2.95(0.22) & 1.019 & 1.005 & 1.014 & 3\end{array}$

\section{Marshall ignimbrites}

$\begin{array}{lrll}6 & 16 & \mathbf{2 8 9} & \mathbf{- 3}(\mathbf{1 4}) \\ 64 & 10 & \mathbf{0 6 9} & \mathbf{- 4}(\mathbf{2 5}) \\ 65 & 9 & \mathbf{3 4 1} \mathbf{1}(\mathbf{1 2})\end{array}$

$0190(14)$
$3393(25)$
$0717(12)$

$\begin{array}{lll}28286(3) & 9.85(0.83) & 1.028 \\ 280-86(3) & 7.30(0.20) & 1.029 \\ 070-82(5) & 8.29(0.27) & 1.028\end{array}$

1.005

1.022

$1.003 \quad 1.026$

$1.005 \quad 1.022$

\section{Whakamaru group ignimbrites}

\begin{tabular}{|c|c|}
\hline $5-10(15)$ & $04312(15)$ \\
\hline $32320(22)$ & $0566(22)$ \\
\hline $280-7(15)$ & 01015 (14) \\
\hline $019-27(14)$ & $286-8(14)$ \\
\hline $343-12(5)$ & $06727(7)$ \\
\hline 3312 (19) & $0607(21)$ \\
\hline $320-36(7)$ & $058-11(14)$ \\
\hline 3084 (14) & $037-21(14)$ \\
\hline $08132(5)$ & $3511(6)$ \\
\hline $023-31(5)$ & $287-9(5)$ \\
\hline $018-31(3)$ & $285-5(3)$ \\
\hline $3596(14)$ & $085-5(26)$ \\
\hline 2909 (13) & 0201 (13) \\
\hline $086-30(11)$ & 3572 (13) \\
\hline
\end{tabular}

$\begin{array}{ll}076 & -75(6) \\ \mathbf{3 3 9} & -\mathbf{7 0}(\mathbf{5}) \\ 027 & -71(12) \\ 001 & 63(6) \\ 274 & 61(7) \\ 069 & -84(9) \\ 342 & 52(15) \\ 049 & 69(3) \\ 078 & -58(5) \\ 003 & 57(4) \\ 006 & 59(3) \\ 295 & 78(22) \\ 294 & -80(5) \\ 271 & -60(10)\end{array}$

$7.80(0.45) \quad 1.022$ $6.98(0.48) \quad 1.028$

$6.49(0.44) \quad 1.031$

$8.08(0.44) \quad 1.023$

$9.50(0.17) \quad 1.020$

$13.24(0.46) \quad 1.030$

$5.83(0.48) \quad 1.017$

$8.85(0.39) \quad 1.031$

$8.22(0.45) \quad 1.040$

$6.92(0.28) \quad 1.037$

$7.77(0.26) \quad 1.039$

$5.99(0.25) \quad 1.023$

$10.16(0.37) \quad 1.025$

$8.03(0.31) \quad 1.019$

$\begin{array}{lll}1.006 & 1.015 & 2 \\ 1.005 & 1.023 & 3 \\ 1.011 & 1.019 & 1 \\ 1.009 & 1.014 & 2 \\ 1.009 & 1.011 & 1 \\ 1.010 & 1.020 & 1 \\ 1.010 & 1.008 & 1 \\ 1.005 & 1.025 & 1 \\ 1.015 & 1.025 & 1 \\ 1.014 & 1.022 & 1 \\ 1.013 & 1.026 & 1 \\ 1.014 & 1.009 & 4 \\ 1.009 & 1.016 & 1 \\ 1.008 & 1.011 & 1\end{array}$




\begin{tabular}{ccccccccc}
\hline \hline Site & $\mathrm{N}$ & $\mathrm{K} 1$ & $\mathrm{~K} 2$ & $\mathrm{~K} 3$ & $\mathrm{Km}(\mathrm{SD})$ & $\mathrm{K} 1 / \mathrm{K} 3$ & $\mathrm{~K} 1 / \mathrm{K} 2$ & $\mathrm{~K} 2 / \mathrm{K} 3$ \\
& & & $10^{-3}$ & $\mathrm{P}$ & $\mathrm{T}$ & $\mathrm{F}$ & $\mathrm{F}$ \\
\hline
\end{tabular}

Whakamaru group ignimbrites (cont.)

\begin{tabular}{|c|c|c|c|c|c|c|c|}
\hline 13 & $35421(8)$ & $0809(8)$ & $32967(6)$ & $6.45(0.47)$ & 1.031 & 1.014 & 1.017 \\
\hline 12 & $35033(11)$ & 0801 (11) & $353-57(6)$ & $7.55(0.32)$ & 1.025 & 1.009 & 1.016 \\
\hline 12 & $022-7(20)$ & $2923(21)$ & $05682(7)$ & $6.57(0.30)$ & 1.017 & 1.006 & 1.011 \\
\hline 11 & 0228 (17) & 2927 (17) & $350-82(7)$ & $5.91(0.27)$ & 1.019 & 1.005 & 1.013 \\
\hline 11 & $01412(11)$ & $287-17(13)$ & $066-67(11)$ & $7.25(0.42)$ & 1.025 & 1.014 & 1.011 \\
\hline 14 & $35915(17)$ & $088-5(17)$ & $343-73(5)$ & $1.33(0.22)$ & 1.060 & 1.019 & 1.040 \\
\hline 11 & $34111(9)$ & 06719 (17) & $031-65(16)$ & $3.42(0.10)$ & 1.059 & 1.028 & 1.030 \\
\hline 45 & $050-11$ (14) & $32745(16)$ & $309-42(12)$ & $6.09(0.19)$ & 1.019 & 1.006 & 1.013 \\
\hline 46 & $0639(8)$ & $3330(8)$ & $067-81(3)$ & $8.14(0.34)$ & 1.047 & 1.010 & 1.037 \\
\hline 15 & $02923(6)$ & $2974(6)$ & $015-67(3)$ & $6.80(0.20)$ & 1.074 & 1.023 & 1.050 \\
\hline 54 & $0543(11)$ & 32421 (14) & $332-69(12)$ & $5.40(0.39)$ & 1.015 & 1.008 & 1.007 \\
\hline 10 & $0609(11)$ & $335-6(19)$ & $089-73(15)$ & $5.16(0.16)$ & 1.034 & 1.007 & 1.027 \\
\hline 66 & 3299 (13) & 06218 (13) & $034-70(3)$ & $10.69(1.25)$ & 1.028 & 1.004 & 1.023 \\
\hline 67 & $055-32(28)$ & $33414(28)$ & $08453(3)$ & $6.19(0.15)$ & 1.060 & 1.008 & 1.052 \\
\hline 68 & $068-18(6)$ & $34317(7)$ & $294-65(7)$ & $9.65(0.32)$ & 1.031 & 1.008 & 1.022 \\
\hline 15 & $299-2(7)$ & $02816(9)$ & $035-75(9)$ & $9.22(0.42)$ & 1.016 & 1.009 & 1.007 \\
\hline 71 & $3102(22)$ & $038-26(21)$ & $04666(8)$ & $0.93(0.07)$ & 1.020 & 1.006 & 1.014 \\
\hline 13 & $010-4(23)$ & $279-11(23)$ & $31987(8)$ & $0.41(0.04)$ & 1.031 & 1.015 & 1.016 \\
\hline 11 & $04125(25)$ & $3145(28)$ & $036-63(19)$ & $2.56(0.19)$ & 1.012 & 1.006 & 1.007 \\
\hline 74 & $350-5(6)$ & $081-7(8)$ & $04281(6)$ & $9.71(0.22)$ & 1.036 & 1.016 & 1.020 \\
\hline 75 & $323-4(31)$ & 05519 (34) & $067-63(21)$ & $5.15(0.58)$ & 1.019 & 1.011 & 1.008 \\
\hline 14 & $03134(22)$ & $302-2(22)$ & $035-53(4)$ & $10.10(0.35)$ & 1.022 & 1.006 & 1.017 \\
\hline 77 & $274-9(11)$ & $34658(36)$ & $35918(39)$ & $4.57(0.30)$ & 1.017 & 1.010 & 1.006 \\
\hline 10 & $08821(21)$ & $002-10(20)$ & $28670(10)$ & $5.81(1.67)$ & 1.026 & 1.009 & 1.017 \\
\hline 17 & $344-15(21)$ & $33243(25)$ & $07018(16)$ & $5.11(0.20)$ & 1.018 & 1.007 & 1.011 \\
\hline 12 & $27233(7)$ & 00712 (15) & $295-56(15)$ & $5.49(0.21)$ & 1.024 & 1.015 & 1.009 \\
\hline 113 & $008-10(8)$ & $2796(9)$ & 04078 & $7.82(0.22)$ & 1.037 & 1.007 & 1.029 \\
\hline $117 \quad 10$ & $3275(18)$ & 05925 (18) & $047-64(6)$ & $7.03(0.34)$ & 1.021 & 1.007 & 1.015 \\
\hline $120 \quad 18$ & $026-18(18)$ & $293-11(18)$ & 35367 (3) & $4.82(0.16)$ & 1.040 & 1.004 & 1.033 \\
\hline 12516 & $011-11(8)$ & $281-4(7)$ & $35179(4)$ & $3.41(0.36)$ & 1.035 & 1.008 & 1.027 \\
\hline $127 \quad 12$ & $314-23(20)$ & $045-1(20)$ & 32267 (4) & $4.96(0.60)$ & 1.058 & 1.012 & 1.046 \\
\hline $128 \quad 14$ & $288-11(25)$ & $019-7(24)$ & 31878 & $7.05(0.15)$ & 1.018 & 1.003 & 1.016 \\
\hline 12914 & $336-23(10)$ & $068-4(10)$ & $34666(3)$ & $7.24(0.30)$ & 1.031 & 1.005 & 1.026 \\
\hline 16921 & $042-20(19)$ & $311-2$ (19) & 02673 (4) & $2.97(0.19)$ & 1.024 & 1.006 & 1.016 \\
\hline $171 \quad 17$ & $320-16(17)$ & $050-2(17)$ & $32673(2)$ & $4.82(0.97)$ & 1.032 & 1.007 & 1.025 \\
\hline
\end{tabular}

\section{Matahina Ignimbrite}

\begin{tabular}{|c|c|c|c|c|c|c|c|}
\hline 82 & 2915 (18) & $018-13(18)$ & $04776(7)$ & $0.54(0.05)$ & 1.033 & 1.014 & 1.019 \\
\hline 84 & $084-26(7)$ & $00724(7)$ & $315-54(5)$ & $4.54(0.21)$ & 1.022 & 1.007 & 1.014 \\
\hline 95 & $328-23(12)$ & $05215(13)$ & $29461(8)$ & $2.15(0.12)$ & 1.014 & 1.006 & 1.008 \\
\hline 96 & $031-10(20)$ & $300-3(20)$ & $01579(2)$ & $6.11(0.19)$ & 1.024 & 1.003 & 1.021 \\
\hline 97 & $062-11(10)$ & 3337 (11) & $274-76(4)$ & $6.61(0.16)$ & 1.018 & 1.003 & 1.015 \\
\hline 11 & $054-8(21)$ & $3246(21)$ & $08480(2)$ & $6.07(0.12)$ & 1.024 & 1.004 & 1.020 \\
\hline 99 & $0270(21)$ & $2966(21)$ & $284-83(5)$ & $8.42(0.25)$ & 1.031 & 1.006 & 1.026 \\
\hline
\end{tabular}

Kaingaroa ignimbrites

$\begin{array}{lrll}29 & 10 & \mathbf{3 2 8} \mathbf{3 6}(\mathbf{2 5}) & 08428(30) \\ 85 & 12 & \mathbf{0 8 3}-\mathbf{6}(\mathbf{1 5}) & 3531(15) \\ 86 & 10 & \mathbf{3 3 0} \mathbf{- 1}(\mathbf{2 5}) & 058-11(25) \\ 154 & 12 & \mathbf{2 8 8} \mathbf{- 9}(\mathbf{1 1}) & 017-1(11) \\ 155 & 13 & \mathbf{0 7 5}-\mathbf{8}(\mathbf{1 6}) & 345-3(18) \\ 156 & 9 & 043-13(31) & 3075(31) \\ 158 & 14 & \mathbf{3 2 6} \mathbf{- 1 0}(\mathbf{2 1}) & 013 \mathbf{5 3}(24)\end{array}$

$023-46(22)$
$275-83(3)$
$072 \quad 81(8)$
$280-82(3)$
$051 \quad 81(11)$
$076 \quad 83(9)$

$053-40(26)$

$\begin{array}{rr}3.05(0.27) & 1.012 \\ 7.10(0.22) & 1.015 \\ 10.77(2.05) & 1.023 \\ 8.16(0.35) & 1.022 \\ 6.77(0.18) & 1.010 \\ 4.91(0.74) & 1.027 \\ 0.40(0.04) & 1.021\end{array}$

1.005

1.004

1.006

1.003

1.002

1.008

1.011
1.007

1.011

1.018

1.016

1.010

1.019

1.009 


\begin{tabular}{|c|c|c|c|c|c|c|c|c|}
\hline $\begin{array}{ll}\text { Site } & \mathrm{N}\end{array}$ & $\overline{\mathrm{K} 1}$ & $\overline{\mathrm{K} 2}$ & $\overline{\mathrm{K} 3}$ & $\begin{array}{c}\mathrm{Km} \text { (SD) } \\
10^{-3}\end{array}$ & $\begin{array}{c}\mathrm{K} 1 / \mathrm{K} 3 \\
\mathrm{P}\end{array}$ & $\begin{array}{c}\text { K1/K2 } \\
\text { L }\end{array}$ & $\begin{array}{c}\mathrm{K} 2 / \mathrm{K} 3 \\
\mathrm{~F}\end{array}$ & $\overline{\text { Type }}$ \\
\hline
\end{tabular}

\section{Mamaku Ignimbrite}

\begin{tabular}{|c|c|c|c|c|c|c|c|}
\hline 10 & $285-2(13)$ & $0136(12)$ & $037-85(9)$ & $7.40(0.38)$ & 1.016 & 1.004 & 1.012 \\
\hline 13 & $016-9(25)$ & $285-10(26)$ & $34078(9)$ & $8.89(0.41)$ & 1.021 & 1.004 & 1.017 \\
\hline 14 & $031-18$ (17) & $301-2(34)$ & $02566(30)$ & $2.08(0.33)$ & 1.010 & 1.005 & 1.005 \\
\hline 18 & $03722(9)$ & $307-1(11)$ & $040-66(7)$ & $5.62(0.17)$ & 1.012 & 1.004 & 1.007 \\
\hline 87 & $041-1$ (13) & $30853(24)$ & $312-38(24)$ & $2.57(0.19)$ & 1.009 & 1.006 & 1.002 \\
\hline 88 & $051-4(45)$ & $321-28(44)$ & $33258(8)$ & $2.73(0.08)$ & 1.010 & 1.003 & 1.006 \\
\hline 13 & $007-7(18)$ & $272-4(14)$ & $32780(15)$ & $2.82(0.67)$ & 1.013 & 1.005 & 1.008 \\
\hline 90 & $28963(17)$ & $06718(28)$ & $344-18(27)$ & $0.06(0.01)$ & 1.114 & 1.075 & 1.035 \\
\hline 13 & $278-8(22)$ & $012-18(22)$ & $34970(4)$ & $8.09(0.22)$ & 1.015 & 1.002 & 1.013 \\
\hline 4 & $046-7(25)$ & $32468(14)$ & $313-18(27)$ & $3.19(0.42)$ & 1.012 & 1.005 & 1.006 \\
\hline 93 & $056-54(61)$ & $07032(61)$ & $35012(40)$ & $0.09(0.01)$ & 1.067 & 1.030 & 1.035 \\
\hline 11213 & $352-25(17)$ & $085-6(18)$ & 00766 (5) & $5.29(0.52)$ & 1.017 & 1.007 & 1.010 \\
\hline 14118 & $009-23(13)$ & $281-3(13)$ & $016-66(5)$ & $4.96(0.26)$ & 1.011 & 1.003 & 1.008 \\
\hline 14811 & $0487(9)$ & $3176(10)$ & $007-80(4)$ & $6.33(0.23)$ & 1.017 & 1.006 & 1.013 \\
\hline 150 & $08212(32)$ & 27679 (38) & $352-9(22)$ & $3.74(0.14)$ & 1.008 & 1.004 & 1.005 \\
\hline 151 & $32421(26)$ & $057-3(30)$ & $302-67(34)$ & $4.12(0.47)$ & 1.012 & 1.007 & 1.004 \\
\hline 152 & 29824 (16) & $03626(24)$ & $347-51(23)$ & $4.94(0.36)$ & 1.011 & 1.006 & 1.005 \\
\hline 153 & $333-5(28)$ & $04427(38)$ & $088-62(38)$ & $4.93(0.28)$ & 1.013 & 1.010 & 1.003 \\
\hline $159 \quad 17$ & $043-26(8)$ & $3155(8)$ & $05465(5)$ & $6.84(0.28)$ & 1.013 & 1.005 & 1.009 \\
\hline 160 & $031-25(37)$ & $05969(44)$ & $3066(27)$ & $1.85(0.15)$ & 1.010 & 1.006 & 1.003 \\
\hline 61 & $329-35(42)$ & $0782(26)$ & $004-43(46)$ & $6.65(0.35)$ & 1.013 & 1.004 & 1.009 \\
\hline 4 & $300-13(30)$ & 0403 (38) & $307-43(46)$ & $4.65(0.24)$ & 1.008 & 1.005 & 1.004 \\
\hline 164 & $35155(43)$ & $072-1(18)$ & $332-30(39)$ & $3.83(0.42)$ & 1.017 & 1.010 & 1.007 \\
\hline 165 & $283-11(43)$ & $043-25(37)$ & $01455(40)$ & $0.31(0.02)$ & 1.025 & 1.014 & 1.011 \\
\hline 166 & 29536 (14) & $004-27(23)$ & 06245 (23) & $3.91(0.30)$ & 1.014 & 1.010 & 1.004 \\
\hline 4 & $04563(26)$ & $052-22(35)$ & $327-6(41)$ & $3.94(0.09)$ & 1.008 & 1.004 & 1.004 \\
\hline 68 & $34513(13)$ & $077-4(22)$ & $330-76(21)$ & $0.26(0.07)$ & 1.04 & 1.019 & 1.020 \\
\hline
\end{tabular}

\section{Oruanui Ignimbrite}

\begin{tabular}{|c|c|c|c|c|c|c|c|}
\hline 19 & 2855 (49) & $349-6(49)$ & $07178(16)$ & $1.60(0.19)$ & 1.049 & 1.032 & 1.017 \\
\hline 20 & $054-11(20)$ & $3194(30)$ & $04981(28)$ & $1.39(0.09)$ & 1.035 & 1.013 & 1.022 \\
\hline 134 & $28578(36)$ & $3537(26)$ & $08010(35)$ & $2.73(0.19)$ & 1.032 & 1.010 & 1.022 \\
\hline 135 & $31639(23)$ & $0363(41)$ & $319-52(45)$ & $2.97(0.14)$ & 1.024 & 1.009 & 1.016 \\
\hline 136 & $334-8(22)$ & $070-16(10)$ & $03970(24)$ & $2.39(0.08)$ & 1.041 & 1.014 & 1.026 \\
\hline 138 & $08515(41)$ & $358-1(32)$ & $30170(25)$ & $2.35(0.30)$ & 1.021 & 1.010 & 1.011 \\
\hline 139 & $28916(18)$ & $016-9(29)$ & $315-66(31)$ & $3.08(0.09)$ & 1.037 & 1.019 & 1.018 \\
\hline 157 & $063-20(34)$ & $333-6(15)$ & $03770(31)$ & $1.99(0.13)$ & 1.022 & 1.009 & 1.013 \\
\hline
\end{tabular}

$\mathrm{K} 1, \mathrm{~K} 2$ and $\mathrm{K} 3$ presented as a mean declination and inclination $\left(\mathrm{R}_{95}\right.$ in brackets) based on $\mathrm{N}$ measurements.Site locations as in Appendix 3. Site classifications as in section 5.4.2. Directions in bold typeface are used as a proxy for flow orientation (see text). 


\subsection{RESULTS}

\subsubsection{Nature of AMS}

Bulk magnetic susceptibilities $(\mathrm{Km})$ for most of the specimens examined are in the range $10^{-2}-10^{-4} \mathrm{SI}$ units, with most being $10^{-3} \mathrm{SI}$ (Table 5.1). These are comparable to measurements of Lamarche and Froggatt (1993) for the Whakamaru Ignimbrite, and similar to those reported for other rhyolitic ignimbrites (Ellwood 1982; Knight et al. 1986; MacDonald and Palmer 1990; Hillhouse and Wells 1991; Seaman et al. 1991). In all sites examined K3 is the most steeply plunging axis as expected from compaction effects. The degree of anisotropy $(\mathrm{K} 1 / \mathrm{K} 3)$ is generally weak, being consistently in the narrow range $1.0-1.07$ or $1-7 \%$ and usually $2-5 \%$, for all of the ignimbrites examined. This produces a theoretical ellipsoid similar to a slightly flattened ball which on average would have a polar axis $2-5 \%$ shorter than the maximum equatorial diameter. This weak anisotropy is typical of ignimbrite fabrics reported in the literature (see above references) and identical to results of Lamarche and Froggatt (1993). Most specimens and sites display an oblate ellipsoid, i.e. K2/K3 > K1/K2 and thus tend to be more foliated than lineated. However, exceptions are described below. Most reported ignimbrite magnetic fabrics are oblate (see above references).

\subsubsection{Classification of AMS flow fabrics}

Previous workers have classified sites according to the nature of their AMS (Knight et al. 1986; Seaman et al. 1991). Several types of magnetic fabric were observed in sites analysed for AMS in this study on the basis of dispersion of multiple specimen measurements and axes orientations. Greater variety of AMS characters were observed in the TVZ ignimbrites, and 7 'types' are proposed. The most common types are analogous to 'categories' proposed by Seaman et al. (1991).

Type 1. Sites with little dispersion of $\mathrm{K} 1, \mathrm{~K} 2$ and $\mathrm{K} 3$ axes for multiple specimen measurements (Figure 5.3). R95 for $\mathrm{K} 1$ and $\mathrm{K} 2$ are $<20^{\circ}$ and often under $10^{\circ}$. For $\mathrm{K} 3$, the $\mathrm{R}_{95}$ value is $2.5-12^{\circ}$. The mean $\mathrm{K} 1$ and $\mathrm{K} 2$ axes plunge up to $15^{\circ}$. The $\mathrm{K} 3$ axis is steeply plunging $\left(54-84^{\circ}\right)$. These sites demonstrate a clear K1 direction which presumably parallels the paleoflow. The steeply plunging K3 axis reflects post-depositional compaction. At some sites the $\mathrm{K} 1$ axis plunges up to $20^{\circ}$. This may reflect undetected tectonic tilting or deposition on a dipping surface. In most cases these possibilities could not be tested as the basal contact of the ignimbrite is not exposed. Paleomagnetic remanence directions from the samples (Chapter 3) show no significant regional tilting has taken place, at least for the younger ignimbrites. Deposition on preexisting surface topography is highly likely in this case. These sites are analogous to Category 1 of Knight et al. (1986), and Category 4 where the K3 axis is inclined 

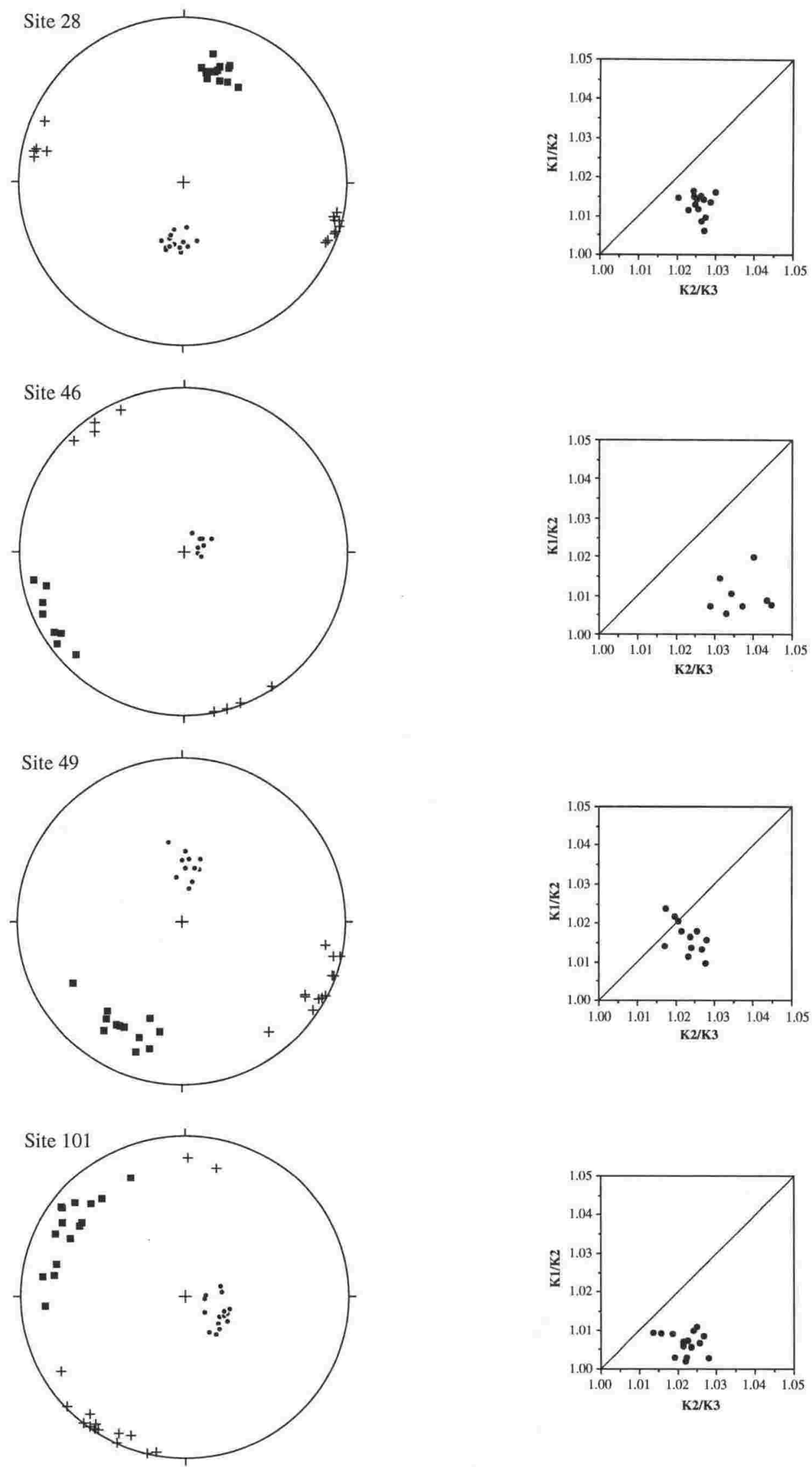

Figure 5.3 Examples of sites classified as Type 1. These sites exhibit little measurement dispersion and reliable flow directions are obtained from the K1 declination. The specimens are dominantly oblate in character. 
greater than $30^{\circ}$ from vertical. Seaman et al. (1991) classified sites similar to these as Category 1 and 1A, and did not separate the sites with a greater plunge, in accord with this study. These workers considered these type of sites to be reliable for inferring paleoflow directions.

Type 2. Sites where $\mathrm{K} 3$ displays little dispersion and is steeply plunging, while $\mathrm{K} 1$ and $\mathrm{K} 2$ display some scatter about a shallow (up to $23^{\circ}$ ) inclination with $\mathrm{R}_{95}>15^{\circ}$ (Figure 5.4). The scatter is produced by the swapping of the $\mathrm{K} 1$ and $\mathrm{K} 2$ axis directions in a few of the specimens. This occurs as the degree of anisotropy is low in these ignimbrites and $\mathrm{K} 1$ is close to $\mathrm{K} 2$ in susceptibility. Otherwise paleoflow interpretation is as in Type 1.

Type 3. Sites which display little dispersion of the $\mathrm{K} 3$ axis, but the $\mathrm{K} 1$ and $\mathrm{K} 2$ axes are scattered about a great circle which may be horizontal, or define a plane with up to $28^{\circ}$ dip (Figure 5.5). In this case, the eigenvectors of the $\mathrm{K} 1$ and $\mathrm{K} 2$ axes are very similar in magnitude and the sample set has no preferred lineation which would define a paleoflow direction. These samples typically define an oblate ellipsoid (Figure 5.5) as the K1/K2 ratio is very close to 1 . Where the $\mathrm{K} 3$ axes are inclined rather than vertical, the site displays an imbricated fabric with $\mathrm{K} 3$ defining a pole to the plane formed by the spread of $\mathrm{K} 1$ and $\mathrm{K} 2$ axes. The declination of the K3 axis may therefore be indicative of the paleoflow direction in localities displaying this behaviour. These sites are referred to as Category 2 by Knight et al. (1986) and Seaman et al. (1991).

Type 4. The direction of maximum susceptibility (K1) displays little dispersion $\left(\mathrm{R}_{95}<15^{\circ}\right.$ ) and plunges $0-30^{\circ}$ (Figure 5.6). Some substitution may occur between K2 and K3 axes. The ellipsoids for this type of site are mainly prolate, with the K2 and K3 eigenvectors similar in magnitude. These sites were only encountered occasionally. The K1 lineation still reflects the paleoflow fabric.

Type 5. Sites where $\mathrm{K} 1$ displays a tight cluster. The $\mathrm{K} 2$ and $\mathrm{K} 3$ axes are scattered on a great circle perpendicular to K1 (Figure 5.7). This type of site has a pronounced lineation or flow direction, equivalent to the $\mathrm{K} 1$ axis, but no foliation. This could arise from differential compaction of an ignimbrite with heterogeneous porosity or lithology, or that little compaction has taken place.

Type 6. A few sites showed substitution between the $\mathrm{K} 1$ and $\mathrm{K} 3$ axes (Figure 5.8). Fabrics of this type show the anisotropy is weak, both lineation and foliation.

Type 7. Sites showing scattered measurements (ca. 30 ) of all 3 axes (Figure 5.9). These sites display a very weak anisotropy which cannot be resolved with the available equipment. 

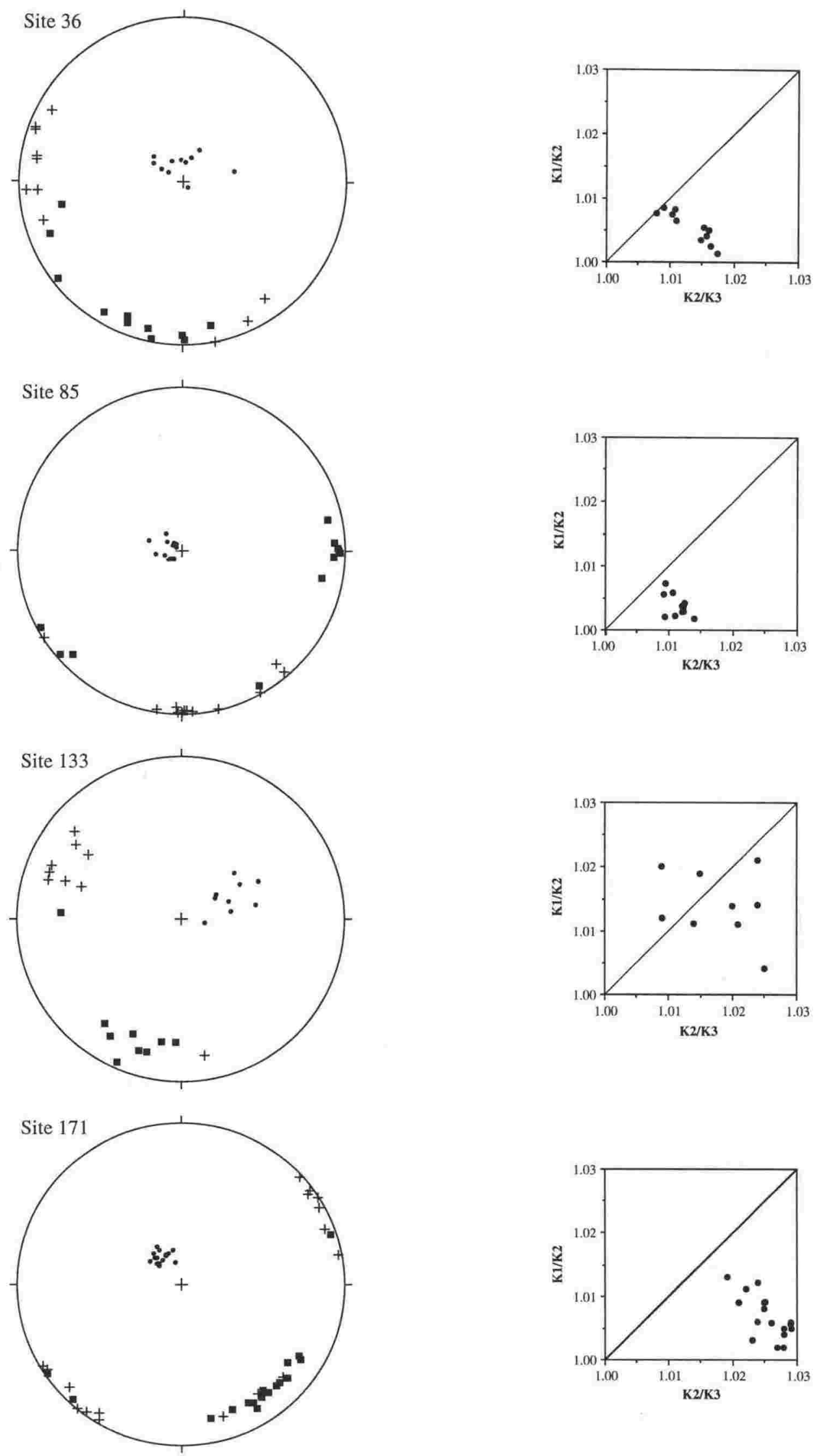

Figure 5.4 Examples of sites classified as Type 2. These are similar to Type 1, except some substitution has occurred between $\mathrm{K} 1$ and $\mathrm{K} 2$. A flow direction is still inferred to be parallel to the mean K1 declination. The similarity in magnitude between the K1 and $\mathrm{K} 2$ eigenvectors is reflected in the dominantly oblate ellipsoids. 

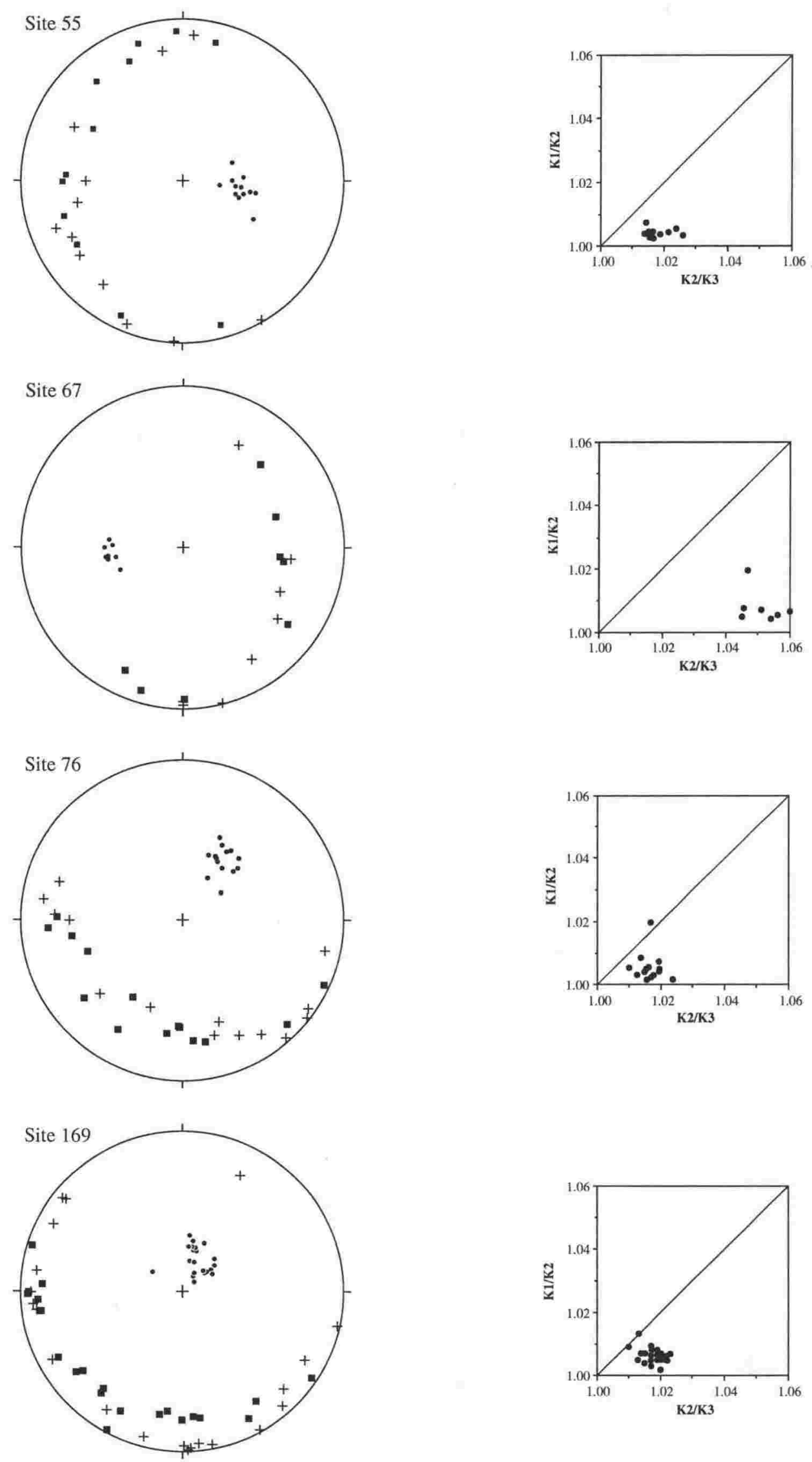

Figure 5.5 Examples of sites classified as Type 3. In these sites, $\mathrm{K} 1$ and $\mathrm{K} 2$ form a great circle, with $\mathrm{K} 3$ defining a pole to the fabric. The mean $\mathrm{K} 3$ declination may be indicative of the flow direction. 

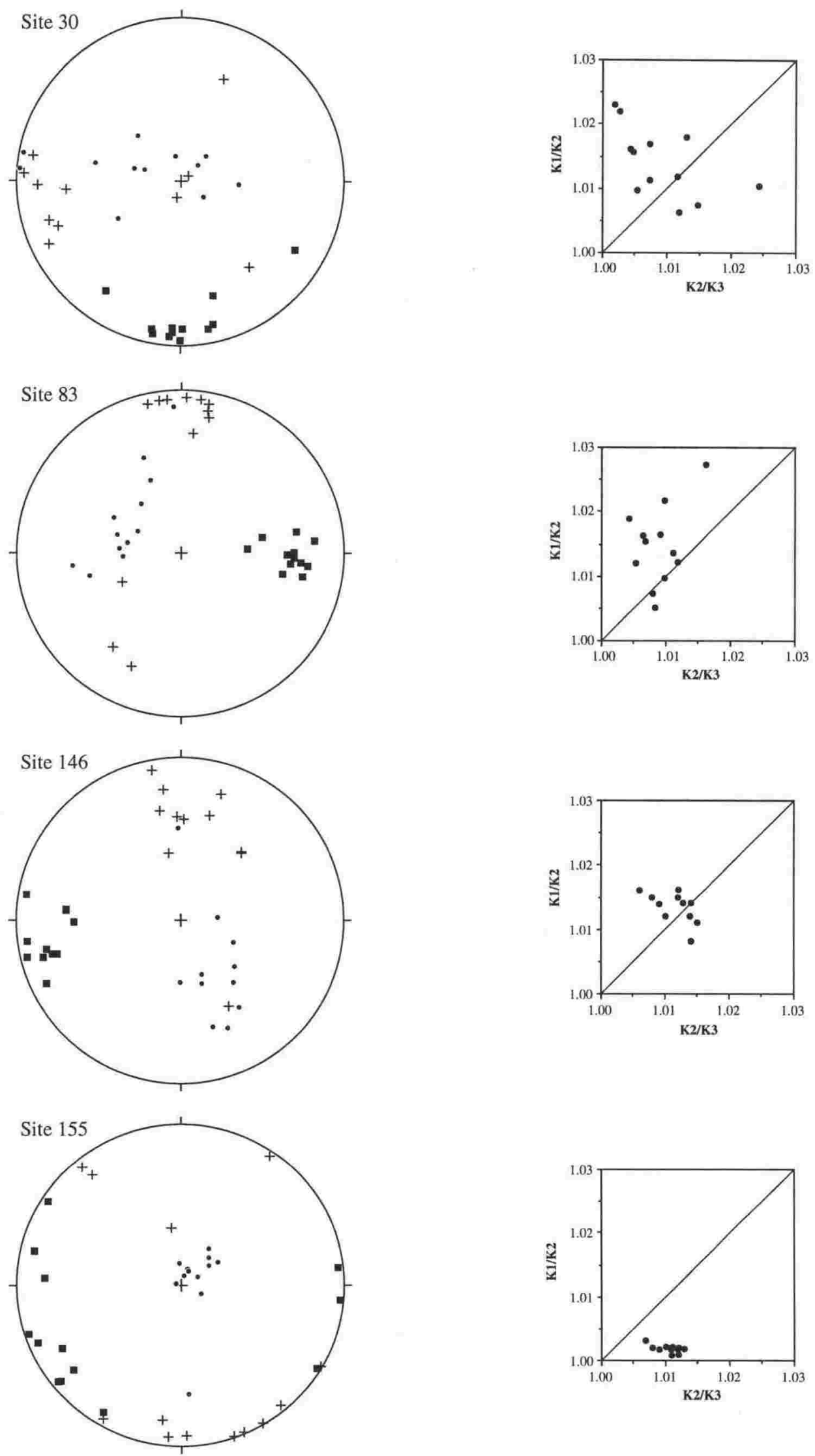

Figure 5.6 Examples of sites classified as Type 4, where some substitution occurs between the $\mathrm{K} 2$ and $\mathrm{K} 3$ axes. The flow direction is interpreted as being parallel to the $\mathrm{K} 1$ declination. Each site has specimens with both prolate and oblate ellipsoids. 

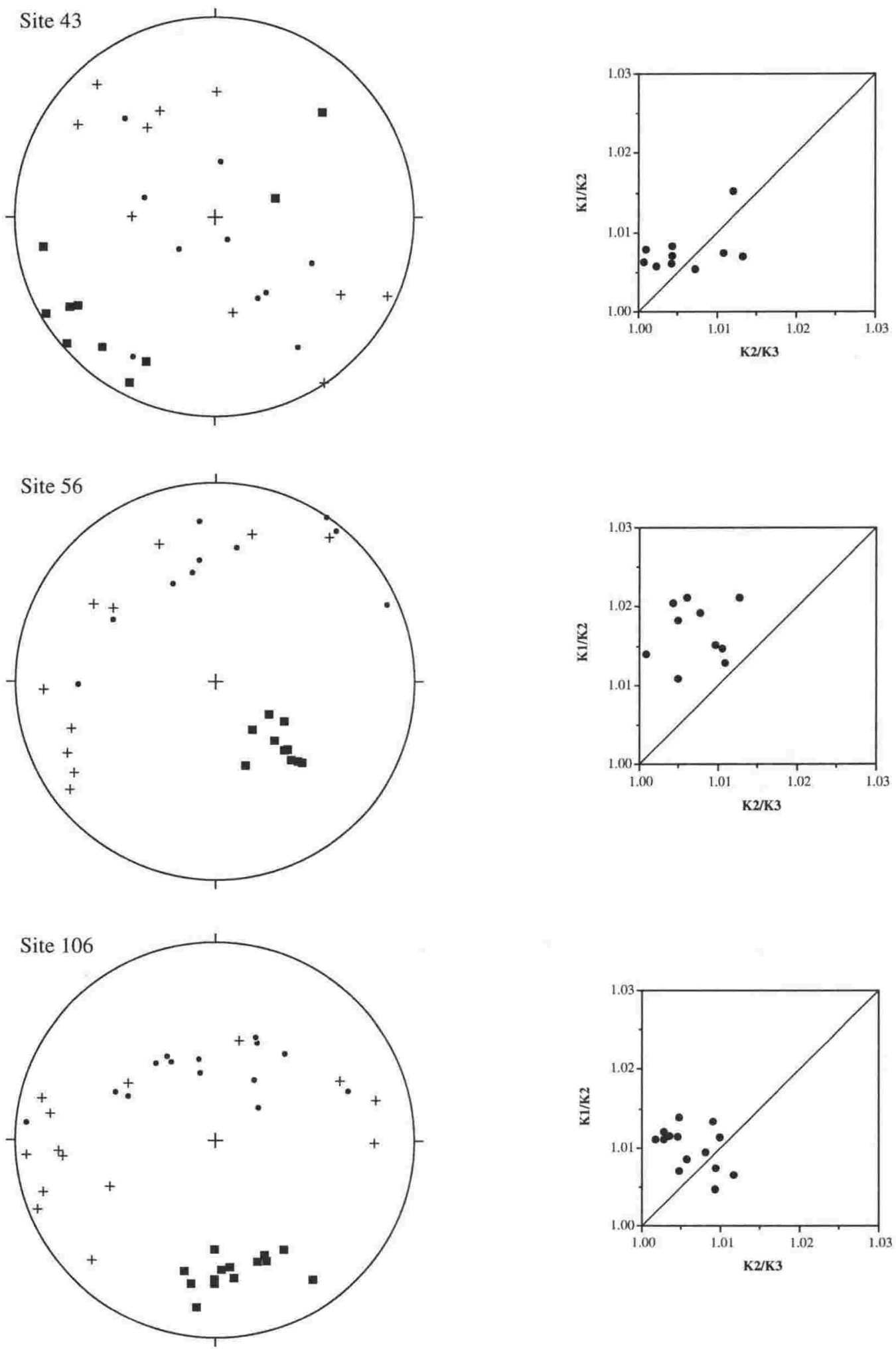

Figure 5.7 Examples of sites classified as Type 5. In these sites, K2 and K3 form a great circle, with $\mathrm{K} 1$ defining a pole. The substitution between $\mathrm{K} 2$ and $\mathrm{K} 3$ reflects the prolate character of these samples. 

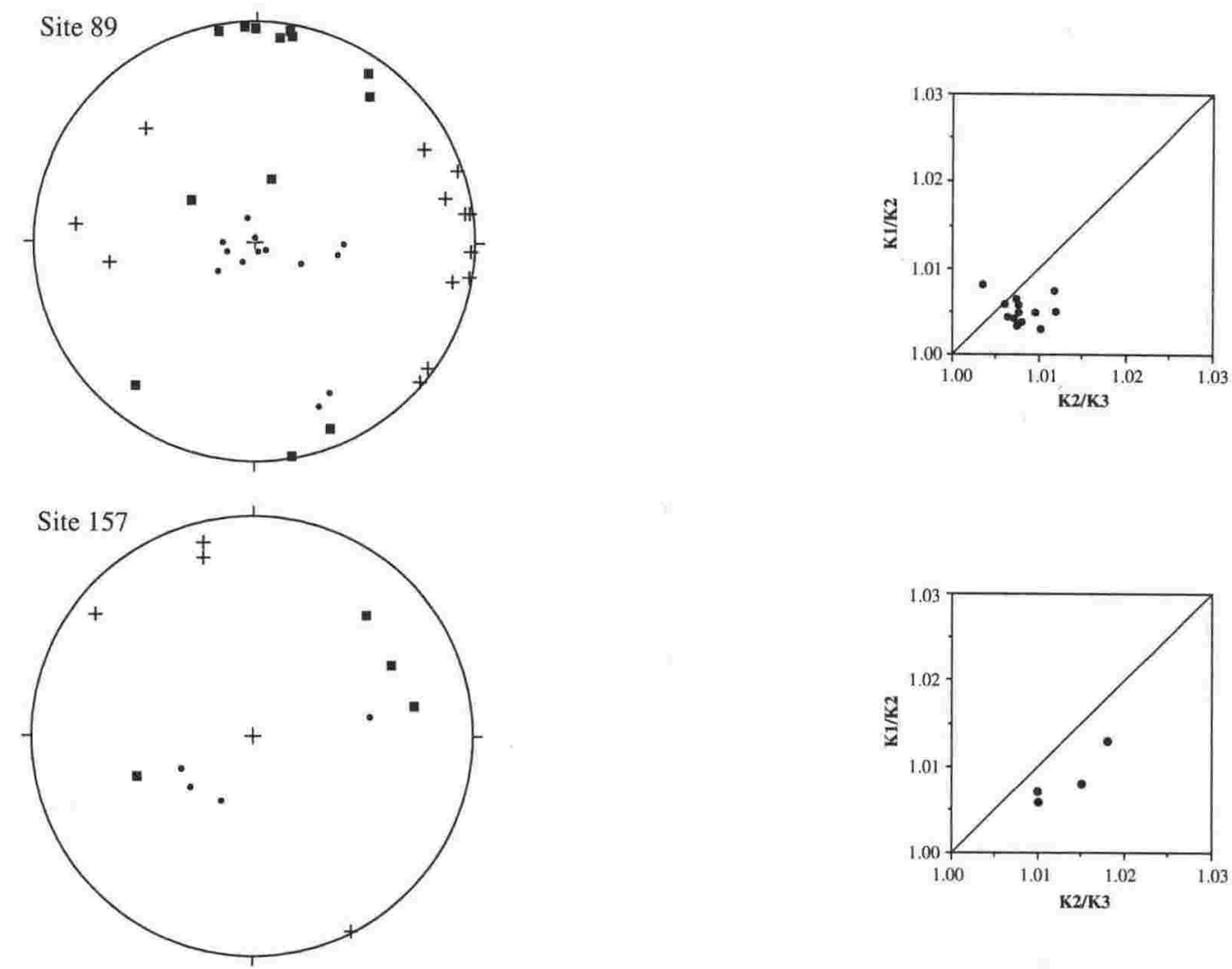

Figure 5.8 Examples of sites classified as Type 6. In a few sites, K3 measurements have substituted for each other. This is a reflection of the low degree of anisotropy in these sites.
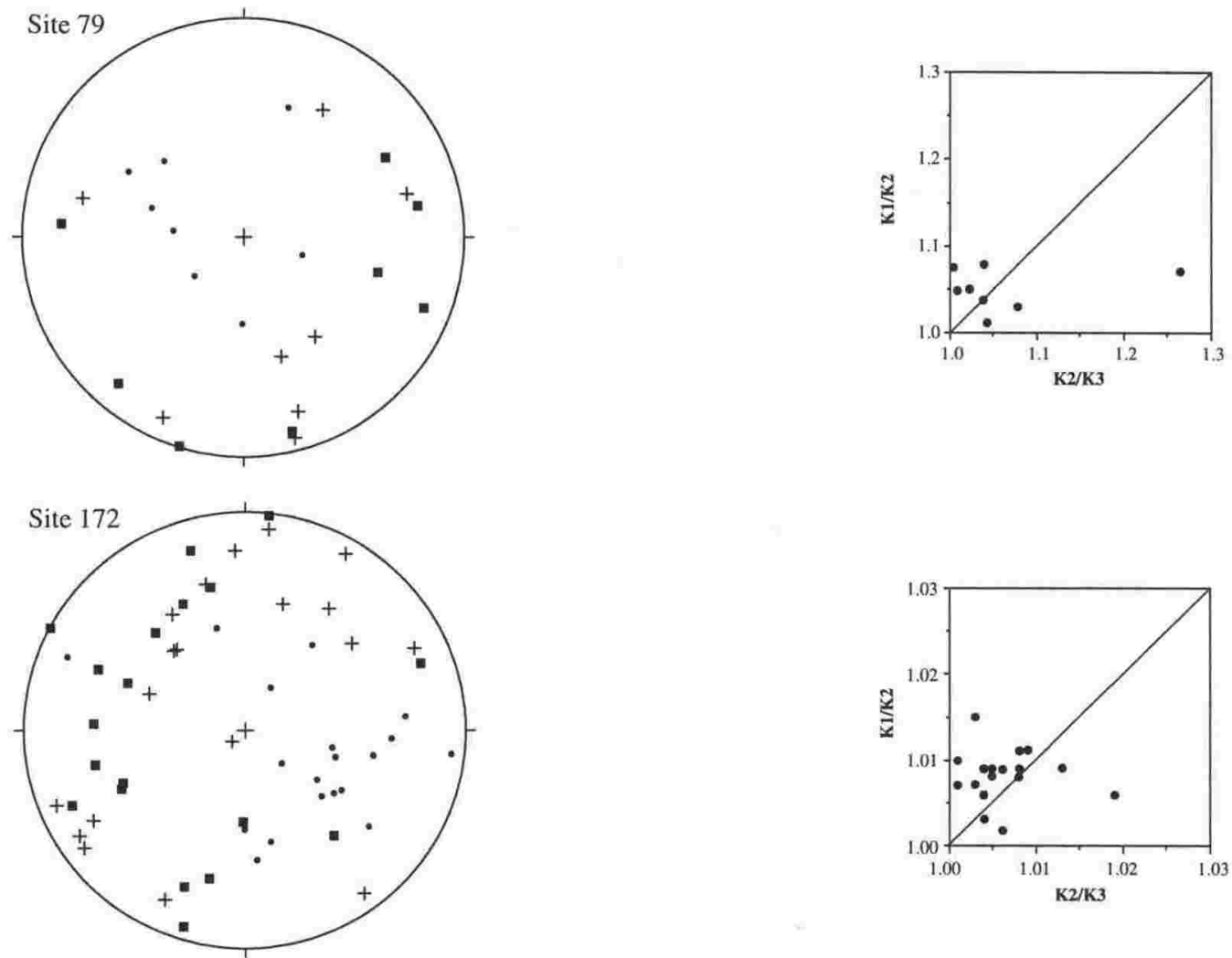

Figure 5.9 Examples of sites classified as Type 7. At a few sites, a lot of scatter in all 3 susceptibility axes is recorded, yielding no definite fabric. 


\subsubsection{Variations within flow units}

Where thick sections of ignimbrites are exposed it is possible to sample a vertical sequence through the unit to investigate possible AMS changes during the eruptive phase. Some investigations (e.g. MacDonald and Palmer 1990) have suggested that the basal parts of a flow may possess a more oblate AMS ellipsoid due to increased compaction.

A deeply incised gorge at Maraetai Dam exposes ca. $220 \mathrm{~m}$ of the Whakamaru Ignimbrite. Three sample sites, at the base (9), middle (8) and top (7) were collected, each with ca. $60 \mathrm{~m}$ of vertical stratigraphic spacing (Figure 5.10). The mean K1 axis has a similar azimuth at each site, suggesting little variation in flow direction occurred in this locality as the eruption progressed. However, the uppermost site (7) has a more northeasterly direction. The basal site (9) has the most steeply inclined $\mathrm{K} 3$ axis and the measurements are more oblate than the above sites (Figure 5.10), with the foliation (K2/K3) up to 1.03 . This is consistent with greater compaction occurring at the base.

Near Waipunga Falls, site 67 was collected from the highly welded zone immediately above the nonwelded base of the Whakamaru Ignimbrite. It displays a pronounced oblate anisotropy with foliation $(\mathrm{K} 2 / \mathrm{K} 3)$ in the range $1.04-1.06$, and lineation $(\mathrm{K} 1 / \mathrm{K} 2)$ between 1.05 and 1.02 (Figure 5.11). In comparison, the AMS foliation is about 1.02 for site 68, collected 10 $\mathrm{m}$ above the base. Little dispersion of the $\mathrm{K} 1$ axis measurement is seen in this upper site compared to the basal site. Again this reflects basal compaction and may suggest that obliteration of the flow fabric accompanies this. Site 68 is characteristic of Type 1 sites (section 5.4.2) with a pronounced $\mathrm{K} 1$ fabric presumably paralleling the flow direction. The basal locality (67) is a type 3 site, showing a developed compaction foliation and a spread of $\mathrm{K} 1$ and K2 measurements. Therefore, Type 3 sites may have undergone more compaction than other types. At both sites in the Waipunga Falls section, the mean K3 axes have a similar declination (which is parallel to $\mathrm{K} 1$ in the upper site). If compaction is the cause of $\mathrm{K} 1$ and $\mathrm{K} 2$ dispersion in the lower site, then both may have originally displayed a similar fabric (a similar flow direction is likely since the two sites are closely spaced). This has important implications for the interpretation of type 3 sites, as the declination of the $\mathrm{K} 3$ axis may therefore be reliable as a proxy for flow direction in the absence of an orthogonal $\mathrm{K} 1$ axis with a clear orientation (see Figure 5.2).

At a section of Whakamaru Ignimbrite in the Kaingaroa Forest, the lower site (71) contains mainly oblate specimens (Figure 5.12a) whereas a site $50 \mathrm{~m}$ stratigraphically above (69) contains mainly prolate specimens. The inferred flow direction is identical for both sites, however K1 displays less scatter in the stratigraphically higher site 69 (Figure 5.12a). Both observations are consistent with greater compaction occurring in the basal flow, and that this may be accompanied by a dispersion in the flow lineation fabric. Another example is the section through Whakamaru in the Tauranga-Taupo River (Figure 5.12b) where the lower site (78) has mainly oblate specimens, and displays compaction foliation. Site 77, $20 \mathrm{~m}$ above 

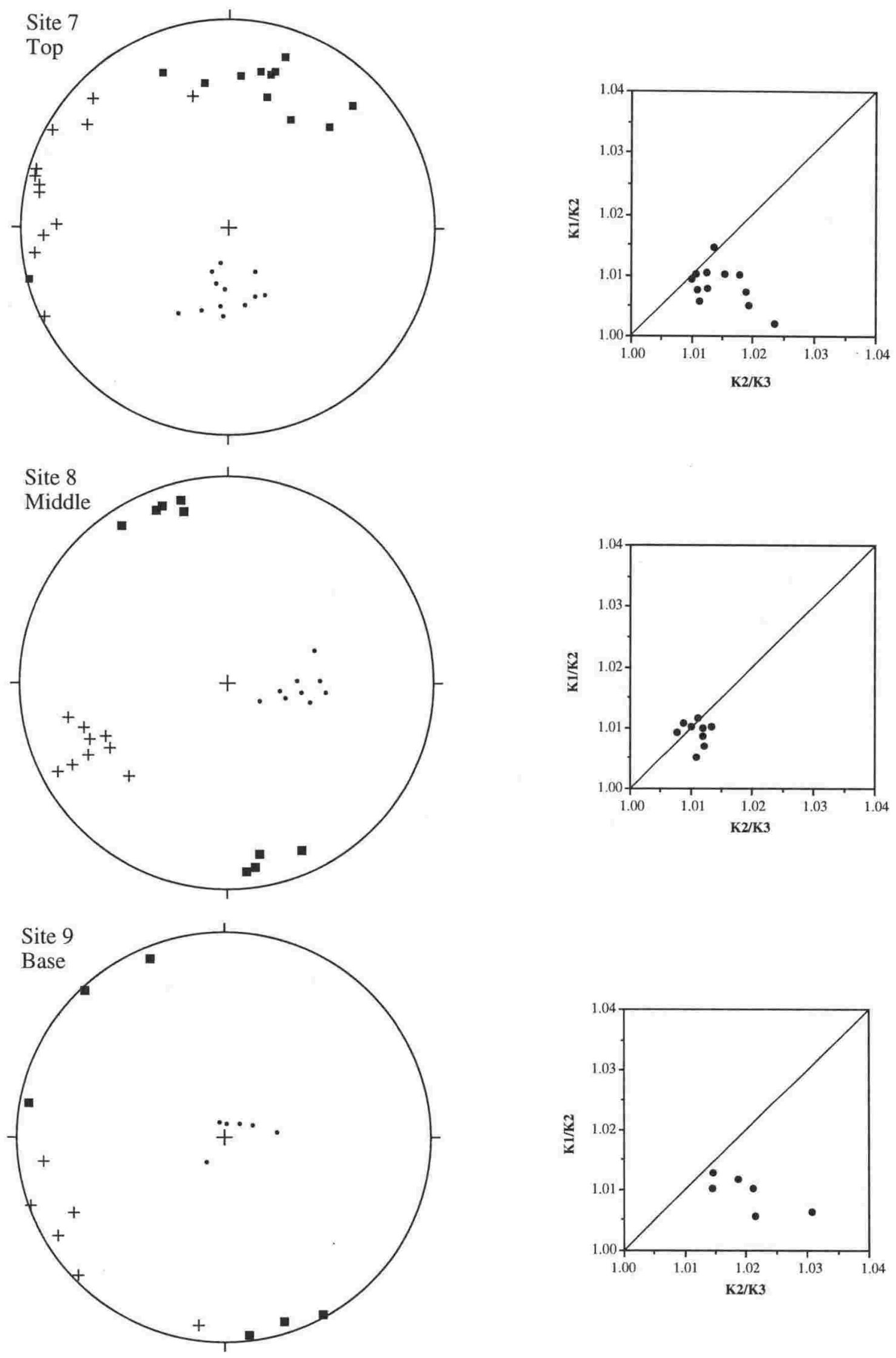

Figure 5.10 AMS measurements for 3 sites collected vertically through the Whakamaru Ignimbrite at Maraetai Dam. Each site is separated by ca. $60 \mathrm{~m}$. The mean $\mathrm{K} 1$ declination is broadly similar in all 3 sites, indicating little variation in paleoflow direction with time. 

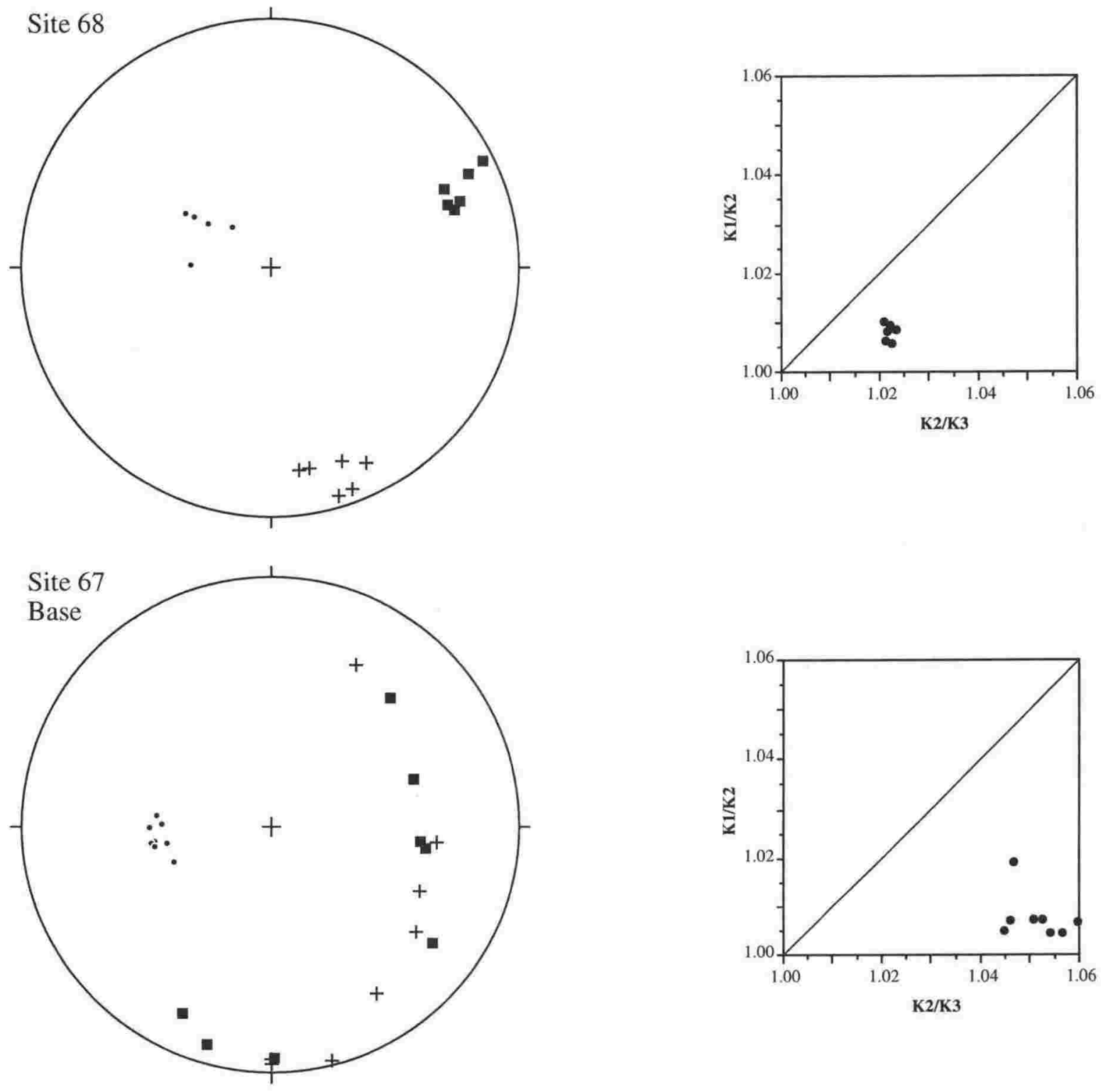

Figure 5.11 AMS measurements from 2 sites sampled from a section through Whakamaru ignimbrite at Waipunga Falls. Site 67 was collected at the base of the unit, site 68 from ca. $10 \mathrm{~m}$ above. The lower site is more oblate, perhaps resulting from compaction. 


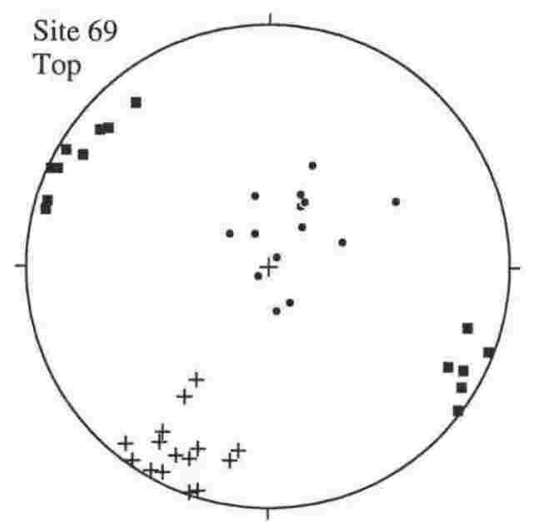

A
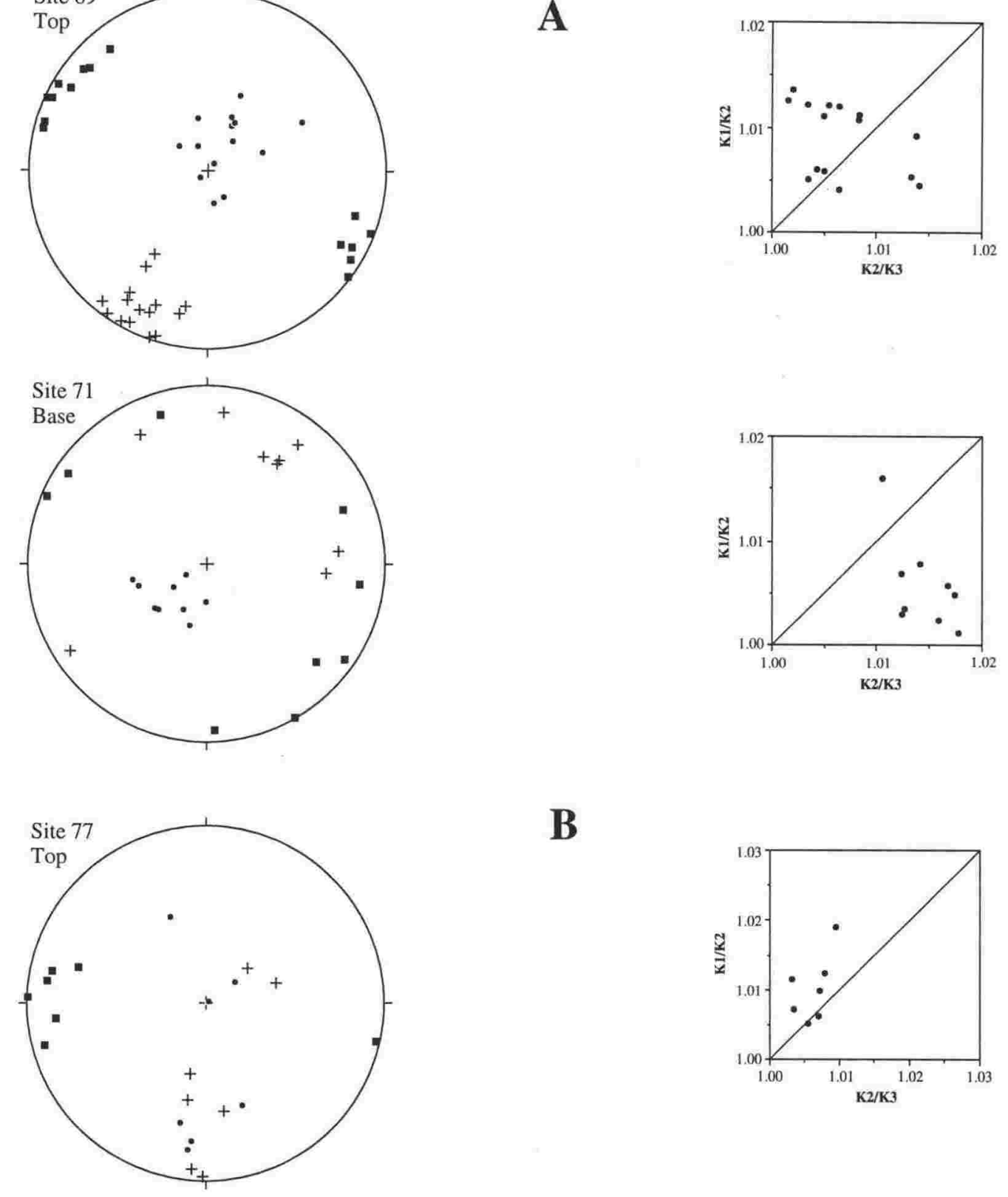

B
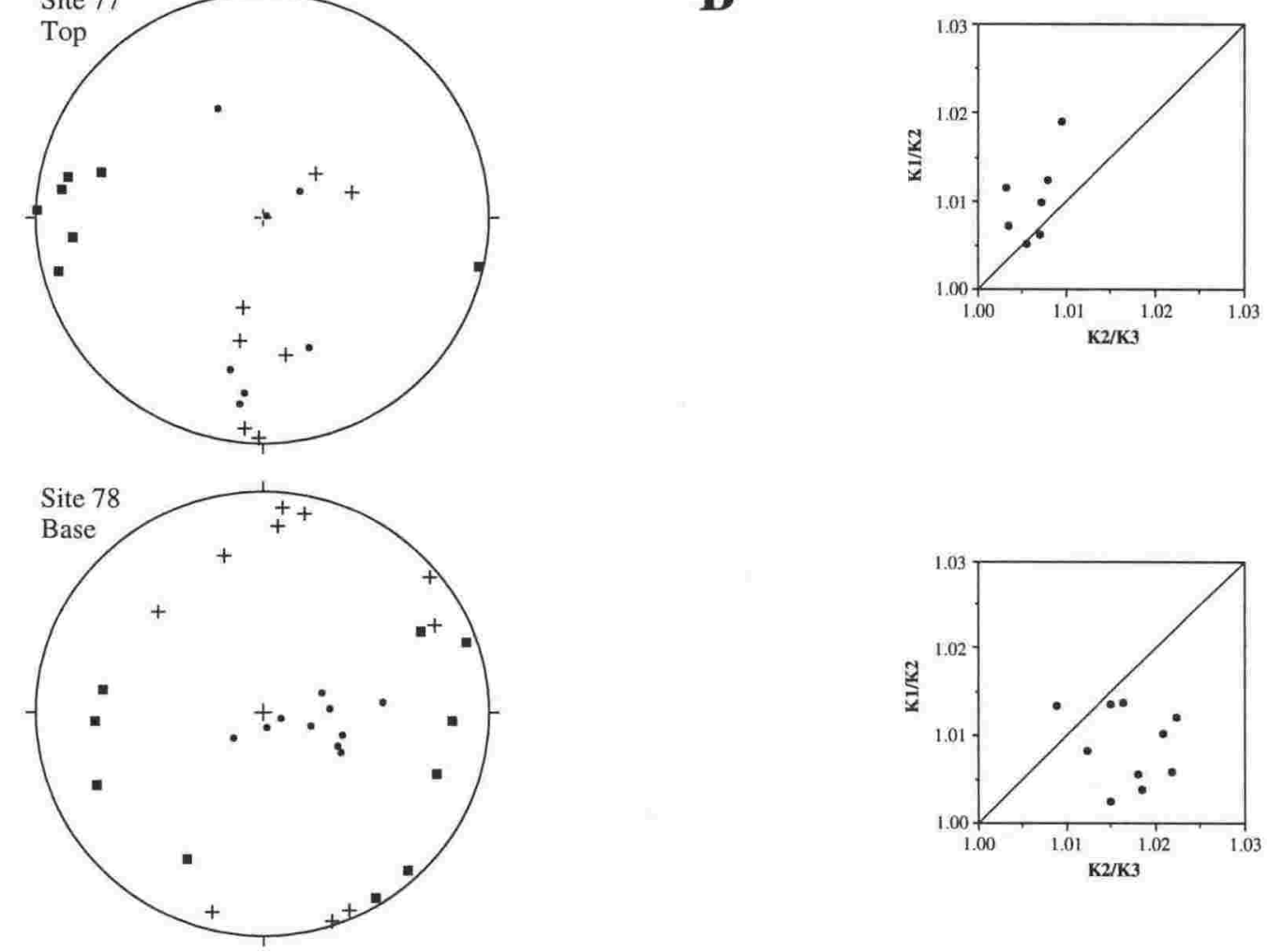

Figure 5.12 (A) AMS data from 2 sites collected from a section of Whakamaru ignimbrite in the Kaingaroa Forest. (B) 2 sites sampled vertically from the Tauranga-Taupo R. In both cases, the stratigraphically higher site displays a mainly prolate AMS ellipsoid and a well-defined K1 declination. The lower sites have a similar mean direction to the upper sites, but a greater dispersion of individual measurements. This is reflected in the oblate nature of the specimens in the lower sites, perhaps due to compaction. 
site 78 , has a well developed $\mathrm{K} 1$ axis in the same direction, but $\mathrm{K} 2$ and $\mathrm{K} 3$ axes scattered on a subvertical great circle. Site 77 is an example of Type 5 fabric where a flow lineation fabric is well developed, but no foliation is apparent. The specimens in this site are mainly prolate (Figure 5.12b) which is consistent with substitution between the K2 and K3 axes since they are similar in magnitude.

A thick $(140 \mathrm{~m})$ section of Mamaku Ignimbrite is exposed in the gorge of the Mangaorewa River north of Rotorua. Four sample sites were taken vertically and display a range of flow fabrics (Figure 5.13). Site 12, near the base of the flow, has a vertical K3 axis, a well developed flow fabric and is typical of a Type 1 site. Site 89 , from $40 \mathrm{~m}$ above, also has a similar flow lineation, but some substitution between $\mathrm{K} 1$ and $\mathrm{K} 3$ occurs. A Type 3 fabric is present in site 91 which is $20 \mathrm{~m}$ above site 89 . This has a well developed $\mathrm{K} 3$ compaction foliation which is inclined $70^{\circ}$ and would suggest a flow direction of NW-SE from the K3 declination. A cube sample site (90) $45 \mathrm{~m}$ above site 91, in the soft vapor-phase altered top of the flow revealed a Type 7 random fabric. In this section there is little evidence of systematic variation with stratigraphic height in the flow.

\subsection{INFERRED PALEOFLOW PATTERNS FOR TVZ IGNIMBRITES}

\subsubsection{Rationale}

At sites where the orientation of K1 axis of the AMS ellipsoid can be reliably defined, usually by low $\mathrm{R}_{95}$ values such as in site types 1 and 2 (section 5.4.2), the paleoflow direction is considered to be parallel. As noted above, being a tensor, the $\mathrm{K} 1$ axis indicates two directions (at $180^{\circ}$ ) and the source of flow is considered to be from the direction of the present TVZ relative to the site. This direction can either reflect the direction of the source or be locally controlled by topography such as flow lobes abutting and being deflected by paleorelief. In sites where $\mathrm{K} 1$ (and $\mathrm{K} 2$ ) are dispersed on a great circle on stereonets, as in type 3 sites, the $\mathrm{K} 1$ direction provides little information on the flow direction. In these sites where $\mathrm{K} 3$ axes are tightly clustered and inclined (rather than vertical), the ellipsoids are imbricated and the K3 axis may be a relic of the flow direction before compaction destroyed the lineation fabric. This is supported by vertical sample profiles in some sections (section 5.4.3). For these sites the declination of the $\mathrm{K} 3$ axis is used as an indicator of paleoflow direction. The mean $\mathrm{K} 1$ or $\mathrm{K} 3$ declination is plotted on maps of the outcrop of the ignimbrite in an attempt to locate source areas and topographic barriers.

\subsubsection{Mangakino-sourced ignimbrites}

Samples from 30 sites were collected from ignimbrites thought to have been derived from the Mangakino Caldera (Figure 5.14). Nineteen sites were collected from the Ongatiti 

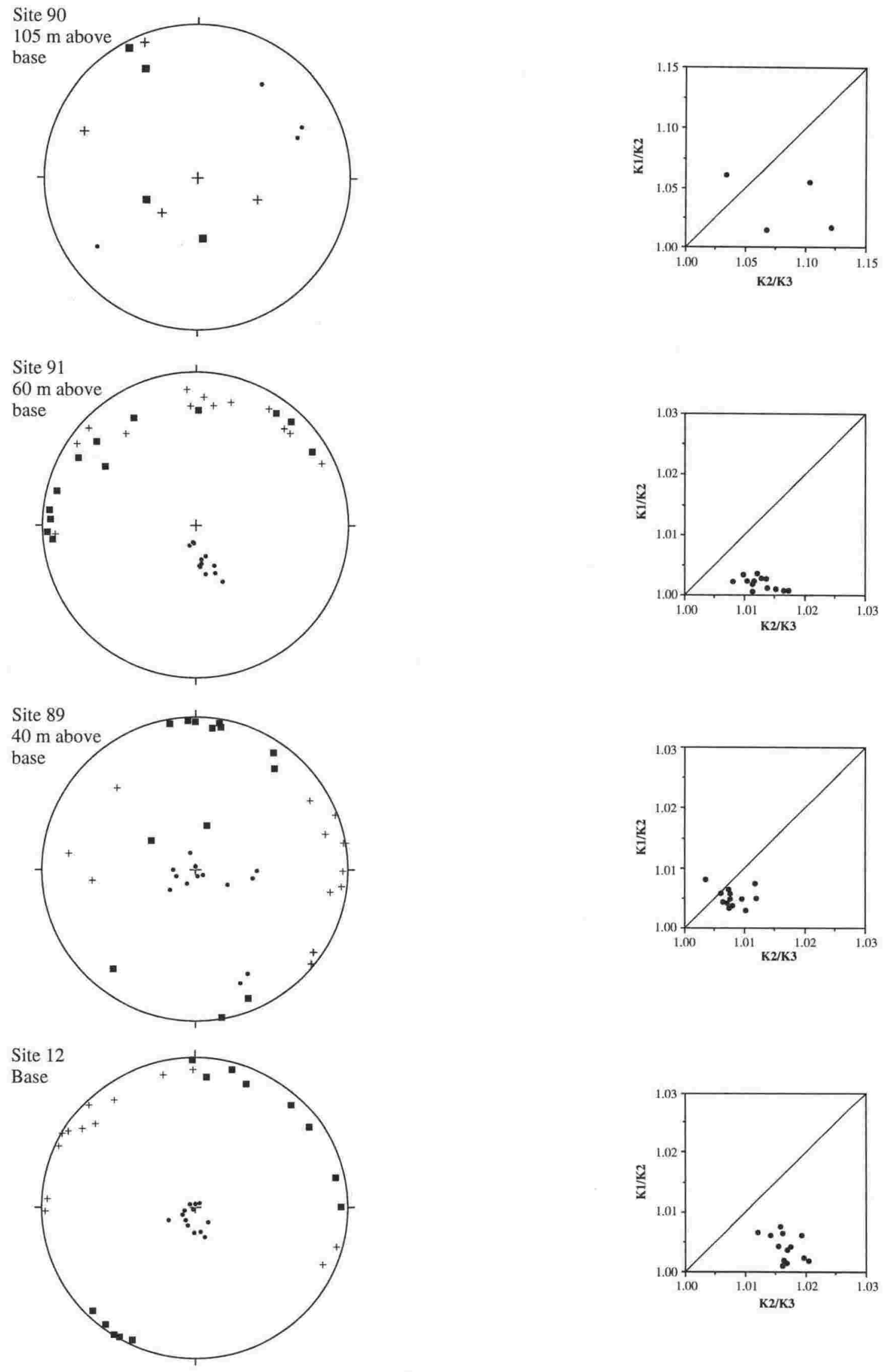

Figure 5.13 AMS measurements for 4 sites collected vertically through the Mamaku Ignimbrite at Mangaorewa Gorge. Vertical sample site spacing shown on figure. In this sequence, no systematic variation with stratigraphic position is observed. 


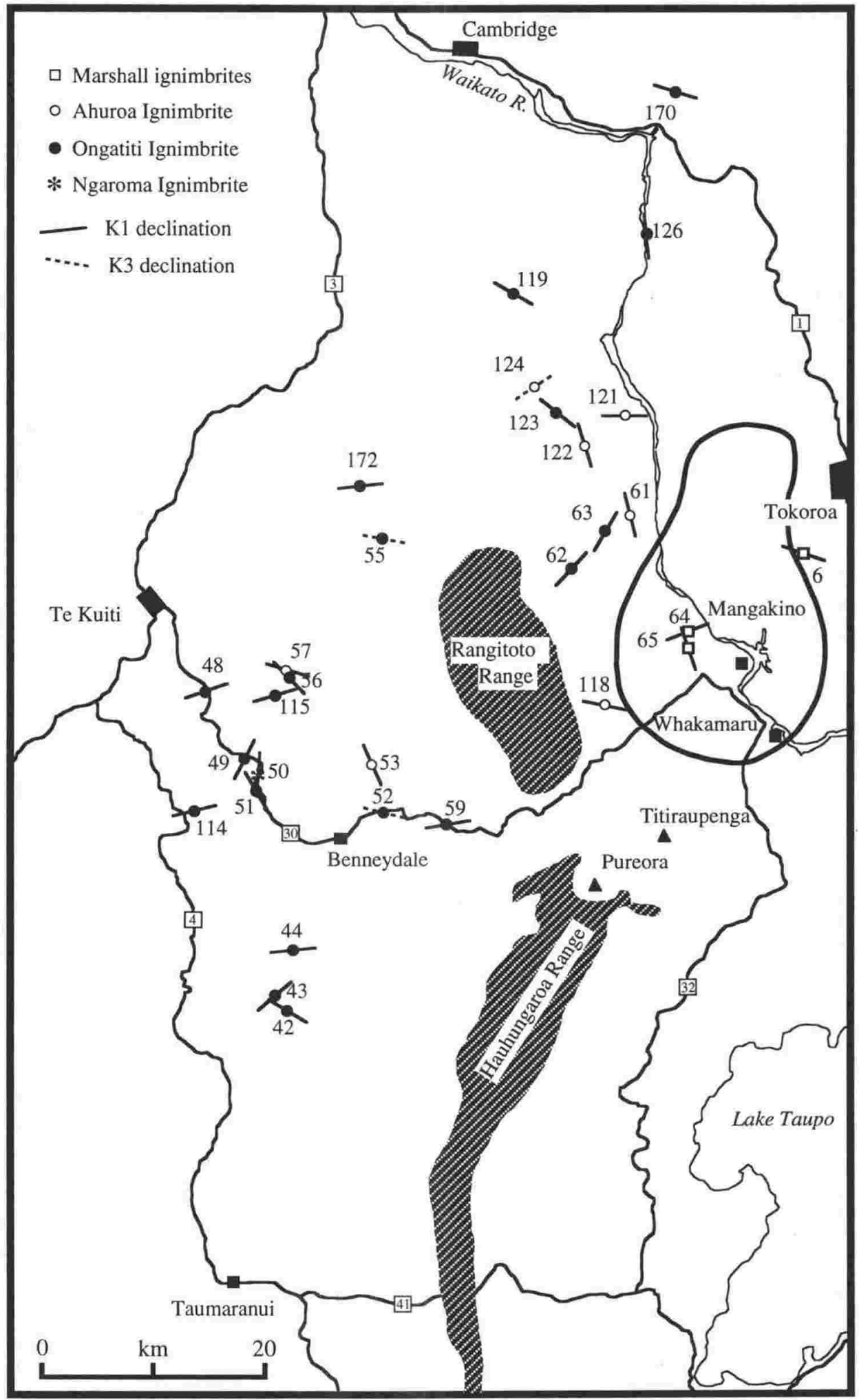

Figure 5.14 Map of the King Country region showing the location of Mangakino Caldera - derived ignimbrite sample sites and their mean K1 or K3 declinations (Table 5.1). Inferred position of Mangakino Caldera from Wilson (1986). 


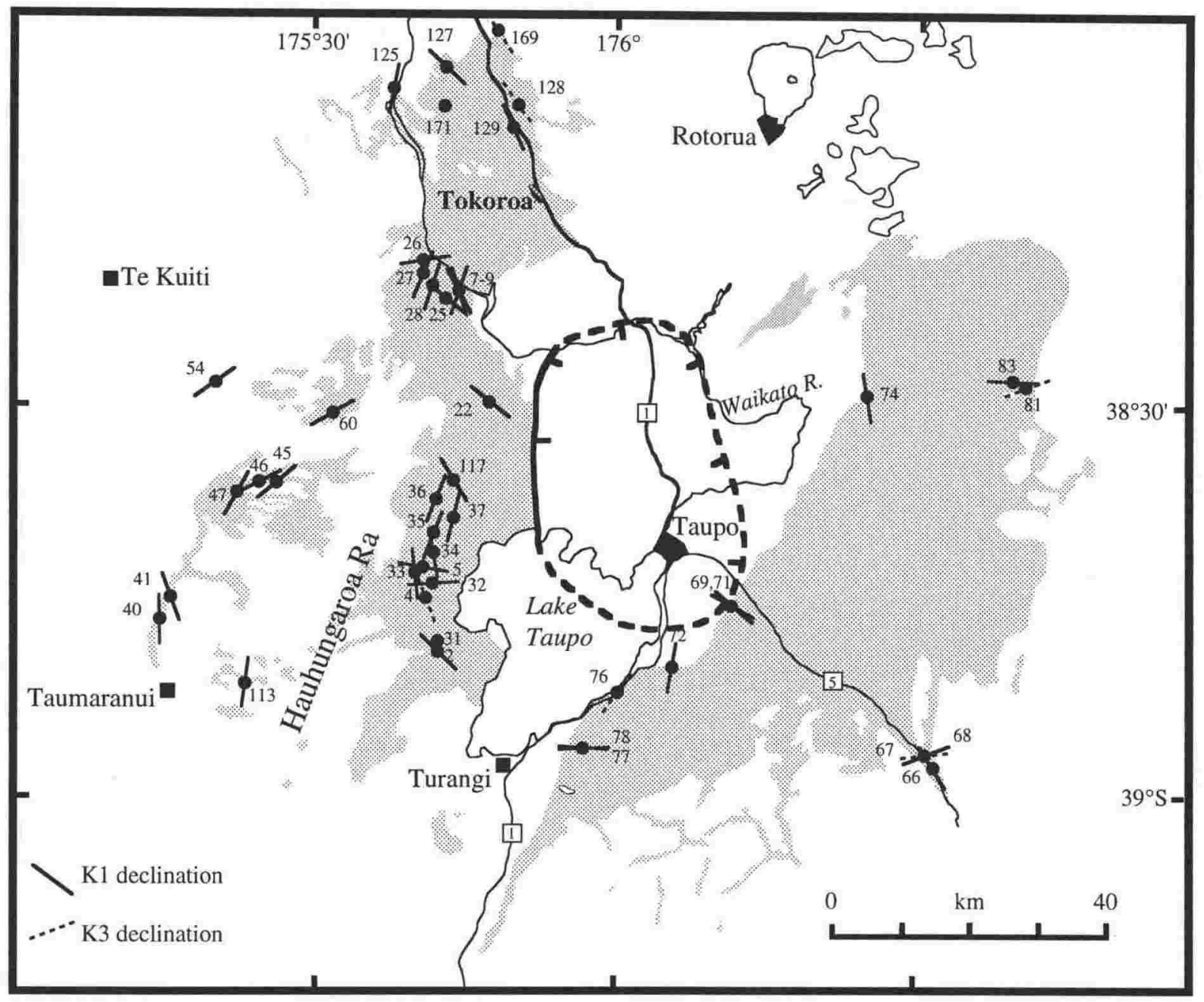

Figure 5.15 Map showing the distribution of Whakamaru group ignimbrites and AMS sample sites. Mean K1 or K3 declinations are shown for each site (Table 5.1). Inferred source for the ignimbrites from Wilson et al. (1986). 
Ignimbrite, and the AMS measurements produced dominantly oblate ellipsoids (Table 5.1). Ten sites classify as Type 1 or 2 , where the $\mathrm{K} 1$ direction is reliably inferred from the declination of the $\mathrm{K} 1$ axis. Two sites are Type 3 and the $\mathrm{K} 3$ declinations are used instead. Most of the sample sites are located west of the caldera inferred from geophysical evidence, and these sites indicate a dominantly east-west flow direction (Figure 5.14). Site 126, collected to the north on the banks of the Waikato River, has a north-south orientation also consistent with the position of the Mangakino Caldera. Seven sites of Ahuroa Ignimbrite were sampled, and all classified as Type 1 or 2 (Table 5.1, Appendix 3). In all sites, the K1 declination has an east-west or northeast-southwest trend. All the sites are located to the west of the inferred Mangakino Caldera, and the suggested flow pattern is similar to the underlying Ongatiti Ignimbrite. Three sites of Marshall ignimbrites were collected, all classifying as Type 1 and 2 (Table 5.1). Their directions (Figure 5.14) do not allow any inferences on source, and their location close to Mangakino may mean the sample sites were located within the caldera at the point of eruption, or that the vent is located east of the other ignimbrites' sources.

The predominance of E-W and NW-SE trending sites in the central King Country (Figure 5.14), suggest ignimbrite emplacement from the east was largely unaffected by the Rangitoto Range (978 $\mathrm{m}$ present highest elevation). In summary, all of the AMS data collected on these ignimbrites is consistent with a source located in the Mangakino Whakamaru area, i.e. the Mangakino Caldera. Small variations in azimuth away from this source area are likely to be due to topographical effects.

\subsubsection{Whakamaru group ignimbrites}

Of 49 sites collected, 34 classify as Type 1 or 2 (Table 5.1). Six sites display type 4 and 5 behaviour. Inferred flow directions from the above site types are parallel to the $\mathrm{K} 1$ axis, and are shown on an outcrop map (Figure 5.15). In 6 sites the $\mathrm{K} 1$ and $\mathrm{K} 2$ axes are sufficiently dispersed to classify as Type 3 . In these cases the $\mathrm{K} 3$ axis declination is interpreted to represent the flow direction (Figure 5.15).

Most sample sites were located north and west of Lake Taupo and mainly define a north-south flow orientation. Fourteen sites were examined on the eastern side of the lake. These directions exhibit a less consistent regional trend, presumably reflecting channeling and local topographic effects. The flow patterns (Figure 5.15) are consistent with a source to the north of Lake Taupo, as suggested by Wilson (1986). This interpretation is not consistent with a rift or chain of point source vents located within the existing Lake Taupo, as suggested by Lamarche and Froggatt (1993). Further interpretation of these data are in Chapter 7. 


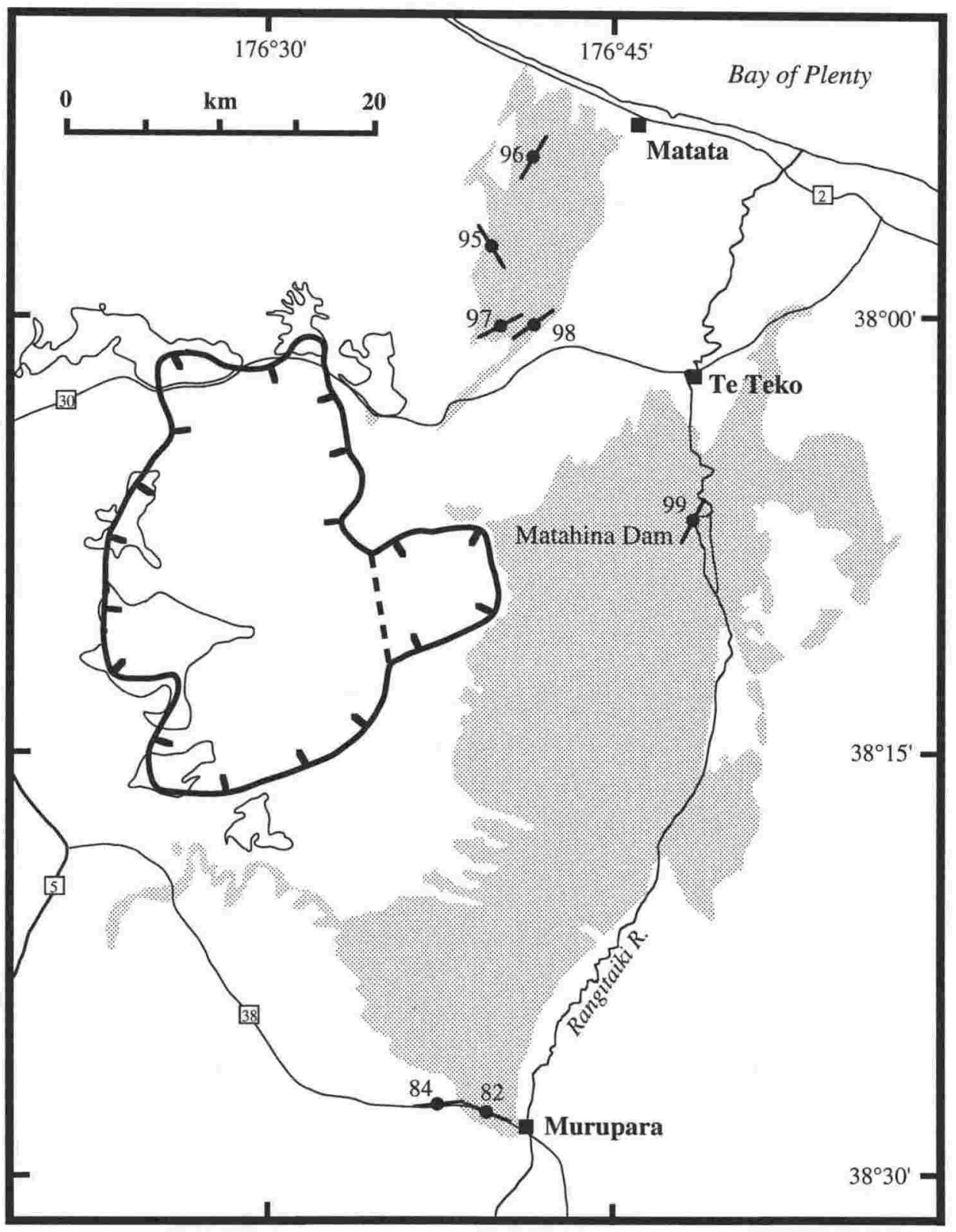

Figure 5.16 Map showing the distribution of Matahina Ignimbrite and inferred source from Bailey and Carr (1994). Sample sites and mean $\mathrm{K} 1$ declinations (Table 5.1) are shown. 


\subsubsection{Matahina Ignimbrite}

Seven sites were collected and measured for their AMS (Table 5.1). Three are type 1 and four are type 2 sites. All K1 measurements have $<21^{\circ}$ scatter and steeply plunging K3 axes with little dispersion. Therefore $\mathrm{K} 1$ is considered to be reliable as a flow indicator for all sites.

A reliable source for the Matahina Ignimbrite is difficult to define due to the sparse sample site distribution (Figure 5.16). However, the northern sample sites 95-98 yield flow directions consistent with a source from the Haroharo Caldera, also suggested by Bailey and Carr (1994). The other sites are likely to have been deflected from a radial path due to local topographic effects.

\subsubsection{Kaingaroa ignimbrites}

Seven sites of the Kaingaroa ignimbrites were collected and analysed for AMS (Table 5.1). Four sites are Type 1 and 2, and sites 29, 155 and 158 classify as Type 4 and 5. Most sites have fairly well clustered mean $\mathrm{K} 1$ declinations (Table 5.1, Appendix 3). The resulting inferred flow pattern (Figure 5.17) is consistent with a source originating from between Reporoa and Waiotapu. This is in the northern part of the Reporoa Caldera, as inferred by Nairn et al. (1994).

\subsubsection{Mamaku Ignimbrite}

The Mamaku Ignimbrite was sampled from 26 sites, 16 of which were cube samples. Lineation values range from $1.002-1.005$ and foliation $1.005-1.013$, with total anisotropy $1.010-1.021$ (Table 5.1). The poor statistical values for the cube sampling sites are due to the small number of specimens per site (3-5). However, many sites still give reliable paleoflow directions. 13 sites are classified as Type 1 or 2 ( 7 of which are core sites, 6 cube sites).

Inferred flow paths generally radiate from the Rotorua lake area (Figure 5.18). The distribution of sample sites reflects the outcrop extent, which is not radial to the inferred vent (Lake Rotorua) being mostly to the north, west and southwest and only small patches to the east. This suggests the west side of the Rotorua Caldera was the primary source of the Mamaku Ignimbrite, and is consistent with AMS fabric azimuths pointing primarily to the western caldera rim. 


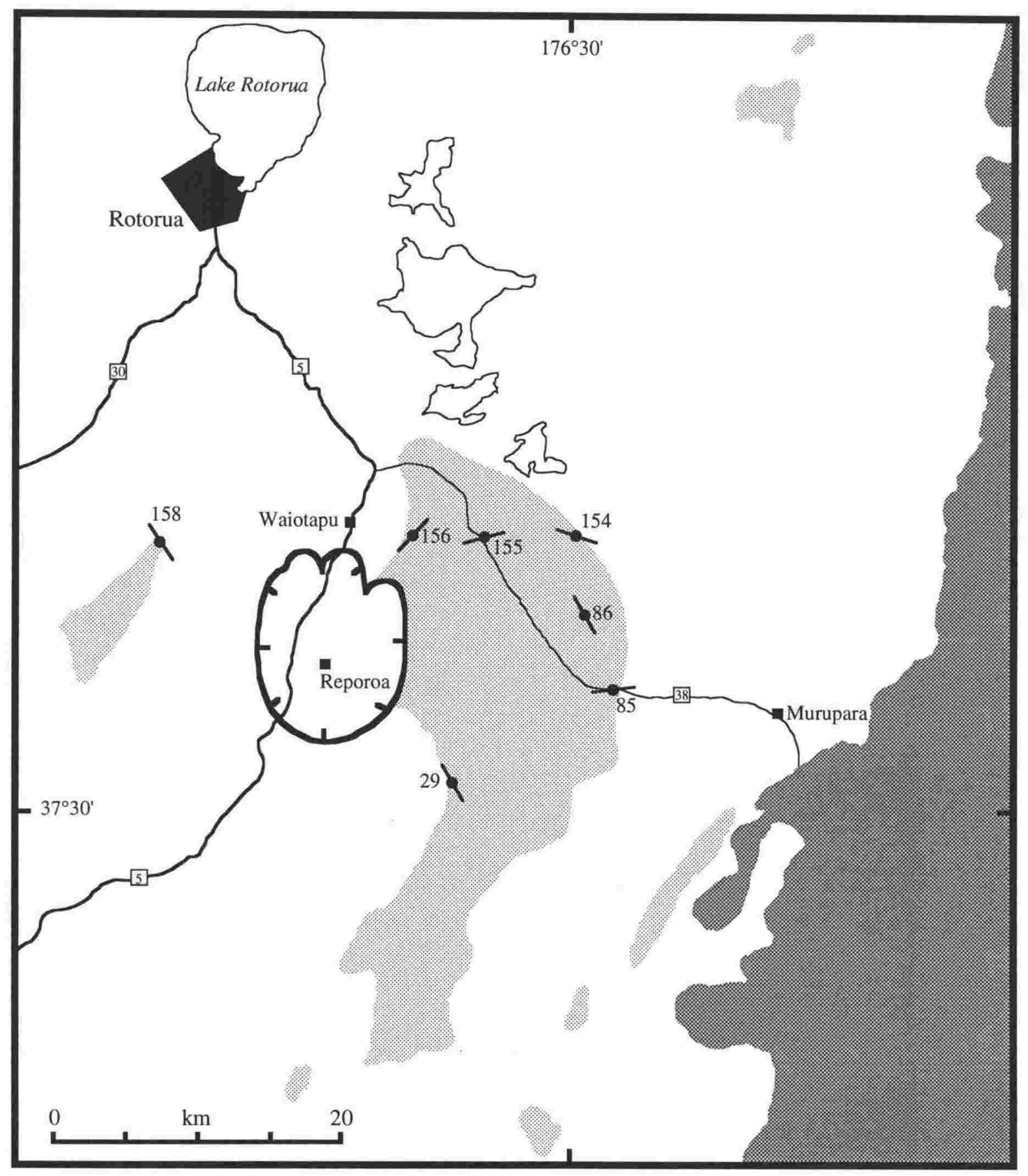

Figure 5.17 Map showing the distribution of Kaingaroa Ignimbrites and inferred source from Nairn et al. (1994). Sample sites and mean K1 declinations (Table 5.1) are shown. 


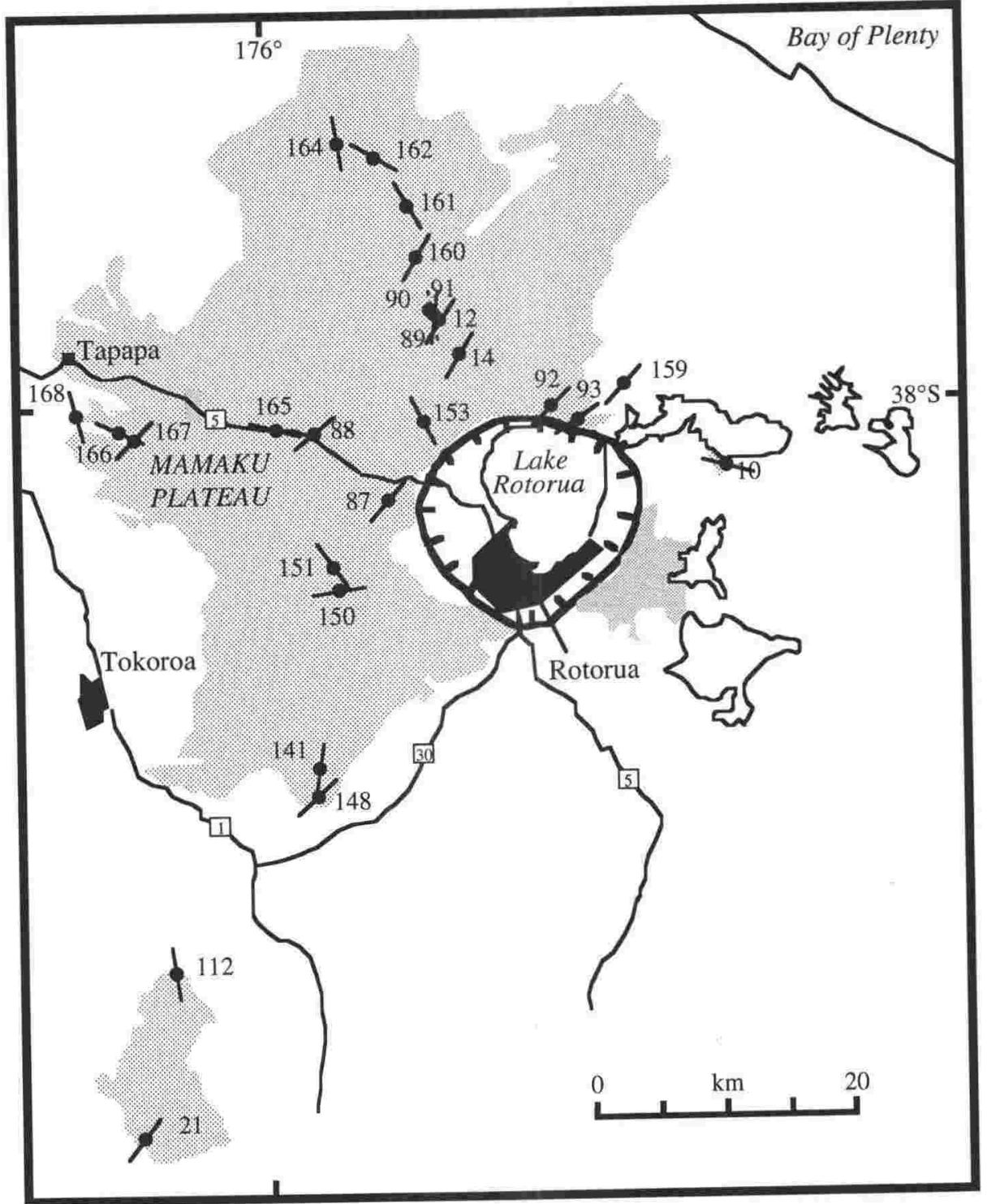

Figure 5.18 Map showing the distribution of Mamaku Ignimbrite and inferred source from Wilson et al. (1984). Sample sites and mean $\mathrm{K} 1$ or $\mathrm{K} 3$ declinations (Table 5.1) are shown. 


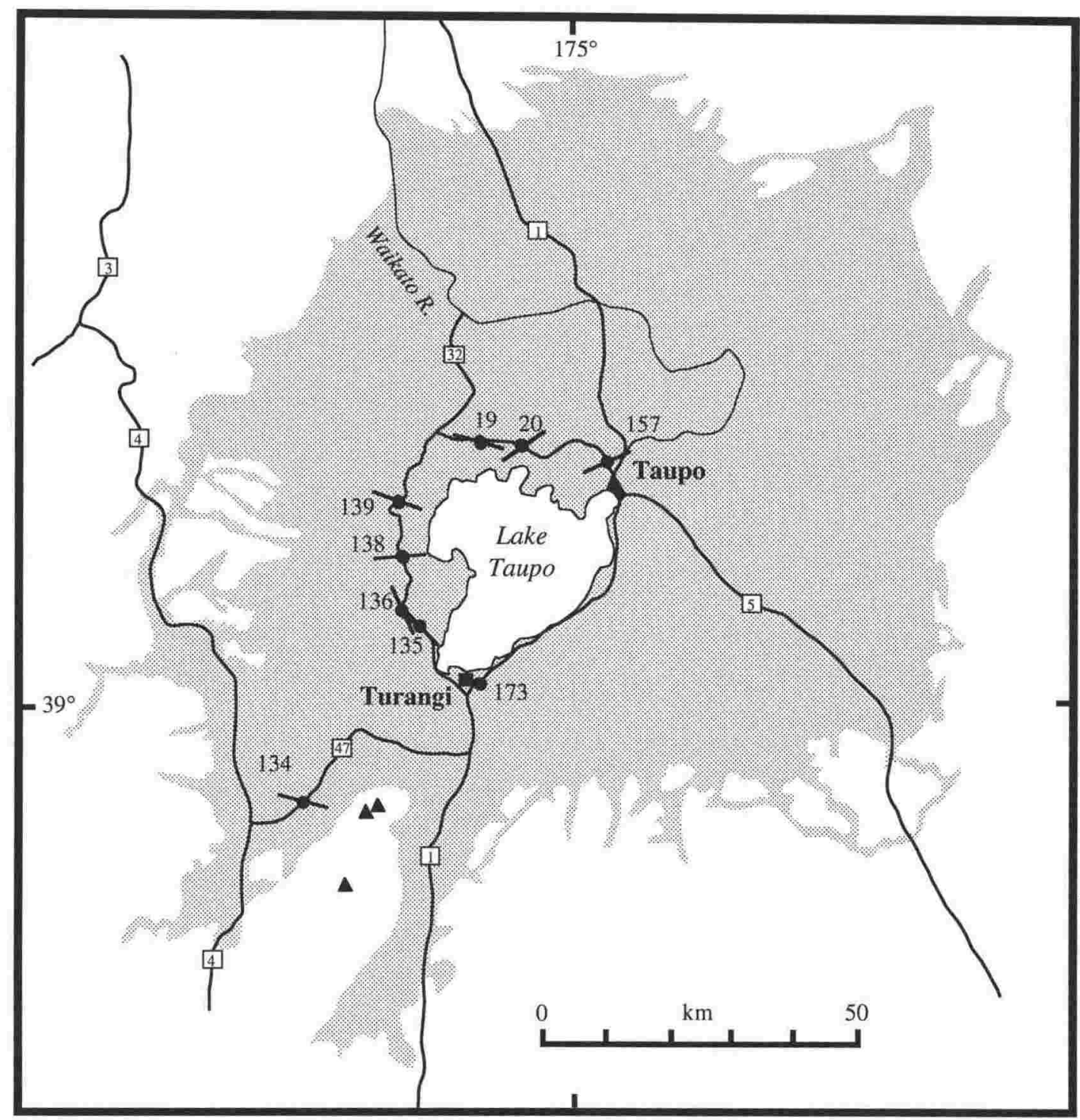

Figure 5.19 Map showing the distribution of Oruanui Ignimbrite surrounding its source at Lake Taupo (Wilson 1991). Sample sites and mean K1 declinations (Table 5.1) are shown. 


\subsubsection{Oruanui Ignimbrite}

Oruanui Ignimbrite was sampled at 8 sites, all of which were unconsolidated and were collected by cutting cubes. Most of the data is statistically poor, being characterised by $\mathrm{R}_{95}$ values mostly in the range $20-45^{\circ}$ (Table 5.1). These values reflect the few specimens collected ( 4 or 5 ) and the lack of fabric developed in the unit. Therefore unconsolidated ignimbrites pose the compound problem of requiring a large sample set where specimens are difficult to collect. The $\mathrm{K} 1$ declination for about half of the sites point toward Lake Taupo (the known source), but the remainder are perpendicular to the lake (Figure 5.19).

\subsection{CONCLUSIONS}

1. Use of the azimuth of the axis of maximum susceptibility (K1) as an indicator of flow direction in widespread ignimbrite sheets in the TVZ, produces paleoflow patterns which are consistent with source areas inferred from other studies.

2. Each of the units sampled are characterised by similar total susceptibility $(\mathrm{Km})$ in the range $10^{-2}$ to $10^{-4} \mathrm{SI}$, and units do not display characteristic $\mathrm{Km}$ values. All ignimbrites display a similar degree of anisotropy (maximum 2-4\%) which is dominantly oblate in form. These features are also characteristic of silicic ignimbrites examined elsewhere (e.g. western USA).

3. Site from different flow units can all be categorised into types on the basis of degree of specimen measurement dispersion. Good paleoflow indicators are characterised by low dispersion of the $\mathrm{K} 1$ and $\mathrm{K} 2$ axes $\left(<20^{\circ}\right)$ at a subhorizontal inclination, reflecting alignment due to flow foliation. K3 is typically steeply inclined to near vertical, due to post-depositional compaction.

4. In some sites, several specimens' axes have substituted for each other and the result is a greater dispersion of data. Substitution of $\mathrm{K} 1$ and $\mathrm{K} 2$ axis declinations is the most common, due to the dominantly oblate nature of ignimbrite AMS ellipsoids. K2 and K3 axis substitution is seen in sites with a high proportion of specimens displaying prolate ellipsoids - where the intermediate and minimum axes of magnetic susceptibility are most similar in magnitude. Provided the substitution is not severe, a reliable estimate of flow direction may still be obtained from these types of sites.

5. Thick sections of Whakamaru group ignimbrites, when sampled vertically for AMS, reveal a steepening plunge of the $\mathrm{K} 3$ axis, and an increased dispersion of $\mathrm{K} 1$ and $\mathrm{K} 2$ directions with depth. These are likely to be the effects of compaction, which may cause the obliteration of the original flow fabric. 
6. Paleoflow patterns in widespread ignimbrite sheets are complicated by paleotopography. Topographic barriers have deflected and entrained flows, therefore simple fabric azimuths do not always point to the source vent. This is particularly important in the TVZ where the tectonic setting results in uplift and erosional dissection over short periods. Measured K1 and $\mathrm{K} 2$ axes are not always subhorizontal and may plunge up to $20^{\circ}$. However, this is not considered to be due to tectonism or post-emplacement flow (as suggested by some workers) as the paleomagnetic remanence directions for the same specimens do not show any disturbance. Instead, the steep plunge may reflect either flow imbrication or deposition on a paleoslope. 


\section{Chapter 6.}

\section{ISOTHERMAL PLATEAU FISSION-TRACK GEOCHRONOLOGY}

\subsection{INTRODUCTION}

Several workers have used the fission-track method to obtain ages of New Zealand eruptives. Kohn (1973) dated glass shards from many of the proximal TVZ units, but these ages were uncorrected for any partial track fading that may have occurred (see section 6.3). Seward $(1974,1975,1976,1979)$ constructed a chronology of the southern North Island by dating distal tephras interbedded with the sedimentary sequences. Earlier attempts used glass, but on the discovery of partial track fading in New Zealand tephras (Seward 1979) zircons were dated instead, yielding similar or older ages. Boellstorff and Te Punga (1977) presented glass ages, uncorrected for partial track fading, on the Pakihikura pumice and Rangitawa pumice. Naeser et al. (1980) published a zircon age for the Mangaroa ash, near Wellington and related it to the recent uplift history of the area. Murphy and Seward (1981) extended the chronology of the TVZ by presenting zircon ages for previously undescribed units in the Matahana Basin. A comprehensive zircon dating study was carried out by Kohn et al. (1992) on the Rangitawa tephra and its proximal correlative, the Whakamaru group ignimbrite.

Previously, the isothermal plateau fission-track (ITPFT) method on glass, which corrects for partial fading of tracks, has only been applied to distal tephra in North America (Westgate et al. 1987; Westgate 1988; Westgate 1989; Westgate et al. 1990; Alloway et al. 1992), Malaysia (Chesner et al. 1991) and New Zealand (Alloway et al. 1993; Shane et al. 1995). This study attempts to date some of the proximal deposits, namely nonwelded bases and plinian fallout in the TVZ using the ITPFT method.

\subsection{FISSION-TRACK DATING METHOD}

When a ${ }^{238} \mathrm{U}$ atom fissions, two highly charged particles are emitted and repelled in opposite directions, forming a single linear trail of damage called a fission track. After the particle has passed through the crystal lattice, it is thought that a narrow trail of positively charged ions is left behind in the disturbed area (or track core), which then repulse each other into interstitial positions, thereby leaving a vacant area along the particle trajectory, called a latent track. These are a few nm wide and $10-20 \mu \mathrm{m}$ long.

Unless viewed by a transmission electron microscope, these latent tracks must be enlarged by a chemical etchant so that they can be viewed by a conventional optical microscope. An etchant works by more rapidly dissolving the ions around the damaged area 
than the rest of the solid, since they possess a higher state of free energy. A variety of reagents are used depending on the material to be etched.

Fission track dating is based on the spontaneous fission of ${ }^{238} \mathrm{U}$ which commonly occurs in trace amounts in many rocks. Theoretically, any solid containing uranium may be dated by the fission-track method, but in rocks there are five commonly used phases: apatite, zircon, natural glass, mica and sphene. These are preferred because of their high U content, thermal stability of tracks and availability. In dating Quaternary tephra, natural glass and zircon are the most preferred phases. Zircon contains sufficient $U$ that individual grains may be dated, however not all tephra contain this mineral, and in distal situations the crystals may be too small $(<75 \mu \mathrm{m})$ to be of use. Volcanic glasses in New Zealand commonly contain 3 $4 \mathrm{ppm}$ U (Shane 1993) which is adequate for dating. General reviews of fission-track techniques and applications include Fleischer et al. (1975) Naeser and Naeser (1984), Wagner and Van den Haute (1992), Sandhu et al. (1993), and Dumitru (in press).

\subsection{PARTIAL FADING OF TRACKS}

Over time, or at high temperature, latent fission-tracks begin to fade (Fleischer et al. 1975). The track core becomes obscured as atoms are restored to their original lattice positions. A fission-track's stability depends mostly on its thermal history (Naeser and Naeser 1988) and the material it was formed in. Zircon fission-tracks are generally very stable.

Volcanic glasses are known to undergo partial track fading at ambient temperatures (Naeser et al. 1980) even within short periods of time in the Quaternary. This results in the spontaneous latent tracks being shorter than the newly produced induced tracks and upon etching, the spontaneous track diameters appear smaller than the induced tracks. Shorter fission tracks within a glass shard means that when etched, some of the smallest tracks are not visible and the measured density is reduced. This results in an anomalously young age being calculated. Uncorrected glass ages have been reported on New Zealand tephras and partial track fading recognised (Seward 1979).

There are 2 approaches to correct for this phenomenon: track diameter measurement and thermal annealing.

\subsubsection{Track size measurement method (Storzer and Wagner 1969)}

The diameter distribution of the spontaneous tracks is compared to the neutroninduced track diameters. If the mean track size is smaller in the spontaneous sample (Ds) than in the aliquot containing both spontaneous and induced tracks (Ds+i), partial fading has occurred and correspondingly the track density has been reduced. This density can be 
corrected by reference to a calibration curve which shows the correlation between areal track density and track size for that sample. This curve is obtained from a series of heating experiments on the irradiated sample (Storzer and Wagner 1969).

Recently, the relationship between spontaneous track size and areal track density has been re-examined. Sandhu and Westgate (1995) have demonstrated there is a $1: 1$ relationship between track diameters and areal density of tracks, given an adequate etch (see section 6.4.4). Theoretical studies had predicted a 1:1 relationship (Van den Haute 1985) but experimentally, it was found the reduction in track length occurred faster than the reduction in track density. Samples that had undergone extensive fading had the largest divergence, producing a curve (Storzer and Wagner 1969). This curve is probably due to under-etching of the samples (Sandhu and Westgate 1995).

To restore the original spontaneous track density $\left(\rho_{\mathrm{s}}\right)$ using the diameter correction method of Sandhu and Westgate (1995), the measured $\rho_{\mathrm{s}}$ is multiplied by Ds+i/Ds. This method was applied successfully to a sample of the nonwelded base of Mamaku Ignimbrite which had undergone partial track fading (Shane et al. 1994).

\subsubsection{Thermal correction methods}

Using heat to correct for partial fading takes advantage of the fact that partially faded tracks have a higher thermal stability, the less stable ones having been eliminated already. A freshly irradiated sample will contain fission tracks with a wide range of thermal stabilities. Therefore if both the natural and irradiated aliquots are heated together in the laboratory, the least stable tracks will be progressively eliminated from first the irradiated sample only, and then both samples, until both aliquots have fission tracks of the same range of thermal stability.

In the step-heating method, the natural and irradiated aliquots are heated together for a given time at progressively higher temperatures and the ratio of spontaneous track density $\left(\rho_{\mathrm{s}}\right)$ to induced track density $\left(\rho_{\mathrm{i}}\right)$ is measured at each step. This ratio, in a sample that has undergone partial track fading, is too low at first and increases until a plateau is reached. The ratio value at this plateau gives an age corrected for any thermal track fading (Storzer and Poupeau 1973; Wagner 1979).

The isothermal plateau technique (Burchart et al. 1975) is similar to the step-heating plateau method, but instead it involves heating the sample at a constant temperature for progressively longer periods of time. Both methods are tedious and time consuming so various short-cuts have been explored (Miller and Wagner 1981; Westgate 1989; Bigazzi et al. 1990)) 


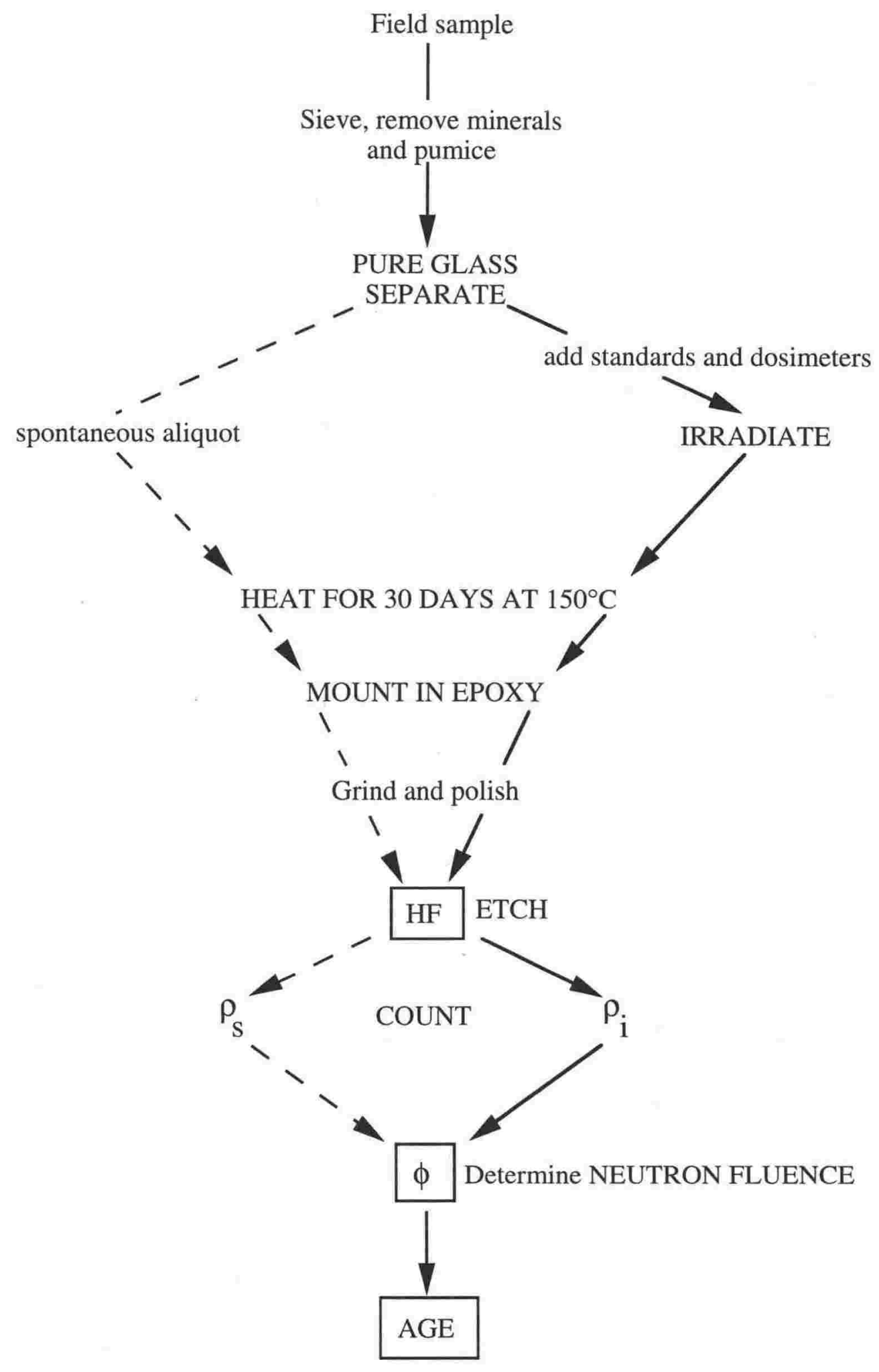

Figure 6.1 Flow chart of the technique used to date volcanic glass by the ITPFT method. 


\subsubsection{Isothermal Plateau Fission-Track method}

A variant of the isothermal plateau method has been recently developed (Westgate 1989; Sandhu et al. 1993) where a single step heat treatment is used to obtain the plateau value for the ratio of $\rho_{\mathrm{s} /} \rho_{\mathrm{i}}$. A coincidence in the spontaneous and induced track mean diameters is produced (Westgate 1989). One single heating of 30 days at $150^{\circ} \mathrm{C}$ completely corrects for any partial track fading and has given successful ages on a number of glasses with different compositions (Westgate 1989; Alloway et al. 1992; Alloway et al. 1993; Sandhu et al. 1993, Shane et al. 1994; Shane et al. 1995).

\subsection{METHODS}

The sample preparation technique for the ITPFT method is summarised in Figure 6.1 and discussed below.

\subsubsection{Sample preparation}

Field samples of tephra are wet sieved at 120 and $250 \mu \mathrm{m}$ to remove fines. In most cases, the $>250 \mu \mathrm{m}$ fraction is dated, if present. The dried samples are then magnetically separated to remove minerals and weathered glass. Blocky or chunky walled glass is easier to date as when polished, they give the greatest surface area; so the samples are then examined under a binocular microscope to see if any improvement can be made on the separates. Ultrasonic treatment for 2 - 3 minutes breaks up thin-walled glass and pumice, which then can be sieved out. Tetrabromoethane density separations remove more of the pumice, and a concentrated non-vesicular glass sample is obtained.

Two aliquots of a sample are used in dating. One split is reserved for counting the spontaneous ${ }^{238} \mathrm{U}$ fission tracks, and the other fraction is irradiated to induce ${ }^{235} \mathrm{U}$ fission.

\subsubsection{Packing a can for irradiation}

Samples to be dated $(<200 \mathrm{mg})$ are wrapped in $\mathrm{Al}$ foil and placed in an aluminium can together with internal glass standards and dosimeters (see below) as in Figure 6.2, noting the exact sample positions within the container. The can is then irradiated at McMaster Nuclear Reactor in Hamilton, Ontario where it is subjected to a neutron fluence of $2.5-3.5 \mathrm{x}$ $10^{15} \mathrm{n} / \mathrm{cm}^{2}$. 


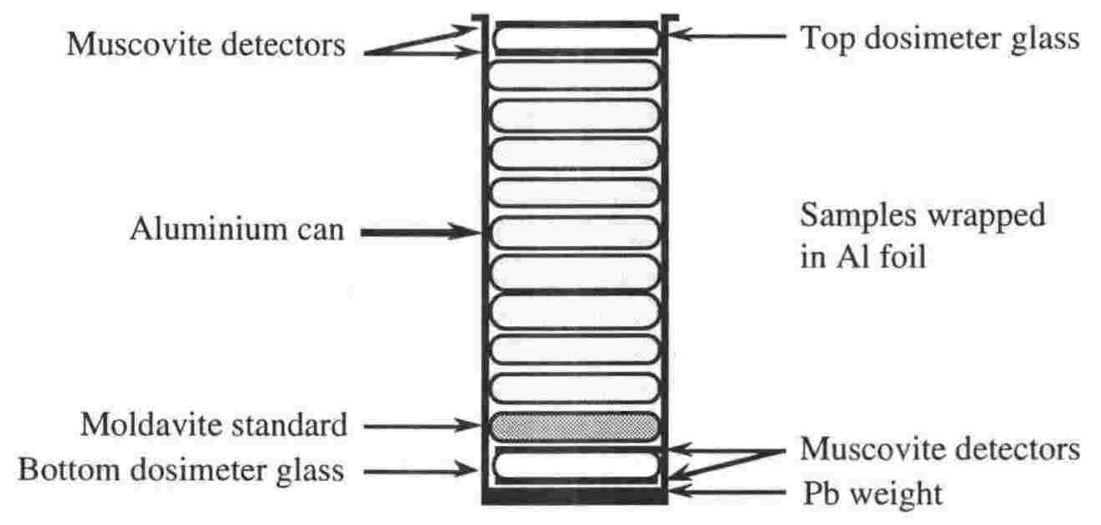

Figure 6.2. Schematic diagram of the typical arrangement of samples and standards for irradiation.

\subsubsection{Unpacking, mounting and polishing}

The can is unpacked carefully, and the sample positions are again noted, in case of any disturbance by reactor technical staff or movement occurring during transport. The moldavite tektite standard is ready to be mounted and polished, along with any non-heat-treated samples. For ITPFT ages, an Al-foil package of the spontaneous aliquot (reserved) is placed with the irradiated split, and the pairs are then heated for 30 days at $150^{\circ} \mathrm{C}$.

Epoxy resin is used to prepare grain mounts of the samples. Strips of lexan film are placed onto a Teflon cutting board, to support the edges of the glass slides. Several drops of epoxy are placed between the strips and the glass shards separately from each packet are added, stirred to remove bubbles and to produce a uniform distribution, and a glass slide placed over the blob. Customarily, 2 grain mounts from the irradiated fraction are made up, and 2-4 spontaneous slides. These are left to harden for 2 days and then identified on the back with a diamond inscriber, before being removed from the Teflon.

Heat treatment causes hydrated glass shards to become more brittle and crack easily, therefore the grain mounts are ground and polished by hand. First, 600 grade silicon carbide paper is used to expose the maximum surface area of the glass shards. Then $0.3 \mu \mathrm{m}$ alumina paste is used to polish the slides on a paper lap until low relief, featureless shard outlines are observed under reflected light. A quick polish with $6 \mu \mathrm{m}$ diamond paste, which gives parallel scratches on the polished mount surface, is then done to facilitate the identification of polished glass area under counting conditions. The mounted slides are then cleaned in an ultrasonic tank for 10 minutes, washed with soap and water, then with absolute alcohol.

\subsubsection{Etching}

Volcanic glass is amorphous, or isotropic in nature and therefore etches with the same rate in all directions. This is in contrast with minerals which have a highly ordered crystal 
structure, and therefore have more complex track shapes which require a longer time to etch to a suitable size than glass (Wagner and Van den Haute 1992).

A solution of $\sim 26 \% \mathrm{HF}$ is used to etch latent fission tracks in glass. The etchant reveals the track as a conical pit that, on the etched glass surface, looks circular or oval depending on the angle that the track is dipping (Figure 6.3). Until the etchant reaches the end of the track, this cone remains pointed at the apex which produces the characteristic 'point of light' encountered during age determinations. Once the end of the latent track has been reached, the etched track starts to bottom out and becomes bowl-shaped, thereby losing its 'point of light' (Figure 6.4). Those tracks lacking this point of light, are not counted during age determination as they are easily confused with bubbles and polishing defects (Wagner and Van den Haute 1992; Sandhu et al. 1993). The same criteria for track identification must be used when determining both the spontaneous and induced track densities, to produce a realistic age estimate.

Under-etching a sample can result in age underestimates because the average track diameters are too small and some smaller tracks may be missed under the microscope. However, over-etching also reduces the amount of countable tracks because they lose their point of light. To achieve the maximum number of tracks visible, the average track diameter should be between 6 and $8 \mu \mathrm{m}$ (Sandhu et al. 1993). Subsequent work by Sandhu and Westgate (1995) show that an average of $7 \mu \mathrm{m}$ is optimum. In glasses this can be achieved in 90-300 seconds, depending on their thermal stability, and the temperature at which the etch is done. Track diameters are measured using an interactive semi-automatic image analysis system.

As each sample has its own etching characteristics, an experimental etch is done on an induced grain mount first. The dry slide is placed in $\sim 26 \%$ HF at room temperature initially for 90 seconds, then washed thoroughly with water. Track diameters are measured after each subsequent step (5-10 seconds) if needed, to see whether the optimum size has been reached. Once a satisfactory etch has been obtained on the experimental slide, the final slides can be etched for the same total period of time. A one-step final etch gives clearer, more defined tracks. To ensure that both the spontaneous and irradiated aliquots undergo the same treatment, all mounts to be counted are etched at the same time. Generally, 1 induced slide and 2-3 spontaneous slides are immersed in the HF together.

\subsection{CALCULATING AN AGE}

The spontaneous fission of ${ }^{238} \mathrm{U}$ follows the law of radioactive decay. If the original amount of ${ }^{238} \mathrm{U}$ in a given sample is known and the fission track density is known, it is possible to calculate an age for the sample. 

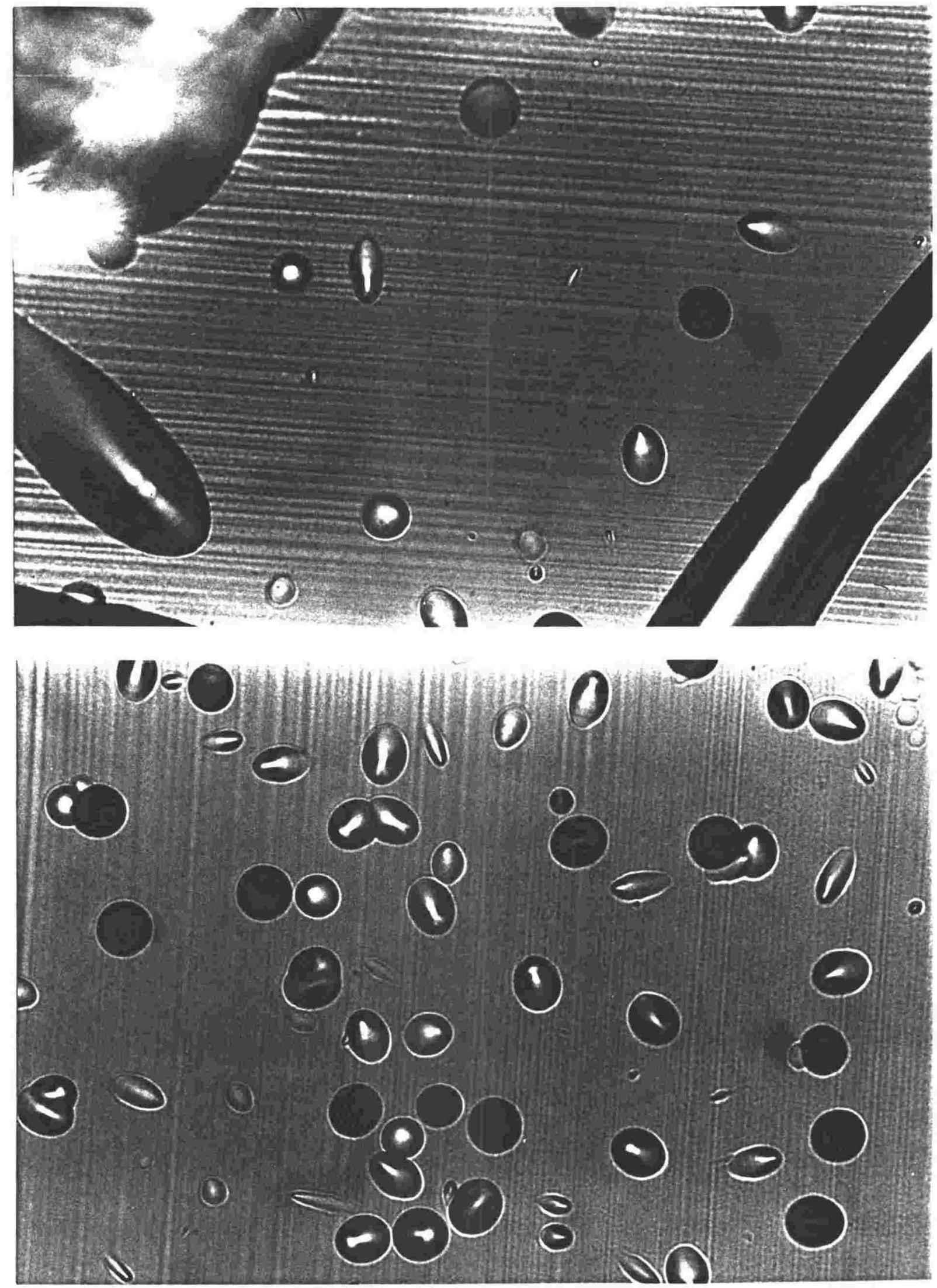

Figure 6.3 Photomicrographs of laboratory-induced fission-tracks in glass shards, revealed on a polished internal surface, and after etching in HF. (top) Mamaku Ignimbrite, (bottom) Huckleberry Ridge tuff (SW Montana). Tracks are either near-circular or elongated and have a point of light. The more subdued features lacking this point are not counted. 
Isotopic dating methods are based on the decay of a naturally radioactive parent atom to a stable daughter atom. In other isotopic dating methods such as $\mathrm{K}$ - $\mathrm{Ar}$ and ${ }^{40} \mathrm{Ar} /{ }^{39} \mathrm{Ar}$ the amount of daughter atoms are measured, whereas in the fission-track method the spontaneous fission track density is measured.

Fission-track ages are calculated using the following equation (Price and Walker 1963):

$$
t=1 / \lambda_{\mathrm{D}} \ln \left[1+\left(\lambda_{\mathrm{D}} / \lambda_{\mathrm{F}}\right)\left(\rho_{\mathrm{S}} / \rho_{\mathrm{i}}\right) \mathrm{gI} \sigma \phi\right]
$$

where,

$\mathrm{t}=$ age in years

$\lambda_{\mathrm{D}}=$ total decay constant for ${ }^{238} \mathrm{U}\left(1.551 \times 10^{-10} \mathrm{yr}^{-1}\right.$; Jaffey et al. 1971)

$\lambda_{\mathrm{F}}=$ decay constant for spontaneous fission of ${ }^{238} \mathrm{U}\left(7.03 \times 10^{-17} \mathrm{yr}^{-1}\right.$; Roberts et al. 1968)

$\mathrm{g}=$ geometry factor ( 1 for the glass ITPFT method)

$\mathrm{I}=$ isotopic ratio ${ }^{235} \mathrm{U} / 238 \mathrm{U}\left(7.252 \times 10^{-3}\right)$

$\sigma=$ cross-section for thermal neutron-induced fission of ${ }^{235} \mathrm{U}\left(580 \times 10^{-24} \mathrm{~cm}^{2}\right.$; Hanna et al. 1969)

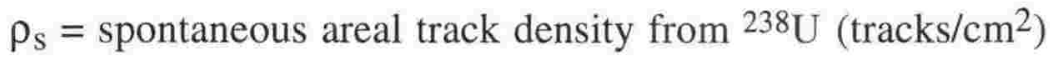

$\rho_{\mathrm{i}}=$ induced areal track density from ${ }^{235} \mathrm{U}$ (tracks $/ \mathrm{cm}^{2}$ )

$\phi=$ thermal neutron fluence (neutrons $/ \mathrm{cm}^{2}$ )

Since the nuclear constants are known, the age equation can also be expressed as:

$$
t=6.45 \times 10^{9} \ln \left[1+9.28 \times 10^{-18}\left(\rho_{s} / \rho_{i}\right) \phi\right]
$$

So the variables needed for an age are the thermal neutron fluence $(\phi)$ and the spontaneous and induced areal track densities $\left(\rho_{\mathrm{s}}, \rho_{\mathrm{i}}\right)$.

\subsubsection{Determination of Thermal Neutron Fluence $(\phi)$}

The neutron fluence is measured from glass dosimeters with a known uranium content. The dosimeters used for this study are NIST SRM 962 with $37.38 \pm 0.08$ ppm U. A dosimeter glass is placed at the top and bottom of the can (Figure 6.2) to measure the flux gradient within so individual fluence measurements can be interpolated for each unknown sample. Both sides of the glass dosimeters are covered with a muscovite external detector which is easier to etch and count than glass.

Once irradiated, the 4 external detectors are etched in $52 \% \mathrm{HF}$ at $25^{\circ} \mathrm{C}$ for 50 minutes to reveal their diamond-shaped tracks which are $4 \mu \mathrm{m}$ in diameter. The counting is done at 500 x magnification by the grid method, using a 5 x 5 eyepiece graticule and measuring $4 / 25$ 


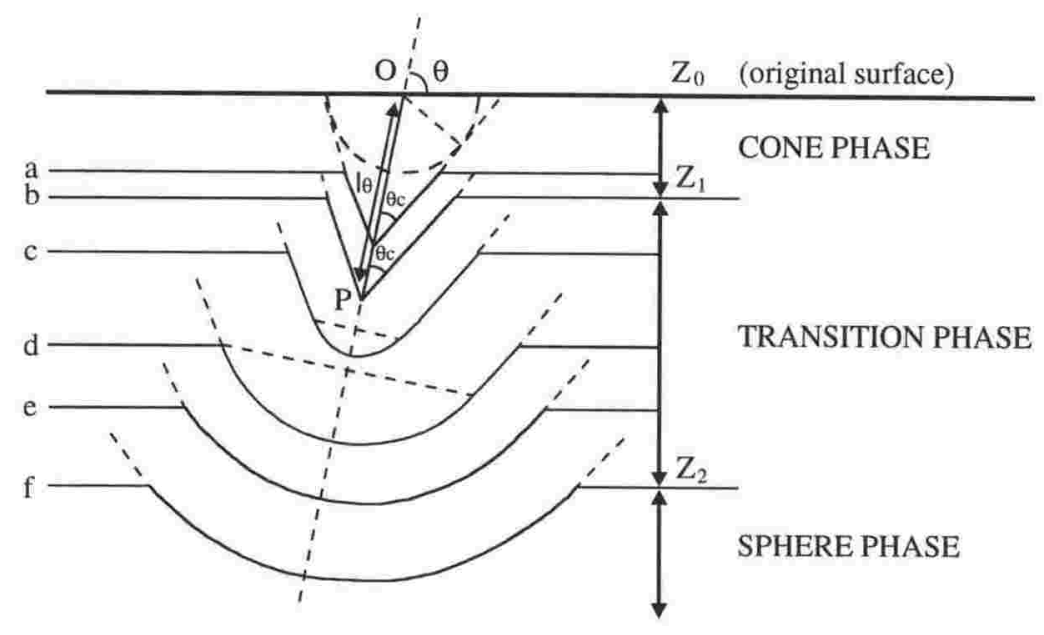

Figure 6.4 Schematic cross section of a fission-track in glass, shown with progressive etching steps a-f. Track length is O-P. In the initial phase, preferential etching occurs along the track producing a circular cone dipping at angle $\theta \mathrm{c}$. When the end of the track is reached at $\mathrm{P}\left(\operatorname{level}_{\mathrm{Z}} \mathrm{Z}\right)$, further etching results in progressive rounding of the cone base to form a rounded bowl shape. At level $Z_{2}$, the track shape is entirely spherical. From Figure 2.6, Wagner and Van den Haute (1992). 
squares in each field of view (Naeser 1976). Typically 4000 tracks are counted on each detector.

The fluence is then calculated using the equation

$$
\phi=B \rho_{\mathbf{m}}
$$

where $\mathrm{B}$ is the muscovite calibration factor $\left(0.53 \times 10^{10}\right)$ for the University of Toronto Lab, using the McMaster Nuclear Reactor. This factor is determined by directly counting the internal $4 \pi$ geometry of the glass dosimeter, and comparing the track density with the value obtained from the muscovite external detectors. $\rho_{m}$ is the induced track density (tracks $/ \mathrm{cm}^{2}$ ).

\subsubsection{Internal standards}

The Moldavite tektite glass is also included in each can to check the accuracy of the neutron fluence estimate. It has a ${ }^{40} \mathrm{Ar} /{ }^{39} \mathrm{Ar}$ plateau age of $15.21 \pm 0.15 \mathrm{Ma}$ (Staudacher et al. 1982). This sample is also counted using a 5 × 5 grid to determine glass area, counting the squares completely covered in polished glass with no defects such as bubbles or cracks.

\subsubsection{Determination of spontaneous and induced areal track densities $\left(\rho_{s}, \rho_{i}\right)$}

Although the grid method (as described for the moldavite standard) may be used for large blocky glass shards, the point counting method is more useful for smaller, thin walled glass shards (Seward 1974; Briggs and Westgate 1978; Naeser et al. 1982) where often the area of exposed glass is less than the size of an individual grid. This method uses a $2 \times 2$ grid at $500 \mathrm{x}$ magnification and every time the central cross-hair lands on polished glass rather than epoxy or unpolished glass, it is recorded as a 'point on glass'. Tracks falling within the 2 x 2 grid are recorded, provided they are on the polished glass surface. Since the area of polished glass is directly proportional to the number of points on glass, an areal track density can be calculated. A reliable track density is obtained when the ratio of tracks to points on glass has stabilised (Figure 6.5). For the track density of the irradiated aliquot, this ratio usually stabilises after 4000 to 20000 tracks (depending on fluence and $U$ content). This can be achieved in $6-8$ hours of counting. At least 100 spontaneous tracks are usually counted to obtain a reasonably small error (10\%, see section 6.5.4). This takes $2-10$ hours, depending mainly on the age of the sample.

The population subtraction method of calculating the induced density $\left(\rho_{\mathrm{i}}\right)$ is used here (Naeser 1967). The irradiated sample contains both spontaneous and induced tracks, therefore the $\rho_{\mathrm{i}}$ is the measured density minus the $\rho_{\mathrm{s}}$. 
Table 6.1 Neutron fluence determinations for irradiation batches used in this ITPFT study.

\begin{tabular}{llccc}
\hline irradiation & detector & $\begin{array}{c}\text { track density } \\
\left(10^{3} / \mathrm{cm}^{2}\right)\end{array}$ & number of tracks & $\begin{array}{c}\text { fluence } \\
\left(10^{15} \mathrm{n} / \mathrm{cm}^{2}\right)\end{array}$ \\
\hline \hline January 1994 & Top/top & 669.92 & 4116 & 3.55 \\
& Top/bottom & 680.01 & 4178 & 3.60 \\
& & & mean & 3.58 \\
& Bottom/top & 639.00 & 3926 & 3.39 \\
& Bottom/bottom & 624.87 & 4799 & 3.31 \\
March 1994 & & mean & $\mathbf{3 . 3 5}$ \\
& Top/top & 588.92 & 4146 & 3.12 \\
& Top/bottom & 580.40 & 4086 & 3.08 \\
& & & mean & 3.10 \\
& Bottom/top & 564.06 & 3971 & 2.99 \\
& Bottom/bottom & 550.57 & 3876 & 2.92 \\
March 1995 & & mean & $\mathbf{2 . 9 6}$ \\
& & & 4623 & 3.48 \\
& Top/top & 656.68 & 4615 & 3.47 \\
& Top/bottom & 655.54 & mean & $\mathbf{3 . 4 8}$ \\
& & & 4503 & 3.39 \\
& Bottom/top & 639.63 & 4523 & 3.41 \\
& Bottom/bottom & 642.47 & mean & $\mathbf{3 . 4 0}$ \\
\hline
\end{tabular}

Thermal neutron fluence was determined by counting fission-tracks (500x magnification) on muscovite detectors covering glass dosimeters (NBS SRM 962: $37.37 \pm 0.08 \mathrm{ppm} \mathrm{U}$ ) placed at top and bottom of irradiated can (see Figure 6.2). Fluences calibrated against the $\mathrm{Cu}$ value determined at NBS (Carpenter \& Reimer 1974). Samples irradiated at McMaster Nuclear Reactor Centre, McMaster University, Hamilton, Ontario, Canada. Fluence for a particular sample is determined by graphical interpolation between dosimeter glass values.

Table 6.2 Fission track ages of Moldavite tektite from Ries Crater, Germany.

\begin{tabular}{|c|c|c|c|c|c|}
\hline \multicolumn{2}{|c|}{ Track density } & \multirow{2}{*}{$\begin{array}{c}\text { Neutron } \\
\text { fluence } \\
\left(10^{15} \mathrm{n} / \mathrm{cm}^{2}\right) \\
\end{array}$} & \multirow{2}{*}{$\begin{array}{l}\text { Etch } \\
\text { time } \\
(\mathrm{s})^{\mathrm{a}}\end{array}$} & \multirow[t]{2}{*}{ Age (Ma) } & \multirow[t]{2}{*}{ Operator } \\
\hline $\begin{array}{l}\text { Spontaneous } \\
\left(10^{2} \mathrm{t} / \mathrm{cm}^{2}\right) \\
\end{array}$ & $\begin{array}{c}\text { induced } \\
\left(10^{4} \mathrm{t} / \mathrm{cm}^{2}\right)\end{array}$ & & & & \\
\hline \multicolumn{6}{|c|}{ January 1994} \\
\hline $131.91(586)^{\mathrm{b}}$ & $19.66(4705)$ & $3.52 \pm 0.03$ & 120 & $15.13 \pm 0.68$ & PS \\
\hline & & March 19 & & & \\
\hline $127.58(694)$ & $16.70(4564)$ & $3.02 \pm 0.02$ & 120 & $14.92 \pm 0.63$ & TB \\
\hline \multicolumn{6}{|c|}{ March 1995} \\
\hline $124.60(750)$ & $18.16(4145)$ & $3.41 \pm 0.03$ & 120 & $14.99 \pm 0.61$ & TB \\
\hline
\end{tabular}

The population subtraction method was used with the reported induced track density being the measured track density minus the spontaneous track density. Ages calculated from the equation of Price and Walker (1963), using the following constraints: $\lambda \mathrm{D}=1.55 \times 10^{-10} \mathrm{yr}^{-1} ; \lambda \mathrm{F}=7.03 \times 10^{-17} \mathrm{yr}^{-1} ; \sigma \mathrm{F}=580 \times 10^{-24}$ $\mathrm{cm}^{2} ; \mathrm{I}=7.252 \times 10^{3}$. Thermal neutron fluence was determined from calibrated muscovite detectors covering glass dosimeters (NIST SRM 962: $37.37 \pm 0.08 \mathrm{ppm}$ ) placed at top and bottom of irradiated can. Fluences calibrated against the $\mathrm{Cu}$ value determined at NIST (Carpenter \& Reimer, 1974). Samples irradiated at McMaster Nuclear Reactor Centre, McMaster University, Hamilton, Ontario, Canada. Error $( \pm 1 \sigma)$ is calculated by combining the Poisson errors in the track counts and on the counts in the detector covering the dosimeters. Mean track diameters are in the range 6-7 $\mu \mathrm{m}$. ${ }^{\mathrm{a}}$ Etched in $26 \% \mathrm{HF}$ at $25^{\circ} \mathrm{C}$. b Number of tracks counted. 
Matahina Ignimbrite

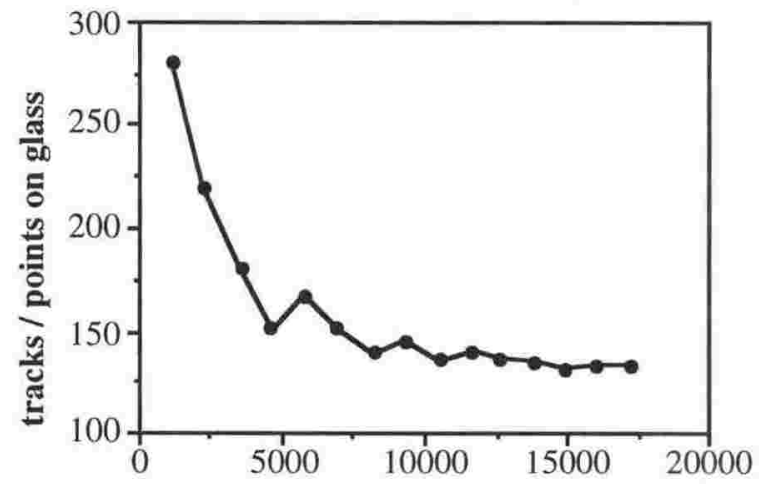

No. of induced + spontaneous tracks

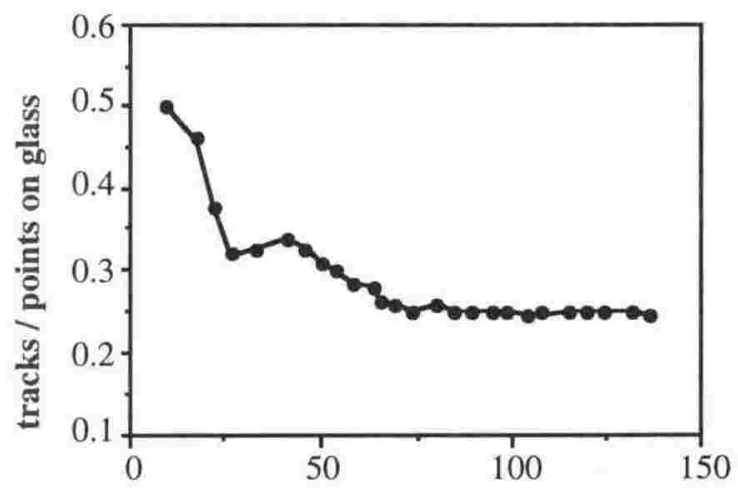

No. of spontaneous tracks

Figure 6.5. The ratio of the number of fission-tracks counted to the points on glass, plotted against number of fission-tracks. When the ratio stabilizes with an increasing track count, a representative track density has been determined.

\subsubsection{Estimation of errors}

The precision of a fission-track age is estimated by combining the Poisson errors in the spontaneous and induced track counts with the counts from the dosimeter detectors:

$$
\sigma(t)=t \sqrt{ }\{1 / \mathrm{Ns}+1 / \mathrm{Ni}+1 / \mathrm{Nd}\}
$$

where,

$\sigma= \pm 1 \sigma$ uncertainty

$\mathrm{t}=$ age in years

$\mathrm{Ns}, \mathrm{Ni}, \mathrm{Nd}=$ numbers of spontaneous, induced and dosimeter tracks counted.

For Quaternary samples, the error is largely determined by Ns, because $\mathrm{Ni}$ and $\mathrm{Nd}$ are usually much larger. For a $10 \%$ error, 100 spontaneous tracks must be counted. However, for a $5 \%$ error, 400 spontaneous tracks are required.

\subsection{RESULTS}

The neutron fluence was measured at the top and bottom of each irradiation can, as described in Section 6.5.1. Numbers of tracks counted on each muscovite detector and calculated fluences are in Table 6.1. A moldavite tektite glass standard from Ries Crater in Germany was added to each irradiation can as a check on the fluence determinations. The ages for the standard in each irradiation batch (Table 6.2) are consistent with the published ${ }^{40} \mathrm{Ar} /{ }^{39} \mathrm{Ar}$ age of $15.21 \pm 0.15 \mathrm{Ma}$ (Staudacher et al. 1982). 


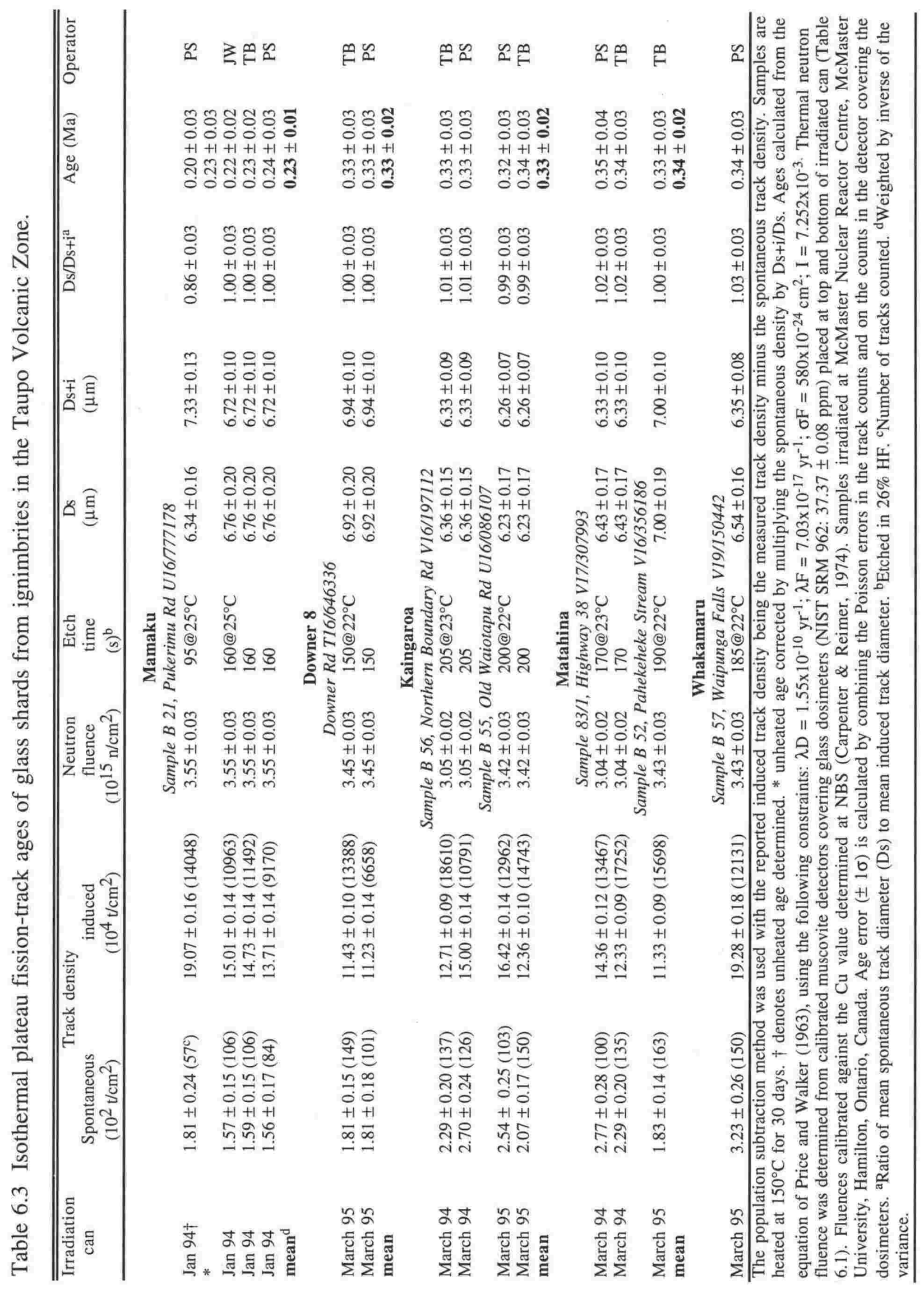


Samples of glass from five different ignimbrite units were dated by the ITPFT method (Table 6.3). Measured track diameters from an unheated samples of Mamaku ignimbrite showed it had undergone partial fading of its spontaneous tracks, with a Ds/Di value of 0.86 (Figure 6.6). This confirms the previous suggestion in Section 6.3 that even late Quaternary glasses may undergo partial track fading at ambient temperatures. Therefore aliquots of every sample were heat treated for 30 days at $150^{\circ} \mathrm{C}$. A concordance in the track size distributions of spontaneous and induced aliquots (Figure 6.7), together with Ds/Di values close to unity (Table 6.3), indicate that this heat treatment has completely corrected for any track fading. Thus the resulting data in Table 6.3 are considered to be eruption ages.

For the ITPFT ages determined in this study, most samples were counted by 2 or 3 operators. The concordant ages suggest little operator bias has occurred, and allow a weighted mean to be calculated for each ignimbrite to reduce the error value. Individual errors for age determinations on the late Quaternary units are in the range of $30-40 \mathrm{ka}$ or $8-10 \%$. The weighted mean of $2-4$ age determinations give errors in the range of $20-10 \mathrm{ka}$ or $5 \%$, which compares well with errors on ${ }^{40} \mathrm{Ar} /{ }^{39} \mathrm{Ar}$ plagioclase ages published for these and other units (Houghton et al. 1995).

\subsubsection{Whakamaru group ignimbrites}

An ITPFT age of $0.343 \pm 0.028 \mathrm{Ma}$ was determined in this study for the Te Whaiti member of the Whakamaru group ignimbrites, exposed along the Napier-Taupo highway at Waipunga Falls (Table 6.3). A zircon fission-track mean age of $0.39 \pm 0.05 \mathrm{Ma}$ was determined from the same locality by Kohn et al. (1992). The ITPFT age is in good agreement with plagioclase ${ }^{40} \mathrm{Ar} /{ }^{39} \mathrm{Ar}$ ages on members of the Whakamaru group (Pringle et al. 1992, Houghton et al. 1995).

Froggatt et al. (1986) and Kohn et al. (1992) have suggested a correlation of the Whakamaru group ignimbrites and to the widespread fallout tephra referred to as Mt Curl and Rangitawa. This tephra has been dated by ${ }^{40} \mathrm{Ar} /{ }^{39} \mathrm{Ar}$, zircon fission-track, ITPFT, and thermoluminescence at $0.333 \pm 0.007 \mathrm{Ma}$ from 19 determinations, which compares well with an astronomically-tuned oxygen isotope stratigraphic age of $0.340 \pm 0.007 \mathrm{Ma}$ (B. Pillans pers. comm.). All of these ages on the distal correlative agree well with the ITPFT age determined here on the proximal ignimbrite.

\subsubsection{Matahina Ignimbrite}

The Matahina eruption was dated from two localities: (1) basal nonwelded ignimbrite exposed on Highway 83 near Murupara, where it overlies Whakamaru and the Bonisch 

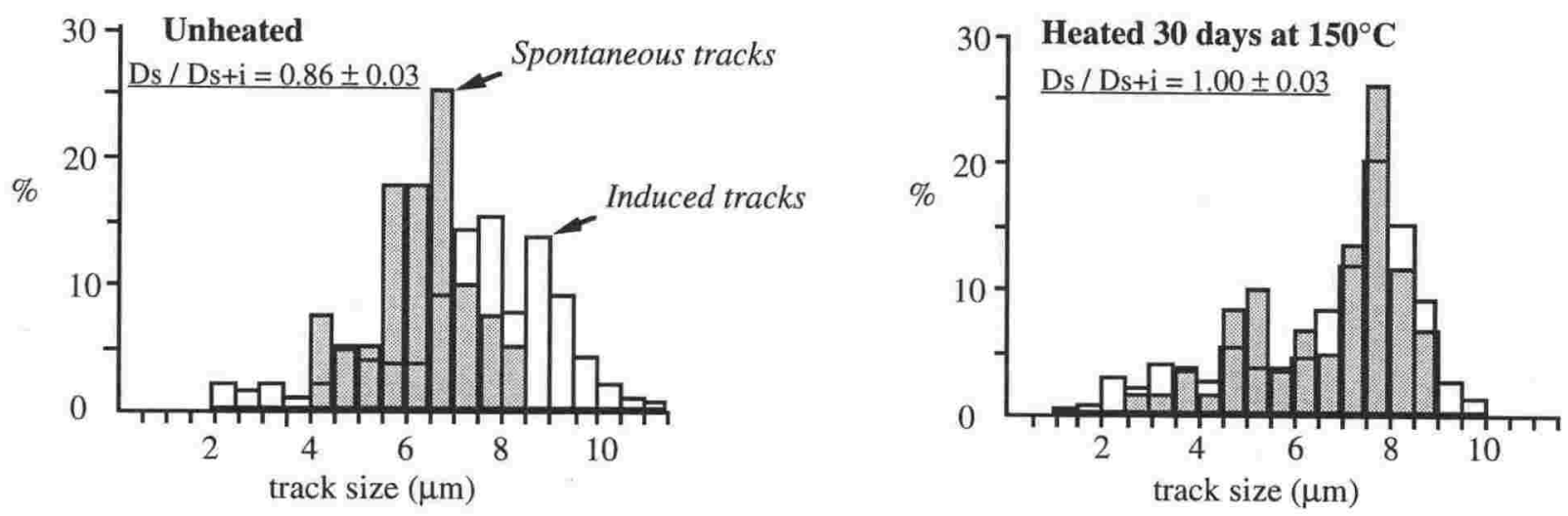

Figure 6.6. Histograms showing the size distribution of fission-tracks for an unheated and heated glass sample of the Mamaku Ignimbrite (sample B 21, site 148). The spontaneous tracks in the unheated sample are smaller than the induced tracks, indicating partial fading has taken place. The heated sample displays a concordance in the two track population size distributions. 
Pyroclastic sequence; and (2) basal plinian lapilli and ash beneath the ignimbrite at Pahekeheke Stream.

The ages from both sites are concordant (Table 6.3) and produce a weighted mean of $0.34 \pm 0.02 \mathrm{Ma}$. This age is significantly older than a glass fission-track age of $0.26 \pm 0.04 \mathrm{Ma}$ (Kohn 1973) and a zircon fission-track age of $0.29 \pm 0.03$ (Nairn 1989). Glass fission-track ages uncorrected for partial track fading only give minimum estimates of age. Other studies have shown the earlier zircon ages on NZ tephra were often underestimates of the eruption age (Black 1992, Alloway et al. 1993, Shane 1994), which may be due to under etching or uncertain neutron fluence. Houghton et al. (1995) reported a younger age for Matahina Ignimbrite $\left(0.28 \pm 0.01 \mathrm{Ma},{ }^{40} \mathrm{Ar} /{ }^{39} \mathrm{Ar}\right)$. This is further discussed in Chapter 7 .

\subsubsection{Kaingaroa ignimbrite}

Kaingaroa ignimbrite was also dated from two separate localities: (1) $\mathrm{kg}_{2}$ from Northern Boundary Road and (2) $\mathrm{kg}_{2}$ from Old Waiotapu Rd in Kaingaroa Forest . The weighted mean age of $0.33 \pm 0.02 \mathrm{Ma}$ was calculated from 4 determinations (Table 6.3). As with Matahina, the ITPFT age is older than previous fission-track estimates (Nairn 1989, Houghton et al. 1995). Houghton et al. (1995) reported a ${ }^{40} \mathrm{Ar} /{ }^{39} \mathrm{Ar}$ age of $0.23 \pm 0.01 \mathrm{Ma}$ for Kaingaroa ignimbrite. This age is considered too young on stratigraphic grounds and is further discussed in Chapter 7.

\subsubsection{Downer Rd 8}

An ignimbrite overlying the Whakamaru Ignimbrite and fallout tephra beds exposed along Downer Rd (T16/646366) is dated at $0.33 \pm 0.02 \mathrm{Ma}$ from a mean of 2 determinations. This age is consistent with its stratigraphic position in relation to the Whakamaru Ignimbrite. The ignimbrite has not been described in the literature but is considered to be either the Chimpanzee or Pokai ignimbrite (Houghton et al. 1995, see Chapter 7, this study). Radiometric ages for this unit have not been previously reported.

\subsubsection{Mamaku Ignimbrite}

Using the track diameter correction method of Sandhu and Westgate (1995), the unheated age determined for Mamaku Ignimbrite $(0.20 \pm 0.03 \mathrm{Ma}$, Table 6.3) can be recalculated as $0.23 \pm 0.03 \mathrm{Ma}$. The corrected age is now in accord with three ITPFT ages also determined on this sample (Table 6.3; Shane et al. 1994).

From the 4 ages, a weighted mean of $0.23 \pm 0.01 \mathrm{Ma}$ was obtained for Mamaku Ignimbrite (Table 6.3). This is significantly older than a zircon fission-track age of $0.14 \pm 0.08$ 

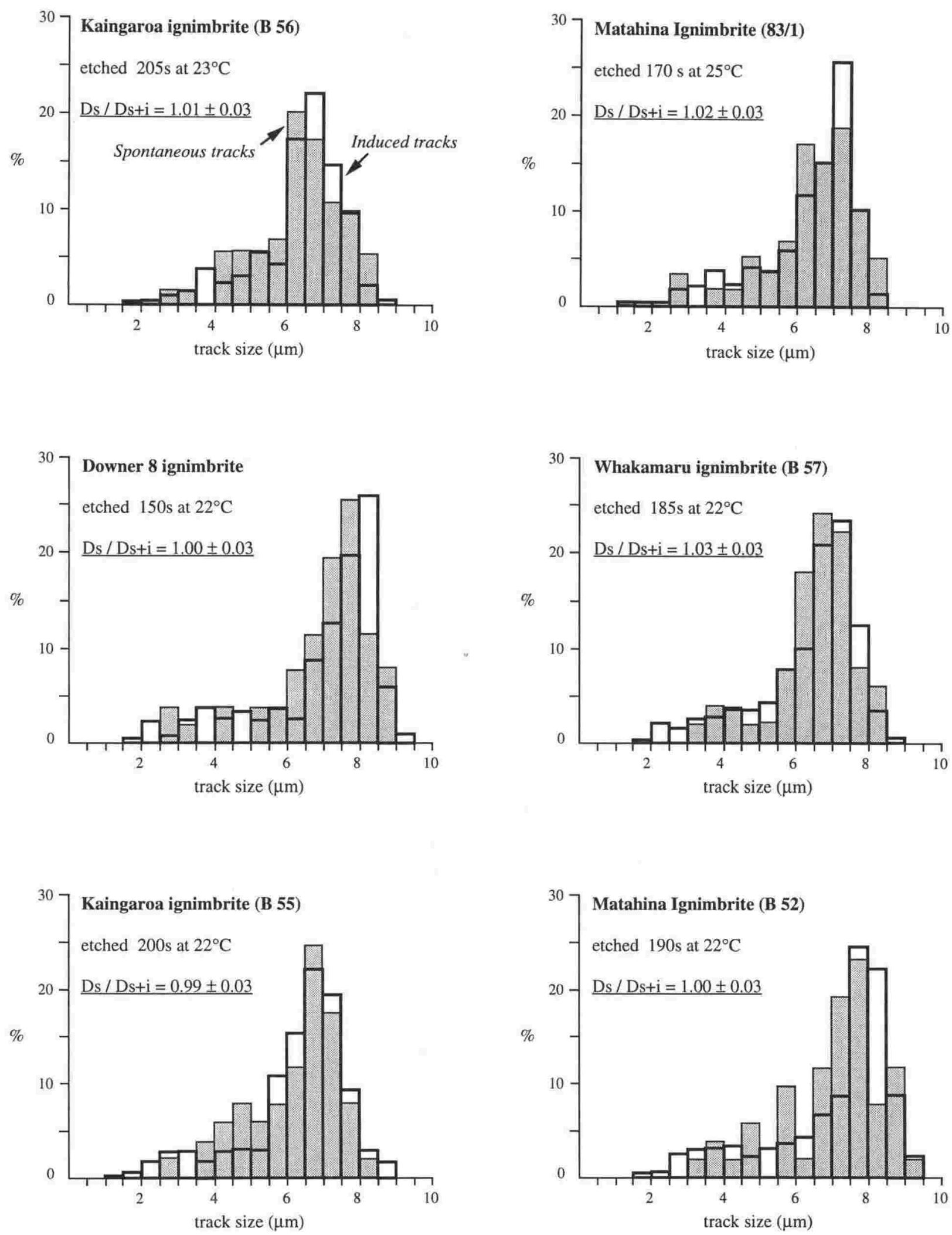

Figure 6.7 Fission-track size distributions of spontaneous and induced + spontaneous track populations for samples dated by the ITPFT method. Samples were heated for 30 days at $150^{\circ} \mathrm{C}$. A coincidence in track diameters indicates any partial track fading has been corrected for. 
Ma (Murphy and Seward 1981). The ITPFT mean age agrees well with a recent ${ }^{40} \mathrm{Ar} /{ }^{39} \mathrm{Ar}$ determination of $0.22 \pm 0.01 \mathrm{Ma}$ (Houghton et al. 1995).

\subsection{CONCLUSIONS}

1. Accurate and precise ITPFT ages can be obtained for proximal ignimbrite units from the glass phase of their nonwelded bases. The typical coarse $(250-500 \mu \mathrm{m})$ chunky shards from nonwelded basal ash are ideal for the ITPFT technique as they provide a large glass surface area for counting.

2. Late Pleistocene units can be greatly affected by partial track fading. For example, spontaneous tracks in Mamaku Ignimbrite $(0.23 \mathrm{Ma})$ are on average $14 \%$ smaller than fission-tracks induced in the laboratory.

3. As found by previous studies on distal tephra beds, a single step heat treatment of $150^{\circ} \mathrm{C}$ for 30 days, and an adequate etch results in the correct age determination for the proximal ignimbrite.

4. The ITPFT ages and their associated uncertainties compare well with ${ }^{40} \mathrm{Ar} /{ }^{39} \mathrm{Ar}$ ages determined from mini-bulk plagioclase separates. The high $\mathrm{K}$ mineral phase sanidine is generally absent in the TVZ eruptives, which precludes the acquisition of ages with smaller analytical uncertainties.

5. The following mean ITPFT ages were obtained: $0.23 \pm 0.01 \mathrm{Ma}$ for Mamaku Ignimbrite, $0.33 \pm 0.02 \mathrm{Ma}$ for Kaingaroa ignimbrite, $0.33 \pm 0.0$ ? Ma for Downer 8, and $0.34 \pm 0.02 \mathrm{Ma}$ for Matahina Ignimbrite. An individual determination of $0.34 \pm 0.03 \mathrm{Ma}$ was also obtained for the Whakamaru group ignimbrite. 


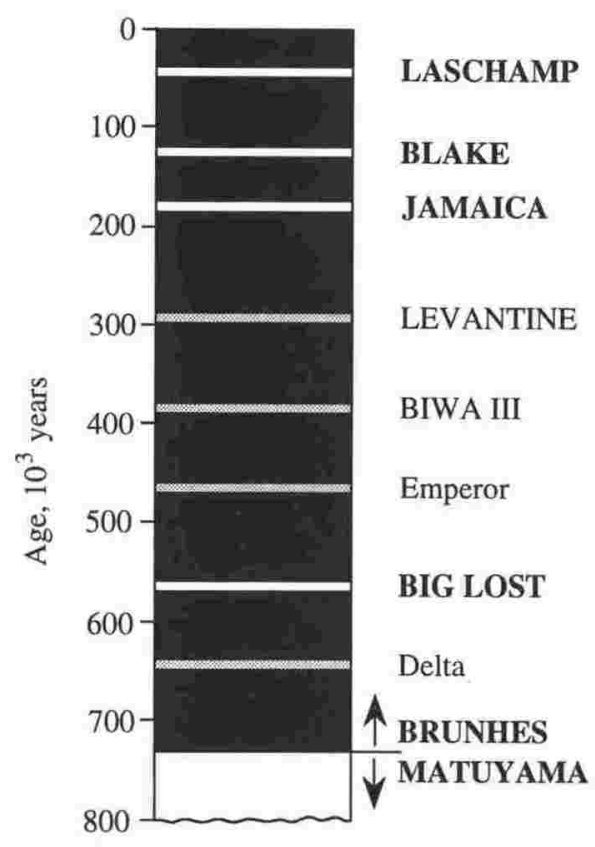

Figure 7.1 Ages of well-identified reversed polarity subchrons within the Brunhes Normal Chron. Solid white bars represent events identified and dated from volcanic rocks, and stippled bars are recorded from sedimentary rocks. From Champion et al. (1988). 


\section{Chapter 7 \\ NEW IMPLICATIONS FOR THE STRATIGRAPHY AND CHRONOLOGY OF THE \\ TAUPO VOLCANIC ZONE}

\subsection{INTRODUCTION}

New geochemical, paleomagnetic and chronological data from this study give insights to the tempo of volcanism in the TVZ and to the origin of some of the widespread units. In the field, the stratigraphic order of the ignimbrites is largely obscured by burial and lack of exposure; subsequent volcanic activity has largely destroyed the physiography of the older calderas. The acquisition of new paleomagnetic data has resulted in the documentation of a Quaternary paleomagnetic excursion, and allows the construction of a general magnetostratigraphy. Geochemical and age data permit possible correlations to distal tephra beds in southern North Island. A discussion of major topics is presented in this chapter.

\subsection{RECOGNITION OF A LATE QUATERNARY PALEOMAGNETIC EXCURSION}

\subsubsection{Paleomagnetic record of the Brunhes Chron}

Several short reversals have been documented within the Brunhes Normal Chron and have been found in both volcanic rocks and sediments. Volcanic rocks are erupted within a very short period, therefore their paleomagnetic signature records only an instant in time. In many cases these rocks are ideal to radiometrically date and therefore obtain age control on the paleomagnetic episode. Continuous sedimentary sequences, both in deep sea cores and sections exposed on land, record a longer time interval and consequently transitional polar paths may be obtained, tracing the behaviour of the geomagnetic field through time. However, age control is often difficult to obtain unless tephra layers are present in the sediments close to the paleomagnetic interval studied. Radiometric ages on these tephra layers may aid in the identification of a polarity event.

Champion et al. (1988) summarised the evidence for 8 short subchrons occurring within the Brunhes Chron (0.78 Ma to present, Shackleton et al. 1990): the Laschamp, Blake, Jamaica, Levantine, Biwa III, Emperor, Big Lost and Delta subchrons (Figure 7.1). These have all been studied in several sections, and correlated on the basis of radiometric ages, sedimentation rates, and transition path behaviour.

Some workers have suggested from deep sea cores and onland sections that paleomagnetic reversals and excursions are associated with low field intensities (Champion et al. 1988; Valet and Meynadier 1993; Verosub 1994; Negrini et al. 1994). By obtaining a near-continuous paleointensity record from deep sea sediments sampled on ODP Leg 138 in the equatorial Pacific, Valet and Meynadier (1993) have calibrated low paleomagnetic 


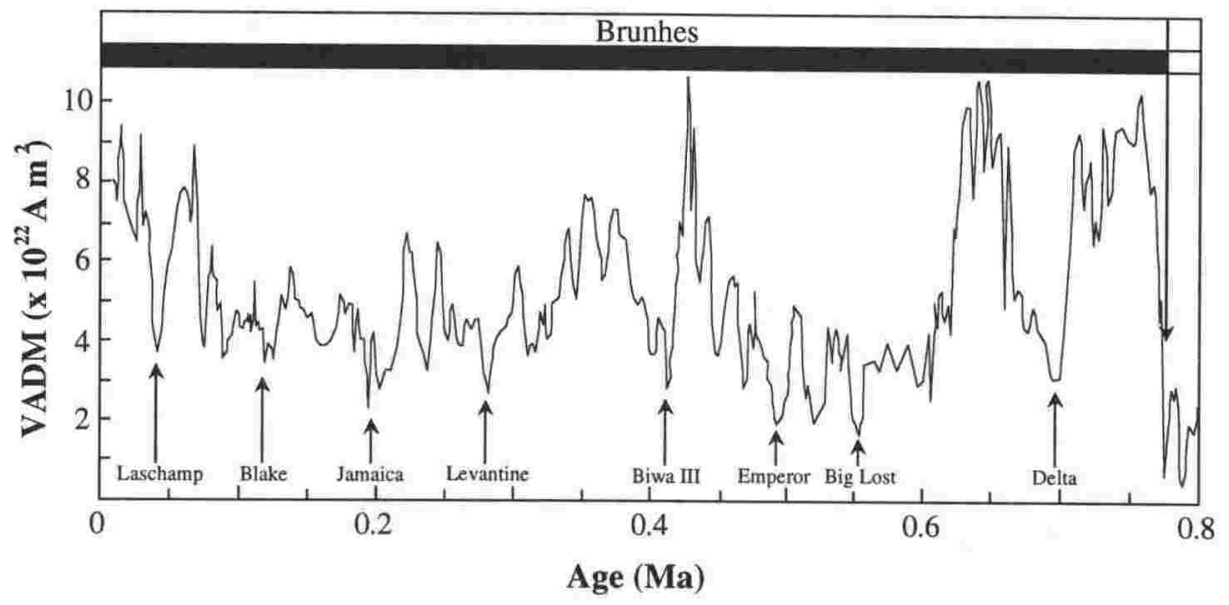

Figure 7.2 Relative variations of the dipole field intensity during the last $0.8 \mathrm{Ma}$, obtained from a composite sequence from ODP sites 848 and 851 . VADM represents virtual axial dipole moment. The position of paleomagnetic excursions and short events observed in previous studies are indicated by arrows, and correlate to intensity minima shown above. From Valet and Meynadier (1993). 
intensity events by astronomical tuning of the oxygen isotope record (Shackleton et al. 1990). This increases the previously estimated ages for the individual polarity events by $2-10 \%$ (Figure 7.2). Previously identified excursions are associated with drops in paleointensity. Other intensity minima are present in this record, and are so far not associated with any known polarity event.

\subsubsection{A geomagnetic polarity episode recorded in the Mamaku Ignimbrite}

Cox (1971) presented paleomagnetic data from a site in the Mamaku Ignimbrite, which was interpreted to be normal polarity. But the data presented clearly showed the unit to have a direction different from a typical dipole field (declination $=118^{\circ}$ and inclination $=-84^{\circ}, \operatorname{Cox}$ 1971). Murphy and Seward (1981) have determined a zircon fission-track age of $0.14 \pm 0.08$ Ma from an exposure of Mamaku Ignimbrite in the Matahana Basin.

Seventeen sites were sampled for paleomagnetic analysis over a wide area, up to 50 $\mathrm{km}$ from Lake Rotorua, the inferred source (Figure 2.8). Samples were collected from exposures displaying a variety of welding intensities, cores were drilled from the intensely welded base and the soft vapour phase altered top of the unit was sampled by cubes. A vertical stratigraphic succession was collected through the type section at Mangaorewa Gorge. All sites, from every stratigraphic level and degree of welding, yielded a concordant remanent direction after demagnetisation (Figure 7.3, Table 3.1). Most specimens displayed a single component remanent magnetisation, where viscous overprints were removed by low intensity AF demagnetisation (10 - $15 \mathrm{mT}$, see Chapter 3). A mean of 25 sites gives a declination of $141^{\circ}$ and inclination of $-72^{\circ}\left(\alpha_{95}=3.7^{\circ}, \mathrm{K}=64\right.$, Table 3.1$)$, which is widely variant from the present-day geomagnetic field and that expected of secular variation (Figure 7.3). Therefore, the Mamaku Ignimbrite was erupted within an excursion of Earth's magnetic field.

The two most southerly sites collected (21 and 112) are from a unit referred to as Mokai ignimbrite. This ignimbrite has previously been correlated to Mamaku on the basis of lithology and stratigraphic position (Wilson et al. 1986) The remanence direction measured from these sites (Table 3.1) confirms this correlation.

Glass shards collected from the nonwelded base of Mamaku Ignimbrite at site 148 (Figure 7.4) was dated by the ITPFT method (see Chapter 6). An age from unheated glass, using the track-diameter correction method (Sandhu and Westgate 1995), of $0.23 \pm 0.03 \mathrm{Ma}$ was obtained. This age agrees well with three ITPFT ages of $0.22 \pm 0.02,0.23 \pm 0.02$ and 0.24 $\pm 0.03 \mathrm{Ma}$ (Table 6.3). An age of $0.23 \pm 0.01 \mathrm{Ma}$ is obtained from a weighted mean from the four determinations. This age is significantly older and more precise than the mean zircon fission-track age of $0.14 \pm 0.08 \mathrm{Ma}$ (Murphy and Seward 1981), and in good agreement with a recently determined ${ }^{40} \mathrm{Ar} /{ }^{39} \mathrm{Ar}$ age of $0.22 \pm 0.01 \mathrm{Ma}$ (Houghton et al. 1995). These ages tightly constrain the excursion recorded in the Mamaku Ignimbrite. Loess coverbeds on the 


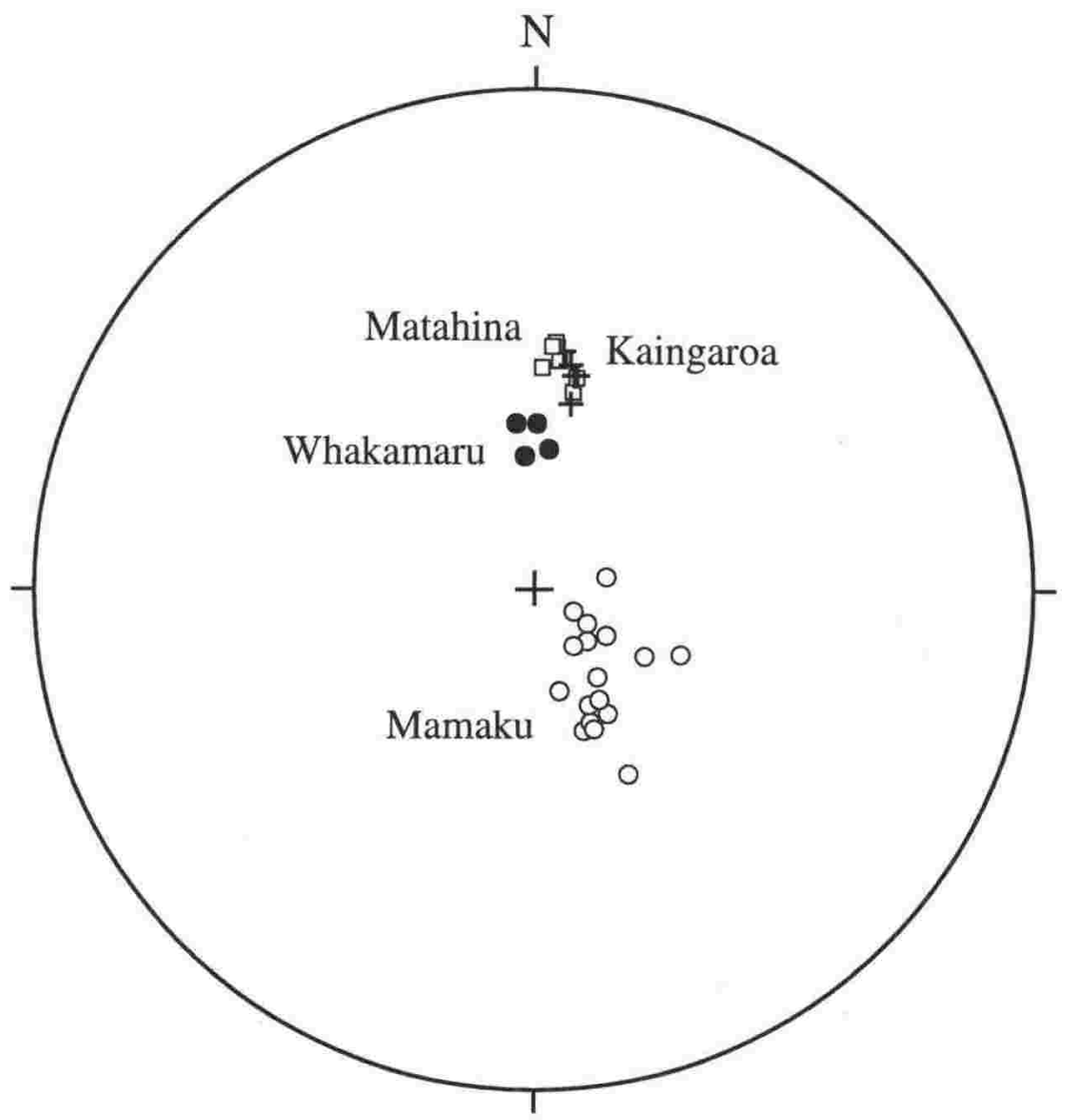

Figure 7.3 Site means of paleomagnetic remanence directions for late Pleistocene ignimbrites in the Bay of Plenty region, plotted on a stereonet. All sites display negative (normal) inclinations, but the declinations for Mamaku Ignimbrite are widely variant from that expected from a typical dipole field. 
Mamaku Plateau record anomalous paleomagnetic remanence directions, similar to the underlying Mamaku Ignimbrite (Froggatt 1988). Similarly aged loess in the Wanganui Basin also displays paleomagnetic directions atypical of a dipole field (Pillans and Wright 1990). Hence, the paleomagnetic episode may be widely recorded in New Zealand. The only other excursion recorded in igneous rocks of the Southern Hemisphere is from basalts of the Auckland area, dated at 23 - 49 ka (Shibuya et al. 1992).

The age of the event recorded in Mamaku Ignimbrite (ca. $0.22-0.23 \mathrm{Ma}$ ) does not precisely match any of the excursions documented in Champion et al. (1988) or Valet and Meynadier (1993), although many of these events are not well constrained by radiometric data. Recently, Herrero-Bervera et al. (1994) have documented a geomagnetic polarity episode recorded in several high-resolution sedimentary sequences in the western USA, and have constrained it by an age of $0.22 \pm 0.01 \mathrm{Ma}$ from a ${ }^{40} \mathrm{Ar} /{ }^{39} \mathrm{Ar}$ age determined on a tephra bed immediately underlying the episode at one locality, and correlated to tephra layers occupying the same stratigraphic position in the other sections studied. These authors consider this event to be considerably older than the Blake event, which it resembles paleomagnetically. The Jamaica Subchron is a possible correlative, with a K-Ar age of $0.18 \pm$ $0.03 \mathrm{Ma}$, averaged from 2 determinations with 1\% radiogenic Ar (Champion et al. 1988). This age has been astronomically tuned by Valet and Meynadier (1993) to ca. 0.195 Ma. A detailed transition record of the Jamaica Subchron could confirm this possible correlation to the event recorded in the western USA, which so far is lacking. Herrero-Bervera et al. (1994) propose the name Pringle Falls geomagnetic polarity episode for this event, recorded in greatest detail at Pringle Falls, Oregon. There, an almost complete reversal of the paleomagnetic field is recorded.

The event recorded in New Zealand at ca. $0.22-0.23$ Ma may therefore correlate to the Pringle Falls geomagnetic episode, which in turn could correlate to the Jamaica Subchron. The transitional direction recorded in the Mamaku Ignimbrite may represent part of the initial stage of field reversal. A geomagnetic field intensity-low is recorded at ca. 0.235 Ma in Valet and Meynadier (1993) between the inferred Jamaica and Biwa II events (Figure 7.2). This could represent a previously unknown excursion associated with the Mamaku and/or Pringle Falls polarity episode. The age of the Mamaku Ignimbrite directly dates material erupted during the event, whereas the age determined by Herrero-Bervera et al. (1994) is on a tephra layer underlying the Pringle Falls episode. If this correlation is correct, the Pringle Falls episode is widely represented and of global significance to Quaternary studies.

\subsection{SOURCE AREAS FOR SOME WIDESPREAD IGNIMBRITES}

As discussed in earlier chapters, the source vents for the widespread ignimbrite sheets in the TVZ are difficult to identify due to deep burial and limited exposure. Anisotropy 


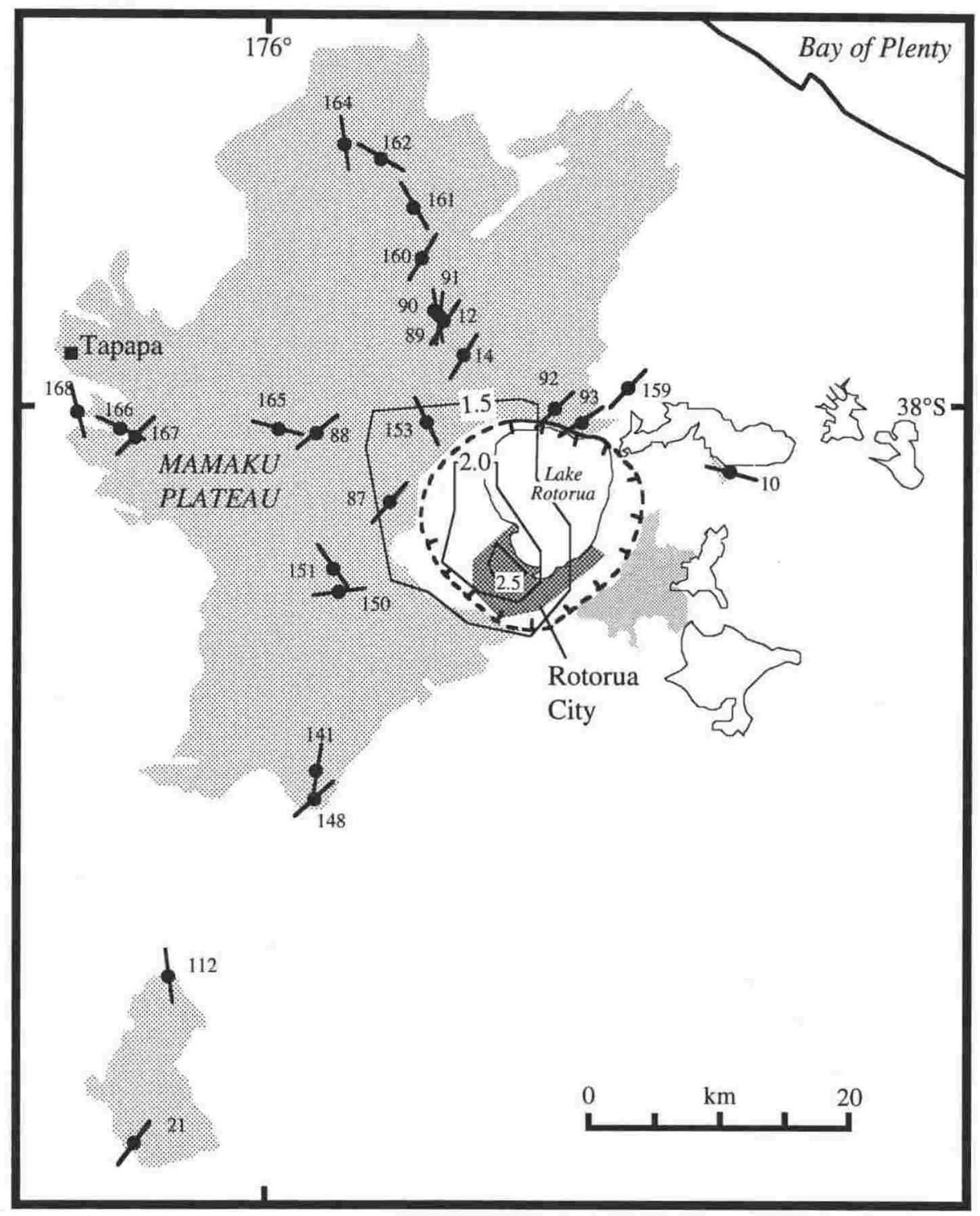

Figure 7.4 Mean azimuths of AMS data, inferred to parallel paleoflow direction (data from Table 5.1) for sites of the Mamaku Ignimbrite. Shaded area represents the outcrop extent of the ignimbrite. Contours (in $\mathrm{km}$ ) represent the depth below sealevel to basement, from geophysical data (Rogan 1982). Inferred caldera outline from Wilson et al. (1984). 
of magnetic susceptibility (AMS) as a measure of magnetic fabric now provides a new tool for investigation (Chapter 5).

\subsubsection{Location of a source vent for Mamaku Ignimbrite}

The azimuths of the measured magnetic fabrics from sites of the Mamaku Ignimbrite mainly point to a source near Lake Rotorua (Figure 7.4). The lake is considered to be located within the collapse structure that resulted from the eruption of Mamaku Ignimbrite (Wilson et al. 1984). Not all site azimuths point directly to the lake area, however some are likely to be influenced by local topography and channeling of the flow during emplacement.

The AMS flow azimuths intersect mainly in an area to the west of Lake Rotorua (Figure 7.4). Geophysical data (Rogan 1982) suggest the greatest depth to basement (ca. 2.5 $\mathrm{km}$ ) is in an area immediately to the west of the present lake (Figure 7.4). Hence, a point source vent in the Ngongotaha-Rotorua city region is likely. This is also consistent with the post-collapse extrusion of the Ngongotaha rhyolite dome in this area (Wilson et al. 1984). To the west, the Mamaku Ignimbrite dips toward Lake Rotorua, due to the effect of downwarping thought to be associated with post-eruption deflation (Walker 1984). Most of the flow was emplaced to the west of the inferred vent, therefore a vent source in the Ngongotaha-Rotorua city region of the caldera would be more consistent with the apparently asymmetric distribution of the Mamaku Ignimbrite relative to the present lake area. The occurrence of distal exposures of the Mamaku Ignimbrite in the Mokai area, north of Lake Taupo, suggests that the area southwest of Lake Rotorua represented a topographic lowland at the time of the $0.23 \mathrm{Ma}$ eruption (Chapter 6). On a broader scale, the area to the west of Lake Rotorua and the Kaimai Range was a topographic depression, being the southernmost extension of the Hauraki Rift (Hochstein and Ballance 1993). This may explain the asymmetric distribution of the Mamaku Ignimbrite, infilling the lowland.

\subsubsection{Source of the Whakamaru ignimbrite}

Compared to the Mamaku Ignimbrite, a source for the Whakamaru group ignimbrites is less evident from field and geophysical data, due to a long period of disruption from later events. The Whakamaru group ignimbrites form two lobes radiating east and west from a source in the central TVZ. Magnetic fabric studies (see Chapter 5) in the western lobe define a flow pattern paralleling the existing Waikato River valley to the north, and to the south along the Hauhungaroa Range (Figure 7.5). Sample sites in the King Country north and west of the Hauhungaroa Range suggest ignimbrite flow originating from the vicinity of Mangakino and radiating toward the west. Fabric orientations of the more southerly sample sites, in the Manunui area $(40,41,113)$ are directed more southward, indicating the flow(s) may have become entrained and traveled along the Waimiha-Ongarue gorge. This flow pattern has two 


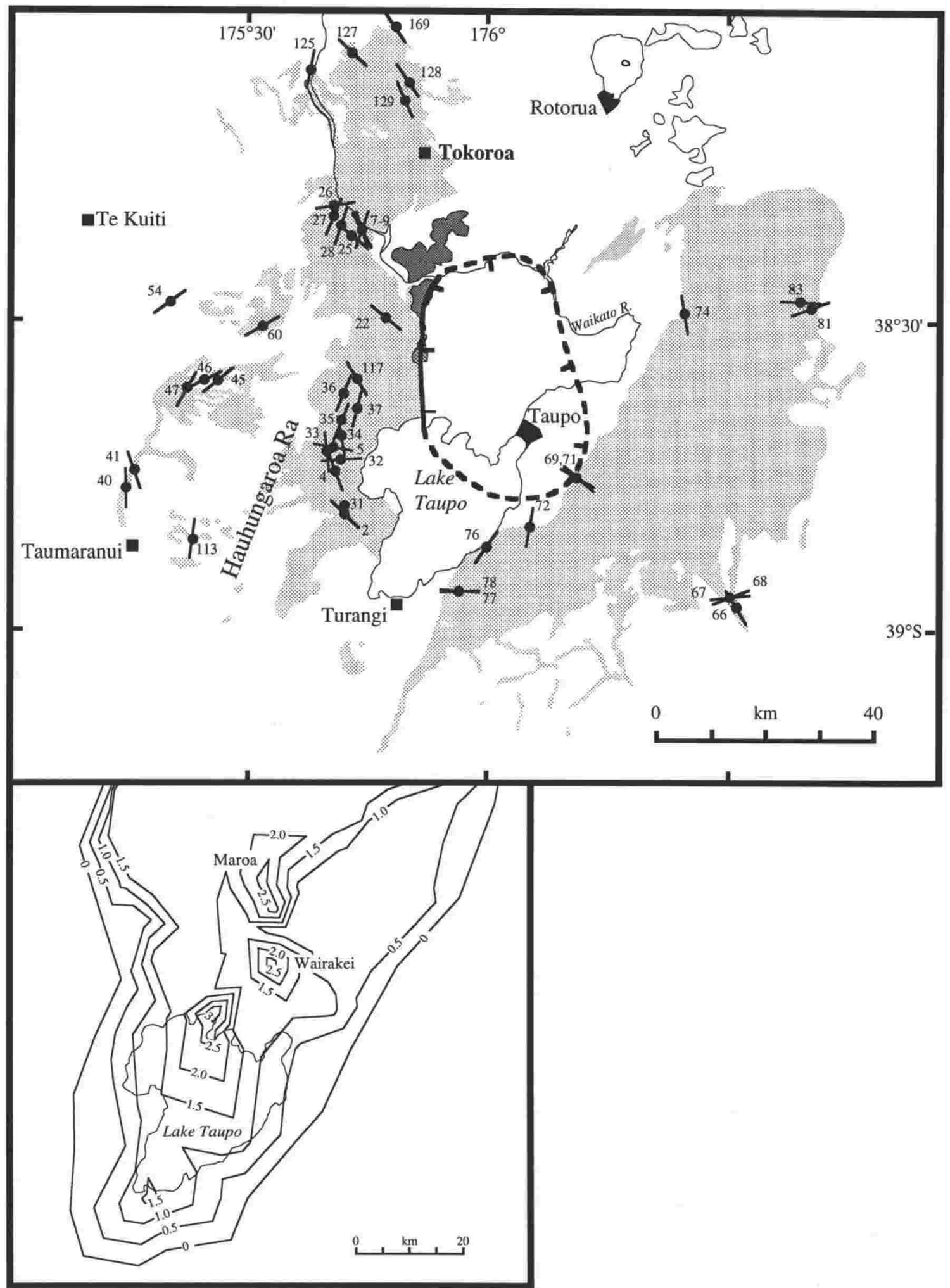

Figure 7.5 Mean azimuth of AMS data, inferred to parallel paleoflow direction (data from Table 5.1) for sites of the Whakamaru group ignimbrites. Shaded area represents the extent of the ignimbrite, inferred caldera outline is from Wilson et al. (1986). Dark shaded area shows the location of the Western Dome Belt (Houghton et al. 1991). Lower map shows contours (in $\mathrm{km}$ ) of depth to basement from geophysical data (from Rogan 1982). Gravity lows associated with Mangakino and Reporoa calderas are omitted for clarity. 
implications: (1) Whakamaru ignimbrites appear to bifurcate, flowing around and along the Hauhungaroa Range, suggesting the range was sufficiently elevated to bar transport directly into the southern King Country; and (2) a source at the north end of the Hauhungaroa Range, in the vicinity of Mangakino and Whakamaru, is required to allow passage through the low lying area north of Titiraupenga and into the King Country. The overall flow pattern in this western area is not consistent with an eruptive source within the present Lake Taupo, suggested by Lamarche and Froggatt (1993). A source vent in the Whakamaru area may be related to the Western Dome Belt (Figure 7.5) and Wilson et al. (1986) indicate this structure may mark the western margin of the Whakamaru Caldera. K-Ar ages show that the dome belt brackets the eruption of the Whakamaru ignimbrite, representing both pre- and post-collapse extrusions (Houghton et al. 1991).

Little magnetic fabric data was collected in the eastern lobe of Whakamaru ignimbrites, however sites $66,69,71,72,76$, and 83 have AMS flow azimuths oriented away from a source north of Lake Taupo (Figure 7.5). Some sites within the ignimbrite (e.g. sites $67,68,77,78$ ) do not point towards a source as inferred above, and in some cases would not be consistent with a source within the TVZ. AMS data from these locations display clustered axis orientations and well developed flow lineations (see Chapter 5), hence these irregular directions do not result from a lack of fabric formation. Instead, they are likely to be due to the effects of paleorelief, which can be demonstrated at sites 67 and 68 near Waipunga Falls (Figure 7.5). There, the ignimbrite has flowed up against a slope of $20^{\circ}$ dip. Magnetic fabric data indicates a ENE-SSW flow azimuth, perpendicular to the expected flow direction from the Taupo region. However, this azimuth parallels the strike of the slope that the ignimbrite abuts, and indicates the topographic barrier deflected the flow. Further southeast at site 66 (Figure 7.5) the ignimbrite flowed into a narrow gorge and the flow fabric direction is parallel to the trend of the gorge. This demonstrates the strong effect of paleotopography on measured flow patterns, which is not always discernible in the field.

Wilson et al. (1986) suggested a source for Whakamaru group ignimbrites centred in the Wairakei area, on the basis of its central location, grain size characteristics and drill core data. This area also coincides with a $2.5 \mathrm{~km}$ depth to basement near Wairakei on the basis of geophysical data (Rogan 1982). However, unlike other calderas such as Okataina and Rotorua, no single large geophysical anomaly defines the whole inferred caldera area. As well as the basement low near Wairakei, another depression $(3 \mathrm{~km})$ is located on the northwest shore of Lake Taupo. The $2.5 \mathrm{~km}$ low associated with the Maroa Caldera (Wilson et al. 1984) also occurs within the inferred Whakamaru Caldera and may have originated before the formation of the Maroa centre. Soengkono (1990) suggests, on the basis of magnetic data, that a basement low occurs immediately east of the Western Dome Belt, an area where many of the AMS site azimuths point. 
In summary, it is inferred that the Whakamaru group originated from a caldera north of Lake Taupo. The western flows appear to radiate from near the site of the Western Dome Belt, the location of a possible vent source.

\subsection{STRATIGRAPHY AND CHRONOLOGY OF MAJOR TVZ IGNIMBRITES}

\subsubsection{Geochemistry of early Mangakino-derived ignimbrites}

Geochemical fingerprinting of glass in ignimbrites of the TVZ has been hindered by welding and vapour-phase alteration. This has prevented correlation both within the TVZ and to distal tephra beds. In this study, the nonwelded basal ash has been collected from ten major units (Ngaroma, Ongatiti, Unit D, Ahuroa, Rocky Hill, Whakamaru, Matahina, Kaingaroa, Downer 8 and Mamaku ignimbrites). In many cases, only one basal exposure has been found, hence correlation within the TVZ on the basis of geochemistry is still not possible at least for the older more dissected units. However, it is now possible to compare the geochemical signatures of these ten units to tephra beds outside the TVZ. Simple correlation to the distal setting is hindered by the large number of units found in the distal basins, compared to the number of events known in the TVZ. For example, at least 54 different eruptive events are recorded in the interval $2.0-0.6 \mathrm{Ma}$ in the East Coast region and Wanganui basin (P Shane, pers. comm. 1995). Not all of these tephra layers are chemically unique and many do not have a widespread distribution. Also, eruptions that produced welded ignimbrites may not be associated with distal tephra beds.

The oldest ignimbrite chemically fingerprinted is the Ngaroma Ignimbrite. This unit is not chemically similar to any of the widespread tephra layers found in the Wanganui basin or East Coast region (Shane 1993). It also appears to be compositionally variable, a feature not commonly observed in the distal tephra beds. Ongatiti Ignimbrite, dated at $1.21 \pm 0.04 \mathrm{Ma}$ (Houghton et al. 1995), is geochemically similar to a $4 \mathrm{~m}$ thick tephra bed occurring below the Jaramillo Subchron in fluvial sediments of the Mangatarata Formation, in the Dannevirke region. This tephra bed has been dated by single crystal laser-fusion ${ }^{40} \mathrm{Ar} /{ }^{39} \mathrm{Ar}$ at $1.24 \pm 0.07$ Ma (tephra 128, Shane 1993). The two units are chemically similar (SC $=0.94$ ) on the basis of EMA data. If the distal tephra bed is not the same eruption that produced the welded Ongatiti Ignimbrite, it is likely to be part of the same eruptive phase.

Glass shards in Unit D display a range in glass composition $\left(\mathrm{SiO}_{2}=75.21-78.02\right.$ wt.\%, Appendix 1) which fall predominantly into two groups. With an age of $1.20 \pm 0.04 \mathrm{Ma}$, Unit D does not match with any of the documented distal tephra beds as these are not chemically bimodal. As noted in Chapter 4, the basal ash of the Ahuroa Ignimbrite is chemically identical to Unit $\mathrm{D}$, hence the two units are probably derived from the same magma batch, consistent with their concordant ${ }^{40} \mathrm{Ar} /{ }^{39} \mathrm{Ar}$ ages. No significant hiatus between the two 


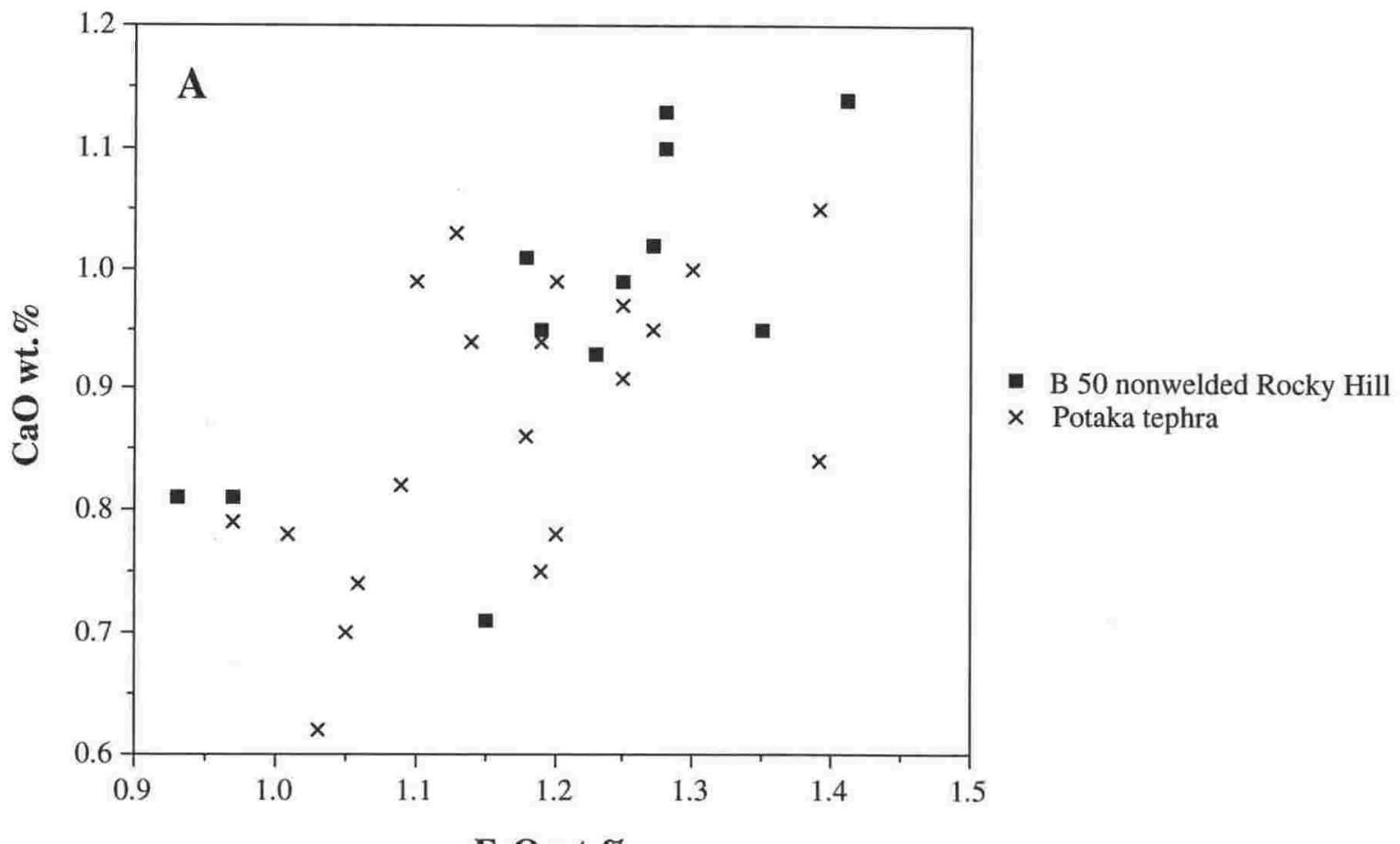

FeO wt.\%

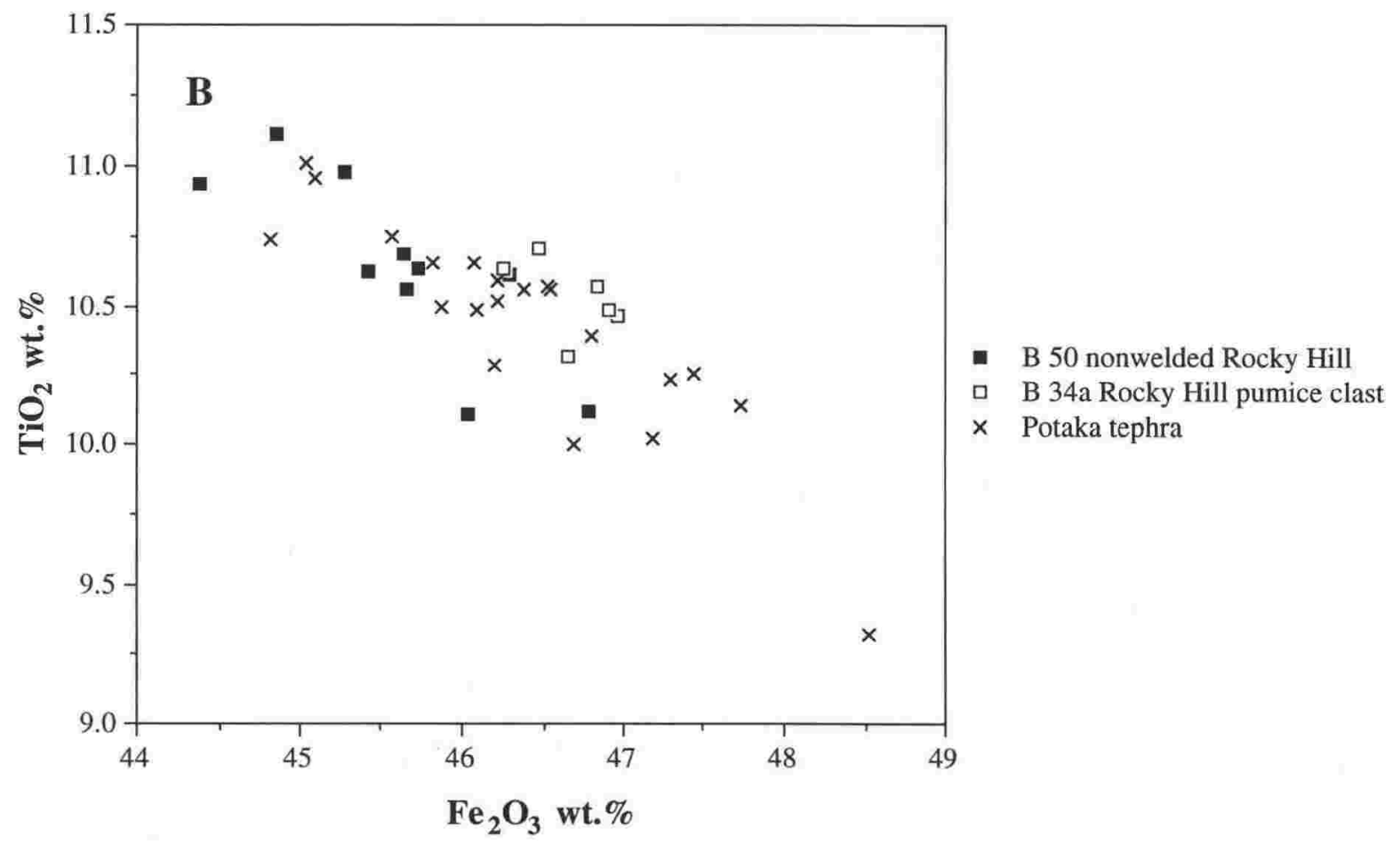

Figure 7.6 A EMA composition of glass shards from nonwelded Rocky Hill Ignimbrite, compared to those from Potaka ignimbrite exposed in Mangaonuku Sm in the Hawke's Bay region (data from Shane 1993).

B EMA composition of Fe-Ti oxides in nonwelded ignimbrite from the base of Rocky Hill Ignimbrite, and in a pumice clast from the welded flow unit. Comparison is made to Fe-Ti oxides from Potaka ignimbrite exposed at Cape Kidnappers (data from Shane 1993). 
units was seen in the field. Unit D is therefore interpreted as the early nonwelded flow phase of the eruption sequence that produced the predominantly welded Ahuroa Ignimbrite.

\subsubsection{Possible correlation of Rocky Hill Ignimbrite/Unit E to the Potaka tephra}

Ash collected from nonwelded ignimbrite at the base of the Rocky Hill Ignimbrite (sample B 50) is geochemically similar to the widespread Potaka tephra (1.0 Ma, Shane 1994). Both units display the same limited compositional range in glass chemistry (Figure 7.6) which is characteristic of the Potaka tephra. Shane (1994) did not consider the Potaka tephra to be a correlative of the Rocky Hill Ignimbrite because of a ${ }^{40} \mathrm{Ar} /{ }^{39} \mathrm{Ar}$ age of $0.95 \pm$ $0.03 \mathrm{Ma}$ reported by Pringle et al. (1992) for the latter. Subsequently, Houghton et al. (1995) has revised this age to $1.00 \pm 0.05 \mathrm{Ma}$ and report that the unit is of normal polarity. The Potaka tephra occurs at the top of the Jaramillo Subchron and contains large phenocrysts of hornblende and biotite, similar to the Rocky Hill Ignimbrite. At the type locality for Rocky Hill Ignimbrite (S16/117107) the welded flow unit consists of rotated blocks containing large pumice clasts, which have been geochemically altered (see Chapter 4). Immediately beneath these blocks is a $2-3 \mathrm{~m}$ thick nonwelded ignimbrite with fresh pumice clasts $(<1 \mathrm{~cm})$ and unaltered matrix glass (from which sample B 50 was taken). This unit is similar in lithology and geochemistry to Potaka tephra. Potaka tephra consists of a nonwelded ignimbrite in places and flowed up to $250 \mathrm{~km}$ from the western TVZ. The Fe-Ti oxides collected from pumices in the welded blocks of Rocky Hill Ignimbrite are compositionally homogeneous and identical to Fe-Ti oxides from the underlying nonwelded unit, suggesting they are magmatically related. These are also chemically similar to Fe-Ti oxides in Potaka tephra (Figure 7.6). Wilson (1986) describes a thin, nonwelded, biotite-bearing ignimbrite occurring stratigraphically below Rocky Hill Ignimbrite, and referred to it as Unit E. The glass sample collected in this study (B 50) could be classified as Unit E, which has been ${ }^{40} \mathrm{Ar} /{ }^{39} \mathrm{Ar}$ dated at $0.97 \pm 0.04 \mathrm{Ma}$ (Houghton et al. 1995), statistically identical to the age of Rocky Hill. Therefore, Unit E may represent the initial violent nonwelded phase of the Rocky Hill eruption sequence. On several lines of evidence, including mineralogical, geochemical, paleomagnetic and geochronological data, the Rocky Hill/Unit E eruptive phase appears to be related to the widespread Potaka tephra.

\subsubsection{Chronology of middle-late Pleistocene ignimbrites}

ITPFT ages determined on glass from nonwelded bases of middle-late Pleistocene ignimbrites in the TVZ reveal a new chronology, and suggest a major period of activity at 0.30 - 0.35 Ma with the eruptions of the widespread Whakamaru, Matahina and Kaingaroa ignimbrites. These new ages confirm that the earlier fission-track ages on glass and zircon 
were underestimates of the eruption age. This was due to partial track fading in glass (Chapter 6) and under-etching of zircon fission-tracks (Kohn et al. 1992). While the ITPFT ages for Whakamaru and Mamaku ignimbrites are in good agreement with recently published ${ }^{40} \mathrm{Ar} /{ }^{39} \mathrm{Ar}$ ages, the ITPFT ages for Matahina and Kaingaroa are statistically older (Table 7.1). Due to the lack of documentation of sampling sites and analytical data for the ${ }^{40} \mathrm{Ar} / 39 \mathrm{Ar}$ ages it is not possible to assess the discrepancy in the ages from the different techniques. As most of the recent chronological studies have shown the early fission-track ages are underestimates, it is surprising that the ${ }^{40} \mathrm{Ar} /{ }^{39} \mathrm{Ar}$ data for Matahina and Kaingaroa ignimbrites are concordant with these earlier ages. Note that most of the ${ }^{40} \mathrm{Ar} /{ }^{39} \mathrm{Ar}$ age data of Houghton et al. (1995) for TVZ eruptives are older than that indicated by earlier studies.

Table 7.1 Comparison of ${ }^{40} \mathrm{Ar} /{ }^{39} \mathrm{Ar}$ ages from Houghton et al. (1995) with ITPFT ages determined in this study.

\begin{tabular}{lcc}
\hline Ignimbrite & ${ }^{40} \mathrm{Ar} /{ }^{39} \mathrm{Ar}$ & ITPFT \\
\hline \hline Mamaku & $0.22 \pm 0.01$ & $0.23 \pm 0.01$ \\
Downer 8 & & $0.33 \pm 0.03$ \\
Kaingaroa & $0.23 \pm 0.01$ & $0.33 \pm 0.02$ \\
Matahina & $0.28 \pm 0.01$ & $0.34 \pm 0.02$ \\
Whakamaru & $0.34 \pm 0.01$ & $0.34 \pm 0.03$ \\
\hline
\end{tabular}

In this respect, the older ITPFT ages for these units were expected. As documented in Chapter 6, the ITPFT ages on Matahina and Kaingaroa ignimbrites have been duplicated by more than one operator, indicating no personal bias, and from two separate exposures of each unit. Geochemical data support the correlations between the sites dated, and allows Kaingaroa to be distinguished from Matahina. An interesting result is that each of the three widespread ignimbrites (Whakamaru, Matahina and Kaingaroa) as well as Downer 8 ignimbrite all have statistically identical eruption ages, although this does not imply simultaneous eruption, due to analytical uncertainty. The chronology is further complicated by the lack of well-documented sections containing two or more units.

However, the Matahina Ignimbrite overlies Whakamaru group ignimbrite at a section near Murupara (Chapter 2). At least 4 paleosols separate fallout units between these two ignimbrites. These paleosols would presumably have developed within 200 years of each eruption, on the basis of the rate of soil formation in the North Island. Well-developed paleosols occur between dated tephra beds from Taupo volcano, which have been erupted within 200 - 300 years of each other (Froggatt and Lowe 1990). Although the actual time required to form all of the paleosols is uncertain, the error range in the ITPFT ages would be sufficient. Glass geochemical data suggests the paleosols may have developed rapidly as the fallout units are chemically similar, and similar to the overlying Matahina Ignimbrite (Chapter 4). Consequently, they may all be part of the same eruptive sequence or derived from the same magma chamber. Some of the fallout beds display $\mathrm{Na}_{2} \mathrm{O} / \mathrm{K}_{2} \mathrm{O}<1$ which is characteristic 
of the underlying Whakamaru ignimbrite and may suggest a common magmatic origin. By analogy, this sequence may be similar to the eruptive record of Taupo volcano during the last ca. $22 \mathrm{ka}$. In this sequence, chemically similar tephra beds are separated by well developed paleosols, representing different eruptive events from the same magma chamber (Froggatt 1982; Stokes et al. 1992). Volcanoes of the TVZ appear to go through cycles of geochemically similar eruptives over periods of tens of thousands of years. This would support the eruption of Matahina Ignimbrite within 10 - 40 ka of Whakamaru group ignimbrites, as indicated by the analytical uncertainty of the ITPFT ages.

Most workers consider Kaingaroa ignimbrite to be stratigraphically younger than Matahina Ignimbrite (e.g. Bailey and Carr 1994) though sections containing both units are not well documented in the literature. Kaingaroa ignimbrite forms an elevated surface or plateau in the Rotorua-Murupara area, whereas Matahina has been more incised. One line of evidence that may support similar ages for Matahina and Kaingaroa ignimbrites is their nearly identical paleomagnetic remanence direction (Chapter 3). This direction is discordant with the remanence obtained from Whakamaru group ignimbrites, indicating their eruptions were not simultaneous with these older units. Measurable differences in paleomagnetic remanence directions can occur within 100 years (Champion and Donnelly-Nolan 1994). Hence, the nearly identical remanences imply either near-simultaneous eruption on the same secular variation loop, or a fortuitous return in secular variation over time.

The fourth similarly aged ignimbrite in the TVZ, according to ITPFT data is the Downer 8 unit $(0.33 \pm 0.03 \mathrm{Ma}$, Table 7.1$)$. This ignimbrite has not been previously documented in the literature. Downer 8 is the most chemically distinctive unit of the ones discussed here, and also dissimilar to the younger Mamaku Ignimbrite (Table 4.3).The age for Downer 8 is supported by its stratigraphic position above the Whakamaru Ignimbrite, and separation by a similar sequence of fallout tephra and paleosols (Chapter 2) as between Whakamaru and Matahina ignimbrites at the Murupara section. At the Downer Rd section, the Matahina Ignimbrite is absent, being replaced by Downer 8. Thus the ignimbrite stratigraphy of the Bay of Plenty area varies laterally.

The ITPFT data indicate a major phase of activity at ca. $0.33-0.35 \mathrm{Ma}$ with the eruption of several ignimbrites from different calderas including Whakamaru, Matahina (Haroharo), Kaingaroa (Reporoa) and Downer 8 (Kapenga?). The distal sedimentary record in the Wanganui basin also contains several widespread tephra beds in this time interval (Pillans 1988, 1994). The oldest unit is the Rangitawa tephra, previously also referred to as Mt Curl tephra (Froggatt et al. 1986; Kohn et al. 1992). These workers suggest a correlation with Whakamaru group ignimbrites on the basis of chronology and geochemistry. Above the Rangitawa tephra is the Fordell ash. Although not directly dated, its age is constrained by palynology, which suggests emplacement during O-isotope stage 9 (Bussell and Pillans 1992). Three other tephra beds are contained in the same loess/paleosol sequence: the Upper, Middle and Lower Griffin Rd tephra beds which all post-date Rangitawa tephra (Pillans 


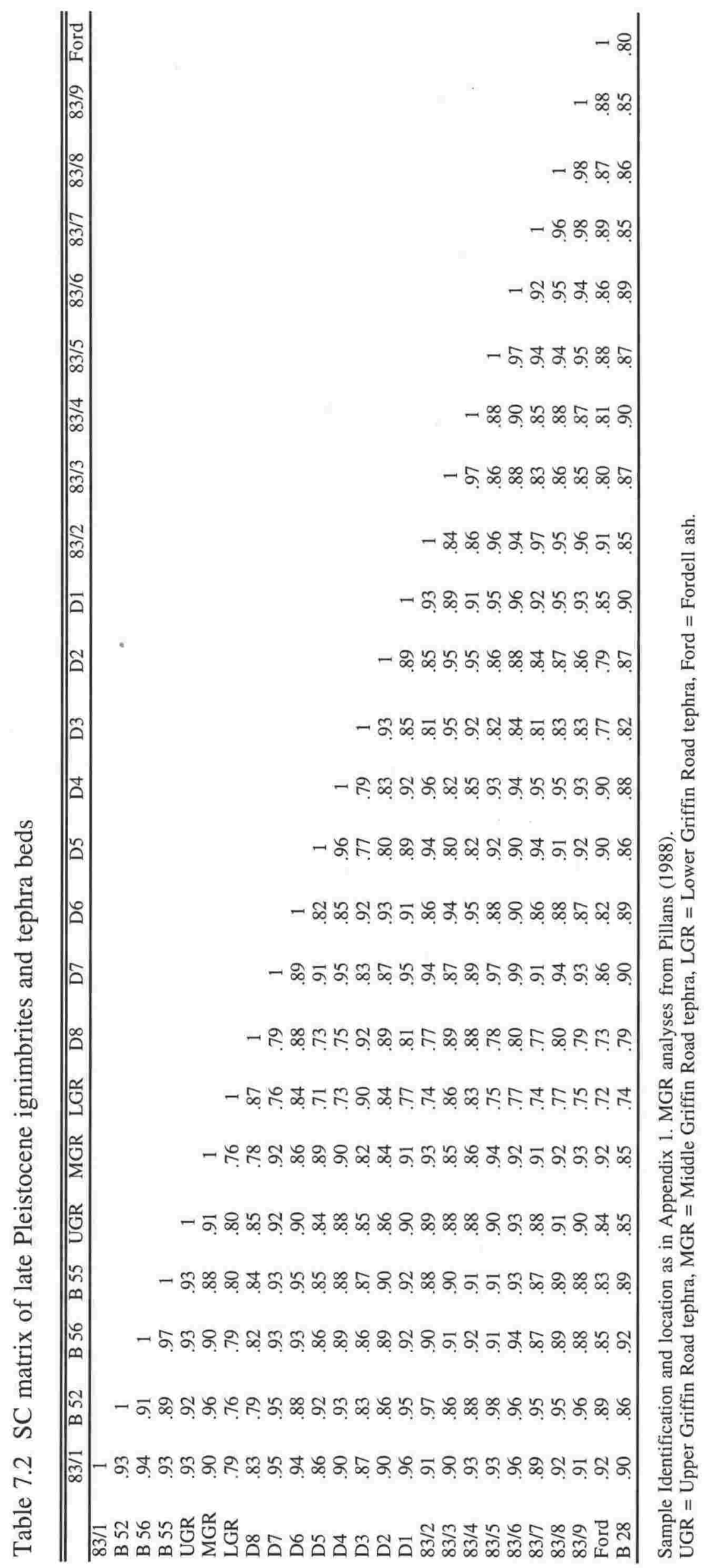


1994). These are constrained by a thermoluminescence age of $0.33 \pm 0.04 \mathrm{Ma}$ on loess underneath the Upper Griffin Rd tephra (Berger et al. 1992). Single shard glass chemistry of these distal tephra beds is presented in Appendix 1. The Upper Griffin Rd tephra bed is chemically similar to Matahina and Kaingaroa ignimbrites, as well as some of the fallout tephra beds in the Murupara and Downer Rd sections (SCs in the range 0.91-0.93, Table 7.2). The Middle Griffin Rd tephra is particularly similar to Matahina Ignimbrite as well as some of these fallout beds (Table 7.2). As several matches are possible on the basis of EMA data, it is not possible to precisely correlate one of the Griffin Rd beds to one of the proximal TVZ beds. However, the similarities in chemistry of these tephra beds provide support for a period of activity at ca. 0.30-0.35 Ma.

\subsection{MAGNETOSTRATIGRAPHY OF THE TVZ}

With the use of published geochronological data and ages determined here, along with paleomagnetic data and field stratigraphy, it is possible to construct a magnetostratigraphy for the TVZ (Figure 7.7). This stratigraphy is based on the emplacement of large rhyolitic ignimbrites and therefore is discontinuous in nature. Nevertheless it provides temporal and spatial constraints to the eruptive history of the TVZ.

The earliest large explosive eruptions from the TVZ were from the Mangakino area (Wilson 1986; Briggs et al. 1993). These voluminous units such as Ngaroma, Ongatiti and Marshall ignimbrites are reversed polarity and mainly confined to the King Country and Waikato region. Their reversed polarity is consistent with Matuyama Chron ages from ${ }^{40} \mathrm{Ar} /{ }^{39} \mathrm{Ar}$ and fission-track dating. Houghton et al. (1995) identified the Jaramillo Subchron from the normal polarity Rocky Hill Ignimbrite and Unit E, dated at $1.00 \pm 0.05$ and $0.97 \pm 0.04$ Ma. The Ahuroa Ignimbrite displays a transitional polarity and may record part of the Cobb Mountain Subchron.

Reversed polarity ignimbrites may underlie a large area of the TVZ, as a reversed polarity unit was collected near Murupara in the Ikawhenua Range, eastern Bay of Plenty (site 80, Table 3.1). This exposure was previously mapped as part of the Whakamaru group's Te Whaiti ignimbrite, but the reversed polarity indicates an older age. Matuyama Chron aged ignimbrites are also found in the Matahana Basin, and were most likely erupted from the Kapenga Caldera.

Brunhes Normal Chron ignimbrites are found throughout the TVZ. Few eruptions are recorded from the early Brunhes, however Houghton et al. (1995) record a few units in this time interval, located in the Matahana basin and Waiotapu areas. The major phase of activity commenced at ca. $350 \mathrm{ka}$ with eruptions from calderas located north of Lake Taupo and in eastern portions of the TVZ. The largest eruptive phase was the Whakamaru group ignimbrites. The new ITPFT ages suggest this nearly coincided with eruptions from Okataina and Reporoa calderas (Matahina and Kaingaroa ignimbrites). The last major sheet forming 


\begin{tabular}{|c|c|c|c|c|c|c|c|c|}
\hline & & & & $\mathrm{Ma}$ & & & & \\
\hline 0 & $\begin{array}{c}0.2 \\
1\end{array}$ & $\begin{array}{r}0.4 \\
\end{array}$ & $\begin{array}{c}0.6 \\
\end{array}$ & $\begin{array}{c}0.8 \\
1\end{array}$ & $\begin{array}{r}1.0 \\
\end{array}$ & 1.2 & 1.4 & 1.6 \\
\hline & \multicolumn{3}{|c|}{ BRUNHES } & \multicolumn{5}{|c|}{$\begin{array}{l}\text { MATUYAMA } \\
\text { o Cobb Mtn }\end{array}$} \\
\hline
\end{tabular}

|Oruanui
Mamaku
Kaingaroa
Matahina
Whakamaru

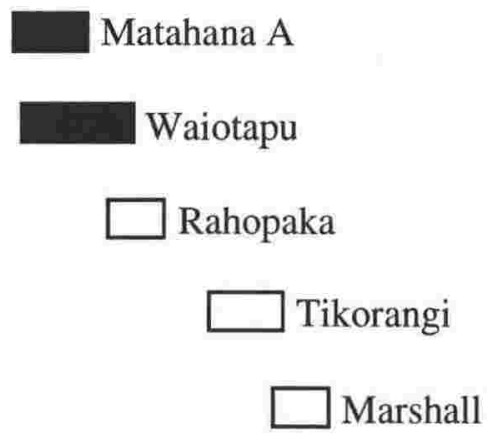

Normal polarity

Reversed polarity

Intermediate polarity
1. Ahuroa

Ongatiti

Ngaroma

Figure 7.7 Paleomagnetic polarities of major ignimbrite sheets in the TVZ, as determined in this study (Chapter 3), compared to their age determined by ${ }^{40} \mathrm{Ar}{ }^{\beta 9} \mathrm{Ar}$ (Houghton et al. 1995) and ITPFT data (Chapter 6). The length of the bar for each unit is representative of the associated age error. 
ignimbritic eruption was centred at a vent just west of Lake Rotorua and produced the Mamaku Plateau. This unit was emplaced during a short-lived excursion in Earth's magnetic field at ca. $230 \mathrm{ka}$.

\subsection{CONCLUSIONS}

1. Mamaku Ignimbrite records an excursion in Earth's magnetic field which occurred at ca. 0.23 Ma. A well documented excursion in the western US is also dated at this time and has been referred to as the Pringle Falls episode. This excursion is yet to be correlated to previously named events, but is an important marker in the Quaternary geomagnetic time scale.

2. AMS studies provide additional evidence for the source of Mamaku Ignimbrite in the Lake Rotorua area. The magnetic fabric data are consistent with a single source vent on the western margin of the present lake.

3. AMS studies of magnetic fabrics in the Whakamaru ignimbrites are consistent with a source north of Lake Taupo, and for the western exposures, a source near the Western Dome Belt. The source may not have been a single vent.

4. The Rocky Hill Ignimbrite and the underlying Unit E are geochemically similar to the widespread Potaka tephra found in distal basins of the southern North Island. The three units are dated at $1 \mathrm{Ma}$ and occur in the Jaramillo subchron. If they are correlatives, the extent of Rocky Hill Ignimbrite is greatly increased, and a direct tie line between the proximal and distal early Pleistocene sequences would be established.

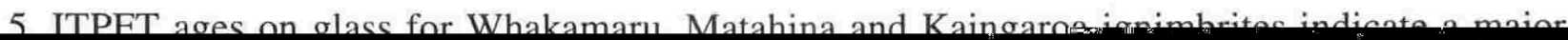

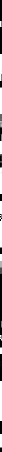




\subsection{FURTHER WORK}

Welded ignimbrites with high NRM intensity provide an opportunity to measure geomagnetic field paleointensities in New Zealand. In particular, the Ahuroa and Mamaku ignimbrites should be investigated as they were erupted during excursions or transitional polarities and may exhibit anomalously low paleointensities.

The paleomagnetic signature of rhyolite domes may be investigated as it could be possible to correlate them to ignimbrite flows if both were emplaced during a short period of time.

The ignimbrite magnetostratigraphy should be extended into the southern Coromandel region. The polarity of Coromandel eruptives would assist in providing temporal constraints on Neogene volcanism.

Further AMS work in the King Country and Waikato regions, focusing on the Rocky Hill Ignimbrite would help constrain vents in the Mangakino area and give more insight into the paleotopography of the area.

AMS studies on units exposed in the Kinleith Forest area (e.g. Waiotapu, Pokai ignimbrites) may be able to test the existence of the Kapenga Caldera.

Chemical fingerprinting of glass from nonwelded bases of ignimbrites and intervening tephra layers should be continued, in an attempt to correlate to the distal eruption record observed in sedimentary sequences.

Electron microprobe and LA-ICPMS investigations of mineral phases and glass inclusions within phenocrysts from welded ignimbrites may allow them to be chemically characterised where unaltered glass is not available.

Glass shards from nonwelded bases of ignimbrites is excellent material to date by the ITPFT method and should be continued, to corroborate existing age data from other methods, and extend New Zealand's Cenozoic eruptive history. 


\section{References}

Adams, C. J.; Graham, I. J.; Seward, D.; Skinner, D. N. B. 1994: Geochronology and geochemical evolution of late Cenozoic volcanism in the Coromandel Peninsula, New Zealand. New Zealand journal of geology and geophysics 37: 357-379.

Alloway, B. V.; Westgate, J. A.; Sandhu, A. S.; Bright, R. C. 1992: Isothermal plateau fissiontrack age and revised distribution of the widespread mid-Pleistocene Rockland tephra in west-central United States. Geophysical research letters 19: 569-572.

Alloway, B. V.; Pillans, B. J.; Sandhu, A. S.; Westgate, J. A. 1993: Revision of the marine chronology in the Wanganui Basin, New Zealand, based on the isothermal plateau fission-track dating of tephra horizons. Sedimentary geology 82: 299-310.

Anders, M.; Geissman, J. W.; Piety, L.; Sullivan, J. T. 1989: Parabolic distribution of circumeastern Snake River Plain seismicity and latest Quaternary faulting: migratory pattern and association with the Yellowstone hotspot. Journal of geophysical research 94: 1589-1621.

Bailey, R. A.; Carr, R. G. 1994: Physical geology and eruptive history of the Matahina Ignimbrite, Taupo Volcanic Zone, North Island, New Zealand. New Zealand journal of geology and geophysics 37: 319-344.

Baksi, A.; Houghton, B. F.; McWilliams, M.; Tanaka, H.; Turner, G. 1991: What is the age of the Brunhes-Matuyama polarity transition? EOS transactions, American Geophysical Union 72: 135.

Berger, G. W.; Pillans, B. J.; Palmer, A. S. 1992: Dating loess up to 800 ka by thermoluminescence. Geology 20: 403-406.

Bigazzi, G.; Marton, P.; Norelli, P.; Rozloznik, L. 1990: Fission track dating of Carpathian obsidians and provenance identification. Nuclear tracks and radiation measurements 17: 391-396.

Black, T. M. 1992: Chronology of the Middle Pleistocene Kidnappers Group, New Zealand and correlation to global oxygen isotope stratigraphy. Earth and planetary science letters 109: 573-584.

Blank, H. R. 1965: Ash-flow deposits of the central King Country, New Zealand. New Zealand journal of geology and geophysics 8: 588-607. 
Boellstorff, J. D.; Te Punga, M. T. 1977: Fission-Track ages and correlation of middle and lower Pleistocene sequences from Nebraska and New Zealand. New Zealand journal of geology and geophysics 20: 47-58.

Borchardt, G. A.; Havard, M. E.; Schmitt, R. A. 1971: Correlation of volcanic ash deposits by activation analysis of glass separates. Quaternary research 1: 247-260.

Briggs, N. D. 1976: Welding and crystallisation zonation in Whakamaru Ignimbrite, central North Island, New Zealand. New Zealand journal of geology and geophysics 19: 189212.

Briggs, N. D.; Westgate, J. A. 1978: A contribution to the Pleistocene geochronology of Alaska and Yukon Territory: fission-track age of distal tephra unit. U. S. Geological Survey open-file report 78-701: 49-52.

Briggs, R. M.; Gifford, M. G.; Moyle, A. R.; Taylor, S. R.; Norman, M. D.; Houghton, B. F.; Wilson, C. J. N. 1993: Geochemical zoning and eruptive mixing in ignimbrites from Mangakino volcano, Taupo Volcanic Zone, New Zealand. Journal of volcanology and geothermal research 56: 175-203.

Burchart, J.; Dakowski, M.; Galazaka, J. 1975: A technique to determine extremely high fission track densities. Bull. acad. polon. sci., sér. sci terre 23: 1-7.

Bussell, M. R.; Pillans, B. 1992: Vegetational and climatic history during oxygen isotope stage 9, Wanganui district, New Zealand, and correlation of Fordell ash. Journal of the Royal Society of New Zealand 22: 41-60.

Butler, R. F. 1992: Paleomagnetism: Magnetic Domains to Geologic Terranes. Boston, Blackwell Scientific Publications. 319 p.

Cañón-Tapia, E.; Walker, G. P. L.; Herrero-Bervera, E. 1995: Magnetic fabric and flow direction in basaltic Pahoehoe lava of Xitle Volcano, Mexico. Journal of volcanology and geothermal research 65: 249-263.

Carey, S. N.; Sigurdsson, H. 1978: Deep sea evidence for distribution of tephra from the mixed magma eruption of the soufriere on St. Vincent, 1902: ash turbidites and airfall. Geology 6: 271-274.

Carpenter, B. S.; Reimer, R. M. 1974: Standard reference materials: calibrated glass standards for fission track use. National Bureau of Standards special publication. 26049: 17. 
Carr, R. G. 1981: A scanning electron microscope study of post-depositional changes in the Matahina Ignimbrite, North Island, New Zealand. New Zealand journal of geology and geophysics 24: 429-434.

Carr, R. G. 1984: The Matahina Ignimbrite, its evolution including its eruption and postdepositional changes.Unpublished $\mathrm{PhD}$ thesis, lodged in the library, The University of Auckland.

Champion, D. E.; Donnelly-Nolan, J. M. 1994: Duration of eruption at the Giant Crater lava field, Medicine Lake volcano, California, based on paleomagnetic secular variation. Journal of geophysical research 99: 15 595-15 604.

Champion, D. E.; Lanphere, M. A.; Kuntz, M. A. 1988: Evidence for a new geomagnetic reversal from lava flows in Idaho: discussion of short polarity reversals in the Brunhes and late Matuyama Polarity Chrons. Journal of geophysical research 93: 11667-11680.

Chesner, C. A.; Rose, W.I.; Deino, A.; Drake, A. D. R.; Westgate, J. A. 1991: Eruptive history of Earth's largest Quaternary caldera (Toba, Indonesia) clarified. Geology 19: 200-203.

Christiansen, R. L.; Blank, H. R. 1972: Volcanic stratigraphy of the Quaternary rhyolite plateau in Yellowstone National Park. U. S. Geological Survey professional paper 729-B. $18 \mathrm{p}$.

Cole, J. W. 1979: Structure, petrology and genesis of Cenozoic volcanism, Taupo Volcanic Zone, New Zealand- a review. New Zealand journal of geology and geophysics 22: 631657.

Cole, J. W. 1990: Structural control and origin of volcanism in the Taupo volcanic zone, New Zealand. Bulletin of volcanology 52: 445-459.

Cox, A. 1969: A paleomagnetic study of secular variation in New Zealand. Earth and planetary science letters 6: 257-267.

Cox, A. 1971: Remanent magnetization and susceptibility of late Cenozoic rocks from New Zealand. New Zealand journal of geology and geophysics 14: 192-207.

Dumitru, T. A. in press: Fission-track geochronology. In: Quaternary Geochronology. Geological Society of America special paper.

Dunbar, N. W.; Kyle, P. R.; Wilson, C. J. N. 1989a: Evidence for limited zonation in silicic magma systems, Taupo Volcanic Zone, New Zealand. Geology 17: 234-236. 
Dunbar, N. W.; Hervig, R. L.; Kyle, P. R. 1989b: Determinations of pre-eruptive $\mathrm{H}_{2} \mathrm{O}$, F and $\mathrm{Cl}$ contents of silicic magmas using melt inclusions, examples from Taupo Volcanic Center, New Zealand. Bulletin of volcanology 51: 177-185.

Ellwood, B. B. 1982: Estimates of flow direction for calc-alkaline welded tuffs and paleomagnetic data reliability from anisotropy of magnetic susceptibility measurements: central San Juan Mountains, southwest Colorado. Earth and planetary science letters 59: 303-314.

Ellwood, B. B.; Hrouda, F.; Wagner, J. J. 1988: Symposia on magnetic fabrics: introductory comments. Physics of the earth and planetary interiors 51: 249-252.

Fleischer, R. L.; Price, P. B.; Walker, R. M. 1975: Nuclear tracks in Solids: Principles and Techniques. Berkeley, University of Caifornia Press. 605 p.

Fleming, C. A. ed. 1959: New Zealand. Lexique stratigraphique international 6 (4).

Fransen, P. J. B. 1982: Geology of the Western Mamaku Plateau and variations in the Mamaku Ignimbrite. Unpublished MSc thesis, lodged in the library, University of Waikato.

Froggatt, P. C. 1982: A study of some aspects of the volcanic history of the Lake Taupo area, North Island, New Zealand. Unpublished PhD thesis, lodged in the library, Victoria University of Wellington.

Froggatt, P. C. 1983: Toward a comprehensive Upper Quaternary tephra and ignimbrite stratigraphy of New Zealand using electron microprobe analysis of glass shards. Quaternary research 19: 188-200.

Froggatt, P. C. 1988: Paleomagnetism of Last Glacial loess from two sections in New Zealand. In: Eden, D. N.; Furkert, R. J. ed. Loess: its distribution, geology and soils. Rotterdam, Balkema. Pp. 59-68.

Froggatt, P. C. 1992: Standardization of the chemical analysis of tephra deposits. Report of the ICCT working group. Quaternary international 13/14: 93-96.

Froggatt, P. C.; Lowe, D. J. 1990: A review of late Quaternary silicic and some other tephra formations from New Zealand: their stratigraphy, nomenclature, distribution, volume and age. New Zealand journal of geology and geophysics 33: 89-109.

Froggatt, P. C.; Wilson, C. J. N.; Walker, G. P. L. 1981: Orientation of logs in the Taupo Ignimbrite as an indicator of flow direction and vent position. Geology 9: 109-111. 
Froggatt, P. C.; Nelson, C. S.; Carter, L.; Griggs, G.; Black, K. P. 1986: An exceptionally large late Quaternary eruption from New Zealand. Nature 319: 578-582.

Grindley, G. W. 1960: Sheet 8 - Taupo. Geologic map of New Zealand 1:250 000. Wellington, New Zealand Geological Survey, Department of Scientific and Industrial Research, Wellington.

Hagstrum, J. T.; Champion, D. E. 1994: Paleomagnetic correlation of Late Quaternary lava flows in the lower east rift zone of Kilauea Volcano, Hawaii. Journal of geophysical research 99: 21 679-21 690.

Hanna, G. C.; Westcott, C. H.; Lemmel, H. D.; Leonard, B. R.; Story, J. S.; Attree, P. M. 1969: Revision of values for the $2200 \mathrm{~m} / \mathrm{s}$ neutron constants for four fissile nuclides. Atomic energy review 7/4: 3-92.

Hatherton, T. 1954: The magnetic properties of the Whakamaru ignimbrites. New Zealand journal of science and technology 35: 421-432.

Healy, J. 1962: Structure and volcanism in the Taupo Volcanic Zone, New Zealand. In: MacDonald, G. A.; Kuno, H. ed. The Crust of the Pacific Basin. Geophysical monograph series 6. Washington DC, American Geophysical Union. Pp. 151-157.

Healy, J. 1964: Volcanic mechanisms in the Taupo Volcanic Zone, New Zealand. New Zealand journal of geology and geophysics 7: 6-23.

Healy, J.; Schofield, J. C.; Thompson, B. N. 1964: Sheet 5 - Rotorua. Geologic map of New Zealand 1:250 000. Wellington, New Zealand Geological Survey, Department of Scientific and Industrial Research, Wellington.

Herrero-Bervera, E.; Helsley, C. E.; Sarna-Wojcicki, A. M.; Lajoie, K. R.; Meyer, C. E.; McWilliams, M. O.; Negrini, R. M.; Turrin, B. D.; Donnelly-Nolan, J. M.; Liddicoat, J. C. 1994: Age and correlation of a paleomagnetic episode in the western United States by ${ }^{40} \mathrm{Ar} /{ }^{39} \mathrm{Ar}$ dating and tephrochronology: the Jamaica, Blake, or a new polarity episode? Journal of geophysical research 99: 24 091-24 103.

Hildreth, W. 1981: Gradients in silicic magma chambers: Implications for lithospheric magmatism. Journal of geophysical research 86:10153-10192.

Hildreth, W.; Mahood, G. 1985: Correlation of ash-flow tuffs. Geological Society of America bulletin 96: 968-974. 
Hillhouse, J. W.; Wells, R. E. 1991: Magnetic Fabric, Flow Directions, and Source Area of the Lower Miocene Peach Springs Tuff in Arizona, California and Nevada. Journal of geophysical research 96: 12 443-12 460.

Hochstein, M. P.; Ballance, P. F. 1993: Hauraki Rift: A Young, Active, Intra-Continental Rift in a Back-Arc Setting. In: Ballance, P. F. ed. South Pacific Sedimentary Basins. Amsterdam, Elsevier Science Publishers. Pp. 295-305.

Houghton, B. F.; Wilson, C. J. N.; Stern, T. A. 1987: Ignimbrite stratigraphy of a $457 \mathrm{~m}$ deep drillhole near Tokoroa. New Zealand Geological Survey record 20: 51-55.

Houghton, B. F.; Lloyd, E. F.; Wilson, C. J. N.; Lanphere, M. A. 1991: K-Ar ages from the Western Dome Belt and associated rhyolitic lavas in the Maroa-Taupo area, Taupo Volcanic Zone, New Zealand. New Zealand journal of geology and geophysics 34: 99101.

Houghton, B. F.; Wilson, C. J. N.; McWilliams, M. D.; Lanphere, M. A.; Weaver, S. D.; Briggs, R. M.; Pringle, M. S. 1995: Chronology and dynamics of a large silicic magmatic system: Central Taupo Volcanic Zone, New Zealand. Geology 23: 13-16.

Jackson, M.; Tauxe, L. 1991: Anisotropy of Magnetic Susceptibility and Remanence: Developments in the Characterisation of Tectonic, Sedimentary and Igneous Fabric. Reviews of Geophysics, supplement: 371-376.

Jaffey, A. H.; Flynn, K. F.; Glendenin, L. E.; Bentley, W. C.; Essling, A. M. 1971: Precision measurements of half-lives and specific activities of ${ }^{235} \mathrm{U}$ and ${ }^{238} \mathrm{U}$. Physics review C4: 1889-1906.

Jelinek, V. 1978: Statistical processing of anisotropy of magnetic susceptibility measured on groups of specimens. Studia geophysica geodetica 22: 50-62.

Keall, J. M. 1988: Volcanology and ignimbrite stratigraphy along the Paeroa Fault, Taupo Volcanic Zone. Unpublished MSc thesis, lodged in the library, Victoria University of Wellington.

Kear, D. 1960: Sheet 4 - Hamilton. Geologic map of New Zealand 1:250 000. Wellington, New Zealand Geological Survey, Department of Scientific and Industrial Research, Wellington.

Knight, M. D.; Walker, G. P. L. 1988: Magma flow directions in dikes of the Koolau complex, Oahu, determined from magnetic fabric studies. Journal of geophysical research 93: 4301-4319. 
Knight, M. D.; Walker, G. P. L.; Ellwood, B. B.; Diehl, J. F. 1986: Stratigraphy, paleomagnetism, and magnetic fabric of the Toba Tuffs: constraints on the sources and eruptive styles. Journal of geophysical research 91: 10 355-10 382.

Kohn, B. P. 1970: Identification of New Zealand tephra layers by emission spectrographic analysis of their titanomagnetites. Lithos 3: 361-368.

Kohn, B. P. 1973: Some studies of New Zealand Quaternary pyroclastic rocks. Unpublished $\mathrm{PhD}$ thesis, lodged in the library, Victoria University of Wellington.

Kohn, B. P. 1979: Identification and significance of a late Pleistocene tephra in Canterbury District, South Island, New Zealand. Quaternary research 11: 78-92.

Kohn, B. P.; Pillans, B.; McGlone, M. S. 1992: Zircon fission track age for middle Pleistocene Rangitawa Tephra, New Zealand: stratigraphic and paleoclimatic significance. Paleogeography, paleoclimatology, paleoecology 95: 73-94.

Lamarche, G.; Froggatt, P. C. 1993: New eruptive vents for the Whakamru Ignimbrite (Taupo Volcanic Zone) identified from magnetic fabric study. New Zealand journal of geology and geophysics 36: 213-222.

Lowe, D. J. 1988: Stratigraphy, age, composition, and correlation of late Quaternary tephras interbedded with organic sediments in Waikato lakes, North Island, New Zealand. New Zealand journal of geology and geophysics 31: 125-165.

MacDonald, W. D.; Palmer, H. C. 1990: Flow directions in ash-flow tuffs: a comparison of geological and magnetic susceptibility measurements, Tshirege member (upper Bandelier Tuff), Valles caldera, New Mexico, USA. Bulletin of volcanology 53: 45-59.

Martin, R. C. 1961: Stratigraphy and structural outline of the Taupo Volcanic Zone. New Zealand journal of geology and geophysics 4: 449-478.

Miller, D. S.; Wagner, G. A. 1981: Fission-track ages applied to obsidian artifacts from South America using the plateau-annealing and the track size age-correction techniques. Nuclear tracks 5: 147-155.

Murphy, R. P.; Seward, D. 1981: Stratigraphy, lithology, paleomagnetism and fission track ages of some ignimbrite formations in the Matahana Basin, New Zealand. New Zealand journal of geology and geophysics 24: 325-331.

Naeser, C. W. 1967: The use of apatite and sphene for fission track age determinations. Geological Society of America bulletin 78: 1523-1526.

Naeser, C. W. 1976: Fission track dating. U. S. Geological Survey open-file report 65: 76-190. 
Naeser, C. W.; Izett, G. A.; Obradovich, J. D. 1980: Fission-track and K-Ar ages of natural glasses. U. S. Geological Survey bulletin 1489.

Naeser, C. W.; Naeser, N. D. 1984: Fission-track dating. In. Mahaney, W. C. ed. Quaternary Dating Methods. New York, Elsevier. Pp. 87-100.

Naeser, C. W.; Naeser, N. D. 1988: Fission-track dating of Quaternary events. Geological Society of America special paper 227: 1-11.

Naeser, N. D.; Westgate, J. A.; Hughes, O. L.; Péwé, T. L. 1982: Fission-track ages of late Cenozoic distal tephra beds in the Yukon Territory and Alaska. Canadian journal of earth sciences 19: 2167-2178.

Nairn, I. A. 1973: Geology of the Waimangu Geothermal Mapping Project Area, Central Volcanic Region, New Zealand. Unpublished open file report. New Zealand Geological Survey, Rotorua.

Nairn, I. A. 1989: Sheet V16AC - Mount Tarawera. Geological Map of New Zealand 1:50 000. Department of Scientific and Industrial Research, Wellington.

Nairn, I. A. in press: Geology of the Okataina Volcanic Centre. Institute of Geological and Nuclear Sciences bulletin.

Nairn, I. A.; Beanland, S. 1989: Geological setting of the 1987 Edgecumbe earthquake, New Zealand. New Zealand journal of geology and geophysics 32: 1-13.

Nairn, I. A.; Wood, C. P.; Bailey, R. A. 1994: The Reporoa Caldera, Taupo Volcanic Zone: source of the Kaingaroa Ignimbrites. Bulletin of volcanology 56: 529-537.

Negrini, R. M.; Erbes, D. B.; Roberts, A. P.; Verosub, K. L.; Sarna-Wojcicki, A. M.; Meyer, C. E. 1994: Repeating Waveform Initiated by a 180-190 ka Geomagnetic Excursion in Western North America: Implications for Field Behaviour during Polarity Transitions and Subsequent Secular Variation. Journal of geophysical research 99: 24 105-24 120.

Nelson, C. S.; Froggatt, P. C.; Gosson, G. J. 1986: Nature, chemistry and origin of late Cenozoic megascopic tephras in Leg 90 cores from the southwest Pacific. In: Kennett, J. P. et al., ed. Initial Reports of the Deep Sea Drilling Project 90, Washington, United States Government Printing Office. Pp 1161-1173.

Northey, D. J. 1982: Seismic studies of the structure beneath Lake Taupo. Unpublished PhD thesis, lodged in the library, Victoria University of Wellington. 
Palmer, K. 1990: XRF analyses of granitoids and associated rocks, St. Johns Range, South Victoria Land, Antarctica. Research School of Earth Sciences geology board of studies publication 5, Victoria University of Wellington. 23 p.

Pillans, B. 1988: Loess chronology in Wanganui Basin, New Zealand. In: Eden, D. N.; Furkert, R. J. ed. Loess: its distribution, geology and soils. Rotterdam, Balkema. Pp. 5968.

Pillans, B. 1994: Direct marine-terrestrial correlations, Wanganui Basin, New Zealand: the last 1 million years. Quaternary science reviews 12: 189-200.

Pillans, B.; Wright, I. 1990: 500,000 yr paleomagnetic record from New Zealand loess. Quaternary research 33: 178-187.

Pillans, B. J.; Roberts, A. P.; Wilson, G. S.; Abbott, S. T.; Alloway, B. V. 1994: Magnetostratigraphic, lithostratigraphic and tephrostratigraphic constraints on Lower and Middle Pleistocene sea-level changes, Wanganui Basin, New Zealand. Earth and planetary science letters 121: 81-98.

Price, P. B.; Walker, R. M. 1963: Fossil tracks of charged particles in mica and the age of minerals. Journal of geophysical research 68: 4847-4862.

Pringle, M. S.; McWilliams, M.; Houghton, B. F.; Lanphere, M. A.; and Wilson, C. J. N. 1992: ${ }^{40} \mathrm{Ar} /{ }^{39} \mathrm{Ar}$ dating of Quaternary feldspar: examples from the Taupo Volcanic Zone, New Zealand. Geology 20: 531-534.

Roberts, J. H.; Gold, R. Armani, R. J. 1968: Spontaneous fission decay-constant of $238 \mathrm{U}$. Physics review 174: 1482-1484.

Rogan, A. M. 1982: A geophysical study of the Taupo Volcanic Zone, New Zealand. Journal of geophysical research 87: 4073-4088.

Sandhu, A. S.; Westgate, J. A.; Alloway, B. V. 1993: Optimizing the isothermal plateau fission-track dating method for volcanic glass shards. Nuclear tracks and radiation measurements 21: 479-488.

Sandhu, A. S.; Westgate, J. A. 1995: The correlation between reduction in fission-track diameter and areal track density in volcanic glass shards and is application in dating tephra beds. Earth and planetary science letters 131: 289-299.

Sarna-Wojcicki, A. M.; Davis, J. O. 1991: Quaternary tephrochronology. In: Morrison, R. B. ed. The Geology of North America, vol. K-2, Quaternary Nonglacial Geology: Conterminous US. Boulder, Colorado, Geological Society of America. Pp. 93-116. 
Sarna-Wojcicki, A. M.; Morrison, S. D.; Meyer, C. E.; Hillhouse, J. W. 1987: Correlations of Upper Cenozoic tephra layers between sediments of the Western United States and Eastern Pacific Ocean and comparison with biostratigraphic and magnetostratigraphic age data. Geological Society of America bulletin 98: 207-223.

Scott, K. B. 1971: Alkali exchange during devitrification and hydration of glasses in ignimbrite cooling units. Journal of geology 79: 100-110.

Seaman, S. J.; Williams, M. L. 1992: Center-to -center analysis and flow fabric characterization in ash-flow tuffs. Bulletin of volcanology 54: 319-328.

Seaman, S. J.; McIntosh, W. C.; Geissman, J. W.; Williams, M. L.; Elston, W. E. 1991: Magnetic fabrics of the Bloodgood Canyon and Shelley Peak Tuffs, southwestern New Mexico: implications for emplacement and alteration processes. Bulletin of volcanology 53: $460-476$.

Seward, D. 1974: Age of New Zealand Pleistocene substages by fission track dating of glass shards from tephra horizons. Earth and planetary science letters 24: 242-248.

Seward, D. 1975: Fission-track ages of some tephras from Cape Kidnappers, Hawke's Bay, New Zealand. New Zealand journal of geology and geophysics 18: 507-510.

Seward, D. 1976: Tephrostratigraphy of the marine sediments in Wanganui Basin, North Island, New Zealand. New Zealand journal of geology and geophysics 19: 9-20.

Seward, D. 1979: Comparison of zircon and glass fission track ages from tephra horizons. Geology 7: 470-482.

Shackleton, N. J.; Berger, A.; Peltier, W. R. 1990: An alternative astronomical calibration of the lower Pleistocene timescale based on ODP site 677. Transactions of the Royal Society of Edinburgh: earth sciences 81: 251-261.

Shane, P. A. R. 1991: Remobilised silicic tuffs in middle Pleistocene fluvial sediments, southern North Island, New Zealand. New Zealand journal of geology and geophysics 34: 489-499.

Shane, P. A. R. 1993: Tephrostratigraphy, magnetostratigraphy and geochronology of some early and middle Pleistocene deposits in New Zealand. Unpublished PhD thesis, lodged in the library, Victoria University of Wellington.

Shane, P. A. R. 1994: A widespread, early Pleistocene tephra (Potaka tephra, 1 Ma) in New Zealand: character, distribution, and implications. New Zealand journal of geology and geophysics 37: 25-35. 
Shane, P. A. R.; Froggatt, P. C. 1991: Glass chemistry, paleomagnetism, and correlation of middle Pleistocene tuffs in southern North Island, New Zealand, and western Pacific.New Zealand journal of geology and geophysics 34 : 203-211.

Shane, P. A. R.; Froggatt, P. C. 1992: Composition of widespread volcanic glass in deep-sea sediments of southern Pacific Ocean: an Antarctic source inferred: Bulletin of volcanology 54: 595-601.

Shane, P. A. R.; Froggatt, P. C. 1994: Discriminant function analysis of glass chemistry of New Zealand and North American tephra deposits. Quaternary research 41: 70-81.

Shane, P.; Black, T; Westgate, J. 1994: Isothermal plateau fission-track age for a paleomagnetic excursion in the Mamaku Ignimbrite, New Zealand, and implications for late Quaternary stratigraphy. Geophysical research letters 21: 1695-1698.

Shane, P.; Froggatt, P.; Black, T.; Westgate, J. 1995: Chronology of Pliocene and Quaternary bioevents and climatic events from fission-track ages on tephra beds, Wairarapa, New Zealand. Earth and planetary science letters 130: 141-154.

Shibuya, H.; Cassidy, J.; Smith, I. E. M.; Itaya,T. 1992: A geomagnetic excursion in the Brunhes epoch recorded in New Zealand. Earth and planetary science letters 111: 4148.

Skinner, D. N. 1986: Neogene volcanism in the Hauraki Volcanic region. Royal Society of New Zealand bulletin 23: 21-47.

Soengkono, S. 1990: Geophysical study of the western Taupo Volcanic Zone. Unpublished $\mathrm{PhD}$ thesis, lodged in the library, The University of Auckland.

Soengkono, S.; Hochstein, M. P.; Smith, I. E. M.; Itaya, T. 1992: Geophysical evidence for widespread reversely magnetised pyroclastics in the western Taupo Volcanic Zone (New Zealand). New Zealand journal of geology and geophysics 35: 47-55.

Staudacher, T. H.; Jessberger, E. K.; Dominik, B.; Kirsten, T.; Schaeffer, O. A. 1982: ${ }^{40}$ Ar/ $/{ }^{39} \mathrm{Ar}$ ages of rocks and glasses from the Nördlinger Ries Crater and temperature history of impact breccia. Journal of geophysical research 51: 1-11.

Stern, T. A. 1986: Geophysical studies of the upper crust within the Central Volcanic Region, New Zealand. In: Smith, I. E. M. ed. Late Cenozoic volcanism in New Zealand. Royal Society of New Zealand bulletin 23: 93-111. 
Stokes, S.; Lowe, D. J.; Froggatt, P. C. 1992: Discriminant function analysis and correlation of late Quaternary tephra deposits from Taupo and Okataina volcanoes, New Zealand, using glass shard major element compositions. Quaternary international 13/14: 103-120.

Storzer, D.; Wagner, G. A. 1969: Correction of thermally lowered fission track ages of tektites. Earth and planetary science letters 5: 463-468.

Storzer, D.; Poupeau, G. 1973: Ages-plateaux de minereaux et verres par la methods des traces de fission. Comptes rendus de l'academie des sciences, Paris 276: 137-139.

Stupavsky, M. 1985: SI-2 magnetic susceptibility and anisotropy instrument operating manual and handbook. Ruthven, Ontario, Sapphire Instruments. 130 p.

Tanaka, H.; Houghton, B. F.; Turner, G. M. 1991: Magnetostratigraphy and Revised Chronology of Volcanism From the Taupo Volcanic Zone, New Zealand. EOS transactions, American Geophysical Union 72: 135.

Valet, J.; Meynadier, L. 1993: Geomagnetic field intensity and reversals during the past four million years. Nature 366: 234-238.

Verosub, K. L. 1994: What in the World is a Geomagnetic Excursion? EOS transactions, American Geophysical Union 75: 190.

Van den Haute, P. 1985: The density and the diameter of fission tracks in glass with respect to age interpretation. Nuclear tracks 10: 335-348.

Vucetich, G. G.; Pullar, W. A. 1969: Stratigraphy and chronology of Late Pleistocene volcanic ash beds in central North Island, New Zealand. New Zealand journal of geology and geophysics 12: 784-837.

Wagner, G. A. 1979: Correction and interpretation of fission-track ages. In: Jäger, E.; Hunziker, J. C. ed. Lectures in isotope geology. Berlin, Springer. Pp. 170-177.

Wagner, G. A.; van den Haute, P. 1992: Fission-track dating. Boston, Kluwer Academic. 285 p.

Walker, G. P. L. 1984: Downsag calderas, ring faults, caldera sizes, and incremental caldera growth. Journal of geophysical research 89: 8407-8416.

Westgate, J. A. 1988: Isothermal plateau fission track age of the late Pleistocene Old Crow tephra, Alaska. Geophysical research letters 15: 376-379.

Westgate, J. A. 1989: Isothermal plateau fission-track ages of hydrated glass shards from silicic tephra beds. Earth and planetary science letters 95: 226-234. 
Westgate, J. A.; Christiansen, E. A.; Boellstorff, J. D. 1977: Wascana Creek Ash (middle Pleistocene) in southern Saskatchewan: characterisation, source, fission track age, paleomagnetism and stratigraphic significance. Canadian journal of earth sciences 14: 357-374.

Westgate, J. A.; Easterbrook, D. J.; Naeser, N. D.; Carson, R. J. 1987: Lake Tapps tephra: an early Pleistocene stratigraphic marker in the Puget Lowland, Washington. Quaternary research 28: 340-355.

Westgate, J. A.; Stemper, B. A.; Péwé, T. L. 1990: A 3 m.y. record of Pliocene-Pleistocene loess in interior Alaska. Geology 18: 858-861.

Wilson, C. J. N. 1986: Reconnaissance stratigraphy and volcanology of ignimbrites from Mangakino Volcano. In: Smith, I. E. M. ed. Late Cenozoic volcanism in New Zealand. Royal Society of New Zealand bulletin 23: 179-193.

Wilson, C. J. N. 1991: Ignimbrite morphology and the effects of erosion: a New Zealand case study. Bulletin of volcanology 53: 635-644.

Wilson, C. J. N. 1993: Stratigraphy, chronology, styles and dynamics of late Quaternary eruptions from Taupo volcano, New Zealand. Philosophical transactions of the Royal Society, London A343: 205-306.

Wilson, C. J. N.; Rogan, A. M.; Smith, I. E.; Northey, D. J.; Nairn, I. A.; Houghton, B. F. 1984: Caldera volcanoes of the Taupo Volcanic Zone, New Zealand. Journal of geophysical research 89: 8463-8484.

Wilson, C. J. N.; Houghton, B. F.; Lloyd, E. F. 1986: Volcanic history and evolution of the Maroa-Taupo area, central North Island. In: Smith, I. E. M. ed. Late Cenozoic volcanism in New Zealand. Royal Society of New Zealand bulletin 23: 194-223.

Wilson, C. J. N.; Switsur, V. R.; Ward, A. P. 1988: A new ${ }^{14}$ C age for the Oruanui (Wairakei) eruption, New Zealand. Geological Magazine 125: 297-300.

Wilson, C. J. N.; Houghton, B. F.; Lanphere, M. A.; Weaver, S. D. 1992: A new radiometric age estimate for the Rotoehu Ash from Mayor Island volcano, New Zealand. New Zealand journal of geology and geophysics 35: 371-374.

Wolff, J. A.; Ellwood, B. B.; Sachs, S. D. 1989: Anisotropy of magnetic susceptibility in welded tuffs: application to a welded-tuff dyke in the Tertiary Trans-Pecos Texas volcanic province, USA. Bulletin of volcanology 51: 299-310. 


\section{Appendix 1}

\section{ELECTRON MICROPROBE ANALYSES OF GLASS SHARDS}

Tephra samples were crushed and wet sieved to obtain the $>60 \mu \mathrm{m}$ size traction. Glass in this fraction was purified with the use of a frantz magnetic separator, mounted in epoxy resin and polished. The shards were analysed with the use of a Jeol 733 Superprobe at Victoria University of Wellington. Operating conditions included a current of $8 \mathrm{nA}$ at $15 \mathrm{kV}$ and a $20 \mu \mathrm{m}$ beam diameter. Analytical methods and standards as in Shane and Froggatt (1992). Some analyses were performed on a CAMEBAX SX-50 microprobe at the University of Toronto, operating with $10 \mathrm{nA}$ current at $15 \mathrm{kV}$, scanning a $10 \mu \mathrm{m}$ area. Glass standards indicate no schematic differences in the two instruments. Individual analyses are recalculated to $100 \%$ on a volatile free basis. A mean and standard deviation is presented for each sample (bold). Total Fe expressed as FeO. Water by difference (also includes other volatiles and minor elements not analysed).

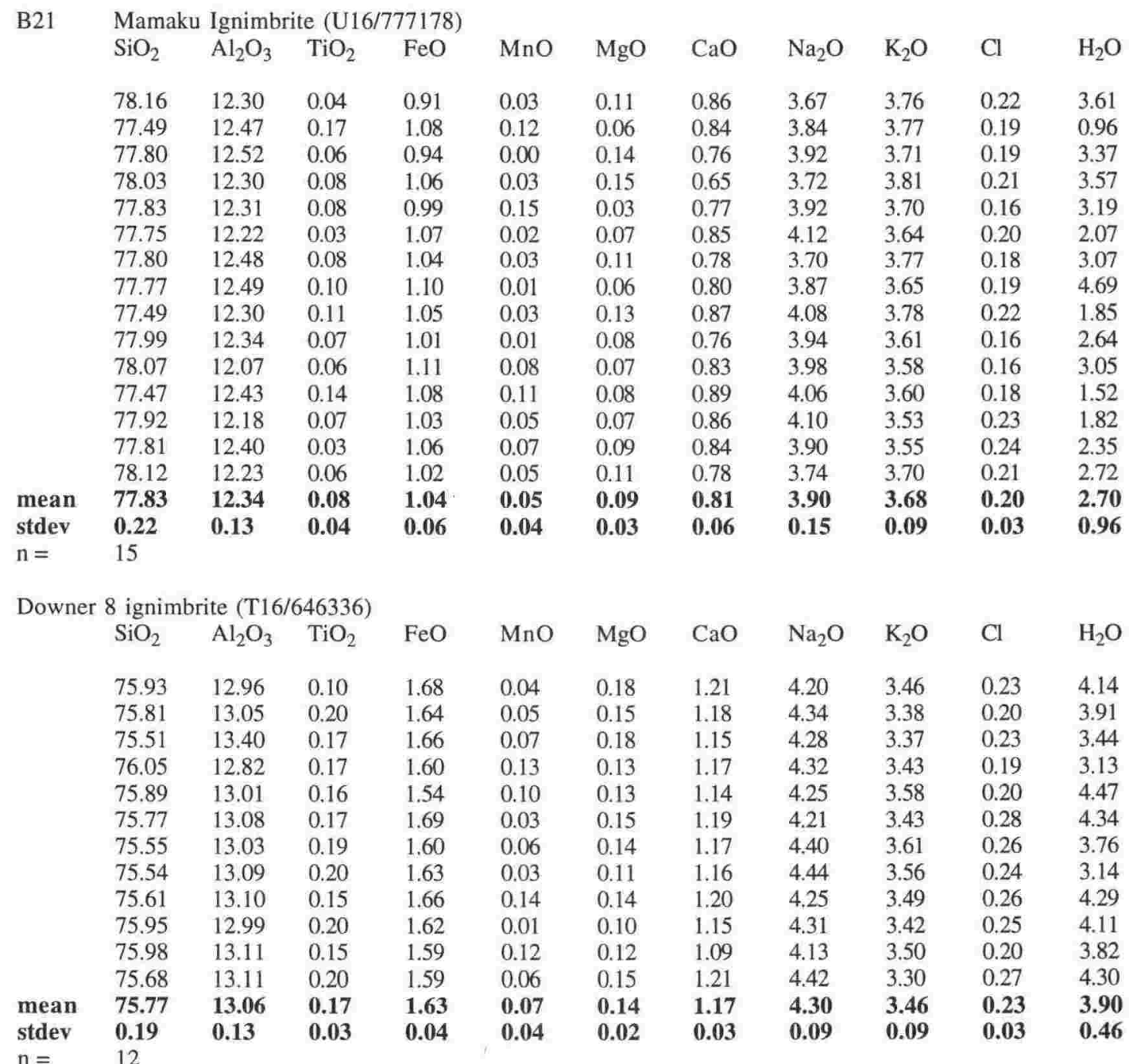


B 55 Kaingaroa ignimbrite (U16/086107)

\begin{tabular}{|c|c|c|c|c|c|c|c|c|c|c|c|}
\hline & $\mathrm{SiO}_{2}$ & $\mathrm{Al}_{2} \mathrm{O}_{3}$ & $\mathrm{TiO}_{2}$ & $\mathrm{FeO}$ & $\mathrm{MnO}$ & $\mathrm{MgO}$ & $\mathrm{CaO}$ & $\mathrm{Na}_{2} \mathrm{O}$ & $\mathrm{K}_{2} \mathrm{O}$ & $\mathrm{Cl}$ & $\mathrm{H}_{2} \mathrm{O}$ \\
\hline & 77.56 & 12.49 & 0.13 & 1.13 & 0.05 & 0.09 & 0.92 & 3.62 & 3.85 & 0.14 & 3.43 \\
\hline & 77.94 & 12.01 & 0.16 & 1.29 & 0.07 & 0.12 & 0.75 & 3.51 & 3.96 & 0.20 & 0.47 \\
\hline & 77.31 & 12.21 & 0.16 & 1.26 & 0.09 & 0.09 & 0.96 & 3.70 & 3.99 & 0.23 & 2.89 \\
\hline & 77.41 & 12.52 & 0.10 & 1.26 & 0.02 & 0.08 & 0.92 & 3.52 & 3.93 & 0.24 & 1.69 \\
\hline & 77.28 & 12.31 & 0.16 & 1.49 & 0.07 & 0.08 & 0.92 & 3.73 & 3.79 & 0.16 & 2.41 \\
\hline & 77.20 & 12.41 & 0.10 & 1.37 & 0.01 & 0.13 & 0.98 & 3.82 & 3.77 & 0.21 & 1.02 \\
\hline & 77.28 & 12.35 & 0.14 & 1.34 & 0.01 & 0.12 & 1.00 & 3.62 & 3.98 & 0.15 & 2.43 \\
\hline & 77.31 & 12.33 & 0.16 & 1.34 & 0.10 & 0.10 & 0.90 & 3.77 & 3.79 & 0.20 & 0.81 \\
\hline & 78.04 & 11.77 & 0.12 & 1.22 & 0.05 & 0.08 & 0.83 & 3.56 & 4.02 & 0.31 & 1.64 \\
\hline & 77.37 & 12.41 & 0.13 & 1.21 & 0.02 & 0.11 & 0.80 & 3.73 & 3.99 & 0.22 & 0.61 \\
\hline & 77.97 & 12.00 & 0.14 & 1.22 & 0.05 & 0.10 & 0.79 & 3.60 & 3.89 & 0.22 & 0.12 \\
\hline & 77.16 & 12.49 & 0.15 & 1.33 & 0.09 & 0.10 & 0.90 & 3.45 & 4.03 & 0.29 & 1.49 \\
\hline mean & 77.49 & 12.27 & 0.14 & 1.29 & 0.05 & 0.10 & 0.89 & 3.64 & 3.92 & 0.22 & 1.58 \\
\hline stdev & 0.32 & 0.23 & 0.02 & 0.09 & 0.03 & 0.02 & 0.08 & 0.11 & 0.09 & 0.05 & 1.04 \\
\hline $\mathrm{n}=$ & 12 & & & & & & & & & & \\
\hline \multirow[t]{13}{*}{ B56 } & \multicolumn{11}{|c|}{ Kaingaroa ignimbrite (V16/197112) } \\
\hline & $\mathrm{SiO}_{2}$ & $\mathrm{Al}_{2} \mathrm{O}_{3}$ & $\mathrm{TiO}_{2}$ & $\mathrm{FeO}$ & $\mathrm{MnO}$ & $\mathrm{MgO}$ & $\mathrm{CaO}$ & $\mathrm{Na}_{2} \mathrm{O}$ & $\mathrm{K}_{2} \mathrm{O}$ & $\mathrm{Cl}$ & $\mathrm{H}_{2} \mathrm{O}$ \\
\hline & 77.80 & 12.28 & 0.17 & 1.23 & 0.02 & 0.07 & 0.89 & 3.54 & 3.77 & 0.20 & 1.19 \\
\hline & 77.73 & 12.32 & 0.10 & 1.25 & 0.10 & 0.11 & 0.87 & 3.50 & 3.87 & 0.19 & 0.62 \\
\hline & 77.85 & 12.23 & 0.11 & 1.29 & 0.03 & 0.15 & 0.82 & 3.49 & 3.84 & 0.15 & 3.27 \\
\hline & 78.06 & 12.08 & 0.14 & 1.19 & 0.06 & 0.10 & 0.72 & 3.53 & 3.98 & 0.20 & 1.92 \\
\hline & 78.08 & 12.08 & 0.15 & 1.11 & 0.01 & 0.11 & 0.81 & 3.63 & 3.87 & 0.18 & 1.29 \\
\hline & 78.02 & 12.16 & 0.12 & 1.24 & 0.05 & 0.04 & 0.75 & 3.59 & 3.89 & 0.19 & 2.28 \\
\hline & 77.90 & 12.35 & 0.13 & 1.24 & 0.01 & 0.12 & 0.86 & 3.53 & 3.67 & 0.21 & 0.87 \\
\hline & 77.92 & 12.23 & 0.09 & 1.23 & 0.04 & 0.12 & 0.85 & 3.60 & 3.76 & 0.16 & 1.95 \\
\hline & 78.17 & 12.13 & 0.16 & 1.11 & 0.12 & 0.07 & 0.78 & 3.59 & 3.74 & 0.17 & 1.36 \\
\hline & 77.34 & 12.37 & 0.19 & 1.30 & 0.09 & 0.15 & 0.86 & 3.65 & 3.85 & 0.25 & 2.57 \\
\hline & 78.20 & 12.08 & 0.11 & 1.14 & 0.00 & 0.11 & 0.76 & 3.74 & 3.73 & 0.17 & 3.01 \\
\hline mean & 77.92 & 12.21 & 0.13 & 1.21 & 0.05 & 0.10 & 0.82 & 3.58 & 3.81 & 0.19 & 1.85 \\
\hline stdev & 0.24 & 0.11 & 0.03 & 0.07 & 0.04 & 0.03 & 0.06 & 0.08 & 0.09 & 0.03 & 0.87 \\
\hline $\mathrm{n}=$ & 11 & & & & & & & & & & \\
\hline \multirow[t]{14}{*}{ B 52} & \multicolumn{11}{|c|}{ Matahina Ignimbrite (V16/356186) } \\
\hline & $\mathrm{SiO}_{2}$ & $\mathrm{Al}_{2} \mathrm{O}_{3}$ & $\mathrm{TiO}_{2}$ & $\mathrm{FeO}$ & $\mathrm{MnO}$ & $\mathrm{MgO}$ & $\mathrm{CaO}$ & $\mathrm{Na}_{2} \mathrm{O}$ & $\mathrm{K}_{2} \mathrm{O}$ & $\mathrm{Cl}$ & $\mathrm{H}_{2} \mathrm{O}$ \\
\hline & 77.63 & 12.46 & 0.13 & 1.03 & 0.02 & 0.07 & 0.85 & 3.79 & 3.74 & 0.27 & 4.07 \\
\hline & 77.87 & 12.41 & 0.07 & 1.01 & 0.00 & 0.09 & 0.83 & 3.70 & 3.78 & 0.23 & 4.32 \\
\hline & 77.77 & 12.39 & 0.10 & 1.07 & 0.00 & 0.08 & 0.90 & 3.87 & 3.56 & 0.25 & 4.06 \\
\hline & 77.80 & 12.39 & 0.08 & 1.09 & 0.00 & 0.07 & 0.82 & 3.85 & 3.63 & 0.26 & 3.59 \\
\hline & 77.65 & 12.52 & 0.08 & 0.99 & 0.07 & 0.06 & 0.86 & 3.86 & 3.68 & 0.23 & 3.81 \\
\hline & 77.43 & 12.37 & 0.15 & 1.13 & 0.07 & 0.11 & 0.88 & 3.97 & 3.64 & 0.24 & 3.85 \\
\hline & 77.64 & 12.46 & 0.06 & 1.14 & 0.00 & 0.08 & 0.79 & 3.85 & 3.67 & 0.30 & 3.66 \\
\hline & 77.55 & 12.39 & 0.16 & 1.01 & 0.06 & 0.08 & 0.82 & 3.94 & 3.74 & 0.26 & 3.36 \\
\hline & 77.63 & 12.31 & 0.05 & 1.03 & 0.00 & 0.10 & 0.83 & 4.20 & 3.60 & 0.25 & 3.79 \\
\hline & 77.74 & 12.25 & 0.10 & 1.06 & 0.06 & 0.06 & 0.82 & 3.98 & 3.73 & 0.20 & 3.36 \\
\hline & 77.74 & 12.28 & 0.12 & 1.10 & 0.10 & 0.09 & 0.84 & 3.78 & 3.74 & 0.21 & 3.12 \\
\hline & 77.97 & 12.26 & 0.03 & 1.07 & 0.07 & 0.05 & 0.81 & 3.98 & 3.56 & 0.21 & 2.46 \\
\hline mean & 77.70 & 12.37 & 0.10 & 1.06 & 0.04 & 0.08 & 0.84 & 3.90 & 3.67 & 0.24 & 3.62 \\
\hline stdev & 0.15 & 0.08 & 0.04 & 0.05 & 0.04 & 0.02 & 0.03 & 0.13 & 0.07 & 0.03 & 0.50 \\
\hline $\mathrm{n}=$ & 12 & & & & & & & & & & \\
\hline \multirow[t]{12}{*}{$83 / 1$} & \multicolumn{11}{|c|}{ Matahina Ignimbrite (analysed at VUW, V17/307993) } \\
\hline & $\mathrm{SiO}_{2}$ & $\mathrm{Al}_{2} \mathrm{O}_{3}$ & $\mathrm{TiO}_{2}$ & $\mathrm{FeO}$ & $\mathrm{MnO}$ & $\mathrm{MgO}$ & $\mathrm{CaO}$ & $\mathrm{Na}_{2} \mathrm{O}$ & $\mathrm{K}_{2} \mathrm{O}$ & $\mathrm{Cl}$ & $\mathrm{H}_{2} \mathrm{O}$ \\
\hline & 77.26 & 12.41 & 0.14 & 1.12 & - & 0.14 & 0.85 & 4.04 & 3.86 & 0.17 & 4.66 \\
\hline & 78.01 & 12.31 & 0.10 & 1.09 & - & 0.06 & 0.95 & 3.69 & 3.58 & 0.19 & 3.09 \\
\hline & 76.59 & 13.27 & 0.14 & 1.10 & - & 0.14 & 0.90 & 4.18 & 3.94 & 0.19 & 8.80 \\
\hline & 77.56 & 12.47 & 0.11 & 1.06 & - & 0.10 & 0.91 & 3.86 & 3.70 & 0.21 & 3.63 \\
\hline & 76.87 & 12.56 & 0.14 & 1.08 & - & 0.12 & 0.96 & 3.97 & 4.15 & 0.15 & 7.27 \\
\hline & 77.73 & 12.44 & 0.12 & 1.07 & - & 0.10 & 0.83 & 3.74 & 3.79 & 0.17 & 4.58 \\
\hline & 77.05 & 12.51 & 0.10 & 1.18 & - & 0.11 & 0.85 & 3.97 & 4.05 & 0.18 & 6.40 \\
\hline & 77.31 & 12.62 & 0.12 & 0.93 & - & 0.11 & 0.91 & 4.00 & 3.80 & 0.20 & 5.45 \\
\hline & 77.62 & 12.35 & 0.16 & 1.12 & - & 0.12 & 0.86 & 3.82 & 3.72 & 0.21 & 2.79 \\
\hline & 77.79 & 12.42 & 0.10 & 1.00 & - & 0.12 & 0.80 & 3.84 & 3.75 & 0.19 & 3.70 \\
\hline
\end{tabular}




\begin{tabular}{|c|c|c|c|c|c|c|c|c|c|c|c|}
\hline mean & 77.38 & 12.54 & 0.12 & 1.07 & & 0.11 & 0.88 & 3.91 & 3.83 & 0.18 & 5.04 \\
\hline st dev & 0.45 & 0.27 & 0.02 & 0.07 & & 0.02 & 0.05 & 0.15 & 0.17 & 0.02 & 1.95 \\
\hline $\mathrm{n}=$ & 10 & & & & & & & & & & \\
\hline \multirow[t]{9}{*}{ B 28} & \multicolumn{11}{|c|}{ Whakamaru group (Manunui Ignimbrite S18/066704, analysed at VUW) } \\
\hline & $\mathrm{SiO}_{2}$ & $\mathrm{Al}_{2} \mathrm{O}_{3}$ & $\mathrm{TiO}_{2}$ & $\mathrm{FeO}$ & $\mathrm{MnO}$ & $\mathrm{MgO}$ & $\mathrm{CaO}$ & $\mathrm{Na}_{2} \mathrm{O}$ & $\mathrm{K}_{2} \mathrm{O}$ & $\mathrm{Cl}$ & $\mathrm{H}_{2} \mathrm{O}$ \\
\hline & 77.65 & 12.00 & 0.19 & 0.98 & - & 0.11 & 0.78 & 3.36 & 4.71 & 0.23 & 3.14 \\
\hline & 77.63 & 11.99 & 0.15 & 0.97 & - & 0.14 & 0.82 & 3.36 & 4.68 & 0.25 & 2.54 \\
\hline & 77.98 & 12.13 & 0.10 & 0.92 & - & 0.11 & 0.76 & 3.36 & 4.42 & 0.22 & 3.44 \\
\hline & 77.78 & 11.91 & 0.13 & 1.06 & - & 0.11 & 0.89 & 3.35 & 4.54 & 0.23 & 3.35 \\
\hline & 77.67 & 11.87 & 0.13 & 0.96 & - & 0.14 & 0.83 & 3.50 & 4.65 & 0.25 & 2.44 \\
\hline & 78.02 & 11.95 & 0.10 & 0.88 & - & 0.13 & 0.79 & 3.31 & 4.69 & 0.13 & 2.02 \\
\hline & 77.88 & 12.14 & 0.09 & 0.77 & - & 0.08 & 0.75 & 3.36 & 4.69 & 0.24 & 2.20 \\
\hline mean & 77.80 & 12.00 & 0.13 & 0.93 & - & 0.12 & 0.80 & 3.37 & 4.63 & 0.22 & 2.73 \\
\hline stdev & 0.16 & 0.10 & 0.03 & 0.09 & - & 0.02 & 0.05 & 0.06 & 0.11 & 0.04 & 0.57 \\
\hline
\end{tabular}

$\mathrm{n}=\quad 7$

B 33 Tephra under Rocky Hill (analysed at VUW, S16/119105)

$\begin{array}{llllllllllll} & \mathrm{SiO}_{2} & \mathrm{Al}_{2} \mathrm{O}_{3} & \mathrm{TiO}_{2} & \mathrm{FeO} & \mathrm{MnO} & \mathrm{MgO} & \mathrm{CaO} & \mathrm{Na}_{2} \mathrm{O} & \mathrm{K}_{2} \mathrm{O} & \mathrm{Cl} & \mathrm{H}_{2} \mathrm{O} \\ & 74.98 & 13.18 & 0.22 & 2.27 & - & 0.16 & 1.38 & 4.50 & 3.06 & 0.25 & 7.84 \\ & 76.34 & 13.00 & 0.18 & 1.96 & - & 0.13 & 1.40 & 3.71 & 3.10 & 0.19 & 5.40 \\ & 75.71 & 12.95 & 0.23 & 2.10 & - & 0.14 & 1.32 & 4.17 & 3.20 & 0.18 & 5.91 \\ & 75.92 & 12.95 & 0.17 & 2.08 & - & 0.11 & 1.27 & 4.10 & 3.19 & 0.19 & 7.35 \\ & 75.64 & 12.89 & 0.21 & 2.09 & - & 0.14 & 1.39 & 4.13 & 3.32 & 0.20 & 5.64 \\ & 75.68 & 13.06 & 0.17 & 2.13 & - & 0.15 & 1.27 & 4.27 & 3.03 & 0.23 & 6.30 \\ & 76.01 & 12.94 & 0.17 & 2.17 & - & 0.15 & 1.30 & 3.72 & 3.34 & 0.20 & 6.60 \\ & 75.52 & 12.78 & 0.23 & 2.24 & - & 0.22 & 1.32 & 4.14 & 3.37 & 0.19 & 7.00 \\ \text { mean } & 75.22 & 13.28 & 0.11 & 2.01 & - & 0.13 & 1.30 & 4.44 & 3.30 & 0.22 & 8.27 \\ \text { stdev } & \mathbf{7 5 . 6 7} & \mathbf{1 3 . 0 0} & \mathbf{0 . 1 9} & \mathbf{2 . 1 2} & - & \mathbf{0 . 1 5} & \mathbf{1 . 3 3} & \mathbf{4 . 1 3} & \mathbf{3 . 2 1} & \mathbf{0 . 2 1} & \mathbf{6 . 7 0} \\ & \mathbf{0 . 4 1} & \mathbf{0 . 1 5} & \mathbf{0 . 0 4} & \mathbf{0 . 1 0} & - & \mathbf{0 . 0 3} & \mathbf{0 . 0 5} & \mathbf{0 . 2 7} & \mathbf{0 . 1 3} & \mathbf{0 . 0 2} & \mathbf{0 . 9 9}\end{array}$

B 49 Ongatiti Ignimbrite (analysed at VUW, S17/098843)

$\begin{array}{lllllllllll}\mathrm{SiO}_{2} & \mathrm{Al}_{2} \mathrm{O}_{3} & \mathrm{TiO}_{2} & \mathrm{FeO} & \mathrm{MnO} & \mathrm{MgO} & \mathrm{CaO} & \mathrm{Na}_{2} \mathrm{O} & \mathrm{K}_{2} \mathrm{O} & \mathrm{Cl} & \mathrm{H}_{2} \mathrm{O} \\ 76.97 & 12.14 & 0.12 & 1.45 & - & 0.14 & 1.03 & 3.60 & 4.23 & 0.33 & 5.21 \\ 77.46 & 11.96 & 0.20 & 1.25 & - & 0.13 & 0.90 & 3.61 & 4.19 & 0.29 & 4.55 \\ 77.22 & 12.17 & 0.18 & 1.39 & - & 0.12 & 0.97 & 3.57 & 4.07 & 0.30 & 4.51 \\ 77.56 & 12.08 & 0.16 & 1.28 & - & 0.10 & 1.02 & 3.50 & 3.95 & 0.36 & 4.53 \\ 77.58 & 12.21 & 0.17 & 1.25 & - & 0.11 & 0.94 & 3.56 & 3.91 & 0.26 & 3.46 \\ 77.50 & 12.21 & 0.08 & 1.26 & - & 0.10 & 0.91 & 3.67 & 3.98 & 0.29 & 3.70 \\ 77.35 & 12.11 & 0.10 & 1.27 & - & 0.10 & 0.99 & 3.83 & 3.97 & 0.28 & 3.95 \\ 77.42 & 12.16 & 0.12 & 1.32 & - & 0.10 & 0.85 & 3.61 & 4.12 & 0.28 & 3.72 \\ 77.28 & 12.19 & 0.16 & 1.27 & - & 0.06 & 0.92 & 3.72 & 4.11 & 0.29 & 4.41 \\ 77.49 & 12.03 & 0.18 & 1.30 & - & 0.17 & 0.89 & 3.70 & 3.94 & 0.29 & 4.65 \\ \mathbf{7 7 . 3 8} & \mathbf{1 2 . 1 3} & \mathbf{0 . 1 5} & \mathbf{1 . 3 0} & - & \mathbf{0 . 1 1} & \mathbf{0 . 9 4} & \mathbf{3 . 6 4} & \mathbf{4 . 0 5} & \mathbf{0 . 3 0} & \mathbf{4 . 2 7} \\ \mathbf{0 . 1 9} & \mathbf{0 . 0 8} & \mathbf{0 . 0 4} & \mathbf{0 . 0 7} & - & \mathbf{0 . 0 3} & \mathbf{0 . 0 6} & \mathbf{0 . 1 0} & \mathbf{0 . 1 1} & \mathbf{0 . 0 3} & \mathbf{0 . 5 4}\end{array}$

B 50 Rocky Hill Ignimbrite (analysed at VUW, S16/117107)

$\begin{array}{llllllllllll} & \mathrm{SiO}_{2} & \mathrm{Al}_{2} \mathrm{O}_{3} & \mathrm{TiO}_{2} & \mathrm{FeO} & \mathrm{MnO} & \mathrm{MgO} & \mathrm{CaO} & \mathrm{Na}_{2} \mathrm{O} & \mathrm{K}_{2} \mathrm{O} & \mathrm{Cl} & \mathrm{H}_{2} \mathrm{O} \\ & 77.11 & 12.31 & 0.09 & 1.41 & - & 0.13 & 1.14 & 3.81 & 3.81 & 0.20 & 3.33 \\ & 77.73 & 12.09 & 0.13 & 1.18 & - & 0.13 & 1.01 & 3.69 & 3.77 & 0.28 & 4.14 \\ & 77.64 & 12.19 & 0.14 & 1.23 & - & 0.10 & 0.93 & 3.70 & 3.83 & 0.23 & 3.40 \\ & 78.01 & 11.96 & 0.13 & 0.97 & - & 0.07 & 0.81 & 3.66 & 4.16 & 0.22 & 3.68 \\ & 77.79 & 12.13 & 0.10 & 1.15 & - & 0.09 & 0.71 & 3.66 & 4.11 & 0.26 & 3.80 \\ & 77.40 & 12.19 & 0.18 & 1.28 & - & 0.17 & 1.13 & 3.68 & 3.73 & 0.25 & 4.01 \\ & 77.36 & 12.23 & 0.17 & 1.27 & - & 0.08 & 1.02 & 3.80 & 3.85 & 0.22 & 3.94 \\ & 78.08 & 12.02 & 0.14 & 1.19 & - & 0.11 & 0.95 & 3.56 & 3.72 & 0.23 & 4.03 \\ & 77.61 & 12.14 & 0.14 & 1.25 & - & 0.09 & 0.99 & 3.70 & 3.83 & 0.25 & 2.95 \\ & 77.83 & 12.06 & 0.12 & 1.28 & - & 0.09 & 1.10 & 3.45 & 3.81 & 0.25 & 3.79 \\ & 78.03 & 12.15 & 0.11 & 0.93 & - & 0.08 & 0.81 & 3.63 & 4.04 & 0.23 & 3.18 \\ \text { mean } & 77.67 & 12.05 & 0.09 & 1.35 & - & 0.10 & 0.95 & 3.68 & 3.85 & 0.25 & 4.17 \\ \text { stdev } & \mathbf{7 . 6 9} & \mathbf{1 2 . 1 3} & \mathbf{0 . 1 3} & \mathbf{1 . 2 1} & - & \mathbf{0 . 1 1} & \mathbf{0 . 9 6} & \mathbf{3 . 6 7} & \mathbf{3 . 8 8} & \mathbf{0 . 2 4} & \mathbf{3 . 7 0} \\ & \mathbf{0 . 1} & \mathbf{0 . 1} & \mathbf{0 . 0 3} & \mathbf{0 . 1 4} & & \mathbf{0 . 0 3} & \mathbf{0 . 1 3} & \mathbf{0 . 1 0} & \mathbf{0 . 1 5} & \mathbf{0 . 0 2} & \mathbf{0 . 4 0}\end{array}$


B51 Ahuroa Ignimbrite (analysed at VUW, S17/897655)

\begin{tabular}{|c|c|c|c|c|c|c|c|c|c|c|c|}
\hline & $\begin{array}{l}\mathrm{SiO}_{2} \\
\text { clear gl }\end{array}$ & $\mathrm{Sl}_{2} \mathrm{O}_{3}$ & $\mathrm{TiO}_{2}$ & $\mathrm{FeO}$ & $\mathrm{MnO}$ & $\mathrm{MgO}$ & $\mathrm{CaO}$ & $\mathrm{Na}_{2} \mathrm{O}$ & $\mathrm{K}_{2} \mathrm{O}$ & $\mathrm{Cl}$ & $\mathrm{H}_{2} \mathrm{O}$ \\
\hline & 77.85 & 12.07 & 0.07 & 1.39 & - & 0.07 & 0.20 & 4.37 & 3.86 & 0.13 & 9.16 \\
\hline & 77.49 & 11.96 & 0.24 & 1.53 & - & 0.05 & 0.74 & 4.31 & 3.44 & 0.23 & 5.50 \\
\hline & 77.72 & 11.96 & 0.06 & 1.45 & - & 0.10 & 0.74 & 4.32 & 3.27 & 0.37 & 4.46 \\
\hline & 77.11 & 12.30 & 0.07 & 1.48 & - & 0.05 & 0.69 & 4.38 & 3.67 & 0.25 & 7.91 \\
\hline & 77.04 & 12.23 & 0.00 & 1.73 & - & 0.00 & 0.61 & 4.61 & 3.78 & 0.00 & 9.49 \\
\hline & 77.41 & 12.24 & 0.11 & 1.45 & - & 0.06 & 0.62 & 4.24 & 3.64 & 0.25 & 9.36 \\
\hline mean & 77.44 & 12.13 & 0.09 & 1.51 & - & 0.06 & 0.60 & 4.37 & 3.61 & 0.21 & 7.65 \\
\hline stdev & 0.32 & 0.15 & 0.08 & 0.12 & - & 0.03 & 0.21 & 0.13 & 0.22 & 0.13 & 2.17 \\
\hline $\mathrm{n}=$ & $\begin{array}{l}6 \\
\text { brown }\end{array}$ & & & & & & & & & & \\
\hline & 76.08 & 12.50 & 0.22 & 2.12 & - & 0.12 & 1.02 & 4.47 & 3.26 & 0.22 & 3.49 \\
\hline & 76.19 & 12.59 & 0.14 & 2.02 & - & 0.10 & 0.99 & 4.42 & 3.35 & 0.19 & 3.39 \\
\hline & 76.66 & 12.40 & 0.13 & 2.03 & - & 0.08 & 0.95 & 4.37 & 3.18 & 0.20 & 3.22 \\
\hline & 76.57 & 12.39 & 0.17 & 2.01 & - & 0.09 & 0.95 & 4.36 & 3.29 & 0.18 & 3.90 \\
\hline & 76.40 & 12.60 & 0.15 & 1.89 & - & 0.09 & 0.96 & 4.40 & 3.30 & 0.21 & 2.76 \\
\hline & 76.30 & 12.33 & 0.18 & 2.02 & - & 0.09 & 1.07 & 4.37 & 3.42 & 0.23 & 2.87 \\
\hline & 76.45 & 12.50 & 0.22 & 2.04 & - & 0.08 & 0.89 & 4.31 & 3.28 & 0.22 & 2.66 \\
\hline & 76.55 & 12.55 & 0.14 & 1.98 & - & 0.13 & 0.95 & 4.19 & 3.29 & 0.19 & 2.26 \\
\hline & 76.12 & 12.56 & 0.20 & 2.05 & - & 0.07 & 0.97 & 4.49 & 3.35 & 0.20 & 2.73 \\
\hline & 75.37 & 13.02 & 0.17 & 2.06 & - & 0.07 & 0.97 & 4.73 & 3.43 & 0.17 & 5.02 \\
\hline & 75.58 & 12.70 & 0.20 & 2.16 & - & 0.11 & 1.13 & 4.48 & 3.48 & 0.16 & 3.56 \\
\hline & 74.95 & 12.97 & 0.18 & 2.3 & - & 0.12 & 1.12 & 4.54 & 3.63 & 0.19 & 5.31 \\
\hline & 75.00 & 13.03 & 0.24 & 2.20 & - & 0.11 & 1.02 & 4.69 & 3.53 & 0.18 & 6.47 \\
\hline mean & 76.02 & 12.63 & 0.18 & 2.07 & - & 0.10 & 1.00 & 4.45 & 3.37 & 0.19 & 3.66 \\
\hline stdev & 0.59 & 0.24 & 0.03 & 0.11 & - & 0.02 & 0.07 & 0.15 & 0.12 & 0.02 & 1.23 \\
\hline $\mathrm{n}=$ & 13 & & & & & & & & & & \\
\hline B 53 & Unit D & allout (a & alysed & VUW, & $7 / 89765$ & & & & & & \\
\hline & $\mathrm{SiO}_{2}$ & $\mathrm{Al}_{2} \mathrm{O}_{3}$ & $\mathrm{TiO}_{2}$ & $\mathrm{FeO}$ & $\mathrm{MnO}$ & $\mathrm{MgO}$ & $\mathrm{CaO}$ & $\mathrm{Na}_{2} \mathrm{O}$ & $\mathrm{K}_{2} \mathrm{O}$ & $\mathrm{Cl}$ & $\mathrm{H}_{2} \mathrm{O}$ \\
\hline & 77.71 & 11.89 & 0.13 & 1.32 & - & 0.05 & 0.58 & 4.22 & 3.87 & 0.23 & 5.27 \\
\hline & 77.56 & 11.93 & 0.09 & 1.46 & - & 0.05 & 0.61 & 4.24 & 3.87 & 0.19 & 6.04 \\
\hline & 77.67 & 11.92 & 0.06 & 1.37 & - & 0.05 & 0.62 & 4.14 & 3.89 & 0.26 & 5.42 \\
\hline & 77.36 & 12.06 & 0.09 & 1.46 & - & 0.05 & 0.71 & 4.27 & 3.77 & 0.21 & 4.76 \\
\hline & 77.66 & 12.03 & 0.09 & 1.31 & - & 0.06 & 0.68 & 4.26 & 3.64 & 0.27 & 4.54 \\
\hline & 77.81 & 11.87 & 0.06 & 1.38 & - & 0.06 & 0.63 & 4.26 & 3.65 & 0.26 & 5.21 \\
\hline & 78.02 & 11.70 & 0.12 & 1.45 & - & 0.07 & 0.62 & 4.13 & 3.66 & 0.23 & 3.52 \\
\hline & 75.33 & 12.71 & 0.23 & 2.27 & - & 0.12 & 1.11 & 4.54 & 3.63 & 0.05 & 3.95 \\
\hline & 75.28 & 12.80 & 0.23 & 2.19 & - & 0.09 & 1.07 & 4.51 & 3.59 & 0.25 & 5.63 \\
\hline & 75.21 & 12.91 & 0.18 & 2,08 & - & 0.10 & 1.06 & 4.61 & 3.68 & 0.16 & 4.79 \\
\hline mean & 76.96 & 12.18 & 0.13 & 1.63 & - & 0.07 & 0.77 & 4.32 & 3.73 & 0.21 & 4.91 \\
\hline stdev & 1.12 & 0.42 & 0.06 & 0.37 & - & 0.02 & 0.21 & 0.16 & 0.11 & 0.06 & 0.73 \\
\hline $\mathrm{n}=$ & 10 & & & & & & & & & & \\
\hline B 54 & Unit D & gnimbrit & (analy & at VL & $S 17 / 8 \mathrm{C}$ & 655) & & & & & \\
\hline & $\mathrm{SiO}_{2}$ & $\mathrm{Al}_{2} \mathrm{O}_{3}$ & $\mathrm{TiO}_{2}$ & $\mathrm{FeO}$ & $\mathrm{MnO}$ & $\mathrm{MgO}$ & $\mathrm{CaO}$ & $\mathrm{Na}_{2} \mathrm{O}$ & $\mathrm{K}_{2} \mathrm{O}$ & $\mathrm{Cl}$ & $\mathrm{H}_{2} \mathrm{O}$ \\
\hline & 77.37 & 12.01 & 0.15 & 1.43 & - & 0.08 & 0.68 & 4.32 & 3.78 & 0.19 & 7.39 \\
\hline & 77.37 & 12.03 & 0.10 & 1.41 & - & 0.08 & 0.59 & 4.24 & 3.91 & 0.26 & 2.91 \\
\hline & 77.86 & 11.78 & 0.08 & 1.43 & . & 0.07 & 0.64 & 4.11 & 3.82 & 0.21 & 3.57 \\
\hline & 77.59 & 11.97 & 0.08 & 1.49 & - & 0.06 & 0.61 & 4.26 & 3.72 & 0.22 & 2.87 \\
\hline & 77.91 & 11.72 & 0.11 & 1.37 & - & 0.06 & 0.60 & 4.23 & 3.74 & 0.25 & 5.39 \\
\hline & 76.27 & 12.48 & 0.21 & 1.87 & - & 0.11 & 1.02 & 4.34 & 3.55 & 0.14 & 4.25 \\
\hline & 76.04 & 12.46 & 0.20 & 1.99 & - & 0.15 & 1.03 & 4.38 & 3.56 & 0.19 & 3.97 \\
\hline & 77.42 & 12.01 & 0.13 & 1.55 & - & 0.06 & 0.69 & 4.31 & 3.63 & 0.21 & 5.71 \\
\hline & 77,93 & 11.98 & 0.12 & 1.38 & - & 0.08 & 0.57 & 4.27 & 3.45 & 0.23 & 4.83 \\
\hline & 76.29 & 12.61 & 0.21 & 2.10 & - & 0.12 & 0.97 & 4.09 & 3.45 & 0.16 & 3.83 \\
\hline & 77.92 & 12.00 & 0.07 & 1.37 & - & 0.06 & 0.59 & 4.17 & 3.62 & 0.20 & 4.58 \\
\hline mean & 77.27 & 12.10 & 0.13 & 1.58 & - & 0.08 & 0.73 & 4.25 & 3.66 & 0.21 & 4.48 \\
\hline stdev & 0.69 & 0.28 & 0.05 & 0.26 & - & 0.03 & 0.18 & 0.09 & 0.14 & 0.03 & 1.26 \\
\hline
\end{tabular}


Downer 1 (T16/646336)

\begin{tabular}{|c|c|c|c|c|c|c|c|c|c|c|}
\hline & $\mathrm{SiO}_{2}$ & $\mathrm{Al}_{2} \mathrm{O}_{3}$ & $\mathrm{TiO}_{2}$ & $\mathrm{FeO}$ & $\mathrm{MnO}$ & $\mathrm{MgO}$ & $\mathrm{CaO}$ & $\mathrm{Na}_{2} \mathrm{O}$ & $\mathrm{K}_{2} \mathrm{O}$ & $\mathrm{Cl}$ \\
\hline & 77.58 & 12.43 & 0.08 & 0.92 & 0.06 & 0.12 & 0.90 & 3.51 & 4.12 & 0.29 \\
\hline & 77.60 & 12.26 & 0.09 & 1.01 & 0.03 & 0.12 & 0.97 & 3.95 & 3.80 & 0.17 \\
\hline & 77.70 & 12.32 & 0.13 & 1.09 & 0.09 & 0.11 & 0.79 & 3.67 & 3.92 & 0.19 \\
\hline & 77.56 & 12.29 & 0.15 & 1.10 & 0.05 & 0.16 & 0.93 & 3.77 & 3.74 & 0.25 \\
\hline & 80.07 & 12.69 & 0.08 & 1.12 & 0.05 & 0.13 & 0.92 & 3.62 & 1.17 & 0.15 \\
\hline & 77.46 & 12.32 & 0.10 & 1.03 & 0.04 & 0.11 & 0.89 & 3.78 & 4.08 & 0.20 \\
\hline & 77.58 & 12.41 & 0.10 & 1.02 & 0.00 & 0.12 & 0.90 & 3.34 & 4.28 & 0.26 \\
\hline & 77.48 & 12.56 & 0.16 & 1.02 & 0.06 & 0.10 & 0.81 & 3.64 & 3.88 & 0.29 \\
\hline & 77.91 & 12.30 & 0.03 & 0.90 & 0.05 & 0.11 & 0.84 & 3.69 & 3.98 & 0.20 \\
\hline & 77.86 & 12.18 & 0.06 & 0.98 & 0.06 & 0.11 & 0.90 & 3.78 & 3.92 & 0.15 \\
\hline & 77.46 & 12.33 & 0.14 & 1.02 & 0.01 & 0.10 & 0.91 & 3.79 & 4.01 & 0.23 \\
\hline & 77.57 & 12.39 & 0.08 & 1.05 & 0.04 & 0.08 & 0.92 & 3.79 & 3.82 & 0.25 \\
\hline & 77.82 & 12.37 & 0.10 & 1.02 & 0.05 & 0.11 & 0.89 & 3.69 & 3.73 & 0.22 \\
\hline & 0.72 & 0.14 & 0.04 & 0.07 & 0.03 & 0.02 & 0.05 & 0.16 & 0.82 & 0.05 \\
\hline
\end{tabular}

Downer 2

$\begin{array}{lllllllllll}\mathrm{SiO}_{2} & \mathrm{Al}_{2} \mathrm{O}_{3} & \mathrm{TiO}_{2} & \mathrm{FeO} & \mathrm{MnO} & \mathrm{MgO} & \mathrm{CaO} & \mathrm{Na}_{2} \mathrm{O} & \mathrm{K}_{2} \mathrm{O} & \mathrm{Cl} & \mathrm{H}_{2} \mathrm{O} \\ 77.87 & 12.24 & 0.13 & 1.03 & 0.14 & 0.15 & 1.05 & 3.68 & 3.41 & 0.30 & 6.57 \\ 78.53 & 12.16 & 0.11 & 0.98 & 0.03 & 0.16 & 1.05 & 2.85 & 3.88 & 0.25 & 6.51 \\ 77.79 & 12.31 & 0.16 & 1.04 & 0.07 & 0.16 & 1.00 & 3.88 & 3.38 & 0.22 & 4.92 \\ 77.82 & 12.23 & 0.17 & 1.19 & 0.00 & 0.16 & 1.01 & 3.83 & 3.42 & 0.17 & 6.34 \\ 78.30 & 11.97 & 0.18 & 1.12 & 0.03 & 0.17 & 1.02 & 3.89 & 3.10 & 0.22 & 4.99 \\ 78.02 & 12.16 & 0.18 & 1.02 & 0.03 & 0.14 & 1.03 & 3.60 & 3.60 & 0.21 & 6.74 \\ 77.62 & 12.46 & 0.12 & 1.06 & 0.13 & 0.11 & 0.87 & 3.38 & 3.99 & 0.27 & 6.8 \\ 77.90 & 12.27 & 0.23 & 1.08 & 0.06 & 0.18 & 1.01 & 3.85 & 3.21 & 0.20 & 5.31 \\ 77.99 & 12.31 & 0.14 & 1.09 & 0.06 & 0.16 & 0.98 & 3.85 & 3.19 & 0.22 & 5.3 \\ 77.62 & 12.24 & 0.11 & 1.12 & 0.03 & 0.14 & 1.02 & 3.50 & 4.00 & 0.23 & 7.02 \\ 78.18 & 12.23 & 0.12 & 1.05 & 0.02 & 0.16 & 1.06 & 3.54 & 3.41 & 0.23 & 6.73 \\ 78.04 & 12.29 & 0.17 & 1.06 & 0.05 & 0.17 & 1.01 & 3.68 & 3.35 & 0.17 & 6.81 \\ \mathbf{7 7 . 9 7} & \mathbf{1 2 . 2 4} & \mathbf{0 . 1 5} & \mathbf{1 . 0 7} & \mathbf{0 . 0 6} & \mathbf{0 . 1 5} & \mathbf{1 . 0 1} & \mathbf{3 . 6 3} & \mathbf{3 . 5 0} & \mathbf{0 . 2 2} & \mathbf{6 . 1 7} \\ \mathbf{0 . 2 7} & \mathbf{0 . 1 2} & \mathbf{0 . 0 4} & \mathbf{0 . 0 5} & \mathbf{0 . 0 4} & \mathbf{0 . 0 2} & \mathbf{0 . 0 5} & \mathbf{0 . 3 0} & \mathbf{0 . 3 1} & \mathbf{0 . 0 4} & \mathbf{0 . 7 9} \\ \mathbf{1 2} & & & & & & & & & & \end{array}$

Downer 3

$\begin{array}{lllllllllll}\mathrm{SiO}_{2} & \mathrm{Al}_{2} \mathrm{O}_{3} & \mathrm{TiO}_{2} & \mathrm{FeO} & \mathrm{MnO} & \mathrm{MgO} & \mathrm{CaO} & \mathrm{Na}_{2} \mathrm{O} & \mathrm{K}_{2} \mathrm{O} & \mathrm{Cl} & \mathrm{H}_{2} \mathrm{O} \\ 77.51 & 12.39 & 0.13 & 1.21 & 0.03 & 0.12 & 0.97 & 3.85 & 3.62 & 0.17 & 5.05 \\ 77.02 & 12.71 & 0.16 & 1.26 & 0.06 & 0.18 & 1.26 & 3.92 & 3.26 & 0.17 & 5.46 \\ 77.81 & 12.26 & 0.13 & 1.13 & 0.07 & 0.14 & 1.06 & 3.28 & 3.90 & 0.23 & 6.33 \\ 77.88 & 12.26 & 0.15 & 1.09 & 0.03 & 0.14 & 0.97 & 3.65 & 3.74 & 0.10 & 4.18 \\ 76.76 & 12.67 & 0.28 & 1.34 & 0.03 & 0.22 & 1.26 & 3.94 & 3.28 & 0.22 & 5.49 \\ 76.78 & 12.57 & 0.19 & 1.35 & 0.01 & 0.20 & 1.19 & 3.98 & 3.49 & 0.23 & 6.71 \\ 77.94 & 12.32 & 0.18 & 1.08 & 0.04 & 0.14 & 0.95 & 3.69 & 3.49 & 0.17 & 5.66 \\ 76.66 & 12.77 & 0.23 & 1.28 & 0.03 & 0.18 & 1.25 & 4.02 & 3.29 & 0.29 & 4.48 \\ 76.67 & 12.81 & 0.22 & 1.16 & 0.07 & 0.22 & 1.26 & 3.86 & 3.52 & 0.20 & 6.22 \\ 77.05 & 12.66 & 0.16 & 1.18 & 0.09 & 0.14 & 1.06 & 4.03 & 3.41 & 0.23 & 4.89 \\ 76.47 & 12.68 & 0.24 & 1.34 & 0.04 & 0.20 & 1.20 & 4.15 & 3.41 & 0.27 & 4.98 \\ 77.35 & 12.38 & 0.16 & 1.09 & 0.04 & 0.10 & 1.03 & 3.85 & 3.80 & 0.20 & 3.5 \\ \mathbf{7 7 . 1 6} & \mathbf{1 2 . 5 4} & \mathbf{0 . 1 8} & \mathbf{1 . 2 1} & \mathbf{0 . 0 5} & \mathbf{0 . 1 6} & \mathbf{1 . 1 2} & \mathbf{3 . 8 5} & \mathbf{3 . 5 2} & \mathbf{0 . 2 1} & \mathbf{5 . 2 5} \\ \mathbf{0 . 5 2} & \mathbf{0 . 2 0} & \mathbf{0 . 0 5} & \mathbf{0 . 1 0} & \mathbf{0 . 0 2} & \mathbf{0 . 0 4} & \mathbf{0 . 1 3} & \mathbf{0 . 2 3} & \mathbf{0 . 2 1} & \mathbf{0 . 0 5} & \mathbf{0 . 9 3}\end{array}$

Downer 4

$\begin{array}{lllllllllll}\mathrm{SiO}_{2} & \mathrm{Al}_{2} \mathrm{O}_{3} & \mathrm{TiO}_{2} & \mathrm{FeO} & \mathrm{MnO} & \mathrm{MgO} & \mathrm{CaO} & \mathrm{Na}_{2} \mathrm{O} & \mathrm{K}_{2} \mathrm{O} & \mathrm{Cl} & \mathrm{H}_{2} \mathrm{O} \\ 77.69 & 12.41 & 0.07 & 0.98 & 0.06 & 0.11 & 0.83 & 3.11 & 4.46 & 0.28 & 5.48 \\ 77.94 & 12.19 & 0.09 & 0.96 & 0.06 & 0.07 & 0.73 & 3.88 & 3.89 & 0.18 & 4.58 \\ 77.72 & 12.30 & 0.03 & 0.94 & 0.07 & 0.05 & 0.73 & 3.87 & 4.04 & 0.23 & 5.29 \\ 77.74 & 12.36 & 0.06 & 0.88 & 0.07 & 0.11 & 0.78 & 3.78 & 4.00 & 0.21 & 4.25 \\ 77.57 & 12.58 & 0.07 & 0.90 & 0.03 & 0.07 & 0.78 & 3.64 & 4.11 & 0.25 & 3.26 \\ 77.52 & 12.50 & 0.04 & 0.99 & 0.05 & 0.09 & 0.76 & 3.83 & 3.94 & 0.27 & 3.41 \\ 77.57 & 12.48 & 0.12 & 0.94 & 0.05 & 0.09 & 0.81 & 3.72 & 4.00 & 0.20 & 3.56 \\ 78.06 & 12.17 & 0.10 & 0.93 & 0.04 & 0.08 & 0.83 & 3.73 & 3.79 & 0.26 & 4.74 \\ 77.57 & 12.39 & 0.09 & 0.93 & 0.10 & 0.08 & 0.81 & 3.83 & 3.90 & 0.29 & 4.6\end{array}$




$\begin{array}{llllllllllll} & 77.61 & 12.40 & 0.07 & 0.97 & 0.01 & 0.10 & 0.78 & 3.84 & 3.95 & 0.27 & 5.45 \\ & 77.65 & 12.28 & 0.07 & 1.02 & 0.03 & 0.09 & 0.81 & 3.88 & 3.94 & 0.22 & 4.82 \\ & 77.60 & 12.31 & 0.06 & 1.06 & 0.04 & 0.11 & 0.78 & 3.82 & 4.01 & 0.20 & 3.98 \\ \text { mean } & \mathbf{7 7 . 6 9} & \mathbf{1 2 . 3 6} & \mathbf{0 . 0 8} & \mathbf{0 . 9 6} & \mathbf{0 . 0 5} & \mathbf{0 . 0 9} & \mathbf{0 . 7 8} & \mathbf{3 . 7 4} & \mathbf{4 . 0 0} & \mathbf{0 . 2 4} & \mathbf{4 . 4 5} \\ \text { stdev } & \mathbf{0 . 1 6} & \mathbf{0 . 1 2} & \mathbf{0 . 0 3} & \mathbf{0 . 0 5} & \mathbf{0 . 0 2} & \mathbf{0 . 0 2} & \mathbf{0 . 0 3} & \mathbf{0 . 2 1} & \mathbf{0 . 1 7} & \mathbf{0 . 0 4} & \mathbf{0 . 7 7} \\ \mathrm{n}= & 12 & & & & & & & & & & \end{array}$

Downer 5

$\begin{array}{llllllllllll} & \mathrm{SiO}_{2} & \mathrm{Al}_{2} \mathrm{O}_{3} & \mathrm{TiO}_{2} & \mathrm{FeO} & \mathrm{MnO} & \mathrm{MgO} & \mathrm{CaO} & \mathrm{Na}_{2} \mathrm{O} & \mathrm{K}_{2} \mathrm{O} & \mathrm{Cl} & \mathrm{H}_{2} \mathrm{O} \\ & 77.95 & 12.36 & 0.05 & 0.99 & 0.08 & 0.11 & 0.70 & 3.57 & 4.02 & 0.18 & 5.14 \\ & 77.64 & 12.33 & 0.06 & 0.98 & 0.07 & 0.07 & 0.79 & 3.69 & 4.13 & 0.22 & 4.33 \\ & 77.67 & 12.40 & 0.06 & 1.00 & 0.08 & 0.08 & 0.71 & 3.71 & 4.06 & 0.21 & 4.37 \\ & 77.35 & 12.48 & 0.13 & 0.93 & 0.00 & 0.06 & 0.68 & 3.78 & 4.31 & 0.29 & 5.52 \\ & 77.58 & 12.26 & 0.01 & 1.01 & 0.04 & 0.10 & 0.73 & 3.76 & 4.24 & 0.25 & 4.59 \\ & 77.53 & 12.42 & 0.09 & 0.93 & 0.02 & 0.07 & 0.70 & 3.85 & 4.16 & 0.22 & 4.13 \\ & 77.75 & 12.35 & 0.04 & 1.02 & 0.03 & 0.05 & 0.78 & 3.55 & 4.22 & 0.21 & 4.92 \\ & 77.86 & 12.18 & 0.10 & 0.91 & 0.06 & 0.07 & 0.76 & 3.76 & 4.16 & 0.13 & 4.44 \\ & 77.62 & 12.44 & 0.05 & 0.97 & 0.03 & 0.07 & 0.75 & 3.87 & 4.03 & 0.17 & 4.73 \\ & 77.81 & 12.38 & 0.07 & 1.00 & 0.03 & 0.10 & 0.75 & 3.78 & 3.86 & 0.20 & 4.47 \\ & 77.49 & 12.30 & 0.09 & 1.03 & 0.07 & 0.07 & 0.80 & 3.75 & 4.17 & 0.22 & 4.64 \\ \text { mean } & 77.66 & 12.53 & 0.04 & 0.89 & 0.06 & 0.06 & 0.64 & 3.76 & 4.17 & 0.18 & 5.09 \\ \text { stdev } & \mathbf{7 . 6 6} & \mathbf{1 2 . 3 7} & \mathbf{0 . 0 7} & \mathbf{0 . 9 7} & \mathbf{0 . 0 5} & \mathbf{0 . 0 8} & \mathbf{0 . 7 3} & \mathbf{3 . 7 4} & \mathbf{4 . 1 3} & \mathbf{0 . 2 1} & \mathbf{4 . 7 0} \\ & & \mathbf{0 . 1 0} & \mathbf{0 . 0 3} & \mathbf{0 . 0 5} & \mathbf{0 . 0 3} & \mathbf{0 . 0 2} & \mathbf{0 . 0 5} & \mathbf{0 . 0 9} & \mathbf{0 . 1 2} & \mathbf{0 . 0 4} & \mathbf{0 . 4 0}\end{array}$
$\mathrm{n}=\quad 12$

Downer 6

\begin{tabular}{|c|c|c|c|c|c|c|c|c|c|c|c|}
\hline & $\mathrm{SiO}_{2}$ & $\mathrm{Al}_{2} \mathrm{O}_{3}$ & $\mathrm{TiO}_{2}$ & $\mathrm{FeO}$ & $\mathrm{MnO}$ & $\mathrm{MgO}$ & $\mathrm{CaO}$ & $\mathrm{Na}_{2} \mathrm{O}$ & $\mathrm{K}_{2} \mathrm{O}$ & $\mathrm{Cl}$ & $\mathrm{H}_{2} \mathrm{O}$ \\
\hline & 77.41 & 12.33 & 0.11 & 1.28 & 0.01 & 0.09 & 0.86 & 3.57 & 4.10 & 0.24 & 5.01 \\
\hline & 76.70 & 12.70 & 0.18 & 1.22 & 0.10 & 0.14 & 1.06 & 3.99 & 3.65 & 0.26 & 4.35 \\
\hline & 76.97 & 12.44 & 0.18 & 1.25 & 0.00 & 0.16 & 1,07 & 4.02 & 3.70 & 0.22 & 3.72 \\
\hline & 77.62 & 12.15 & 0.12 & 1.11 & 0.02 & 0.08 & 0.97 & 3.81 & 3.94 & 0.18 & 4.82 \\
\hline & 77.22 & 12.19 & 0.16 & 1.35 & 0.02 & 0.12 & 1.00 & 3.75 & 3.94 & 0.25 & 4.92 \\
\hline & 76.83 & 12.45 & 0.18 & 1.12 & 0.06 & 0.16 & 1.08 & 3.91 & 3.94 & 0.27 & 3.81 \\
\hline & 77.34 & 12.51 & 0.13 & 1.13 & 0.05 & 0.12 & 0.99 & 3.92 & 3.61 & 0.20 & 4.79 \\
\hline & 76.79 & 12.81 & 0.13 & 1.22 & 0.03 & 0.13 & 1.09 & 4.10 & 3.45 & 0.26 & 5.08 \\
\hline & 77.47 & 12.25 & 0.18 & 1.35 & 0.00 & 0.08 & 0.89 & 3.69 & 3.86 & 0.23 & 4.84 \\
\hline & 77.68 & 12.07 & 0.11 & 1.24 & 0.02 & 0.10 & 0.97 & 3.63 & 3.94 & 0.23 & 4.29 \\
\hline & 76.91 & 12.79 & 0.12 & 1.18 & 0.04 & 0.16 & 1.16 & 3.90 & 3.52 & 0.23 & 4.52 \\
\hline mean & 77.18 & 12.43 & 0.14 & 1.22 & 0.03 & 0.12 & 1.01 & 3.84 & 3.79 & 0.23 & 4.56 \\
\hline stdev & 0.35 & 0.26 & 0.03 & 0.08 & 0.03 & 0.03 & 0.09 & 0.17 & 0.21 & 0.03 & 0.47 \\
\hline $\mathrm{n}=$ & 11 & & & & & & & & & & \\
\hline \multicolumn{12}{|c|}{ Downer 7} \\
\hline & $\mathrm{SiO}_{2}$ & $\mathrm{Al}_{2} \mathrm{O}_{3}$ & $\mathrm{TiO}_{2}$ & $\mathrm{FeO}$ & $\mathrm{MnO}$ & $\mathrm{MgO}$ & $\mathrm{CaO}$ & $\mathrm{Na}_{2} \mathrm{O}$ & $\mathrm{K}_{2} \mathrm{O}$ & $\mathrm{Cl}$ & $\mathrm{H}_{2} \mathrm{O}$ \\
\hline & 77.78 & 12.30 & 0.10 & 1.02 & 0.02 & 0.09 & 0.81 & 3.63 & 4.07 & 0.17 & 3.93 \\
\hline & 76.47 & 12.68 & 0.13 & 1.26 & 0.11 & 0.13 & 1.10 & 4.25 & 3.63 & 0.23 & 3.26 \\
\hline & 77.58 & 12.17 & 0.14 & 1.24 & 0.01 & 0.09 & 0.88 & 3.76 & 3.89 & 0.23 & 4.37 \\
\hline & 77.42 & 12.52 & 0.09 & 0.86 & 0.00 & 0.03 & 0.74 & 3.34 & 4.70 & 0.30 & 2.44 \\
\hline & 77.96 & 12.38 & 0.08 & 0.96 & 0.07 & 0.09 & 0.74 & 3.58 & 3.93 & 0.19 & 4.44 \\
\hline & 77.71 & 12.13 & 0.12 & 1.00 & 0.03 & 0.08 & 0.76 & 3.87 & 4.01 & 0.28 & 3,47 \\
\hline & 77.57 & 12.53 & 0.00 & 0.72 & 0.03 & 0.05 & 0.75 & 3.35 & 4.71 & 0.28 & 3.03 \\
\hline & 77.46 & 12.40 & 0.10 & 1.00 & 0.04 & 0.09 & 0.88 & 3.78 & 4.00 & 0.24 & 3.95 \\
\hline & 77.85 & 12.26 & 0.14 & 1.05 & 0.06 & 0.14 & 0.98 & 3.77 & 3.52 & 0.24 & 4.16 \\
\hline & 77.95 & 12.20 & 0.19 & 1.05 & 0.03 & 0.16 & 1.01 & 3.72 & 3.46 & 0.22 & 5.02 \\
\hline & 77.33 & 12.61 & 0.07 & 1.03 & 0.04 & 0.06 & 0.67 & 3.79 & 4.20 & 0.20 & 2.93 \\
\hline & 77.55 & 12.38 & 0.12 & 1.24 & 0.00 & 0.08 & 0.87 & 3.68 & 3.91 & 0.18 & 4.65 \\
\hline mean & 77.55 & 12.38 & 0.11 & 1.04 & 0.04 & 0.09 & 0.85 & 3.71 & 4.00 & 0.23 & 3.80 \\
\hline stdev & 0.40 & 0.18 & 0.05 & 0.16 & 0.03 & 0.04 & 0.13 & 0.24 & 0.40 & 0.04 & 0.78 \\
\hline $\mathrm{n}=$ & 12 & & & & & & & & & & \\
\hline \multicolumn{12}{|c|}{$83 / 2(V 17 / 307993)$} \\
\hline & $\mathrm{SiO}_{2}$ & $\mathrm{Al}_{2} \mathrm{O}_{3}$ & $\mathrm{TiO}_{2}$ & $\mathrm{FeO}$ & $\mathrm{MnO}$ & $\mathrm{MgO}$ & $\mathrm{CaO}$ & $\mathrm{Na}_{2} \mathrm{O}$ & $\mathrm{K}_{2} \mathrm{O}$ & $\mathrm{Cl}$ & $\mathrm{H}_{2} \mathrm{O}$ \\
\hline & 77.83 & 12.31 & 0.08 & 1.03 & 0.00 & 0.08 & 0.85 & 3.78 & 3.77 & 0.26 & 3.26 \\
\hline & 77.42 & 12.41 & 0.10 & 1.15 & 0.00 & 0.07 & 0.84 & 3.82 & 3.87 & 0.31 & 3.4 \\
\hline & & 12.24 & 0.02 & 1.06 & 0.06 & 0.09 & 0.94 & 3.89 & 3.80 & 0.28 & 89 \\
\hline
\end{tabular}




$\begin{array}{llllllllllll} & 77.70 & 12.31 & 0.10 & 1.13 & 0.03 & 0.09 & 0.87 & 3.83 & 3.66 & 0.27 & 3.59 \\ & 77.86 & 12.35 & 0.10 & 1.04 & 0.01 & 0.07 & 0.82 & 3.73 & 3.78 & 0.24 & 3.66 \\ & 78.01 & 12.14 & 0.04 & 1.05 & 0.09 & 0.08 & 0.88 & 3.72 & 3.78 & 0.21 & 4.38 \\ & 77.84 & 12.33 & 0.16 & 1.02 & 0.02 & 0.08 & 0.80 & 3.84 & 3.70 & 0.22 & 3.3 \\ & 77.84 & 12.41 & 0.05 & 1.12 & 0.05 & 0.07 & 0.88 & 3.70 & 3.68 & 0.20 & 3.7 \\ & 78.04 & 12.38 & 0.07 & 0.95 & 0.04 & 0.09 & 0.86 & 3.77 & 3.59 & 0.20 & 3.95 \\ & 77.53 & 12.53 & 0.07 & 1.01 & 0.00 & 0.08 & 0.80 & 3.91 & 3.84 & 0.23 & 3.32 \\ & 77.39 & 12.56 & 0.05 & 1.04 & 0.05 & 0.10 & 0.87 & 3.79 & 3.88 & 0.27 & 3.64 \\ \text { mean } & \mathbf{7 7 . 7 3} & \mathbf{1 2 . 3 6} & \mathbf{0 . 0 8} & \mathbf{1 . 0 5} & \mathbf{0 . 0 3} & \mathbf{0 . 0 8} & \mathbf{0 . 8 5} & \mathbf{3 . 8 0} & \mathbf{3 . 7 6} & \mathbf{0 . 2 4} & \mathbf{3 . 5 5} \\ \text { stdev } & \mathbf{0 . 2 2} & \mathbf{0 . 1 2} & \mathbf{0 . 0 4} & \mathbf{0 . 0 6} & \mathbf{0 . 0 3} & \mathbf{0 . 0 1} & \mathbf{0 . 0 4} & \mathbf{0 . 0 7} & \mathbf{0 . 0 9} & \mathbf{0 . 0 4} & \mathbf{0 . 3 9}\end{array}$

\begin{tabular}{|c|c|c|c|c|c|c|c|c|c|c|c|}
\hline & $\mathrm{SiO}_{2}$ & $\mathrm{Al}_{2} \mathrm{O}_{3}$ & $\mathrm{TiO}_{2}$ & $\mathrm{FeO}$ & $\mathrm{MnO}$ & $\mathrm{MgO}$ & $\mathrm{CaO}$ & $\mathrm{Na}_{2} \mathrm{O}$ & $\mathrm{K}_{2} \mathrm{O}$ & $\mathrm{Cl}$ & $\mathrm{H}_{2} \mathrm{O}$ \\
\hline & 76.84 & 12.73 & 0.19 & 1.20 & 0.07 & 0.17 & 1.16 & 3.85 & 3.60 & 0.20 & 3.91 \\
\hline & 77.72 & 12.47 & 0.07 & 1.00 & 0.06 & 0.07 & 0.83 & 3.81 & 3.79 & 0.19 & 3.6 \\
\hline & 77.04 & 12.59 & 0.18 & 1.30 & 0.07 & 0.16 & 1.20 & 3.63 & 3.61 & 0.23 & 4.28 \\
\hline & 77.82 & 12.41 & 0.09 & 1.13 & 0.03 & 0.17 & 1.12 & 3.47 & 3.51 & 0.25 & 3.66 \\
\hline & 77.88 & 12.21 & 0.11 & 1.12 & 0.05 & 0.17 & 1.03 & 3.65 & 3.57 & 0.22 & 3.49 \\
\hline & 77.42 & 12.53 & 0.16 & 1.31 & 0.05 & 0.19 & 1.28 & 3.55 & 3.23 & 0.28 & 3.45 \\
\hline & 76.87 & 12.74 & 0.14 & 1.23 & 0.04 & 0.14 & 1.09 & 3.93 & 3.61 & 0.22 & 3.83 \\
\hline & 77.37 & 12.76 & 0.10 & 0.97 & 0.01 & 0.05 & 0.80 & 3.75 & 4.06 & 0.12 & 3.58 \\
\hline & 77.83 & 12.32 & 0.13 & 1.26 & 0.00 & 0.16 & 1.13 & 3.64 & 3.25 & 0.28 & 4.32 \\
\hline & 77.01 & 12.58 & 0.12 & 1.46 & 0.05 & 0.21 & 1.31 & 3.60 & 3.50 & 0.16 & 3.45 \\
\hline mean & 77.38 & 12.53 & 0.13 & 1.20 & 0.04 & 0.15 & 1.09 & 3.69 & 3.57 & 0.21 & 3.76 \\
\hline stdev & 0.42 & 0.18 & 0.04 & 0.15 & 0.02 & 0.05 & 0.17 & 0.14 & 0.24 & 0.05 & 0.32 \\
\hline $\mathrm{n}=$ & 10 & & & & & & & & & & \\
\hline \multicolumn{12}{|l|}{$83 / 4$} \\
\hline & $\mathrm{SiO}_{2}$ & $\mathrm{Al}_{2} \mathrm{O}_{3}$ & $\mathrm{TiO}_{2}$ & $\mathrm{FeO}$ & $\mathrm{MnO}$ & $\mathrm{MgO}$ & $\mathrm{CaO}$ & $\mathrm{Na}_{2} \mathrm{O}$ & $\mathrm{K}_{2} \mathrm{O}$ & $\mathrm{Cl}$ & $\mathrm{H}_{2} \mathrm{O}$ \\
\hline & 77.84 & 12.46 & 0.10 & 0.97 & 0.03 & 0.08 & 0.87 & 3.71 & 3.74 & 0.19 & 4.11 \\
\hline & 77.41 & 12.47 & 0.11 & 1.22 & 0.00 & 0.14 & 1.22 & 3.57 & 3.65 & 0.22 & 3.75 \\
\hline & 77.96 & 12.30 & 0.16 & 1.17 & 0.06 & 0.14 & 1.14 & 3.21 & 3.58 & 0.28 & 3.71 \\
\hline & 77.88 & 12.37 & 0.14 & 1.03 & 0.00 & 0.10 & 0.86 & 3.64 & 3.74 & 0.25 & 4.58 \\
\hline & 77.72 & 12.29 & 0.12 & 1.00 & 0.07 & 0.08 & 0.82 & 3.88 & 3.76 & 0.25 & 3.95 \\
\hline & 77.56 & 12.38 & 0.15 & 1.17 & 0.05 & 0.16 & 1.16 & 3.52 & 3.66 & 0.21 & 4.02 \\
\hline & 77.88 & 12.46 & 0.08 & 1.05 & 0.02 & 0.15 & 1.00 & 3.61 & 3.54 & 0.20 & 4.25 \\
\hline & 77.85 & 12.22 & 0.14 & 1.12 & 0.06 & 0.17 & 1.11 & 3.56 & 3.55 & 0.23 & 4.2 \\
\hline & 77.48 & 12.46 & 0.20 & 1.14 & 0.04 & 0.12 & 1.19 & 3.77 & 3.43 & 0.17 & 3.84 \\
\hline & 76.49 & 13.14 & 0.15 & 1.28 & 0.07 & 0.14 & 1.32 & 3.83 & 3.43 & 0.16 & 4.27 \\
\hline mean & 77.61 & 12.45 & 0.13 & 1.12 & 0.04 & 0.13 & 1.07 & 3.63 & 3.61 & 0.21 & 4.07 \\
\hline stdev & 0.44 & 0.26 & 0.03 & 0.10 & 0.03 & 0.03 & 0.17 & 0.19 & 0.12 & 0.04 & 0.27 \\
\hline
\end{tabular}

$83 / 5$

$\begin{array}{lllllllllll}\mathrm{SiO}_{2} & \mathrm{Al}_{2} \mathrm{O}_{3} & \mathrm{TiO}_{2} & \mathrm{FeO} & \mathrm{MnO} & \mathrm{MgO} & \mathrm{CaO} & \mathrm{Na}_{2} \mathrm{O} & \mathrm{K}_{2} \mathrm{O} & \mathrm{Cl} & \mathrm{H}_{2} \mathrm{O} \\ 77.48 & 12.41 & 0.07 & 1.13 & 0.16 & 0.09 & 0.92 & 3.69 & 3.79 & 0.26 & 3.7 \\ 77.79 & 12.62 & 0.10 & 1.00 & 0.04 & 0.06 & 0.84 & 3.56 & 3.80 & 0.19 & 4.2 \\ 77.42 & 12.41 & 0.05 & 1.03 & 0.02 & 0.10 & 0.93 & 3.76 & 3.99 & 0.28 & 3.02 \\ 77.72 & 12.55 & 0.15 & 1.03 & 0.02 & 0.01 & 0.86 & 3.58 & 3.91 & 0.17 & 3.89 \\ 77.39 & 12.60 & 0.10 & 1.09 & 0.02 & 0.07 & 0.88 & 3.69 & 3.92 & 0.25 & 4.26 \\ 77.99 & 12.43 & 0.04 & 1.01 & 0.09 & 0.12 & 0.89 & 3.47 & 3.70 & 0.24 & 4.98 \\ 77.01 & 12.51 & 0.13 & 1.10 & 0.11 & 0.08 & 0.88 & 4.05 & 3.89 & 0.23 & 3.65 \\ 77.73 & 12.32 & 0.10 & 1.10 & 0.06 & 0.09 & 0.90 & 3.53 & 3.94 & 0.23 & 3.95 \\ 77.50 & 12.23 & 0.11 & 1.08 & 0.03 & 0.09 & 0.82 & 3.92 & 3.97 & 0.25 & 3.28 \\ 77.89 & 12.30 & 0.04 & 0.99 & 0.02 & 0.07 & 0.82 & 3.56 & 4.12 & 0.19 & 4.6 \\ 77.53 & 12.55 & 0.14 & 1.06 & 0.03 & 0.08 & 0.88 & 3.60 & 3.90 & 0.23 & 4.19 \\ 77.67 & 12.50 & 0.11 & 0.94 & 0.02 & 0.08 & 0.83 & 3.67 & 3.97 & 0.21 & 3.69 \\ \mathbf{7 7 . 5 9} & \mathbf{1 2 . 4 5} & \mathbf{0 . 1 0} & \mathbf{1 . 0 5} & \mathbf{0 . 0 5} & \mathbf{0 . 0 8} & \mathbf{0 . 8 7} & \mathbf{3 . 6 7} & \mathbf{3 . 9 1} & \mathbf{0 . 2 3} & \mathbf{3 . 9 5} \\ \mathbf{0 . 2 6} & \mathbf{0 . 1 2} & \mathbf{0 . 0 4} & \mathbf{0 . 0 6} & \mathbf{0 . 0 5} & \mathbf{0 . 0 3} & \mathbf{0 . 0 4} & \mathbf{0 . 1 7} & \mathbf{0 . 1 1} & \mathbf{0 . 0 3} & \mathbf{0 . 5 4}\end{array}$

$\begin{array}{ll}\text { stdev } & \mathbf{0 . 2} \\ \mathrm{n}= & 12\end{array}$

$83 / 6$

$\begin{array}{lllllllllll}\mathrm{SiO}_{2} & \mathrm{Al}_{2} \mathrm{O}_{3} & \mathrm{TiO}_{2} & \mathrm{FeO} & \mathrm{MnO} & \mathrm{MgO} & \mathrm{CaO} & \mathrm{Na}_{2} \mathrm{O} & \mathrm{K}_{2} \mathrm{O} & \mathrm{Cl} & \mathrm{H}_{2} \mathrm{O} \\ 77.65 & 12.46 & 0.08 & 1.07 & 0.00 & 0.10 & 0.90 & 3.76 & 3.76 & 0.22 & 5.37\end{array}$




$\begin{array}{llllllllllll} & 77.79 & 12.40 & 0.11 & 0.88 & 0.05 & 0.07 & 0.88 & 3.78 & 3.83 & 0.20 & 4.22 \\ & 77.68 & 12.58 & 0.09 & 1.07 & 0.02 & 0.06 & 0.89 & 3.72 & 3.66 & 0.22 & 4.38 \\ & 77.64 & 12.45 & 0.12 & 1.00 & 0.05 & 0.07 & 0.83 & 3.73 & 3.93 & 0.19 & 4.53 \\ 77.62 & 12.38 & 0.12 & 1.11 & 0.03 & 0.09 & 0.89 & 3.62 & 3.91 & 0.21 & 3.89 \\ & 77.39 & 12.75 & 0.01 & 1.02 & 0.03 & 0.12 & 0.86 & 3.87 & 3.77 & 0.18 & 5.18 \\ 77.55 & 12.44 & 0.14 & 1.07 & 0.02 & 0.08 & 0.80 & 3.76 & 3.90 & 0.24 & 4.83 \\ & 77.89 & 12.52 & 0.12 & 1.03 & 0.00 & 0.07 & 0.81 & 3.57 & 3.77 & 0.24 & 4.45 \\ & 77.52 & 12.32 & 0.14 & 1.03 & 0.01 & 0.08 & 0.82 & 3.96 & 3.83 & 0.28 & 4.22 \\ & 77.64 & 12.41 & 0.12 & 1.09 & 0.04 & 0.09 & 0.91 & 3.66 & 3.84 & 0.18 & 3.66 \\ & 77.37 & 12.58 & 0.06 & 1.04 & 0.01 & 0.11 & 0.98 & 3.73 & 3.83 & 0.27 & 4.3 \\ & 77.54 & 12.57 & 0.17 & 1.09 & 0.05 & 0.10 & 0.90 & 3.53 & 3.76 & 0.28 & 4.71 \\ \text { mean } & \mathbf{7 7 . 6 1} & \mathbf{1 2 . 4 9} & \mathbf{0 . 1 1} & \mathbf{1 . 0 4} & \mathbf{0 . 0 3} & \mathbf{0 . 0 9} & \mathbf{0 . 8 7} & \mathbf{3 . 7 2} & \mathbf{3 . 8 2} & \mathbf{0 . 2 3} & \mathbf{4 . 4 8} \\ \text { stdev } & \mathbf{0 . 1 5} & \mathbf{0 . 1 2} & \mathbf{0 . 0 4} & \mathbf{0 . 0 6} & \mathbf{0 . 0 2} & \mathbf{0 . 0 2} & \mathbf{0 . 0 5} & \mathbf{0 . 1 2} & \mathbf{0 . 0 8} & \mathbf{0 . 0 4} & \mathbf{0 . 4 9} \\ \text { n= } & 12 & & & & & & & & & & \end{array}$

$83 / 7$

$\begin{array}{lllllllllll}\mathrm{SiO}_{2} & \mathrm{Al}_{2} \mathrm{O}_{3} & \mathrm{TiO}_{2} & \mathrm{FeO} & \mathrm{MnO} & \mathrm{MgO} & \mathrm{CaO} & \mathrm{Na}_{2} \mathrm{O} & \mathrm{K}_{2} \mathrm{O} & \mathrm{Cl} & \mathrm{H}_{2} \mathrm{O} \\ 78.57 & 12.21 & 0.03 & 0.50 & 0.02 & 0.07 & 0.86 & 3.74 & 3.73 & 0.28 & 9.4 \\ 77.74 & 12.44 & 0.04 & 0.97 & 0.05 & 0.08 & 0.93 & 3.95 & 3.54 & 0.26 & 3.19 \\ 77.59 & 12.49 & 0.11 & 1.04 & 0.08 & 0.08 & 0.89 & 3.78 & 3.67 & 0.26 & 2.58 \\ 77.36 & 12.39 & 0.06 & 1.17 & 0.09 & 0.08 & 0.91 & 3.88 & 3.79 & 0.26 & 1.8 \\ 77.62 & 12.42 & 0.12 & 1.03 & 0.02 & 0.06 & 0.97 & 3.90 & 3.59 & 0.27 & 2.67 \\ 77.96 & 12.34 & 0.08 & 0.96 & 0.00 & 0.08 & 0.89 & 3.76 & 3.69 & 0.24 & 3.45 \\ 77.80 & 12.54 & 0.08 & 0.71 & 0.01 & 0.06 & 0.94 & 3.90 & 3.69 & 0.27 & 2.87 \\ 77.61 & 12.43 & 0.10 & 0.93 & 0.04 & 0.09 & 0.94 & 3.85 & 3.72 & 0.28 & 2.39 \\ 78.07 & 12.30 & 0.07 & 1.04 & 0.01 & 0.08 & 0.92 & 3.87 & 3.41 & 0.23 & 2.58 \\ 77.63 & 12.28 & 0.07 & 0.99 & 0.06 & 0.10 & 0.98 & 3.89 & 3.70 & 0.30 & 2.69 \\ 77.90 & 12.35 & 0.09 & 0.72 & 0.00 & 0.08 & 0.86 & 4.01 & 3.76 & 0.23 & 2.89 \\ 77.60 & 12.22 & 0.11 & 1.06 & 0.01 & 0.09 & 0.92 & 3.83 & 3.87 & 0.29 & 2.49 \\ \mathbf{7 7 . 7 9} & \mathbf{1 2 . 3 7} & \mathbf{0 . 0 8} & \mathbf{0 . 9 3} & \mathbf{0 . 0 3} & \mathbf{0 . 0 8} & \mathbf{0 . 9 2} & \mathbf{3 . 8 6} & \mathbf{3 . 6 8} & \mathbf{0 . 2 6} & \mathbf{3 . 2 5} \\ \mathbf{0 . 3 1} & \mathbf{0 . 1 0} & \mathbf{0 . 0 3} & \mathbf{0 . 1 9} & \mathbf{0 . 0 3} & \mathbf{0 . 0 1} & \mathbf{0 . 0 4} & \mathbf{0 . 0 8} & \mathbf{0 . 1 2} & \mathbf{0 . 0 2} & \mathbf{1 . 9 8} \\ & & & & & & & & & & \end{array}$

$\begin{array}{ll}\text { stdev } & \mathbf{0 . 3} \\ \mathrm{n}= & 12\end{array}$

$83 / 8$

$\begin{array}{lllllllllll}\mathrm{SiO}_{2} & \mathrm{Al}_{2} \mathrm{O}_{3} & \mathrm{TiO}_{2} & \mathrm{FeO} & \mathrm{MnO} & \mathrm{MgO} & \mathrm{CaO} & \mathrm{Na}_{2} \mathrm{O} & \mathrm{K}_{2} \mathrm{O} & \mathrm{Cl} & \mathrm{H}_{2} \mathrm{O} \\ 77.83 & 12.61 & 0.10 & 1.04 & 0.08 & 0.08 & 0.84 & 3.62 & 3.56 & 0.24 & 2.59 \\ 77.83 & 12.32 & 0.07 & 0.90 & 0.04 & 0.09 & 0.87 & 3.90 & 3.69 & 0.28 & 2.39 \\ 77.90 & 12.39 & 0.08 & 0.91 & 0.05 & 0.07 & 0.95 & 3.93 & 3.55 & 0.17 & 2.82 \\ 77.82 & 12.36 & 0.10 & 1.06 & 0.02 & 0.09 & 1.01 & 3.86 & 3.40 & 0.27 & 2.69 \\ 78.01 & 12.26 & 0.07 & 0.91 & 0.00 & 0.09 & 0.96 & 3.90 & 3.58 & 0.22 & 2.49 \\ 77.62 & 12.41 & 0.10 & 1.04 & 0.09 & 0.08 & 0.97 & 3.91 & 3.55 & 0.23 & 2.62 \\ 77.92 & 12.22 & 0.07 & 1.11 & 0.05 & 0.07 & 0.93 & 3.90 & 3.49 & 0.23 & 2.39 \\ 77.42 & 12.64 & 0.08 & 1.05 & 0.03 & 0.10 & 0.90 & 3.87 & 3.63 & 0.27 & 2.57 \\ 77.44 & 12.33 & 0.12 & 1.02 & 0.06 & 0.09 & 0.93 & 4.06 & 3.56 & 0.38 & 3.03 \\ 77.73 & 12.30 & 0.09 & 0.94 & 0.09 & 0.09 & 0.97 & 3.86 & 3.60 & 0.33 & 2.4 \\ 77.66 & 12.23 & 0.10 & 1.06 & 0.04 & 0.09 & 0.95 & 3.86 & 3.74 & 0.27 & 1.95 \\ 77.81 & 12.38 & 0.08 & 0.80 & 0.06 & 0.07 & 0.92 & 3.86 & 3.76 & 0.26 & 2.86 \\ \mathbf{7 7 . 7 5} & \mathbf{1 2 . 3 7} & \mathbf{0 . 0 9} & \mathbf{0 . 9 9} & \mathbf{0 . 0 5} & \mathbf{0 . 0 9} & \mathbf{0 . 9 3} & \mathbf{3 . 8 8} & \mathbf{3 . 5 9} & \mathbf{0 . 2 6} & \mathbf{2 . 5 7} \\ \mathbf{0 . 1 8} & \mathbf{0 . 1 3} & \mathbf{0 . 0 2} & \mathbf{0 . 0 9} & \mathbf{0 . 0 3} & \mathbf{0 . 0 1} & \mathbf{0 . 0 5} & \mathbf{0 . 1 0} & \mathbf{0 . 1 0} & \mathbf{0 . 0 5} & \mathbf{0 . 2 8} \\ \mathbf{7 2} & & & & & & & & & & \end{array}$

$\begin{array}{llllllllllll} & \mathrm{SiO}_{2} & \mathrm{Al}_{2} \mathrm{O}_{3} & \mathrm{TiO}_{2} & \mathrm{FeO} & \mathrm{MnO} & \mathrm{MgO} & \mathrm{CaO} & \mathrm{Na}_{2} \mathrm{O} & \mathrm{K}_{2} \mathrm{O} & \mathrm{Cl} & \mathrm{H}_{2} \mathrm{O} \\ & & & & & & & & & & & \\ & 77.86 & 12.18 & 0.16 & 1.05 & 0.10 & 0.05 & 0.92 & 3.79 & 3.63 & 0.26 & 2.8 \\ 78.18 & 12.35 & 0.08 & 0.55 & 0.01 & 0.05 & 0.90 & 3.88 & 3.76 & 0.24 & 3.27 \\ 77.72 & 12.46 & 0.08 & 1.04 & 0.07 & 0.09 & 0.97 & 3.69 & 3.65 & 0.23 & 2.95 \\ 78.16 & 12.22 & 0.08 & 0.95 & 0.08 & 0.05 & 0.90 & 3.91 & 3.46 & 0.17 & 2.74 \\ 77.69 & 12.33 & 0.10 & 1.00 & 0.08 & 0.07 & 0.97 & 3.88 & 3.65 & 0.24 & 2.65 \\ 77.60 & 12.43 & 0.09 & 1.14 & 0.00 & 0.07 & 0.93 & 3.89 & 3.63 & 0.23 & 2.74 \\ 77.63 & 12.37 & 0.09 & 1.04 & 0.01 & 0.08 & 0.94 & 3.89 & 3.68 & 0.26 & 2.27 \\ & 77.25 & 12.53 & 0.07 & 1.07 & 0.10 & 0.12 & 1.01 & 3.94 & 3.70 & 0.22 & 2.52 \\ & 77.47 & 12.65 & 0.08 & 1.00 & 0.06 & 0.08 & 0.98 & 3.92 & 3.55 & 0.19 & 2.32 \\ & 77.83 & 12.54 & 0.07 & 0.93 & 0.03 & 0.08 & 0.92 & 3.80 & 3.59 & 0.19 & 2.56 \\ \text { mean } & \mathbf{7 7 . 7 4} & \mathbf{1 2 . 4 1} & \mathbf{0 . 0 9} & \mathbf{0 . 9 8} & \mathbf{0 . 0 6} & \mathbf{0 . 0 8} & \mathbf{0 . 9 4} & \mathbf{3 . 8 6} & \mathbf{3 . 6 3} & \mathbf{0 . 2 2} & \mathbf{2 . 6 8} \\ \text { stdev } & \mathbf{0 . 2 9} & \mathbf{0 . 1 5} & \mathbf{0 . 0 3} & \mathbf{0 . 1 6} & \mathbf{0 . 0 4} & \mathbf{0 . 0 2} & \mathbf{0 . 0 4} & \mathbf{0 . 0 8} & \mathbf{0 . 0 8} & \mathbf{0 . 0 3} & \mathbf{0 . 2 9}\end{array}$


Lower Griffin Rd

$\begin{array}{llllllllllll} & \mathrm{SiO}_{2} & \mathrm{Al}_{2} \mathrm{O}_{3} & \mathrm{TiO}_{2} & \mathrm{FeO} & \mathrm{MnO} & \mathrm{MgO} & \mathrm{CaO} & \mathrm{Na}_{2} \mathrm{O} & \mathrm{K}_{2} \mathrm{O} & \mathrm{Cl} & \mathrm{H}_{2} \mathrm{O} \\ & & & & & & & & & & & \\ & 75.91 & 13.05 & 0.26 & 1.33 & 0.11 & 0.26 & 1.40 & 4.37 & 3.09 & 0.22 & 3.51 \\ 75.49 & 13.33 & 0.27 & 1.57 & 0.01 & 0.26 & 1.45 & 4.28 & 3.13 & 0.21 & 3.55 \\ & 77.69 & 12.42 & 0.14 & 1.05 & 0.01 & 0.11 & 0.95 & 3.92 & 3.48 & 0.24 & 3.74 \\ & 77.99 & 12.01 & 0.06 & 1.03 & 0.06 & 0.05 & 0.67 & 3.99 & 3.89 & 0.24 & 4.32 \\ & 76.95 & 12.52 & 0.21 & 1.29 & 0.02 & 0.16 & 1.09 & 4.08 & 3.47 & 0.21 & 3.99 \\ & 75.93 & 13.19 & 0.32 & 1.23 & 0.07 & 0.27 & 1.45 & 4.05 & 3.29 & 0.20 & 3.42 \\ & 75.65 & 13.31 & 0.27 & 1.40 & 0.11 & 0.26 & 1.59 & 4.13 & 3.03 & 0.24 & 3.41 \\ & 77.92 & 12.33 & 0.14 & 1.09 & 0.05 & 0.14 & 0.97 & 3.81 & 3.21 & 0.34 & 5.11 \\ & 76.18 & 13.08 & 0.26 & 1.37 & 0.00 & 0.27 & 1.42 & 4.05 & 3.18 & 0.19 & 4.65 \\ & 75.86 & 12.99 & 0.30 & 1.31 & 0.07 & 0.27 & 1.50 & 4.32 & 3.15 & 0.23 & 3.23 \\ & 76.03 & 13.13 & 0.27 & 1.30 & 0.09 & 0.25 & 1.54 & 4.10 & 3.06 & 0.23 & 3.31 \\ \text { mean } & 76.30 & 13.14 & 0.25 & 1.27 & 0.08 & 0.26 & 1.42 & 4.00 & 3.09 & 0.19 & 3.79 \\ \text { stdev } & \mathbf{7 6 . 4 9} & \mathbf{1 2 . 8 8} & \mathbf{0 . 2 3} & \mathbf{1 . 2 7} & \mathbf{0 . 0 6} & \mathbf{0 . 2 1} & \mathbf{1 . 2 9} & 4.09 & \mathbf{3 . 2 6} & \mathbf{0 . 2 3} & \mathbf{3 . 8 4} \\ & \mathbf{0 . 4 4} & \mathbf{0 . 0 8} & \mathbf{0 . 1 5} & \mathbf{0 . 0 4} & \mathbf{0 . 0 8} & \mathbf{0 . 2 9} & \mathbf{0 . 1 6} & \mathbf{0 . 2 5} & \mathbf{0 . 0 4} & \mathbf{0 . 5 8}\end{array}$

$n=12$

Upper Griffin Rd

$\begin{array}{lllllllllll}\mathrm{SiO}_{2} & \mathrm{Al}_{2} \mathrm{O}_{3} & \mathrm{TiO}_{2} & \mathrm{FeO} & \mathrm{MnO} & \mathrm{MgO} & \mathrm{CaO} & \mathrm{Na}_{2} \mathrm{O} & \mathrm{K}_{2} \mathrm{O} & \mathrm{Cl} & \mathrm{H}_{2} \mathrm{O} \\ 77.31 & 12.24 & 0.08 & 1.49 & 0.00 & 0.05 & 0.91 & 3.90 & 3.74 & 0.27 & 3.71 \\ 77.09 & 12.45 & 0.13 & 1.48 & 0.04 & 0.13 & 0.96 & 4.21 & 3.21 & 0.31 & 5.13 \\ 77.65 & 11.90 & 0.13 & 1.33 & 0.10 & 0.07 & 0.74 & 4.10 & 3.74 & 0.23 & 4.01 \\ 77.10 & 12.23 & 0.12 & 1.67 & 0.10 & 0.11 & 1.06 & 3.96 & 3.36 & 0.30 & 5.79 \\ 77.45 & 12.42 & 0.14 & 1.43 & 0.02 & 0.11 & 0.95 & 4.06 & 3.21 & 0.20 & 6.55 \\ 77.89 & 12.20 & 0.12 & 1.20 & 0.04 & 0.05 & 0.64 & 4.00 & 3.71 & 0.15 & 5.39 \\ 77.30 & 12.10 & 0.14 & 1.52 & 0.03 & 0.08 & 1.07 & 4.19 & 3.35 & 0.22 & 4.40 \\ 78.13 & 11.97 & 0.13 & 1.30 & 0.07 & 0.04 & 0.72 & 3.94 & 3.54 & 0.16 & 6.00 \\ 76.99 & 12.35 & 0.11 & 1.45 & 0.07 & 0.12 & 1.02 & 4.19 & 3.38 & 0.32 & 5.29 \\ 77.50 & 12.32 & 0.12 & 1.24 & 0.03 & 0.07 & 0.76 & 4.03 & 3.69 & 0.24 & 5.44 \\ 76.96 & 12.31 & 0.13 & 1.53 & 0.08 & 0.08 & 1.03 & 4.12 & 3.54 & 0.22 & 4.60 \\ 77.01 & 12.56 & 0.15 & 1.42 & 0.03 & 0.13 & 0.98 & 4.30 & 3.23 & 0.20 & 5.06 \\ 77.85 & 12.16 & 0.13 & 1.22 & 0.04 & 0.08 & 0.64 & 4.01 & 3.64 & 0.22 & 2.84 \\ \mathbf{7 7 . 4 0} & \mathbf{1 2 . 2 5} & \mathbf{0 . 1 2} & \mathbf{1 . 4 1} & \mathbf{0 . 0 5} & \mathbf{0 . 0 9} & \mathbf{0 . 8 8} & \mathbf{4 . 0 8} & \mathbf{3 . 4 9} & \mathbf{0 . 2 3} & \mathbf{4 . 9 4} \\ \mathbf{0 . 3 8} & \mathbf{0 . 1 9} & \mathbf{0 . 0 2} & \mathbf{0 . 1 4} & \mathbf{0 . 0 3} & \mathbf{0 . 0 3} & \mathbf{0 . 1 6} & \mathbf{0 . 1 2} & \mathbf{0 . 2 1} & \mathbf{0 . 0 5} & \mathbf{1 . 0 1} \\ \mathbf{. 3} & & & & & & & & & & \end{array}$

$\begin{array}{lllllllllll}\text { stdev } & 0.38 & 0.19 & 0.02 & 0.14 & 0.03 & 0.03 & 0.16 & 0.12 & 0.21 & 0.05\end{array}$

$\mathrm{n}=13$

Fordell

$\begin{array}{lllllllllll}\mathrm{SiO}_{2} & \mathrm{Al}_{2} \mathrm{O}_{3} & \mathrm{TiO}_{2} & \mathrm{FeO} & \mathrm{MnO} & \mathrm{MgO} & \mathrm{CaO} & \mathrm{Na}_{2} \mathrm{O} & \mathrm{K}_{2} \mathrm{O} & \mathrm{Cl} & \mathrm{H}_{2} \mathrm{O}\end{array}$

$\begin{array}{lllllllllll}77.94 & 12.12 & 0.05 & 0.98 & 0.06 & 0.05 & 0.62 & 4.05 & 3.86 & 0.25 & 4.24\end{array}$

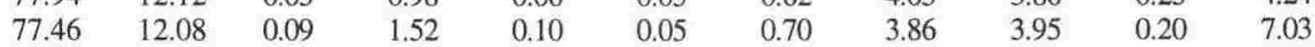

$\begin{array}{lllllllllll}78.14 & 12.04 & 0.11 & 1.02 & 0.01 & 0.06 & 0.60 & 4.02 & 3.74 & 0.25 & 5.29\end{array}$

$\begin{array}{lllllllllll}78.01 & 12.26 & 0.02 & 1.06 & 0.00 & 0.05 & 0.58 & 3.90 & 3.86 & 0.26 & 7.11\end{array}$

$\begin{array}{lllllllllll}77.72 & 12.18 & 0.05 & 1.14 & 0.07 & 0.03 & 0.59 & 4.08 & 3.82 & 0.31 & 4.49\end{array}$

$\begin{array}{lllllllllll}77.85 & 12.16 & 0.08 & 1.10 & 0.04 & 0.04 & 0.63 & 3.85 & 3.99 & 0.25 & 4.48\end{array}$

$\begin{array}{lllllllllll}77.32 & 12.26 & 0.17 & 1.22 & 0.03 & 0.10 & 0.73 & 4.04 & 3.85 & 0.27 & 2.64\end{array}$

$\begin{array}{lllllllllll}77.73 & 12.43 & 0.09 & 1.10 & 0.06 & 0.03 & 0.55 & 3.93 & 3.80 & 0.27 & 4.97\end{array}$

$\begin{array}{lllllllllll}78.09 & 11.99 & 0.09 & 1.23 & 0.04 & 0.09 & 0.68 & 3.92 & 3.68 & 0.18 & 6.46\end{array}$

$\begin{array}{lllllllllll}77.78 & 12.01 & 0.09 & 1.09 & 0.06 & 0.06 & 0.64 & 4.09 & 3.95 & 0.23 & 3.23\end{array}$

$\begin{array}{lllllllllll}77.52 & 12.17 & 0.12 & 1.35 & 0.05 & 0.08 & 0.78 & 4.09 & 3.67 & 0.14 & 2.56\end{array}$

$\begin{array}{lllllllllll}77.57 & 12.03 & 0.07 & 1.08 & 0.08 & 0.02 & 0.61 & 4.22 & 4.01 & 0.31 & 4.24\end{array}$

$\begin{array}{llllllllllll} & 77.80 & 12.28 & 0.05 & 1.01 & 0.05 & 0.05 & 0.51 & 3.90 & 4.13 & 0.21 & 4.99 \\ \text { mean } & 77.77 & \mathbf{1 2 . 1 6} & \mathbf{0 . 0 8} & \mathbf{1 . 1 5} & \mathbf{0 . 0 5} & \mathbf{0 . 0 6} & \mathbf{0 . 6 3} & \mathbf{4 . 0 0} & \mathbf{3 . 8 7} & \mathbf{0 . 2 4} & \mathbf{4 . 7 5} \\ \text { stdey } & \mathbf{0 . 2 5} & \mathbf{0 . 1 3} & \mathbf{0 . 0 4} & \mathbf{0 . 1 5} & \mathbf{0 . 0 3} & \mathbf{0 . 0 2} & \mathbf{0 . 0 8} & \mathbf{0 . 1 1} & \mathbf{0 . 1 3} & \mathbf{0 . 0 5} & \mathbf{1 . 4 8}\end{array}$

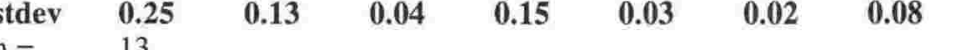




\section{Appendix 2}

\section{FE - TI OXIDE ANALYSES OF IGNIMBRITES}

Analyses represent individual crystals. A mean and standard deviation is presented for each sample (bold). Determined on a Jeol 733 Superprobe at Victoria University of Wellington using a $12 \mathrm{nA}$ current at $15 \mathrm{kV}$ and a $2 \mu \mathrm{m}$ beam diameter. Analytical $\mathrm{Fe}$ expressed as $\mathrm{FeO}$. $\mathrm{Fe}_{2} \mathrm{O}_{3}$ and $\mathrm{FeO}$ recalculated by stoichiometry on a ulvospinel basis (Stormer model). ${ }^{1}$ Analytical total. ${ }^{2}$ Recalculated total.

\begin{tabular}{|c|c|c|c|c|c|c|c|c|c|c|c|c|}
\hline & $\mathrm{SiO}_{2}$ & $\mathrm{TiO}_{2}$ & $\mathrm{Al}_{2} \mathrm{O}_{3}$ & $\mathrm{FeO}^{*}$ & $\mathrm{MnO}$ & $\mathrm{MgO}$ & $\mathrm{ZnO}$ & Total 1 & $\mathrm{Fe}_{2} \mathrm{O}_{3}$ & $\mathrm{FeO}$ & Total $^{2}$ & ulvosp. \\
\hline B 1 & \multicolumn{12}{|c|}{ Matahina Ignimbrite, Herepuru Rd () } \\
\hline & 0.04 & 8.05 & 1.16 & 84.16 & 0.99 & 0.33 & 0 & 94.72 & 52.13 & 37.25 & 99.95 & 0.24 \\
\hline & 0.16 & 8.06 & 1.64 & 84.98 & 0.7 & 0.43 & 0.28 & 96.26 & 52.36 & 37.87 & 101.5 & 0.24 \\
\hline & 0.15 & 12.72 & 1.97 & 78.13 & 0.5 & 0.69 & 0.08 & 94.23 & 40.98 & 41.26 & 98.35 & 0.39 \\
\hline & 0.02 & 6.04 & 1.79 & 85.13 & 0.43 & 0.39 & 0.14 & 93.93 & 54.98 & 35.66 & 99.45 & 0.18 \\
\hline & 0.14 & 8.54 & 1.6 & 82.03 & 0.72 & 0.54 & 0.15 & 93.72 & 49.66 & 37.34 & 98.7 & 0.26 \\
\hline & 0.09 & 13.93 & 1.4 & 80.31 & 0.74 & 0.62 & 0.19 & 97.28 & 49.66 & 37.34 & 98.7 & 0.26 \\
\hline & 0.11 & 10.32 & 1.54 & 82.92 & 0.58 & 0.51 & 0.25 & 96.22 & 47.96 & 39.77 & 101.04 & 0.30 \\
\hline & 0.08 & 9.25 & 2.83 & 82.12 & 0.59 & 1.34 & 0.32 & 96.53 & 49.32 & 37.74 & 101.47 & 0.27 \\
\hline & 0.21 & 11.41 & 2.55 & 80.31 & 0.51 & 0.77 & 0.35 & 96.11 & 44.22 & 40.52 & 100.54 & 0.35 \\
\hline & 0.13 & 16.41 & 2.31 & 75.89 & 0.46 & 0.94 & 0.18 & 96.32 & 34.63 & 44.73 & 99.79 & 0.50 \\
\hline & 0.12 & 9.44 & 3.01 & 82.72 & 0.51 & 0.62 & 0.12 & 96.54 & 48.2 & 39.35 & 101.37 & 0.29 \\
\hline & 0.38 & 8.45 & 1.34 & 84.33 & 0.51 & 0.48 & 0.03 & 95.53 & 50.88 & 38.54 & 100.62 & 0.25 \\
\hline & 0.56 & 5.84 & 1.57 & 87.39 & 0.46 & 0.29 & 0.25 & 96.37 & 56.05 & 36.96 & 101.98 & 0.17 \\
\hline
\end{tabular}

B 2 Ongatiti Ignimbrite, Kopaki Rd (S17/034985)

\begin{tabular}{|c|c|c|c|c|c|c|c|c|c|c|c|c|}
\hline & 0.1 & 11.36 & 1.4 & 80.2 & 0.63 & 0.67 & 0.24 & 94.6 & 44.88 & 39.82 & 99.1 & 0.34 \\
\hline & 0.13 & 10.86 & 1.38 & 80.27 & 0.61 & 0.77 & 0.28 & 94.28 & 45.72 & 39.13 & 98.86 & 0.32 \\
\hline & 0.08 & 11.48 & 1.38 & 80.71 & 0.71 & 0.49 & 0.27 & 95.12 & 45 & 40.22 & 99.63 & 0.34 \\
\hline & 0.12 & 11.1 & 1.26 & 81.02 & 0.58 & 0.65 & 0.1 & 94.82 & 45.72 & 39.88 & 99.4 & 0.33 \\
\hline & 0.07 & 11.13 & 1.42 & 79.04 & 0.58 & 0.57 & 0.2 & 93 & 44.18 & 39.29 & 97.43 & 0.34 \\
\hline & 0.13 & 11.23 & 1.54 & 79.58 & 0.63 & 0.53 & 0.53 & 94.17 & 44.48 & 39.56 & 98.63 & 0.34 \\
\hline & 0.11 & 11.51 & 1.45 & 80.21 & 0.58 & 0.62 & 0.27 & 94.75 & 44.57 & 40.1 & 99.22 & 0.34 \\
\hline mean & 0.11 & 11.24 & 1.40 & 80.15 & 0.62 & 0.61 & 0.27 & 94.39 & 44.94 & 39.71 & 98.90 & 0.33 \\
\hline stdev & 0.02 & 0.23 & 0.08 & 0.66 & 0.05 & 0.09 & 0.13 & 0.69 & 0.60 & 0.41 & 0.73 & 0 \\
\hline
\end{tabular}

B 3 Ongatiti Ignimbrite, type locality (S17/117100)

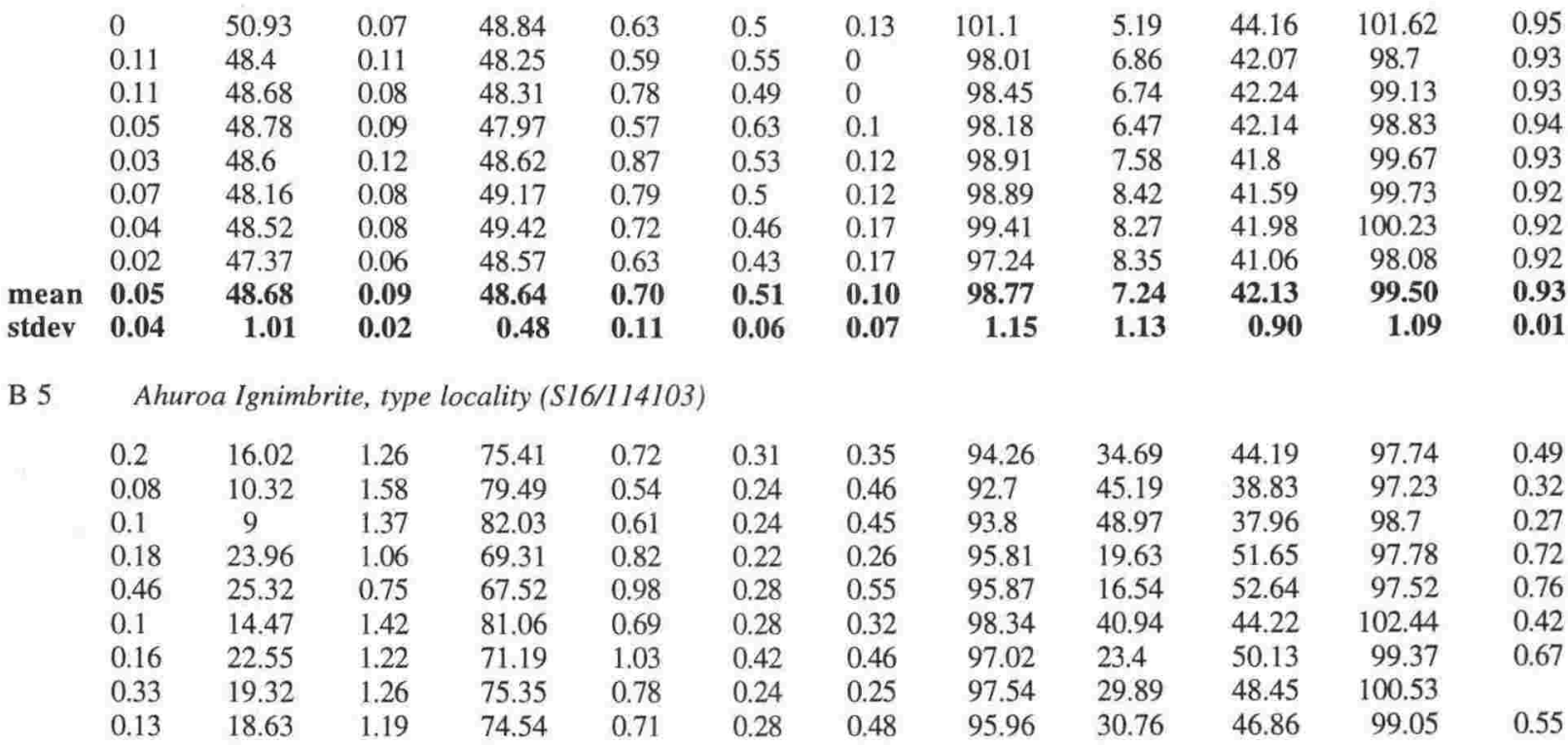


$\begin{array}{llllllllllll}0.13 & 39.65 & 0.34 & 53.87 & 1.34 & 0.36 & 0.39 & 96.07 & 22.67 & 33.47 & 98.35 & 0.77\end{array}$

B 6 Ahuroa Ignimbrite, Ranginui Rd (T17/403077)

\begin{tabular}{|c|c|c|c|c|c|c|c|c|c|c|}
\hline 0.16 & 18.07 & 1.31 & 76.56 & 1.16 & 0.6 & 0.21 & 98.08 & 33.47 & 46.45 & 101.43 \\
\hline 0.17 & 18.32 & 1.42 & 76.25 & 0.96 & 0.53 & 0.35 & 97.99 & 32.68 & 46.84 & 101.26 \\
\hline 0.1 & 18.22 & 1.41 & 75.24 & 1.07 & 0.56 & 0.26 & 96.87 & 32.27 & 46.21 & 100.1 \\
\hline 0.17 & 18.54 & 1.35 & 75.44 & 1.03 & 0.53 & 0.16 & 97.22 & 31.76 & 46.86 & 100.4 \\
\hline 0.14 & 18.88 & 1.42 & 74.34 & 1.1 & 0.48 & 0.38 & 96.73 & 30.64 & 46.77 & 99.8 \\
\hline 0.12 & 18.48 & 1.34 & 73.87 & 1.16 & 0.4 & 0.21 & 95.58 & 30.73 & 46.23 & 98.66 \\
\hline 0.18 & 18.25 & 1.38 & 74.1 & 0.98 & 0.46 & 0.09 & 95.42 & 30.94 & 46.26 & 98.52 \\
\hline 0.13 & 17.59 & 1.38 & 74.87 & 0.94 & 0.56 & 0.38 & 95.86 & 32.77 & 45.38 & 99.14 \\
\hline 0.15 & 18.29 & 1.38 & 75.08 & 1.05 & 0.52 & 0.26 & 96.72 & 31.91 & 46.38 & 99.91 \\
\hline 0.03 & 0.38 & 0.04 & 0.98 & 0.09 & 0.06 & 0.11 & 1.03 & 1.06 & 0.49 & 1.10 \\
\hline
\end{tabular}

B 7 Ongatiti Ignimbrite, Totman Rd (T15/484627)

\begin{tabular}{|c|c|c|c|c|c|c|c|c|c|c|c|c|}
\hline & 0.11 & 11.2 & 1.46 & 79.7 & 0.58 & 0.58 & 0.18 & 93.8 & 44.48 & 39.68 & 98.26 & 0.34 \\
\hline & 0.17 & 11.48 & 1.32 & 81.82 & 0.65 & 0.61 & 0.29 & 96.35 & 45.83 & 40.58 & 100.94 & 0.33 \\
\hline & 0.12 & 11.09 & 1.46 & 81.31 & 0.53 & 0.58 & 0.25 & 95.33 & 45.83 & 40.07 & 99.92 & 0.32 \\
\hline & 0.17 & 11.24 & 1.39 & 81.63 & 0.74 & 0.55 & 0.18 & 95.9 & 45.86 & 40.37 & 100.49 & 0.33 \\
\hline & 0.16 & 11.02 & 1.5 & 81.07 & 0.58 & 0.58 & 0.31 & 95.23 & 45.72 & 39.93 & 99.81 & 0.33 \\
\hline & 0.1 & 11.36 & 1.37 & 82.19 & 0.63 & 0.54 & 0.17 & 96.36 & 46.14 & 40.67 & 100.98 & 0.33 \\
\hline mean & 0.14 & 11.23 & 1.42 & 81.29 & 0.62 & 0.57 & 0.23 & 95.50 & 45.64 & 40.22 & 100.07 & 0.33 \\
\hline 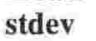 & 0.03 & 0.17 & 0.07 & 0.87 & 0.07 & 0.03 & 0.06 & 0.96 & 0.59 & 0.39 & 1.01 & 0.01 \\
\hline
\end{tabular}

B $8 \quad$ Lower ignimbrite, Lichfield Quarry (T16/588398)

$\begin{array}{llllllllllll}0.11 & 12.82 & 1.93 & 77.02 & 1.36 & 0.49 & 0.19 & 93.93 & 40.57 & 40.52 & 97.99 & 0.39 \\ 0.16 & 11.55 & 1.18 & 78.43 & 1 & 0.37 & 0.23 & 92.91 & 43.21 & 39.55 & 97.23 & 0.35 \\ 0.11 & 11.42 & 1.8 & 79.44 & 1.26 & 0.37 & 0.37 & 94.8 & 44.17 & 39.69 & 99.19 & 0.34 \\ 0.1 & 10.57 & 1.51 & 79.85 & 1.17 & 0.21 & 0.26 & 93.68 & 45.43 & 38.97 & 98.23 & 0.32 \\ 0.12 & 10.92 & 1.53 & 79.24 & 1.48 & 0.41 & 0.27 & 93.97 & 44.97 & 38.78 & 98.48 & 0.33 \\ 0.16 & 12.09 & 1.52 & 80.44 & 1.1 & 0.7 & 0.43 & 96.45 & 44.45 & 40.45 & 100.9 & 0.35 \\ 0.14 & 10.27 & 1.41 & 79.85 & 2.54 & 0.24 & 0.28 & 94.73 & 46.89 & 37.6 & 99.42 & 0.30 \\ 0.14 & 11.35 & 1.73 & 80.05 & 1.27 & 0.41 & 0.31 & 95.25 & 44.73 & 39.8 & 99.73 & 0.34 \\ & & & & & & & & & & & \\ 0.11 & 18.63 & 1.57 & 74.78 & 0.84 & 0.57 & 0.14 & 96.65 & 31.05 & 46.85 & 99.76 & 0.55 \\ 0.15 & 6.44 & 1.68 & 86.06 & 0.5 & 0.15 & 0.15 & 95.13 & 54.7 & 36.84 & 100.62 & 0.19\end{array}$

B 9 Whakamaru? Downer Rd (T16/646335)

\begin{tabular}{lcllllllllll}
0.12 & 14.8 & 1.31 & 75.85 & 0.77 & 1.02 & 0.32 & 94.2 & 37.71 & 41.91 & 97.98 & 0.44 \\
0.11 & \multicolumn{1}{c}{5} & 1.59 & 83.9 & 0.49 & 0.56 & 0.16 & 91.81 & 55.69 & 33.79 & 97.38 & 0.15 \\
0.16 & 7.16 & 1.56 & 83.36 & 0.62 & 0.57 & 0.15 & 93.57 & 52.44 & 36.17 & 98.83 & 0.21 \\
0.18 & 6.94 & 1.53 & 82.63 & 0.58 & 0.59 & 0.04 & 92.48 & 52.1 & 35.75 & 97.71 & 0.21 \\
0.06 & 6.54 & 1.6 & 84.31 & 0.72 & 0.41 & 0.36 & 94 & 52.09 & 35.76 & 97.7 & 0.21 \\
0.13 & 10.85 & 1.42 & 79.99 & 0.63 & 1.01 & 0.18 & 94.2 & 45.76 & 38.81 & 98.78 & 0.32 \\
0.08 & 9.24 & 1.36 & 80.4 & 0.51 & 0.78 & 0.27 & 92.64 & 47.98 & 37.22 & 97.45 & 0.28 \\
& & & & & & & & & & & \\
0.05 & 50.83 & 0.06 & 45.2 & 1.78 & 0.9 & 0.28 & 99.08 & 3.42 & 42.12 & 99.08 & 0.97 \\
0.01 & 46.34 & 0.2 & 49.16 & 1.34 & 1.3 & 0.03 & 98.37 & 12.42 & 37.99 & 99.62 & 0.88 \\
0.08 & 46.19 & 0.21 & 47.96 & 1.15 & 1.24 & 0.08 & 96.91 & 10.87 & 38.18 & 98 & 0.89
\end{tabular}

B 10 Whakamaru Ignimbrite, Western Bay Rd (T18/436647)

\begin{tabular}{|c|c|c|c|c|c|c|c|c|c|c|c|}
\hline 0.03 & 8.04 & 1.39 & 81.58 & 0.68 & 0.43 & 0.19 & 92.34 & 50.15 & 36.46 & 97.37 & 0.24 \\
\hline 0.07 & 7.87 & 1.45 & 80.96 & 0.61 & 0.38 & 0.46 & 91.81 & 49.86 & 36.09 & 96.81 & 0.24 \\
\hline 0 & 7.5 & 1.55 & 81.99 & 0.65 & 0.83 & 0.24 & 92.76 & 51.68 & 35.49 & 97.93 & 0.22 \\
\hline 0.23 & 6.86 & 1.84 & 82.05 & 1.03 & 0.51 & 0.37 & 92.88 & 51.96 & 35.3 & 98.09 & 0. \\
\hline 0.13 & 6.95 & 2.89 & 83.51 & 0.81 & 0.84 & 0.17 & 95.3 & 52.7 & 36.09 & 100.58 & \\
\hline 0.07 & 8.42 & 2.38 & 81.62 & 0.66 & 0.81 & 0.18 & 94.14 & 49.57 & 37.02 & 99.11 & \\
\hline 0.13 & 6.47 & 2.21 & 83.86 & 0.63 & 0.70 & 0.10 & 94.09 & 53.59 & 35.64 & 99.47 & \\
\hline 0.17 & 7.46 & 1.81 & 83.96 & 0.61 & 0.81 & 0.13 & 94.95 & 52.63 & 36.6 & 100.22 & \\
\hline 0.14 & 5.21 & 1.57 & 85.18 & 1.00 & 0.71 & 0.30 & 94.12 & 56.98 & 33.91 & 99.82 & \\
\hline mean 0.11 & 7.20 & 1.90 & 82.75 & 0.74 & 0.67 & 0.24 & 93.60 & 52.12 & 35.84 & 98.82 & 0 \\
\hline dev $\quad 0.07$ & 0.97 & 0.50 & 1.42 & 0.17 & 0.18 & 0.12 & 1.20 & 2.29 & 0.91 & 1.32 & \\
\hline 0.01 & 46.9 & 0.1 & 45.44 & 2.81 & 1.05 & 0.18 & 96.5 & 9.03 & 37.31 & 97.4 & \\
\hline 0.28 & 14.08 & 1.8 & 74.01 & 0.65 & 0.46 & 0.24 & 91.5 & 35.89 & 41.72 & 95.12 & \\
\hline
\end{tabular}


B 11 Waiotapu, Rawhiti Rd Quarry (U16/772211)

\begin{tabular}{|c|c|c|c|c|c|c|c|c|c|c|c|c|}
\hline & 0.13 & 13.41 & 0.71 & 77.02 & 1.37 & 0.38 & 0.39 & 93.39 & 40.38 & 40.69 & 97.46 & 0.39 \\
\hline & 0.11 & 13.13 & 0.71 & 78.17 & 1.23 & 0.4 & 0.27 & 94.01 & 41.48 & 40.84 & 98.18 & 0.38 \\
\hline & 0.15 & 13.45 & 0.74 & 78.17 & 0.85 & 0.29 & 0.26 & 93.89 & 40.53 & 41.7 & 97.97 & 0.40 \\
\hline & 0.09 & 13.9 & 1.22 & 79.28 & 0.9 & 0.32 & 0.19 & 95.89 & 40.64 & 42.71 & 99.97 & 0.41 \\
\hline & 0.16 & 13 & 0.86 & 78.03 & 1.33 & 0.26 & 0.32 & 93.96 & 41.31 & 40.86 & 98.1 & 0.38 \\
\hline mean & 0.13 & 13.38 & 0.85 & 78.13 & 1.14 & 0.33 & 0.29 & 94.23 & 40.87 & 41.36 & 98.34 & 0.39 \\
\hline stdev & 0.03 & 0.35 & 0.22 & 0.80 & 0.24 & 0.06 & 0.07 & 0.96 & 0.49 & 0.85 & 0.96 & 0.01 \\
\hline & 0.09 & 11.47 & 0.83 & 79.24 & 1.3 & 0.5 & 0.16 & 93.58 & 44.57 & 39.13 & 98.06 & 0.33 \\
\hline & 0 & 11.94 & 1.02 & 80.55 & 1 & 0.51 & 0.25 & 95.27 & 44.82 & 40.22 & 99.76 & 0.34 \\
\hline & 0.12 & 11.57 & 1.38 & 80.04 & 0.67 & 0.52 & 0.24 & 94.53 & 44.3 & 40.18 & 98.98 & 0.34 \\
\hline mean & 0.07 & 11.66 & 1.08 & 79.94 & 0.99 & 0.51 & 0.22 & 94.46 & 44.56 & 39.84 & 98.93 & 0.34 \\
\hline stdev & 0.06 & 0.25 & 0.28 & 0.66 & 0.32 & 0.01 & 0.05 & 0.85 & 0.26 & 0.62 & 0.85 & 0.01 \\
\hline & 0.01 & 49.71 & 0.06 & 46.83 & 1.92 & 1.35 & 0.12 & 100 & 7.31 & 40.23 & 100.72 & 0.93 \\
\hline & 0.16 & 49.47 & 0.05 & 46.33 & 2.04 & 1.57 & 0 & 99.63 & 7.24 & 39.81 & 100.35 & 0.93 \\
\hline mean & 0.09 & 49.59 & 0.06 & 46.58 & 1.98 & 1.46 & 0.06 & 99.82 & 7.28 & 40.02 & 100.54 & 0.93 \\
\hline stdev & 0.11 & 0.17 & 0.01 & 0.35 & 0.08 & 0.16 & 0.08 & 0.26 & 0.05 & 0.30 & 0.26 & 0.00 \\
\hline
\end{tabular}

B 12 Mamaku Ignimbrite, Pukerimu Rd (U16/784204)

$\begin{array}{llrllllllllrr} & 0.08 & 12.08 & 1.59 & 79.63 & 0.83 & 0.75 & 0.23 & 95.19 & 43.69 & 40.32 & 99.57 & 0.36 \\ 0.09 & 11.43 & 1.01 & 81.15 & 0.99 & 0.48 & 0.32 & 95.47 & 45.79 & 39.95 & 100.06 & 0.33 \\ 0.07 & 11.74 & 1.18 & 81.28 & 1.02 & 0.58 & 0.37 & 96.24 & 45.61 & 40.24 & 100.81 & 0.34 \\ 0.1 & 12.31 & 1.13 & 79.76 & 0.77 & 0.57 & 0.27 & 94.91 & 43.43 & 40.68 & 99.26 & 0.36 \\ 0 & 11.33 & 1.19 & 80.89 & 0.82 & 0.48 & 0.22 & 94.93 & 45.61 & 39.85 & 99.85 & 0.33 \\ & 0.15 & 12.13 & 1.05 & 79.99 & 0.92 & 0.46 & 0.19 & 94.89 & 43.71 & 40.66 & 99.27 & 0.36 \\ & 0.09 & 12.07 & 1.09 & 79.95 & 0.8 & 0.63 & 0.27 & 94.89 & 44.03 & 40.33 & 99.31 & 0.35 \\ \text { mean } & \mathbf{0 . 0 8} & \mathbf{1 1 . 8 7} & \mathbf{1 . 1 8} & \mathbf{8 0 . 3 8} & \mathbf{0 . 8 8} & \mathbf{0 . 5 6} & \mathbf{0 . 2 7} & \mathbf{9 5 . 2 2} & \mathbf{4 4 . 5 5} & \mathbf{4 0 . 2 9} & \mathbf{9 9 . 7 3} & \mathbf{0 . 3 5} \\ \text { stdev } & \mathbf{0 . 0 4} & \mathbf{0 . 3 8} & \mathbf{0 . 1 9} & \mathbf{0 . 7 0} & \mathbf{0 . 1 0} & \mathbf{0 . 1 0} & \mathbf{0 . 0 6} & \mathbf{0 . 5 0} & \mathbf{1 . 0 6} & \mathbf{0 . 3 2} & \mathbf{0 . 5 7} & \mathbf{0 . 0 1} \\ & & & & & & & & & & & & \\ & 0.09 & 49.96 & 0.41 & 48.99 & 1.33 & 1.96 & 0.16 & 102.9 & 9.93 & 40.05 & 103.9 & 0.91\end{array}$

B 13 Pokai ignimbrite? Pukerimu Rd (U16/784204)

$\begin{array}{llllllllllll}0.09 & 13.52 & 1.27 & 79.57 & 0.93 & 0.38 & 0.29 & 96.06 & 41.5 & 42.22 & 100.21 & 0.40 \\ 0.11 & 14.93 & 1.32 & 77.8 & 0.71 & 0.5 & 0.12 & 95.48 & 38.14 & 43.49 & 99.31 & 0.44 \\ 0.09 & 14.23 & 1.42 & 78.29 & 0.84 & 0.54 & 0.1 & 95.51 & 39.55 & 42.7 & 99.47 & 0.42 \\ 0.09 & 13.82 & 1.18 & 79.4 & 0.76 & 0.37 & 0.18 & 95.81 & 40.81 & 42.68 & 99.89 & 0.41 \\ 0.13 & 14.71 & 1.3 & 78.01 & 0.77 & 0.53 & 0.15 & 95.6 & 38.66 & 43.22 & 99.47 & 0.43 \\ 0.12 & 12.28 & 1.99 & 77.18 & 0.61 & 0.41 & 0.13 & 92.72 & 40.65 & 40.6 & 96.79 & 0.39 \\ 0.16 & 14.77 & 1.33 & 79.43 & 0.78 & 0.46 & 0.22 & 97.14 & 39.5 & 43.89 & 101.13 & 0.43 \\ 0.04 & 49.05 & 0.06 & 46.55 & 1.16 & 0.92 & 0.14 & 97.92 & 5.93 & 41.22 & 98.51 & 0.94 \\ 0 & 46.21 & 0.14 & 51 & 1.53 & 0.8 & 0 & 99.69 & 13.8 & 38.58 & 101.06 & 0.87\end{array}$

B 14 Rahopaka Ignimbrite, Pukerimu Rd (U16/788205)

\begin{tabular}{|c|c|c|c|c|c|c|c|c|c|c|c|}
\hline & 8.95 & 1.42 & 83.4 & 0.8 & 0.33 & 0.38 & 95.35 & 50.28 & 38.15 & 100.39 & 0.26 \\
\hline & 8.69 & 1.49 & 83.88 & 0.65 & 0.34 & 0.22 & 95.32 & 50.76 & 38.2 & 100.42 & 0.26 \\
\hline & 8.97 & 1.42 & 83.25 & 0.86 & 0.3 & 0.34 & 95.18 & 50.18 & 38.1 & 100.21 & 0.26 \\
\hline & 0.35 & 1.17 & 81.83 & 0.85 & 0.31 & 0.23 & 93.73 & 48.6 & 38.1 & 98.61 & 0.27 \\
\hline & 9.02 & 1.49 & 82.82 & 0.76 & 0.34 & 0.11 & 94.69 & 49.35 & 38.41 & 99.66 & 0.27 \\
\hline & 9.08 & 1.36 & 83.86 & 0.72 & 0.31 & 0.34 & 95.81 & 50.21 & 38.68 & 100.86 & 0.27 \\
\hline mean & 0.14 & 1.39 & 83.17 & 0.77 & 0.32 & 0.27 & 95.01 & 49.90 & 38.27 & 100.03 & 0.26 \\
\hline stdev & 0.12 & 0.12 & 0.77 & 0.08 & 0.02 & 0.10 & 0.72 & 0.78 & 0.23 & 0.79 & 0.00 \\
\hline & 46.06 & 0.04 & 50.2 & 1.58 & 0.77 & 0.2 & 98.98 & 13.09 & 38.43 & 100.29 & .87 \\
\hline & 45.97 & 0.1 & 49.75 & 1.31 & 0.7 & 0.05 & 97.95 & 12.15 & 38.82 & 99.18 & \\
\hline mean & 46.02 & 0.07 & 49.98 & 1.45 & 0.74 & 0.13 & 98.47 & 12.62 & 38.63 & 99.74 & 0.87 \\
\hline stdev & 0.04 & 0.04 & 0.32 & 0.19 & 0.05 & 0.11 & 0.73 & 0.66 & 0.28 & 0.78 & \\
\hline & 6.66 & 1.72 & 82.01 & 1.04 & 0.27 & 0.37 & 92.45 & 51.69 & 35.5 & 97.63 & 0.21 \\
\hline & \multicolumn{11}{|c|}{ Tikorangi ignimbrite, Tikorangi track (U16. 787209 ) } \\
\hline & 11.01 & 4.56 & 76.93 & 0.54 & 1.42 & 0.13 & 94.73 & 42.06 & 39.08 & 98.94 & 0.36 \\
\hline & 0.07 & 3.04 & 76.38 & 0.45 & 2.72 & 0.2 & 96.24 & 41.08 & 39.41 & 100.38 & 0.39 \\
\hline & 8.75 & 1.49 & 82.87 & 0.43 & 0.54 & 0.16 & 94.35 & 49.91 & 37.96 & 99.35 & 0.26 \\
\hline
\end{tabular}




$\begin{array}{llllllllllrl}0.11 & 12.42 & 1.91 & 79.3 & 0.54 & 0.73 & 0.28 & 95.29 & 42.56 & 41 & 99.55 & 0.37 \\ 0.12 & 7.62 & 2.23 & 80.34 & 1.17 & 2.17 & 0.11 & 93.76 & 51.81 & 33.72 & 98.95 & 0.21 \\ 0.08 & 13.85 & 3.32 & 75.31 & 0.54 & 2.99 & 0.14 & 96.23 & 39.91 & 39.4 & 100.23 & 0.41 \\ 0.05 & 13.81 & 3.02 & 75.1 & 0.42 & 2.84 & 0 & 95.25 & 39.65 & 39.42 & 99.22 & 0.41 \\ 0.17 & 10.59 & 4.7 & 77.23 & 0.3 & 2.13 & 0.24 & 95.36 & 43.55 & 38.05 & 99.72 & 0.34 \\ 0.18 & 11.5 & 4.7 & 75.82 & 0.41 & 3.36 & 0.16 & 96.12 & 42.93 & 37.19 & 100.43 & 0.35 \\ 0.15 & 10.87 & 4.69 & 77.15 & 0.28 & 2.88 & 0.15 & 96.18 & 44.07 & 37.49 & 100.59 & 0.33 \\ 0.25 & 12.21 & 3.89 & 75.94 & 0.54 & 3.01 & 0 & 95.83 & 41.9 & 38.24 & 100.04 & 0.37 \\ 0 & 42.67 & 0.32 & 51.27 & 0.43 & 2.09 & 0.05 & 96.83 & 19.01 & 34.17 & 98.73 & 0.81 \\ 0.07 & 43.65 & 0.26 & 52.35 & 0.46 & 0.93 & 0.12 & 97.84 & 16.94 & 37.11 & 99.54 & 0.83 \\ 0.05 & 43.51 & 0.42 & 52.87 & 0.59 & 1.26 & 0.05 & 98.74 & 18.42 & 36.3 & 100.6 & 0.82\end{array}$

B 16 Unit B, Tikorangi Rd (U16/801183)

\begin{tabular}{lcllllllllll}
0.14 & 10.88 & 1.52 & 80.95 & 0.91 & 0.51 & 0.26 & 95.17 & 45.96 & 39.59 & 99.78 & 0.32 \\
0.13 & \multicolumn{1}{c}{7.91} & 1.71 & 85.68 & 0.58 & 0.7 & 0.31 & 95.11 & 55.96 & 35.35 & 100.7 & 0.18 \\
0.11 & 7.69 & 84.18 & 0.7 & 0.6 & 0.2 & 95.37 & 52.2 & 37.21 & 100.62 & 0.23 \\
0.06 & 7.25 & 1.48 & 84.76 & 0.84 & 0.4 & 0.37 & 95.17 & 53.66 & 36.48 & 100.54 & 0.21 \\
0.09 & 4.21 & 1.66 & 86.35 & 0.65 & 0.42 & 0.31 & 93.68 & 58.59 & 33.63 & 99.56 & 0.13 \\
0.08 & 9.51 & 1.4 & 81.16 & 0.77 & 0.76 & 0.26 & 93.93 & 48.34 & 37.68 & 98.78 & 0.28 \\
0.14 & 19.67 & 1.14 & 72.15 & 1.67 & 0.87 & 0.21 & 95.85 & 28.94 & 46.11 & 98.75 & 0.57 \\
0.15 & 7.97 & 1.39 & 88.12 & 0.77 & 0.52 & 0.32 & 93.22 & 50.71 & 36.5 & 98.32 & 0.24 \\
0.1 & 47.27 & 0.17 & 49.12 & 1.69 & 1.51 & 0 & 99.87 & 12.11 & 38.22 & 101.07 & 0.88 \\
0 & 47.61 & 0.15 & 49.59 & 1.36 & 1.46 & 0.12 & 100.28 & 12.07 & 38.73 & 101.5 & 0.88
\end{tabular}

B 17 Pokai ignimbrite? Tikorangi Rd (U16/803185)

$\begin{array}{llllllllllll}0.11 & 11.67 & 1.49 & 81.72 & 0.63 & 0.45 & 0.19 & 96.25 & 45.21 & 41.04 & 100.79 & 0.34 \\ 0.19 & 12.6 & 1.4 & 80.85 & 0.63 & 0.48 & 0.14 & 96.29 & 43.24 & 41.94 & 100.62 & 0.37 \\ 0.14 & 17.38 & 1.23 & 77.06 & 0.92 & 0.52 & 0.16 & 97.41 & 34.53 & 45.99 & 100.87 & 0.51 \\ 0.11 & 14.17 & 1.51 & 78.48 & 0.93 & 0.53 & 0.44 & 96.16 & 39.97 & 42.52 & 100.17 & 0.42 \\ 0.16 & 11.87 & 0.97 & 79.93 & 2.09 & 0.15 & 0.6 & 95.78 & 44.77 & 39.64 & 100.26 & 0.34 \\ 0.13 & 16.11 & 1.29 & 77.47 & 0.85 & 0.5 & 0.12 & 96.47 & 36.4 & 44.7 & 100.12 & 0.47 \\ 0.14 & 11.63 & 1.86 & 80.72 & 0.89 & 0.52 & 0.44 & 96.19 & 44.73 & 40.47 & 100.68 & 0.34 \\ 0.15 & 14.57 & 1.36 & 78.33 & 0.74 & 0.42 & 0.17 & 95.74 & 38.87 & 43.36 & 99.63 & 0.43 \\ 0.06 & 14.4 & 1.44 & 79.24 & 0.97 & 0.44 & 0.5 & 97.03 & 40.3 & 42.98 & 101.09 & 0.42\end{array}$

B 18b Pokai ignimbrite? Junction of Pukerimu and Tikorangi Rd (U16/787205)

\begin{tabular}{|c|c|c|c|c|c|c|c|c|c|c|c|c|}
\hline & 0.07 & 6.97 & 1.91 & 83.18 & 0.9 & 1.4 & 0.18 & 94.61 & 53.86 & 34.72 & 100.01 & 0.20 \\
\hline & 0.08 & 6.53 & 1.89 & 84.02 & 0.92 & 1.59 & 0.18 & 95.22 & 55.33 & 34.24 & 100.75 & 0.18 \\
\hline & 0.1 & 7.05 & 1.76 & 83.57 & 0.67 & 1.25 & 0.36 & 94.76 & 53.82 & 35.15 & 100.15 & 0.20 \\
\hline & 0.09 & 7.18 & 1.97 & 84.32 & 0.94 & 1.49 & 0.16 & 96.14 & 54.49 & 35.29 & 101.61 & 0.20 \\
\hline & 0.1 & 7.33 & 1.98 & 82.87 & 0.91 & 1.42 & 0.36 & 94.97 & 53.21 & 34.99 & 100.3 & 0.21 \\
\hline & 0.15 & 6.63 & 1.84 & 83.63 & 1.1 & 1.19 & 0.14 & 94.68 & 54.38 & 34.7 & 100.14 & 0.19 \\
\hline ean & 0.10 & 6.95 & 1.89 & 83.60 & 0.91 & 1.39 & 0.23 & 95.06 & 54.18 & 34.85 & 100.49 & 0.20 \\
\hline dev & 0.03 & 0.31 & 0.08 & 0.53 & 0.14 & 0.15 & 0.10 & 0.57 & 0.73 & 0.38 & 0.60 & 0.01 \\
\hline & 0.05 & 42.62 & 0.27 & 52.18 & 0.9 & 1.99 & 0.19 & 98.19 & 20.47 & 33.76 & 100.25 & 0.80 \\
\hline & 0.04 & 40.53 & 0.29 & 53.24 & 1.15 & 2.19 & 0.17 & 97.6 & 24.41 & 31.28 & 100.06 & 0.76 \\
\hline & 0.08 & 40.54 & 0.25 & 54.22 & 0.93 & 2.39 & 0.51 & 98.92 & 25.92 & 30.9 & 101.52 & \\
\hline an & 0.06 & 41.23 & 0.27 & 53.21 & 0.99 & 2.19 & 0.29 & 98.24 & 23.60 & 31.98 & 100.61 & 0.78 \\
\hline lev & 0.02 & 1.20 & 0.02 & 1.02 & 0.14 & 0.20 & 0.19 & 0.66 & 2.81 & 1.55 & 0.79 & 0.03 \\
\hline
\end{tabular}

B 19 Matahana A? Junction of Pukerimu and Tikorangi Rd (U16/787205)

$\begin{array}{lccccccccccc}0.13 & 8.23 & 4.71 & 76.29 & 0.55 & 3.58 & 0.08 & 93.58 & 48.05 & 33.05 & 98.39 & \\ 0.06 & 4.33 & 1.25 & 86.92 & 0.6 & 0.32 & 0.13 & 93.61 & 58.82 & 33.99 & 99.5 & 0.13 \\ 0 & 2.97 & 2.23 & 87.72 & 0.55 & 0.69 & 0 & 94.15 & 61.19 & 32.66 & 100.29 & 0.09 \\ 0.04 & 7.19 & 1.81 & 84.85 & 0.47 & 0.72 & 0 & 95.08 & 53.57 & 36.65 & 100.45 & 0.21 \\ 0.05 & 8.67 & 1.69 & 83.13 & 0.69 & 1.05 & 0.27 & 95.56 & 51.5 & 37.11 & 100.68 & 0.25 \\ 0.08 & 10.2 & 1.4 & 82.53 & 0.77 & 0.62 & 0.28 & 95.88 & 48.26 & 39.1 & 100.72 & 0.30 \\ 0.18 & 7.72 & 4.71 & 77.58 & 0.58 & 3.31 & 0.1 & 94.18 & 49.28 & 33.23 & 99.12 & 0.23 \\ 0.08 & 9.05 & 4.81 & 77.26 & 0.5 & 3.63 & 0.16 & 95.47 & 47.8 & 34.25 & 100.28 & 0.27 \\ 0.08 & 50.49 & 0.04 & 47.71 & 0.93 & 1.26 & 0.21 & 100.71 & 6.21 & 42.13 & 101.34 & 0.94 \\ 0.06 & 50.66 & 0.08 & 48.88 & 1 & 0.81 & 0.11 & 101.6 & 6.45 & 43.07 & 102.25 & 0.94\end{array}$


B 20

Matahana A? $1.5 \mathrm{~m}$ above sample 19 (U16/787205)

$\begin{array}{lcccccccccrc}0 & 8.42 & 5.38 & 75.16 & 0.61 & 4.15 & 0 & 93.71 & 47.59 & 32.33 & 98.49 & 0.25 \\ 0.1 & 7.91 & 5.25 & 76.81 & 0.61 & 4.13 & 0.17 & 94.97 & 49.47 & 32.3 & 99.94 & 0.23 \\ 0.14 & 8.44 & 5.44 & 77.14 & 0.48 & 4.08 & 0.11 & 95.83 & 48.64 & 33.38 & 100.7 & 0.25 \\ 0.15 & 8.6 & 4.8 & 75.98 & 0.52 & 4.05 & 0.04 & 94.13 & 47.83 & 32.95 & 98.93 & 0.25 \\ 0.15 & 12.54 & 2.53 & 74.81 & 0.79 & 2.54 & 0.11 & 93.48 & 41.15 & 37.78 & 97.59 & 0.37 \\ 0.11 & 7.21 & 4.95 & 79.18 & 0.6 & 2.72 & 0.23 & 95 & 50.47 & 33.76 & 100.05 & 0.22 \\ 0.157 & 6.89 & 6.39 & 76.64 & 0.46 & 3.7 & 0.11 & 94.35 & 49.28 & 32.29 & 99.29 & 0.22\end{array}$

B 21 Mamaku Ignimbrite, Pukerimu Rd, near Pine Rd (U16/777178)

\begin{tabular}{|c|c|c|c|c|c|c|c|c|c|c|c|c|}
\hline & 0.07 & 11.78 & 1.23 & 81,17 & 0.81 & 0.63 & 0.17 & 95.85 & 45.23 & 40.47 & 100.39 & 0.34 \\
\hline & 0.15 & 11.57 & 1.19 & 81.31 & 0.85 & 0.6 & 0.27 & 95.92 & 45.55 & 40.33 & 100.5 & 0.33 \\
\hline & 0.1 & 11.53 & 0.98 & 79.99 & 1.06 & 0.49 & 0.12 & 94.26 & 44.43 & 39.74 & 98.75 & 0.34 \\
\hline & 0.1 & 11.67 & 0.95 & 82.08 & 0.82 & 0.51 & 0.2 & 96.32 & 46.01 & 40.68 & 100.94 & 0.33 \\
\hline & 0.11 & 12.36 & 1.02 & 80.11 & 0.66 & 0.47 & 0.21 & 94.94 & 43.41 & 41.05 & 99.29 & 0.36 \\
\hline & 0.13 & 11.67 & 0.99 & 81.69 & 0.87 & 0.35 & 0.14 & 95.85 & 45.43 & 40.81 & 100.39 & 0.34 \\
\hline mean & 0.11 & 11.76 & 1.06 & 81.06 & 0.85 & 0.51 & 0.19 & 95.52 & 45.01 & 40.51 & 100.04 & 0.34 \\
\hline stdev & 0.03 & 0.31 & 0.12 & 0.84 & 0.13 & 0.10 & 0.05 & 0.77 & 0.94 & 0.46 & 0.84 & 0.01 \\
\hline
\end{tabular}

B 22 Pukerimu ignimbrite, Rawhiti Rd (U16/808216)

$\begin{array}{rlllllllllll}0.06 & 13.96 & 1.28 & 77.34 & 1.48 & 0.37 & 0.29 & 94.78 & 39.71 & 41.61 & 98.76 & 0.41 \\ 0.09 & 11.79 & 1.9 & 78.27 & 0.98 & 0.39 & 0.32 & 93.73 & 42.59 & 39.95 & 98.01 & 0.36 \\ 0.16 & 15.46 & 1.55 & 74.56 & 1.16 & 0.57 & 0.17 & 93.64 & 35.28 & 42.81 & 97.17 & 0.47 \\ 0.12 & 12.98 & 1.83 & 77.48 & 0.69 & 0.71 & 0.1 & 93.92 & 40.46 & 41.07 & 97.96 & 0.40 \\ 0.12 & 17.13 & 1.43 & 75.02 & 1 & 0.53 & 0.05 & 95.28 & 33.28 & 45.07 & 98.61 & 0.51 \\ 0.23 & 11.83 & 1.71 & 79.8 & 0.93 & 0.47 & 0.38 & 95.34 & 43.63 & 40.54 & 99.72 & 0.35 \\ 0.18 & 16.4 & 1.45 & 75.08 & 0.81 & 0.57 & 0.36 & 94.85 & 34.29 & 44.22 & 98.29 & 0.49 \\ 0.18 & 14.78 & 1.41 & 78.29 & 0.86 & 0.66 & 0.12 & 96.31 & 38.85 & 43.33 & 100.19 & 0.43 \\ 0.13 & 25.09 & 2.01 & 65.61 & 1.7 & 1.59 & 0.21 & 96.34 & 17.41 & 49.94 & 98.08 & 0.76\end{array}$

B 23 Kaingaroa ignimbrite, Old Waiotapu Rd (U16/085108)

\begin{tabular}{|c|c|c|c|c|c|c|c|c|c|c|}
\hline 0.12 & 14.76 & 1.3 & 76.79 & 0.76 & 0.73 & 0.32 & 94.78 & 38.08 & 42.53 & 98.6 \\
\hline 0.1 & 12.28 & 1.62 & 79.19 & 0.94 & 0.62 & 0.21 & 94.92 & 42.95 & 40.55 & 99.26 \\
\hline 0.14 & 11.4 & 1.39 & 80.6 & 0.9 & 0.56 & 0.91 & 95.89 & 45.56 & 39.6 & 100.47 \\
\hline 0.08 & 10.67 & 1.56 & 79.16 & 1.13 & 0.59 & 0.11 & 93.3 & 45.17 & 38.51 & 97.83 \\
\hline 0.12 & 11.9 & 1.53 & 80.8 & 0.63 & 0.64 & 0.19 & 95.82 & 44.44 & 40.81 & 100.26 \\
\hline 0.13 & 12.69 & 0.153 & 78.99 & 0.75 & 0.72 & 0.06 & 94.86 & 42.14 & 41.07 & 99.09 \\
\hline 0.12 & 12.28 & 1.26 & 79.26 & 0.85 & 0.64 & 0.30 & 94.93 & 43.06 & 40.51 & 99.25 \\
\hline 0.02 & 1.40 & 0.55 & 1.44 & 0.18 & 0.07 & 0.31 & 0.94 & 2.77 & 1.36 & 1.00 \\
\hline
\end{tabular}

B 24 Rahopaka ignimbrite, Rusa Rd (U16/813187)

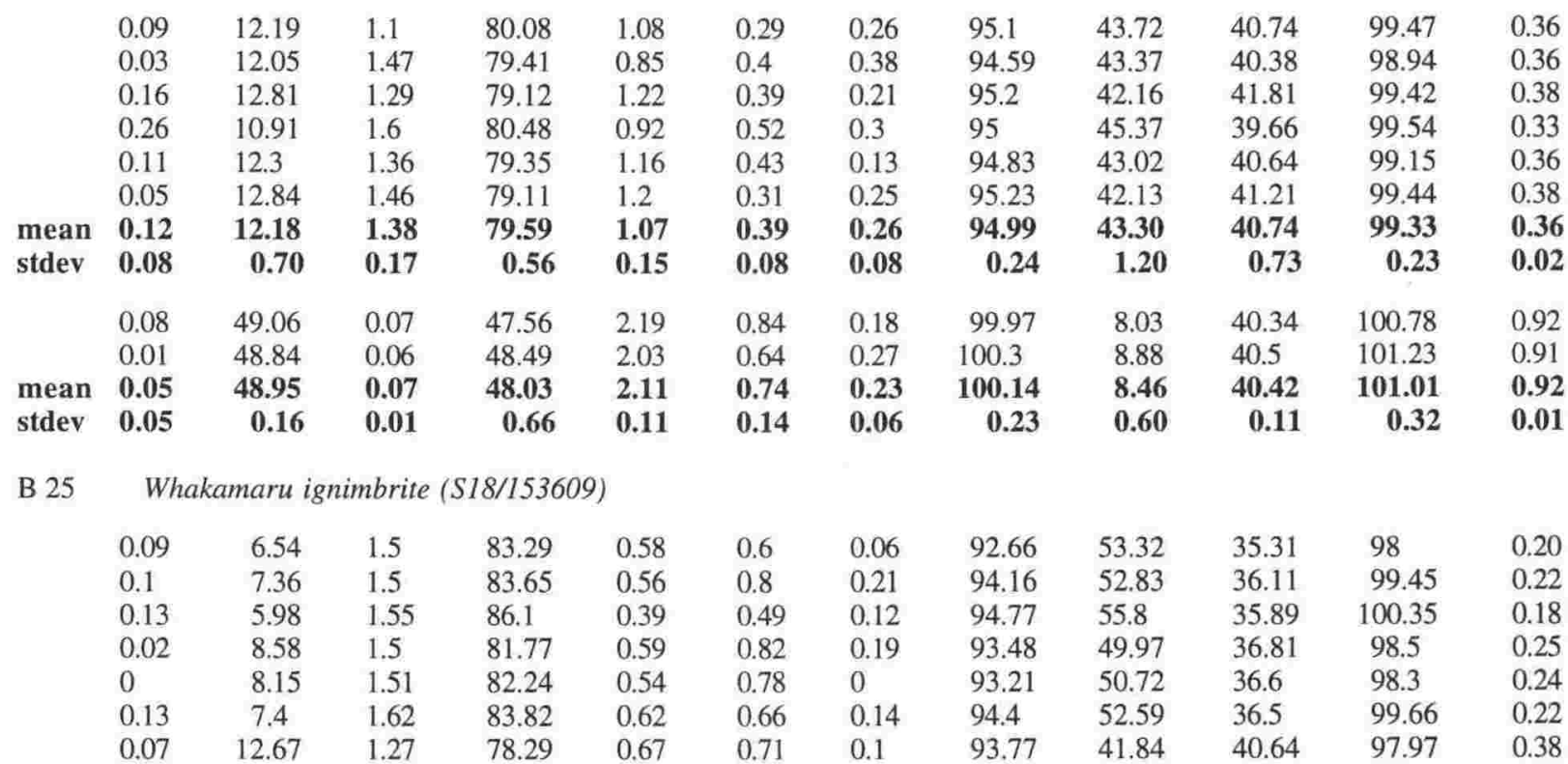


B 26

Whakamaru ignimbrite (S18/165683)

\begin{tabular}{|c|c|c|c|c|c|c|c|c|c|c|c|c|}
\hline & 0.1 & 7.79 & 1.33 & 83.37 & 0.57 & 0.19 & 0.32 & 93.66 & 51.41 & 37.12 & 98.82 & 0.23 \\
\hline & 0.08 & 8.94 & 1.37 & 82.85 & 0.41 & 0.74 & 0.18 & 94.57 & 50.02 & 37.85 & 99.58 & 0.26 \\
\hline & 0.18 & 8.8 & 1.42 & 83.09 & 0.54 & 0.61 & 0.25 & 94.89 & 50.15 & 37.97 & 99.91 & 0.26 \\
\hline & 0.1 & 7.98 & 1.17 & 84.68 & 0.78 & 0.26 & 0.08 & 95.04 & 52.3 & 37.62 & 100.29 & 0.23 \\
\hline & 0.08 & 8.85 & 1.53 & 82.8 & 0.58 & 0.73 & 0.14 & 94.72 & 50.1 & 37.72 & 99.73 & 0.26 \\
\hline & 0.13 & 8.75 & 1.5 & 81.95 & 0.57 & 0.63 & 0.16 & 93.69 & 49.41 & 37.49 & 98.64 & 0.26 \\
\hline & 0.1 & 9.03 & 1.5 & 82.67 & 0.52 & 0.71 & 0.19 & 94.71 & 49.71 & 37.94 & 99.7 & 0.27 \\
\hline an & 0.11 & 8.59 & 1.40 & 83.06 & 0.57 & 0.55 & 0.19 & 94.47 & 50.44 & 37.67 & 99.52 & 0.25 \\
\hline & 0.04 & 0.49 & 0.13 & 0.84 & 0.11 & 0.23 & 0.08 & 0.56 & 1.03 & 0.30 & 0.59 & 0.01 \\
\hline
\end{tabular}

B 27 Whakamaru ignimbrite (S18/165683)

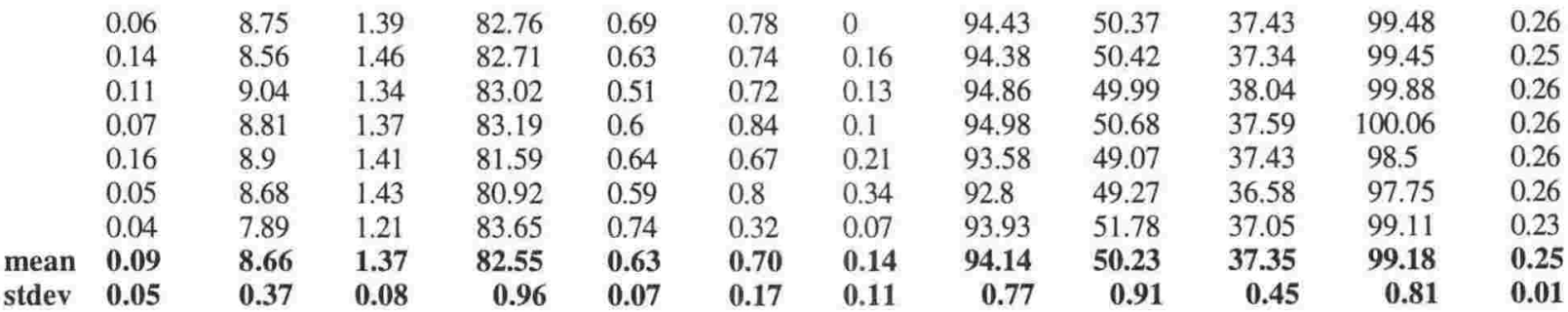

B 28 Whakamaru ignimbrite (S18/066704)

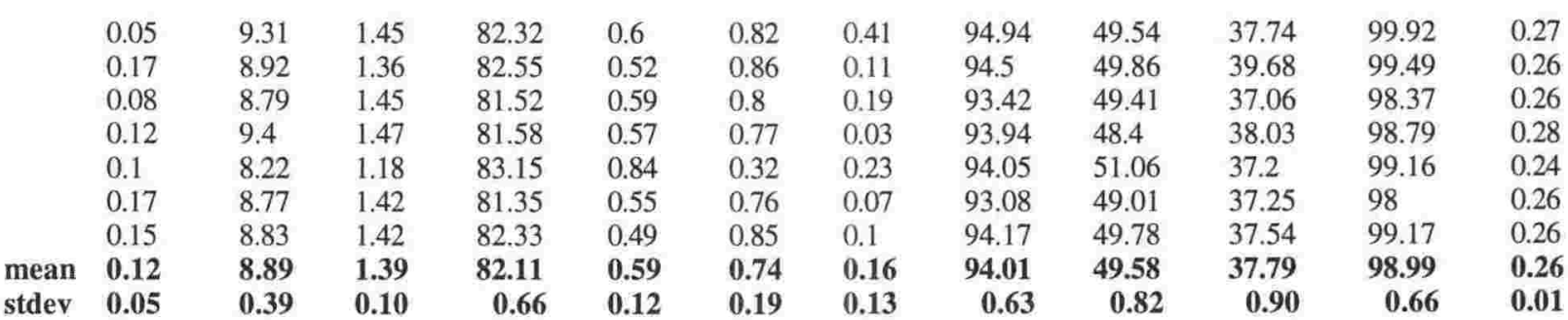

B 29 Ongatiti Ignimbrite, nonwelded base (S17/092993)

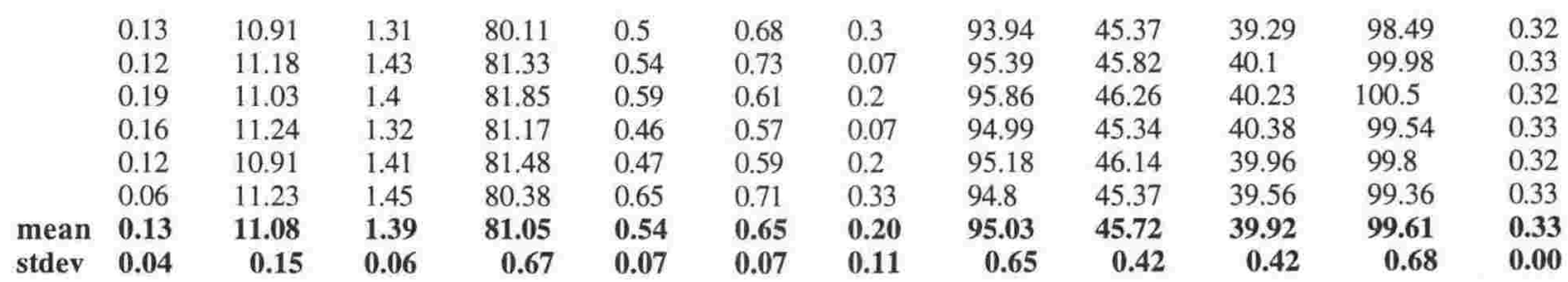

B 30 Ongatiti Ignimbrite, Tapuwae Rd (S17/140910)

\begin{tabular}{|c|c|c|c|c|c|c|c|c|c|c|c|}
\hline 0.16 & 10.89 & 1.4 & 81.21 & 0.54 & 0.4 & 0.18 & 94.78 & 45.69 & 40.09 & 99.36 & 0.33 \\
\hline 0.18 & 11.18 & 1.28 & 80.21 & 0.94 & 0.21 & 0.21 & 94.2 & 44.66 & 40.02 & 98.69 & 0.34 \\
\hline 0.19 & 10.53 & 1.41 & 81.87 & 0.69 & 0.27 & 0.32 & 95.27 & 46.64 & 39.91 & 99.95 & 0.31 \\
\hline 0.15 & 10.75 & 1.32 & 81.32 & 0.65 & 0.25 & 0.24 & 94.67 & 45.96 & 39.97 & 99.28 & 0.32 \\
\hline 0.08 & 10.91 & 1.4 & 81.4 & 0.63 & 0.28 & 0.2 & 94.88 & 45.87 & 40.12 & 99.5 & 0.33 \\
\hline 0.15 & 10.85 & 1.36 & 81.20 & 0.69 & 0.28 & 0.23 & 94.76 & 45.76 & 40.02 & 99.36 & 0.32 \\
\hline 0.04 & 0.24 & 0.06 & 0.61 & 0.15 & 0.07 & 0.05 & 0.39 & 0.71 & 0.09 & 0.45 & 0.01 \\
\hline
\end{tabular}

B 31 Ongatiti Ignimbrite (S17/137913)

\begin{tabular}{|c|c|c|c|c|c|c|c|c|c|c|c|}
\hline 0.17 & 11.15 & 1.3 & 81.7 & 0.54 & 0.58 & 0.15 & 95.58 & 45.96 & 40.34 & 100.2 & 0.33 \\
\hline 0.1 & 11.29 & 1.31 & 81.57 & 0.71 & 0.65 & 0.19 & 95.83 & 46.05 & 40.14 & 100.43 & 0.33 \\
\hline 0.14 & 10.64 & 1.48 & 81.84 & 0.62 & 0.43 & 0.18 & 95.33 & 46.59 & 39.92 & 100 & 0.32 \\
\hline 0.11 & 11.18 & 1.54 & 80.7 & 0.56 & 0.57 & 0.22 & 94.87 & 45.21 & 40.02 & 99.41 & 0.33 \\
\hline 0.16 & 11.2 & 1.34 & 82.16 & 0.53 & 0.51 & 0.13 & 96.05 & 46.12 & 40.66 & 100.65 & 0.33 \\
\hline 0.07 & 10.58 & 1.48 & 82.86 & 0.67 & 0.38 & 0.09 & 96.13 & 47.46 & 40.16 & 100.89 & 0.31 \\
\hline 0.13 & 11.01 & 1.41 & 81.81 & 0.61 & 0.52 & 0.16 & 95.63 & 46.23 & 40.21 & 100.26 & 0.32 \\
\hline 0.04 & 0.31 & 0.10 & 0.71 & 0.07 & 0.10 & 0.05 & 0.48 & 0.75 & 0.26 & 0.52 & 0.01 \\
\hline 0.06 & 18.3 & 1.11 & 74.25 & 0.68 & 0.59 & 0.33 & 95.3 & 31.45 & 45.95 & 98.47 & 0.54 \\
\hline 0.1 & 9.55 & 1.6 & 82.99 & 0.43 & 0.46 & 0.33 & 95.45 & 48.9 & 38.99 & 100.36 & 0.28 \\
\hline 0.09 & 12.64 & 1.43 & 79.3 & 0.51 & 0.48 & 0 & 94.45 & 42.02 & 41.49 & 98.66 & 0.38 \\
\hline
\end{tabular}


B 32a Ongatiti Ignimbrite, single pumice clast (S16/198218)

\begin{tabular}{|c|c|c|c|c|c|c|c|c|c|c|c|}
\hline & 0.1 & 11.43 & 1.38 & 81.49 & 0.59 & 0.64 & 0.07 & 95.7 & 45.58 & 40.48 & 100.27 \\
\hline & 0.06 & 11.36 & 1.32 & 80.32 & 0.62 & 0.64 & 0.34 & 94.66 & 45.11 & 39.73 & 99.18 \\
\hline & 0.13 & 11.55 & 1.47 & 81.56 & 0.49 & 0.59 & 0.21 & 95.98 & 45.32 & 40.78 & 100.54 \\
\hline & 0.05 & 11 & 1.29 & 81.68 & 0.61 & 0.68 & 0.06 & 95.35 & 46.49 & 39.85 & 100.03 \\
\hline & 0.05 & 11.3 & 1.36 & 81.23 & 0.62 & 0.55 & 0.08 & 95.2 & 45.57 & 40.22 & 99.76 \\
\hline & 0.12 & 11.33 & 1.32 & 81.77 & 0.59 & 0.6 & 0.31 & 96.03 & 46.02 & 40.36 & 100.65 \\
\hline mean & 0.09 & 11.33 & 1.36 & 81.34 & 0.59 & 0.62 & 0.18 & 95.49 & 45.68 & 40.24 & 100.07 \\
\hline stdev & 0.04 & 0.18 & 0.06 & 0.53 & 0.05 & 0.05 & 0.13 & 0.52 & 0.50 & 0.39 & 0.55 \\
\hline
\end{tabular}

B 32b Ongatiti Ignimbrite, single pumice clast (S16/198218)

\begin{tabular}{|c|c|c|c|c|c|c|c|c|c|c|}
\hline 0.09 & 10.97 & 1.44 & 81.05 & 0.76 & 0.6 & 0.21 & 95.11 & 46.02 & 39.64 & 99.73 \\
\hline 0.06 & 11.19 & 1.47 & 81.91 & 0.53 & 0.65 & 0.34 & 96.14 & 46.38 & 40.18 & 100.8 \\
\hline 0.09 & 11.54 & 1.44 & 81.7 & 0.58 & 0.56 & 0.34 & 96.25 & 45.64 & 40.63 & 100.82 \\
\hline 0.1 & 11.55 & 1.54 & 80.79 & 0.69 & 0.6 & 0.18 & 95.44 & 44.91 & 40.38 & 99.95 \\
\hline 0.09 & 11.13 & 1.36 & 81.6 & 0.57 & 0.59 & 0.23 & 95.56 & 46.11 & 40.11 & 100.19 \\
\hline 0.07 & 11.09 & 1.37 & 82.02 & 0.622 & 0.64 & 0.21 & 96.01 & 46.6 & 40.09 & 100.69 \\
\hline 0.08 & 11.25 & 1.44 & 81.51 & 0.63 & 0.61 & 0.25 & 95.75 & 45.94 & 40.17 & 100.36 \\
\hline 0.02 & 0.24 & 0.07 & 0.49 & 0.09 & 0.03 & 0.07 & 0.45 & 0.60 & 0.33 & 0.47 \\
\hline
\end{tabular}

B 32c Ongatiti Ignimbrite, single pumice clast (S16/198218)

\begin{tabular}{|c|c|c|c|c|c|c|c|c|c|c|c|c|}
\hline & 0.14 & 11.45 & 1.4 & 81.59 & 0.49 & 0.68 & 0.03 & 95.78 & 45.5 & 40.65 & 100.34 & 0.34 \\
\hline & 0.17 & 10.99 & 1.23 & 81.7 & 0.62 & 0.63 & 0.12 & 95.46 & 46.32 & 40.02 & 100.1 & 0.32 \\
\hline & 0.11 & 10.94 & 1.4 & 81.9 & 0.55 & 0.63 & 0.17 & 95.71 & 46.53 & 40.03 & 100.36 & 0.32 \\
\hline & 0.11 & 11.15 & 1.38 & 80.98 & 0.61 & 0.57 & 0.27 & 95.06 & 45.61 & 39.94 & 99.64 & 0.33 \\
\hline & 0.13 & 11.57 & 1.48 & 80.92 & 0.6 & 0.69 & 0.15 & 95.55 & 44.99 & 40.44 & 100.05 & 0.34 \\
\hline & 0.16 & 10.7 & 1.3 & 80.8 & 0.54 & 0.62 & 0.29 & 94.4 & 46.06 & 39.36 & 99.03 & .32 \\
\hline mean & 0.14 & 11.13 & 1.37 & 81.32 & 0.57 & 0.64 & 0.17 & 95.33 & 45.84 & 40.07 & 99.92 & 3 \\
\hline stdev & 0.03 & 0.33 & 0.09 & 0.47 & 0.05 & 0.04 & 0.10 & 0.52 & 0.57 & 0.45 & 0.51 & 01 \\
\hline \multicolumn{12}{|l|}{ B 33} & \\
\hline \multirow{9}{*}{$\begin{array}{l}\text { mean } \\
\text { stdev }\end{array}$} & 0.12 & 13.1 & 3.27 & 75.9 & 0.45 & 3.11 & 0.21 & 96.15 & 41.44 & 38.61 & 100.31 & 8 \\
\hline & 0.11 & 14.16 & 3.5 & 74.17 & 0.59 & 3.11 & 0.16 & 95.8 & 38.72 & 39.33 & 99.68 & 42 \\
\hline & 0.12 & 14.07 & 3.28 & 74.79 & 0.7 & 3.27 & 0.04 & 96.28 & 39.61 & 39.15 & 100.24 & \\
\hline & 0.11 & 13.7 & 3.38 & 74.13 & 0.47 & 3.15 & 0.12 & 95.05 & 39.3 & 38.77 & 99 & 41 \\
\hline & 0.21 & 12.74 & 3.84 & 74.29 & 0.37 & 3.45 & 0.08 & 94.99 & 40.57 & 37.78 & 99.05 & \\
\hline & 0.13 & 13.55 & 3.45 & 74.66 & 0.52 & 3.22 & 0.12 & 95.65 & 39.93 & 38.73 & 99.66 & \\
\hline & 0.04 & 0.62 & 0.23 & 0.74 & 0.13 & 0.15 & 0.07 & 0.61 & 1.08 & 0.60 & 0.63 & \\
\hline & 0.06 & 42.39 & 0.43 & 52.13 & 0.62 & 0.196 & 0.05 & 97.63 & 20.12 & 34.03 & 99.66 & \\
\hline & 0.16 & 7.48 & 2.06 & 80.72 & 0.42 & 0.86 & 0.4 & 92.1 & 50.19 & 35.56 & 97.13 & \\
\hline
\end{tabular}

B 34a Rocky Hill Ignimbrite, single pumice clast (S16/117110)

\begin{tabular}{|c|c|c|c|c|c|c|c|c|c|c|}
\hline 0.06 & 10.71 & 1.55 & 81.36 & 0.65 & 0.66 & 0.05 & 95.04 & 46.48 & 39.53 & 99.7 \\
\hline 0.11 & 10.57 & 1.44 & 81.68 & 0.46 & 0.53 & 0.46 & 95,25 & 46.83 & 39.54 & 99.94 \\
\hline 0.14 & 10.49 & 1.54 & 81.82 & 0.47 & 0.62 & 0.21 & 95.3 & 46.91 & 39.62 & 100 \\
\hline 0.16 & 10.46 & 1.5 & 81.65 & 0.66 & 0.62 & 0.24 & 95.29 & 46.96 & 39.39 & 100 \\
\hline 0.09 & 10.63 & 1.54 & 80.9 & 0.58 & 0.65 & 0.24 & 94.62 & 46.26 & 39.27 & 99.27 \\
\hline 0.08 & 10.32 & 1.6 & 81,01 & 0.54 & 0.62 & 0.21 & 94.37 & 46.65 & 39.03 & 99.05 \\
\hline 0.11 & 10.53 & 1.53 & 81.40 & 0.56 & 0.62 & 0.24 & 94.98 & 46.68 & 39.40 & 99.66 \\
\hline 0.04 & 0.14 & 0.05 & 0.38 & 0.09 & 0.05 & 0.13 & 0.39 & 0.27 & 0.22 & 0.41 \\
\hline
\end{tabular}

B 49 Ongatiti Ignimbritebase (S17/098843)

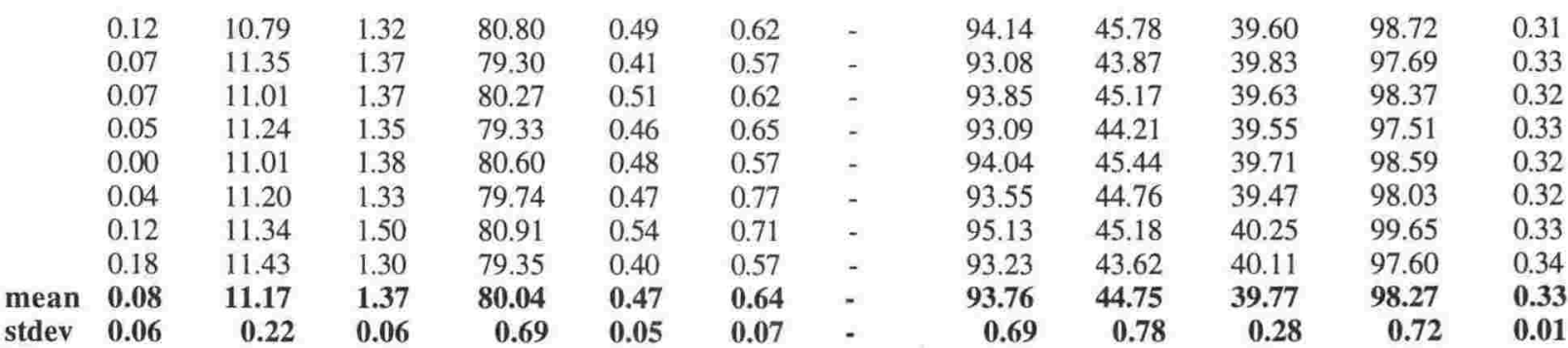


B 50

Rocky Hill Ignimbrite nonwelded base (S16/117107)

\begin{tabular}{|c|c|c|c|c|c|c|c|c|c|c|c|c|}
\hline & 0.10 & 10.11 & 1.54 & 80.18 & 0.41 & 0.58 & - & 92.93 & 46.03 & 38.77 & 97.53 & 0.30 \\
\hline & 0.14 & 10.56 & 1.42 & 80.49 & 0.41 & 0.56 & - & 93.61 & 45.65 & 39.41 & 98.18 & 0.31 \\
\hline & 0.09 & 11.11 & 1.62 & 80.25 & 0.51 & 0.63 & - & 94.21 & 44.86 & 39.88 & 98.71 & 0.32 \\
\hline & 0.07 & 10.12 & 1.35 & 80.92 & 0.49 & 0.56 & - & 93.54 & 46.78 & 38.82 & 98.24 & 0.29 \\
\hline & 0.07 & 10.93 & 1.50 & 79.07 & 0.52 & 0.67 & - & 92.77 & 44.39 & 39.13 & 97.21 & 0.32 \\
\hline & 0.10 & 10.61 & 1.45 & 81.49 & 0.41 & 0.52 & - & 94.57 & 46.30 & 39.83 & 99.22 & 0.31 \\
\hline & 0.12 & 10.62 & 1.43 & 80.00 & 0.51 & 0.64 & - & 93.34 & 45.41 & 39.14 & 97.89 & 0.31 \\
\hline & 0.08 & 10.63 & 1.47 & 80.44 & 0.44 & 0.64 & - & 93.71 & 45.72 & 39.30 & 98.30 & 0.31 \\
\hline & 0.10 & 10.98 & 1.50 & 80.55 & 0.40 & 0.64 & - & 94.21 & 45.28 & 39.80 & 98.76 & 0.32 \\
\hline & 0.04 & 10.68 & 1.38 & 80.31 & 0.53 & 0.55 & - & 93.53 & 45.63 & 39.25 & 98.11 & 0.31 \\
\hline mean & 0.09 & 10.64 & 1.47 & 80.37 & 0.46 & 0.60 & - & 93.64 & 45.61 & 39.33 & 98.22 & 0.31 \\
\hline stdev & 0.03 & 0.33 & 0.08 & 0.62 & 0.05 & 0.05 & & 0.57 & 0.69 & 0.40 & 0.59 & 0.01 \\
\hline \multicolumn{13}{|c|}{ 397655) } \\
\hline & 0.05 & 18.29 & 1.31 & 74.34 & 0.75 & 0.51 & - & 95.34 & 31.24 & 46.33 & 98.48 & 0.52 \\
\hline & 0.11 & 18.33 & 1.28 & 74.96 & 0.77 & 0.52 & - & 95.98 & 31.50 & 46.62 & 99.14 & 0.52 \\
\hline & 0.16 & 17.66 & 1.35 & 75.20 & 0.80 & 0.46 & - & 95.63 & 32.40 & 46.64 & 98.88 & 0.51 \\
\hline & 0.14 & 18.70 & 1.33 & 74.64 & 0.82 & 0.54 & - & 96.18 & 30.77 & 46.95 & 99.25 & 0.53 \\
\hline & 0.12 & 18.63 & 1.34 & 75.55 & 0.83 & 0.54 & - & 97.02 & 31.60 & 47.11 & 100.20 & 0.53 \\
\hline & 0.08 & 18.34 & 1.38 & 72.33 & 0.77 & 0.55 & - & 93.45 & 29.59 & 45.70 & 96.42 & 0.54 \\
\hline & 0.14 & 17.98 & 1.57 & 74.08 & 0.59 & 0.55 & - & 94.90 & 31.02 & 46.16 & 98.01 & 0.52 \\
\hline & 0.08 & 18.44 & 1.36 & 75.45 & 0.87 & 0.51 & - & 96.71 & 31.80 & 46.83 & 99.90 & 0.52 \\
\hline mean & 0.11 & 18.30 & 1.37 & 74.57 & 0.78 & 0.52 & - & 95.65 & 31.24 & 46.54 & 98.79 & 0.52 \\
\hline stdev & 0.04 & 0.34 & 0.09 & 1.04 & 0.08 & 0.03 & - & 1.13 & 0.83 & 0.46 & 1.19 & 0.01 \\
\hline \multicolumn{13}{|l|}{$83 / 1$} \\
\hline & 0.09 & 11.06 & 1.54 & 80.07 & 0.65 & 0.51 & - & 93.92 & 44.78 & 39.77 & 98.41 & 0.32 \\
\hline & 0.08 & 10.61 & 1.42 & 81.54 & 0.69 & 0.56 & - & 94.91 & 46.65 & 39.57 & 99.57 & 0.30 \\
\hline & 0.17 & 10.68 & 1.42 & 80.97 & 0.62 & 0.39 & - & 94.24 & 45.70 & 39.85 & 98.83 & 0.31 \\
\hline & 0.10 & 10.51 & 1.41 & 81.28 & 0.58 & 0.51 & - & 94.39 & 46.41 & 39.52 & 99.04 & 0.30 \\
\hline & 0.26 & 10.59 & 1.33 & 80.34 & 0.63 & 0.49 & - & 93.68 & 45.42 & 39.47 & 98.24 & 0.32 \\
\hline & 0.18 & 10.86 & 1.57 & 80.96 & 0.63 & 0.58 & - & 94.78 & 45.61 & 39.92 & 99.35 & 0.32 \\
\hline & 0.11 & 10.37 & 1.43 & 81.28 & 0.73 & 0.48 & - & 94.40 & 46.64 & 39.31 & 99.07 & 0.30 \\
\hline & 0.11 & 10.70 & 1.45 & 82.27 & 0.64 & 0.50 & . & 95.66 & 46.88 & 40.09 & 100.40 & 0.31 \\
\hline & 0.16 & 10.01 & 1.49 & 81.10 & 0.76 & 0.56 & - & 94.07 & 47.00 & 38.81 & 98.79 & 0.29 \\
\hline & 0.16 & 10.67 & 1.60 & 80.57 & 0.58 & 0.47 & . & 94.06 & 45.41 & 39.71 & 98.60 & 0.31 \\
\hline an & 0.14 & 10.61 & 1.47 & 81.04 & 0.65 & 0.51 & - & 94.41 & 46.05 & 39.60 & 99.03 & 0.31 \\
\hline ted & 0.05 & 0.28 & 0.08 & 0.63 & 0.06 & 0.05 & . & 0.58 & 0.76 & 0.36 & 0.62 & 0.01 \\
\hline
\end{tabular}




\section{Appendix 3 STEREOGRAPHIC PROJECTIONS OF AMS DATA}

This appendix contains a stereographic projection for each site of AMS data. Measurements are plotted on the lower hemisphere. 
Site 2.

Whakamaru ignimbrite

T18/439615

Type 2

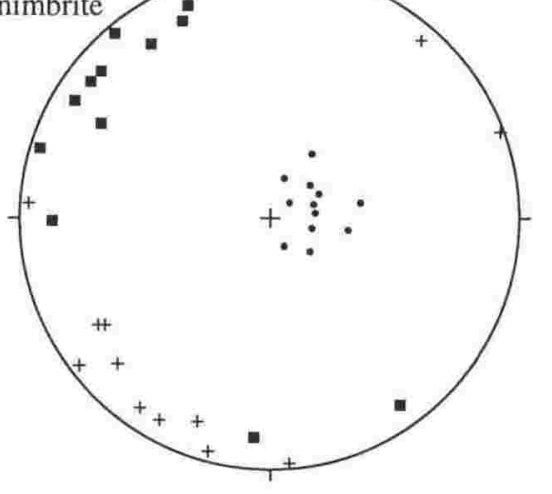

Site 4.

Whakamaru ignimbrite

T18/425686

Type 3

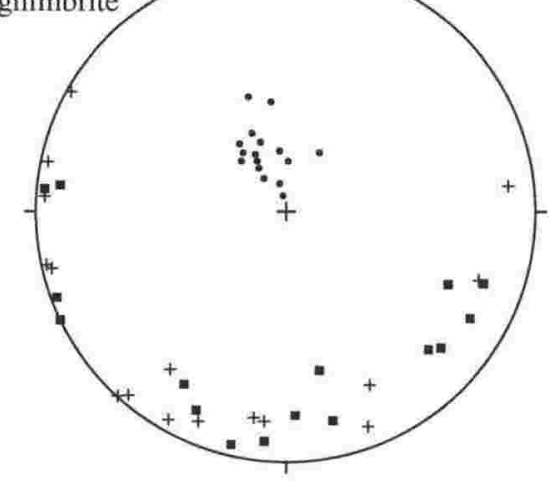

Site 6.

Marshall ignimbrite (I)

T16/578211

Type 2

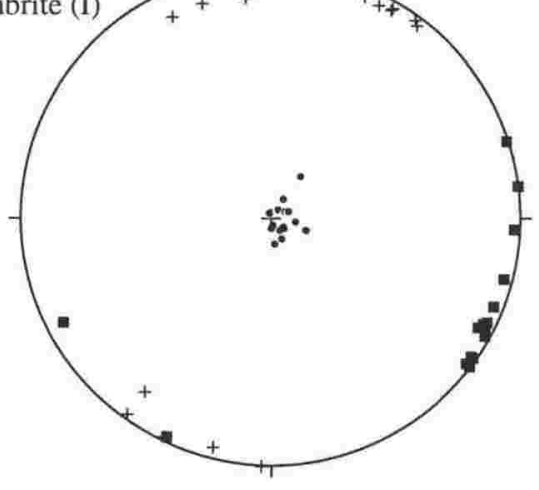

Site 8 .

Whakamaru ignimbrite

T16/493136

Type 1

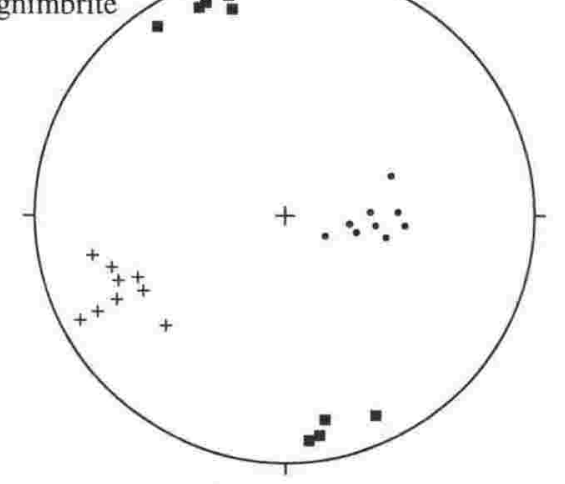

- K1 axis (maximum)

$+\mathrm{K} 2$ axis (intermediate)

- K3 axis (minimum)
Site 5 .

Whakamaru ignimbrite T18/422734

Type 1

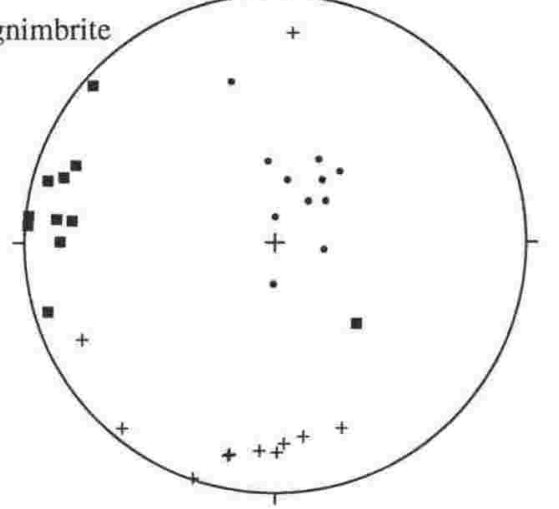

Site 7.

Whakamaru ignimbrite T16/492139

Type 2

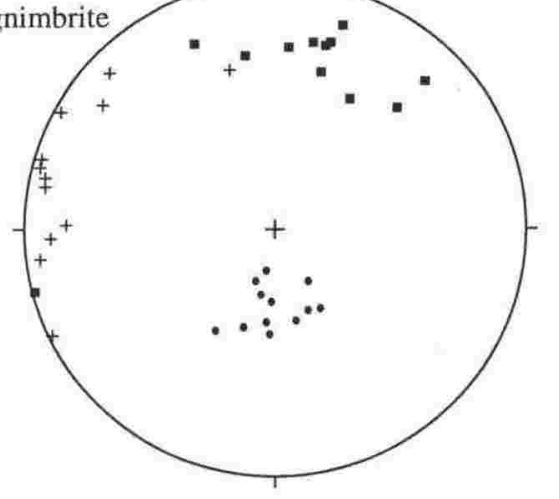

Site 9.

Whakamaru ignimbrite T16/495134 Type 1

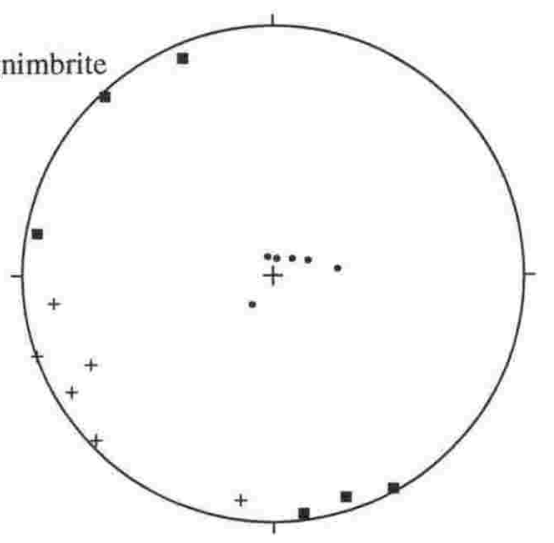


Site 10.

Mamaku ignimbrite

V15/110439

Type 2

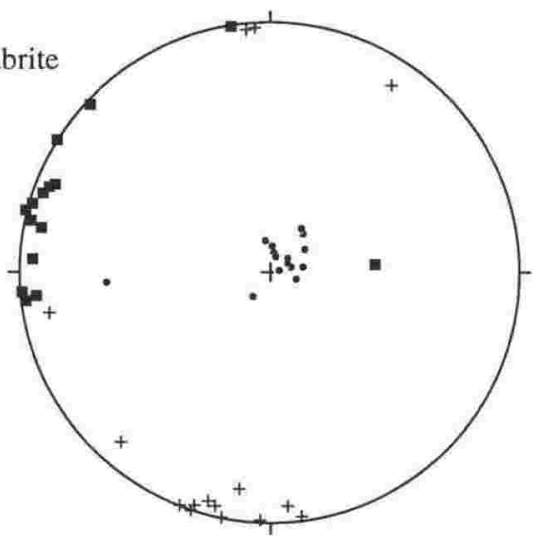

Site 12

Mamaku ignimbrite U15/887552

Type 1

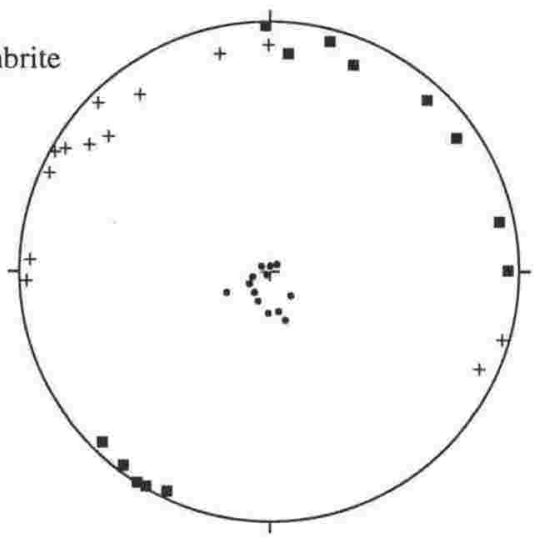

Site 14

Mamaku ignimbrite

U15/904523

Type 4

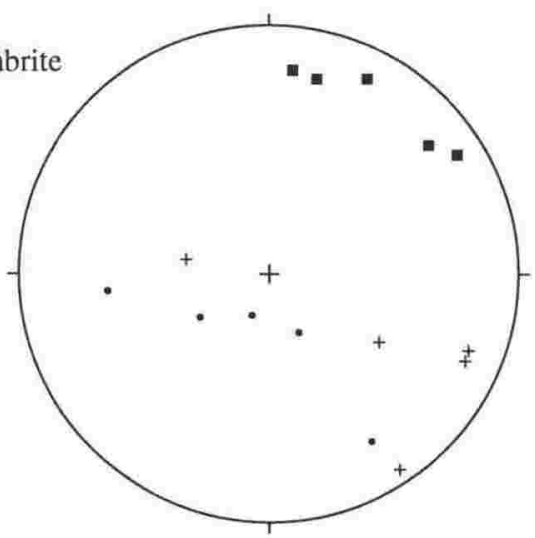

Site 20.

Oruanui ignimbrite

T17/618830

Type 5

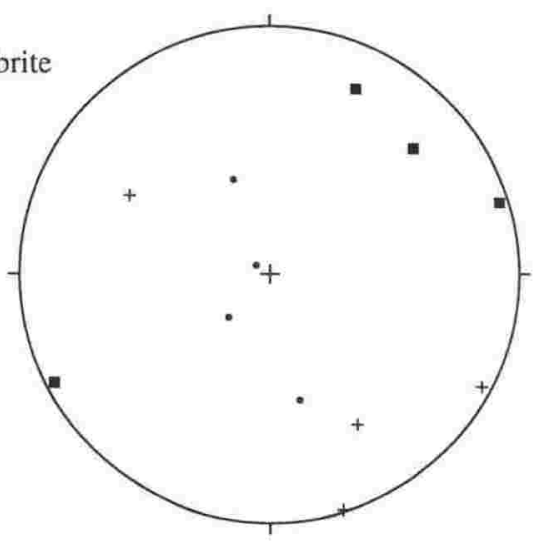

Site 11.

Mamaku ignimbrite V15/103444

Type 2

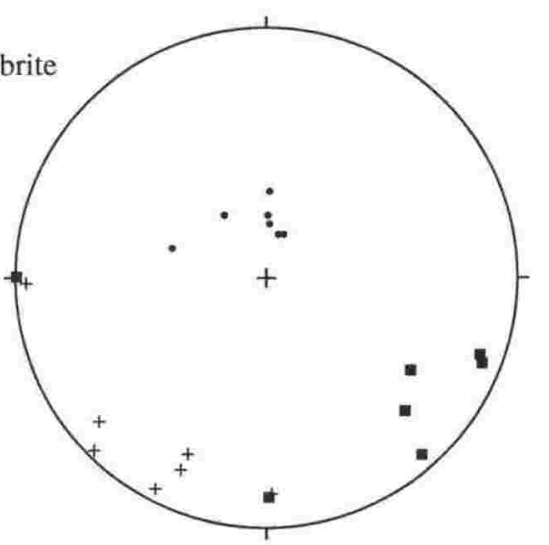

Site 13.

?

U15/884556

Type?

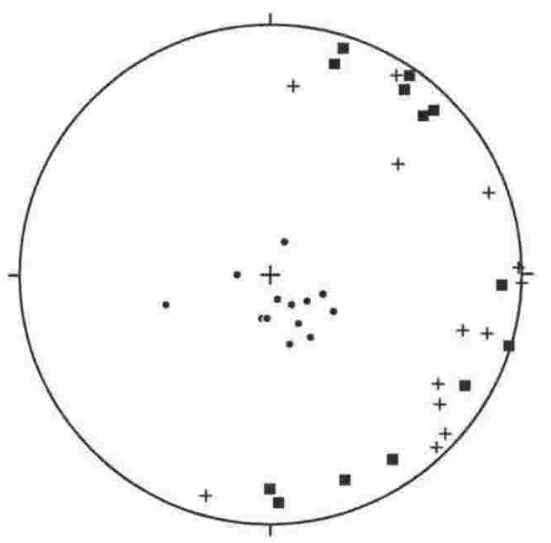

Site 19.

Oruanui ignimbrite T17/554833

Type 2

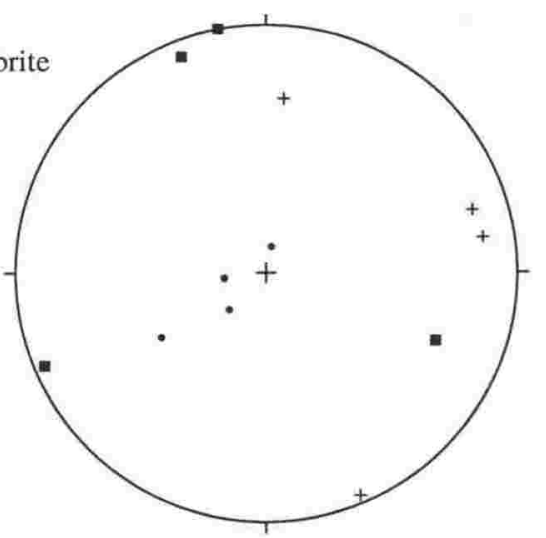

Site 21.

Mamaku ignimbrite T17/642901

Type 2

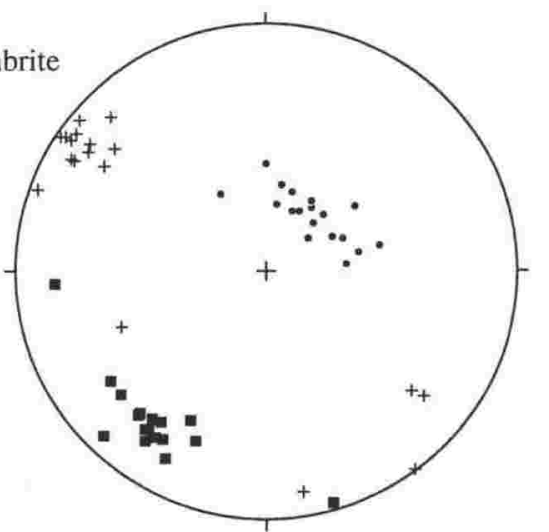


Site 22.

Whakamaru ignimbrite T17/535972

Type 1

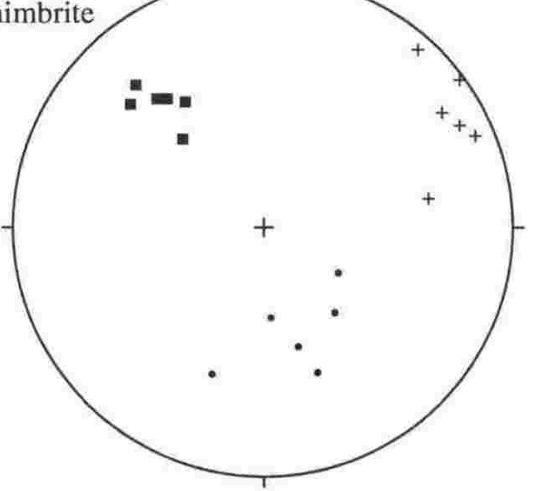

Site 26.

Whakamaru ignimbrite

T16/452182

Type 1

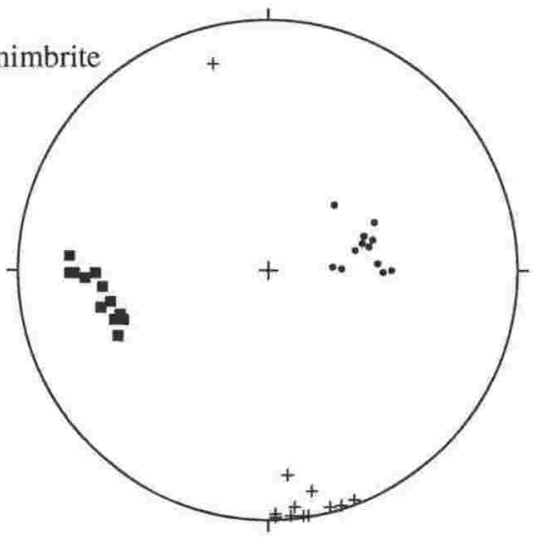

Site 28.

Whakamaru ignimbrite

T16/454155

Type 1

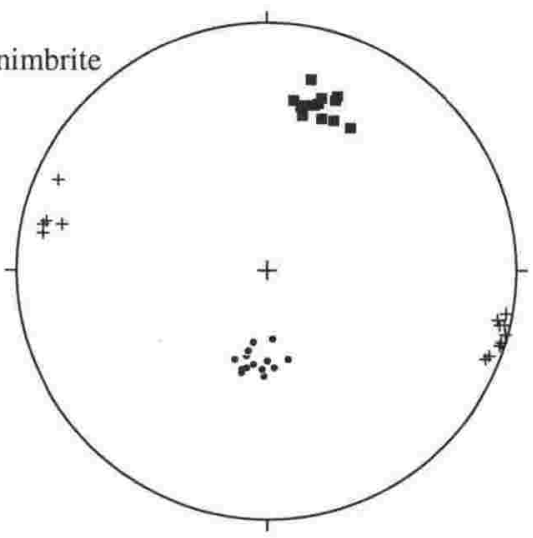

Site 30 .

Whakamaru ignimbrite T18/415543 Type 4

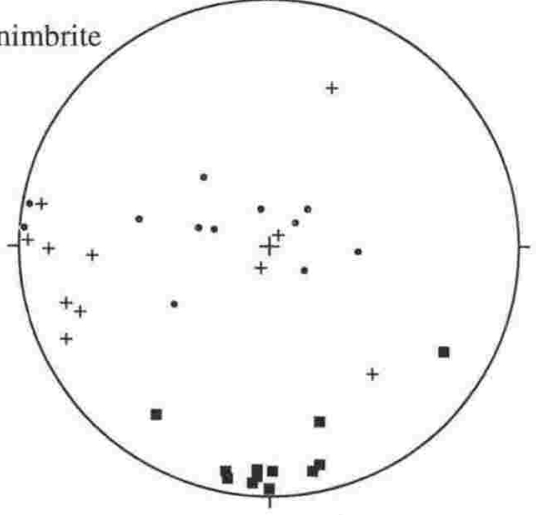

Site 25.

Whakamaru ignimbrite T16/464134

Type 1

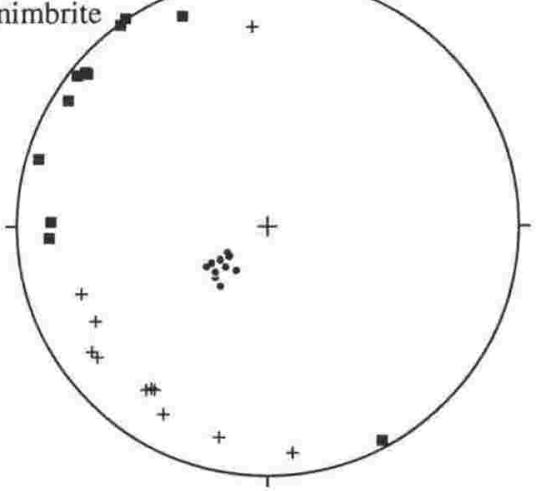

Site 27.

Whakamaru ignimbrite

T16/445173

Type 1

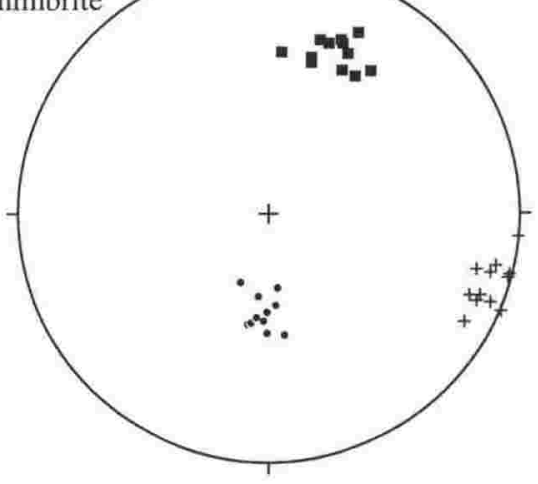

Site 29.

Kaingaroa ignimbrite V17/108936 Type 5

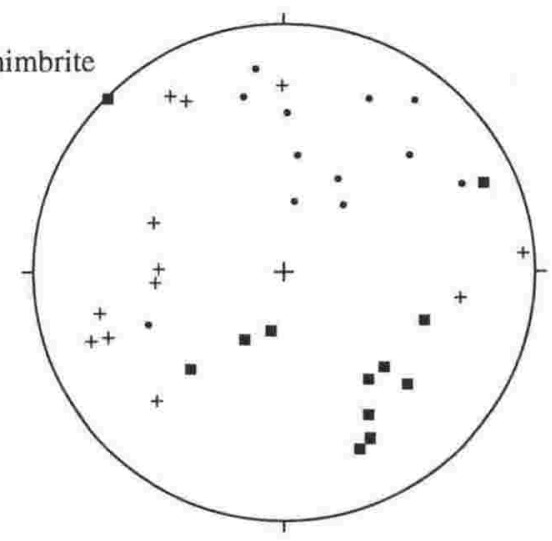

Site 31 .

Whakamaru ignimbrite

T18/437623

Type 1

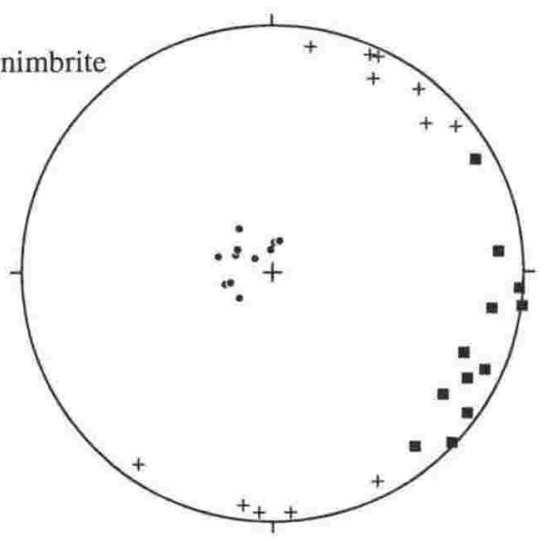


Site 32 .

Whakamaru ignimbrite

T18/436708

Type 1

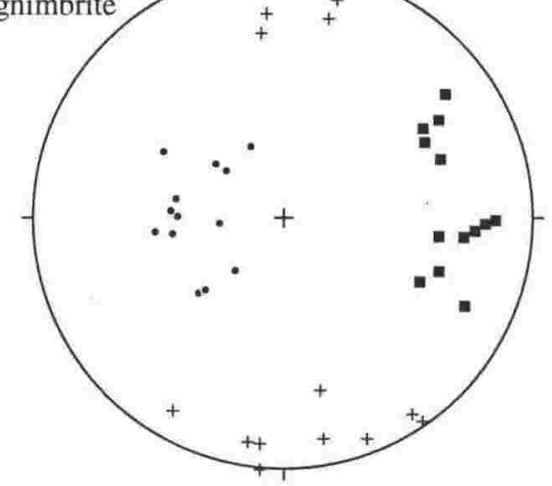

Site 34 .

Whakamaru ignimbrite

T18/438755

Type 1

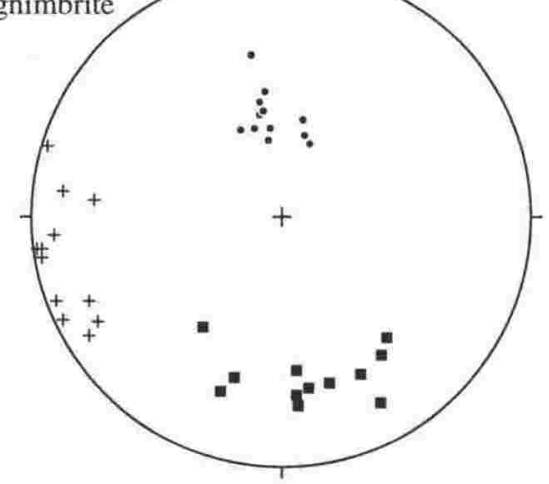

Site 36.

Whakamaru ignimbrite

T17/452834

Type 2

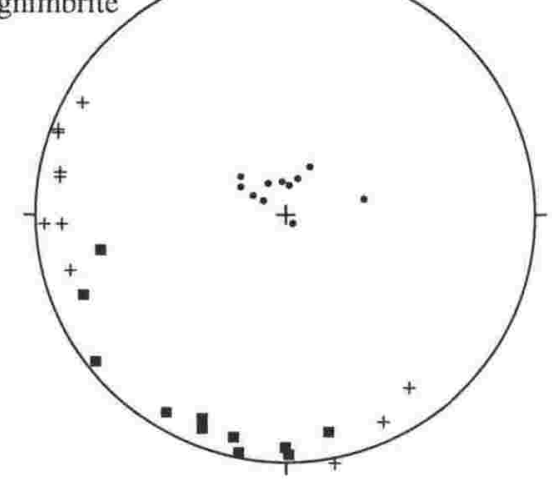

Site 40.

Whakamaru ignimbrite

S18/066704

Type 2

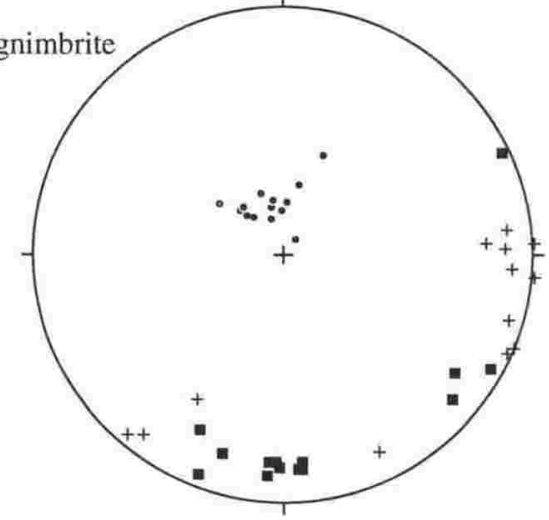

Site 33.

Whakamaru ignimbrite

T18/410723

Type 1

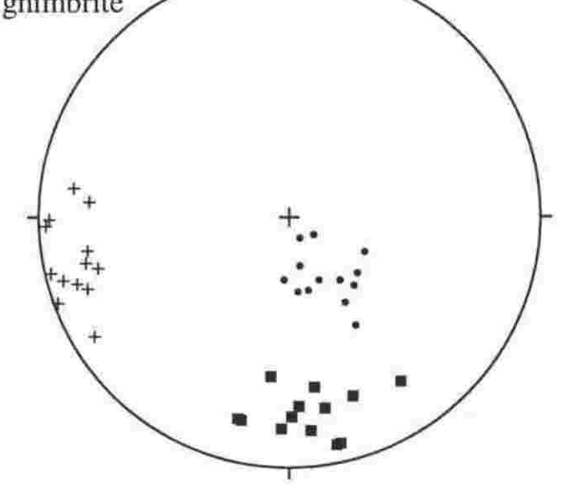

Site 35 .

Whakamaru ignimbrite

T18/445784

Type 2

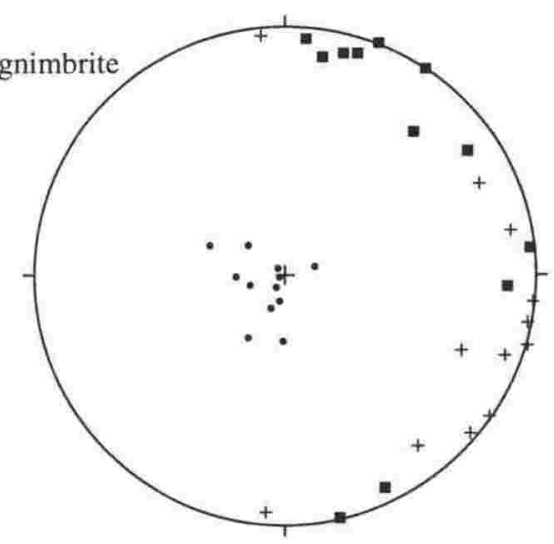

Site 37.

Whakamaru ignimbrite T17/466805

Type 4

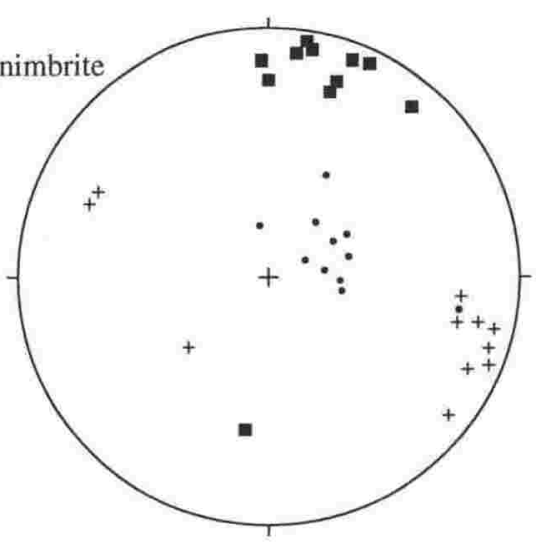

Site 41.

Whakamaru ignimbrite S18/066704 Type 1

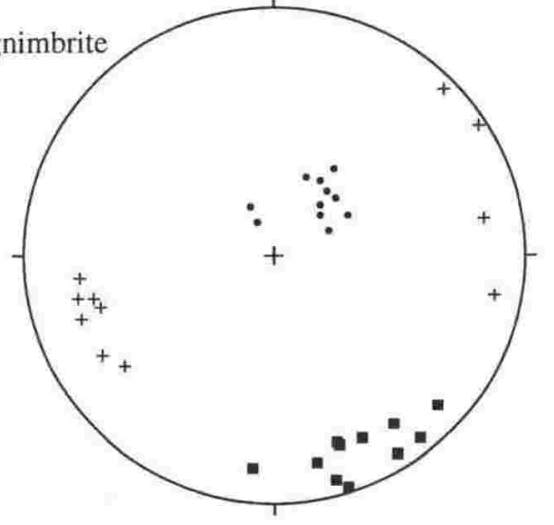


Site 42.

Ongatiti ignimbrite S17/114804 Type 5

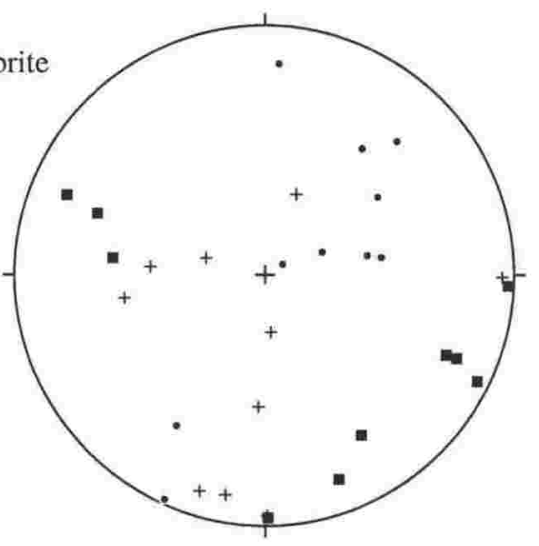

Site 44.

Ongatiti ignimbrite S17/121853

Type 2

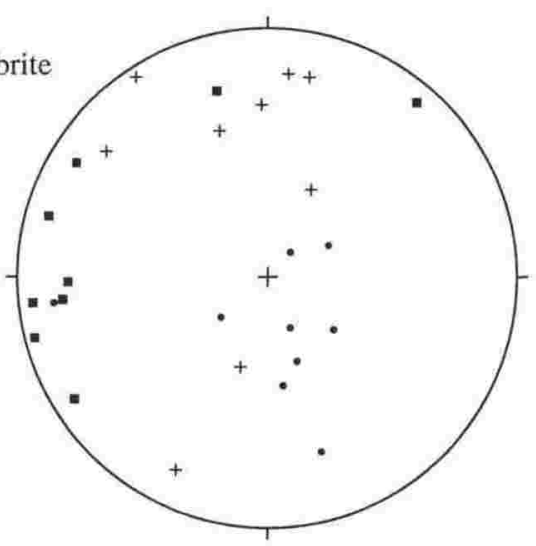

Site 46.

Whakamaru ignimbrite

S17/189862

Type 1

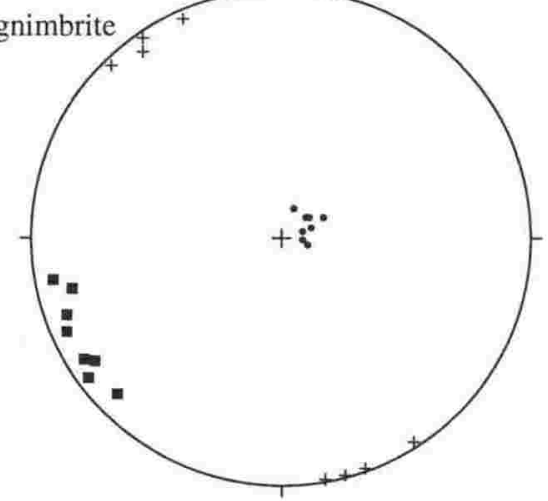

Site 48.

Ongatiti ignimbrite S17/039088 Type 1

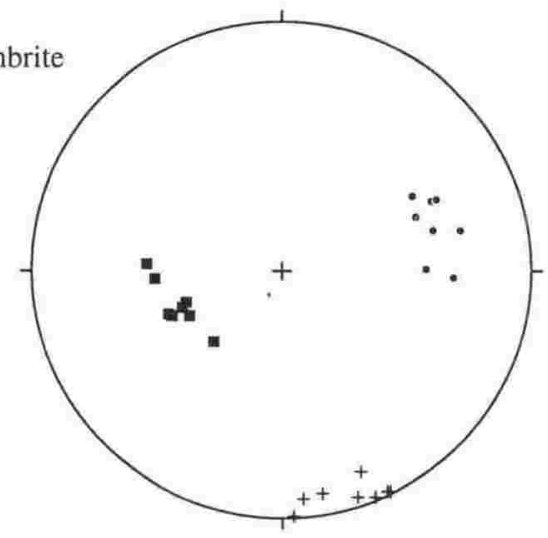

Site 43.

Ongatiti ignimbrite S17/104818 Type 5

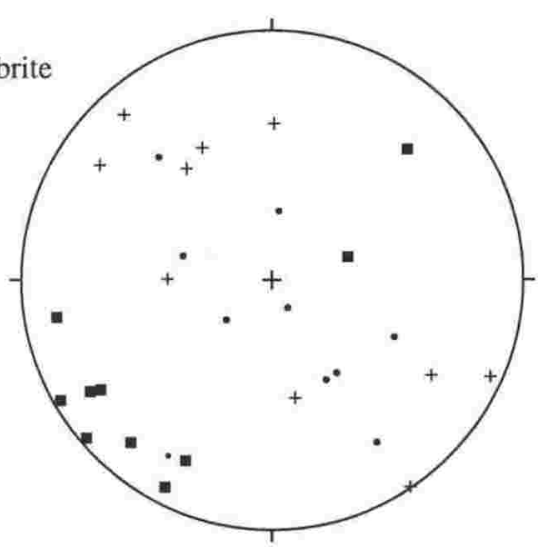

Site 45.

Whakamaru ignimbrite S17/216857

Type 4

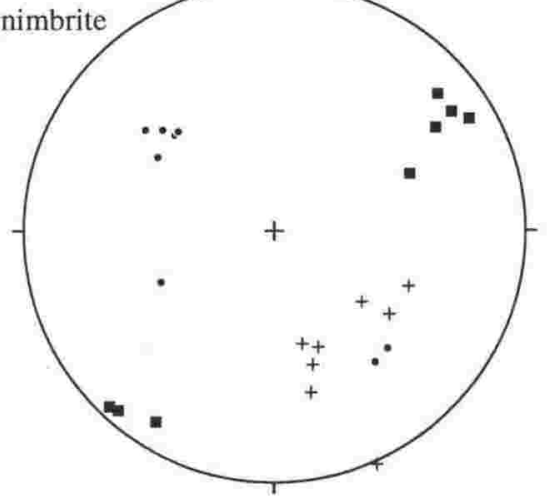

Site 47.

Whakamaru ignimbrite S17/163847

Type 1

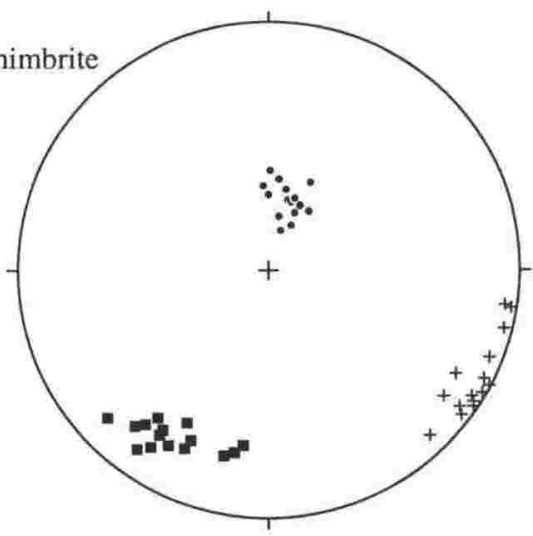

Site 49.

Ongatiti ignimbrite \$17/076025 Type 1

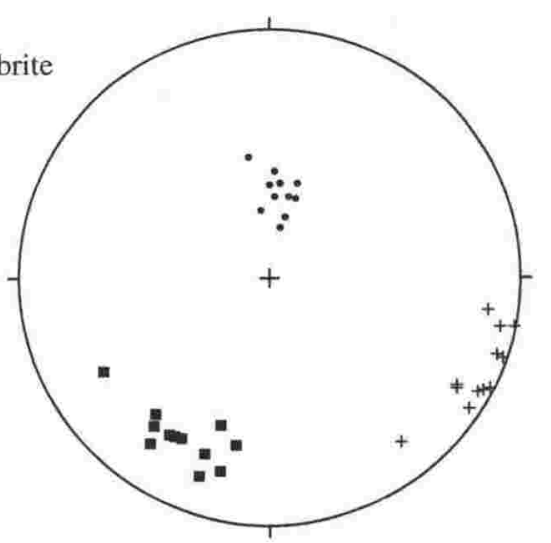


Site 50.

Ngaroma ignimbrite

S17/092013

Type 2

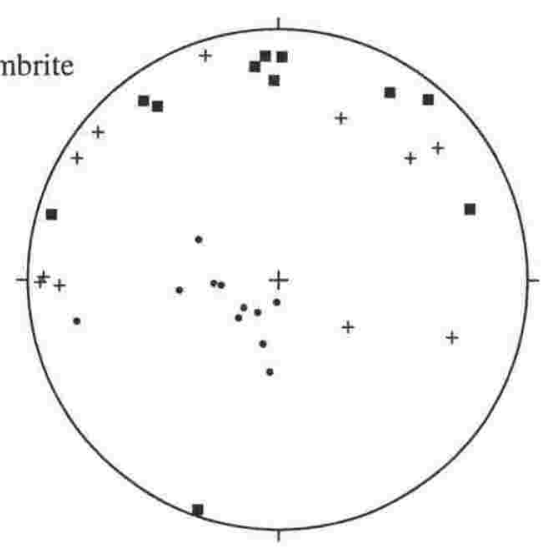

Site 52.

Ongatiti ignimbrite S17/202981 Type 3

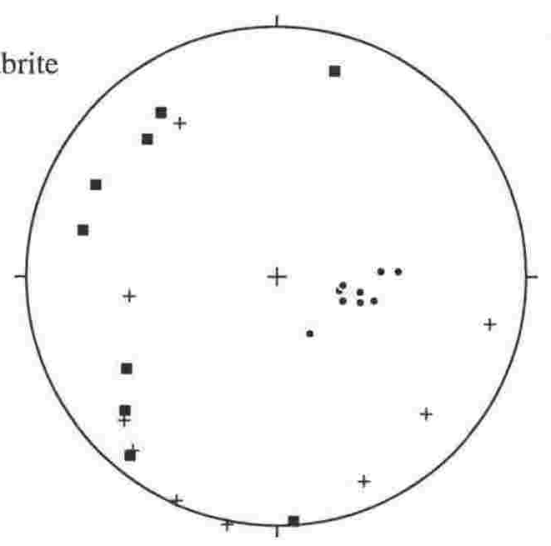

Site 54.

Whakamaru ignimbrite S17/148018

Type 1

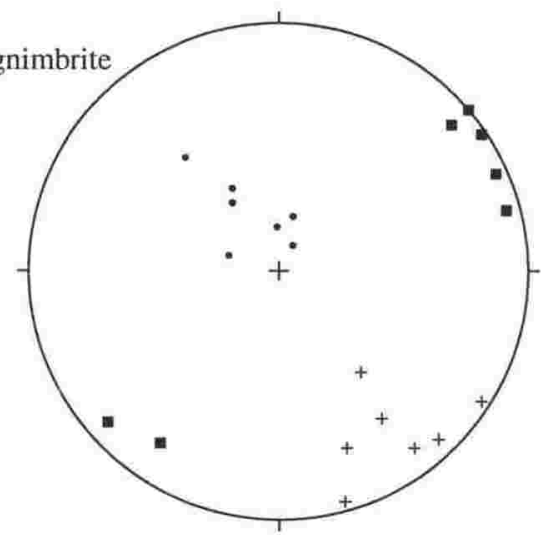

Site 56.

Ongatiti ignimbrite S17/118099 Type 5

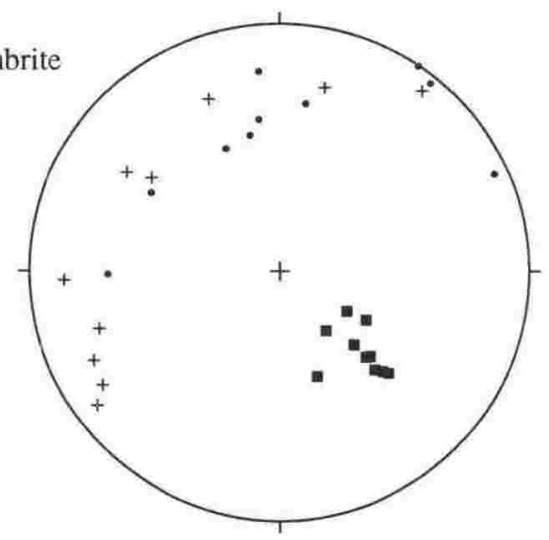

Site 51.

Ongatiti ignimbrite S17/087001 Type 1

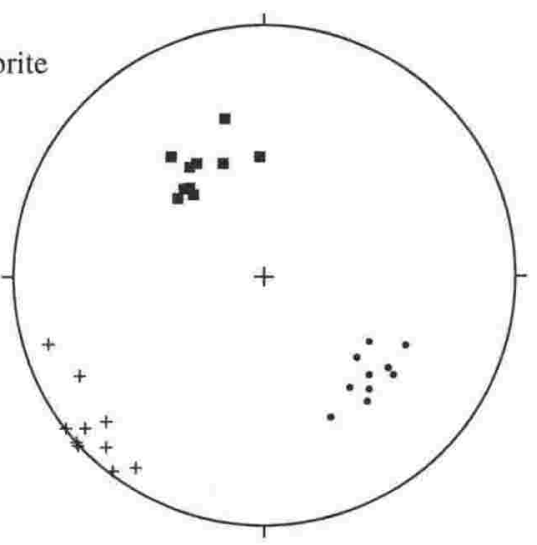

Site 53.

Ahuroa ignimbrite S17/189022 Type 2

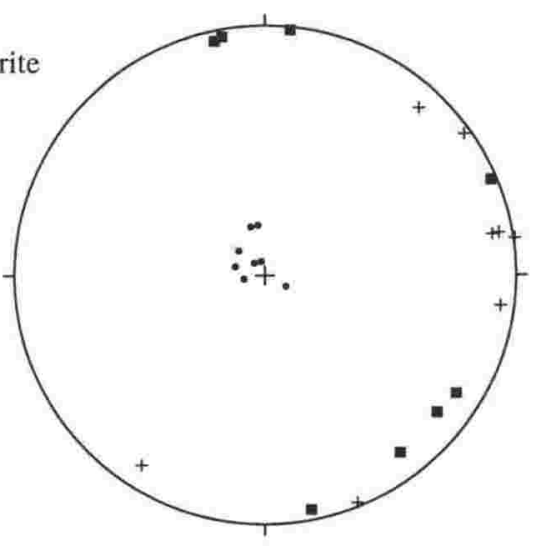

Site 55.

Ongatiti ignimbrite S16/198218 Type 3

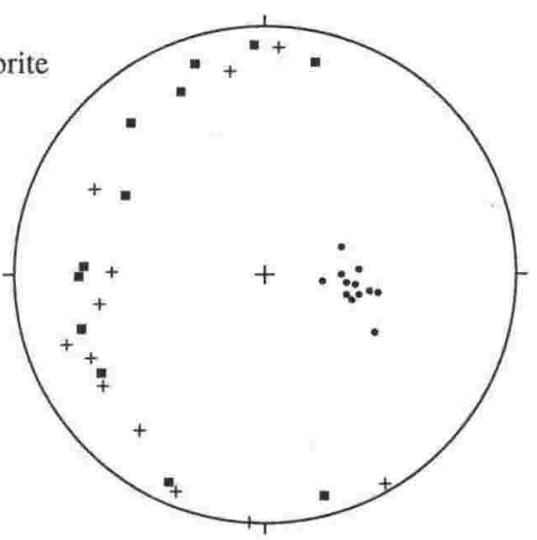

Site 57.

Ahuroa ignimbrite S16/113103 Type 1

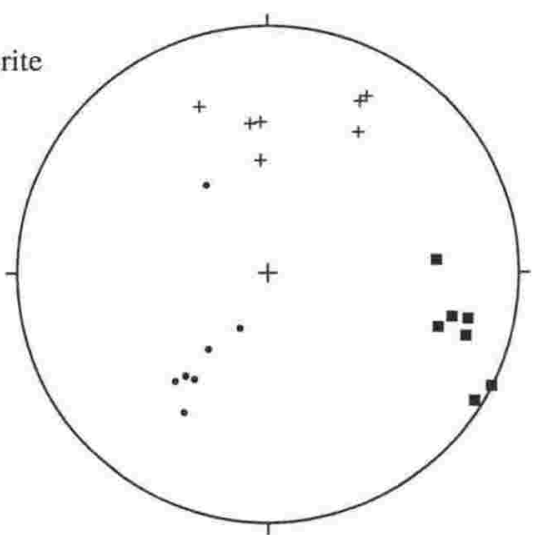


Site 59.

Ongatiti ignimbrite S17/259966 Type 1

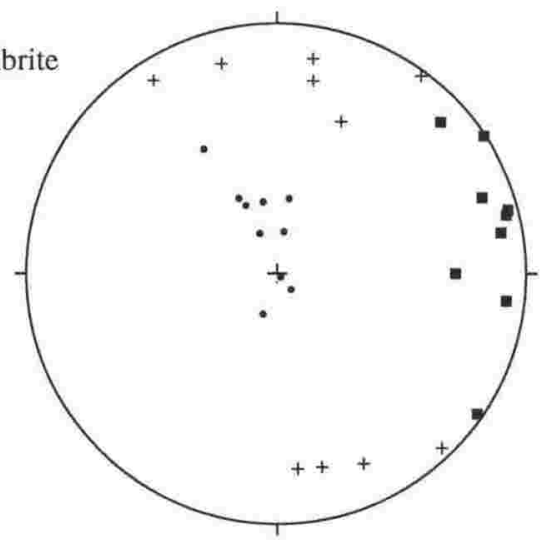

Site 61.

Ahuroa ignimbrite T16/423237

Type 2

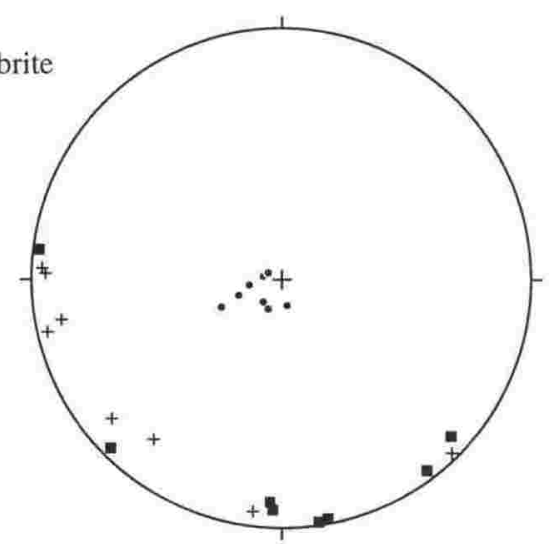

Site 63.

Ongatiti ignimbrite T16/398231 Type 2

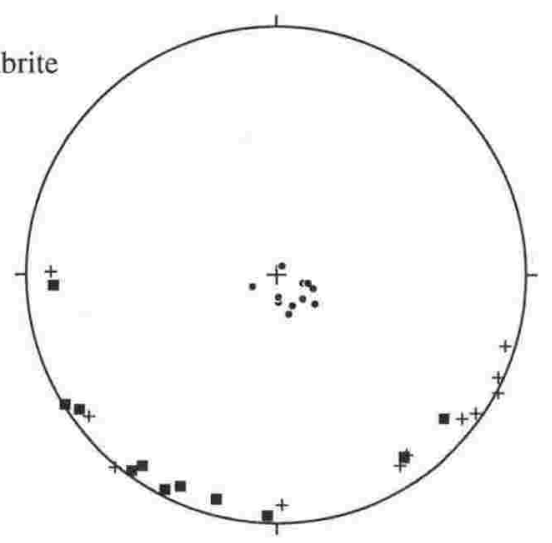

Site 65.

Marshall ignimbrite T16/471131 Type 1

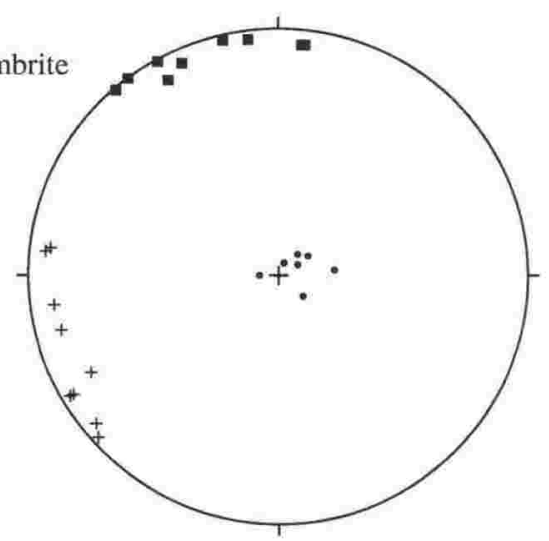

Site 60.

Whakamaru ignimbrite T17/305959

Type 4

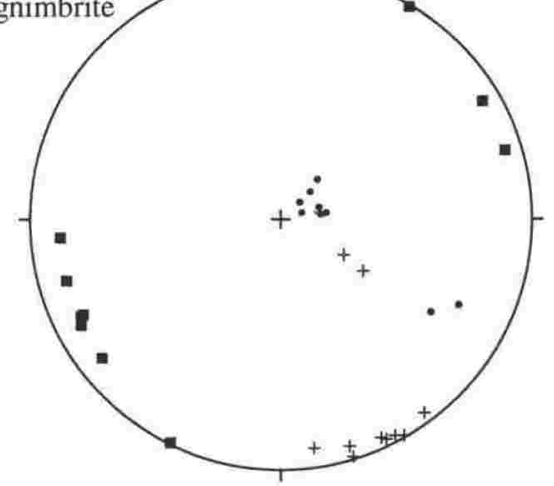

Site 62.

Ongatiti ignimbrite

T16/368197

Type 2

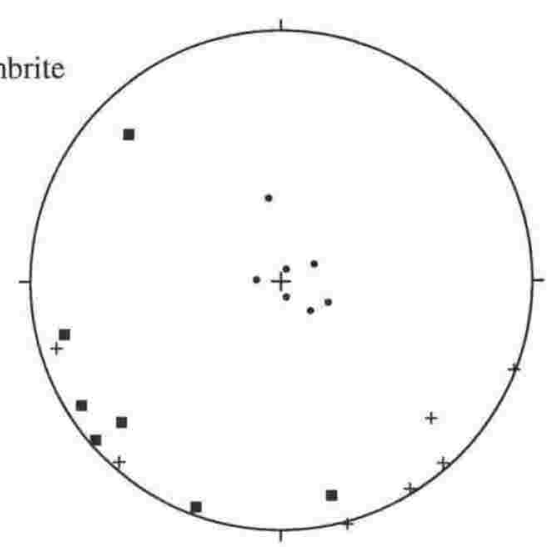

Site 64.

Marshall ignimbrite

T16/470142

Type 2

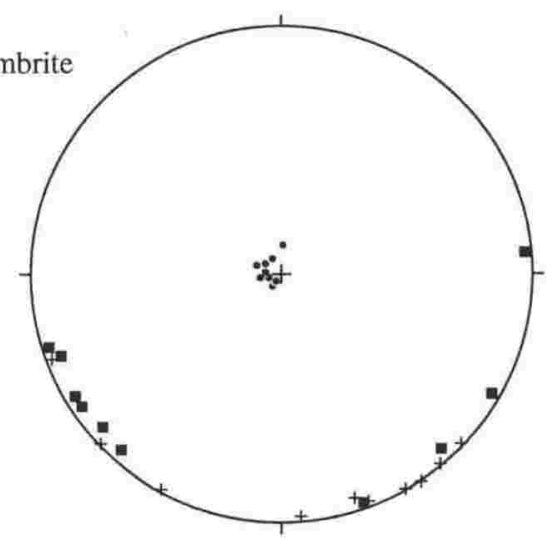

Site 66.

Whakamaru ignimbrite

V19/155428

Type 1

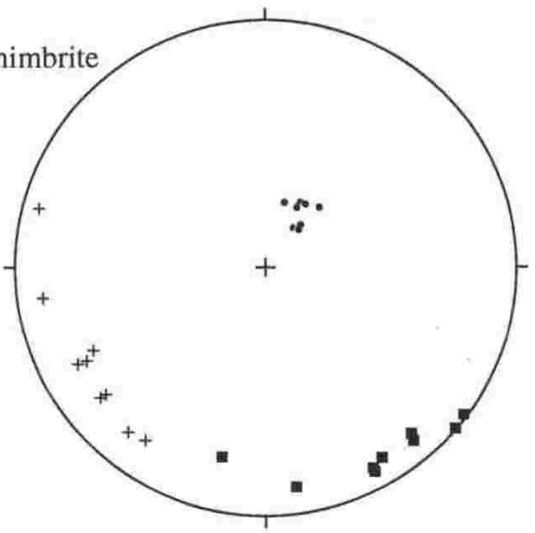


Site 67.

Whakamaru ignimbrite

V19/150442

Type 3

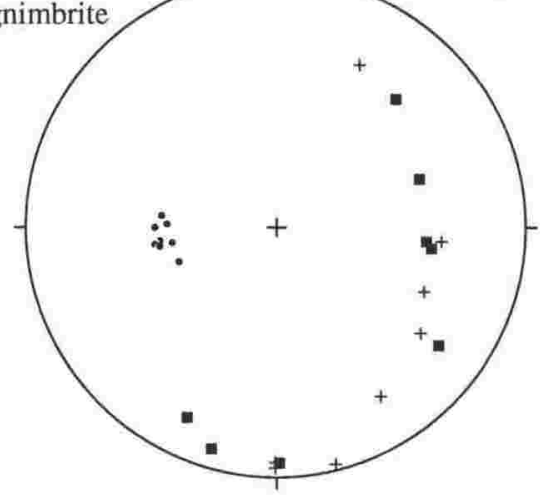

Site 69.

Whakamaru ignimbrite

U18/861639

Type 1

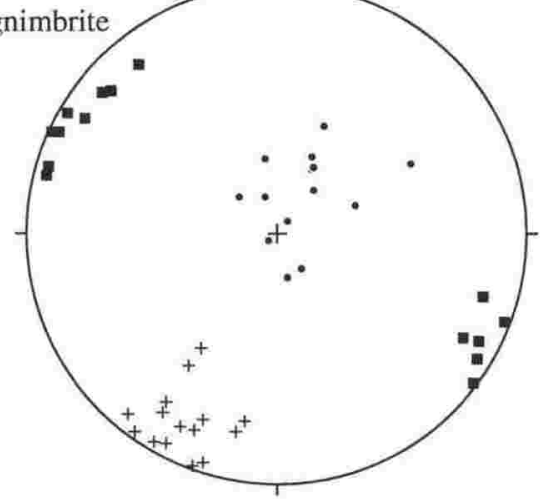

Site 72.

Whakamaru ignimbrite U18/819579

Type 2

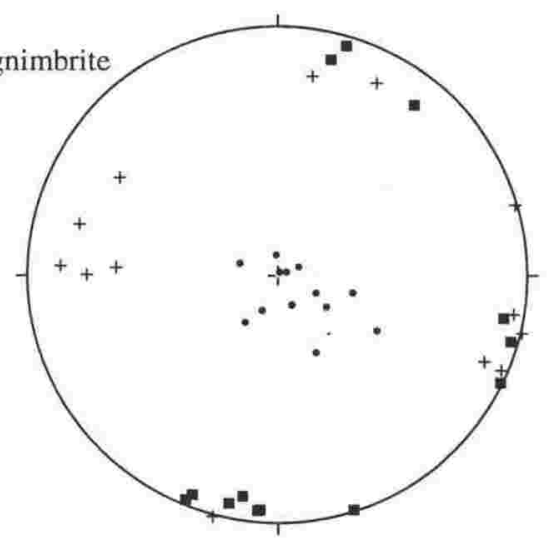

Site 74.

Whakamaru ignimbrite U17/063949 Type 1

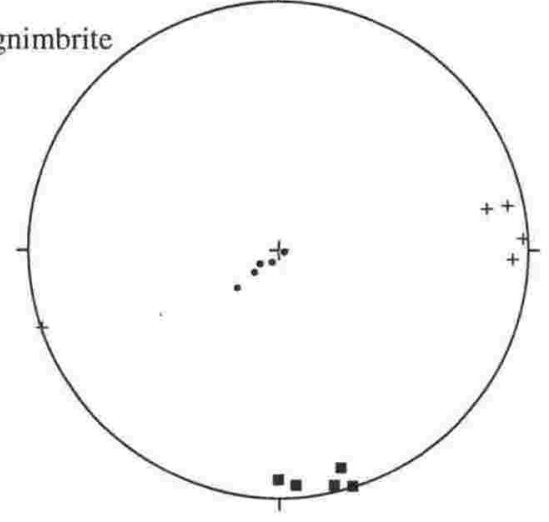

Site 68.

Whakamaru ignimbrite V19/150442

Type 1

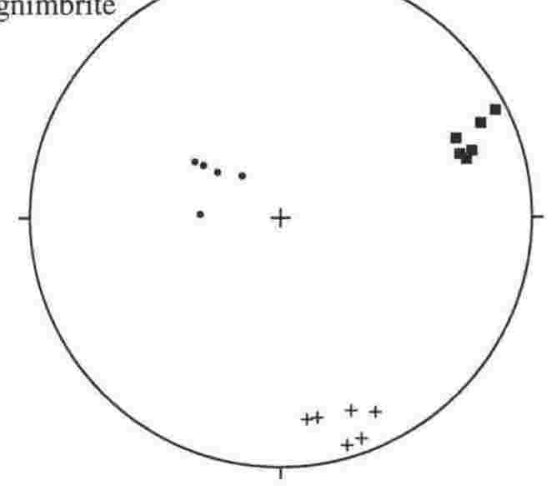

Site 71.

Whakamaru ignimbrite U18/860640 Type 2

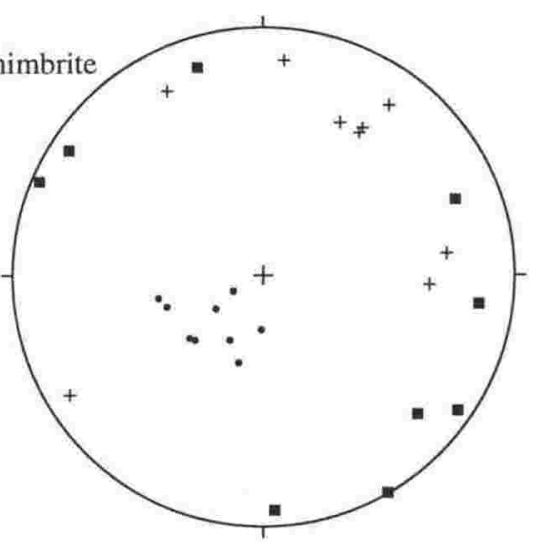

Site 73.

Whakamaru ignimbrite U18/819579

Type 7

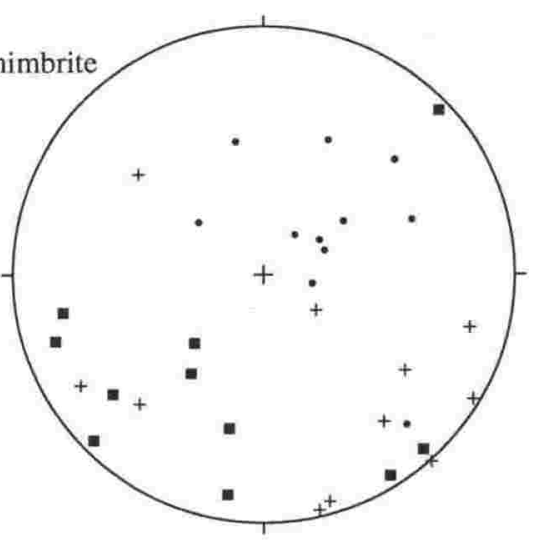

Site 75.

Whakamaru ignimbrite

U18/749549

Type 7

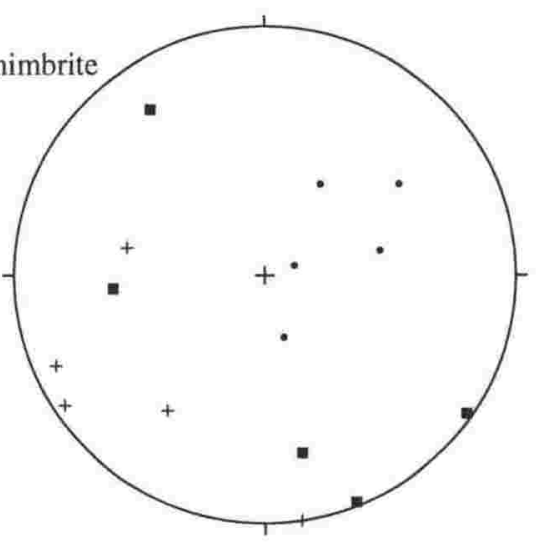


Site 76.

Whakamaru ignimbrite

T18/695544

Type 3

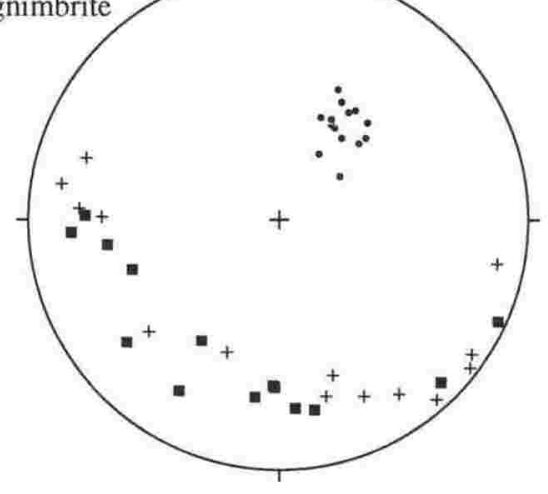

Site 78.

Whakamaru ignimbrite T19/656456

Type 1

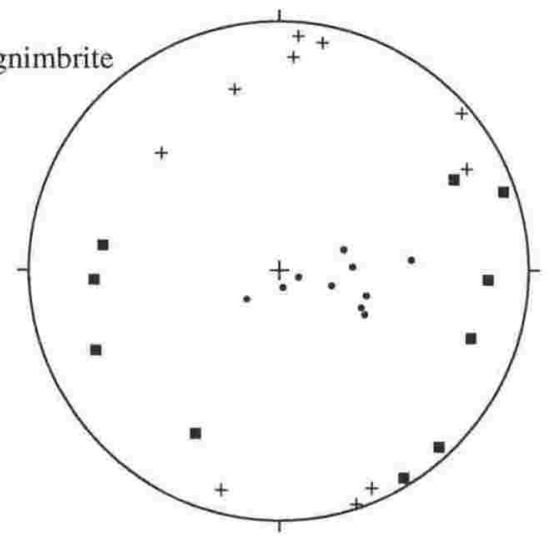

Site 80.

Uncertain

V17/394844

Type 5?

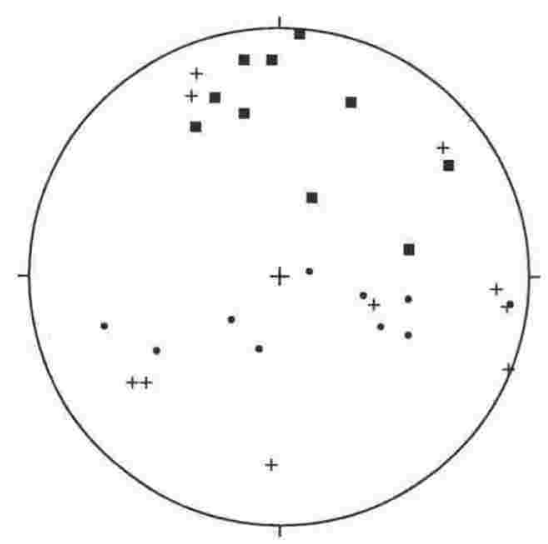

Site 82.

Matahina ignimbrite V17/307993 Type 2

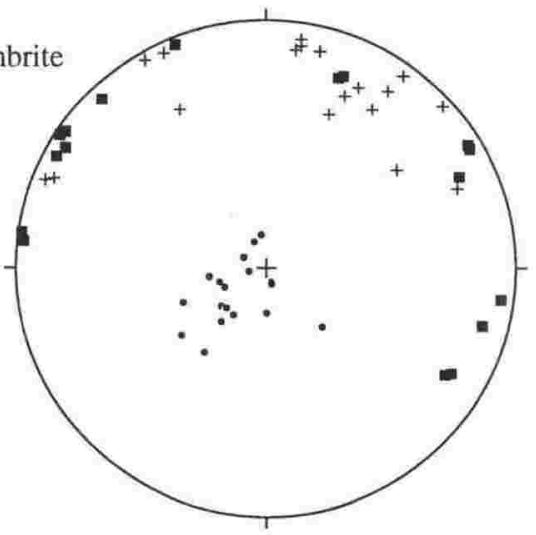

Site 77.

Whakamaru ignimbrite T19/656456 Type 5

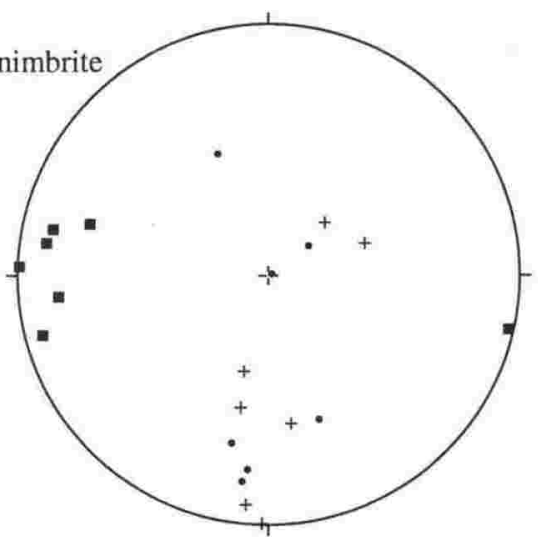

Site 79.

Waiotapu ignimbrite? U16/998147 Type 7

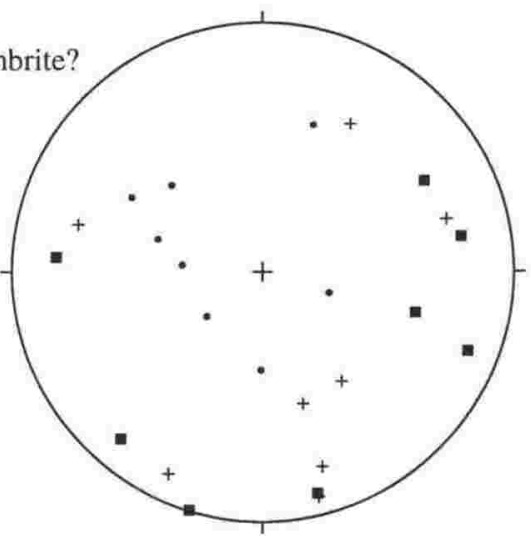

Site 81.

Whakamaru ignimbrite V17/327984 Type 3

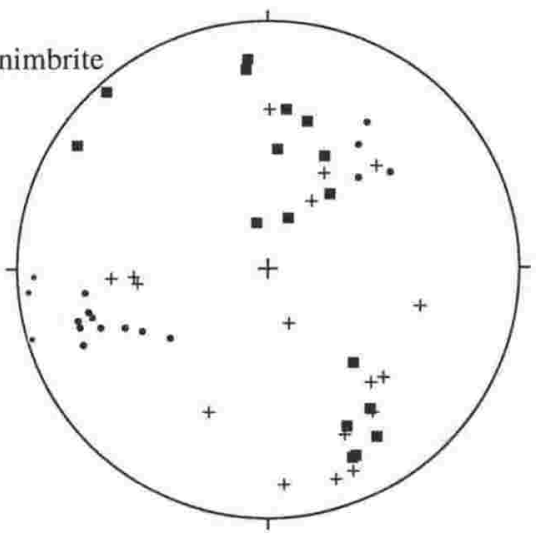

Site 83.

Whakamaru ignimbrite V17/305993 Type 4

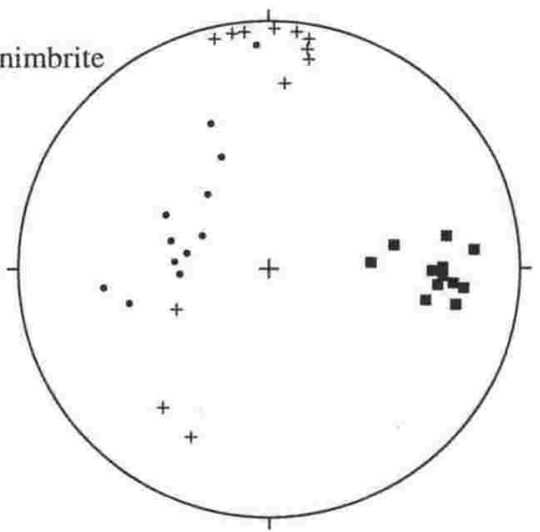


Site 84.

Matahina ignimbrite V17/275996

Type 1

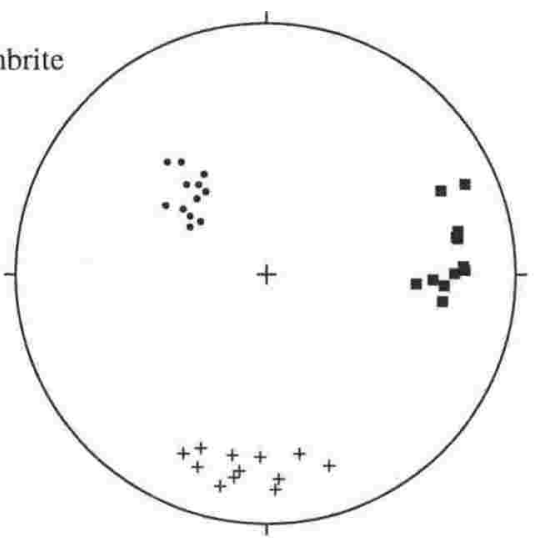

Site 86.

Kaingaroa ignimbrite

V17/194054

Type 2

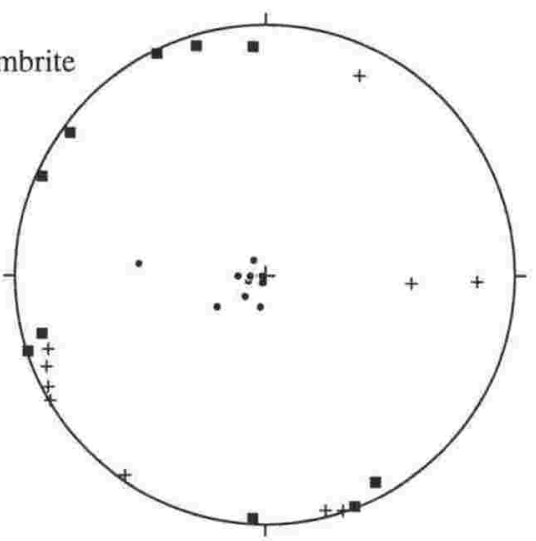

Site $\mathbf{8 8}$.

Mamaku ignimbrite cubes

U15/781470

Type 2

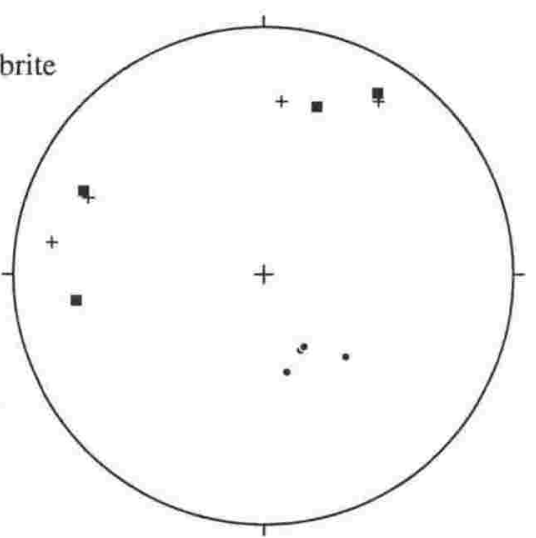

Site 90.

Mamaku ignimbrite cubes U15/882557

Type 1?

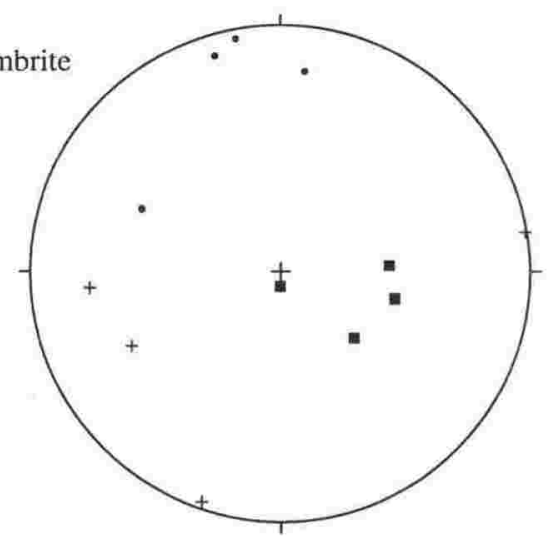

Site 85 .

Kaingaroa ignimbrite

V17/217003

Type 2

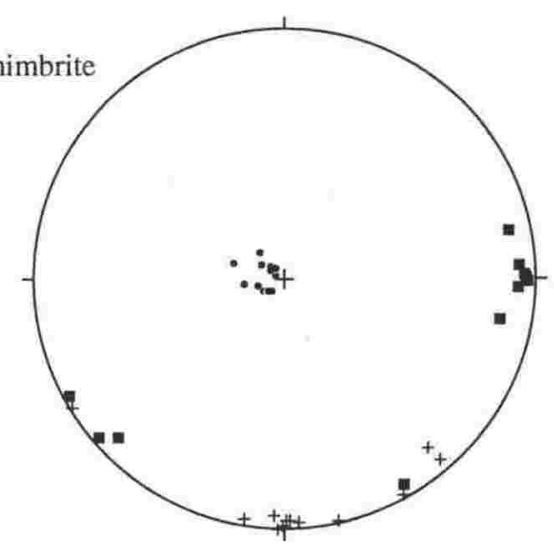

Site 87.

Mamaku ignimbrite cubes

U15/840408

Type 1

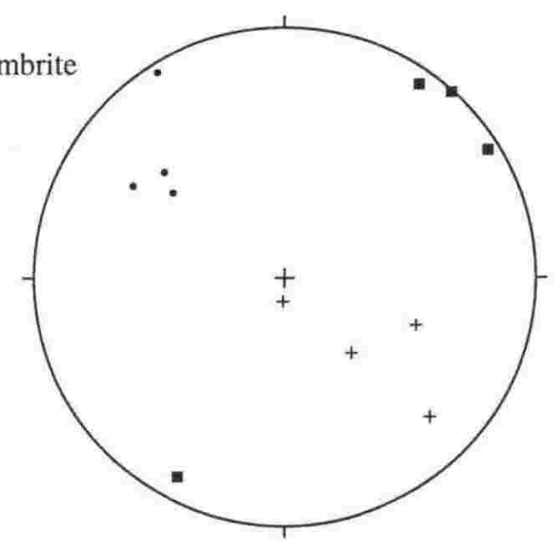

Site 89.

Mamaku ignimbrite U15/885556

Type 6

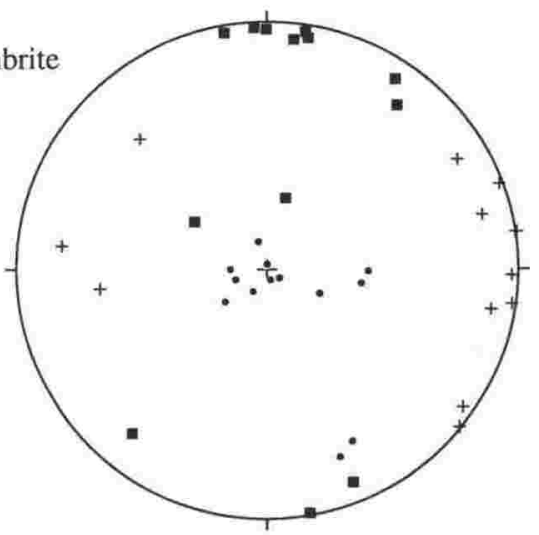

Site 91.

Mamaku ignimbrite U15/884555

Type 3

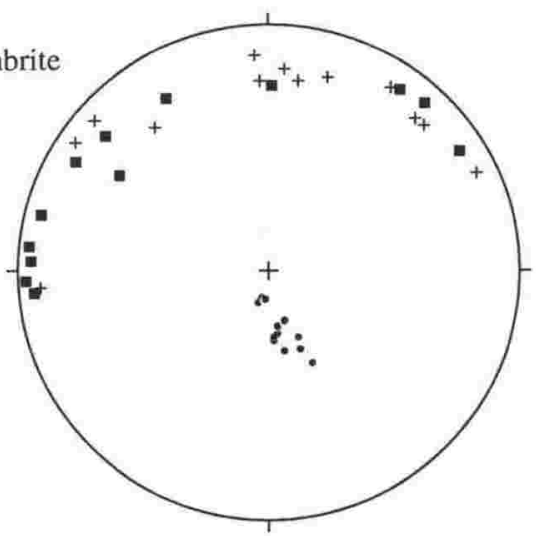


Site 92.

Mamaku ignimbrite

cubes

U15/976480

Type 1

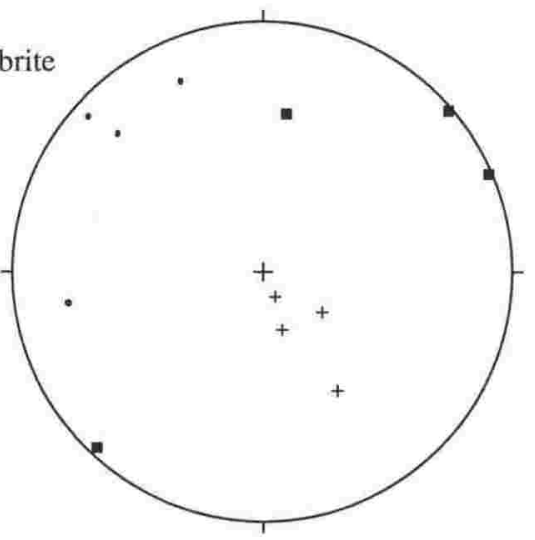

Site 94.

Matahina ignimbrite cubes V15/316517

Type 1

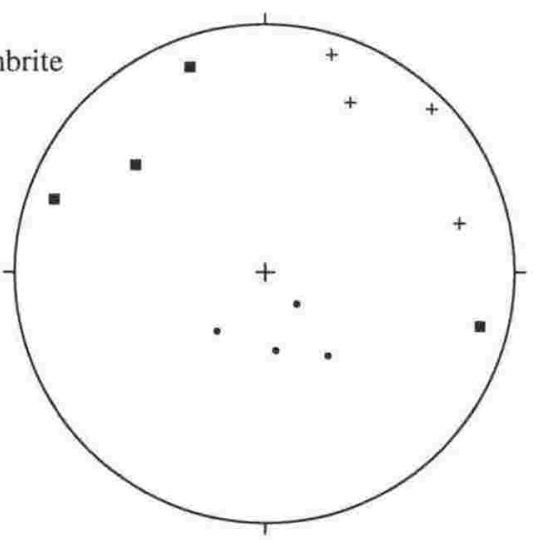

Site 96.

Matahina ignimbrite

V15/342576

Type 2

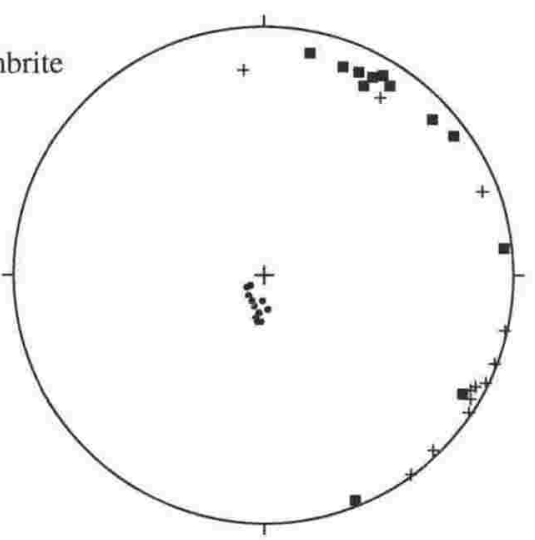

Site 98.

Matahina ignimbrite

V15/343478

Type 2

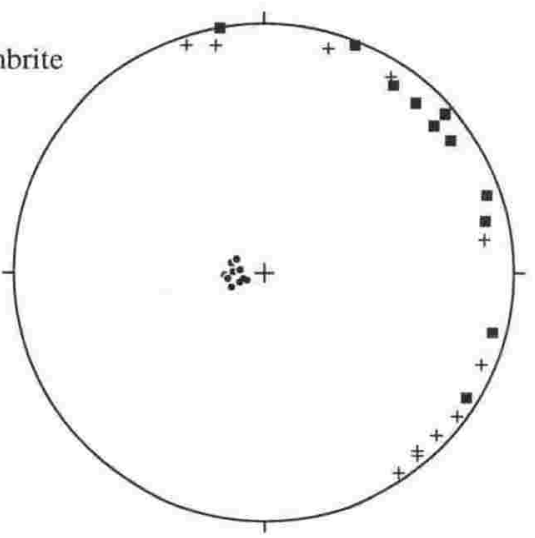

Site 93.

Mamaku ignimbrite

cubes

U15/000464

Type 7

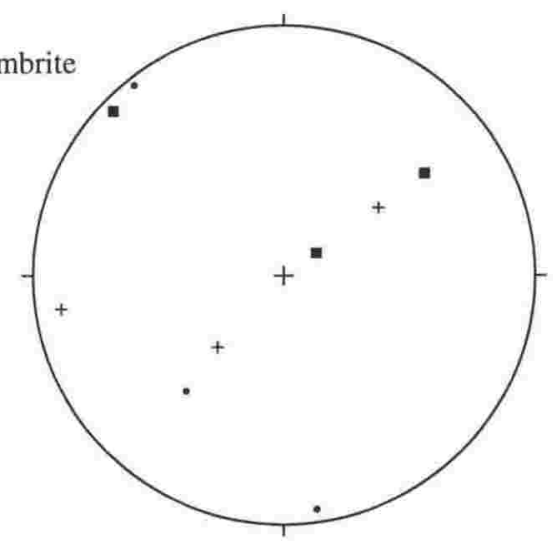

Site 95.

Matahina ignimbrite V15/316523

Type 1

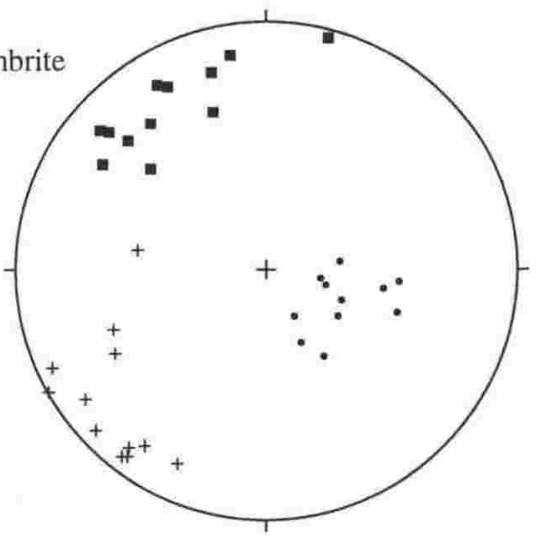

Site 97.

Matahina ignimbrite V15/318477

Type 1

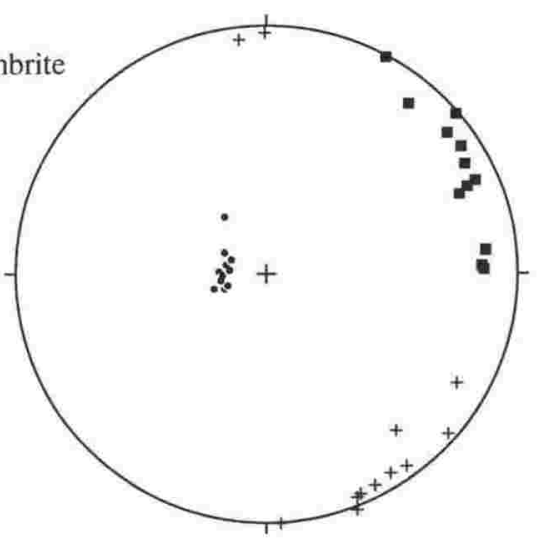

Site 99.

Matahina ignimbrite V16/440353

Type 2

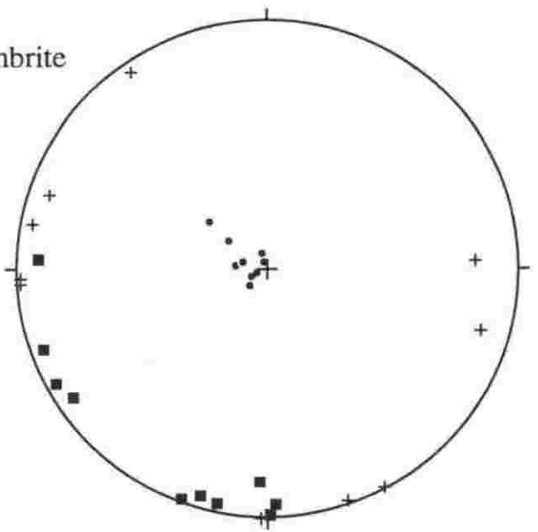


Site 100.

Whakamaru? McCoy Rd + +

W15/

Type 2

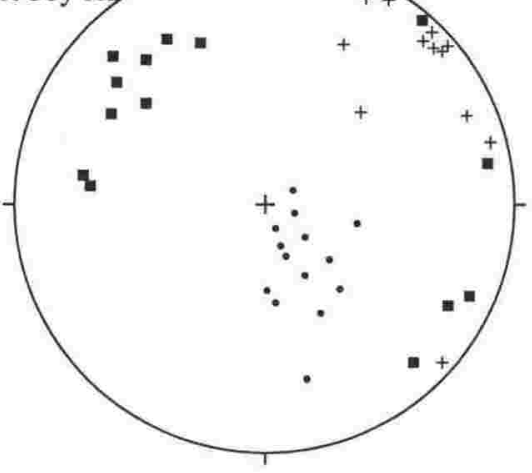

Site 102.

Maroa

U17/845053

Type 2

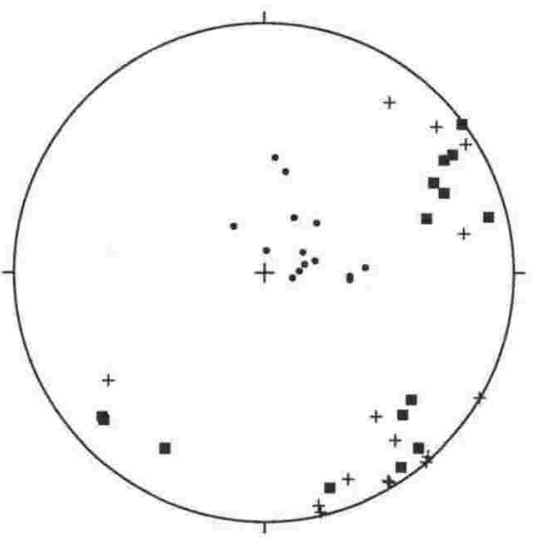

Site 104.

Maroa

U16/842124

Type 2

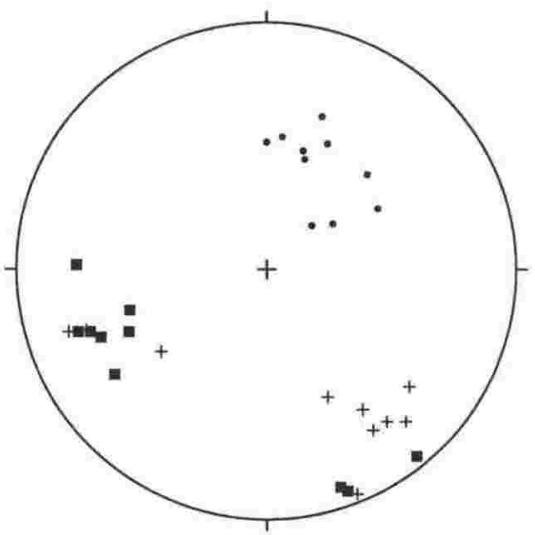

Site 106.

Maroa

U16/872157

Type 5

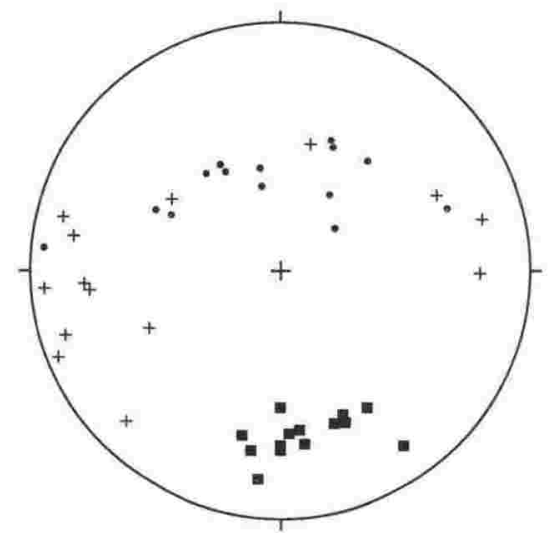

Site 101.

Paeroa?

U17/876068

Type 1

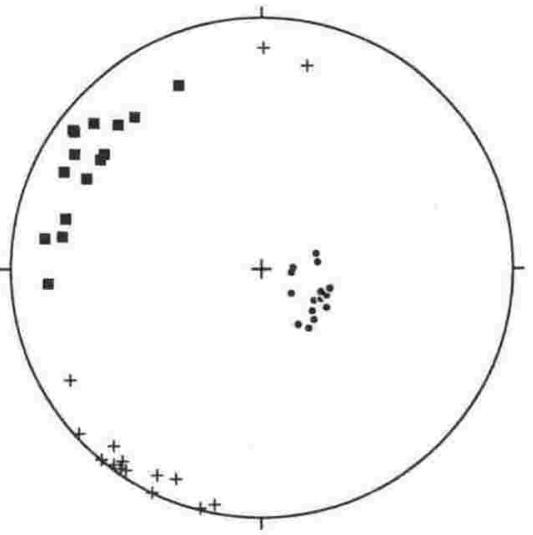

Site 103.

Maroa

U16/862104

Type 1

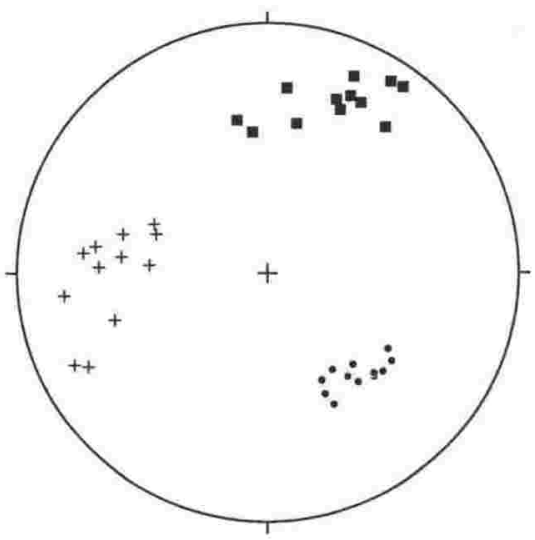

Site 105.

Maroa

U16/881181

Type 2

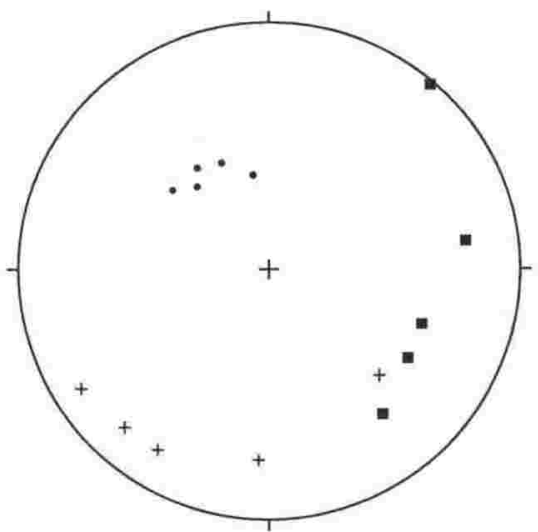

Site 107.

Maroa

U16/834129

Type 7

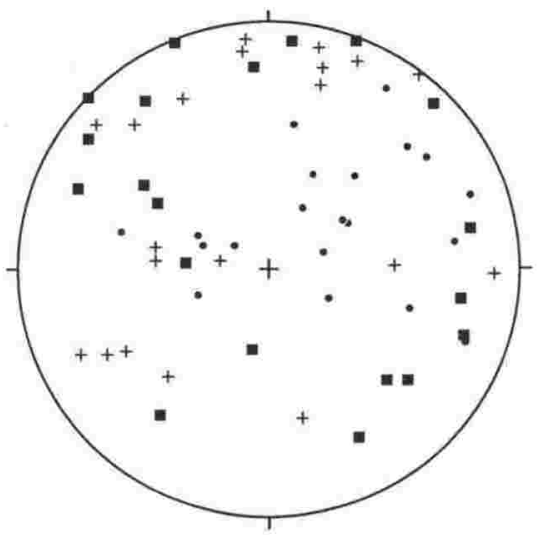


Site 108.

Maroa

U16/831135

Type 1

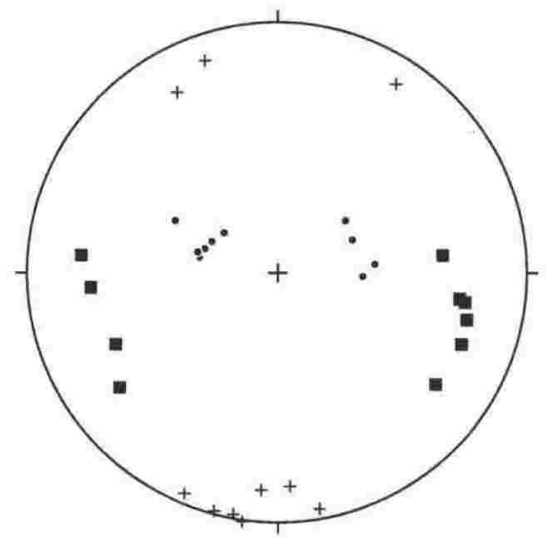

Site 110.

Maroa

U17/821083

Type 1

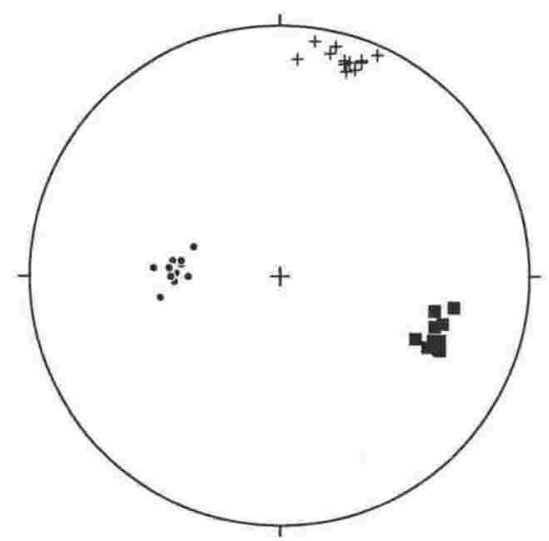

Site 112.

Mamaku ignimbrite T17/672043

Type 2

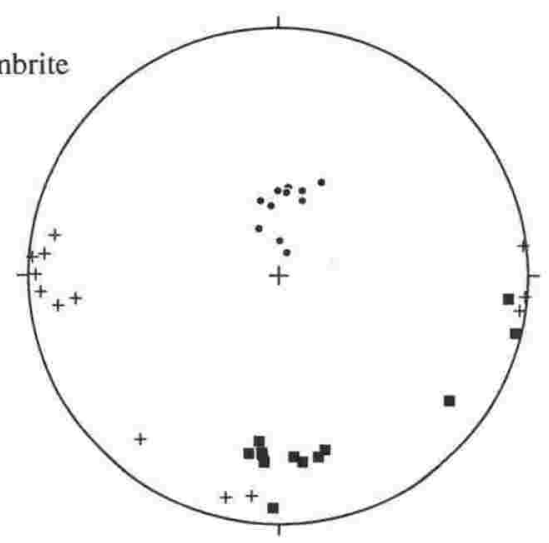

Site 114.

Ongatiti Ignimbrite S17/034985 Type 1

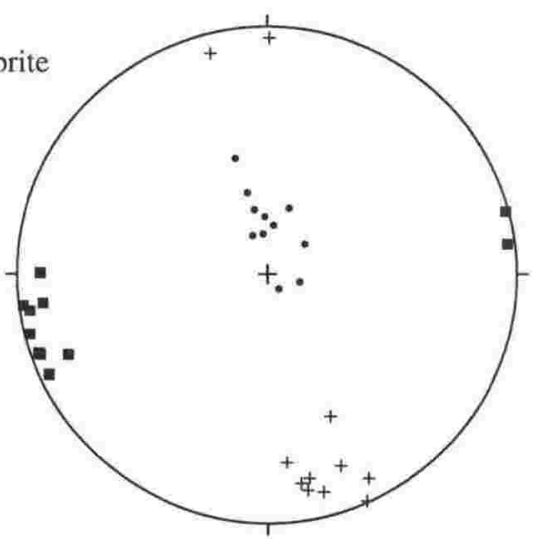

Site 109.

Ohakuri

U17/ 797058

Type 4

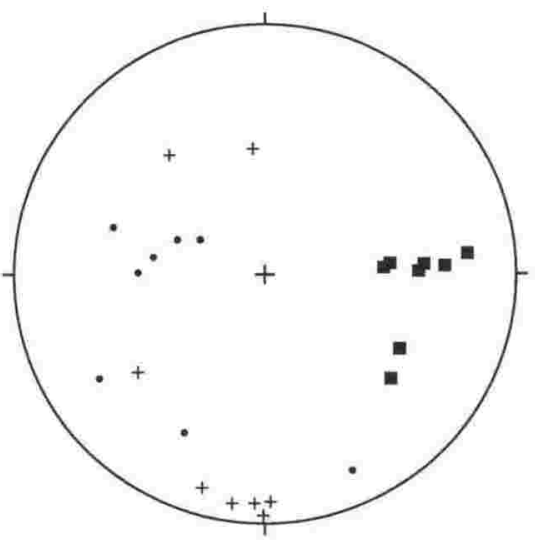

Site 111.

Maroa

U17/787078

Type 1

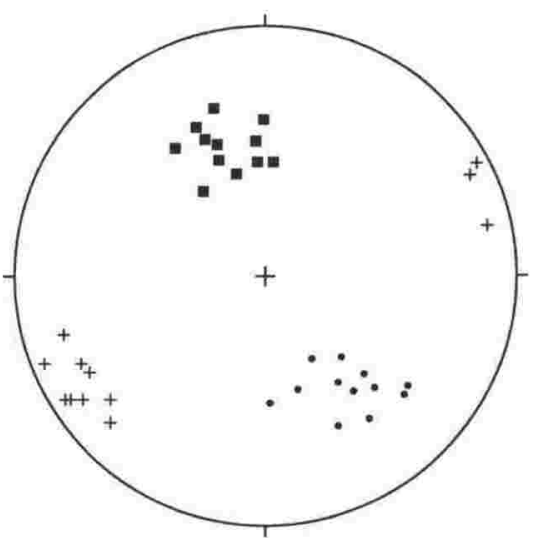

Site 113.

Whakamaru ignimbrite

S18/165587

Type 1

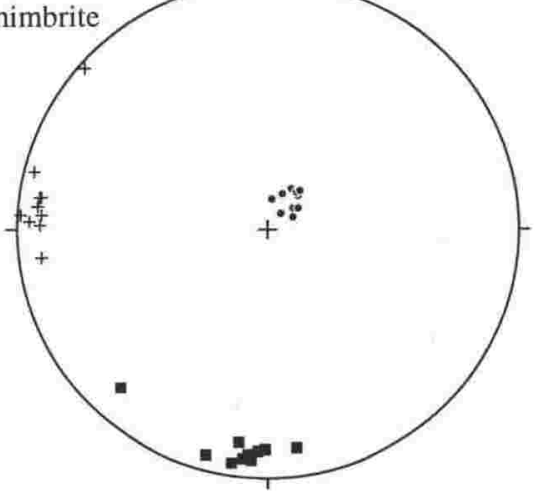

Site 115.

Ongatiti Ignimbrite

S17/105086

Type 2

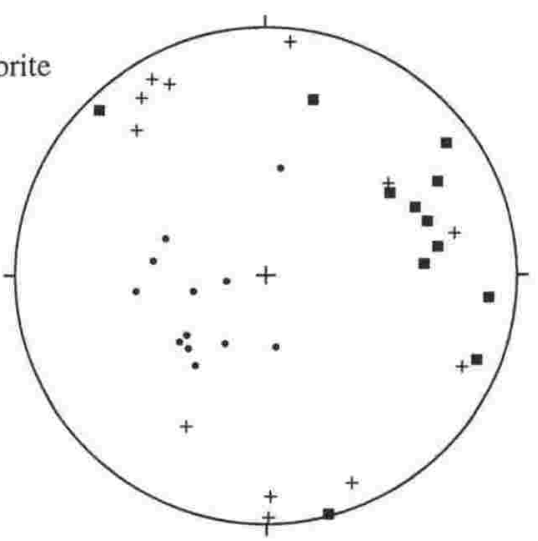


Site 117.

Whakamaru ignimbrite

T17/474886

Type 2

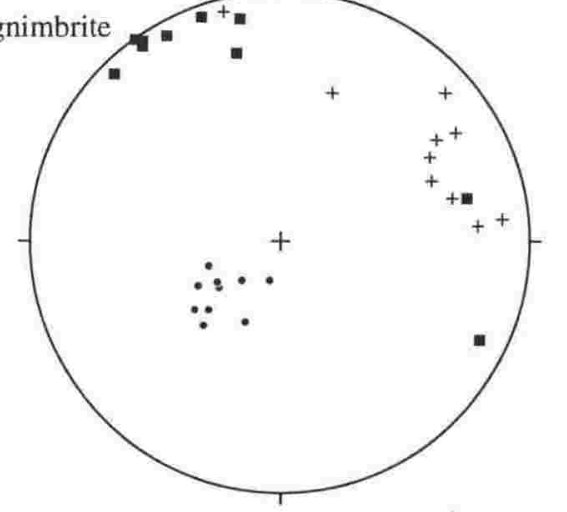

Site 119.

Ongatiti Ignimbrite

T15/314440

Type 1

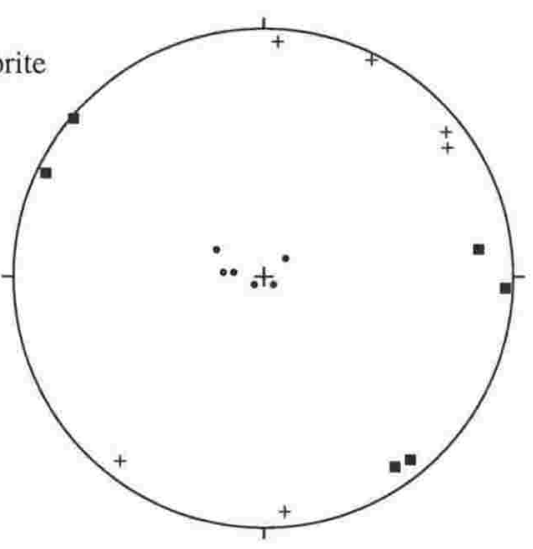

Site 121.

Ahuroa Ignimbrite T16/418331 Type 2

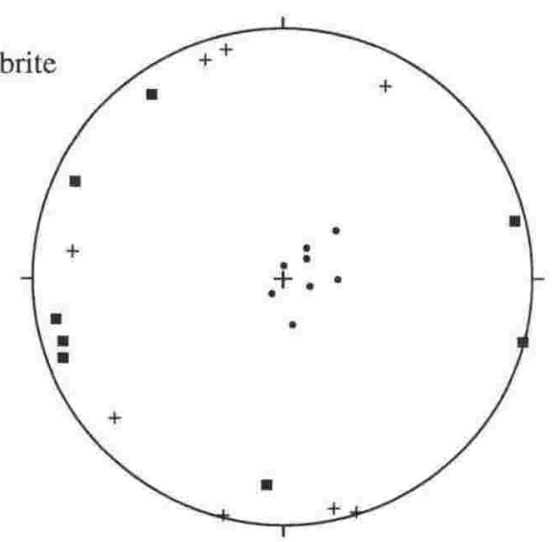

Site 123.

Ongatiti/Waipari T16/354336 Type

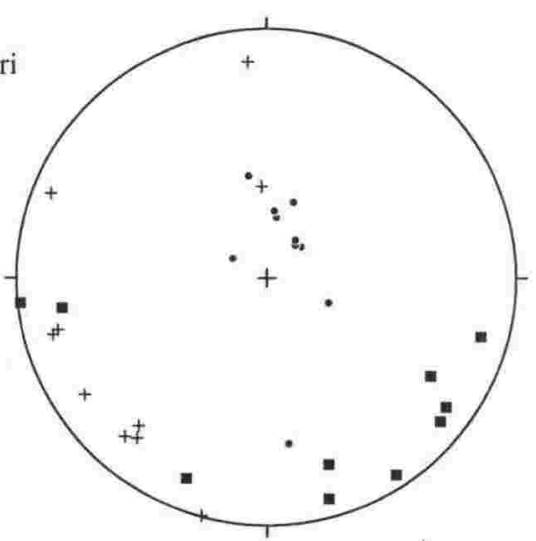

Site 118.

Ahuroa Ignimbrite T17/403077

Type 1

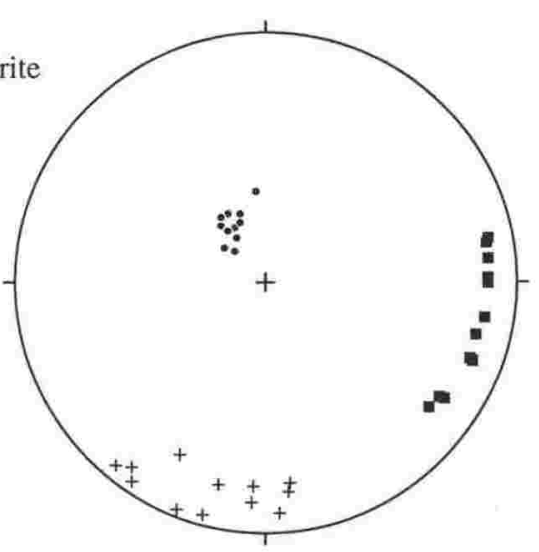

Site 120.

Whakamaru ignimbrite T16/388356

Type 2

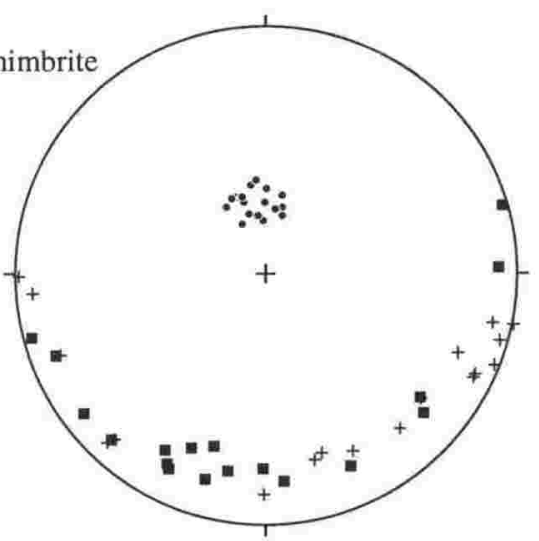

Site 122.

Ahuroa Ignimbrite T16/382306

Type 2

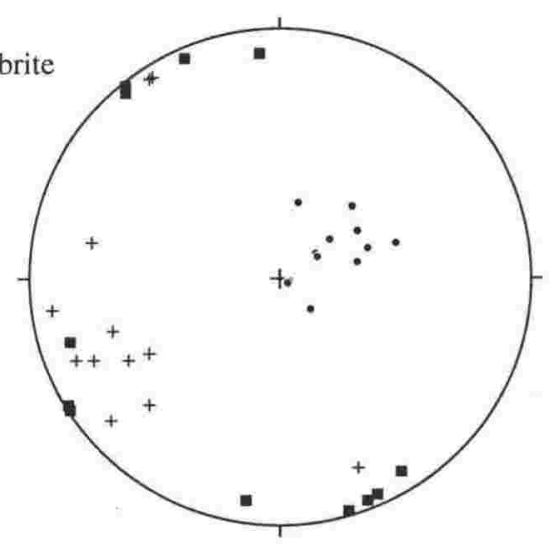

Site 124.

Ahuroa Ignimbrite T16/337360 Type 2

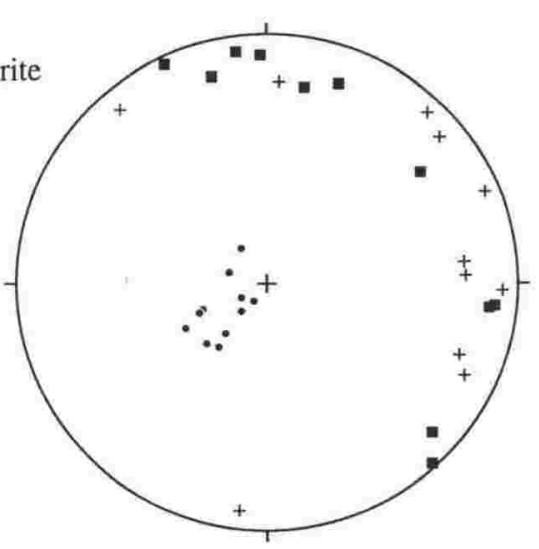


Site 125.

Whakamaru ignimbrite

T15/420448

Type 1

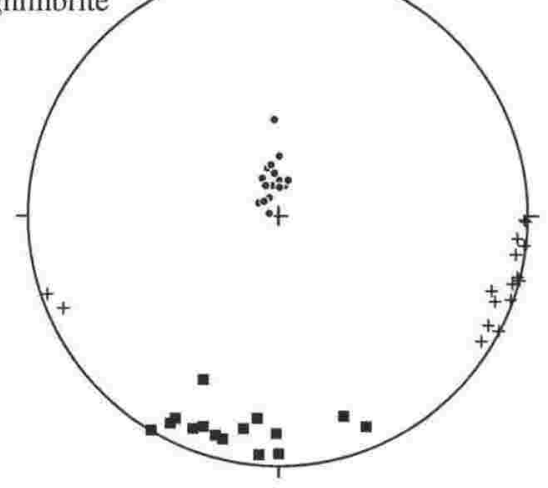

Site 127.

Whakamaru ignimbrite T15/488463

Type 2

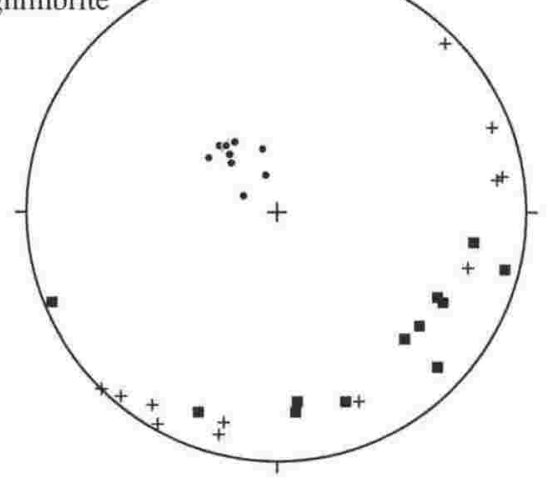

Site 129.

Whakamaru ignimbrite T16/588398

Type 1

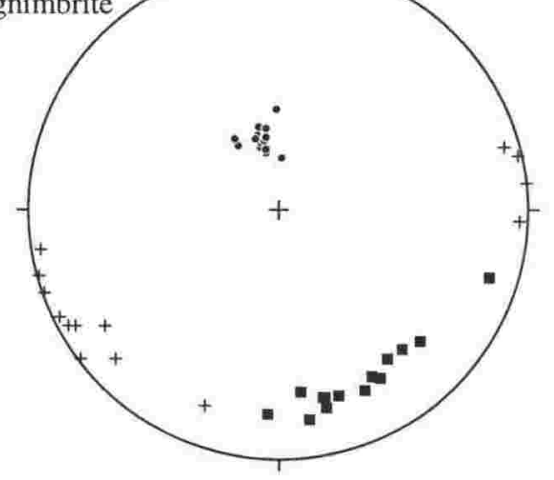

Site 132.

Pokai?

T16/672261

Type 2

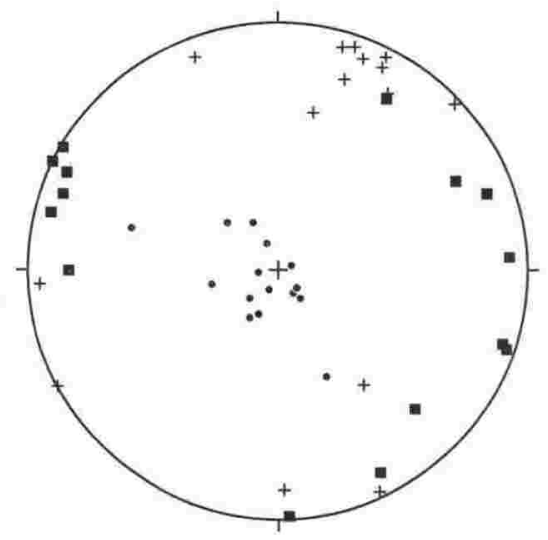

Site 126.

Ongatiti Ignimbrite

T15/437495

Type 2

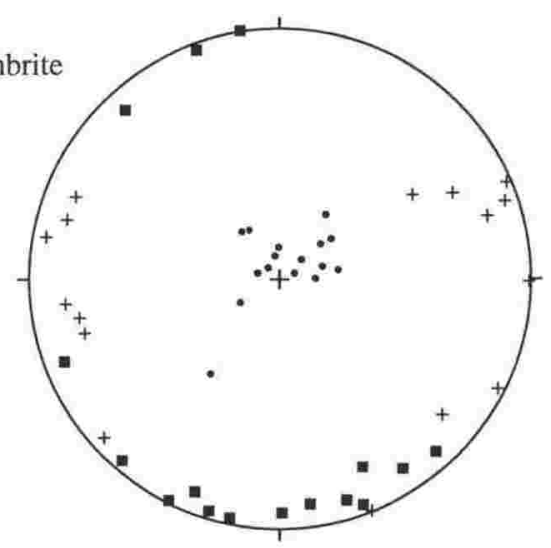

Site 128.

Whakamaru ignimbrite

T16/588398

Type 2

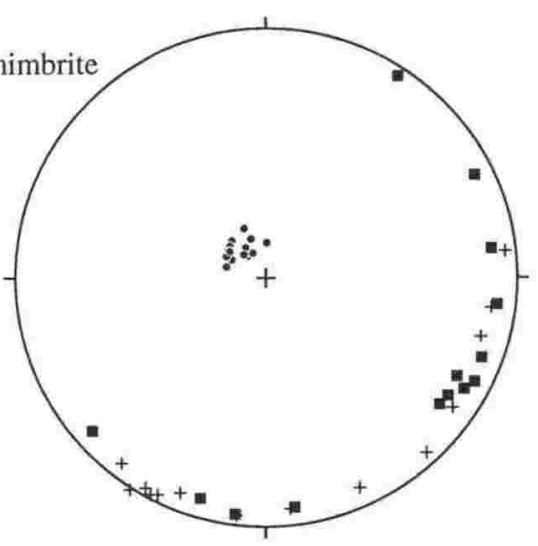

Site 130.

Pokai?

T16/660337

Type 2

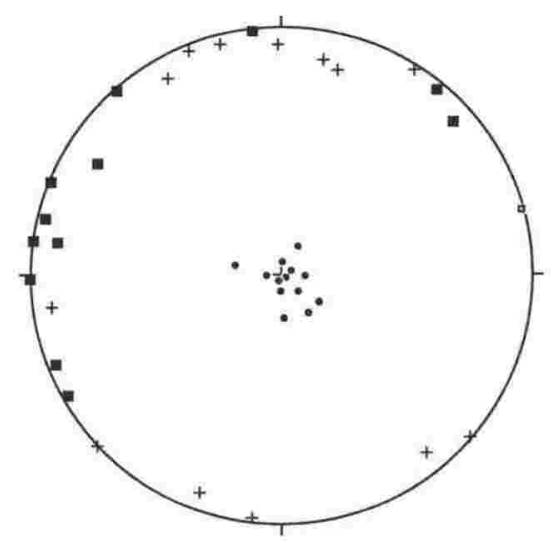

Site 133.

Maroa?

U17/757803

Type 2

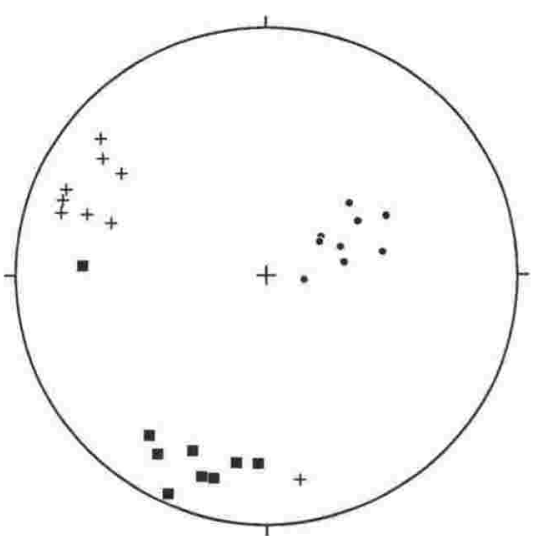


Site 134 .

Oruanui Ignimbrite S19/285270

Type 6

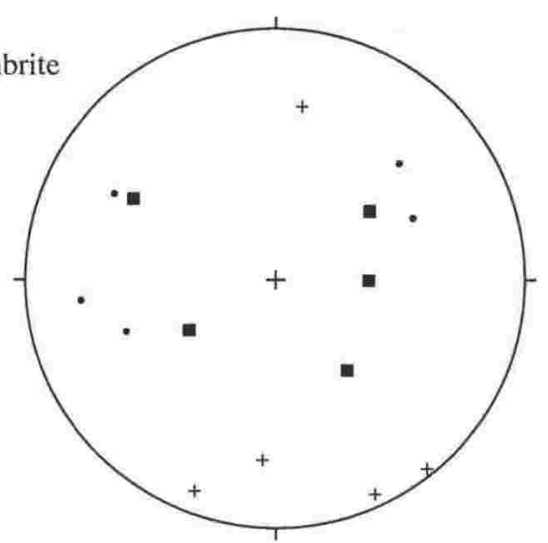

Site 139.

Oruanui Ignimbrite T18/428751

Type 1

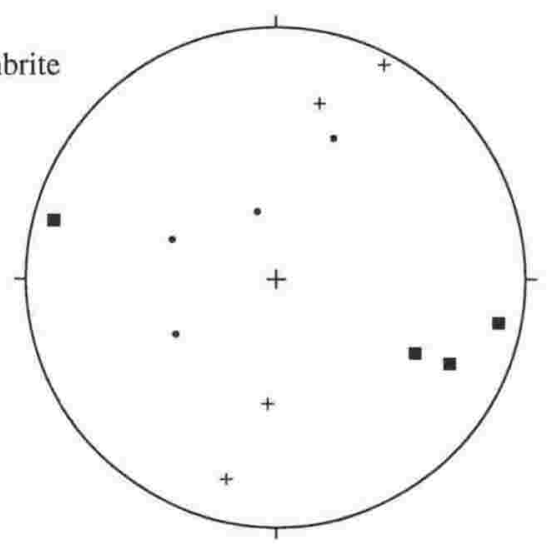

Site 141.

Mamaku Ignimbrite U16/784204

Type 2

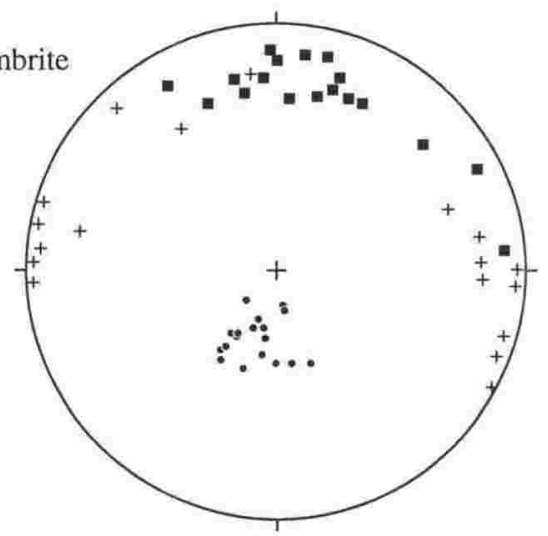

Site 143.

Tikorangi Ignimbrite U16/787209

Type 2

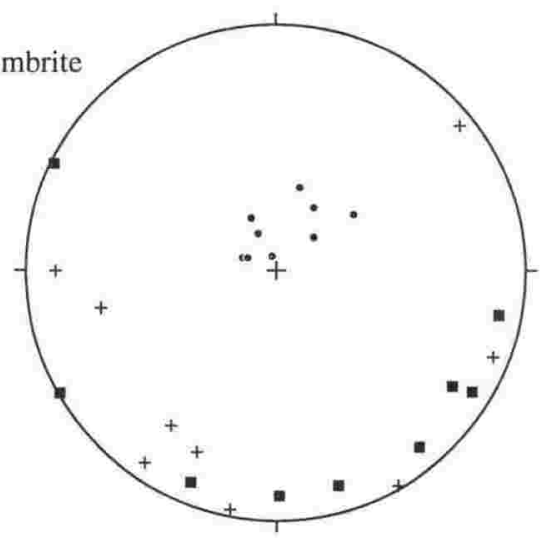

Site 135.

Oruanui Ignimbrite

T18/453523

Type 5

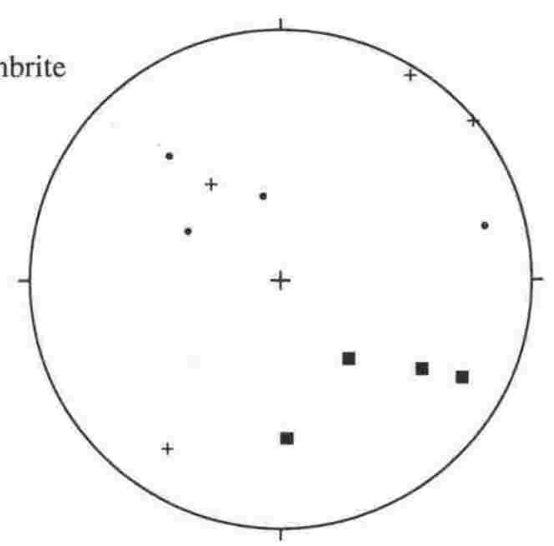

Site 140.

Waiotapu ignimbrite

U16/772211

Type 2

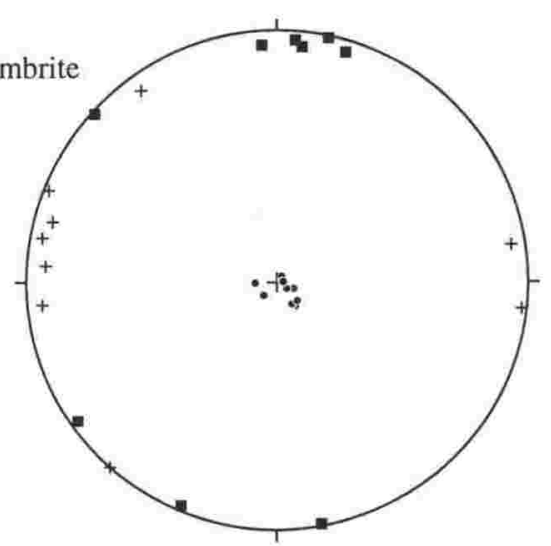

Site 142.

Rahopaka Ignimbrite

U16/788205

Type?

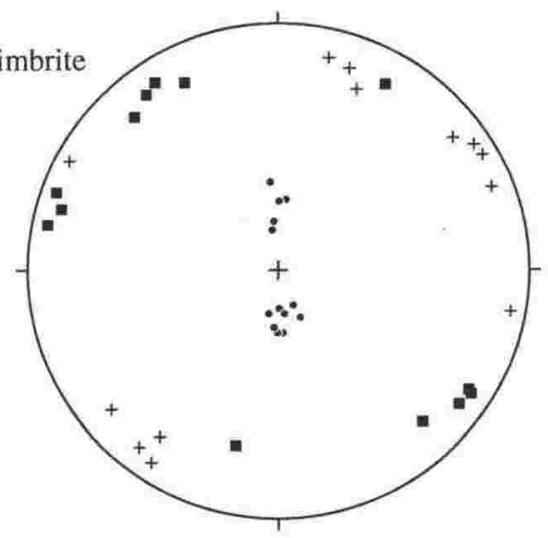

Site 144.

Tikorangi Ignimbrite

U16/788207

Type 2

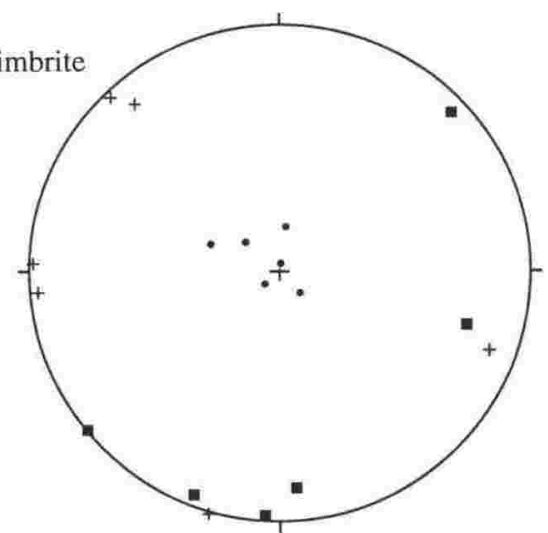


Site 145.

Rahopaka Ignimbrite U16/813187

Type 1

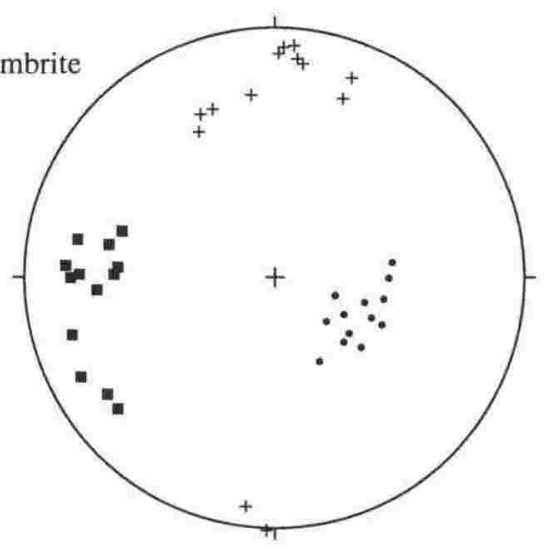

Site 148.

Mamaku Ignimbrite U16/777178

Type 1

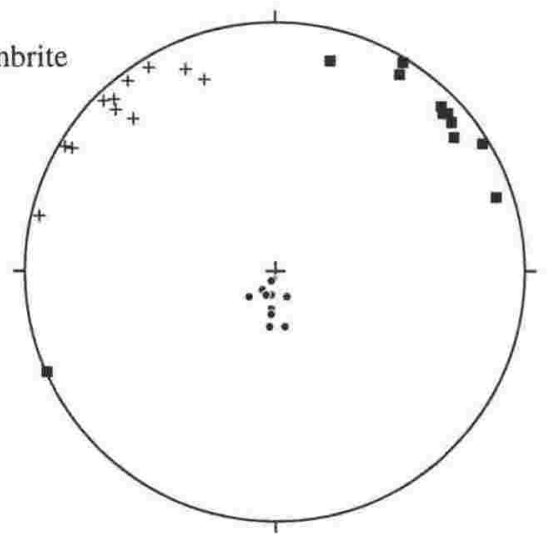

Site 150.

Mamaku Ignimbrite cubes U16/804340 Type 5

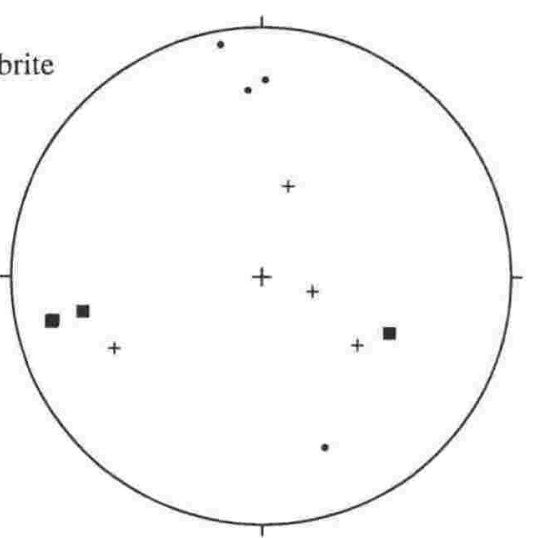

Site 152.

Mamaku Ignimbrite cubes U15/801443 Type 1

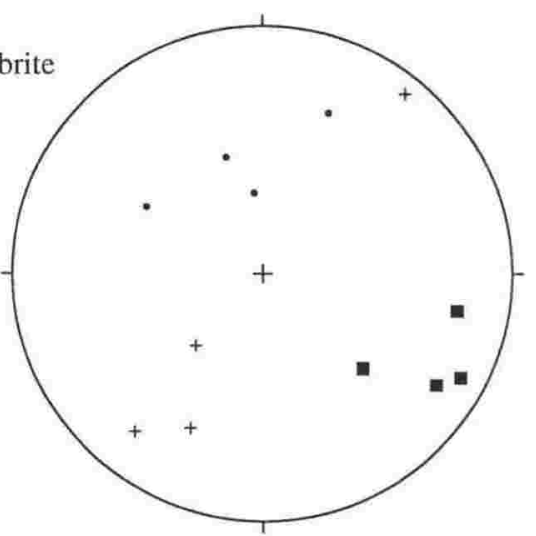

Site 146.

Matahana B

U16/801183

Type 4

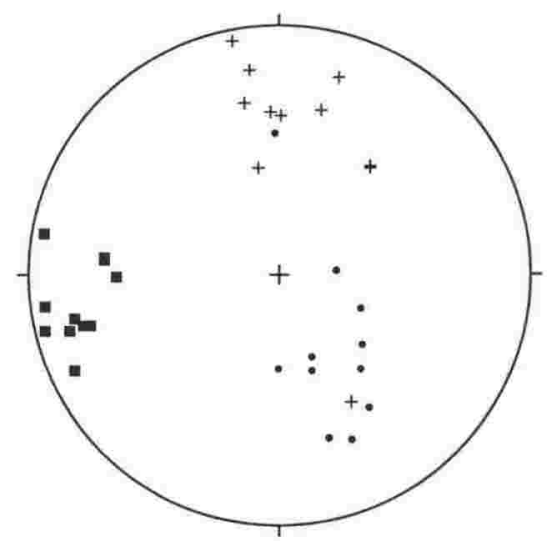

Site 149.

Pukerimu/Tikorangi ignimbrite U16/808216 Type 2

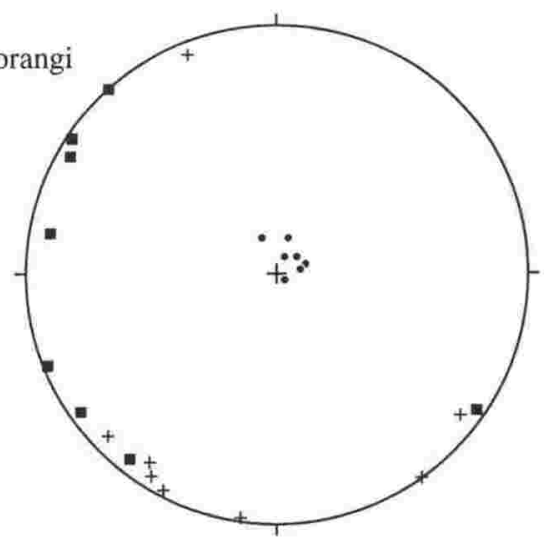

Site 151.

Mamaku Ignimbrite cubes U16/801364 Type 1

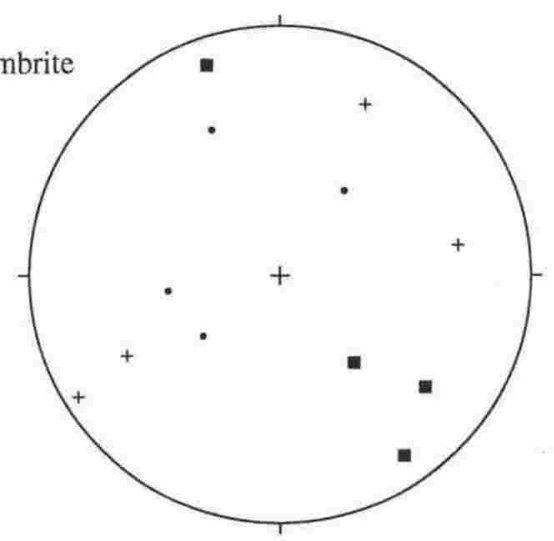

Site 153.

Mamaku Ignimbrite cubes

U15/868472

Type 5

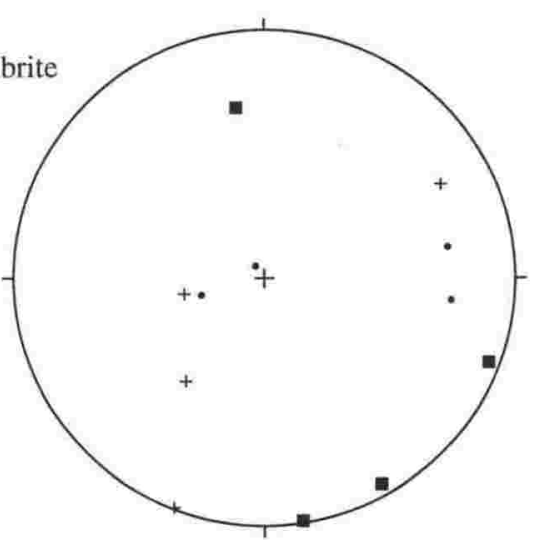


Site 154.

Kaingaroa ignimbrite V16/194112

Type 1

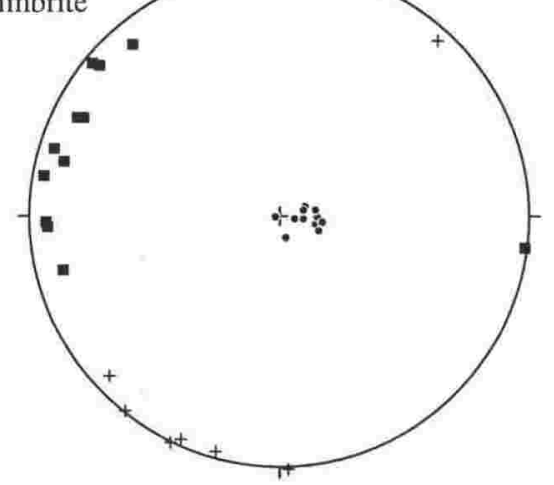

Site 156.

Kaingaroa ignimbrite U16/085108 Type 2

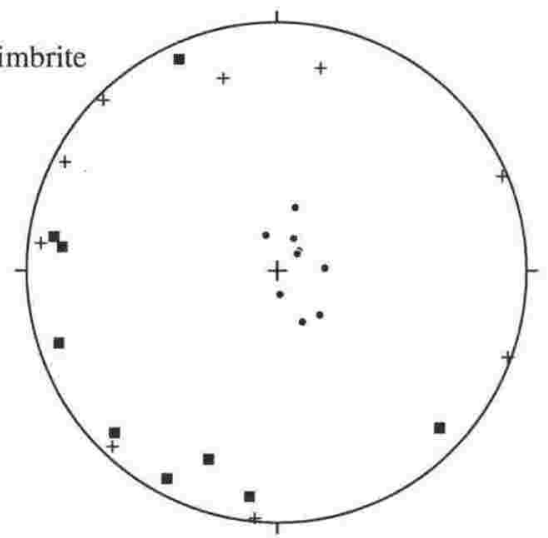

Site 158.

Kaingaroa ignimbrite U16/902112

Type 5

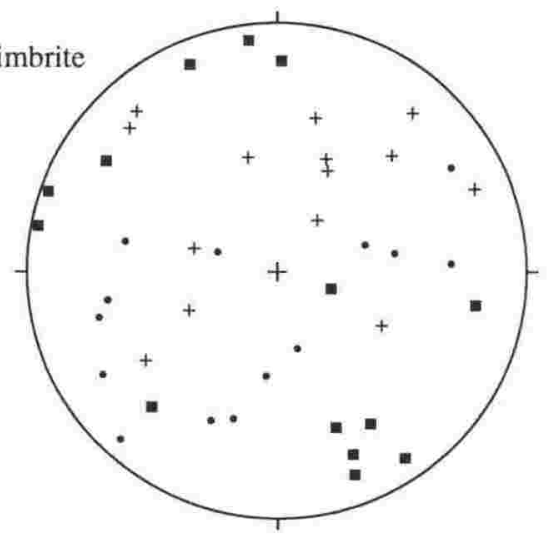

Site 160.

Mamaku Ignimbrite cubes U15/874607 Type $5 / 6$

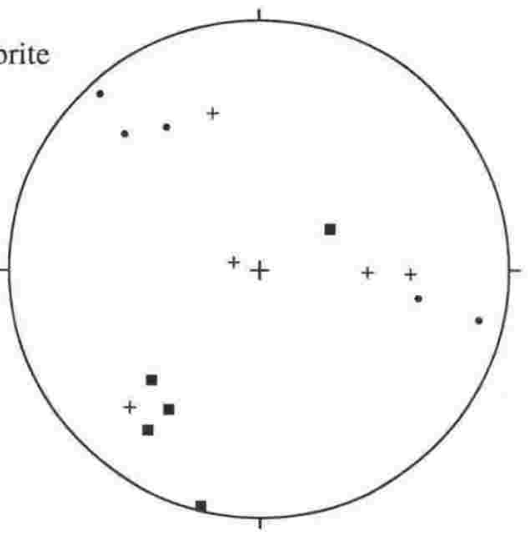

Site 155.

Kaingaroa ignimbrite

V16/128106

Type 4

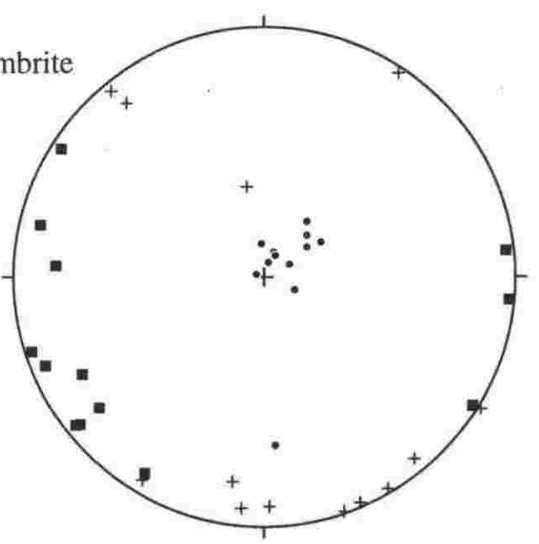

Site 157.

Oruanui Ignimbrite

U18/763794

Type $1 / 6$

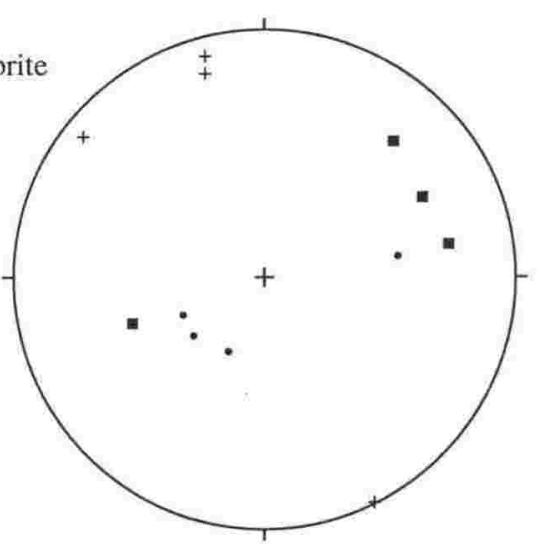

Site 159.

Mamaku Ignimbrite

U15/038495

Type 1

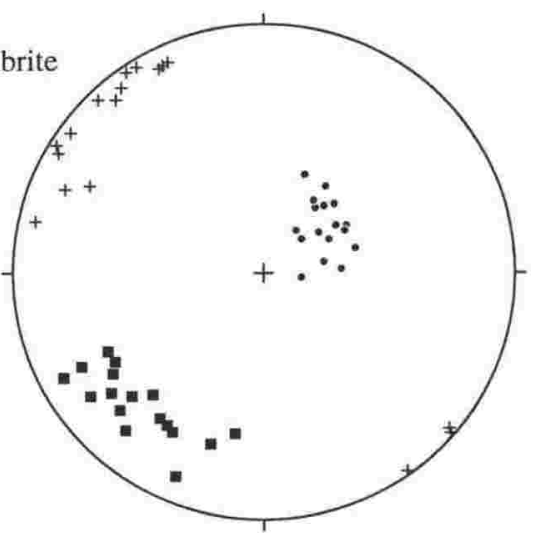

Site 161.

Mamaku Ignimbrite cubes

U15/872644

Type 6

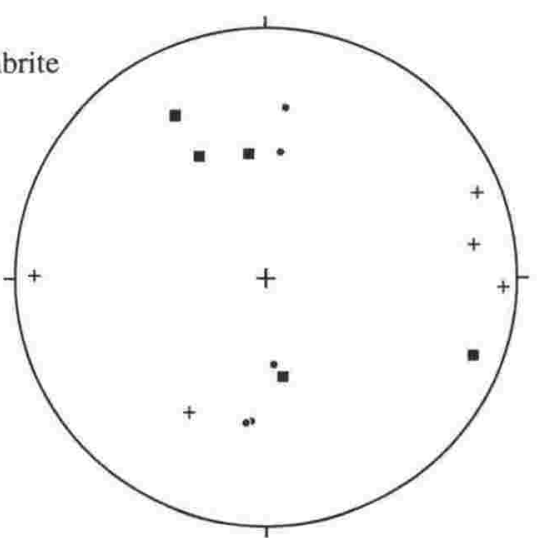


Site 162.

Mamaku Ignimbrite cubes U15/832677 Type 4

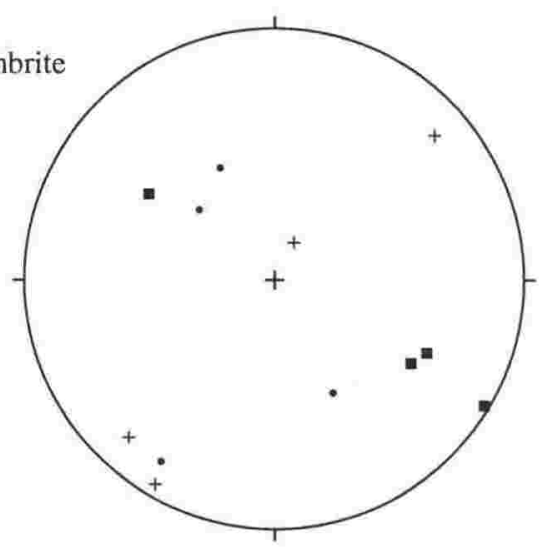

Site 164.

Mamaku Ignimbrite cubes

U15/804693

Type 6

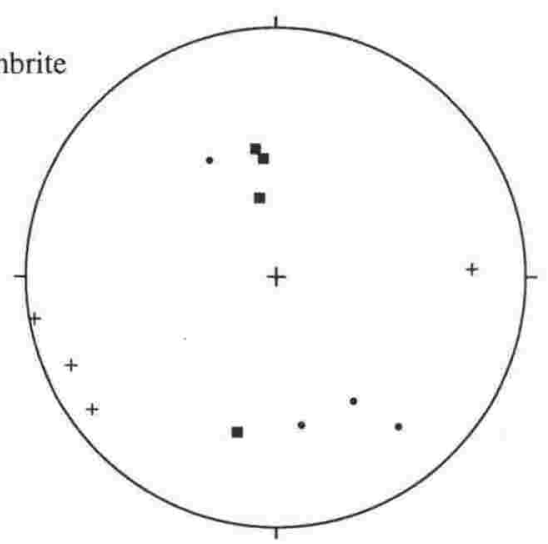

Site 166.

Mamaku Ignimbrite cubes

T15/635469

Type 1

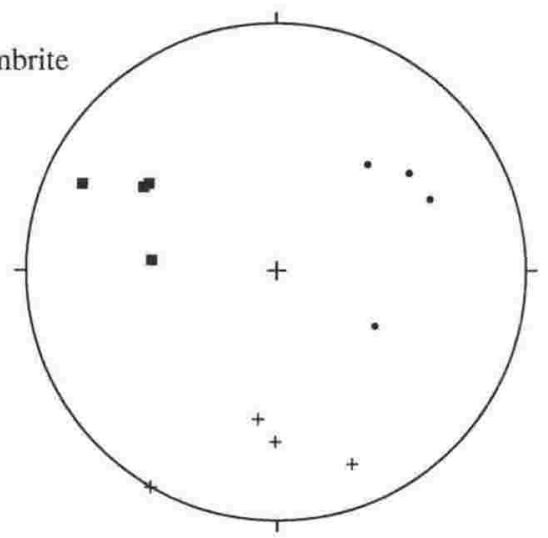

Site 168.

Waimakariri ignimbrite

T15/595484

Type 1

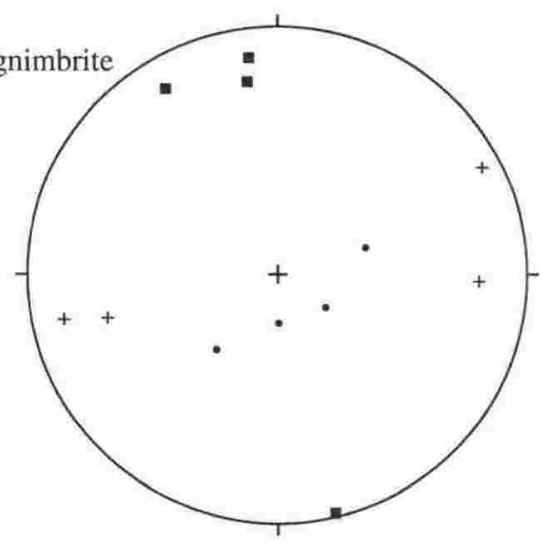

Site 163.

Waiteariki ignimbrite

U14/759717

Type 2

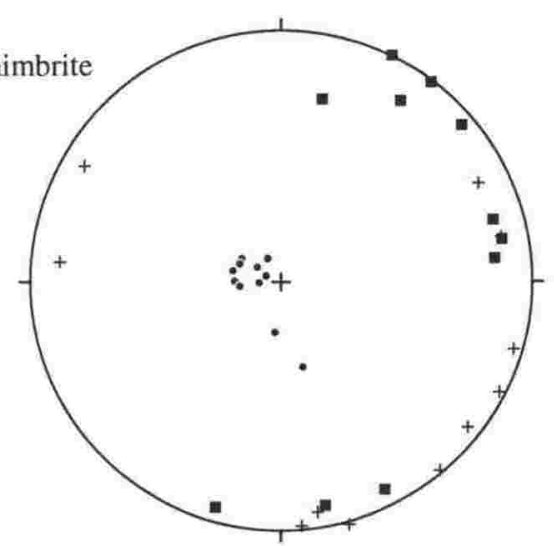

Site 165.

Mamaku Ignimbrite cubes

U15/746476

Type 7 ?

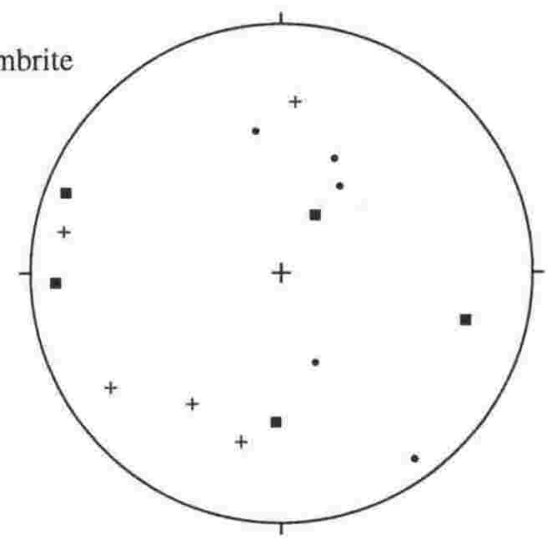

Site 167.

Mamaku Ignimbrite cubes

T15/642468

Type 5

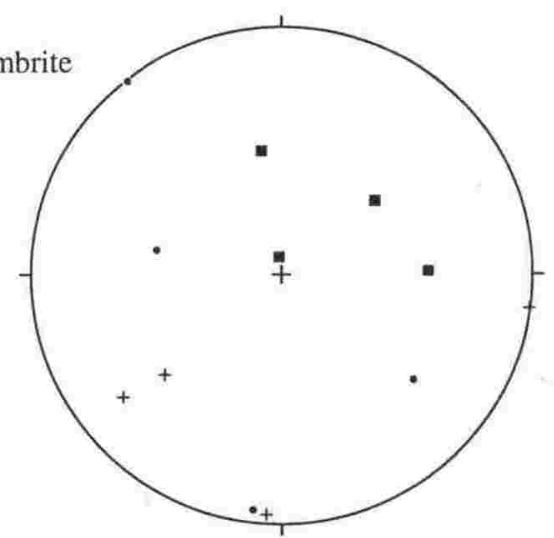

Site 169.

Ongatiti Ignimbrite

T15/569497

Type 3

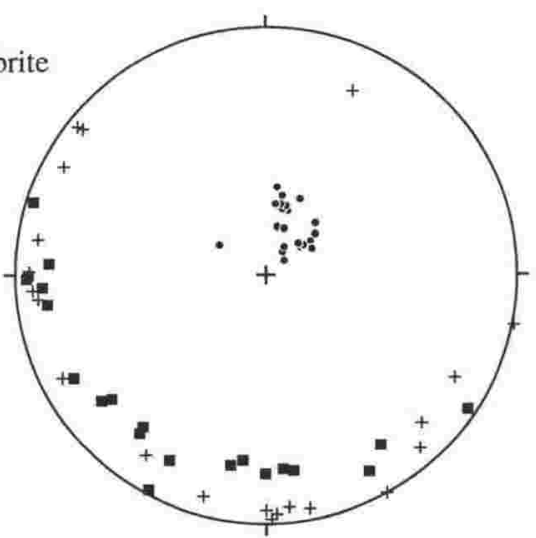


Site 170.

Ongatiti Ignimbrite T15/463618

Type 4

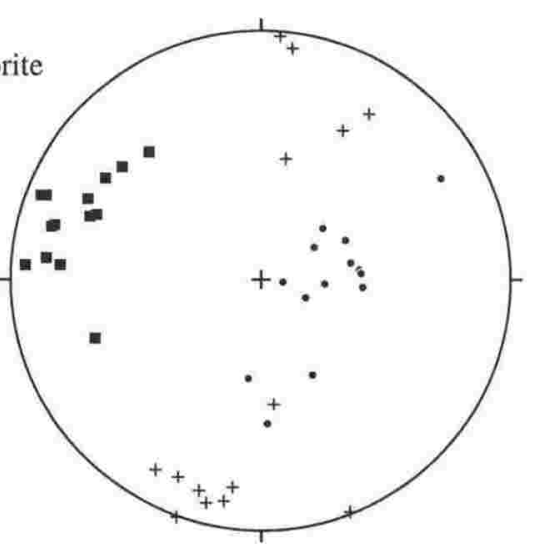

Site 172.

Ongatiti Ignimbrite S16/179272

Type 7

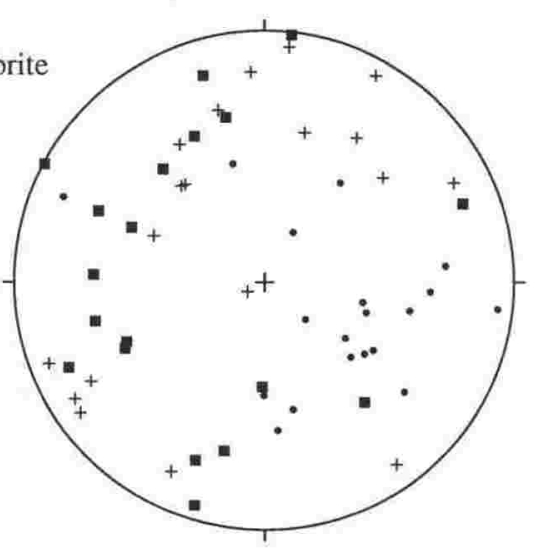

Site 171.

Whakamaru ignimbrite

T15/487415

Type 2

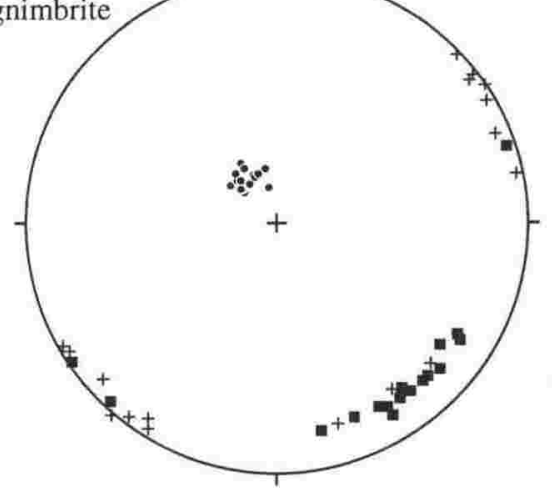




\section{Appendix 4 SUPPORTING PAPER}

Isothermal plateau fission-track age for a paleomagnetic excursion in the Mamaku Ignimbrite, New Zealand, and implications for late Quaternary stratigraphy.

Geophysical research letters 21:1695-1698.

Phil Shane, Tasha Black and John Westgate

In this paper, T Black determined the paleomagnetic data for the Mamaku Ignimbrite and one of the ITPFT ages. 


\title{
Isothermal plateau fission-track age for a paleomagnetic excursion in the Mamaku Ignimbrite, New Zealand, and implications for late Quaternary stratigraphy
}

\author{
Phil Shane, Tasha Black ${ }^{1}$ and John Westgate \\ Department of Geology, University of Toronto, Toronto, Ont. M5S 3B1, Canada
}

\begin{abstract}
Mamaku Ignimbrite, the youngest of the large, welded ignimbrite sheet-forming eruptions from the Taupo Volcanic Zone in New Zealand, is dated at $230 \pm 12 \mathrm{ka}$ by the isothermal plateau fission-track (ITPFT) method on glass. This age is older and more precise than that indicated by previous studies, requiring the revision of loess/paleosol coverbed chronologies. The eruption occurred during a paleomagnetic excursion allowing the ignimbrite to be easily distinguished from other eruptive events by paleomagnetic methods. This excursion is one of the few such events recorded in igneous rocks in the Southern Hemisphere, may be widely recorded in New Zealand, and is now temporally well constrained.
\end{abstract}

\section{Introduction}

The Mamaku Ignimbrite is the product of a large rhyolitic eruption which resulted in the collapse and formation of the Rotorua caldera [Wilson et al., 1984] in the North Island of New Zealand during the late Quaternary. It is the most recent of the large, welded ignimbrite sheet-forming eruptions of the Taupo Volcanic Zone. The eruption, estimated to have a volume $>300 \mathrm{~km}^{3}$, produced an extensive plateau at an elevation $150-600 \mathrm{~m}$ to the west of the caldera and present site of Lake Rotorua (Fig. 1), covering an area $>3000 \mathrm{~km}^{2}$. Subsequently, loess, paleosols and rhyolitic and andesitic tephras have accumulated on the plateau, recording the fluctuating climatic conditions of the latest Quaternary [Kennedy, 1988; Kimber et al., 1994]. As this event is important in the physiographic history of the region and is a temporal control horizon, its age is critical for late Quaternary studies of the North Island. Murphy and Seward [1981] determined a zircon fission-track age of $140 \pm 80 \mathrm{ka}$ for a unit considered to be Mamaku Ignimbrite, but did not present the precise sample locality. This age has been widely referenced in the literature. Cox [1971] presented data from a site of the ignimbrite (near site 12, Fig. 1) showing an instantaneous paleomagnetic pole position widely variant from a typical dipole field. Here we present a revised age and stratigraphy for the Mamaku Ignimbrite based on ITPFT ages and paleomagnetism.

Mamaku Ignimbrite occurs in a sequence of voluminous

\footnotetext{
${ }^{1}$ Also at Research School of Earth Sciences, Victoria University of Wellington, P O Box 600, Wellington, New Zealand.
}

Copyright 1994 by the American Geophysical Union.

Paper number 94GL01576

0094-8534/94/94GL-01576\$03.00 ignimbrites in the Rotorua area, including both reversed and normal polarity units [Murphy and Seward, 1981]. However the relative stratigraphic order of the units is largely obscured due to limited exposure and few sections containing two or more ignimbrites. Of the late Quaternary units. Whakamaru (ca. $350 \mathrm{ka}$ ) [Kohn et al., 1992], Matahina and Kaingaroa Ignimbrites are widespread. With the difficulty of geochemical characterisation due to pervasive devitrification and vapour phase alteration, ignimbrite recognition is based mainly on field character. Thus we collected samples from several sites of each ignimbrite in an attempt to characterise them via their instantaneous pole positions.

\section{Paleomagnetism}

We collected samples from sites of Mamaku Ignimbrite including both hard, welded vitric tuff and loose, poorly welded tuff exposures from proximal and distal localities (Fig. 1). At sites $12,89,90$ and 91 , we collected samples in vertical sequence through the ignimbrite where it reaches a thickness of ca. $200 \mathrm{~m}$. The samples, along with those from other ignimbrites were subjected to standard $\mathrm{AF}$ demagnetisation and sequential measurement on a spinner magnetometer. Measured intensities at each step (ca. $40-4000 \mathrm{~mA} / \mathrm{m}$ ) were well in excess of the detection limit of the magnetometer $(0.03$ $\mathrm{mA} / \mathrm{m}$ ). Each of the 17 sites of Mamaku Ignimbrite (109 specimens) gave a consistent paleomagnetic pole direction (Table 1) producing a mean declination of $144^{\circ}$ and inclination of $-71^{\circ}\left(\alpha_{95}=1.6^{\circ}\right)$. Some specimens displayed a single component magnetism, while in others a weak viscous normal overprint was removed in the initial demagnetisation steps (Fig. 2). No consistent variation is seen relating to either degree of welding or stratigraphic position. In addition, our anisotropy of magnetic susceptibility measurements show the maximum susceptibility directions are subparallel to the deposition surface and generally radial to the caldera in azimuth, and thus do not affect the remanent magnetism. Minor site differences in pole direction for Mamaku Ignimbrite are likely to be caused by latest Quaternary tectonic warping of the Mamaku Plateau and/or residual normal overprinting.

The instantaneous pole position for Mamaku Ignimbrite is significantly different to that of the present day for New Zealand, and those of other late Pleistocene ignimbrites in the Rotorua area (Fig. 3). We interpret the steep inclination and south-easterly declination of the Mamaku Ignimbrite pole to represent an excursion. This feature of the Mamaku Ignimbrite allows it to be easily distinguished from other units (Fig. 3), and supports the correlation to the distal ignimbrite previously referred to as Mokai at sites 21 and 112, which occurs in a similar stratigraphic position to Mamaku. 


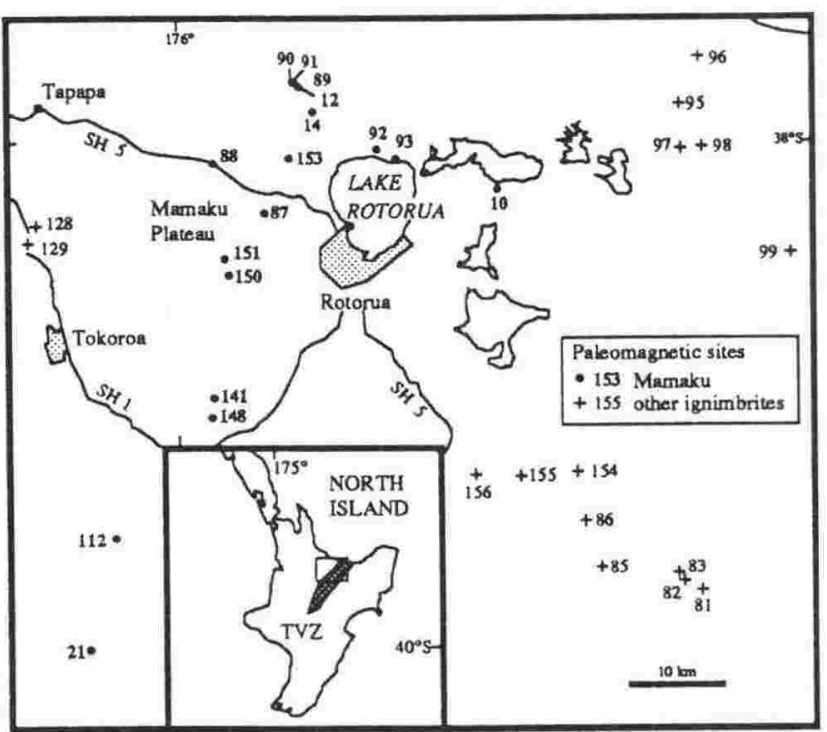

Figure 1. Locality map of Lake Rotorua (source of Mamaku Ignimbrite) and environs, showing ignimbrite sample sites.

Age

We obtained fresh glass shards from the unwelded ash of the base of the basal ignimbrite at site 148 for determining ages using the ITPFT method of Westgate [1989]. As fossil spontaneous fission tracks may fade at ambient temperatures in volcanic glasses, a correction must be applied for accurate age determination. In the ITPFT method, glasses are heated at $150^{\circ} \mathrm{C}$ for 30 days which results in a concordance in spontaneous (Ds) and induced (Di) track diameters, and thus corrects for any previous track fading. An age may also be corrected for an unheated sample by multiplying the spontaneous track density by $\mathrm{Di} / \mathrm{Ds}$, given an adequate etch. Sandhu and Westgate (unpublished data) have found a close concordance between ages corrected in this way and isothermal plateau ages. Electron microprobe analyses revealed the glass in the Mamaku Ignimbrite is chemically homogeneous. The

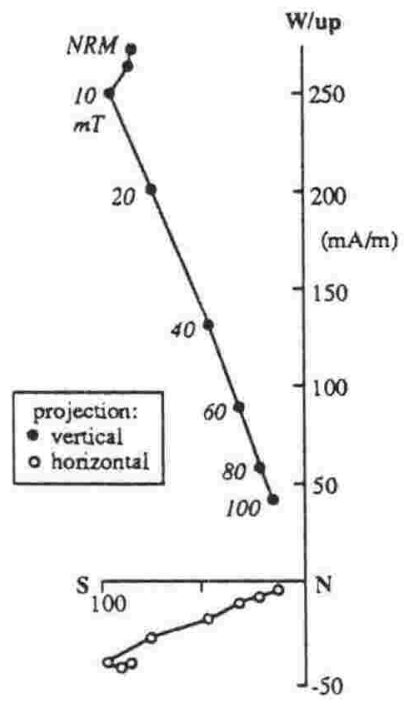

Figure 2. Typical demagnetisation behaviour of Mamaku Ignimbrite (site 89) shown on a vector component plot. A weak viscous overprint is removed at $10 \mathrm{mT}$ to reveal a stable magnetism. unheated glass produced an age of $201 \pm 27 \mathrm{ka}$ but $\mathrm{Ds} / \mathrm{Di}=0.86$ indicating that partial track fading has occurred (Table 2). The diameter-corrected age is $233 \pm 31 \mathrm{ka}$. This is in good agreement with 3 ITPFT ages of $222 \pm 22,229 \pm 22$ and $242 \pm$ $27 \mathrm{ka}$ determined by 3 different workers on the same sample (Table 2). The weighted mean age of Mamaku Ignimbrite is thus $230 \pm 12 \mathrm{ka}$.

This age does not correspond precisely to any widely reported paleomagnetic excursion in the late Quaternary [e.g. Champion et al., 1988], however not all such events are well constrained in age. The Jamaica Subchron is dated by two K-Ar ages on basalts with low \% radiogenic $\mathrm{Ar}$ at $182 \pm 31 \mathrm{ka}$ [Champion et al., 1988]. Astronomical-tuning of deep sea isotope records place this event at $195 \mathrm{ka}$ [Valet and Meynadier, 1993]. Mamaku Ignimbrite may have erupted in the early stages of this event or represent a previously

Table 1. Paleomagnetic data for Mamaku Ignimbrite and other late Quaternary ignimbrites in the Rotorua area.

\begin{tabular}{|c|c|c|c|c|c|c|}
\hline Site & Grid ref. & Decl. & Incl. & $\mathrm{n}$ & K & $\alpha_{95}$ \\
\hline \multicolumn{7}{|c|}{ Mamaku } \\
\hline 10 & V $15 / 110439$ & 116 & -63 & 7 & 511 & 2.5 \\
\hline 12 & U15/887552 & 127 & -79 & 8 & 207 & 3.6 \\
\hline 14 & U15/904523 & 158 & -65 & 5 & 576 & 2.9 \\
\hline 21 & $\mathrm{~T} 17 / 642901$ & 123 & -67 & 10 & 1243 & 1.3 \\
\hline 87 & U15/840408 & 127 & -75 & 4 & 116 & 8.6 \\
\hline 88 & $\mathrm{U} 15 / 781470$ & 129 & -82 & 4 & 151 & 6.5 \\
\hline 89 & U15/885556 & 161 & -64 & 9 & 90 & 5.2 \\
\hline 90 & U15/882557 & 154 & -67 & 4 & 874 & 2.7 \\
\hline 91 & U15/884555 & 152 & -64 & 8 & 378 & 2.7 \\
\hline 92 & U15/976480 & 151 & -67 & 4 & 232 & 5.2 \\
\hline 93 & U15/000464 & 153 & -55 & 3 & 585 & 4.2 \\
\hline 112 & T17/672043 & 166 & -72 & 9 & 1994 & 1.1 \\
\hline 141 & U16/784204 & 137 & -77 & 11 & 488 & 2.0 \\
\hline 148 & $\mathrm{U} 16 / 777178$ & 157 & -64 & 7 & 457 & 2.6 \\
\hline 150 & U16/804340 & 145 & -71 & 4 & 1654 & 2.0 \\
\hline 151 & U16/801364 & 146 & -77 & 4 & 299 & 4.6 \\
\hline 153 & U15/868472 & 087 & -77 & 4 & 358 & 4.2 \\
\hline mean & & 144 & -71 & 109 & 72 & 1.6 \\
\hline \multicolumn{7}{|c|}{ Kaingaroa } \\
\hline 85 & V17/217003 & 009 & -53 & 6 & 2564 & 1.2 \\
\hline 86 & V17/194054 & 007 & -51 & 7 & 419 & 2.7 \\
\hline 154 & V16/194112 & 010 & -52 & 8 & 347 & 2.8 \\
\hline 155 & V16/128106 & 010 & -58 & 9 & 182 & 3.6 \\
\hline 156 & U16/085108 & 006 & -49 & 7 & 526 & 2.4 \\
\hline \multicolumn{7}{|c|}{ Matahina } \\
\hline 82 & $\mathrm{~V} 17 / 307993$ & 011 & -57 & 12 & 1248 & 1.2 \\
\hline 95 & V $15 / 316523$ & 006 & -52 & 12 & 417 & 2.0 \\
\hline 96 & $\mathrm{~V} 15 / 342576$ & 002 & -53 & 8 & 1929 & 1.2 \\
\hline 97 & $\mathrm{~V} 15 / 318477$ & 005 & -49 & 7 & 294 & 3.3 \\
\hline 98 & $\mathrm{~V} 15 / 343478$ & 011 & -54 & 7 & 323 & 3.1 \\
\hline 99 & V16/440353 & 004 & -50 & 7 & 667 & 2.2 \\
\hline \multicolumn{7}{|c|}{ Whakamaru } \\
\hline 81 & V $17 / 327984$ & 007 & -67 & 7 & 1028 & 1.7 \\
\hline 83 & V17/305993 & 357 & -69 & 12 & 1225 & 1.2 \\
\hline 128 & T16/588398 & 355 & -63 & 14 & 1739 & 0.9 \\
\hline 129 & T16/588398 & 003 & -64 & 9 & 284 & 2.9 \\
\hline
\end{tabular}

Grid ref. from the NZMS map series.

Samples demagnetised in optimum fields of $20-60 \mathrm{mT}$. $\mathrm{n}=$ number of specimens

Fisher precision statistics: $\mathrm{K}$ and $\alpha_{95}$ 
Table 2. Fission-track ages of glass shards from Mamaku Ignimbrite at site 148 .

\begin{tabular}{|c|c|c|c|c|c|c|}
\hline \multicolumn{2}{|c|}{ Track density } & Neutron & Etch & $\mathrm{Ds} / \mathrm{Di}$ & Age (ka) & Operator \\
\hline $\begin{array}{l}\text { Spontaneous } \\
\left(10^{2} \mathrm{~V} / \mathrm{cm}^{2}\right)\end{array}$ & $\begin{array}{c}\text { induced } \\
\left(10^{3} \mathrm{t}^{\mathrm{cm}} \mathrm{cm}^{2}\right)\end{array}$ & $\begin{array}{c}\text { fluence } \\
\left(10^{15} \mathrm{n} / \mathrm{cm}^{2}\right)\end{array}$ & $\begin{array}{l}\text { time } \\
(s)^{\mathrm{a}}\end{array}$ & & & \\
\hline
\end{tabular}

Mamaku Ignimbrite unheated diameter corrected $^{\mathrm{c}}$ isothermal plateau isothermal plateau isothermal plateau weighted mean ${ }^{\mathrm{d}}$
$1.81(57)^{\mathrm{b}}$
$1.57(106)$
$1.59(106)$
$1.56(84)$

190.7 (14048)

$150.1(10963)$

$137.1(9170)$

$131.91(580)$

183.4 (4705)

Moldavite $^{\mathrm{e}}$

$\begin{array}{rrr}3.55 & 90 & 0.86 \\ 3.55 & 160 & 1.00 \\ 3.55 & 160 & 1.00 \\ 3.55 & 160 & 1.00\end{array}$

$201 \pm 27$

$233 \pm 31$

$222 \pm 22$

$229 \pm 22$

$242 \pm 27$

$230 \pm 12$

PS

JW

TB

PS

Ages determined by the ITPFT method and calculated as in Westgate [1989]. Samples heated at $150^{\circ} \mathrm{C}$ for 30 days. Induced track density determined by subtraction of the spontaneous track density. $\mathrm{Ds} / \mathrm{Di}=$ the ratio of the mean spontaneous track diameter and induced track diameter. Mean track diameters are in the range $6-7.5 \mu \mathrm{m}$. ${ }^{a}$ Etched in $26 \% \mathrm{HF}$ at $25^{\circ} \mathrm{C}$. ${ }^{b}$ Number of tracks counted. ${ }^{\mathrm{C}} \mathrm{Age}$ corrected by multiplying the spontaneous density by Di/Ds. ${ }^{d}$ weighted by the inverse of the variance excluding uncorrected, unheated age. ${ }^{e}$ Laboratory standard used as a check on the fluence estimates, ${ }^{40} \mathrm{Ar} /{ }^{39} \mathrm{Ar}$ age $=15.21 \pm$ $0.15 \mathrm{Ma}$ [Staudacher et al., 1982].

unknown event. In either case, this excursion is important as it is now well constrained in age. Loess units above the Mamaku Ignimbrite also display paleomagnetic directions similar to the ignimbrite [Froggatt, 1988], as do comparably aged loess elsewhere in North Island [Pillans and Wright, 1990]. Thus the excursion may be widely recorded in New Zealand. Apparently, the only other record of an excursion in igneous rocks of the Southern Hemisphere is in basaltic rocks of the Auckland area of New Zealand, dated at 23-49 ka [Shibuya et al., 1992].

\section{Implications for late Quaternary stratigraphy}

Previously, the chronology for the coverbed sequence of loess and paleosols on the Mamaku Plateau was constrained by the age of $140 \mathrm{ka}$ for the Mamaku Ignimbrite, i.e. corresponding to the middle of glacial O-isotope stage 6

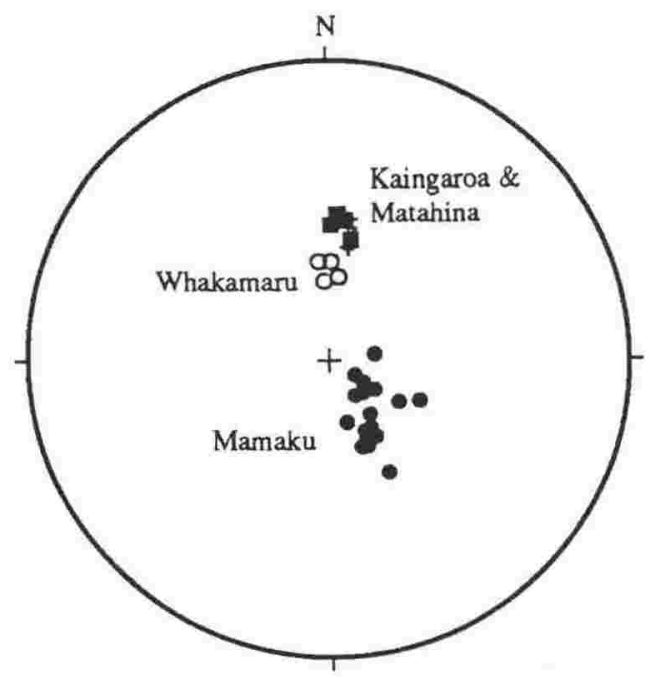

Figure 3. Stereographic projection showing the mean instantaneous paleomagnetic pole position for sites of late Quaternary ignimbrites in the Rotorua area. All inclinations are normal.
[Kennedy, 1988]. However, the error for this age estimate is relatively large ( $\pm 80 \mathrm{ka})$ [Murphy and Seward, 1981]. Loess units overlying the ignimbrite are tephric and thought to be derived via erosion during sparsely vegetated glacial or stadial periods. The intervening paleosols represent weathering, organic accumulation and the establisbment of vegetation during periods similar in climate to the present. Based on such a chronology, thick sequences such as at Tapapa (Fig. 1,4)
A Tephra ages

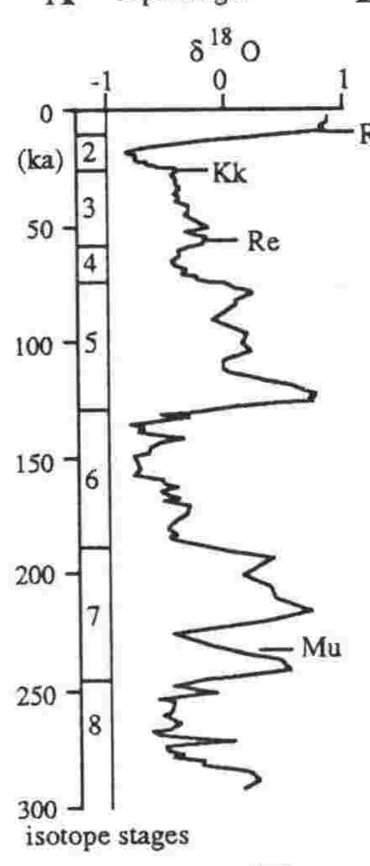

$\square$ paleosol $\square$ loess
B Previous O-isotope correlation

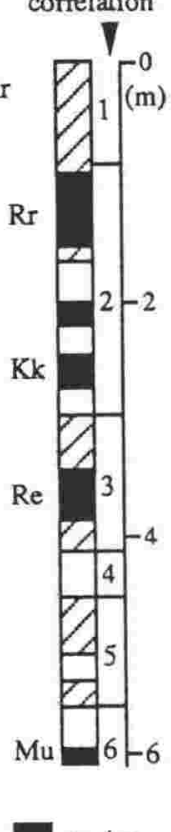

$\mathrm{Rr}=\operatorname{Rotorua~}(13 \mathrm{ka}), \mathrm{Kk}=\mathrm{Kawakawa}(22 \mathrm{ka})$, $\mathrm{Re}=$ Rotoehu $(50 \mathrm{ka}), \mathrm{Mu}=\mathrm{Mamaku} \mathrm{Ig}(230 \mathrm{ka})$

Figure 4. A, tephrochronology of a thick loess/paleosol sequence at Tapapa including the revised age for Mamaku Ignimbrite, and correlation to the O-isotope record [after Martinson et al., 1987]. B, lithology and previous chronology from Kennedy [1988] and Kimber et al., [1994]. 
were considered to represent a complete record of the last 140 $\mathrm{ka}$, which included loess accumulation in the stadials of stage 5 as well as during full glacials.

Our new mean ITPFT age $(230 \pm 12 \mathrm{ka})$ with its relatively small error, would place the Mamaku Ignimbrite in interglacial stage 7 (Fig. 4), nearly $100 \mathrm{ka}$ older than previously assumed. This is further supported by the occurrence of a paleosol at the base of the ignimbrite, and the development of a paleosol into its top, at some localities. In our revised chronology for the Mamaku Plateau area (Fig. 4), we do not attempt to assign each lithological unit to an O-isotope stage due to the lack of control points for the interval above Mamaku Ignimbrite and below the Rotoehu ash (ca. 50-60 ka). Breaks in deposition appear to occur in the magnetic susceptibility record [Froggatt, 1988], therefore the sedimentary record may be incomplete. Our new chronology does show a much longer record of the late Quaternary is present at Tapapa. Thus loess previously assigned to stadials of stage 5 could instead represent full glacials (e.g. stage 6) (Fig. 4). We conclude that the formation of the extensive Mamaku Plateau and caldera now occupied by Lake Rotorua occurred at ca. $230 \mathrm{ka}$.

Acknowledgements. The research was funded by internal research grants from Victoria University of Wellington, and from the Natural Sciences and Engineering Research Council of Canada. Paul Froggatt. G. Wagner and an anonymous referee are thanked for their comments.

\section{References}

Champion, D. E., M. A. Lanphere, M. A. Kuntz. Evidence for a new geomagnetic reversal from lava flows in Idaho: discussion of short polarity reversals in the Brunhes and Matuyama Polarity Chrons, $J$. Geophys. Res., 93, 11667-11680, 1988.

Cox, A., Remanent magnetisation and susceptibility of late Cenozoic rocks from New Zealand, N.Z.J. Geol. Geophys., 22, 192-207, 1971.

Froggatt, P. C., Paleomagnetism of Last Glacial loess from two sections in New Zealand, in Loess: Its distribution, geology and soils, edited by D. N. Eden and R. J. Furkert, pp. 59-68, Balkema, Rotterdam, 1988.
Kennedy, N. M., Late Quaternary loess associated with the Mamaku Plateau, North Island, New Zealand, in Loess: Its distribution, geology and soils, edited by D. N. Eden and R. J. Furkert, pp. 71-80. Balkema, Rotterdam, 1988.

Kimber, R. W. L., N. M. Kennedy, A. R. Milnes, Amino acid racemization dating of a 140000 year old tephra-loess-paleosol sequence on the Mamaku Plateau near Rotorua, New Zealand, Aust. J. Earth Sci., 41,19-26, 1994.

Kohn, B. P., B. Pillans, M. S. McGlone, Zircon fission track age for middle Pleistocene Rangitawa Tephra. New Zealand: stratigraphic and paleoclimatic significance, Paleogeogr., paleoclimatol., paleoecol., 95, 73-94, 1992.

Martinson, D. G., N. G. Pisias. J. D. Hays. J. Imbrie. T. C. Moore and N. J. Shackleton, Age dating and orbital theory of the ice ages: development of a high resolution 0 to 300,000-year chronostratigraphy, Quat. Res., 27, 1-29, 1987

Murphy, R. P., D. Seward, Stratigraphy, lithology, paleomagnetism, and fission-track ages of some ignimbrite formations in the Matahana Basin. New Zealand, N.Z.J. Geol. Geophys., 24, 325-331, 1981.

Pillans, B., I. Wright, 500,000 year paleomagnetic record from New Zealand loess, Quat. Res., 33, 178-187, 1990.

Shibuya, H., J.Cassidy, I. E. M. Smith and T. Itaya, A geomagnetic excursion in the Brunhes epoch recorded in New Zealand, Earth Planet. Sci. Lett., III, 41-48, 1992.

Staudacher, T. H., E. K. Jessberger, B. Dominik, T. Kirsten, and O. A. Schaeffer, ${ }^{40} \mathrm{Ar} /{ }^{39} \mathrm{Ar}$ ages of rocks and glasses from the Nordlinger Ries Crater and temperature history of impact breccia, J. Geophys., $51,1-11,1982$

Valet, J., L. Meynadier, Geomagnetic field intensity and reversals during the past four million years. Nature, 366, 234-238, 1993.

Westgate, J. A., Isothermal plateau fission-track ages of hydrated glass shards from silicic tephra beds, Earth Planet. Sci. Lett., 95, 226-234. 1989.

Wilson, C. J. N., A. M. Rogan, I. E. M. Smith, D. J. Northey, I. A. Nairn, B. F. Houghton, Caldera volcanoes of the Taupo Volcanic Zone, New Zealand, J. Geophys. Res., 89, 8463-8484, 1984.

T. Black, P. Shane and J. Westgate. Department of Geology, University of Toronto, Toronto, Ont. M5S 3B1. Canada

(Received April 11, 1994; accepted May 25, 1994.) 